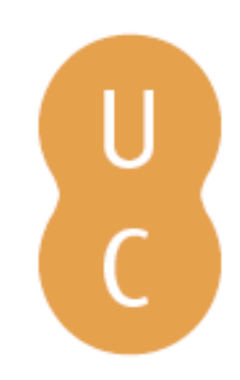

\title{
nombalina
}

\section{A escola primária como rito de civilização: ler, escrever, contar e se comportar em Portugal (1820-1910)}

\author{
Autor(es): Boto, Carlota
}

Publicado por: Imprensa da Universidade de Coimbra

URL

persistente: URI:http://hdl.handle.net/10316.2/5657

DOI: $\quad$ DOI:http://dx.doi.org/10.14195/978-989-26-0572-2

Accessed : $\quad$ 26-Apr-2023 15:25:08

A navegação consulta e descarregamento dos títulos inseridos nas Bibliotecas Digitais UC Digitalis, UC Pombalina e UC Impactum, pressupõem a aceitação plena e sem reservas dos Termos e Condições de Uso destas Bibliotecas Digitais, disponíveis em https://digitalis.uc.pt/pt-pt/termos.

Conforme exposto nos referidos Termos e Condições de Uso, o descarregamento de títulos de acesso restrito requer uma licença válida de autorização devendo o utilizador aceder ao(s) documento(s) a partir de um endereço de IP da instituição detentora da supramencionada licença.

Ao utilizador é apenas permitido o descarregamento para uso pessoal, pelo que o emprego do(s) título(s) descarregado(s) para outro fim, designadamente comercial, carece de autorização do respetivo autor ou editor da obra.

Na medida em que todas as obras da UC Digitalis se encontram protegidas pelo Código do Direito de Autor e Direitos Conexos e demais legislação aplicável, toda a cópia, parcial ou total, deste documento, nos casos em que é legalmente admitida, deverá conter ou fazer-se acompanhar por este aviso.

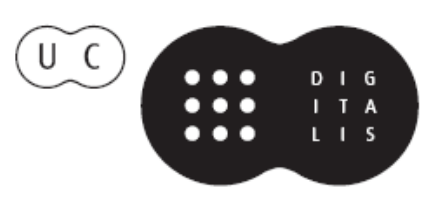




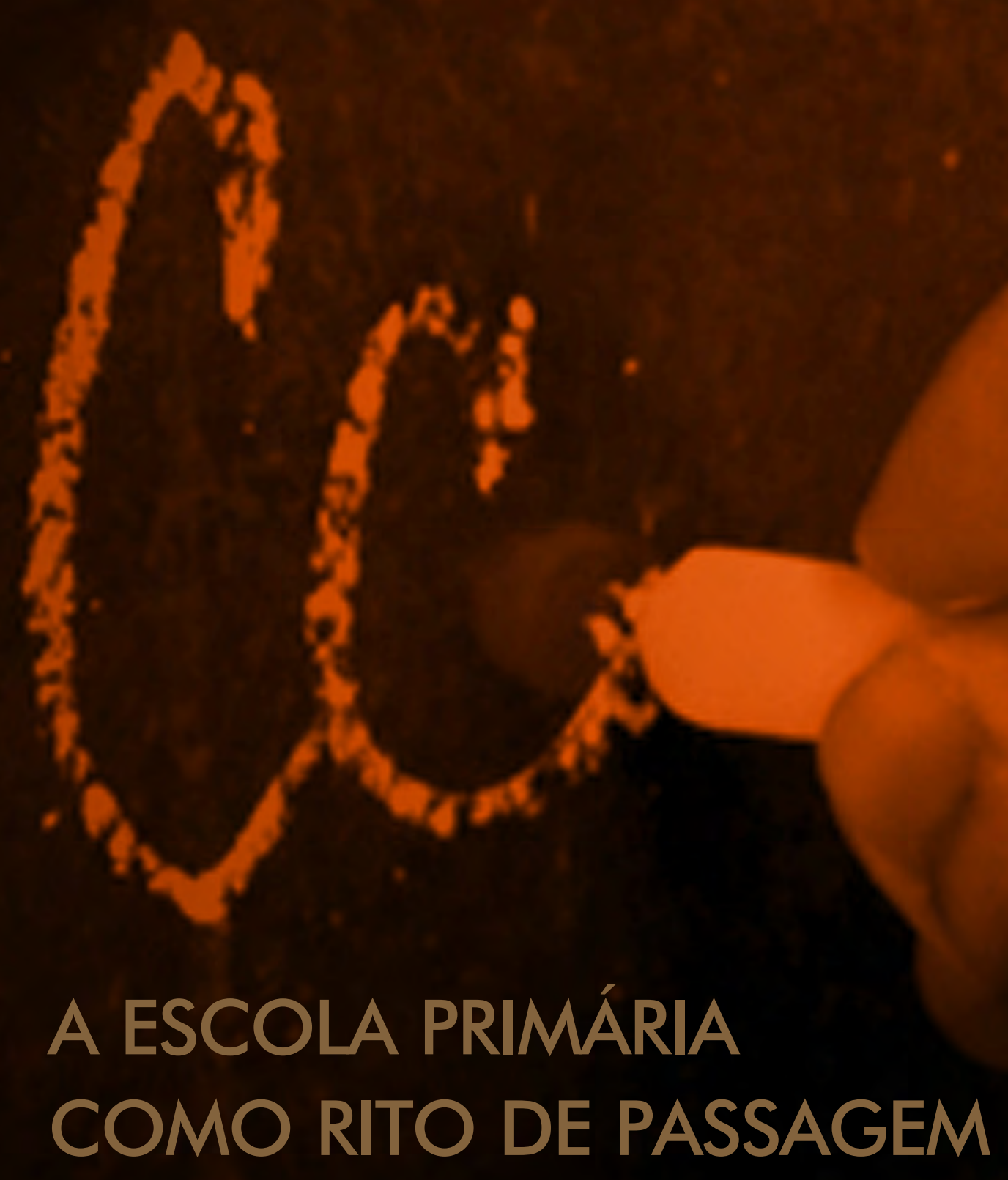

LER, ESCREVER, CONTAR E SE COMPORTAR

\section{CARLOTA BOTO}


(Página deixada propositadamente em branco) 


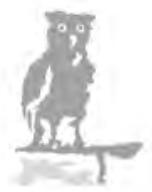

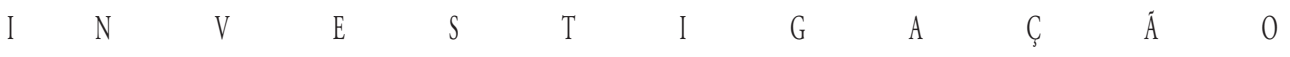

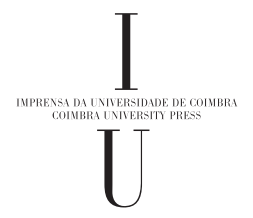




\section{EDIÇĀO}

Imprensa da Universidade de Coimbra

Email: imprensauc@ci.uc.pt

URL: http://www.uc.pt/imprensa_uc

Vendas online: http://www.livrariadaimprensa.com

\section{CONCEPÇÃO GRÁFICA}

António Barros

INFOGRAFIA DA CAPA

Carlos Costa

PRÉ-IMPRESSÃO

Mickael Silva

\section{EXECUÇÃO GRÁFICA}

www.artipol.net

ISBN

978-989-26-0160-1

ISBN Digital

978-989-26-0572-2

DOI

http://dx.doi.org/10.14195/978-989-26-0572-2

DEPÓSITO LEGAL

$344078 / 12$ 


\section{A ESCOLA PRIMÁRIA COMO RITO DE PASSAGEM}

LER, ESCREVER, CONTAR E SE COMPORTAR

\section{CARLOTA BOTO}

IMPRENSA DA UNIVERSIDADE DE COIMBRA

COIMBRA UNIVERSITY PRESS 
(Página deixada propositadamente em branco) 
"Trago a fisga no bolso de trás / E na pasta o caderno dos deveres / Mestre-escola, eu sei lá se sou capaz / De escolher o melhor dos dois saberes / O meu pai diz que o Sol é que nos faz / Minha mãe manda-me ler a lição / Mestre-escola, eu sei lá se sou capaz / Faz-me falta ouvir outra opiniāo."

(João Monge e João Gil, A fisga, Rio Grande)

"Por seres tão inventivo

Epareceres contínuo

Tempo tempo tempo tempo

Es um dos deuses mais lindos

Tempo tempo tempo tempo"

(Oração ao Tempo, Caetano Veloso) 
(Página deixada propositadamente em branco) 
Com amor e gratidão, dedico este trabalho ao meu Pai, 
(Página deixada propositadamente em branco) 


\section{SUMÁRIO}

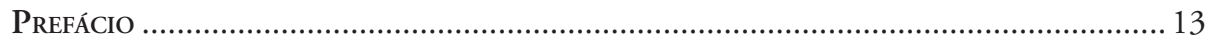

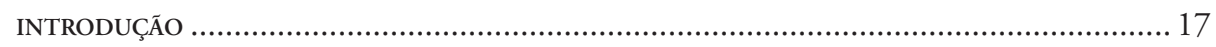

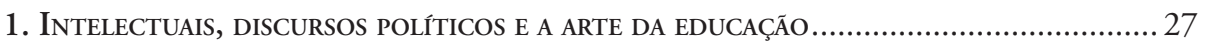

A CARÊNCIA DE ESCOLAS COMO PROBLEMA NACIONAL.................................................... 27

A PEDAGOGIA SOB O SIGNO DA POLÍTICA: ALVORADA DO LIBERALISMO ..................................29

CarvalHo E O PAPEL DA EDUCAÇão DOMÉSTICA

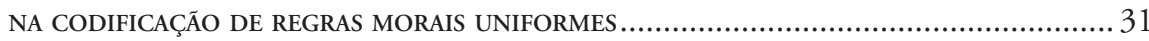

A difusÃo ESCOLAR COMO CHAVE PARA SUPERAÇÃo DA DECADÊNCIA PÁTRIA .......................... 34

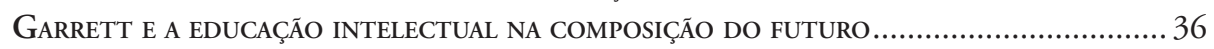

O Cariz Pedagógico do pensamento de Alexandre Herculano...................................... 44

A ESCOLA MODERADORA DA AVIDEZ DA LEITURA:

António Feliciano de Castilho ..................................................................... 50

O poema educacional de António Feliciano de Castilho:

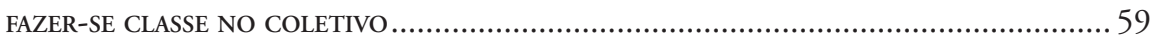

2. INTELECTUAIS, PERCURSOS PEDAGÓGICOS E A CIÊNCIA DA EDUCAÇÃO.............................. 67

A GERAÇÃO DE 70: TRADIÇÃo E CRÍTICA NA LUTA DE REPRESENTAÇÕES................................... 67

EÇa de Queirós, Ramalho Ortigão e As Farpas da leitura ...................................... 74

JoÃo de Deus, a GERAÇÃO DE 70 E A CARTILHA MATERNAL............................................ 78

JoÃo de DEUS: do MÉTOdo de LEITURA À LEITURA do MÉTOdo ...................................... 85

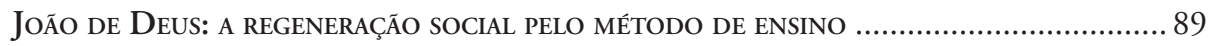

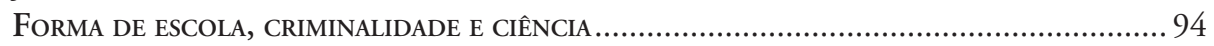

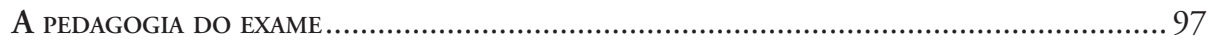

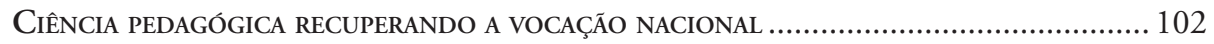

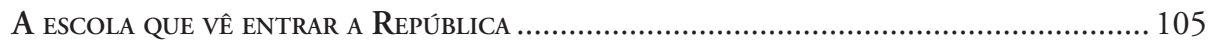




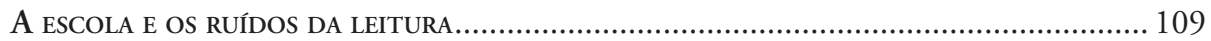

A AMBIÊNCIA EDUCATIVA IMPRESSA EM PANORÂMICAS FOLHAS PERIÓDICAS

O MODELO ESCOLAR E A PERSISTÊNCIA DO ARCAÍSMO

NO CONTEXTO DA PRETENDIDA REGENERAÇÃO

A ESCOLA QUE CLASSIFICA, ORDENA, INSTRUI ............................................................... 122

A DISTRAÇÃO, A CRIANÇA ANORMAL E O DESENVOLVIMENTO INFANTIL............................... 132

IMPASSES DA HEREDITARIEDADE E A NOVA PEDAGOGIA ................................................. 137

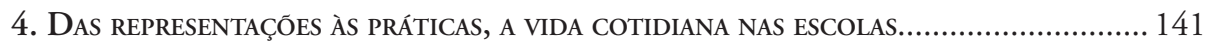

RoTINA E INOVAÇĀO: A GEOGRAFIA DA ESCOLA PASSADA................................................ 141

A ESCOLA COMO SIGNO DE PODER LOCAL: RIVALIDADE COMUNITÁRIA ................................ 146

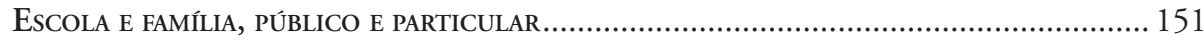

A COMPOSIÇÃO DOS SABERES ESCOLARES SOB O SIGNO DA MEMÓRIA …................................ 157

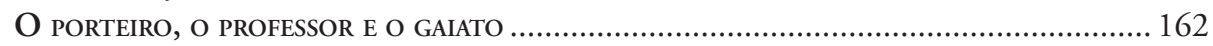

UM PROFESSOR DE MORAL ESTRAGADA: SUAS TESTEMUNHAS E SEUS ADVERSÁRIOS ............... 170

5. TEMPO E ESPaÇO do ENSINO: O TRAÇADO do CURRículo

(INSPEÇÃO ÀS ESCOLAS EM 1867)

INSPEÇÃO ESTATÍSTICA, ROTINA ESCOLAR E ROTEIROS DE APRENDIZADO............................ 179

ZELO, MORAL, CIVILIDADE DOCENTE E APROVEITAMENTO DOS ALUNOS................................ 184

Os RELATÓRIOS DE INSPEÇÃo ÀS ESCOLA PÚBLICAS DO ANO LETIVO DE 1866-67:

ABORDAGEM PRELIMINAR.

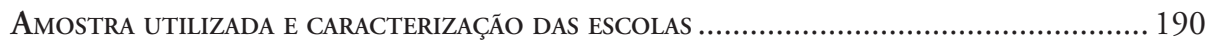

O ESPAÇO FÍSICO DA ESCOLA E O FUNCIONAMENTO DE SUA ESTRUTURA ADMINISTRATIVA .... 197

O PERFIL DO PROFESSOR E SUAS CONDIÇŌES FÍSICAS, MORAIS E PEDAGÓGICAS ...................... 203

FORMAÇÃO DOS PROFESSORES: ESTADO CIVIL, SITUAÇÃO FUNCIONAL

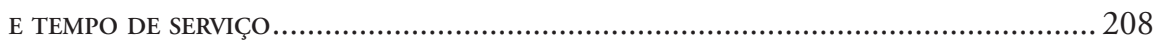

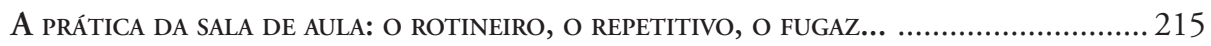

FREQÜÊNCIA, RECOMPENSAS E CASTIGOS: DISPOSITIVOS DO PODER ESCOLAR ....................... 222

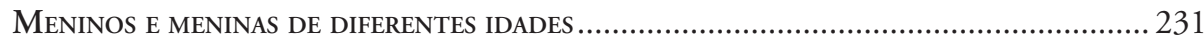

INSPETOR E PROFESSOR AVALIAM LEITURA, ESCRITA, CONTAS E DOUTRINA CRISTÃ ................ 235

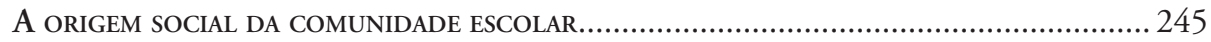

OS COMPÊNDIOS MAIS UTILIZADOS E A REALIDADE DA LEITURA ESCOLAR ........................... 247

OS MANUSCRITOS DOS ALUNOS CONTANDO

DA ESCOLA QUE OS GUARDOU 
6. O RITUAL ESCOLAR: ENTRE VOZES E VERSŌES

(INSPEÇÃO ÀS ESCOLAS EM 1875)

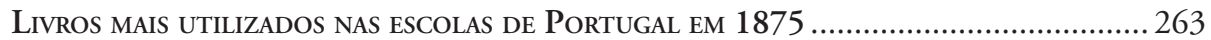

Modos E MANEIRAS DE INSPECIONAR ALUNOS E PROFESSORES ....................................... 272

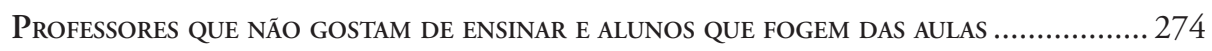

VELHOS PROFESSORES, MÉTODOS FACÍLIMOS E LEITURA EM LIVRO ................................... 277

ESTÍMULO DO PROFESSOR E ÊXITO DO ALUNO: UMA VIA DE MÃO-DUPLA ............................ 282

O MÉTODO SIMULTÂNEO COMO MAESTRO DA ORQUESTRA ESCOLAR .................................2 288

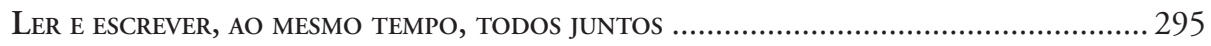

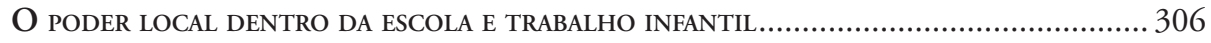

FRONTE DO MESTRE: PAI, MÉDICO, SACERDOTE, JUIZ: A CIÊNCIA PELA VIRTUDE ................... 312

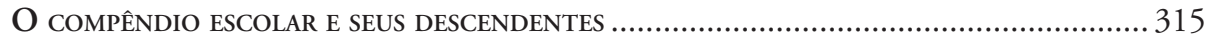

7. O LIVRO DA ESCOLA QUER FORMAR PROFESSORES E CIVILIZAR ALUNOS ...........................319

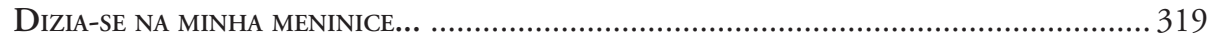

EU AINDA PERTENÇO ÀQUELE TEMPO... DO MANUAL ENCYCLOPEDICO ............................. 328

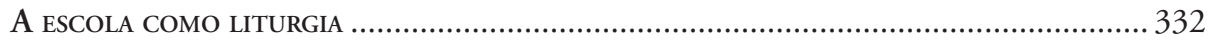

MÉTOdo FACÍlIMO PARA APRENDER A LER NO MAIS CURTO ESPAÇO DE TEMPO POSSÍvEL ...... 335

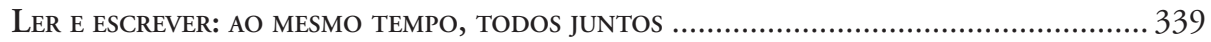

Método Legográfico ou Cartilha NaCional de Caldas Aulete ................................... 348

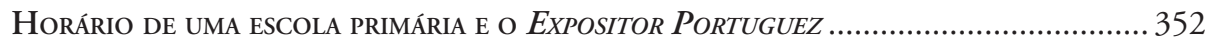

Os VALORES QUE A ESCOLA REFERENDAVA E, NA OUTRA MARGEM, INSTITUÍA ....................... 354

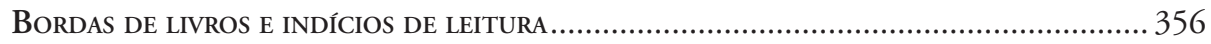

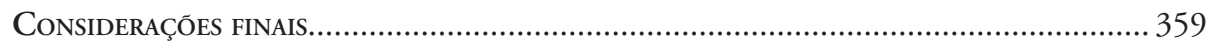

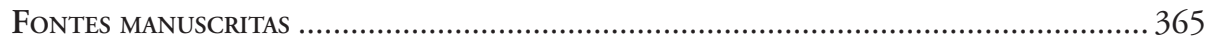

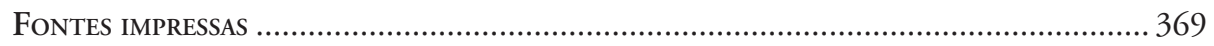

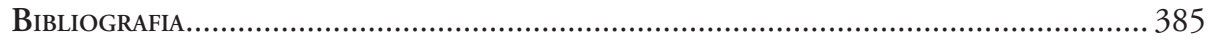


(Página deixada propositadamente em branco) 


\section{Prefácio}

Em boa hora, a Imprensa da Universidade de Coimbra decidiu publicar o estudo de Carlota Boto, Ler, Escrever, Contar e se Comportar: A Escola Primária como Rito no Século XIX Português, obra fundamental no panorama da história da educação no Portugal oitocentista, mas que, até agora, somente pôde exercer a sua influência nos meios mais especializados, pois o seu acesso esteve limitado aos poucos exemplares da tese de doutoramento que, em 1997, a autora apresentou à Universidade de São Paulo, instituição onde hoje é docente e investigadora.

Em termos cronológicos, Carlota Boto escolheu o período compreendido entre 1820 e 1910. E, se as conotações políticas dessas duas datas não foram estranhas a esta balizagem, pensamos, porém, que a sua opção foi sobretudo ditada por motivos epistemológicos. Em causa está a certeza de que só colocando o seu inquérito na média duração poderia inteligir melhor quer as incidências do movimento das ideias pedagógicas em desenvolvimento desde o Iluminismo, quer a estruturação da escola seriada portuguesa, quer ainda as práticas mediante as quais a escolarização foi sendo implantada naquela fase histórica.

Tendo como ponto de partida trabalhos desenvolvidos, entre outros, por Rómulo de Carvalho, Joaquim Ferreira Gomes, Rogério Fernandes e António Nóvoa, o percurso que trilhou distingue-se pela grande relevância que dá à explicação/compreensão dos nexos existentes entre a institucionalização da escola primária e os seus processos de socialização tanto de saberes-fazeres elementares, como de ideias e comportamentos apostados na interiorização de uma nova identidade nacional. Daí a ênfase que pôs na demonstração da seguinte hipótese: sob a Monarquia Constitucional, porém segundo uma progressão temporal condicionada por múltiplas resistências, a construção da escola primária foi tributária de uma narrativa portadora de um sentido otimista e teleológico da história de Portugal. Para isso, ao mesmo tempo que ensinava a ler, a escrever e a contar, essa escola empenhou-se em transmiti-lo às crianças das diferentes camadas da sociedade, tendo em vista a solidificação de um consenso nacional compaginável com os valores liberais saídos vitoriosos com a derrota do absolutismo em 1834 .

Para alcançar o seu objetivo, Carlota Boto acompanhou o modo como se coseu o elo entre as representaçôes/pensamentos e as práticas/rituais no funcionamento do sistema escolar português do século XIX e fez a hermenêutica dos discursos que sobre ele foram sendo emitidos por diferentes instâncias (pensamento político, imprensa, associaçôes de classe, etc.). E, verificou que estas, independentemente das suas divergências, viam na questão escolar o grande e prioritário desafio que tinha de ser 
urgentemente resolvido para, finalmente, se modernizar o país e se enraizar o débil sistema representativo que o governava.

Partindo deste nível para um plano mais concreto, também soube pôr em realce, com brilho, o papel dos rituais e de outras práticas do dia-a-dia da vida escolar, bem como o dos condicionamentos, positivos e negativos, decorrentes dos efeitos da escolarização nos trabalhos e nos dias que ritmavam a penosa vida das comunidades rurais na sua luta pela subsistência. E esta ótica permitiu-lhe confrontar o utopismo e o voluntarismo paidético - caraterístico dos projetos pedagógicos de matriz iluminista - com a inércia e a resistência levantadas, de uma maneira mais ativa ou mais passiva, por populações ainda pouco receptivas à retirada das crianças das tarefas da economia familiar e ainda fracamente convencidas das vantagens que a educação podia trazer às suas expetativas de mobilidade social.

Ora, para sustentar cognitivamente as suas interpretaçōes, e para fugir ao tom ensaístico que estas temáticas comummente convidam a cultivar, a autora valeu-se de uma sólida documentação - relatórios das inspeçôes escolares, ditados e exercícios dos alunos, inúmeros compêndios escolares (especialmente cartilhas), livros de civilidade e catecismos usados para ensinar a ler e a escrever -, demonstrando assim que, se, para se fazer historiografia, não bastam os documentos, sem estes aquela fica reduzida a um "romance histórico", como há mais de século e meio denunciava Alexandre Herculano - o grande mestre na prática dos dois géneros que ela bem conhece.

Destarte, não surpreende que a sua análise também tenha acompanhado a longa polémica sobre a conveniência, ou não, de se democratizar o ensino primário, e que tenha reconstituído a concomitante querela à volta dos métodos de ensino (método de Lancaster, método Castilho, método de João de Deus), que seriam mais adequados à aprendizagem do ler e do escrever, e acerca das teorias da educação, em particular quando, nos finais de Oitocentos, estas começaram a reivindicar um estatuto de cientificidade inspirado nos ecos da psicologia experimental e no impacto de filosofias de cunho positivista e evolucionista. Não por acaso, essa também foi a conjuntura que coincidiu com a última etapa daquilo a que António Nóvoa chamou a profissionalização do ofício de professor.

Por sua vez, o relato pelo qual Carlota Boto equaciona a escolarização primária como um ritual - que socializa o contato das populaçôes infantis com a cultura letrada - e a elucidação de como isso ocorreu fora da família (e muitas vezes em oposição a ela) constituem os momentos fortes da originalidade da obra, cujos méritos têm sido reconhecidos pelos maiores historiadores da educação portuguesa.

Com efeito, a autora demonstrou que a escola primária portuguesa que chegou à República ainda não tinha a marca da uniformidade, embora já possuísse algumas regularidades quanto a métodos de ensino e quanto à sua organização interna, características definidoras do conceito de escola seriada. E estas perspetivas possibilitaram-lhe não só surpreender a forma como as comunidades e as juntas de paróquia desempenharam um papel próprio, interferindo na vida e na dinâmica escolar - desde logo, através do fornecimento de material didático -, como evidenciar algo que, com frequência, era visto como uma realidade excessivamente homogénea: a Escola do Estado-Nação almejava ser, igualmente, a escola das diversas comunidades, ao procurar conciliar, dentro do possível, o nacional com o local, transmitindo e reiventando tradições. 
O quadro evolutivo da escola primária oitocentista, traçado neste livro, oferece, ainda, um outro grande contributo para este campo de estudos: com ele, passa a existir uma sólida base de referência para as comparaçóes com o que veio a ocorrer no decurso da I República (e até nos primeiros anos após o golpe militar de 28 de Maio de 1926). E não temos dúvidas de que este horizonte possibilitará, aos futuros investigadores, um melhor entendimento das continuidades e das rupturas que as políticas educativas dos dois regimes instaurados após a queda da Monarquia Constitucional provocaram na "formação das almas" das crianças portuguesas.

Fernando Catroga 
(Página deixada propositadamente em branco) 


\section{INTRODUÇÃo}

"Valeu a pena farejar-te na traça dos livros e nos chamados instantes inesqueciveis." (Carlos Drummond de Andrade, Discurso)

O trabalho que vem a público - tese de doutorado em História Social defendida na FFLCH/USP sob o título Ler, escrever, contar e se comportar: a escola primária como rito do século XIX português (1820-1910) em 8 de setembro de 1997 - permanece sendo, para mim, o mais importante trabalho que já escrevi. Após mais de 15 anos de conclusão da tese, a Imprensa da Universidade de Coimbra, graças à intervenção generosa do Prof. Dr. Fernando Catroga, deu-me a oportunidade de publicar em livro uma edição do texto originalmente defendido. Decidi - pensando no livro - alterar o título original para A escola primária como rito de passagem: ler, escrever, contar e se comportar, em virtude das modificaçôes requeridas para edição do trabalho; que o tornam ligeiramente distinto do escrito original da tese.

Ao discorrer sobre o que chamou "operação historiográfica”, Michel de Certeau diz que a produção do conhecimento histórico tem como exigência um lugar social de produção, o estatuto de uma dada objetividade, que o autor caracteriza por "prática científica” e, finalmente, uma escrita. Essa escrita obedece a normas postas de maneira quase consuetudinária pelos pares e pela instituição que organiza a produção do discurso historiográfico. Certeau comenta que a produção em História dirige-se a um "nós" muito preciso. Esse "nós" é composto antes pelos parceiros e colegas de ofício do que pelo público não pertencente ao meio. Existem leis instituídas pela comunidade acadêmica, leis que ditam como este ou aquele resultado será bem ou mal recebido por seus pares. O texto histórico - continua Certeau - não deve, pois, dialogar exclusivamente com os documentos, embora estes permaneçam sendo sua matéria-prima. Para além e na outra margem da documentação, o texto histórico debate e interpela as questões intelectuais, as tendências e as orientações da pesquisa de sua época. Assim, evidentemente, poder-se-ia compreender porque a pesquisa em história vem inevitavelmente atada ao tempo dos documentos e simultaneamente ao tempo de sua própria escrita.

A História da Educação, como campo do saber, situa-se institucionalmente na confluência, nem sempre pacífica, de duas áreas distintas - o estudo da história e o estudo da educação -, igualmente necessárias à guisa de referenciais teóricos e metodológicos. Tal constatação implica o reconhecimento de que os pilares norteadores 
da pesquisa em História da Educação exigem tanto as referências metodológicas e bibliográficas do campo da história quanto as do campo da educação. Isso exige um esforço interdisciplinar. Por tal razão a Nouvelle Histoire francesa foi verdadeiramente uma saída temática e um encontro metodológico, posto que trouxe novos horizontes para o problema da investigação historiográfica e, com eles, a possibilidade de fornecer um estatuto diferenciado para temáticas atinentes a problemas pedagógicos. Com a inegável ampliação do manancial de objetos de investigação históricos, os historiadores se debruçaram com maior freqüência sobre um assunto que até então estava praticamente circunscrito aos pedagogos: a história da escola e das instituiçôes educativas. Assim como a história da escolarização, outros domínios ganharam força pela ação dos historiadores dos Annales: história da família, da infância e da vida privada; história do cotidiano e da cultura popular em suas distintas expressões. No caso da história da escola, devem-se levar em consideração as intersecçôes e as distâncias entre o pensamento educacional de uma dada época e as práticas, os gestos, as rotinas corriqueiras do dia-a-dia escolar. Compreender o cotidiano da escola, tanto no significado que ela tem para a comunidade que, bem ou mal, a ela recorre quanto nas práticas cotidianas desenvolvidas por seus atores principais - professores e alunos - requer compreender o que a escola diz que faz e o que ela, de fato, faz.

Com o objetivo de empreender estudo da escola portuguesa no período compreendido entre 1820 e 1910, procuramos estabelecer critérios analíticos que possibilitassem a identificação dos aspectos concernentes às práticas pedagógicas mediante sua confluência com os discursos produzidos sobre educação em Portugal no período em tela. Essa época coincide com o que poderíamos chamar de século XIX português - ou seja, com a vigência mais plena de uma ampla etapa transitória, que não é mais marcada pelo absolutismo, mas que inicia em Portugal a vigência liberal, sem, entretanto, romper as fronteiras fidalgas e aristocráticas da monarquia portuguesa. Um século é sempre uma fronteira simbólica que demarca, no artifício da cronologia, certas tendências de período longo. Por ser assim, permitimo-nos atualizar o século XIX, adaptando-o, no caso, à situação portuguesa, sob o exemplo do historiador francês René Rémond, que dirá que o século XIX foi para a França a etapa compreendida entre 1815 e 1914 . Na verdade, o século é uma construção a posteriori, tendo em vista uma periodização inteligível do tempo. Consideradas todas as características do período compreendido entre 1820 e 1910 na história portuguesa, entendemos que ele corresponde mais ao século XIX do que a etapa artificial e linear que vai de 1801 a 1900. Por essa trilha metodológica, propusemo-nos a historiar o cotidiano, pressupondo nele uma história dos atores que vivem a escola; perfazendo o relato da instituição que abriga sujeitos que agenciam o cotidiano escolar, para, finalmente entrelaçar esse ensaio da escola que passou com as representaçóes configuradas no imaginário pedagógico. Sendo assim, pretendemos retomar os cruzamentos entre as representações e as práticas do ensino, considerando a reconstrução pela escrita de alguns aspectos que pontuaram o universo simbólico acerca da educação em Portugal de um século atrás.

Partimos da hipótese de que haveria um diálogo, muitas vezes frustrado, entre o pensamento sobre a escola e as ações cotidianas engendradas na prática. Tal hipótese abarca, porém, a incursão por uma dinâmica de pesquisa pautada, talvez, pelo que 
Guinzburg qualifica de "paradigma indiciário"1. Os objetivos do trabalho efetuado situam-se, pois, no entrelaço de aspectos vários: as estratégias institucionais de conformação do estudante primário português; os relatos da dinâmica interna à escola, os quais nem sempre correspondem a tais prescriçóes legais e intelectuais, dadas as especificidades de cada região, as camadas sociais que no espaço escolar interagem e a própria formação do professor; o pensamento pedagógico e o eco de uma filosofia evolucionista da história como referencial para agenciar essa formação de um futuro por suposto passível de ser constantemente aperfeiçoado; a percepção das camadas populares acerca da utilidade social do conhecimento veiculado pela escola; e, finalmente, uma análise crítica dos conteúdos e saberes escolares como um dado de recriação da realidade, tal como se pretendia falar dela às crianças.

Para compor a estrutura do trabalho apresentado, procuramos recortar e dividir os capítulos a partir da uma metodologia interna a cada um deles. Tratam-se assim de sete movimentos com que o objeto foi, ao fim e ao cabo, construído. Cada capítulo pretende constituir uma unidade de sentido, dotada de divisão interior e de uma linguagem própria. Os diferentes capítulos, entretanto, cruzam-se uns com os outros e procuramos traçar essa confluência no próprio corpo do texto. Estabelecemos para isso feixes temáticos e metodológicos que, interagindo uns com os outros, pudessem, cada qual a seu modo, contribuir para a reconstituição da vida rotineira, das práticas sociais e do pensamento pedagógico da escola projetada.

No primeiro e no segundo capítulos conferimos prioridade ao movimento das idéias educacionais. Para tanto, detivemo-nos no discurso político e intelectual sobre a matéria educativa, considerando que os intelectuais são os homens que, de algum modo, formularam o conhecimento sobre a matéria, conhecimento esse que, a partir do debate de seu tempo, será apropriado, irradiado e divulgado, com diferentes estilos e ritmos, pelos veículos da imprensa, por revista e por jornais da época - cuja expressão cultural será caracterizada no terceiro capítulo. Pudemos observar que tanto no debate dos intelectuais menos ou mais conhecidos, quanto nos órgãos da imprensa especializada encarregada da formação da opinião pública -, em linhas gerais, há uma trilha matriz do raciocínio sobre a educação, evidentemente pontuada por exceçôes, com cada período emprestando um pouco do outro que o antecede e legando algo àquele que o sucede. Entre 1820 e 1850, há a predominância da discussão sobre o problema político da educação como alicerce de formação de uma nova sociabilidade, de um sentimento claramente nacional, de uma preparação instrutiva para a cidadania e para a legitimação da ordem liberal. Portanto, a maioria dos intelectuais defende a referência moderna da educação pública, gratuita, obrigatória, e universal. Já entre 1850 e 1870, diríamos que, para o caso português, sobretudo pela iniciativa demarcadora de Castilho, o debate seria substantivamente deslocado. O centro deixava de ser as finalidades da escola, naquilo que os antigos estudantes teriam aproveitado da vida escolar para a tarefa da sua posterior identidade de cidadãos do país. A principal questão que inquietará os intelectuais e os homens da imprensa no referido período reside, fundamentalmente, no problema do método. Por que a escola que existia não dava certo? Julgava-se-se que os pais não enviavam as crianças

${ }^{1}$ Carlo GUINZBURG, Mitos, emblemas e sinais: morfologia e história, p. 143. 
à escola por não acreditarem na capacidade efetiva de a escola realmente ensinar as habilidades básicas da leitura, da escrita e do cálculo. Quando António Feliciano de Castilho, no início dos anos 50, apresenta seu método, é isso que ele alega. Assim, o problema da metodologia, da didática, das técnicas e estratégias do aprendizado, bem como a discussão sobre os conteúdos culturais a serem veiculados pela escola seriam a grande prioridade nessa época, quando havia - paralelamente, e não por acaso - uma notória e progressiva intensificação do número de compêndios produzidos e aprovados pelo Conselho Superior de Instrução Pública. Finalmente, a partir de 1870, e até 1910, o debate pedagógico terá o predomínio da discussão sobre a pedagogia como uma sistematizada "ciência da educação".

Um novo universo de leituras vinha pelos trilhos dos caminhos de ferro, pelos novos meios de transporte e comunicações. O progresso da técnica de tipografia e a agilidade que o mundo da impressão já possuía, no caso português e, particularmente, na Europa como um todo, eram, cada vez com maior intensidade, alavancas para propiciar a tradução de numerosas obras, que passavam a ser manuseadas, lidas e incorporadas por um público a cada dia mais numeroso. Desde aqueles polêmicos anos 70 , os teóricos da educação apontavam para o estudo do desenvolvimento infantil, a analogia entre esse processo individual e o percurso de evolução da espécie. Entendia-se, conseqüentemente, que alguns procedimentos educacionais deveriam ser urgentemente providenciados para que a desenvolução da criança ocorresse em uma trilha cientificamente orientada, de acordo com o que - diziam eles - já estaria comprovado no exterior. Tal debate sobre o desenvolvimento infantil, por sua vez, é feito com alguma reticência, posto que seu desdobramento quase automático é o de que, assim como a evolução da criança viria já esboçada por suas determinações genéticas, os destinos das nações também estariam automaticamente inscritos no caminho tomado pela raça que as compõe. Desse modo, fala-se sempre em etnia e em evolução, mas procura-se também acentuar os componentes do talento e da vocação, da educação e da instrução como pressupostos. A educação seria uma forma de lutar contra os obstáculos do meio, mas também contra os limites da hereditariedade... Seja como for, há um progressivo deslocamento do discurso, que se torna ainda mais nítido na abordagem da matéria educativa por parte da imprensa, sobre a qual discorreremos no terceiro capítulo.

No quarto capítulo, trabalhamos a confluência do debate ocorrido em alguns congressos e conferências de educadores, que tiveram lugar nos anos 80. Ali eram bastante nítidas as preocupaçôes educativas dos profissionais da instrução, no tocante ao cotidiano da escola. Focava-se o tema do método de ensino. Acreditava-se que a organização escolar portuguesa carecia de parâmetros de organização do tempo, de demarcação dos horários, de melhor adequação do espaço e do mobiliário. Interpretamos alguns relatos que contam de solicitaçôes encaminhadas por populaçôes em abaixo- assinados, pedindo escola ou procurando interferir em decisóes centrais como a contratação e a transferência de professores. Vistoriamos alguns processos de queixa das populaçóes contra esse ou aquele professor, que tratava mal seus alunos ou que cobrava por aulas ministradas em escolas públicas. Procuramos narrar fatos presenciados pelo cotidiano das escolas e que evidenciam a tensão institucional no que diz respeito aos lugares e às posiçôes de poder. Havia, muitas vezes, conflito entre o domínio do mestre e a autoridade do Comissário dos Estudos ou até mesmo do porteiro da escola. Nesse diálogo entre o pensamento pedagógico e a prática educativa está 
contido o assunto desta tese. Não se trata apenas de indagar o que se dizia sobre a escola; não se procurava mais apreender o que dela se falava; mas sim, lá dentro, o que essa escola dizia de si própria, quem eram seus atores dominantes e como as relações de mando e de disputas de representações ali se organizavam. Aqueles processos movidos por ou contra professores, pais e alunos revelavam, antes de tudo, a dinâmica da escola. Em cada momento, será possível ouvir a voz de diferentes atores, representando, cada qual a seu modo, o conjunto da instituição. Verificam-se aqui os primeiros indícios do que poderíamos considerar como ritual da escola portuguesa do século XIX.

No quinto e sexto capítulos a busca pela compreensão dessa ritualidade cotidiana da escola persiste sendo o motivo da análise. Voltados para o dia-a-dia da rotina escolar, encontramos relatórios de inspetores que, desde os anos 50, retratam o funcionamento das escolas, suas carências, suas dificuldades humanas e materiais. Particularmente os Relatórios referentes aos anos letivos de 1866-1867 e 1874-1875 trazem dados extremamente precisos, que permitem reconstituir a forma sob a qual a escola pública primária portuguesa se apresentava no período. $\mathrm{O}$ tratamento dado à amostragem pretendia trazer uma abordagem simultaneamente qualitativa e quantitativa da rotina escolar em seus usos e costumes. Tratava-se do parecer proferido pelos inspetores em suas visitas às escolas. Através de tal registro, o material escolar e a disposição física da sala de aula, incluindo o próprio mobiliário, seriam vistoriados. O impresso padronizado do relatório de 1867 possibilitava uma aproximação mais aprofundada em termos quantitativos. Transformamos em números ${ }^{2}$ os dados sobre o edifício escolar (a quem ele pertencia, quanto se pagava de renda pelo seu aluguel, etc.), as dimensões da sala de aula, a superfície interna do prédio, o número de janelas de que dispunham as classes, a ventilação, as condiçôes higiênicas, as condições pedagógicas do local onde se situava a casa de escola. Procuramos os números relativos à mobília e aos utensílios de sala de aula (mesas, bancos, cadeiras, tinteiros, quadros-negros, lousas pequenas, coleção de pesos e medidas, papel, livros, penas, tinta, etc.); sobre a situação do professor, sobre a disciplina e o "regime" escolar; sobre os métodos e modos de ensino utilizados para ensinar a primeira leitura; sobre as recompensas, os castigos, os registros de matrículas e de faltas, etc. Além disso, tencionamos fazer um inventário (tanto para a inspeção de 1867 quanto para a de 1875) dos registros dos livros utilizados pela escola e pelos alunos. Quais eram os compêndios de que a sala de aula portuguesa se valia naquela época determinada? Buscamos ainda mapear a idade dos estudantes, o tempo médio de freqüência à escola e a classificação dos alunos - pela avaliação do inspetor e do professor nas diferentes matérias. O relatório de 1875 - por ter um espaço maior para a palavra do inspetor no julgamento das condiçôes gerais da escola, do mobiliário, do professor, da freqüência e do aproveitamento dos alunos - possibilitou-nos a reconstituição de alguns relatos de histórias de vida escolar, narrados a partir da experiência de inúmeros professores, que apareciam retratados pela voz da inspeção.

\footnotetext{
${ }^{2}$ Para essa tarefa, contamos com a assessoria especializada de Monica Domenech, que nos auxiliou no tratamento estatístico das fontes.
} 
Finalmente, no sétimo capítulo, rastreamos os compêndios didáticos que, segundo a pesquisa que pudemos efetuar, teriam sido os que maior utilização tiveram em Portugal do século XIX. Os livros de escola eram todos eles acompanhados por um muito particular processo editorial, que passava por uma aprovação e uma recomendação do Conselho Superior da Instrução Pública. Existia, particularmente a partir dos anos 50 - em movimento que acompanha a fase de intensificação das preocupaçóes com o método de ensino - uma estratégia bastante intensa de divulgação dos livros didáticos. Julgava-se até que a carência de preparação do pessoal docente poderia ser minorada com a confecção e utilização, em sala de aula, de obras, que, em geral, disporiam de um caráter enciclopédico, contendo tudo quanto se julgasse necessário para um professor primário ensinar a seus discípulos, em termos de conteúdo e de valores. Qual o segredo do livro didático que obtinha êxito? Seria exclusivamente a força editorial de alguns desses numerosos autores? Seria o conteúdo ou a disposição pedagógica dos compêndios o que levava legiões de educadores a optar por um conjunto relativamente restrito de obras? $\mathrm{O}$ que tais livros contavam às crianças sobre $\mathrm{o}$ seu país, sobre o homem, sobre o mundo? Quais eram os saberes escolares realmente valorizados e como eles se traduziriam na efetiva utilização dos compêndios em sala de aula?

À luz do exposto, as hipóteses do trabalho que submetemos ao crivo da crítica são as seguintes:

1. Para a história da educação portuguesa, a escola primária aparece como se de um ritual se tratasse: ritual esse sobre o qual se estruturariam tanto os debates acerca do tema quanto as formas cotidianas de se tornar escola, todos os dias. Que tipo de ritualização escolar seria essa?

2. Pareceu-nos, desde o princípio, necessário questionar a maneira pela qual a instituição escolar lidava com a dinâmica da leitura e com o universo valorativo metodologicamente contido nessa competência que, pouco a pouco, deveria vir a se irradiar, pelo caminho da vulgarização do impresso, cada vez mais acessível, cada vez em número maior. Observou-se que a relação entre a escola e a cultura do escrito é tanto de complementaridade quanto de competição. A escola não vem exatamente para ensinar a ler; ela, antes disso, explica ao estudante o que se deve ler e o que não se deve ler, controlando, com isso, a leitura solta, fluente, criativa, sem fronteiras e por vezes demolidora de valores prescritos. A relação entre a escolarização e a cultura do escrito é, por assim dizer, profundamente tensa. Ao mesmo tempo em que a escola entende o texto como um poder de emancipação humana, verifica-se que há temor por parte da sociedade quanto a esse potencial de liberdade intrínseco ao saber ler. Pretendia-se, pois, regrar, pela escola, os sentidos da leitura... O território do livro, as perigosas mensagens do impresso, poderiam ser tanto destruidores de hábitos quanto criadores de novas necessidades sociais, que, por si, pareciam já ameaçar setores governantes. Por isso, delegava-se à escola o necessário cuidado para com aqueles mundos de papel...

3. Há interlocução, concorrência, hostilidade entre a vida escolar e o universo familiar. A escola como agência de instrução e de moralização das camadas juvenis da sociedade ocupava com a modernidade um espaço que até então 
pertencia inequivocamente à família. Portanto, talvez não fosse tão cooperativa essa relação entre pais e mestre... Cabia à escola a transição entre a família e a vida social: nisso lhe competia reproduzir uma demarcação de lugares que supostamente lhe seria anterior. Mas, exclusivamente para proceder a um ritual de reprodução, a tradição e a cultura familiar talvez fossem por si suficientes. Era necessário avançar, inventar um futuro que parecesse aos olhos dos contemporâneos o aperfeiçoamento do presente. A ilusão quanto a um futuro de perfectibilidade parecia sempre acompanhar pensamento e prática educativa em Portugal do XIX. Estaria também nisso, por outro lado, o potencial criador, talvez transgressor da lógica da permanência, da conservação, da preservação da ordem... A escola portuguesa produzia, pelo ritual com que organizava sua rotina, um mundo todo seu, bem diferente do mundo do lar. Aquela escola que, para muitas crianças era vista como um tormento, sem dúvida, para outras, representava a possibilidade de libertação e de emancipação da tirania das famílias: a viabilidade do ingresso em uma lógica social que jamais se confinaria exclusivamente às dimensões do clã familiar. Concorrentes na ordem da dominação simbólica, escola e família surgem - a partir da tese aqui defendida - como instituições intransitivas e, entre si, como redutos quase irreconciliáveis...

4. A escola primária portuguesa, entre 1820 e 1910, não é ainda a instituição incosteste do estado-nação. Não traz ainda a marca da homogeneidade, não é uniforme. Traz, entretanto, certas regularidades, certas constâncias, tanto na sua estrutura interna quanto nos métodos e procedimentos de ensino de que se valia. Porém seu funcionamento é extremamente tributário de iniciativas locais de municípios, juntas de paróquia, confrarias religiosas, que forneciam material e mobiliário, revelando, talvez mais do que o Estado central, a face oculta da escolarização de massas em seu processo de constituição.

5. Poderíamos ainda falar do papel constritivo da vida escolar e da preparação nele suposta para a vida do trabalho, para a adequação do indivíduo à idade adulta. Buscamos tentar descobrir, por casos particulares, que tipo de solicitação a família fazia da escola; e além disso, como a escola se comportava perante os atores nela envolvidos e vice-versa... A escolarização, tal como apareceu aos nossos olhos, traça uma dinâmica toda sua, por meio de ritos e de percursos que parecem se repetir. O trabalho que nos propusemos a elaborar a título de tese de doutoramento partiu dessa inquietação: centrar o objeto de estudo sobre o imaginário pedagógico e, na outra margem, sobre a vida rotineira da escola primária portuguesa. Com o fito de responder às questôes de pesquisa acima elencadas, buscamos rastrear os indícios do discurso sobre a escola, naquilo que ela era e no que supostamente deveria vir a se tornar. O presente estudo procura interrogar o testemunho das fontes, com a finalidade de, na longa duração de quase um século, perceber as rupturas e permanências de uma atmosfera educacional, cujos alicerces tenham talvez algo a dizer à nossa contemporaneidade pedagógica.

Gostaria de demonstrar meu reconhecimento àqueles que me permitiram elaborar esta tese e tornaram possível a presente publicação. Em primeiro lugar, na pessoa do Prof. Dr. José Ênio Casalecchi, agradeço à Faculdade de Ciências e Letras da 
UNESP - campus de Araraquara ${ }_{s}$ onde firmei meu mais importante alicerce profissional. Agradeço também à Universidade de São Paulo, particularmente à Faculdade de Educação e ao Departamento de História da Faculdade de Filosofia, Letras e Ciências

Humanas. A USP me formou e a USP construiu meu modo de ser. E isso é para sempre. Sou grata ao CNPq, pela Bolsa Doutorado-SWE que recebi durante os 16 meses que passei em Portugal; e à CAPES, pela Bolsa Auxílio-Deslocamento (PICD) usufruída entre 1991 e 1992. Destaco também minha gratidão ao Instituto de História e Teoria das Idéias da Faculdade de Letras da Universidade de Coimbra, à Biblioteca Geral da Universidade de Coimbra, ao Arquivo Nacional da Torre do Tombo, à Biblioteca Nacional de Lisboa e à Biblioteca Municipal de Coimbra, onde realizei a maior parte da pesquisa que deu origem a este texto.

Ao Prof. Dr. Carlos Guilherme Mota, orientador deste trabalho, registro minha dívida e gostaria de prestar meu tributo de reconhecimento e admiração. O Prof. Mota, com sua peculiar destreza pedagógica, aliou, na difícil tarefa de orientação, estímulos, desafios, confiança e incentivo. Dotado de uma singular habilidade criativa, socializa o conhecimento, partilhando-o, debatendo e, sobretudo, apontando caminhos e alternativas, assinalando e corrigindo equívocos, atentando, enfim, para as coisas mais importantes. Agradeço também aos professores José Mário Pires Azanha, Jorge Nagle, Marta Maria Chagas de Carvalho e Fernando Novais. Eles ofereceram suporte teórico e metodológico para que eu conseguisse encontrar o eixo deste trabalho - o que, há de se convir, é um dos momentos mais difíceis de uma tese. A duas grandes amigas - Ruth Maria Chittó Gauer e Denice Barbara Catani -, cuja presença, incentivo e auxílio foram determinantes no momento da defesa desta tese, meu reconhecido 'muito obrigada'. Agradeço também a assessoria estatística de Monica Domenech.

Agradeço ao Prof. Dr. Fernando Catroga pela direção deste trabalho durante sua fase mais decisiva. Como investigador, ofereceu-me o que pode haver de mais exigente e rigoroso; como intelectual, debateu comigo as grandes questóes que abalam seu tempo e seu país; como amigo - junto de sua amável esposa Ana - foi sempre presente. Por fim, devo a ele a publicação deste trabalho pela Imprensa da Universidade de Coimbra. Eu nunca encontrarei palavras que expressem devidamente minha dívida de gratidão para com o Prof. Catroga. Há, contudo, outros pesquisadores portugueses a quem também eu devo agradecer - dentre os quais eu destaco: Prof. Dr. Rogério Fernandes; Prof. Dr. António Gomes Ferreira; Prof. Dr. António Nóvoa; Prof. Dr. Justino Magalhães; Prof. Dr. Joaquim Ferreira Gomes; Profa. Dra ${ }^{a}$. Margarida Louro Felgueiras; Profa Dra Maria Manuela Bastos Tavares Ribeiro; Prof. Dr. José de Oliveira Barata; Prof. Dr. Carlos Reis; Profa. Dra . Ana Cristina Araújo; Profa. Dra . Isabel Nobre Vargues; Prof. Dr. Luís Reis Torgal. Serei eternamente reconhecida ao Prof. Dr. Rui Martins, e à Profa. Dra . Eugenia Cunha, à Doutora Ana Luísa Mateus, à Doutora Elsa Machado e ao Eng. Carlos Pinto pelo apoio e pela fraternidade expressos ao longo dos dezesseis meses em que eu vivi em Coimbra. Sou muito grata a alguns funcionários da Universidade de Coimbra: da Biblioteca Geral, agradeço à Bibliotecária Dra. Dulce, a Sra. Dona Odete, a Sra. Dona Ana, responsáveis pelo setor de Reservados. Do Instituto de Teoria e História das Ideias, agradeço a Maria do Rosário Azenha. Agradeço também aos meus familiares em Portugal, especialmente ao Tio Joaquim e a Tia Maria de Lourdes, ao Manuel Maria e à Ana, à Didi e ao Chico, à Teresa, à Lena, ao Zé Manuel e à Fátima. Sou muito grata à família do Embaixador Adriano de Carvalho pelos momentos felizes que sempre me proporcionou. 
No Brasil, também foram muitos os amigos, que, de um modo ou de outro, acompanharam a elaboração desta tese: Pedro Dallari, Milton Lahuerta, Evaldo Sintoni, Raul Fiker, Márcia Teixeira de Souza, Marco Aurélio Nogueira, José Castilho Marques Neto, Mariana Broens, Maria Teresa Santos Cunha, Maria Helena Câmara Bastos, José Vaidergorn, João Furtado, Paulo Roberto Pepe, Rosimar Aparecida Moreira, Angela Viana Machado Fernandes, Rosa Fátima de Souza, Maria Aparecida Rodrigues de Lima Grande, Leda Aparecida Pedroso, Maristela Angotti, Ricardo Ribeiro, João Amorim, Jaime Francisco Parreira Cordeiro, Maria Lucia S. Hilsdorf, Maria Teresa Miceli Kerbauy, Vera T. Valdemarin, Dóris Accioly Silva, Roseli Fischmann, Angelo Del Vecchio, Mônica Guimarães Teixeira do Amaral e Waldemar Ferreira Netto.

Meu pai conviveu tão de perto com este trabalho que sinto como se ele o tivesse escrito junto comigo. De alguma maneira, Pai, nesta escrita eu procurei um pouco a história de sua história. Sem seu apoio - tenho certeza - eu não teria sido capaz de suportar a disciplina que este percurso me exigiu. Agradeço a minha mãe, por ter confiado em mim sempre que eu julgava que não iria conseguir. Agradeço às minhas irmãs Ana Maria e Maria Antonieta, a meus cunhados Carlos Eduardo Siqueira Bueno e Renato Scarlassari e a meus sobrinhos Luís Felipe e Luís Carlos. Agradecendo a Alessandra Aparecida de Souza, eu me recordo de todos os meus alunos, que são o esteio de minha vida. Luiz Henrique e Rodrigo Scarlassari ainda não tinham nascido quando terminei esta tese de doutorado. Mas eles me ajudaram, agora, a escolher o título deste livro. Meu "muito obrigado" também a vocês dois.

Finalmente, sou grata à Imprensa da Universidade de Coimbra que tornou possível esta publicação. 
(Página deixada propositadamente em branco) 


\title{
I. INTEleCtuAis, discursos políticos E A ARTE DA EDUCAÇÃo
}

\author{
"Pelas constelaçôes é que esse espaço lemos..." \\ (Antero de Quental, No Templo, Odes modernas)
}

\section{A carência de escolas como problema nacional}

Compreender a história da escola em suas dimensões subjetivas supõe perscrutar um imaginário por meio do qual podemos indagar quais eram, em cada época e em cada país, as representações sociais que acompanham a acepção de escola; e, na outra margem, averiguar em que medida tais concepçôes têm correspondência nas práticas desenvolvidas nas salas de aula. Compreender o movimento da escola portuguesa nesse período que principia com a Revolução Liberal (1820) e termina com a República (1910) supõe o seguinte questionamento: o que era a escola para os portugueses desse século? Como era percebida a transferência de parcela da responsabilidade educativa da família para uma instituição que, em princípio, deveria contar com a tutela do Estado? Em que medida o ensino era ou não uma estratégia de setores da sociedade, com o fito de incutir valores burgueses, formar o consenso social, preparar o trabalhador? No presente capítulo, trabalharemos com discursos entrecruzados, que permitirão uma breve incursão sobre aquilo que consideramos ser o olhar intelectual acerca do problema do ensino português nas diferentes etapas desses anos de monarquia constitucional. Como a escola era percebida e sentida pela população portuguesa nesse século XIX? Quais eram as representações sobre o ofício da instrução mais em voga no período? O que diziam os intelectuais sobre o moderno tema do ensino universal da leitura? Em que medida Portugal viria a construir um imaginário letrado que, a pouco e pouco, ganharia terreno sobre o universo da oralidade? Qual a dinâmica política que fazia por criar um discurso específico sobre a cidadania e a vida democrática, que, em certa medida, era um discurso escolar? Será pela interface que tais questôes poderão no conjunto contribuir para desvendar o inextricável panorama da escola portuguesa, entre aquilo que dela se dizia e o que, de fato, se procurava nela engendrar.

Percebem-se nitidamente três etapas distintas nesse trajeto. Basicamente, poder-se-ia dizer que a tônica do debate educativo no período compreendido entre 1820 e 1850 centra-se sobretudo nos temas atinentes à questão política da educação e da escolarização. O setor progressista compreendia a instrução como uma fonte de esclarecimento, capaz de engendrar os dispositivos necessários para a preparação da cidadania liberal e, pelo 
desejo de alguns, democrática. Os conservadores, por seu turno - nesta primeira fase alertam com veemência os contemporâneos sobre os perigos contidos nesse eventual esclarecimento suposto como intrínseco à aquisição de cultura. Eles julgavam - talvez com alguma razão - que a ampliação das referências teóricas e intelectuais na cognição da realidade tornaria o indivíduo mais crítico, socialmente mais propenso à transgressão. Por sua vez, na etapa compreendida entre 1850 e 1870, o objeto mais destacado dos estudiosos da educação foi explicitamente o tema do método de ensino. Acreditava-se que a escola para todos não se firmara em Portugal pelo simples fato de não se ter conhecimento algum dos mecanismos do aprendizado, particularmente do primeiro aprendizado: o ler, escrever e contar. Não sabendo ensinar, a escola que havia era então rejeitada e Portugal mantinha-se, de tal maneira, com significativa carência de letras. Finalmente, a partir de 1870 - com a imensa contribuição dos episódios que envolviam o grupo-geração conhecido como Geração de 70 - passou-se a compreender o fenômeno educativo como se de uma ciência se tratasse. Sob tal clivagem, que perduraria até o final do período estudado (1910), a escolarização passou a ser entendida mediante referências teóricas e metodológicas que procuravam assinalar o problema da escola como uma hipótese científica de desenvolvimento nacional. De qualquer maneira, existe uma crença comum, que os defensores da escola, qualquer que fosse o período, inarredavelmente partilharam: a educação se apresenta na história e no trajeto dos povos como uma atitude coletiva imprescindível para garantir a perfectibilidade entre as geraçôes. A esperança de que cada geração viesse a aperfeiçoar - mantendo e inovando, aprimorando e desenvolvendo - o tempo de seus antepassados pareceu-nos ser, no traçado do debate educativo em todo o século XIX português, pressuposto epistemológico para o pensamento sobre a escolarização.

António Nóvoa destaca que as bandeiras da Revolução Francesa, ou - como prefere o autor - seus 'slogans educativos' seriam em Portugal plataformas discursivas posteriores à implantação efetiva do ensino secularizado por Pombal. Era como se, no caso português, curiosamente, a prática precedesse a instância da representação, dada a ambiguidade metodológica do próprio projeto pombalino. A Revolução Francesa, que inaugura uma forte referência simbólica, vem para Portugal com o liberalismo; e o modo pelo qual irá se impor atenderia a algumas especificidades típicas da circunscrição histórica desse lastro de iberismo. Porém, para além dela, havia que se reconhecer a resistência da matriz de Estado legada por Pombal, naquilo que parecia ser o desejo de refundar ou reinventar a nação. A arquitetura escolar fazia parte integrante desse projeto. Nas palavras de Nóvoa:

“Antes de 1789, Portugal possuía já um sistema estatal de ensino, cuja estrutura tinha contornos semelhantes aos que foram delineados um pouco por toda a Europa durante o 'século da escola'. Mas os objetivos e os conteúdos desse sistema não estão todavia impregnados do ideário que a Revolução Francesa difundirá ao longo do século XIX. Isso não seria possível antes da instauração do Estado liberal (1820-1834), cunhado pela ideologia burguesa, tal como esta se havia definido na Europa ocidental dessa época."3

\footnotetext{
${ }^{3}$ António NÓVOA, Notas sobre la influencia de la Revolución Francesa en la educación en Portugal, p. 190.
} 
Em termos de uma duração relativamente longa - 1820-1910 -, procuraremos apreender certas regularidades - e também algumas das variantes - mediante as quais o tema da instrução popular vinha a povoar o imaginário discursivo. Para perscrutar esse olhar coletivo sobre a escolarização e seu significado social, buscaremos reconhecer a organização de racionalidades abrangentes, passíveis de se apresentarem como eixos discursivos por meio dos quais o problema posto tornava-se inteligível para aquela dada época. O que nos interessa efetivamente é depreender matrizes de pensamento que, de alguma forma, perfilhassem um modo de interpretação da questão educativa partilhado pelos contemporâneos.

Como sugere Rosanvallon, tal abordagem possibilitaria a identificação de 'nós históricos', ou sistemas de representações simbólicas capazes de revelar a cultura política (e especificamente o lugar tomado pelos projetos de escolarização nas práticas efetivadas por tal cultura política) do período estudado. Estaríamos, a partir daqui, dando início a um estudo mais abrangente acerca das interfaces e mesmo intersecções entre tais representações e as práticas diretamente implementadas, no âmbito da história da educação portuguesa. Para isso, entretanto, deveremos posteriormente nos debruçar sobre a questão do cotidiano dessa escola.

\section{A Pedagogia sob o signo da política: alvorada do liberalismo}

Luís da Silva Mousinho de Albuquerque era um bacharel em Medicina que, havendo estudado na França, fazia parte de uma agremiação intelectual de estudo e de reflexão acerca de Portugal. Em 1823, Albuquerque, ainda durante a fase miguelista, fôra nomeado como provedor da Casa da Moeda, que - como destaca Rômulo de Carvalho - era uma "instituição que possuía laboratórios de Física e de Química e cujo provedor tinha a obrigação, por lei, de reger aulas daquelas matérias. Mouzinho de Albuquerque, que de há muito se interessava pela ciência e estava habilitado para o desempenho daquele cargo, exerceu-o com proficiência excepcional. As suas aulas eram frequentadas não só por alunos matriculados mas por diversas pessoas que a elas queriam assistir." 4

Em 1823, Mouzinho redigiria e publicaria seu projeto de reforma da instrução pública apresentando o direito dos povos ao ensino como alicerce diametralmente correspondente ao dever dos governos em assegurar ao mesmo povo a educação. Muitos estudiosos posteriormente reiterariam o vínculo teórico entre os escritos de Mouzinho de Albuquerque e os debates da Convenção francesa. A obra de Luís Albuquerque buscará apreender (aprofundando-se neste que considera "o primeiro plano completo que em Portugal conhecemos para o estabelecimento de um ensino liberal"5) a reforma preconizada, mediante alguma filiação a todo um conjunto de referenciais históricos com os quais o próprio autor dialogava; e que certamente não se teriam reduzido ao trabalho da Convenção, mas lhe seriam anteriores, reportando-se à Constituinte francesa de 1791. O reformador português decerto conhecia as várias

\footnotetext{
${ }^{4}$ Rómulo de CARVALHO, História do ensino em Portugal, p. 537.

${ }^{5}$ Luís ALBUQUERQUE, Notas para a História do ensino em Portugal, p.82.
} 
etapas da Revolução Francesa em relação à pedagogia. Se o suporte teórico desdobrava-se da França revolucionária, acreditamos que, de fato, a matriz daquele plano teria sido fundamentalmente o Rapport de Condorcet, seja pela divisão dos quatro degraus de ensino, seja pela própria fundamentação teórica, subjacente ao discurso de Mouzinho de Albuquerque.

Acerca do impacto histórico e simbólico que o imaginário a propósito da Revolução Francesa traria para Portugal, Maria Manuela Bastos Tavares Ribeiro assinala o que segue:

"Poderoso mito, sem dúvida o maior da primeira metade do século XIX, alimentado, naturalmente, pela visão romântica da história. De fato, o século XIX não cessou de refazer a Revolução Francesa. Não exatamente a Revolução dos fins do século XVIII, mas sim o movimento revolucionário iniciado em 1789 - promessa de igualdade - logo, uma empresa interminável, sem limites de tempo e de espaço."

Estavam postas na dimensão subjetiva da intelectualidade portuguesa todas as condições para que a apreciação do evento revolucionário em França fosse efetuada antes como uma mitologia de fundação do Estado do que pela clivagem eminentemente histórica de sua ocorrência. Havia, nesse gesto da apropriação do que, ao fim e ao cabo, ocorrera lá fora, desejo de universalidade. Mouzinho de Albuquerque dirige-se aos deputados, apresentando-lhes o que acredita ser a reforma das instituiçôes para a consequente prosperidade nacional. No parecer do relator, a própria moral pública, entrelaçada à indústria e à agricultura, exigia com urgência o derramamento das "luzes", irradiadas à generalidade dos cidadãos. A instrução popular seria, pois, o dispositivo capaz de conferir legitimidade aos alicerces do liberalismo arquitetado. Dívida do governo e direito dos povos, a universalização da escola derivaria da própria acepção de bem público, o qual, por sua vez, coincidiria, em última instância, com a felicidade e a plena realização dos talentos de que é composta a sociedade. Tal empreendimento, por si só, traria prosperidade à nação, regenerando-a dos vícios que eventualmente houvessem contribuído para certa decadência.

O pressuposto do autor, nitidamente tributário da Ilustração, reside na dimensão eminentemente pública das aptidões individuais. À sociedade caberia transformar em benefício coletivo quaisquer riquezas particulares. Ora, haveria, para tanto, uma via de mão dupla a ser trilhada no caso da instrução: o Estado despende os recursos necessários para a educação popular, tendo em vista, a seu tempo, obter o retorno de tal investimento, materializado na transfiguração do potencial de indivíduos bem formados em expectativa de melhoramento ou prosperidade do País, tanto sob o aspecto econômico quanto na dimensão política.

Acerca da matriz francesa sobre a qual os estudiosos concordam estar assente esse projeto, caberá um aprofundamento com o fito de verificar comparativamente - como sugerem Torgal e Vargues - quais foram os planos ou autores que de fato embasaram a proposta de Mouzinho de Albuquerque, fornecendo suporte teórico às iniciativas pedagógicas por ele sinalizadas. Diante disso, tudo indica de fato que o texto de

${ }^{6}$ Maria Manuela Bastos Tavares RIBEIRO, A memória da Revolução Francesa nos movimentos revolucionários de 1848 em Portugal e no Brasil, In: Revista de história das idéias - volume 11, p. 357. 
Albuquerque se remete à apropriação por parte do autor de inúmeras estratégias de ação preconizadas por Condorcet, no Rapport que enviara à Assembléia Legislativa francesa em 1792, como representante que era na Comissão de Instrução Pública. Indubitavelmente, pelas semelhanças textuais, poderíamos, desde logo, afirmar que Albuquerque leu Condorcet. Desde a proposta de quatro níveis de ensino - escolas primárias, secundárias, liceus e academias - até a sugestão de 'conselhos diretores da instrução', há alguma semelhança entre o texto de Mouzinho e os escritos de Condorcet. Para este, no topo da estrutura educativa, haveria uma 'Sociedade Nacional das Ciências e das Artes', que o reformador português denominaria 'Conselho de Aperfeiçoamento da Instrução Pública'. Abarcando também o tema dos compêndios escolares, a própria argumentação tecida parece dialogar com aquele referencial francês. Seja, portanto, pelos assuntos abordados, seja pela orientação analítica da abordagem, visualiza-se, no referido projeto, o código das Luzes filtrado pelo cariz da Revolução de 1789.

Em seu trabalho sobre intelectuais portugueses da primeira metade do século XIX, Maria de Lourdes Costa Lima dos Santos ressalta o papel desempenhado pelo "exílio, lugar de aprendizagem", na ocasião. Fundamentalmente o período que se segue à reação conservadora miguelista, conviverá com a emigração e, através dela, por paradoxal que pareça, com a infiltração de idéias novas trazidas pelos portugueses radicados no estrangeiro. Através da intensificação de práticas editoriais, de atividades de tradução e do exercício mais efetivo do jornalismo, as idéias ganhavam nova dinâmica, tanto no que tange à sua produção e/ou apropriação quanto no que concerne à sua circulação. Por meio da comunicação que os ditos estrangeirados mantinham entre si e do círculo que estabeleciam em termos de contatos internacionais, essa elite de pensadores do XIX português dá a ver aos conterrâneos as grandes questôes intelectuais de seu tempo, permitindo, mediante a irradiação escrita dessas idéias inovadoras, a publicização e mesmo vulgarização dos grandes quadros teóricos e conceituais que vinham com o novo século. Como sugere Santos, ocorrerá um "alargamento do capital cultural e social dos emigrados que havia de ter importantes repercussôes sobre o evoluir da intelligentsia liberal"7.

A propósito do espraiar das idéias pedagógicas no período do confronto entre liberais e miguelistas, pode-se anotar a proeminência adquirida pelo tema da educação como dispositivo regenerador da nação e da nacionalidade em crise, estratégia capaz de 'refundar' - para utilizar um termo caro a Fernando Catroga - o sentimento e a alma do país. Nessas novas representações acerca do tema da escola, destacam-se folhetos, impressos, brochuras e almanaques, de modo a que se pudesse dar a ver o tema da pedagogia para um público mais ampliado.

\section{Carvalho e o papel da educação doméstica na codificação de regras morais uniformes}

Manoel Pedro Henrique de Carvalho põe a público, através de uma tipografia lisboeta, no ano de 1834, uma breve brochura intitulada Memória sobre a maneira de dirigir a educação nacional, segundo a forma de cada governo e sobre o modo de firmar

${ }^{7}$ Maria de Lourdes Costa Lima dos SANTOS, Intelectuais portugueses na primeira metade de oitocentos, p. 117. 
a moral da nação. O próprio título já se revela elucidativo do intento. Naquele ano de expatriação de D. Miguel, o mesmo ano em que morre D. Pedro e principia o reinado de Maria II, Carvalho parte da suposição de que a existência de boas leis seria condição insuficiente para a pátria no caso de não haver instrumentos capazes de garantir seu efetivo cumprimento. A instrução liberal, como estratégia de âmbito público a ser ativada, deveria, no parecer do autor, transformar-se em bandeira a ser abraçada por todos os amigos da causa constitucional. A instrução popular, reconhecida aqui como ofício precípuo dos governos, faria por distinguir, inclusive, a forma de administração dos povos.

Radicando a diversidade de modelos pedagógicos na distinção entre as diferentes formas de governo, o autor acentua a primazia do direito paterno sobre a formação das crianças, destacando com isso que não se deveria enviar ninguém à escola contra a vontade dos pais. Haveria de se nortear o ensino mediante a harmonia posta em uma aliança tríplice: pais, mestres, mundo. Para tanto, algumas medidas são sugeridas, tais como a qualificação dos mestres para o ofício que desempenharão, a seleção de livros elementares adequados para a formação das novas gerações de escolares e, fundamentalmente, o fortalecimento de um sistema de estabelecimentos públicos de educação, a ser custeado e mantido pelo Estado.

A preocupação com a formulação doutrinária de um substrato teórico de educação liberal ancora-se na expectativa de engendrar mecanismos capazes de consolidar um regime representativo - ainda que monárquico - alicerçado sobre uma constituição. Nesse caso, haveria de se preencher a lacuna deixada naquele intervalo entre o regime despótico que se pretendia deposto e o universo da liberdade que, entretanto, não havia ainda conseguido ultrapassar a letra formal da legislação.

$\mathrm{O}$ autor ressalta as marcas prioritárias do homem em convívio com estruturas de poder: por um lado, o medo seria o grande móvel; na outra margem, a esperança. O monarca absolutista lida fundamentalmente com a inculcação do medo, desejando, pela mesma lógica, a obediência passiva. O governo representativo, por seu turno, protege e objetiva o conhecimento verdadeiro, lutando contra possíveis obstáculos à racionalidade, expressos mediante atitudes amedrontadas, preconceituosas, supersticiosas. Politicamente, isso implicaria a formação e esclarecimento da opinião pública, que seria por si esperança e fonte iluminista de aperfeiçoamento do percurso civilizatório pela via da irradiação da cultura letrada. Além disso, desejava-se aqui direcionar instrução e forma de governo para proceder ao reerguimento da nação outrora gloriosa e naquela ocasião reconhecidamente decadente. Sobre a instável grandeza geográfica decorrente da anexação dos territórios conquistados, havia de se acrescer a força de domínio simbólico e espiritual, a ser adquirida pela via do conhecimento letrado. No parecer do autor, a vontade do governo era fator primordial para dar sustentação a uma política educativa capaz de reerguer o país da condição decadentista. Recordando o que supunha ser a vocação liberal de D. Pedro IV, que legitimamente outorgara a Carta Constitucional, considera-se que tal Constituição conteria os destinos do então

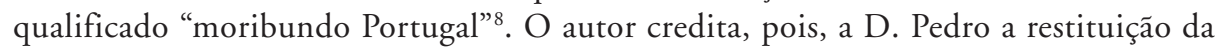
sã justiça, mediante o rompimento do tempo de tirania que tomara conta, no período

${ }^{8}$ Id. Ibid., p. 15. 
miguelista, de seu "povo dócil e social" . Não se pretende, pela trilha ilustrada, alterar tal docilidade. A ordenação e o equilíbrio social seriam, pelo contrário, mecanismos essenciais de retomada da rota do desenvolvimento português.

Convicto de que a ação de leis repressivas agiria como obstáculo de práticas criminosas, o autor atenta para o impulso, quase instintivo, que muitas vezes o ser humano apresenta para cometer o mal. Tal alerta desloca o eixo da análise de Carvalho acerca dos dispositivos de coerção para centrar-se sobre estratégias de obtenção de consenso social, de táticas persuasivas; em duas palavras: educação moral. Esta é caracterizada como atributo humano, capaz de ser aperfeiçoado em consonância com os trilhos da própria civilização. Pressupondo a acepção de cientificidade da ação moral, Carvalho entende que, composta enquanto tal, "do resultado das nossas experiências e dos nossos discursos e reflexôes" ${ }^{10}$, será aperfeiçoada pelo percurso da experiência de vida e, em outra dimensão, pelo caminho percorrido pela espécie.

Daí surgia a necessidade social de obtenção de regras morais uniformes, válidas para todos para normalizar e regrar a harmonia do conjunto da coletividade. A unificação dos referenciais de conduta ética apresentar-se-ia como exigência de regulação política. Aqui principia, na argumentação de Carvalho, a defesa da expansão e multiplicação dos preceitos pedagógicos, ou, em suas palavras, do "ensino direto", de modo a edificar, mediante esse empreendimento, uma sólida e adequada perspectiva moral. Reconhecendo a carência de "tempo e vontade" por parte dos conterrâneos quanto ao tema da instrução, o autor vê, ainda, outras limitações para o indivíduo comum enveredar pela trilha da ciência. Em seu parecer, apenas os legisladores efetivamente precisariam de conhecimentos mais aprofundados, posto que lidam com matéria que exige rigor e exatidão. A maior parte da sociedade, pelo contrário, orienta suas ações por combinação de observações e experiências. Daí talvez a força do exemplo a ser dado por governos e legisladores, caracterizados como mestres do gênero humano, responsáveis, enquanto tal, pela difusão da educação moral, que, neste discurso, não se confunde, em hipótese alguma, com a universalização das primeiras letras.

Se a instrução, por si só, poderia, aos olhos de Carvalho, trazer felicidade pessoal, ela, entretanto, não se mostraria capaz de satisfazer as necessidades moralizantes que já então eram colocadas como tarefa também da escola. A escola, organizada como estava no caso português desse princípio do XIX, não se revelara eficaz nem quanto à transmissão das suas competências específicas, nem quanto ao pretendido efeito de fortalecimento de algumas condutas e crenças desejadas pelos grupos sociais dominantes. Com essa impressão, ao defender a secularização do ensino, bem como a crítica velada à prioridade do ensino superior, Carvalho se distancia de qualquer projeto de generalização do ensino para camadas mais amplas da população. As habilidades da leitura e da escrita eram, em seu entender, perigosas enquanto não se houvesse realizado um verdadeiro ato de conversão coletiva. Reverter a situação viciada em que o país se encontrava não seria exatamente uma tarefa da escola, mas antes da família e da lei. Por ser assim, à "profusão de liçôes", prefere-se sugerir a necessária orientação educacional a ser ministrada pelos pais, no ambiente doméstico familiar; como se os

\footnotetext{
${ }^{9}$ M. P. Henrique de CARVALHO, op. cit., p. 16.

${ }^{10}$ Id. Ibid., p.35.
} 
próprios mestres, frutos de um regime corrompido, ameaçassem a teia social, enquanto sujeitos naturalmente propensos à corrupção das geraçôes mais jovens. Parece haver o temor da ação combinada de uma pedagogia cívica que tornasse a infância refém da corporação dos professores. O descrédito com que Carvalho visualiza a educação estendida a camadas majoritárias da população passa pelo descaso por ele conferido ao tema do povo. Derivada do exemplo, a moral prescinde da escolarização e o que no título se lê como "educação nacional" reduz-se na verdade à pauta de diretrizes públicas para uma pedagogia política desenvolvida pelos governantes. Educação nacional, sim, para modelar formas e fôrmas de governo; escola... ainda não.

Tal interpretação acerca do tema da escola não é, entretanto, partilhada por inúmeros outros sujeitos políticos da época, que, procurando ocupar o lugar progressista na vida pública, compreendiam a educação, no lastro de um iluminismo engajado, como alavanca prioritária para se erguer o futuro, através da concomitante superação das insígnias culturais da decadência portuguesa. Tal orientação supunha como alicerce a construção social de uma escola pública e dirigida pelo Estado; escola capaz de ser a alavanca da cidadania e da consolidação dos desejos e dos anseios por transformações. Indiscutivelmente o debate estava assim colocado entre os partidários e os opositores de uma escolarização de primeiras letras estendida a todos, assumida, enquanto tal, como questão do Estado no nível das políticas públicas; uma escola para preparar os homens para a vida civil.

\section{A difusão escolar como chave para superação da decadência pátria}

O texto Reflexôes sobre educação pública, publicado em Lisboa, no ano de 1835, como brochura da tipografia de Filippe Nery, e assinado por alguém que se vale das abreviaturas J. A. B. (de modo a ocultar a própria identidade), apresentará parecer bastante distinto daquele exarado por Carvalho ${ }^{11}$. Ao contrário deste último, J. A. B. revelar-se-á convencido da capacidade que todo homem tem de aprender. Acreditar no poder social da educação corresponderia, aqui, a efetuar uma aposta nas expectativas de aprimoramento humano pela desenvolução da espécie. J. A. B. solicita na introdução de seu texto a indulgência de seus concidadãos para com esse seu atrevido gesto de refletir e comentar sobre a educação pública - em suas palavras, matéria transcendente. No parecer do autor, a conquista política do liberalismo deveria ser, a qualquer custo, acompanhada do esforço para garantir, ampliar, e efetivar pelo coletivo as liberdades fixadas pela prescrição normativa da lei.

Haveria em Portugal, naquela altura, uma preocupante carência de indivíduos instruídos, fator que ocasionaria, dentre outros efeitos, o atraso português perante a industrialização, agricultura, comércio e administração; enfim, J. A. B. situa o obscurantismo popular como, a um só tempo, escudo e emblema da decadência. Além disso, critica a excessiva valorização da formação superior. É a educação voltada para utilidades

${ }^{11} \mathrm{O}$ texto de M. P. Henrique de Carvalho, ao qual já nos referimos acima, foi publicado também como brochura em Lisboa no ano de 1834, "como licença da Comissão de Censura", pela tipografia Santa Catharina. Recorde-se que o título completo daquela obra era Memoria sobre a maneira de dirigir a educação nacional segundo a forma de cada governo e sobre a maneira de firmar a moral da Nação. 
práticas o que J. A. B. defende, dividindo sua exposição em três eixos: classificação das escolas e das matérias de ensino, sustentação das escolas, métodos de ensino.

Ao discorrer sobre os aspectos concernentes à classificação das escolas, J. A. B. destaca a necessidade de voltar as atenções para a escolarização primária, ainda que isso pudesse ocorrer sob o custo de uma correspondente diminuição de investimento na instrução secundária e no ensino superior. Fica claro, pelo movimento das idéias no texto, de que se trata de um projeto acerca da universalização da escola primária propriamente dita, incluindo nisso a escolarização das meninas, posto que esse seria o degrau de ilustração suficiente para indivíduos que no futuro se dedicariam a ofícios mecânicos. Revelando-se leitor dos revolucionários franceses, J. A. B. defende a orientação curricular expressa pelo Relatório de Talleyrand, cuja matéria de instrução primária fora fundamentalmente "o ensino e a prática da moral e da religião; a leitura; a escrita; os elementos de Língua Portuguesa; o cálculo e o desenho necessários a todas as classes; afinal, os exercícios ginásticos que forem praticáveis em cada localidade" ${ }^{12}$.

Ao referir-se aos aspectos propriamente institucionais da vida rotineira das escolas, o autor destaca o silêncio e o medo como fatores proeminentes da ordenação pedagógica. Existiria, sob tal enfoque, rigoroso processo disciplinador, calcado antes na normatividade e inspiração do temor do que no efeito da autoridade do mestre. A escola portuguesa, no conteúdo e na forma, é aqui veementemente questionada por configurar seu futuro a partir da lapidação de homens fracos no ânimo e parcos no espírito.

Sob este argumento, considera-se que o português, desde a infância, é incentivado a utilizar de modo errôneo os atributos da mente e do espírito com que a natureza o dotou. O autor destaca a corrupção dos costumes como um mal engendrado pela sociedade e reproduzido de maneira localizada pelas instituiçôes do mesmo corpo social. Desse modo, com sociedade e governo imorais, as escolas refletiriam, como num espelho, os vícios que estariam para além dos seus muros. Reformar a escola seria, sob esse prisma, tarefa de largo alcance, dado que suporia a regeneração de outras instâncias da estrutura social.

Defende-se, sob tais pilares, a rigorosa intervenção governamental sobre a organização da instrução pública. Obtida a almejada regeneração, talvez, no futuro, as escolas pudessem ficar em mãos da iniciativa particular. Mas em tempos como aquele, de transição, o Estado era - como reconhece o autor - instrumento fundamental para a construção desse futuro. A propósito dos critérios adotados para a manutenção das escolas, sugere-se que se recorra às contribuições dos alunos, com subsídios do Estado. Referenciado - como vimos - pelo modelo francês, o autor declara que as escolas primárias, devendo ser gratuitas, haviam de contar com um excedente de despesas, à guisa de incentivo e de efetivo investimento na instituição, até "para convidar os Pais a mandarem para ela as crianças; porque ainda não está chegada a época em que poderão ser castigados quando se recusarem e, muito menos, aquela em que o farão sem receio de castigos, nem esperanças de recompensa." 13 Acerca da alocação de recursos públicos, sugere-se a introdução de critérios municipalistas para o tratamento da questão relativa

\footnotetext{
${ }^{12}$ J. A. B. , op. cit. , p. 8.

${ }^{13}$ J. A. B., Reflexões sobre educação pública, p. 21.
} 
ao financiamento do ensino. J. A. B. preconiza a transferência de recursos para que os municípios custeassem a organização de um sistema público de ensino.

A instrução primária - nessa sugestão de ruptura com a matriz centralizadora herdada do pombalismo - deveria ser constituída como atribuição das municipalidades. Em termos administrativos, são indicados os Procuradores de Escola, cuja tríplice função seria: advogar a causa da instrução nas instâncias das Juntas de Província, onde teriam voto; fiscalizar o funcionamento das escolas e a atuação dos professores e diretores; prestar contas do estado da instrução na localidade pela qual é responsável perante o Conselho Promotor da Instrução Pública, ao qual caberia todos os anos publicar relatório circunstanciado a respeito da situação geral das Escolas do Reino. Seria esse último, portanto, o órgão encarregado da inspeção.

Tendo exposto seus parâmetros administrativos quanto à organização e gestão das escolas, J. A. B. passa a referir-se aos métodos indicados para trazer exequibilidade ao processo do ensino. Ressalta o efeito pernicioso de metodologias usualmente adotadas, cujo único efeito residiria no cultivo e enaltecimento da memória, estilo perante o qual o aluno tinha seu raciocínio travado pelo fato de habituar-se a esquecer no dia seguinte aquilo que, na véspera, haveria aprendido. A idéia de um aprendizado contínuo passaria pela perspectiva de uma avaliação também cotidiana. O grande óbice para conferir êxito a tal modelo era exatamente o esquema de aulas livres, sem regulamentação legal quer quanto à duração dos cursos, quer quanto à própria estrutura dos mesmos.

Relata-se a preocupação quanto aos parâmetros norteadores da escolha dos mestres, os quais deveriam brilhar, não apenas por seu notório saber, mas principalmente pela apresentação de padrões de conduta civil exemplares, bem como por sua moral irrepreensível. $\mathrm{Na}$ verdade, credita-se ao conhecimento esse preparo para o exercício consciente de imperativos morais autônomos. O mestre iniciaria o discípulo na vereda da árvore enciclopédica, desde o balbucio da escolarização elementar. Ali estariam supostamente contidos, de maneira traduzida, os saberes acumulados pela história da Humanidade no longo percurso transcorrido pela civilização. Porém, havia algo para além disso: ao mestre caberia também indicar a senda da virtude, formando, acima da inteligência, o coração humano.

\section{Garrett e a educação intelectual na composição do futuro}

Será mediante a atuação de Almeida Garrett e de Alexandre Herculano que a educação portuguesa ganhará efetiva identidade teórica, enquanto projeto liberal. Produzir-se-ia, então, uma leitura inaudita do panorama social e político e a escola passaria, desde logo, a ser entendida como dispositivo de produção do consenso, de fortalecimento das raízes autênticas da nacionalidade em suas supostas tradiçôes, e de estruturação de uma ordem de produção e reprodução de valores divulgados como códigos civilizatórios. A nacionalidade portuguesa, enquanto problema intelectual a ser resolvido, viria a ter, sob novas representaçōes simbólicas, um contorno bastante próprio. Garrett e Herculano, além de discorrerem sobre a escola, desenvolvem táticas outras de pedagogia política, com o fito de espraiar suas visões e versões sobre o mundo e sobre a caminhada da civilização. Garrett fala a Portugal, escrevendo como pedagogo da rainha; ou, talvez pedagogo do futuro. Herculano assume O Panorama 
como a sua escola de propagação dos 'conhecimentos úteis'. Ambos, de qualquer modo, surgem como sujeitos de uma enunciação privilegiada. São agentes de novas representações, que antecedem em muito as novas práticas de escolarização, de um Portugal que vai sendo desenhado pelos ditames da própria repercussão que o Iluminismo adquire no desenrolar da primeira metade do século XIX.

Em um ensaio onde discorre sobre a memória histórica e a produção de uma memória mítica pelo culto cívico efetuado a propósito da imagem de D. Pedro IV em Portugal do XIX, Catroga nos traz suporte teórico e metodológico para abordarmos o tema do pensamento de Almeida Garrett e de Alexandre Herculano, que, de fato, teriam sido, a seu tempo, louvados e enaltecidos como só aos 'grandes homens' permite a história. Na construção de uma certa memória nacional, haveria, talvez, uma dimensão pedagógica para falar de pátria e de exemplaridade no mesmo acorde. O imaginário popular, ao se apropriar e debater as idéias do suposto herói, cria uma memória. Investido, então, por "exemplaridade típica" e "capacidade profética"14 , o grande homem fala do passado ao futuro. Pelo menos, seria essa sua única função. Para Catroga, construíam-se no século XIX memórias comprometidas com esse projeto de fabricação do homem incomum: "a personalidade do grande homem passa a ser apresentada como a resultante de um esforço de auto-aperfeiçoamento e o seu valor é medido à luz dos méritos da sua coparticipação na edificação de um tempo histórico acumulativo que, inexoravelmente, estaria a impelir a humanidade para uma crescente perfeição." 15

Grandes homens, tal como já os qualificavam os próprios contemporâneos, a diferença fundamental que Garrett e Herculano teriam em relação aos demais autores aqui abordados reside no fato de eles serem conhecidos, lidos, comentados, quer por teóricos da literatura, quer por profissionais da política, quer por especialistas desta ou daquela área acadêmica. Sem dúvida, passamos agora a tratar de autores que possuem notoriedade, que tiveram, portanto, seus escritos já conhecidos, já analisados, e já debatidos por parte da intelectualidade portuguesa, em inúmeros trabalhos. Pretendemos, então, contribuir com outro olhar, voltado especificamente para o filtro mediante o qual Garret e Herculano julgavam a escola. Percorrer os escritos de Garrett, de Herculano, e até de Castilho significa enveredar por um movimento do discurso educativo que deixou rastros, que fez escola, que teve enfim a repercussão dos clássicos. Procuramos retomá-los com o propósito de apreender regularidades e confluências dos discursos, e para verificar onde eles se particularizam.

No parecer de Teófilo Braga - que, aos olhos de Alberto Ferreira teria sido quem deu prosseguimento à obra de João Baptista da Silva Leitão de Almeida Garrett (1799-1854) ${ }^{16}$ - a melancolia foi a musa dos trabalhos de Almeida Garret, tanto

14 "Como na obra dos grandes homens é a história que se revela, a aferição da sua magnitude pertencerá à posteridade. Evocá-la será comemorá-la: o grande homem emerge investido de uma exemplaridade típica e de uma capacidade profética que se imporia seguir e escutar." (Fernando CATROGA, O culto cívico de D. Pedro IV e a construção da memória liberal, In: Revista de história das idéias / volume 12, 1990, p. 448)

${ }^{15}$ Fernando CATROGA, O culto cívico de D. Pedro IV e a construção da memória liberal, In: Revista de história das idéias / volume 12, 1990, p. 446.

${ }^{16}$ Alberto Ferreira julga que Teófilo Braga, ao apresentar-se como discípulo de Garrrett, teria apreendido "alguns rasgos do seu gênio", que, segundo ele, estariam postos nos atributos de coragem cívica, curiosidade intelectual e espírito crítico quanto à interpretação do processo histórico (Alberto FERREIRA, Perspectiva do romantismo português, p. 54). 
pelo fato de representar com nitidez a alma e o espírito de um povo que carregava consigo o traço da tristeza, quanto pela orientação impressa pelo efeito de um dado modelo de educação. Exilado pela mácula de liberal, partidário de D. Pedro, Garrett deveria sujeitar-se à condição de estrangeirado e refugiado do miguelismo em Inglaterra. Foi durante o exílio que, em 1829, escreveu o tratado Da educação, endereçado à futura rainha, Dona Maria da Glória, que contava então com apenas dez anos de idade. Como destaca Rómulo de Carvalho, antes de ser banido por D. Miguel, Garrett trabalhava no Ministério do Reino, órgão responsável pelos assuntos da instrução. Durante dois anos, chegou inclusive a ocupar o posto de chefe da Repartição do Ensino Público ${ }^{17}$. Talvez tenha vindo daí seu despertar para a reflexão acerca de temas relativos aos sistemas educacionais e sua organização técnica, administrativa e pedagógica. Além da redação do tratado Da educação, Garrett discorrera acerca da política escolar quando apresenta ao já então D. Pedro IV o projeto de reforma da instrução resultante dos trabalhos desenvolvidos por comissão nomeada pelo próprio $\mathrm{rei}^{18}$.

Da educação é, antes de tudo, a sistematização de regras e preceitos norteadores da formação de uma rainha. Entretanto, como bem recorda Rogério Fernandes, apesar do subtítulo - "cartas dirigidas a uma senhora ilustre, encarregada da instituição de uma jovem princesa" - Da educação "não é um tratado de príncipes, mas um tratado de educação geral, que em sua generalidade até essa espécie compreende. Defendia como princípio basilar a nacionalização do ensino, isto é a apropriação de sistemas, programas e métodos de ensino a nossos costumes e circunstâncias." ${ }^{19}$ Embora se tratasse de uma obra que refletia sobre um modelo de educação a ser estendido e ampliado, não havia, como também anotou Rogério Fernandes, observância ou expectativa de equalização das oportunidades públicas no tocante à educação. Pelo contrário: tanto as distâncias sociais quanto a distinção de sexos deveriam se refletir nos níveis diferenciados do sistema educativo ${ }^{20}$.

Acerca, no caso específico, das hesitações de Garrett perante a opção entre o arcaísmo e a inovação, Maria de Lourdes C. L. dos Santos revela a ausência de familiaridade do autor Da educação para com as camadas economicamente inferiores. Pontuando a referência de Garrett como exemplar da tendência aristocratizante, a referida autora declara que ele, "negando embora o presente, não escolheria o futuro"21. Garrett, sob tal enfoque,

\footnotetext{
${ }^{17}$ Rómulo de CARVALHO, História do ensino em Portugal, p. 545.

${ }^{18}$ A carta que acompanha o texto revela a tonalidade política do discurso pedagógico de Almeida Garrett, sendo também bastante ilustrativa do espírito de época: "o projeto da reforma geral dos estudos e da educação do Reino, que eu apresentei á Comissão por Vossa Majestade nomeada para esse fim, já por ela aprovada, vai subir á Augusta Presença de Vossa Majestade Imperial. Eu tenho, Senhor, perdido n'este trabalho o resto de saúde que me deixaram doze anos de cárceres e desterros. Mas somente rogo a Vossa Majestade a mercê de ser ouvido sobre ele, e que antes de se resolver o mutilar ou alterar qualquer parte dele, seja permitido expor, e desenvolver as suas razões, a quem há mais de dez anos, com improbo estudo, dispendiosas viagens e longas vigílias, medita neste trabalho, e que há seis meses tem consagrado á sua redação os dias todos e a maior parte das noites (Carta de GARRETT dirigida ao Imperador D. Pedro IV, como vogal e secretário da Comissão da Reforma Geral dos Estudos, em 17 de Abril de 1834)".

${ }^{19}$ Rogério FERNANDES, O pensamento pedagógico português, p. 96.

${ }^{20}$ Rogério FERNANDES, O pensamento pedagógico português, p. 102.

${ }^{21}$ Maria de Lourdes Costa Lima dos SANTOS, Intelectuais portugueses na primeira metade dos oitocentos, p. 56.
} 
identificava-se com o povo enquanto princípio teórico instituinte na mesma proporção em que, na prática, dele se distanciaria. Com representaçóes e estilos absolutamente distintos, não havia qualquer empatia natural entre as camadas excluídas do acesso à cultura e os intelectuais que dela falavam. Tomar a educação por bandeira significava, no caso de Garrett, a estruturação de um dado padrão civilizatório em sintonia com as nações avançadas da Europa naquele que se supunha a si próprio o século do progresso. A isso, viria somado um vago desejo de unificação, de demarcação de uma identidade nacional, marcada por um tom civilizatório. O desejo de tornar Portugal competitivo no mundo europeu produz esse discurso sobre a escolarização.

Garrett critica, como óbice ao desenvolvimento do povo português, o sentimento de miserabilidade que dele se apoderara. Em 1827, escrevia uma crônica onde, ressaltando a docilidade daquela gente, enfatiza o sentimento de insegurança coletiva que dela tomava conta. O povo português perdera a grandeza e a glória de outrora para permanecer no caminho lento que vinha sendo impulsionado por uma trajetória que não condizia com os avanços da civilização. A ilustração do povo situa-se, nessa lógica, como pressuposto para alicerçar instituiçôes livres na plataforma de uma sociedade nova que se acreditava desenhar. O impulso civilizador teria, sob tal enfoque, duas vias de acesso: a reforma institucional mediante instrução do povo, capaz de capacitá-lo no sentido de seu aprimoramento subjetivo, ou a revolução, que, aí sim, derrocaria impiedosamente as balizas do antigo regime, para construir, sobre as ruínas, os pilares do que se acreditava ser o inteiramente outro.

Ao provocar temor e encantamento, a referência da Revolução Francesa é constantemente evocada pela marca da ruptura que esta supostamente traria consigo; mais do que isso, tratava-se de um exemplo, fosse para ser acatado, fosse para ser negado. A Revolução em França era o exemplo da idéia de nação levada a seu extremo: por um lado a libertação e por outro a inscrição da violência que fizera sangrar algumas das premissas éticas e políticas do movimento. É, portanto - como vimos - com olhar mesclado entre a curiosidade e o medo, que o século XIX português observa os efeitos e a referência do fenômeno francês.

As novas inflexões da política e da economia mundial são, por sua vez, tomadas pelo autor como dispositivos de desequilíbrios das tradicionais e já arcaicas oligarquias, originando distintas e inovadoras relaçôes sociais em um sistema estruturado perante circunstâncias muitas vezes inspiradas por modelos transnacionais. Isso ocasionaria, segundo o antigo aristocrata, uma órbita planetária da civilização moderna. ${ }^{22} \mathrm{~A}$ alternativa da liberdade advinha, pois, através de caminhos sempre entrelaçados, e que compreenderiam desde o desenvolvimento da indústria nacional até um projeto de colonização eficaz, balizados todos eles pela atitude de irradiação das luzes, mediante a consecução de planos educativos delimitados e forjados como instrumento de consolidação e prosperidade nacional.

Convencido da necessidade do regime constitucional, é também mediante tal convicção política que Garrett abordará o tema da educação. Foi pensando na futura rainha, Dona Maria da Glória, que foi publicado em Inglaterra, ainda durante o período de seu exílio em Londres (1829), o tratado Da educação. Garrett aqui pretendia

${ }^{22}$ Almeida GARRETT, Portugal na balança da Europa, p. 198. 
traçar diretrizes norteadoras da condução educativa daquela que, anos depois, deveria conduzir os destinos do reino. Imediatamente posto como marco na história das idéias pedagógicas de seu tempo e em seu país, o livro seria depois qualificado por Teófilo Braga como "pueril e sem ciência pedagógica" 23 .

Não apenas o título de seu tratado faz lembrar o Rousseau do Emílio; Da educação de Garrett parece ter nascido com a pretensão manifesta de ser a expressão portuguesa da feição iluminista de apostar na educação da criança para, através daí, regenerar o próprio gênero adulto ${ }^{24}$. Garrett principia seu trabalho destacando a metodológica oscilação de quem "antes propóe como quem duvida do que assevera como quem sabe" 25 . Revela-se, entretanto, convicto de que dos rumos pedagógicos da futura soberana dependeria o futuro da pátria. Credita a si próprio a missão de redigir aquele que seria o suporte teórico nacional para um modelo de educação portuguesa, modelo exemplar, a ser evidentemente implantado a partir da Corte.

Pelo conteúdo e pelo estilo, Garrett pretendia então produzir um tratado que, à portuguesa, abarcasse aspectos da educação física (higiene e ginástica), moral (ou do coração: deveres da família, sociedade, cidade, Estado e religião) e intelectual (matérias de ensino, tais como alfabeto, gramática, aritmética, geometria, história, geografia, etc...). Declara-se, em tal classificação, a tarefa de urbanidade a ser desempenhada pela instituição escolar, cuja baliza, antes de outra coisa, seria o estabelecimento de prescrições de ordem moral e regras de conduta civil que a elas se adequassem. O Estado deveria assumir um papel tutelar quanto ao oferecimento de uma educação pública, ainda que as acepçôes de tal formação não fossem por si equânimes. Há em Garrett a explicitação daquilo que o autor acreditava ser a necessidade de modelos educativos diferenciados, capazes de reger a formação das distintas camadas da sociedade. O território da escola se diferenciaria quanto ao encaminhamento pedagógico das crianças, na medida em que elas tivessem proveniência de setores privilegiados ou de setores economicamente desfavorecidos. Todavia, apesar da estipulação de um núcleo comum de matérias, mantinham-se, como era habitual à época, distinções entre a instrução oferecida aos meninos e aquela que se destinaria às meninas, abarcando algumas especificidades em termos de prendas domésticas, que de algum modo enclausuravam o papel social reservado para a mulher. Haveria finalmente um modelo pedagógico caritativo, voltado fundamentalmente para crianças órfãs ou indigentes. Por tais razôes, detectamos, já à partida, a negação da escola única no projeto de Garrett; como já faziam, aliás, outros teóricos da educação portuguesa daquela altura. De qualquer modo, inscrever-se-ia ali toda a dimensão pedagógica que o julgamento acerca da decadência de Portugal viria então assumindo. É por essa chave que em sua obra, concebida para orientar as diretrizes pedagógicas de uma única menina, Garrett declara a crença de que

${ }^{23}$ Teófilo Braga, História da literatura portuguesa - volume V / o Romantismo , p. 148.

${ }^{24}$ Acerca dos referenciais teóricos que alicerçaram a concepção pedagógica de Garrett, valemo-nos do livro de Fernando Augusto Machado, Almeida Garrett e a introduçāo do pensamento educacional de Rousseau em Portugal.

${ }^{25}$ Visconde de Almeida GARRETT, Da educação; cartas dirigidas a uma senhora ilustre, encarregada da instituição de uma jovem princesa, p. V. 
disso "dependerá a felicidade, talvez a existência, - os futuros todos de uma nação inteira, de uma nação até aqui tão infeliz." 26

Revelando sua pretensa identificação com o que qualifica de "arte de formar homens”, Garrett aponta como objetivo de seu sistema a formação tríplice do corpo, do coração e do espírito. Convicto de que o ato de educar seria a necessária prevenção do ato de punir, Garrett aponta cuidados com a higiene e a robustez do físico como a medicina preventiva da orgânica social. Para a boa conformação do físico, os mestres deveriam atentar para a compostura moral. O autor recomenda, para tanto, brandura, serenidade e docilidade.

Se a educação intelectual teria por princípio o reconhecimento das condições do educando perante critérios consoantes à posição que ele viria posteriormente a ocupar em sociedade, a educação moral alicerçar-se-ia sobre um único e inarredável preceito, apontado como formador do coração humano: a idéia de justiça; idéia esta apresentada como natural e necessária para a vida em sociedade. O senso de justiça que a educação deve desenvolver firmar-se-ia perante a disposição humana de acatar, respeitar e obedecer normas religiosas, civis ou sociais. A esfera privada e o âmbito público combinam-se aqui, quando, da premissa posta por uma ética engendrada no coletivo, derivariam padrões de conduta individuais que, calcados naqueles mesmos preceitos, produziriam no homem a acepção de honra. Na verdade, a escola projetada vê a criança como se fosse um vassalo dos mais velhos, ensinando conteúdos e formas escolarizadas, à guisa de preparação para a vida em sociedade.

Tais saberes que a escola produz decorreriam de uma apropriação que a mesma escola faz dos valores e conhecimentos estipulados pelos grupos dominantes em cada sociedade. São tais grupos que orientam o que e como deve ser ensinado. Por sua vez, a escola recebe tal orientação, filtrando-a de acordo com procedimentos infinitamente sutis, até reinventá-los pela prática cotidiana. Os conteúdos escolares, na proposta pedagógica de Garrett, seriam dispostos de maneira a que a criança encare como natural, aceite e perpetue a ordem das coisas. A justiça aqui corresponde, não resta dúvida, à manutenção e valorização do existente como única possibilidade oferecida pela história, e, mesmo assim, a justiça é ainda posta como a mais nobre dentre todas as virtudes: a justiça que modela a honra, que estipula deveres naturalizados para com Deus, para com o Estado, para com o semelhante, para consigo próprio. A norma, a regra, a definição vem sempre de fora, devendo ser absorvida sem restriçôes pelos espíritos juvenis, tarefa essa que pertenceria à educação: orientadora dos eixos que conduziriam no futuro homem a sua sociabilidade. A criança desde cedo aprenderia o homem como se deve ser... Haveria, perante tal cartilha, uma incessante relação de dívida do indivíduo para com a Humanidade. Desde a nascença, se estaria em débito para com seres aos quais, de algum modo, se deve a sobrevivência: os pais são os primeiros credores de tal tributo a ser pago por dever da natureza.

Tomada como dever natural, a obediência se estende aos laços conjugais e à própria condição de cidadania: a pátria que origina o ser civil quer dele contributo, até por

\footnotetext{
${ }^{26}$ Visconde de Almeida GARRETT, Da educação, p. 4. Confirmando o sentimento nostálgico de seu povo, imerso na saudade de um futuro nunca alcançado, continua o autor: "eu tive a boa fortuna de receber uma educação 'portuguesa velha', sólida de bons princípios de religião, de moral, de sãos elementos de instrução, e, conquanto fosse mal aproveitada, das melhores que se dão, não direi em Portugal, mas pela Europa" (Id. Ibid., p.5)
} 
retribuição. Toda uma rede de constrições encadeia o indivíduo, enclausurando-o em seu lugar de súdito, sujeito a leis que ele não determinou; isso se aprende na infância. Garrett, com tudo isso, trará feição teórica a muito do que poderá ser compreendido como o território dos valores que seriam naquele século perfilhados pelos compêndios didáticos portugueses. No liberalismo pretendido, o âmbito civil desdobra-se dos parâmetros da moralidade prescrita; a ética pública deveria ser posta como um desdobramento das relações de família. Fazer da justiça o princípio da civilidade humana corresponde a assumi-la com base na idéia de retribuição: aos pais, à sociedade, ao Estado, ao cônjuge, a Deus. Ao supor a piedade e caridade como pilares da crença, o dever do cristão extrapola o âmbito da intimidade e aproxima-se de uma conduta generosa em termos da sua interface social.

Garrett explicita seu parecer sobre a educação intelectual: se todos carecem da necessidade de saber, fazem-no de maneira desigual, atendendo, por um lado, às disposiçôes de espírito e, por outro, à projeção do próprio futuro, o que evidentemente variará de acordo com a origem de classe de cada indivíduo. As propensóes do educando, bem como sua índole, seriam também fatores relevantes, embora não descartassem o determinante econômico quase como uma última instância da vida e fundamentalmente do sucesso escolar. Tal condicionante revela o tom ambíguo desse liberalismo que a rigor deveria voltar-se à equalização das oportunidades sociais.

Como ponto de partida da instrução, Garrett sugere o aprendizado prioritário do idioma nacional ${ }^{27}$. Garrett justifica o papel disciplinador delegado à educação, que deveria - a sociedade assim o quer - agir sobre os instintos e sobre a conformação do caráter, em substituição à própria índole. A ação educativa deveria, nessa medida, transformar a vivacidade e espontaneidade da puerícia em hábitos de asseio, ordem, regularidade; enfim, um processo de domesticação das paixões para a estruturação de costumes e formas de conduta civil, de urbanidade. A civilidade, na composição escolar de Garrett, seria - pode-se dizer - meta superior à razão. É ela quem conduz um povo, oferecendo-lhe modos e formas que, no conjunto, criariam as tradiçôes nacionais, tal como a pedagogia pretendia. Sendo por si educativa, a rotina recordava a própria progressão da vida, que, no conjunto, é também rotineira.

A tarefa pedagógica consistiria em ritual de passagem, no qual elementos do espontâneo, do ato criador da razão infantil, seriam sistematicamente vedados e substituídos pela versão adulta, condição da verdade e da realidade. As fábulas são aqui tomadas como produtos da invenção e do fingimento; e, enquanto tal, deveriam ser - no parecer de Garrett - eliminadas do processo do ensino. Tudo o que incitasse à fantasia afastava do real e, assim o fazendo, seria antipedagógico. Como alternativa, o autor recomenda o contato da puerícia com histórias tidas por reais, exemplares e verdadeiras, elaboradas em Portugal e à portuguesa, ainda que sob a referência de modelos estrangeiros, já que - como desabafa Garrett - "a traduzir estamos nós, portugueses há século e meio e desde então ainda não temos um livro" 28 .

De acordo com a leitura política de Garrett, em consonância com seu modo de ser liberal, não caberia ao sujeito histórico a alteração de dados objetivos de sua existência

\footnotetext{
${ }^{27}$ Visconde de Almeida GARRETT, Da educação, p. 30.

${ }^{28}$ Visconde de Almeida GARRETT, Da educação, p. 101.
} 
(classe social, posição posta pelo nascimento), mas, ao contrário, sob o influxo de quadros mentais arcaicos, aristocráticos e basicamente estamentais, não haveria - no parecer do autor - qualquer liberdade para o movimento, para a mobilidade social. Ao indivíduo caberia, portanto, o reconhecimento de sua identidade individual e coletiva, a compreensão das forças que teriam delimitado tal situação e a aceitação dessa realidade supostamente intransponível. A vida individual e a vida dos povos seriam retratadas pela educação, de modo a conformar a fisionomia desse mesmo indivíduo, desse mesmo povo. Existiriam, sob tal ponto de vista, estados comuns à condição de qualquer homem - como esposo, filho e pai - e haveria, por outro lado, estados diferenciados pela proveniência de classe. Essa seria a ordem natural das coisas e à educação caberia apenas respeitá-la. Percebe-se então que - em Garrett - a igualdade do gênero humano é relativizada, mediante uma acepção de soberania tributária do absolutismo: soberano é o governante a quem os súditos devem obediência. A soberania, enquanto categoria intrínseca à própria nacionalidade, não consta pois da pedagogia liberal de Almeida Garrett. Consciente de seu controverso discurso, Garrett explicita que o soberano deverá ser, pela sua própria condição, moralmente irrepreensível. Ora, considerando-se que Portugal deveria ser governado por uma rainha, a futura soberana havia de ser preparada para exercer tal encargo que o Estado e a Constituição lhe conferiam.

O ensino oferecido ao príncipe teria como eixo o estudo da História nacional, por cujos rudimentos se poderiam extrair preceitos condutores da vida moral. Acontecimentos gloriosos, recordaçôes de fatos notáveis, crônicas de heroísmo, todo esse conjunto revelaria virtualmente para o pupilo a própria vocação de Portugal. No princípio, para utilizar o enredo de Garrett, era a História: "por este livro aprenderá a ler nosso pupilo. A ler digo: não a conhecer as letras, a soletrá-las em sílabas ou a ligar estas em palavras; mas a ler, isto é, a recitar orações e períodos, a graduar as inflexões da voz, as pausas, a entender, enfim, um discurso, um livro, - a ler na lata acepção do termo." 29 Nessa direção, ele alude aos princípios intelectuais que norteiam a habilidade da escrita; para a caligrafia, sugere a utilização do tratado de Ventura. ${ }^{30}$ Propõe, também, estratégias para o ensino da tabuada, capazes de conduzir à memória, mediante um anterior processo de entendimento. Em suma, haveria necessidade de se ensinar pelo modo simultâneo, devendo o aprendizado da leitura e a habilidade da escrita se tornarem também processos concomitantes. A escrita caligráfica, sendo eminentemente mecânica, deveria tornar-se raciocinada, mediante a dedução de idéias, tal como orientava o estilo pedagógico já implantado nos novos métodos de se ensinar a tabuada.

Percebe-se nitidamente que a preocupação de Garrett com essas questôes de ordem metodológica derivava do insucesso da educação e particularmente da escola em Portugal. Naquelas décadas que principiavam o século XIX, independentemente das possíveis inflexões políticas, o curso da educação persistia sendo o mesmo: moroso, lento e fracassado no ensino das primeiras letras. O analfabetismo em Portugal seria, durante todo o século XIX, uma realidade denunciada, não obstante não ter sido nesse

${ }^{29}$ Visconde de Almeida GARRETT, Da educação, p. 149-150.

${ }^{30}$ Trata-se provavelmente do compêndio de Duarte Ventura, Arte de aprender a ler a letra manuscrita para uso das escolas em 10 liçôes progressivas do mais fácil ao mais difícil. Este texto é qualificado por Garrett como a mais perfeita e admirável obra para o ensino da caligrafia em língua portuguesa. 
período efetivamente enfrentada. Temos, portanto, o plano das idéias, das representaçôes e dos discursos antecipando-se sempre às práticas sociais, embora também ele fosse - em última instância - uma prática...

A pedagogia portuguesa do século XIX, quando representa a mulher, coloca-a invariavelmente no seu lugar de esposa e de mãe. A tônica religiosa do discurso era, em geral, indisfarçável e o lugar do feminino, sublimado, passava a ser habitualmente encarado diante daquilo que, por si, ele viria a representar para um 'outro' masculino, fosse o marido, fosse o filho. Obediente, dócil, resignado e virtuoso, o rosto feminino é então indubitavelmente traçado pelo homem, - como sujeito da enunciação e como razão de ser da própria existência feminina. O estatuto da mulher portuguesa é, portanto, o ser duplo do homem, o seu olhar ao espelho, aquilo que, no máximo, lhe serviria de complemento. Receptáculo das vindouras gerações, a mulher é antes de tudo um ser biológico, devendo ser pois instruída fundamentalmente enquanto mãe que deverá, nesse encargo, encarregar-se dos anos iniciais da educação da criança. Garrett, ao dirigir-se especialmente à educação da futura soberana, e, dadas as configurações específicas e diferenciadas de ambos os sexos, enquadra o caso da rainha no que chama de "uma nova espécie, não participante de ambas, mas ela própria uma peculiar e de gênero seu" ${ }^{31}$. Era como se a rainha deixasse de ser mulher ao se afirmar soberana... Se à mulher convém o recato, a soberana não pode agir com timidez; devendo, pelo contrário, ser enérgica. Se à mulher cabe obedecer, ocupar o trono equivale a mandar. A rainha deixa seu feminino para ocupar o lugar político reservado aos homens: mais do que ninguém, ela deve ser educada e preparada para esse seu ofício eminentemente masculino. Em tal transmutação, "a classe supre o sexo e a posição social a natureza: a educação intelectual de uma rainha é de varão e não de mulher." ${ }^{2}$ Sem dúvida alguma, teria sido antes por sua inquietação política que Garrett pensou a pedagogia. Talvez mais do que a preocupação com o povo, o que o intrigava era esse modo de gerir o feminino do Estado.

\section{O cariz pedagógico do pensamento de Alexandre Herculano}

A figura de Alexandre Herculano deixou profundas marcas no tempo que se lhe seguiu, até porque a leitura que fez dele a Geração de 70 inscreveu-se na memória coletiva da nação portuguesa. Teófilo Braga - que se identificava como um representante da moderna geração - explicita seu tributo em nome dela àquele que, antes de qualquer outra coisa, soube observar e respeitar o futuro, contrariando, com isso, grande parte dos intelectuais do seu tempo:

"Havia em Portugal um homem que era ouvido como um oráculo; Herculano era considerado como uma consciência inquebrantável e a sua voz, acostumada à energia do protesto, quando se pronunciava, fortalecia-se com o assentimento dos espíritos. Nunca ninguém exerceu um poder tão grande, na forma a mais espontaneamente reconhecida; as opiniôes

\footnotetext{
${ }^{31}$ Visconde de Almeida GARRETT, Da educação, p.188.

32 Visconde de Almeida GARRETT, Da educação, p. 193.
} 
entregavam-se à sua afirmação, como um povo se entrega a um salvador. Tinha o poder espiritual sobre a Nação." 33

Pinheiro Chagas também destacaria, como atributos inarredáveis de Herculano, a defesa da justiça e do direito contra qualquer manifestação de tirania. Inatacável por sua honradez, Herculano diferenciar-se-ia de Almeida Garrett por sua preocupação com o povo, um olhar entre distante e próximo que tinha como máxima finalidade a descoberta da verdadeira alma nacional. Herculano, enquanto narrador, não se reconhece partícipe do povo português, mas julga estar nele a essência da alma nacional; torna o povo sujeito e objeto de seu discurso e pensamento, sujeito e objeto de sua enunciação.

Na mesma direção, Antero de Quental ressalta a nobreza de caráter e a integridade impoluta de Herculano como a expressão mais acabada das idéias, do temperamento, da própria sensibilidade do homem português. Herculano tornara-se célebre pela análise política e pelo tom de profecia mediante o qual construía seu discurso histórico. Enquanto historiador - como anota Paulo Archer de Carvalho - Herculano procuraria o desenho da nação, os milhares de homens que se sobreporiam, na prática da história vivida, a duas ou três individualidades particularmente ilustres. A partir da constatação da decadência portuguesa, Herculano desenha o traçado possível da regeneração pretendida, traçado esse que passava, no conjunto, pelo contorno de uma escola voltada ao tempo e ao país do futuro. Qualificando-o, em sua individualidade, como o representante singular da alma mais profunda da nação, disse Antero sobre seu predecessor:

"Na fisionomia moral de Alexandre Herculano, há certas linhas que fazem lembrar o perfil
enérgico e simples dos heróis típicos da nacionalidade portuguesa. Pertence a essa grande
linhagem, que acabou com ele - e o seu século, admirando-o, considerava-o todavia com um
certo espanto ininteligente, como se sentisse vagamente que aquele homem pertencia a um
mundo extinto, um mundo cujo altivo sentir ninguém já compreendia." ${ }^{34}$

Olhando por outra direção, Oliveira Martins critica o individualismo de Herculano, individualismo esse calcado em todo um suporte teórico iluminista, kantiano. Herculano - ao tomar a razão humana como fonte de todo desenvolvimento e o conhecimento como dispositivo natural para bem caracterizar a condição humana - teria seu pensamento estreitamente vinculado a uma ética liberal, calcada no individualismo em política e no livre-câmbio em economia. Para Oliveira Martins, deveria existir, pelo contrário, um princípio orgânico capaz de extrapolar o governo "das maiorias ignaras, dos números brutos" 35 . Seduzido pelas doutrinas cientistas, combinadas a uma romântica vaga socialista, Oliveira Martins sugere a coesão social como oposição à fratura do todo no indivíduo liberal.

Contrário à democracia, Herculano repele aquilo que julgava ser a conversão do homem em molécula. Temeroso dos possíveis efeitos da entrada do povo na história, o referencial da Revolução Francesa parecia-lhe emblemático. Suas reflexões sobre

\footnotetext{
${ }^{33}$ TEÓFILO BRAGA, História da literatura portuguesa / volume V - O romantismo, p. 161.

${ }^{34}$ Antero de QUENTAL, Alexandre Herculano, p. 12.

${ }^{35}$ OLIVEIRA MARTINS, Alexandre Herculano, p. 80-81.
} 
instrução pública derivam certamente da premissa dessa irracionalidade popular como um perigo que sempre ameaça a democracia. Preparar o povo ordeiro, trabalhador, disciplinado, respeitoso, tornava-se, pois, tarefa precípua do educador das vontades coletivas, que, por definição, seria o intelectual. O medo do povo, o reconhecimento de seu lugar histórico e a aposta na instrução popular seriam aspectos de um mesmo problema, no pensamento social de Herculano. Instruir multidóes seria talvez o melhor antídoto contra a tentação revolucionária. E, seja como for como recorda Adolpho Coelho - , Herculano reconhecia na Revolução Francesa o alicerce originário da proposta do ensino universal, o que o levaria, na prática, a defender a via das reformas institucionais como alicerce para o desenvolvimento e mesmo o progresso projetados. ${ }^{36}$ Em Herculano, todavia, o conhecimento escolar não teria prioridade propedêutica. A instrução escolar seria um veículo da prosperidade material e da superação da decadência através desse destaque conferido à ordem da economia.

Fernando Catroga considera que a concepção de Alexandre Herculano acerca da decadência portuguesa é o alicerce condutor de todos os seus escritos. Para o caso português, a decadência coincidiria fundamentalmente com a época das navegações, que teria conduzido Portugal do pico mais elevado da glória à ruína do império colonial. Além disso, teria sido o próprio absolutismo, com a destruição das municipalidades e das liberdades medievais em nome do perverso poder central, quem ocasionou o "desvio do percurso que a sociedade portuguesa devia ter percorrido para

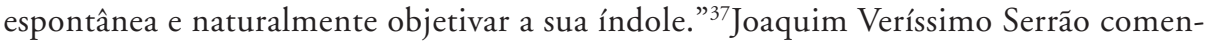
tará a esse respeito, indicando que "a concepção histórica de Herculano era contrária à expansão ultramarina por entender que a nação vivera na Idade Média o seu período de glória, quando a ação dos reis anteriores ao absolutismo e a força regional dos municípios haviam fortalecido o organismo português." 38

Poder-se-ia dizer que a preocupação de Herculano com a instrução pública era derivada de suas intensas e incessantes preocupaçôes com o destino coletivo de um país que perdera sua vocação. Aquilo que a aventura marítima deitara por terra, talvez a cultura pudesse então resgatar. Por acreditar que os povos mais desenvolvidos do continente europeu foram os que apostaram nos benefícios da instrução primária, Herculano enxerga o tema da escola com olhar de homem público, preocupado, por um lado, com a possibilidade de aperfeiçoamento do indivíduo e, por outro, com a capacitação coletiva para um consciente exercício da cidadania e da vida do trabalho. Entrar para o seleto mundo da cultura significaria uma pausa na dimensão do espontâneo travada fundamentalmente pela ruptura com a condição do popular; significaria, portanto, afastar-se da tendência das multidóes ignorantes.

${ }^{36}$ Adolpho COELHO, Alexandre Herculano e o ensino público, p. 62.

${ }^{37}$ Fernando CATROGA, Alexandre Herculano e o historicismo romântico, In: A história através da história, p. 81. De acordo com Catroga, Herculano entendia como puramente negativo o valor real da dita glória dos descobrimentos e das conquistas marítimas. "Com esta tese, em que são responsabilizados a centralização política, a aventura colonial e o centralismo católico e inquisitorial (com suas nocivas consequências econômicas, politicas e morais), Herculano fixou um dos diagnósticos mais controversos sobre a história de Portugal que, dai para a frente, será um ponto de referência obrigatório nas interrogaçôes sobre o nosso destino." (Id. Ibid., p. 81).

${ }^{38}$ Joaquim Veríssimo SERRÃO, Herculano e a consciência do liberalismo português, p. 61. 
Os especialistas ressaltam a relevância da edição dos Opúsculos, efetuada por Herculano, a pedido dos editores da Bertrand no último quartel de sua vida. Ao abordar no tomo VIII de seus Opúsculos, o tema da instrução popular como questão pública, Herculano advoga a universalização do ensino como reforma necessária ao processo civilizatório, contraponto imprescindível da indesejada e nefasta revolução. A escola, fonte de prosperidade coletiva, agiria como alicerce da edificação do bem comum. Conferindo à Revolução em França uma identidade de inauguração de uma nova era, é - como vimos - com receio que Herculano situa sua referência, posto que, em nome da liberdade dos povos, ela teria acionado o recurso à violência e à tirania. A organização das escolas representaria uma medida de caráter público, inclusive para precaver a possibilidade da revolução. O caminho de Portugal não deveria confundir-se com o percurso francês, embora fosse necessário apropriar-se de muitas de suas insígnias. Para superação do regime antigo, para regeneração do país decadente, a reforma intelectual portuguesa era tida aqui como estratégia prioritária. Com o fito de - aos olhos do intelectual - proporcionar "felicidade futura", fortalecer o poder municipal contra as ingerências centralizadoras e "auxiliar a religião a moralizar o país", diminuindo a necessidade de "leis violentas", caberia à instrução pública a manifesta tarefa de prevenção dos desvios sociais, de conformação de corpos e mentes dóceis, ciosos da mais harmoniosa ordenação social.

A aquisição do conhecimento coincidiria, no plano individual, com a dignificação de cada um perante o juízo da vida social tomada como existência coletiva. Mas para que isso pudesse efetivamente ocorrer, não bastava o ensino escolar do 'ler, escrever e contar'. Era necessário um corpo de saberes elementares capaz de efetivar uma preparação mais global. Herculano defende o estabelecimento de dois níveis de ensino complementares: um, elementar, necessário à vida pública e à felicidade do país; outro, superior, necessário à felicidade individual... Duas trilhas de instrução, a primeira obrigatória e a segunda facultativa. Nas palavras de Herculano: "a primeira representará o direito da república, a segunda o de cada um de seus membros" ${ }^{39}$ No parecer do autor, entretanto, um projeto de instrução, qualquer que fosse ele, deveria abordar um conjunto de temas indispensáveis: "matéria da instrução; organização das escolas; métodos de ensino; (...) concorrência, a capacidade e ao mesmo tempo a sustentação dos professores; direção das escolas; e frequência dos discípulos" ${ }^{20}$. Eram todas questôes urgentes a requererem dispositivos legais imediatos. A ausência de organização e de projeto é sempre destacada por aquele que diz que "a chamada instrução primária é em Portugal mais uma palavra e uma verba de orçamento que outra coisa" ${ }^{41}$. Herculano vê a necessidade de a escola se adequar às novas condições necessárias ao país, com o desenvolvimento do trabalho e da indústria.

Defensor da perspectiva de democratização da instrução particularmente em seu nível primário, Herculano critica os métodos habitualmente utilizados na escola portuguesa de primeiras letras, onde, após os primeiros elementos introdutórios no idioma pátrio, o aluno se defrontaria com complexos estudos de Latim, uma "língua

\footnotetext{
${ }^{39}$ Alexandre HERCULANO, Opúsculos / Tomo VIII - Questões públicas, p. 148.

${ }^{40}$ Alexandre HERCLANO, Opúsculos / Tomo VIII - Questões públicas, p. 141.

${ }^{41}$ Alexandre HERCULANO, Opúsculos / Tomo VIII - Questões públicas, p. 125.
} 
de um povo que desapareceu há mais de um milheiro de anos”². A escola portuguesa pouco ensinaria relativamente à religião, à vida civil, ao mundo físico e moral. Além disso, não contemplava as exigências de um século no qual o impulso vital era justamente o aproveitamento das conquistas postas no campo da razão. A escola portuguesa pecava pela ausência de organização. Era imprescindível adequar o ensino aos padróes exigidos pela civilização européia. Outrossim, Herculano pondera sobre a necessidade de se ter em conta diversidades regionais que perpassavam da geografia aos costumes. A boa lei seria - aos olhos do intelectual - não aquela efetuada por imitação e amálgama de outras experiências de povos alheios; mas antes a que se revelasse capaz de acomodar-se ao modo de ser nacional, em suas similitudes e em seus contrastes. Herculano vê no século XIX a urgência de se estruturar a reforma da escola até como estratégia de demarcação do território da nacionalidade.

A perspectiva da multidão surge como ameaça desagregadora e é posta por Herculano como efeito provocado parcialmente por aquele já constatado descaso pela instrução. O povo-multidão aterroriza ao trazer consigo o potencial da revanche social, contrariando o processo civilizatório. Privado do mundo da cultura, o ser da multidão subsiste como "besta-fera" - para usar a expressão de Herculano - com brutalidade de quem já não se mostra capaz de ser conduzido pela clivagem da razão: "é necessário regê-lo com vara de ferro para que não se converta em uma besta-fera, ao passo que o povo ilustrado facilmente se governa, sendo ao mesmo tempo impossível oprimi-lo". ${ }^{43}$

No pensamento pedagógico de Alexandre Herculado, a sensibilidade romântica coabita com o núcleo essencial dos ideais iluministas. Conforme já explicitamos anteriormente, ao reportar-se a outros países (considerados mais adiantados) para falar de escola, Herculano recorda a lei francesa e prussiana quanto aos dispositivos concernentes à estruturação administrativa e curricular da escolarização tanto elementar quanto secundária e superior ${ }^{44}$. O significado do ler e escrever era, por suposto, a propagação de um movimento histórico imprescindível para fortalecer a riqueza nacional. Herculano sugere grade curricular apropriada a finalidades civis, urbanas e pragmáticas:

"O ensino geral elementar deve abranger: $1^{\circ}$ ) A leitura de impressos e manuscritos; $2^{\circ}$ ) A escrita; $3^{\circ}$ ) Os princípios de aritmética até a regra de três, inclusive; $4^{\circ}$ ) $\mathrm{O}$ catecismo religioso; $\mathrm{O}$ ensino geral superior deve abranger: $1^{\circ}$ ) A gramática portuguesa e os exercícios de ler e escrever corretamente, servindo de textos para leitura e temas o Novo Testamento; 20) Os elementos de história pátria e de geografia; $3^{\circ}$ ) A aritmética completa, os elementos de geometria e as suas aplicações usuais, especialmente o desenho linear e as noçōes mais necessárias de agrimensura; $4^{\circ}$ ) Os rudimentos de física e com especialidade os de mecânica, os princípios de química aplicada às artes, os elementos de botânica aplicada à agricultura e idéias gerais sobre higiene popular." 45

\footnotetext{
${ }^{42}$ Alexandre HERCULANO, Composiçōes várias, p. 40.

${ }^{43}$ Alexandre HERCULANO, Composiçōes várias, p. 59-60.

${ }^{44}$ Herdeiro da tradição religiosa do iluminismo português, é com desconfiança que Herculano avalia a escola laica preconizada pela França revolucionária, preferindo adotar o enfoque da lei prussiana, onde o aprendizado da moral estaria profundamente vinculado a um catecismo religioso, posto como primeiro guia diretor da formação da meninice.
}

${ }^{45}$ Alexandre HERCULANO, Opúsculos / Tomo VIII - Questões públicas, p. 150-151. 
Percebe-se aqui o intuito de Herculano de substituição de um sistema de escolarização propedêutico, herdeiro das humanidades clássicas, em prol de uma opção que privilegiaria o conhecimento de cunho prático. Este, por sua vez, objetivaria a utilidade social, especialmente no que concerne à agricultura e ao aprimoramento das técnicas de plantio. Em Herculano, reconhece-se a suposição da vocação agrícola de Portugal, a ser respaldada pelo necessário conhecimento da agrimensura e da botânica. O ensino de caráter politécnico apresentava-se como esperança de deter o longo período decadentista no qual o reino se enfronhara. Para Herculano, a estrutura que orientava a instrução secundária exclusivamente como fonte de preparação para a carreira universitária revelaria o descompasso de um país que não se fizera capaz de acompanhar o ritmo dos tempos: ao formar um excessivo contingente de doutores em uma terra incapaz de lidar com os desafios postos por técnicas agrícolas renovadas, Portugal não soubera identificar, na inflexão da história, o domínio que a classe média, a pouco e pouco, passaria a exercer. Fortalecer a economia nacional era, então, requisito imperativo para superar o domínio das arcaicas e desajustadas fidalguias, em um tempo no qual o reino perdera já sua grande fonte de sustentação, materializado nas riquezas extraídas do Brasil.

As escolas secundárias deveriam ser estruturadas mediante o exemplo profissional da escola politécnica, cujo projeto poderia também contemplar a própria formação de mestres de escolas primárias superiores. Em virtude disso, julgava-se proceder à "regeneração intelectual e moral do povo português. Sob tal ponto de vista, "propriedade de todos; do nobre e do humilde; do abastado e do pobre" ${ }^{46}$ - dever e direito individual e social - , a escolarização assim constituída, só não era ainda exigida à força pelas multidóes porque estas permaneciam envoltas na ignorância que lhes impedia de reconhecer a instrução como edifício por excelência da prosperidade e da "felicidade de seus filhos".

É com olhar militante que Herculano chama a si o compromisso de intelectual, engajado em seu tempo, procurando ver além dele e falando para tempos futuros. Com diversos estilos - da história à literatura ${ }^{47}$ - Herculano deixa mensagens aos contemporâneos, erigindo-se, quer pelo discurso, quer pelos atos, como líder e exemplo de geraçōes portuguesas. O Panorama - revista fundada e dirigida por Herculano em 1837 - é reconhecidamente a primeira tentativa sistematizada e de largo alcance de um periódico de cariz enciclopédico, destinado à instrução das camadas médias da sociedade portuguesa. Herculano, ao dirigir aquele periódico voltado para propagação de "conhecimentos úteis", torna-se concomitantemente diretor, colaborador e redator de seu projeto jornalístico, que, por sua vez, representou iniciativa pioneira, copiada por inúmeros outros periódicos, que viriam logo a seguir.

Herculano foi, para os contemporâneos e para a posteridade, um marco intelectual, um guia, cuja referência era, como vimos, por todos reconhecida. Como historiador, acreditava na existência de uma "índole nacional", mediante a qual se expressaria o espírito do povo e as próprias feições morais da alma de cada nação.

\footnotetext{
${ }^{46}$ Alexandre HERCULANO, Da eschola polythecnica e do collegio dos nobres, p. 11.

${ }^{47}$ Sobre os aspectos literários, Saraiva comenta que, mesmo em relação à poesia, "Herculano atribui uma função pública, doutrinária e intervencionista, e tenta dar através dela expressão à contemporaneidade, versando temas de interesse político, social e religioso." (A. J. SARAIVA e Óscar LOPES, História da literatura portuguesa, p. 742).
} 
Nessa medida, entendia o estudo da história como uma possibilidade viva de retirada de liçôes do passado, voltadas para o presente. ${ }^{48}$ Romântico em literatura, era iluminista quando abordava o problema da instrução. Seu liberalismo embaraçado negava a alternativa democrática. O substrato de seu parecer político expressava-se no modo pelo qual discorria acerca do tema da instrução pública, onde surgem com bastante nitidez - os aspectos relativos ao povo, à nacionalidade; e, ao contrário de seus escritos históricos e literários, ali ele falava inquestionavelmente voltado para o futuro. Seu modo de ver a escola e a instrução deixa-nos também preciosos rastros, tornando-se necessário, porém, percorrê-los pelos vestígios que o tempo de seus sucessores fez por revelar.

\section{A escola moderadora da avidez da leitura: António Feliciano de Castilho}

De algum modo, o problema da instrução se colocava, para os homens da política portuguesa, como uma hipótese de prosperidade. Instruir as populações rurais, que até então viviam na ignorância, significaria retomar e desenvolver a economia do país, pela irradiação de hábitos, de conhecimentos, de técnicas e inovações quanto aos processos agrícolas. Supunha-se, pois, regenerar, a partir do desenvolvimento pedagógico da nação agrícola, a própria idéia nacional. Por outro lado, temia-se que a educação das camadas menos favorecidas, pela erradicação das superstições e das crendices populares, pudesse efetivamente ocasionar uma carência ética, um vazio de valores, uma ausência de parâmetros norteadores da conduta civil. A moralidade seria, sob essa outra hipótese, ameaçada. Os protagonistas da intelectualidade e da política na época hesitavam em relação a tal escolha. Na verdade a escola era uma aposta, que poderia ou não se tornar uma correta opção de futuro. De qualquer maneira reconhecia-se que o progresso, tal como ocorrera, teria acarretado consigo a degeneração dos costumes. Urgia, pois, adequar esse progresso a uma reconstrução dos comportamentos e das atitudes valorosas, ministrando às camadas populares os 'conhecimentos úteis', que, no parecer de Herculano e Castilho, pudessem ilustrar sem corromper.

O mundo do livro parecia querer ganhar vida própria e, cada vez mais, pareciam necessárias estratégias para regrar aquela leitura. Era preciso - supunha-se - regular a cultura letrada pelo auxílio moralizador reservado à escola; instituição que, ao mesmo tempo, disciplina, modela e normatiza a ação das letras. A multiplicação do impresso ampliava o público leitor. O gesto da leitura, extensivo a novos grupos sociais, criava novas sociabilidades - "quer se considere o caráter todo-poderoso do texto e o seu poder de condicionamento sobre o leitor, o que significa fazer desaparecer a leitura enquanto prática autônoma; quer se considere como primordial a liberdade do leitor,

48 "Neste horizonte, a suposição dessa entidade metafisica chamada alma, espírito ou indole do povo, por mais cientista que fosse a sua caracterização, remetia para uma visão essencialista de história. Esta aparecia como a explicitação diacrônica, com avanços e recuos da indole da Nação, e os seus grandes ciclos são elevados a modelo, a reatualizar, por comparação e analogia, ou a evitar, quando é exemplo de desarmonia e de decadência. De certo modo, pode mesmo afirmar-se que a indole funciona como uma espécie de substância sempre onipresente à própria história, fundamento a-histórico da historicidade da Nação" (Fernando CATROGA, Alexandre Herculano e o historicismo romântico, In: A história através da história, p.69-70). 
produtor inventivo de sentidos não pretendidos e singulares - o que significa encarar os atos de leitura como uma coleção indefinida de experiências irredutíveis umas às outras" ${ }^{49}$. Perante o texto, a leitura produz sentidos próprios, significados inusitados, absolutamente independentes de quaisquer injunções que vão das intençóes do autor à ortodoxia do processo de editoração do impresso. Há, por ser assim, pluralidade de competências, de expectativas, de disposiçôes dos leitores e de comunidades de leitura: atos partilhados, seja em termos de repertório, seja no que diz respeito aos próprios significados que, por dispositivos de apropriação, vão se configurando. O tema da leitura, do livro e das práticas sociais que, à volta dele se constituíam, parece-nos estratégico para a compreensão do pensamento educacional português durante todo o período dos 'oitocentos'.

Com António Feliciano de Castilho (1800-1875), o debate educativo português ganhará novas feições. A discussão, antes centrada quase exclusivamente sobre as implicações políticas da extensão da escola para as camadas majoritárias da população, agora passará a discutir a questão dos métodos e das técnicas mais adequadas ao ensino preconizado. Castilho era poeta, bacharel em direito por Coimbra e sócio da Academia Real das Ciências de Lisboa. Foi membro do Conselho Superior de Instrução Pública e, em 1870, recebia o título de Visconde de Castilho. Sua passagem pela pedagogia consiste na publicação e na polêmica desenvolvida em torno de seu Methodo Portuguez-Castilho para o ensino rapido e aprasivel do ler, escrever e bem falar, cujas cinco primeiras edições datam de 1850, 1853, 1857 e 1908. A preocupação de Castilho com assuntos educativos centrava-se substantivamente na questão da ineficiência e inoperância da escola, tal como esta se encontrava em Portugal, e na busca de uma reinvenção metodológica que pudesse efetivamente tornar do ensino algo concorrido, algo atraente. Castilho tinha pleno domínio do poder de irradiação de sua palavra. Era um polemista; mas era também um poeta; e era finalmente um homem público de seu tempo, que, indubitavelmente, soube fazer uso de sua popularidade. Parafraseando alguém, caberia mesmo dizer que se pode ser contra ou a favor de Castilho na educação portuguesa. Entretanto jamais se permitirá passar sem sua referência. Castilho traria visibilidade ao tema da metodologia do ensino, transformando-o irredutivelmente no epicentro de sua reflexão.

Pretendendo-se também representante do espírito das luzes, em um século que convive com o efeito irradiador do projeto iluminista, António Feliciano de Castilho tanto se aproxima quanto se distancia das proposições e dos pareceres emitidos por Herculano acerca do problema da instrução. Com efeito, fala-se muito do lugar ocupado por Castilho enquanto interlocutor da Geração de 70, como interlocutor, mais do que protagonista, da famosa polêmica que a História optou por intitular Questão Coimbrã. Conhece-se, na outra margem, o Castilho pedagogo, atento para os temas atinentes à instrução, debruçado sobre seu também polêmico método de alfabetização, sonhando talvez equacionar o problema educativo com que seu tempo lhe acenava. É preciso compreender a confluência entre ambos os cenários. Em sua obra Felicidade pela Agricultura, o poeta situa a ciência como fonte imprescindível para a prosperidade da instrução. Compreendidas como a grande conquista da modernidade e

${ }^{49}$ Roger CHARTIER, A história cultural: entre práticas e representaçôes, p. 121. 
particularmente do legado da Ilustração, as verdades da ciência corriam à época expressas por folhas, textos, livros. O mundo do impresso teria alcançado profundo efeito irradiador, mediante formas inúmeras de apropriação dos temas novos que conquistavam passo a passo a cena cotidiana. Se tempos houve em que saber era privilégio e se tal imaginário permanecia como atmosfera mental partilhada, os tempos novos pareciam exigir do século XIX uma readequação de seu modo de compreender o problema da instrução popular. Na vereda do discurso, Castilho aqui se aproximaria, guardados alguns matizes, da percepção de Herculano: acreditava viver num século em que o domínio da ciência surgia como fonte de civilização e desenvolvimento dos povos; e que, na verdade, a instrução assumiria papel proeminente como contraponto desse desenvolvimento no campo das ciências, das técnicas, da cultura. Entretanto não é sem temor que se recebe esse brinde. No caso específico de Castilho, a própria construção do texto parece em si reveladora de práticas de leitura que - diziase - andavam por aí à solta.

Embora reconhecendo que "o ler, escrever e contar devem ser populares e plebeus; patrimônio geral e não privilégio; regra e não exceção, e tão rara exceção como é hoje" ${ }^{50}$, Castilho pretende efetuar procedimentos de controle sobre o que ler, como ler e quando ler... Compreendendo a habilidade da leitura como uma inestimável aquisição da humanidade, Castilho chega a caracterizar o acesso à decodificação do texto como uma tendência, uma propensão do século XIX. Para Castilho, a escola primária seria o meio socialmente controlado para regrar o efeito da leitura, trazendo equilíbrio, ponderação e bom-senso àquilo que, em princípio, seria atividade subversiva: a liberdade das vozes e indagaçôes da leitura. Em qualquer hipótese, alegre ou não, a escola deveria ser - de acordo com Castilho - minuciosamente regrada mediante procedimentos disciplinadores e moderadores da avidez da leitura. A curiosidade para imersão no território do texto é assim veementemente combatida. Não se deve ler tudo; nem ao menos ler muito. Há de se ler bem as leituras moralmente proveitosas... Para isso, que viesse a escola. Poder-se-ia desde já antecipar que, em larga medida, o discurso pedagógico português será, no século XIX, tributário desse imaginário crescente a respeito do impacto e do valor da leitura na sociabilidade e na conformação dos costumes. Ao que parece, a própria preocupação em relação à escola derivaria, essencialmente, da inquietação perante práticas de leitura que corriam sem quaisquer mecanismos de controle. A escola moderna surgiria, pois, como a instituição autorizada para o ensino da leitura.

Ao caracterizar o estado da instrução em Portugal, Castilho salienta a precariedade das instalações escolares e as dificuldades vividas pelos mestres por elas responsáveis. No parecer do poeta, do equacionamento dessa situação dependeria o progresso industrial e agrícola da terra portuguesa. Por tal orientação, ele sugere que sejam introduzidos e implementados métodos pedagógicos fáceis, claros e eficazes, possibilitando, a partir deles, o êxito do processo da alfabetização para todas as crianças. Defende também a criação de escolas normais para irradiação dos referidos métodos, bem como o recebimento, por parte do professorado, de salário condigno, à luz da utilidade social de seu trabalho e do desgaste trazido pelo penoso ofício. As escolas deveriam ser estendidas

\footnotetext{
${ }^{50}$ António feliciano de CASTILHO, Felicidade pela Instrução, p.16.
} 
e repartidas por todas as povoações, de maneira a possibilitar o efetivo acesso das crianças ao caminho do conhecimento. Finalmente, Castilho propunha "que um centro diretor da instrução pública traga perenemente Comissários volantes, de grande ilustração e zelo, a visitar as escolas, a corrigi-las, a aperfeiçoá-las em todo o sentido e a tomar conta do mérito comparativo dos professores." ${ }^{51}$ Por tal orientação, Castilho sugere prêmios, distribuição de livros gratuitos, ordenados mais condizentes com a elevada tarefa social do professorado e construções de escolas como estratégia de consolidação de um sistema mais aperfeiçoado de instrução. Os gastos seriam cobertos mediante cobrança de tributos especiais, supondo, por custo de oportunidades, a supressão de outros gastos, por vezes mais vultuosos e sem dúvida mais supérfluos. O montante arrecadado por heranças vacantes, por exemplo, bem como os fundos de loterias, passariam a integrar essas verbas específicas destinadas à instrução. Além das escolas regulares, deveria haver "escolas ambulantes para os povoados pequenos; professores nômades, bem estipendiados, que vão de terrinha em terrinha dando o seu curso do mais indispensável das matérias primárias, por exemplo, o ler, escrever e contar" ${ }^{52}$.

Castilho propõe - como complemento da enorme tarefa cultural que a escola cumpriria - a fundação, nas vilas e aldeias, de escolas só para adultos, de maneira a preencher instrutivamente as horas de serão dos dias de trabalho, bem como as manhãs e tardes de domingo e dias santificados. Os objetivos de tal iniciativa eram explicitamente catequizantes e moralizadores. Desse modo, "o camponês, depois de cultivar a terra, cultivará o seu espírito; depois de ter dado à sua pátria riquezas físicas, dar-se-lhe-á a si próprio, melhorado, que é riqueza moral muito maior" ${ }^{53}$. Nessa dimensão, atribuía-se à composição escolar a tarefa instrutiva de desenvolvimento de habilidades e de capacidades. Porém, mais do que isso, a escola agiria como local de agregação, de coesão social, de transmissão de toda uma teia de valores e de significados morais, cuja preservação e reforço eram postos como necessários ao desenvolvimento da nação, compreendida esta como um coletivo dotado de identidade moral. No parecer de Castilho, era imprescindível atentar para a idoneidade dos mestres, condição primeira para o exercício do magistério. A preocupação com a moralização do ofício da instrução suporia também a frequência periódica a cursos especiais de moral, decência, direito político e jurisprudência.

O valor atribuído ao sexo feminino vem, no caso, condicionado às relações sociais: a mulher deve ser educada porque será esposa, mãe, educadora e vizinha do homem... Não é por valor autônomo, mas por relação a 'outro', que se deverá instruir a mulher. Seja como for, Castilho deposita na escola o papel de regeneração dos vícios e corrupção do tecido social. Chega, em vista disso, a propor criação de escolas nas cadeias, com o fito de deter vícios e corrupções que nelas se concentrassem. O caráter sacralizado de que se reveste o lugar institucional da escola primária seria diametralmente contraposto à situação presente na escola portuguesa: ineficaz e morosa. Castilho

${ }^{51}$ António Feliciano de CASTILHO, Felicidade pela Agricultura, p.48. Com uma inspeção regular, poderiam ser aferidos os progressos da instrução, de modo que "nos nove meses letivos, cada professor haverá dado, sob pena de grave multa em seus vencimentos, dois terços pelo menos dos seus alunos prontos no ler, escrever, contar, nos rudimentos religiosos, nos da civilidade, nos da gramática portuguesa, e nos da higiene.” (A. F. CASTILHO, Felicidade pela Instrução, p.21)

${ }^{52}$ António Feliciano de CASTILHO, Felicidade pela Agricultura, p.49.

${ }^{53}$ Id.Ibid., p. 50. 
comenta o estado do ensino e as possibilidades de remediá-lo. Ao criticar a situação das escolas, ele pretendeu criar o método; e, com ele equipada, a instrução portuguesa caminharia, de maneira irrevogável, em direção à perfeição. Em seus escritos sobre a situação das escolas, Castilho se solidariza com o magistério português, de quem não se poderia nada exigir naquelas condições pouco alentadoras.

Ao explicitar a crítica à escola de seu tempo, Castilho não se contenta, entretanto, com a denúncia dos aspectos materiais. Pelo contrário: adentrará e explorará largamente o problema da inadequação dos métodos como verdadeiros óbices aos progressos da instrução e, consequentemente, da própria civilização. Em um dos textos onde abarca o tema da escrita, Castilho buscará apresentar quase uma genealogia do ato de ler, explicitando sua concepção evolucionista perante o desenrolar das sociedades do século XIX. De fato a própria História, pela narração de Castilho, adquire conotação nitidamente teleológica, percorrendo estágios infantis e adolescentes, até finalmente adquirir o estatuto avançado que lhe confere a era da escrita - "escrita, que é para as palavras o que o falar é para as idéias" ${ }^{4}$. Essa percepção da escrita como manifestação gráfica da fala será muito cara à pedagogia portuguesa de meados do XIX.

Declarando objetivar a popularização do ler, escrever e contar, Castilho produzirá um método de alfabetização, introduzindo nele elementos que pretendiam ser, não apenas inovadores para o caso português, mas - mais do que isso - absolutamente contrários ao que corriqueiramente se vinha fazendo na escola. Para tanto, ao pretender fundar o novo absoluto, a própria acepção de escrita deveria ser substantivamente alterada. A competência da leitura é compreendida como posterior e derivada da habilidade da fala, posto que supõe a compreensão do valor da linguagem. Isso significa que, ainda que se pretendesse renovador, o método Castilho supunha o aprendizado da escrita posteriormente à aquisição da leitura, tal como ocorria cotidianamente no interior das escolas portuguesas. Para Castilho, haveria inclusive uma anterioridade lógica da leitura sobre a escrita. A leitura seria tão mais racional, natural e fácil quanto fosse eficaz o processo de mnemônica para a fixação dos valores sonoros contidos na figura das letras. Ora, se na compreensão de Castilho o segredo da língua reside na sonoridade das letras, estas situavam-se como o princípio mesmo da alfabetização. Criticando os modos tradicionais de proceder à soletração, Castilho atribui à nomenclatura do alfabeto as dificuldades no aprendizado do ler. Seu trabalho, então, centrar-se-á no estudo do método. O pressuposto que norteia os escritos de Castilho é o da dependência entre os pares ler-escrever e escrever-falar, onde o ler se subordinaria ao escrever e a escrita estaria subordinada à fala; daí a suposição de todo o processo da leitura remeter-se à fala.

A primeira edição do método intitulado Leitura Repentina vem a público em 1850 , já recorrendo a certos artifícios editoriais para buscar uma antecipada celebridade ${ }^{55}$.

\footnotetext{
${ }^{54}$ António Feliciano de CASTILHO, Noções rudimentares para uso das escolas, p. 82.

55 De facto, a epígrafe da primeira edição do Método de Castilho buscará direcionar a leitura e o leitor, afirmando de maneira ortodoxa a eficácia do mesmo método, que não se assemelha a nenhum outro, que desde logo não é um, mas o método. Nos termos de seu criador, "os que houverem meditado, repetirão o que a experiência declarou: que, de todos os métodos conhecidos, é este o eficacíssimo" (A. F. CASTILHO, Método Portuguez-Castilho para o ensino rapido e aprasivel do ler escrever e bem falar, p.13).
} 
Castilho, nesse começo, declarou ser o seu método uma adequação do método de Lemare, adaptado do francês para o português. Seria então de Lemare a ideia de memorização do som das letras através de imagens que a ele se ligassem, bem como a identificação em cada palavra das letras cuja união a compõe. Reconhecendo ser de Lemare a autoria e, portanto, a "glória da invenção", Castilho reivindicaria para si nessa primeira edição de seu método a adaptação, posto que, ao adotar a idéia fundamental, necessitara refazer a invenção, "criar quase tudo de novo" 56 . Com tal alegação, Castilho pretende se tornar o arauto da causa da instrução em língua portuguesa, demarcando suas distinções e revelando inúmeras estratégias de ensino supostamente imprescindíveis para o êxito de seu método. Sem dúvida, quando pensa o tema da leitura, Castilho acredita ser a escola o local de produção dessa competência partilhada. Por outro lado, ao debruçar-se sobre questões de método, pretende institucionalizar sua descoberta. É assim que a segunda edição do método, datada de 1853, e dedicada a "Sua Alteza Imperial - O Príncipe D. Pedro" altera o título original, apresentando-se agora como Método Castilho para o ensino rápido e aprasivel do ler impresso, manuscrito e numeração; e do escrever: obra tão própria para as escolas como para o uso das famílias. O então já conhecido Método de Leitura Repentina não obtivera àquela altura o sucesso pretendido pelo criador.

Ao travar interlocução com os homens de imprensa, Castilho revela a pretensão de se apropriar da opinião pública, apresentando ele mesmo sua obra como se de um ato civilizatório se tratasse. Sugerindo aos jornalistas que persuadissem o povo a apreciar seu trabalho, Castilho demonstra seus interesses editoriais, bem como o sonho de posteridade prematura. É através de Castilho que o tema da educação portuguesa adquire, para o grande público, coloração metodológica. Não se tratava apenas de discorrer sobre os benefícios da instrução. Isso era já insuficiente. Não se tratava tampouco de conquistar a opinião pública para erguer a escolarização. Tratava-se, isso sim, de fazer repercutir um modelo alternativo e posto como infalível para edificar os alicerces de uma nova escola; ainda que para um velho país...

"Cada escola deveria ser, quanto possível, espaçosa, clara, arejada, mobilada e abastecida
de todo o necessário, tendo cômodos para a residência do Mestre e um terreiro ou pátio
com suas sombras verdes para espairecimento dos alunos, e, nos dias formosos, até para
ali se darem liçóes. Uma aula assim, humana e hospedeira por dentro, por fora risonha e
convidativa, contribuiria admiravelmente, e melhor que raciocínios e exortaçôes, para que
o povo confluísse a se instruir. Não há vício que não empregue em seu favor as artes da
sedução; por que não há-de uma nação seduzir-se a si mesma para se civilizar?"

Castilho deseja garantir a eficácia da instrução. Seu método quer, antes de tudo, persuadir corações e corpos infantis, adquirindo credibilidade pela confiança das crianças a que se dirige. Com o propósito de ensinar pela sedução, Castilho dirige-se às salas de aula. E, para elas, acreditava apontar leis capazes de reger o processo lógico do aprendizado da leitura. Preocupado com a escuta da linguagem das palavras

\footnotetext{
${ }^{56}$ António Feliciano de CASTILHO, Methodo Portuguez-Castilho...,p.19.

${ }^{57}$ António Feliciano de CASTILHO, Felicidade pela Instrução, p.31.
} 
faladas, Castilho parte da oralização, compreendendo que este nível precede o ato da escrita. Acerca disso, dizia ele que a voz do homem, antes de expressar o pensamento, seria um desdobramento das afeiçóes e do ânimo. Pelas palavras, poder-se-ia averiguar o corpo da frase, perscrutando nele as inflexôes da alma. Ainda no prólogo da segunda edição de seu método, Castilho destaca como achado seu a verbalização da fala. Ao buscar refazer a história do método e de seus postulados, o autor salienta, à partida, que "as verdades mais óbvias são às vezes as últimas que se acham" ${ }^{58}$. Em sua perspectiva, da arte da fala se haveria desmembrado a possibilidade da escrita, em torno da qual, posta a necessidade de comunicação do ser humano, cria-se o hábito da leitura. Por ser assim, qualquer movimento do aprendizado do ler e escrever passaria, no entender do poeta, necessariamente pela oralidade.

Com Castilho a reflexão sobre o ensino adquire dimensão técnico-pedagógica, onde o que está em jogo é a descoberta de instrumentos e estratégias de ensino diferenciadas e singulares em relação ao que corriqueiramente se costumava fazer. Ao vozear as letras, Castilho supõe alterar a própria acepção de método e, quem sabe, de leitura. Compreendendo que a habilidade da leitura deriva da competência da fala, o método de Castilho, que se pretende explicitamente simples, eficaz e rápido, combina, analisa e disseca sons da palavra falada, decompondo-a em seus elementos fônicos e recompondo-a na sua totalidade de significado. É para tanto que Castilho sugere práticas entrelaçadas de decomposição das palavras em letras, atribuindo a estas a sonoridade que lhes seria original, para reconstituir, no final, a lógica da palavra inteira.

A bem dizer, em nada nos importa a polêmica a propósito da originalidade ou não de Castilho face ao método de ensino desenvolvido por Lemare. Importa salientar, isso sim, em que medida se cria em solo português um novo discurso pedagógico para situar o tema do ensino das primeiras letras. Além disso, caberia indagar às fontes qual o impacto e a repercussão desse novo olhar lançado para o problema. De certo modo, parece-nos inegável o fato de ter havido aqui a força persuasiva de um estilo obstinado pela criação do fato. Ao abordar a trajetória de Castilho, a historiografia da educação em Portugal, por vezes, assume o discurso da própria fonte. Em alguns casos, retoma-se o teor argumentativo da vertente crítica expressa na Geração de 70. Com sede explícita de posteridade, Castilho é perigoso... Há sempre ardis na construção de seu texto tendentes a pontuá-lo e à sua biografia como o apóstolo da instrução renovada e renovadora. Porém parece-nos inegável o delineamento de questões que, embora pudessem afligir os entusiastas da escolarização, não costumavam ser expostas com tanta veemência, como é o caso do uso imoderado da palmatória, por exemplo. Sob tal aspecto, inegavelmente Castilho foi contundente, mesmo que, na construção de seu discurso, o método se tivesse caracterizado como dispositivo único e irrepreensível para remediar os males da instrução, colocando-a a postos, no caminho das multidões. É assim que Castilho atenta prioritariamente para aspectos concernentes à eficácia do método, naquilo que compreende ser a tarefa de reconstrução da escola. A esse respeito - segue o autor - era preciso começar pelo aprendizado da pronúncia, dado que a arte da fala seria, dentre as três formas de comunicação verbal, a primeira e fundamental. A partir dela, alguns elementos deveriam ser considerados: a índole particular da

\footnotetext{
${ }^{58}$ António Feliciano de CASTILHO, Methodo Portuguez-Castilho, p.48.
} 
infância, a amenidade e clareza do método, a economia de tempo, o ritmo, a simultaneidade e a agilidade do aprendizado ${ }^{59}$.

Pelas palavras de Castilho, reconhecemos o perfil do professor, nessa exaltação do modo de ensino simultâneo. $\mathrm{O}$ ensino simultâneo era apreendido como fator decisivo para obtenção do êxito da escolarização primária. "Ensinar a todos como se eles fossem um só” era, para Castilho, o principal desafio pedagógico do século XIX, século de edificação das grandes redes públicas de escolarização. $\mathrm{O}$ modo simultâneo de ensino coletivo era posto como o segredo de uma pedagogia que pretendia encontrar cientificamente um "método universal de ensinar tudo a todos". A busca do método aliava-se a estratégias variadas capazes de adequar, de maneira ordenada e disciplinada, a distribuição ritmada e compassada do tempo e dos horários, do espaço e dos segredos de sua distribuição; e nesse controle do tempo e do espaço - que só o modo simultâneo efetivamente possibilitaria - estaria contido o grande segredo da relação do ensino-aprendizado: o aluno, tido por único ser moral, sendo vários, era um só, apreendido pelo singular naquela atmosfera eminentemente coletiva. Nessa direção, as estratégias indicadas combinariam atividades de canto, de palmas, de marchas, com o objetivo precípuo de transformar o heterogêneo, variado e desagregado, em uma totalidade uniforme, normatizada, mecanicamente regulada por um único regente da orquestra escolar: o mestre...

Existiria assim uma forma escolar que mobilizaria por conhecimento e afeto a conduta disciplinada e organizada dos estudantes, tomados aqui como série, em uma acepção classificatória e orgânica. Haveria, no ritmo e na disposição do tempo e dos espaços rotineiros da vida escolar, toda uma arquitetura da "classe", pela projeção de um eficaz ensino coletivo. O ritmo compassado apresentar-se-ia como estratégia para conformação desse tão visado modo simultâneo de ensino. Este, por sua vez, cumpriria o papel de reinventar o método de ensinar a ler e, a partir dali, readequaria, até onde Castilho entendia, o estado das "letras" em Portugal. Por sua metodologia, a letra escrita deriva e desdobra-se da palavra falada que, por essa razão, deveria vir à frente do processo de ensino da leitura. Pelo fato de o objeto da leitura ser a palavra, esta deveria ser decomposta para que o aluno procedesse ao reconhecimento de seus elementos sonoros correspondentes aos valores da escuta das letras. A essa "biforme repetição do mesmo processo", Castilho deu o nome de "leitura auricular alternada" ${ }^{60}$. Na escola portuguesa era comum a sobrevivência de padrôes individuais para o ensino da leitura, que, pouco a pouco, viriam a ser substituídos pelo modo simultâneo. Poder-se-ia mesmo arriscar dizer que todo o século XIX português teria sido um grande esforço de objetivação e implantação dos alicerces do ensino simultâneo. Aliás, sabe-se que essa é uma das marcas da escola

\footnotetext{
${ }^{59}$ Era muito comum naquela época o princípio da brevidade do método ser pontuado como um dos objetivos precípuos do modelo de aprendizado expresso em compêndios. A ideia de um ensino ágil evidencia-se, não apenas em prefácios, mas nos próprios títulos de alguns manuais escolares, como é o caso do Methodo facillimo para aprender a ler tanto a letra redonda como a manuscrita no mais curto espaço de tempo, de E. A. Monteverde. Castilho, como se percebe, não foge a essa orientação de seu tempo. Posteriormente, quem discordará dessa orientação será João de Deus, que, em seus escritos proferirá parecer contrário a esse tendência, quase generalizada na época, de valorização excessiva do tempo curto para o aprendizado, insistindo na idéia de que a rapidez não seria a única vantagem de um bom método de ensino.
}

${ }^{60}$ Id. Ibid., p. 98. 
moderna: o ensino que regra temporalidade e espaço, com vistas a favorecer, agilizar e otimizar os resultados do aprendizado coletivo. Não se pretendia ensinar a um aluno. Desejava-se saber ensinar o grupo-classe. A própria diversidade de material manuscrito e impresso trazido pelos alunos para a sala de aula era reveladora dessa dificuldade da estrutura escolar quanto à normatização de um padrão uniforme de ensino coletivo. Embora todo o século XIX português atentasse para a urgência de resolução desse problema, o ensino simultâneo só vigoraria com certa representatividade no último quartel do século. Aqui, sem dúvida, nós ainda estaríamos em um momento anterior, preso à individualização do aprendizado da leitura. Embora já se tenha anotado que a escrita é a língua da escola ao passo que a linguagem familiar pauta-se pela oralidade, o professor em Portugal valia-se de sinais que expressavam o valor utilitário da escrita no cotidiano das pessoas e dos ofícios. Para tanto, o mestre-escola mandava "cada discípulo trazer qualquer papel de letra de mão: uma folha de um processo, um rol da tenda, uma carta de uma cozinheira, quase sempre sem pontuação, sem ortografia de espécie alguma, sem o mínimo laivo de senso comum" ${ }^{61}$.

Se Herculano condicionava sua defesa da instrução à existência de uma escola primária superior e complementar àquela restrita ao ensino de primeiras letras, Castilho também atrela seu parecer político sobre o tema da escolarização. Defendia, sim, a extensão do acesso às oportunidades educacionais, mas, concomitantemente, idealizava a criação de um novo e diferente modo de ser escola. A forma escolar aqui propugnada não caberia nos antigos moldes e tradicionais modelos, os quais engessavam e perenizavam a instituição no que ela tinha de velho. A utopia do novo e da inovação fazia parte da obsessão do pedagogo reformador. As alterações previstas principiariam pela própria forma de olhar para a tarefa do professor... Mas, além disso, como vimos, sugeria-se um modo alternativo de se perceber a dinâmica do aprendizado da leitura. Finalmente a reinvenção do que Anne Marie Chartier denominou de "fazeres ordinários da classe", mediante o entrecruzar de atividades ritmadas e compassadas, capazes de reorganizar o habitus, a rotina, o próprio cotidiano das salas de aula. ${ }^{62}$ A dimensão emancipadora tributária do discurso das Luzes quando fala de educação subordina-se, com Castilho, à adoção de seu projeto escolar. Isso significa dizer que Castilho não quer aquilo que denominava escola antiga; Castilho defende exclusivamente a escola que nasceu de sua pena. Aliás, segundo ele, essa seria a única instituição pedagógica assente em bases naturais. Sob tal convicção, o autor sente-se à vontade inclusive para propor modificações quanto ao mobiliário escolar, tendo em vista alterações na dimensão física da sala de aula.

${ }^{61}$ António Feliciano de CASTILHO, Methodo Portuguez - Castilho, p. 105.

${ }^{62}$ Nas palavras da educadora: "esse fazer ordinário da classe não possui estatuto algum no discurso de transmissão do saber profissional efetuado pela instituição escolar. Com efeito, ele é largamente ignorado nas instituições de formação que, durante toda a sua história, parecem menos preocupadas em transmitir tais práticas elementares do que preconizar a renovação das condutas pedagógicas ou didáticas, Deverá isso ser abandonado ao 'ver fazer e ouvir dizer', às transmissões invisiveis que se fazem nesse terreno (...)? Seria essa efetivamente a parte oculta do iceberg?" (Anne Marie CHARTIER, Les faire ordinaires de la classe: un enjeu pour la recherche et pour la formation, Faculdade de Educação da USP, manuscrito, p. 12) 


\section{O poema educacional de António Feliciano de Castilho: fazer-se classe no coletivo}

A atividade da escrita deveria vir acompanhada por um dado conjunto de atitudes e comportamentos agendados pela escola para os futuros adultos, em que se transformaria a presente infância. Por tal razão, par e passo com o aprendizado da leitura e da escrita, estipulam-se ensinamentos de toda uma moralidade de cariz religioso, que, embora seja, por definição, incompatível com o conhecimento, estrutura-se como protagonista dos saberes elementares da escola. Desse modo, os conteúdos internos à alfabetização serão expressos, usualmente, mediante preceitos de Doutrina Cristã, Civilidade, Higiene - componentes substantivos do feitio típico dessa primeira escolarização. O método de Castilho, prevendo situações antepostas à realidade, conjectura, inclusive, abolir "malquerenças" entre mestres e discípulos, favorecendo nesses últimos a aceitação do ambiente escolar, além da orientação das atividades de leitura através das quais pudesse haver a interiorização de hábitos de mnemônica, acentuação e pronúncia, necessários ao desenvolvimento cognitivo. Da leitura auricular às figuras que recordam letras, das "inflexões da pontuação", aos cantos e palmas, obter-se-ia o "contentamento de quem aprende..." 63

A partir do conjunto de conhecimentos iniciais básicos, a escolarização procederia a um aprofundamento enciclopédico a partir do estudo de inúmeras áreas, tomadas como imprescindíveis para a formação das gerações novas. O conhecimento escolar, que parece ser em cada época o modo como a escola se apropria dos níveis de cultura de seu tempo, surge na história como se de uma opção se tratasse. No caso da escolha de Castilho teremos o seguinte elenco: Física, Geometria, História Natural, Química, Economia Doméstica, Jurisprudência, História Universal, História Sagrada, História de Portugal, Música, Desenho. Evidentemente esse conjunto disciplinar representava, na estrutura do currículo planejado por Castilho, uma continuidade do estudo aprofundado da Aritmética e da língua materna, em sua normatividade gramatical.

Verifica-se aí o modo pelo qual Castilho concebe a interface das matérias, ainda que não propusesse grandes novidades à guisa de conteúdos programáticos. O diálogo do pedagogo com o que acreditava ser a escola velha aparece de maneira recorrente em seus escritos. Acerca disso, julgava Castilho que seu modo de ensinar era original desde o processo de decifração das letras. Ao contrário dos procedimentos tradicionais, a letra é nomeada pelo som, que teria no vocábulo, em um modelo de soletração moderna, a originalidade que Castilho parecia querer reivindicar. Cada letra seria associada a uma respectiva história, vindo acompanhada pela figura geradora, a qual, por sua vez, ficaria, pela mnemonização, gravada na mente do aprendiz. Cabe recordar que o método dito "português" foi bastante criticado a seu tempo, particularmente por professores presos ao tradicional modelo de ensino, o qual Castilho passaria a designar como "adversário". O método inventado pelo poeta era, pelos oponentes, taxado de pueril, de dispendioso, de trabalhoso - não factível, portanto, para escolas de um único professor. Castilho, de modo recorrente, compra a polêmica, tentando persuadir os professores no reconhecimento das virtudes postas

${ }^{63}$ António Feliciano de CASTILHO, Felicidade pela instrução..., p.124. 
inclusive naqueles que eram, à partida, os aparentes defeitos do Método. A premissa básica, nesse assunto, pautava-se na necessidade de o mestre fazer-se menino para se recordar: "o mestre, que já foi menino, que lida com eles e os deve conhecer, pode (sem se desautorizar) nivelar-se até certo ponto com a infância; enquanto a infância, que nunca passou, nem pela austeridade da velhice, nem pela circunspecção da virilidade, não pode deixar de ser aquilo que Deus a fez." ${ }^{64}$

Em sua trajetória pedagógica, Castilho soube identificar e contrapor-se aos argumentos de seus adversários. Costumava, em suas polêmicas, apropriar-se das premissas do interlocutor, tomando-as para si em um ato de inversão, para, a partir delas, alcançar o argumento capaz de calar a oposição. Essas peças de retórica podem ser constatadas nos escritos reunidos sob os títulos de Ajuste de contas com os adversários do Método Português e Resposta aos novissimos impugnadores do Método Português. A primeira trata-se de um discurso de Castilho em novembro de 1854 , na sala da Philarmónica de Coimbra. O público a quem ele se dirigia era constituído por professores régios e particulares, por estudantes e, segundo consta, por lentes da Universidade. Referenciando-se por essa mocidade acadêmica, o poeta apresenta seu método como a "carta de alforria da puerícia", a alavanca de obtenção da emancipação intelectual do povo, através de seu aprimoramento moral, civil, religioso, intelectual e político. Tais seriam os objetivos manifestos para o âmbito da escolarização primária. O segundo texto - datado de 1855 - consiste na argumentação de Castilho contrariando a resposta que a Comissão de Professores - ao acatar o desafio do poeta - teria encaminhado sobre a comparação entre o Método Português e o antigo procedimento pedagógico em vigor nas escolas primárias. Sempre pronto para o debate e decidido a desmascarar os senões dos adversários, Castilho, aceitando e já respondendo aos "provocadores", apresenta, a dada altura, um "inventário de tudo quanto até hoje tem constado haver-se dito, escrito ou impresso contra o Método Português". Já com fama de ditador em matéria de educação - "crê ou morre" era sua tácita insígnia - Castilho era criticado por haver, no parecer de seus opositores, transformado a escola em um território de experimentações pedagógicas, negando com isso, não apenas as tradiçôes da Pedagogia, mas também as próprias tradiçôes nacionais, posto que teria pretendido inclusive alterar os padrôes ortográficos da língua portuguesa. Dizia-se mal também da busca da rapidez no processo de alfabetização, sob a alegação de que "se se aprende depressa, também se há de esquecer depressa" ${ }^{65}$. Apresentava-se como outro inconveniente do Método a prioridade do canto, das palmas, do ritmo, já que isso, a despeito de aliviar o enfado da infância em relação à escola, não a predisporia - pela mesma razão - para as "durezas da vida", além de não prepará-la para estudos posteriores. Castilho desdenha dos que recusam o ensino simultâneo. A leitura escolar precisaria ser feita em coro, com atividades ritmadas dotadas de nítida conotação disciplinadora, bem como as demais atividades previstas para um grupo-classe. Como fazer isso, entretanto, naquelas escolas que, a cada dia, recebiam novos estudantes, não possuindo turmas uniformes de alunos de mesma idade e nível de aprendizado similar? Essa questão, quando se contrapôs às respostas que os professores deram aos

\footnotetext{
${ }^{64}$ Id. Ibid., p. 110.

${ }^{65}$ António Feliciano de CASTILHO, Ajuste de contas com os adversários do Método Português, p. 20.
} 
quesitos por ele apresentados à quisa de comparação de seu método com o da escola antiga, Castilho comenta pela ilustração: trata-se, no caso, de uma mãe quando, pela primeira vez, leva os dois filhos à escola antiga...

"À porta da escola antiga, pára, limpando o suor, e espera para entrar, que se conclua uma execução estrondosa, que lá dentro se está fazendo. Ressoam promiscuamente os estalidos dos golpes, os ais e implorações do paciente, os impropérios, e ainda as ameaças, do juiz-algoz. Aperta as mãos dos seus dois pobrezitos, e mais ternamente a do que lhe há-de ficar ali. Entram enfim. De quanta virtude não há mister o nosso assisado analfabeto, para levar a cabo o seu propósito! Tudo o que vê, lhe repugna; de toda parte assombra a sujeição servil, a desconfiança mútua, o desamor e a aversão." 66

A função moralizadora da escola de primeiras letras, tão ressaltada pela recente historiografia da educação, é finalidade explícita da instituição. No caso de Portugal do século XIX, pretendia-se uma escola unificada, capaz de forjar hábitos de religiosidade, urbanidade e, consequentemente, disciplina social. Porém, a todo o momento, deparamo-nos com o depoimento dos contemporâneos, queixosos do estado da instrução, descrevendo e relatando uma escola que não se mostrava capaz de cumprir tal tarefa que lhe fôra, à guisa de projeto, designada. Castilho procura situar-se sempre como o arauto de uma nova era, na qual a escola transformada possibilitaria maneiras renovadas de olhar para a etapa da infância. Insistindo em sua argumentação pedagógica, o autor do Método Português apresenta a causa da educação como uma obra de arte a ser edificada; de todos os seus poemas, o que ele mais intensamente teria amado. De fato, Castilho parece pretender, na entrelinha, o reconhecimento como pedagogo de um talento que, enquanto poeta, não teria sido, a seus olhos, suficientemente reverenciado.

Em sua tarefa de reflexão sobre o método, Castilho crê atribuir racionalidade àquilo que anteriormente se fazia sem regras, "ao acaso e à toa" ${ }^{67}$. Contrapõe a estrutura lógica de seu projeto à dinâmica anteriormente ultrapassada e desconexa do que caracteriza por "escola velha", na qual professores sem orientação agiriam por sucessivos ensaios e erros, na atividade pautada exclusivamente pelo critério da rotina e da imitação de modelos que, com o correr dos tempos, vinham se tornando cada vez mais antigos. Castilho realmente foi precursor, ao pretender inventar ritos, regras e padróes de eficácia para uma escola portuguesa que, até então, caminhava pautada pelo acaso, pela indeterminação, pela inconstância de um cotidiano pouco sistemático e quase alheio às prescrições normativas. Também sob esse aspecto, o antigo método deixava a desejar. Em última instância, Castilho pretendeu transformar o corriqueiro savoir faire de uma escola que sequer sabia dizer porque fazia isso e não aquilo em um corpo de conhecimentos, dotado de uma estrutura e de uma normatividade que lhe seriam próprias: um conhecimento especificamente escolar. $\mathrm{O}$ poeta atribui à escola finalidades mais amplas do que ela própria: esse saber interno e específico da escolarização deveria ter, por definição, estirpe civilizadora.

${ }^{66}$ António Feliciano de CASTILHO, Resposta aos novíssimos impugnadores do Método Português, vol. I, p.81-82.

${ }^{67}$ A. F. CASTILHO, Resposta aos novissimos impugnadores do Methodo Portuguez, vol. II, p.145. 
Confiante no sucesso de seu método, Castilho reconhece que uma das críticas possíveis decorreria do alcance de seu êxito, com a consequente diminuição do tempo escolar: "se aprenderem depressa - diz-se - como se hão-de depois as famílias livrar das crianças, que até agora se mandavam para as escolas?" ${ }^{8}$ Sob esse aspecto, Castilho compara o efeito da boa escola ao da vacinação, que, fazendo com que as crianças vivam, certamente possibilitará o acréscimo de trabalho dos pais e da sociedade para com elas. Para o criador do método, a escolarização, além do mais, era alvo de um receio social: "não convém derramar prodigamente a instrução pelo povo. Para que é este empenho de pôr todo o povo a ler, se ele não tem quê, nem com que o compre?" ${ }^{69} \mathrm{~A}$ época parecia compactuar com um 'fascínio pânico' pelas práticas de leitura, e a mesma escola que é propalada como a regeneradora da nação é temida como foco de subversão do tecido social. A idéia de uma instrução que desorganiza os espaços, engendrando a negação de quaisquer trabalhos manuais e trazendo confusão à estabilidade dos ofícios e dos lugares previamente determinados, permeia esse imaginário. Enfim, o conhecimento, ao ser irradiado pela via da escolarização, poderia ser uma arma ameaçadora das próprias instituiçôes. Castilho procura fugir do impasse, respondendo às possíveis nefastas consequências da leitura de livros impróprios com a prescrição de outras leituras, de outros textos, adequados à tarefa formadora da escolarização. O livro era já um suporte acessível, que circulava pelas aldeias, vilarejos e cidades. Enquanto artefato, não estava sob controle desta ou daquela autoridade. Não conviria concorrer, pois, com o efeito dos progressos da ciência e da técnica. Havia de se adequar os tempos e as novas necessidades sociais a essa situação que, no decorrer do XIX, parecia cada vez mais irreversível.

A civilização fazia-se, no discurso, por obras; urgia providenciar leitura para que se procedesse à tarefa redentora da escola primária: a escola que moraliza, civiliza, ensina a ler e a ser... A leitura escolar, prefixando a própria "forma escolar", dever-se-ia mostrar reveladora de um universo valorativo que, até certo ponto, estaria agendado, antecipando-se, pela pauta da escola, à realidade. Em qualquer hipótese, Castilho oferecia a possibilidade de instrução também para os adultos; e pela sua cara Revista Universal Lisbonense:

"Curso público e gratuito de leitura e escrita repentina pelo método de A. F. de Castilho e de caligrafia pelo sr. D. Pedro Sebastiá e Vila. - Este curso já anda anunciado em todos os periódicos de Lisboa e para o qual se continuavam a receber matrículas no palácio do Sarmento, rua dos Navegantes á Estrela, há de se abrir infalivelmente no dia 15 do corrente julho ao escurecer. São admitidas a frequentá-lo pessoas de qualquer sexo e idade, tendo por isso de se dividir a totalidade dos discípulos em três turmas para polícia moral e boa ordem no ensino, a saber homens, mulheres e crianças. Admitem-se igualmente a presenciar os trabalhos quaisquer senhoras e cavalheiros." ${ }^{70}$

\footnotetext{
${ }^{68}$ António Feliciano de CASTILHO, Ajuste de contas com os adversários do Méthodo Portuguez, p.55.

${ }^{69}$ Id. Ibid., p.24.

${ }^{70}$ REVISTA Universal Lisbonense, 2 série - tomo 5,1852-1853, p.11.
} 
Sobre o mesmo curso de 'leitura popular', oferecido na casa em que Castilho residia, anuncia-se posteriormente que o acesso teria sido restrito aos 'alunos dóceis' $\mathrm{e}$ às pessoas munidas de senhas. Estas só seriam entregues com a condição de a pessoa assinar nome e morada em livro próprio para esse registro, devendo, ainda, portar-se com 'decência e urbanidade'. ${ }^{71}$ Com esses cursos de Leitura Repentina, Castilho conseguia certamente boa divulgação, por periódicos da época, de seu novo método, conquistando efetiva notoriedade através desse concreto efeito irradiador de suas idéias. O curso certamente não era tão aberto assim, posto que - como assegura a Revista Castilho teria pleno controle do acesso, à entrada.

A polêmica enfrentada pelo Método Castilho de Leitura Repentina evidencia a dimensão política do discurso educacional. Castilho, ao comentar assuntos de educação, tocava nas grandes feridas da escola portuguesa. Ao contrário da maioria dos intelectuais que lhe eram contemporâneos ou antecessores, Castilho desejava remeter o problema para além das questôes correntes no discurso de defesa da escola. Por que a escola propugnada não existia na realidade? Quem era a verdadeira escola portuguesa sobre a qual pouco se dizia? Por que as populaçōes não procuravam devidamente os benefícios da instrução para os seus filhos? Que tipo de castigos eram empregados pelos professores? A facilitação do aprendizado produziria como efeito imediato o desejo pela instrução. Para isso, havia de se alterar o método; tornar a escola um local de prazer. Castilho inova quando advoga a necessidade de subversão do espaço escolar. Para ele, a defesa da escola estaria condicionada à sua transformação. Por sua vez, a transformação exigiria adoção do novo método.

Como observa Luís Albuquerque, ao criar seu método de alfabetização, Castilho efetuou intensa campanha junto à imprensa e autoridades da época, tendo em vista a consagração da sua Leitura Repentina como método oficial e único do ensino das primeiras letras em escolas portuguesas. Pode-se mesmo dizer que Castilho intitula de velho tudo aquilo que não corresponde à metodologia que criara e que supunha ser única. Contrapondo-se ao que entendia ser o ensino catequético da escola então existente, é com os saberes dessa escola, com o conteúdo da cultura escolar, que o poeta irá dialogar. Para Castilho a prática do ensino da caligrafia consistia em atividade vã e nociva, na medida em que, ao contrário do que se poderia supor à época, esse escrever primoroso nada teria a ver com a necessária legibilidade de uma escrita clara e corrente. Assim o campo da caligrafia não faria parte - no entender do poeta da índole da escola primária. O povo, da escola primária esperava "o ler claro e fácil, o escrever fácil e claro, o calcular exato e pronto" ${ }^{72}$. O resto era supérfluo.

O poeta apresenta como dificuldade maior da alfabetização em língua portuguesa a pequena correlação entre a escrita das letras e sua leitura, chegando a propor sugestões quanto a uma modificação ortográfica da língua, de modo a facilitar a alfabetização pelo método que criara. Talvez nisso residisse parte do intenso fervilhar de debates sobre o mesmo. Castilho entendia que, se as letras não possuírem alguma "relação perceptível" com o som, elas fugirão da memória; daí a criação de imagens que fossem geradoras de histórias relacionadas a cada letra. No parecer do criador,

\footnotetext{
${ }^{71}$ Id. Ibid., p.33-34.

${ }^{72}$ Id. Ibid., p. 156
} 
"a letra, sombra daquela pintura historiada, ficou, portanto, e para logo, e para sempre, estampada no cérebro com o som que lhe pertencia. É porque, onde só reinavam trevas, contradições e repugnâncias, se acendeu a luz, e se introduziu a harmonia"73. Além desse recurso mnemônico, Castilho pretende substituir a ortografia etimológica por aquilo que supunha ser a "ortografia racional" 74 . A preocupação do educador com as geraçôes de portugueses que se mostravam incapazes de decifrar o enigma da leitura convida-o a procurar desvendar os nódulos que obscureciam o processo da alfabetização. Propõe que se recorra ao ensino simultâneo; e nele a procedimentos que facultassem a boa memorização do traçado das letras. Com isso, entretanto, havia um entendimento prévio sobre a escola a ser frontalmente contrariado. Aos métodos tradicionais, Castilho pretendia opor o princípio do prazer, proporcionado fundamentalmente pelo aprendizado bem-sucedido.

Também a propósito da forma do ensino, Castilho é veemente em sua condenação do uso da palmatória, apresentada como meio irracional de se obter do aluno a atenção. Exemplo da 'anti-lógica', os castigos escolares revelariam a tenebrosa face oculta da escola portuguesa, que culpava e punia o aluno por seu próprio fracasso. A recorrência a estilos de punição diversos era uma característica essencial dessa geometria escolar que se vinha aos poucos traçando. Encontramos registros variados sobre o uso de castigos físicos e morais, embora nem sempre o discurso pedagógico explicitasse tal dimensão. A crítica de Castilho a esse respeito é contundente e impiedosa para os partidários da antiga escola.

Em universo de mútua aversão, discípulos e mestres às voltas com a contrariedade, muitos dos castigos aplicados pareciam ser comuns e usuais nas escolas de maneira geral. No parecer de Castilho, a própria imobilidade das crianças em sala de aula era por si só um castigo. Sentados ou em pé para que lhes fosse tomada a lição, a verdade é que os alunos se mantinham imóveis sempre; e quando a isso se acrescia a dura realidade do castigo, mantinha-se a situação, já agora perpetuada:

“(...) de joelhos, talvez em cima de um pau anguloso; ou de pé, e como em pelourinho de afronta, sobre o pedestal de um banco, e cingido de insígnias estúpidas, vis e desmoralizantes para o paciente e para os circunstantes; ou saltando, gemendo, e bramindo sob o peso da férula ou da vara; espetáculo de circo, onde com tempo se vai ensinando insensibilidade e crueza aos que encetam a vida. ${ }^{75}$

Ao evidenciar as vicissitudes da escola portuguesa, e talvez por causa disso, Castilho engendrará um novo estilo de discurso a propósito da escolarização. O que estará em jogo, a partir daqui, não será mais o valor intrínseco da instrução, mas antes o lugar social ocupado pela instituição da escola. Em função disso, o tema do método ganharia forma, perpassando, desde então, o discurso pedagógico português. Castilho sugeria procedimentos voltados para a organização da sala de aula e para a disposição

\footnotetext{
${ }^{73}$ A. F. CASTILHO, Resposta aos novissimos impugnadores do Methodo Portuguez, volume II, p.115.

74 “(...) segundo a qual cada elemento da palavra falada só por um sinal gráfico se represente, e cada elemento da palavra escrita só num elemento fônico se traduza." (A. F. CASTILHO, Resposta aos novissimos impugnadores...vol. I, p.160)

${ }^{75}$ Id. Ibid., p.34.
} 
do mobiliário a ela pertencente. Era um novo rosto que se desejava para a situação escolar. A modificação pretendida visava sobretudo a institucionalização do modo simultâneo, até então praticamente inexistente. Os bancos estariam dispostos dois a dois, todos voltados para o quadro-negro, que ficaria em frente da mesa do professor. A disposição dos banquinhos dos alunos deveria formar um ângulo obtuso, como o que vem reproduzido em ilustraçôes de livros com que o educador ensina seu método. Na frente da sala, existiria um estrado e - sobre ele - um assento para o professor. Haveria, também, "um quadro preto de madeira, em que se possa escrever com giz, e que se monta, ou adapta, quando é preciso, em maior ou menor altura, segundo convém"76. A sala de aula de uma classe de leitura repentina contaria, ainda, para ficar completa, com giz, esponja (ou pano para apagar), vara para apontar, coleção de estampas com figuras das letras, estantes armadas com os quadros do alfabeto, um exemplar do livro do método para o professor, "uma ardósia para cada discípulo, com a competente pena de pedra, lápis ou gesseto" 77 . Na prática, haveria disciplina e ordem nessa escola aqui proposta:

"O professor ocupa o estrado, tendo de estar sempre à vista a vigiar e quase sempre em ação. Os matriculados, que já começaram a ler, estão rigorosamente separados e ocupam os bancos últimos. Os que não conheciam as letras sentam-se nos primeiros. Os que só as conheciam, ou pouco mais, formam o centro. Havendo discípulos dos dois sexos na mesma aula, completa separação dos rapazes e das raparigas. (...) No meio de cada banco, estará um dos discípulos, escolhido pelas suas boas qualidades, para vigiar os seus vizinhos da direita e da esquerda, e fazê-los estar em ordem. Este cargo dos discípulos-vigias pode-se ganhar e perder, segundo o mérito e demérito do aluno." ${ }^{" 78}$

Os alunos seriam estrategicamente distribuídos e o ritual escolar era favorecido pelo roteiro metodológico: aprendizado por palmas, cantos e marchas, onde o ritmo deve ser sempre dado pelo tempo do coletivo. Em Castilho há claramente a prospecção da disciplina de que fala Foucault: "arte das distribuiçôes”, fabricam-se com ela corpos dóceis, submissos, exercitados. Se, por um lado, a disciplina subtrai, por outro ela acrescenta. Sua pedra de toque é o controle, sendo que este opera por rarefações, por deslocamentos, por intercâmbios e intervalos. Arranjos variados se formam e se transformam, na circulação dos poderes assim distribuídos. A escolarização caminha para a uniformização. Para tanto, recompunham-se os espaços, pelo encontro de séries que, aos poucos, tornassem homogêneo o que era até então disperso. O jogo da escola foi assim montado nesse percurso que acompanha o século XIX português. Entende-se que a escolarização só se transformaria em efetiva demanda das populaçôes no momento em que se houvesse de fato atingido esse ideal da uniformidade: classes homogêneas, lugares demarcados na fila, alunos repartidos em fileiras e classificados por colunas, atividades como cantos, palmas, marchas... Tudo por uma única sonoridade.

\footnotetext{
${ }^{76}$ António Feliciano de CASTILHO, Methodo Portuguez-Castilho..., p.121.

${ }^{77}$ Id. Ibid., p. 123.

${ }^{78}$ A. F. CASTILHO, Methodo Portuguez-Castilho, p.125-126.
} 
A escola era percebida como um mundo a ser construído. O mestre ocupa, nessa constelação, lugar de destaque. Pelas palavras de Castilho, temos o seu retrato:

"Afabilidade grave; uma paciência quase inesgotável; suma abnegação; vigilância contínua; severidade inexorável nos casos que a requererem; renunciação a todo o desejo de brilhar perante os ignorantes com termos escolhidos e pomposos; clareza máxima, e suma ordem no encadear as idéias; atenção escrupulosíssima a tudo o que tem de ensinar, e a tudo quanto os discípulos lhe respondem; familiaridade e humildade no estilo, nas comparações, nos exemplos, em tudo que se emprega com vantagem para a doutrinação." 79

O perfil projetado para o mestre de primeiras letras ultrapassava, na perspectiva do autor do Método Português, caracterizações de ordem psicológica ou mesmo moral, que compunham, por assim dizer, o senso comum acerca dos deveres do professor da época. Ao mestre-escola - no parecer de Castilho - caberia um cuidadoso treinamento para adestrar todos os órgãos de seu corpo - desde a postura física, a ereção da espinha dorsal até a potência e volume da voz - como dispositivos a serem usados na composição de seu papel, para a tarefa de liderança, à qual ele estaria inevitavelmente vinculado, na direção firme daquele corpo coletivo e disciplinado constituído por seu grupo-classe. Ao docente caberia regular a arquitetura toda da vida escolar.

Os partidários do Método Castilho agiam como se suas bases fossem inatacáveis. No julgamento desses adeptos incondicionais, teria sido a resistência à mudança da escola e da mentalidade corrente em Portugal quem havia dificultado o êxito dos processos de Leitura Repentina. Verifica-se, nos Relatórios do Conselho Superior de Instrução Pública, entre os anos 1844 e 1859, a presença do debate sobre o método de ensino de Castilho, e mesmo a simpatia que alguns inspetores tinham em relação a ele. Ocorre que, mesmo os mais empenhados, reconheciam a dificuldade de sua efetiva aplicação e o Conselho Superior de Instrução Pública mostrava-se, na ocasião, disposto a estudar o método para melhor pronunciar um juízo sobre o mesmo. De todo modo, por seus acertos e desacertos e por haver deslocado o problema da pedagogia do universo estritamente político para a dimensão técnico-pedagógica, Castilho demarcou um ponto de inflexão na história das idéias educacionais em Portugal do XIX.

${ }^{79}$ António Feliciano de CASTILHO, Methodo Portuguez-Castilho..., p.129-130. 


\title{
2. Intelectuais, Percursos Pedagógicos E A CiênCia da EdUCAÇÃo
}

\author{
"O povo, esse, reza. É a única coisa que faz além de pagar."
}

(Eça de Queirós. Uma campanha alegre 1, p. 22)

\section{A Geração de 70: Tradição e crítica na luta de representações}

Como bem observa António José Saraiva, o movimento de idéias efetuado pela designada Geração de 70 aconteceu exatamente no decurso dos anos em que ocorria a plena consolidação do capitalismo português. Coimbra - nas palavras de Saraiva ligava-se agora às redes de caminho-de-ferro. As novas gerações, por sua vez, substituíam "uma cultura clérico-aristocrática por uma cultura laica, burguesa e dirigida a um mais numeroso público alfabetizado". ${ }^{80}$ Ocorre que a prosperidade material objetiva não fôra acompanhada por alterações correlatas no plano das consciências, da subjetividade e da própria situação cultural do país. Embora pareça nítido que a geração nova só existiu porque seus protagonistas haviam feito leituras novas, parece óbvio que aqueles jovens intelectuais eram acompanhados por camadas ampliadas de leitores que os novos tempos haviam, por sua vez, preparado.

A Questão Coimbrã (1865), que faz despontar aquele grupo, e que - nas palavras de Catroga - "daria início a uma das controvérsias que maiores repercussões teve na vida cultural portuguesa" 81 , principia como uma polêmica da juventude contra o tradicionalismo de Castilho e seus discípulos e protegidos, partidários da escola ultra-romântica liderada pelo velho mestre. Naquela altura, o eixo da contenda foi um elogio que Castilho fizera ao trabalho de Pinheiro Chagas, de quem o poeta se dizia padrinho. Ao redigir o posfácio do Poema da mocidade de Pinheiro Chagas, Castilho, ao mesmo tempo em que elogiava seu jovem poeta, censurava outro grupo de "jovens de Coimbra, acusando-os de exibicionismo livresco, de obscuridade propositada e de tratarem de temas que nada tinham a ver com a poesia." 82 Antero de Quental, em carta aberta intitulada Bom senso e bom gosto, responde às acusações de Castilho e, a partir de então, estaria ali criada a disputa, polarizada

\footnotetext{
${ }^{80}$ A. J. SARAIVA e Óscar LOPES, História da literatura portuguesa, p. 833.

${ }^{81}$ Fernando CATROGA, Positivistas e republicanos, In: A história através da história, p. 87.

${ }^{82}$ A. J. SARAIVA e Óscar LOPES, História da literatura portuguesa, p. 837.
} 
pelos aliados de ambos os lados. O Grupo-Geração de 70 estaria desde então constituído como referência e símbolo da inovação portuguesa contra o arcaísmo e o tradicionalismo. Em 1871, Antero organiza as chamadas Conferências Democráticas do Casino Lisbonense, onde deveriam ser tratadas as diferentes idéias que vinham sendo recentemente produzidas nas distintas formas de expressão do conhecimento, da cultura e das artes.

Acerca do movimento da nova geração, Catroga observa que, desde a Questão Coimbrã, a despeito da orientação estética que qualquer um dos lados perfilhasse, havia sem dúvida uma "estratégia de ataque mais global aos valores em que assentavam o regime monárquico-constitucional e os padrôes morais dos seus grupos dirigentes." ${ }^{3}$ Para Nóvoa, haveria uma dimensão pedagógica a partir da qual podem ser interpretadas as preocupações levantadas por Antero, tanto na Questão Coimbrã quanto nas Causas da decadência dos povos peninsulares - texto produzido por Antero de Quenal como conferência para as reunióes do Casino de 1871. Antonio Machado Pires compreende que a Questão Coimbrã (1865), contrapondo dois universos mentais distintos, alicerçava-se na crítica da geração jovem à tradição e ao argumento de autoridade dos antigos, personificados pela figura de Castilho. As Conferências do Casino Lisbonense (1871) seriam uma iniciativa liderada por um Antero de 29 anos, com o objetivo de fazer um balanço da história peninsular e portuguesa naquele quase final do século XIX.

A idéia de uma reforma nos procedimentos de ensino é apresentada como bandeira norteadora da primeira intervenção política de Antero, quando este elegia a polêmica com Castilho como a oportunidade de criação de um fato que proporcionasse o debate sobre a intelectualidade da época. Para Fernando Catroga, por sua vez, eram os próprios integrantes da chamada Geração de 70 que reivindicavam para si a originalidade firmada perante a radical distinção que a si mesmos atribuíam em relação às gerações precedentes. Eles julgavam trazer consigo, pela primeira vez, algum "sentimento de mundo", aquilo que os contemporâneos entendiam por "novo culto da Humanidade"; no caminho para a desejada realização da justiça, da liberdade, em missão quase profética que teriam eles próprios delegado aos intelectuais. O mundo da cultura adquiriria, sob tal perspectiva, uma nova dimensão, dado que ao intelectual caberia apontar os caminhos do tempo novo, após criteriosa interpretação do presente, tendo por objetivo o traçado do futuro. Reformar a sociedade era, para essa geração, levar à radicalidade o território da cultura. Havia nisso todo um imaginário intrinsecamente pedagógico. Como sublinha Catroga, Antero de Quental encarava o presente a partir das idéias de queda e de decadência, a serem ultrapassadas mediante uma "forte vontade de reconversão espiritual". O futuro seria - pelas palavras de Catroga - uma "promessa de consumação plena do sentido do tempo" "84, e a regeneração das consciências poderia produzir um novo consenso social, estabelecido, substancialmente, por uma vontade coletiva, por um ato de voluntária adesão, que, por sua vez, seria estruturada mediante conversão intelectual.

As Conferências do Casino tinham como objetivo irradiar e impulsionar o debate sobre as questōes que seus artífices julgavam ser prementes: filosofia, ciência moderna,

\footnotetext{
${ }^{83}$ Fernando CATROGA, Positivistas e republicanos, In: A história através da história, p. 87.

${ }^{84}$ Fernando CATROGA, Política, história e revolução em Antero de Quental, In: Antero de Quental, p. 30.
} 
situação de Portugal na Europa e no mundo. Os protagonistas daquele cenário portavam a marca da secularização e da racionalidade. Mas eram também sensíveis à causa dos trabalhadores reunidos na Internacional. Havia o chamado da revolução socialista; havia a atração representada pelo convite que a Europa parecia fazer a Portugal. Tratava-se, no caso, de uma geração que apostava quase irrestritamente na ciência, como se de seus progressos dependesse a própria evolução da Humanidade. Antero de Quental destacava, mesmo assim, a necessidade de o âmbito científico ser sempre matizado pelo fundamento da filosofia, da vontade e da "apropriação prognóstica do futuro" ${ }^{85}$. E esta - como ressalta Catroga - pautava-se na suposição de que "a idéia de justiça seria, em última análise, a verdadeira matriz da história, cuja evolução, mediada pela ciência social, conduziria à liquidação da opressão do homem pelo homem" 86 . Há-de se interpretar sob essa chave o conflito com Castilho e a oportunidade histórica das Conferências do Casino. Existe ali uma perspectiva pedagógica que nos parece pouco trabalhada pelos estudiosos do tema.

No princípio dos anos 60, Antero era reconhecido líder e dirigente no âmbito da Academia. Havendo já publicado conhecidas poesias, firmava-se na intelectualidade pelo teor da sua crítica política e social. Lia, e lia muito; mais do que isso, incitava seus colegas à leitura. Talvez o tema da leitura tenha sido a pedra de toque da Questão Coimbrã, já que o que se falava então era sobre um novo modo de olhar o mundo e retratá-lo. Os partidários da contenda que, contra Castilho, tomaram o partido de Antero de Quental (e mesmo outros - como Ramalho Ortigão - que se identificavam com a literatura de Antero, desaprovando, porém, o estilo pessoal da polêmica), todos eles sentiam essa pertença a um grupo, que não se colocava apenas pela idade, mas fundamentalmente pela comunhão de idéias supostamente renovadas. Eram inúmeros os autores que passavam a ser assim conhecidos: Hegel, Michelet, Hugo, Proudhon etc. O socialismo utópico e o pensamento dialético tomavam forma na própria poesia anteriana. O despertar daquela geração para a leitura vinha ao encontro de novas formas de olhar também para o problema social, para a dinâmica política, enfim, para a própria vida democrática. Basicamente o contato inicial com a circulação das idéias literárias, políticas ou mesmo pedagógicas, os intérpretes e historiadores têm atribuído, em grande parte, à liderança de Antero de Quental, que reconhecidamente vivificou o debate acadêmico de então.

Nas entrelinhas do texto, podemos supor também que teria havido, por aquela altura, uma maior e mais facilitada difusão daquele 'bardo de idéias novas', a que tanto se referiam os protagonistas de cenário intelectual. Uma sólida estratégia comercial, editorial, em termos da circulação e do acesso ao livro, fazia-se bastante nítida à época. Daí suspeitarmos que, talvez, o mercado editorial tivesse algo a ver com o brilho dos

85 "É certo que, para os positivistas, a maior complexidade dos fenômenos sociais, quando comparada com a da natureza e a sua irrepetibilidade, debilitavam um pouco a clareza das previsóes, tornando-os, de certo modo, mais fortuitos, embora essa mesma característica permitisse que a ação dentro de certos limites pudesse condicionar, positiva ou negativamente, a evolução da sociedade. Daí que o acesso à previsão científica não convidasse ao quietismo. A apropriação prognóstica do futuro incitava à ação, tendo em vista antecipar o que teoreticamente se sabia ser inevitável. "(Fernando CATROGA, Positivistas e republicanos, In: A história através da história, p. 93).

${ }^{86}$ Fernando CATROGA, Os caminhos polémicos da 'geração nova', In: José MATTOSO, História de Portugal / quinto volume, p. 571. 
jovens de $70 \ldots$ A análise dos textos da época revela, ainda, um perfil contestatório passível de ser interpretado como crítica às estruturas e instituiçôes educacionais, guardiãs da tradição e da autoridade. Quando, por exemplo, em Bom senso e bom gosto, Antero cria a polêmica com Castilho, ele se refere a seu interlocutor como partidário do que qualificaria como "escola do elogio mútuo", na qual o debate acadêmico e intelectual teria sido sacrificado em prol de espírito de confraria sectária; ali, obras e autores passavam a ser apenas reverenciados, mesmo que o custo disso fosse o próprio espírito crítico. Antero desqualifica o grupo de Castilho, afirmando que lhe faltariam idéias; e o estilo sozinho não sustentava essa falta.

Além disso, o culto da autoridade, tão apreciado por alguma intelectualidade portuguesa à época, foi o grande inimigo que, em nome de sua geração, Antero pretendeu pôr abaixo. Antero alega que o crime imperdoável cometido pela dita escola de Coimbra seria a força da inovação. Em nome da tradição, seus adversários encontravam falsas questôes para deixar em silêncio aquilo que, de fato, seria o essencial: nas palavras de Antero - "essa falta de querer caminhar por si, de dizer e não repetir, de inventar e não copiar" ${ }^{37}$. $\mathrm{O}$ jovem poeta sacraliza a missão social do escritor, apresentado como incorruptível juiz moral, pleno em idealismo e em sabedoria. A vocação do escritor para a interpretação das questôes sociais é muito apontada por essa geração, constituindo talvez a própria marca que os unia e que os diferenciava dos antecessores em termos do discurso; posto que, na vida prática, tanto Herculano quanto Garrett, ou mesmo o próprio Castilho, já teriam tido essa iniciativa de aproximação das camadas leitoras, para, apregoando 'ensinamentos úteis', formar e preparar o espírito público, as opinióes intelectualmente transformadas. O lugar do escritor era, entretanto, utilizado, sob a perspectiva dos jovens de 70, como alguma coisa que deve estar, por definição, no campo do insuspeito, do incorruptível, quase para além do bem e do mal. Essa pertença da virtude ao escritor engajado, na esteira da ilustração, mas já sob os ventos do positivismo, dignifica o campo do conhecimento, principalmente pelo fato de ser esse um território de poder; um poder que tenderia a ser, inclusive, potencializado, pela palavra do escritor, às populações leitoras. Para os jovens da Geração de 70, o tema da leitura viria codificado pela suposição de um pacto entre escritor e leitor; pacto esse desprendido, despojado, generoso, de ambas as partes.

Um novo imaginário da leitura percorreria todo o século XIX, chegando a esse último quartel já com contornos bem definidos. A torrente de leitores precisaria ser sim dirigida e orientada, mas nada poderia ser feito a não ser ilustrar o raciocínio pela aquisição e habilidade do escrito. Havia uma pedagogia pública da leitura. A escrita e o escritor, aos olhos dos protagonistas da época, roubariam o lugar da oralidade do poder. É como se o mundo do impresso se revelasse capaz de estruturar novos

${ }^{87}$ Antero de Quental, Bom-senso e bom-gosto, In: Bom senso e bom gosto (a Questão Coimbrã), volume I, p. 236. Na sequência, o poeta provoca o adversário: "todos os outros crimes eram contra as idéias: haveria sempre um perdão para eles. Mas esta falta era contra as pessoas: e essas tais são imperdoáveis. Inovar é dizer aos profetas, aos reveladores encartados: 'há alguma coisa que vós ignorais; alguma coisa que nunca pensastes nem dissestes; há mundo além do círculo que se vê com os vossos óculos de teatro; há mundo maior do que os vossos sistemas, mais profundo do que os vossos folhetins; há universo um pouco mais extenso e mais agradável sobretudo do que os vossos livros e os vossos discursos. Isto sim que é intolerável! Isto, sim, que é infame e revoltante e impio e subversivo! Contra isto, sim, às armas, ergamo-nos na nossa força, mostremos o que somos e o que podemos... Escrevamos três folhetins e um prólogo "(Id. Ibid., p. 236) 
alicerces para referenciar o ato da política. Pouco a pouco, intelectuais gestavam o sonho do domínio pela força das letras. $\mathrm{Na}$ Questão Coimbrã, a anotação para a posteridade parecia atitude deliberada pelos próprios atores. Seria uma república dos sábios que eles no fundo desejavam contrapor à monarquia? Esses escritores entendiam - especialmente Antero - que a revolução viria pelo movimento da idéia em um tipo de passeio do espírito universal. Deslocar o foco do poder era, sendo assim, assumir-se eles próprios como arautos do campo da idéia; isso corresponderia a uma realocação dos centros decisórios e das estratégias da política. O tema da leitura passa a ser, agora, uma prioridade, um dispositivo, quase uma arma, na órbita desse inusitado olhar sobre a matéria da cultura.

Nessas andanças dirigidas pela preocupação com o campo letrado, destacam-se as considerações de Antero por ocasião das Conferências do Casino, em 1871, tanto em seu discurso de apresentação do programa daquela iniciativa quanto, fundamentalmente, no texto lido a 27 de maio de 1871, na sala do Casino Lisbonense, sob o título Causas da decadência dos povos peninsulares nos últimos três séculos. No discurso de apresentação, o intuito daquelas conferências era resumido por Antero de Quental: "mais forte que nunca, a questão de saber como deve regenerar-se a organização social" ${ }^{88}$. Com tal objetivo, tratava-se de investigar em que medida a sociedade vinha se estruturando e o que poderia ser feito para alterar o rumo que havia sido tomado a dada altura do percurso histórico. Urgia descobrir onde estaria posta a causa da decadência, até como estratégia para poder agir contra ela. Já nessa primeira declaração de princípios, Antero declara ser essa a finalidade das Conferências:

\begin{abstract}
"Abrir uma tribuna, onde tenham voz as idéias e os trabalhos que caracterizam este momento do século, preocupando-nos, sobretudo, com a transformação social, moral e política dos povos; ligar Portugal com o movimento moderno, fazendo-o assim nutrir-se dos elementos vitais de que vive a Humanidade civilizada; procurar adquirir a consciência dos fatos que nos rodeiam na Europa; agitar na opinião pública as grandes questões da Filosofia e da Ciência moderna; estudar as condições da transformação política, econômica e religiosa da sociedade portuguesa; tal é o fim das Conferências democráticas." ${ }^{99}$
\end{abstract}

Formando as idéias, de acordo com esse espírito, a consciência pública viria a ser preparada para presidir a revolução antevista pelo orador, revolução nos costumes e na subjetividade social. É como se Antero apresentasse ali o preâmbulo do que se preparava para declarar depois, quando trataria especificamente de analisar as razões da decadência dos povos peninsulares, uma "desalentadora evidência", a ser reconhecida e superada de modo a que o tecido social fosse emendado e regenerado. Para o expositor, havia algo, nos passados três séculos, que provocara a decadência daquela que foi um dia uma das mais fortes nações européias. A partir do cumprimento da vocação marítima, os povos ibéricos perderam a liderança na Europa e o eixo decisório transferiu-se para o Norte. De caráter eminentemente cristão, os peninsulares

\footnotetext{
${ }^{88}$ Antero de QUENTAL, Programa das conferências democráticas, In: Causas da decadência dos povos peninsulares, p. 7.

${ }^{89}$ Antero de QUENTAL, Programa das conferências democráticas, In: Causas da decadência dos povos peninsulares, p. 8.
} 
teriam sido vitimados pelo seu próprio espírito de conquista, não demonstrando habilidade de consolidar pela colonização a aventura que presidira as navegações. De fato - declara Antero - "nunca povo algum absorveu tantos tesouros, ficando ao mesmo tempo tão pobre!" 90

A crítica ao francesismo era acentuada entre os autores mais destacados da época. Havia - e isso já preocupava o próprio Eça de Queirós - uma política de imposição dos valores culturais franceses, não apenas através da tradução de textos, mas da incorporação dos conteúdos culturais do romance francês, em seu modo de olhar para a civilização, além - naquilo que nos interessa mais diretamente - da elaboração de compêndios que imitavam os livros escolares franceses, fossem esses dirigidos ao público da escola primária, secundária ou até superior. Assim, eram os suportes da cultura escolar que viriam a ser absorvidos nessa obsessão mimética. O Estado português, com isso, no parecer dos expoentes da Geração de 70, impunha a referência francesa, perdendo consequentemente os parâmetros da alma nacional. A identidade dessa alma, a pouco e pouco, perecia. Por efeito de uma religiosidade marcada pelo selo da Inquisição, os costumes morais e mesmo a energia da vontade e da determinação haviam sido "esmagados, destruídos pelo medo"; e, como resultado, via-se uma sociedade paralisada pela inércia de três séculos decadentistas. A compreensão dessa decadência, para ser efetuada, exigiria, entretanto, o entendimento dos variados componentes que, aliados uns aos outros, formariam a índole ou o temperamento próprios da nação. Assim como Herculano, Antero procurava fugir das interpretações que apresentavam o elemento étnico como fator prioritário na consolidação da "alma nacional" 1 . Os motivos da decadência do país seriam de três ordens: um de ordem moral, outro de caráter político e um último de origem econômica.

Para Antero, a liberdade moral era o contrário da dogmática expressa pelo Concílio de Trento e perpetuada pelo catolicismo português; a classe média era oposta ao absolutismo e ao primado aristocrático da sociedade portuguesa; e, por fim, a indústria era o espírito burguês, mercantil, por excelência, antítese do espírito medieval que estava dado na aventura das conquistas longínquas - "o oposto do espírito de conquista, antipático ao trabalho e ao comércio”. Esse texto de Antero marcou a história da cultura portuguesa. Se a decadência se apresentava aos olhos dos conterrâneos como uma realidade inquestionável, eles próprios acreditavam na possibilidade de sua superação. Educar e instruir eram tidos por instrumentos para reeerguer; ou, para usar os termos de Antero, regenerar. Não se tratava do mesmo estilo de regeneração que queriam os franceses quando, durante a Revolução, recorriam à palavra. No caso português, regenerar significava recuperar a grandeza que a história perdera: a educação era o veículo.

${ }^{90}$ Antero de QUENTAL, Causas da decadência dos povos peninsulares, p. 24.

${ }_{11}$ "Deste modo, para Antero, pelo menos neste periodo, reduzir a compreensão do gênio nacional ou da alma nacional a um princípio único é querer de propósito acanhar a história. Tal método, se era válido quando aplicado a povos etnicamente mais homogêneos, seria desapropriado à explicação de uma nação sem base rácica definida, como a portuguesa. É que a formação dos povos modernos europeus não foi fruto de uma raiz fisiológica exclusiva, mas de elementos complexos, uns fatais, outros livres, uns criados, outros herdados, cuja síntese constitui a idéia da sua nacionalidade - raça, instituiçôes, religião, tradição histórica, e vocação política e econômica no meio dos outros povos. " (Fernando CATROGA, Positivistas e republicanos, In: A história através da história, p. 105). 
O atraso devia-se, entre outras coisas, ao arcaísmo de uma religião que estava também em decadência desde que, no século XVI, fôra reformada. Assim, os povos prósperos e íntegros não eram os da tradição católica, mas os protestantes, até porque os dogmas e os procedimentos ritualísticos da religiosidade católica eram impeditivos do espírito crítico e criativo, posto que havia sempre um Deus escondido, no confessionário, ou na perseguição dos pecadores; aquele Deus a quem nada escapa, que vê tudo, tudo ouve e irá julgar os transgressores, em virtude de tudo que eles tentaram esconder. Em Portugal do século XIX, toda uma cultura do confessionário parecia, aos olhos dos contemporâneos, absolutamente estruturada, atingindo todos os setores da vida social, a começar, evidentemente, pela educação:

“(...) métodos de ensino, ao mesmo tempo brutais e requintados, esterilizam as inteligências, dirigindo-se à memória, com o fim de matarem o pensamento inventivo, e alcançam alhear o espírito peninsular do grande movimento da ciência moderna, essencialmente livre e criadora: a educação jesuítica faz das classes elevadas máquinas ininteligentes e passivas; do povo, fanáticos corruptos e cruéis: a funesta moral jesuítica, explicada (e praticada) pelos seus casuístas, com as suas restrições mentais, as suas sutilezas, os seus equívocos, as suas condescendências, infiltra-se por toda a parte, como um veneno lento, desorganiza moralmente a sociedade, desfaz o espírito de família, corrompe as consciências com a oscilação contínua da noção do dever, e aniquila os caracteres, sofismando-os, amolecendo-os: o ideal da educação jesuítica é um povo de crianças mudas, obedientes e imbecis (...) " ${ }^{2}$

A segunda razão da decadência seria - diz Antero - o absolutismo, que, gerando em terras portuguesas uma cultura centralista, em termos políticos, era frontalmente contrário à tradição localista. Não haveria - na ordem absolutista - equilíbrio de poderes, por causa da excessiva centralização e da consequente diminuição do papel das paróquias e municípios. Além disso, em franca dissonância com a maior parte dos países europeus, as monarquias ibéricas impediram o desenvolvimento da burguesia, impondo a manutenção de uma mentalidade aristocrática que viria a se tornar cada vez mais ultrapassada e obsoleta. Foi a monarquia absoluta que habituou o povo a esperar por soluçôes prontas, vindas, se possível, pelo alto e sem iniciativa ou impulso para a luta pela liberdade. E, por fim, quando supostamente a liberdade política era alcançada, o povo, inerte, não foi capaz de fazer uso dela. Como observa Catroga, Antero entende que a inquisição e o jesuitismo mataram o poder local, impedindo, com isso, o advento de uma cultura democrática e republicana. Por sua vez, clericalismo e absolutismo liquidaram juntos o "momento de apogeu - os Descobrimentos -, bloqueando a modernização econômica, política e cultural do país que estes podiam ter propiciado." ${ }^{93}$ Finalmente, o último fator de decadência era de ordem econômica: as conquistas.

Antero destaca que o espírito da era moderna correspondia às idéias de trabalho e de indústria, distanciando-se do espírito de aventura que comandara a empresa das navegaçôes. A lei econômica da produção teria passado a dominar a vida das nações que acompanhavam a tendência de seu tempo. Ao deixar de fazer isso, Portugal ficara para

\footnotetext{
${ }^{92}$ Antero de QUENTAL, Causas da decadência..., p. 46-47.

${ }^{93}$ Fernando CATROGA, Positivistas e republicanos, In: A história através da história, p. 108.
} 
trás. Seja como for, a decadência portuguesa estaria expressa em um constante olhar para trás, pela saudade de um passado que se foi, na dificuldade secular de projeção do futuro. O parecer de Antero foi, sem dúvida, uma das principais marcas de sua geração, revelando-se também matriz de grande parte do pensamento político imediatamente posterior. No plano da história da cultura, muito do que se passaria a dizer sobre o tema da escolarização e da pedagogia, a partir dali, teria a ver com essa crença vincada em uma lei da evolução histórica, 'inflexível e impassível', capaz de presidir o movimento e o destino das nações. A educação passará a ser considerada tática e estratégia para interferir no caminho entre o passado e o futuro.

\title{
Eça de Queirós, Ramalho Ortigão e As Farpas da leitura
}

As Conferências do Casino haviam sido saudadas por Eça de Queirós como a palavra da revolução, em sua forma científica, revolução essa que principiaria pelo ato de relatar ao povo suas misérias. Falar de Portugal era, aos olhos do escritor, o primeiro passo para o enfrentamento do rol de problemas e dificuldades que assolavam o país, particularmente nos aspectos concernentes ao mundo da cultura. As conferências eram esperadas, então, como a voz da lógica e do bom-senso ${ }^{94}$. Com a proibição e o encerramento das Conferências do Casino, da zona perigosa da fala, parte-se para a escrita e a leitura. Como sublinha Eça de Queirós n'As Farpas de Julho de 1871:

\begin{abstract}
"Sejamos lógicos; fechemos as Conferências do Casino onde se ouvem doutrinas livres, mas expulsemos os livros onde se lêem doutrinas livres. Ouvir ou ler dá os mesmos resultados para a inteligência, para a memória, e para a ação: é a mesma entrada para a consciência de duas portas paralelas. Façamos calar o sr. Antero de Quental, mas proibamos na alfândega a entrada dos livros de Vítor Hugo, Proudhon, Langlois, Feuerbach, Quinet, Littré, toda a crítica francesa, todo o pensamento alemão, toda a idéia, toda a história. Dobremos a cabeça sobre a nossa ignorância e sobre a nossa inércia, e deixemo-nos apodrecer, mudos, vis, inertes, na torpeza moral e no tédio." 95
\end{abstract}

Recorda Saraiva que, "no mesmo ano em que decorrem as Conferências do_Casino, e orientadas no mesmo sentido de crítica geral da sociedade portuguesa" ${ }^{96}$, As Farpas foram um conjunto de publicaçōes mensais, sob a autoria de Ramalho Ortigão e Eça de Queirós, satirizando os debates socio-políticos mais candentes na época e procurando ironizar e caricaturar as instituições vigentes. Os redatores destacavam, frequentemente, em suas

94 "As conferências hão-de encontrar resistências. Em primeiro lugar o nosso público inteligente e literário, ama sobretudo o bel-esprit, a oratória, a frase. Moda peninsular. Ora as conferências pela sua natureza científica e experimental - exigem justamente o contrário dos aparatos retóricos. São a demonstração, não são a apóstrofe; são a ciência, não são a eloquência. As declamaçôes têm tirado à democracia o seu caráter privativo de realidade e de ciência. Temos ouvido cantar a democracia, berrá-la, soluçá-la: é tempo de a vermos demonstrar. Deixemos no bengaleiro a nossa perpétua inclinação nacional de escutar odes - e entremos só com a tendência humana de resolver problemas." (EÇA DE QUEIRÓS, Uma campanha alegre / volume I, p. 37)

${ }^{95}$ EÇA DE QUEIRÓS, Uma campanha alegre / volume I, p. 61.

${ }^{96}$ A. J. SARAIVA e Óscar LOPES, História da literatura portuguesa, p. 840. De acordo com estes comentaristas, "cada número constituía um comentário crítico e satírico aos acontecimentos e instituiçôes, orientado segundo um ideário cuja principal fonte era, nos primeiros tempos, a obra de Proudhon.” (Id. Ibid. , p. 841). 
crônicas a carência de leitura da sociedade portuguesa de então. Descreviam um país onde ninguém comprava livros e a leitura nem de longe se apresentava enquanto forma concorrida de distração. Com espírito preguiçoso, Portugal perdera o sentimento de cidade e fundamentalmente o sentimento de pátria, transformando-se no país das sempre passadas conquistas e da inatividade enfastiada do presente. ${ }^{97}$ Ora, a reflexão acerca do problema da leitura evoca quase imediatamente a questão da escola. Como se viu, em Portugal, particularmente a partir da Geração de 70, passará a se considerar o tema da escolarização como uma necessidade imprescindível para superação da constatada decadência e, ao mesmo tempo, como veículo da cidadania moderna. A intelectualidade portuguesa da época se preocupará com o problema da preparação de novos leitores. A leitura escolar torna-se importante rito institucional. Livros didáticos existiam já em grande escala; disputavam, uns com os outros. Ganhavam terreno as polêmicas metodológicas e o discurso sobre a pauta especificamente escolar, os saberes pedagógicos escolarizados e, em tudo isso, a leitura ocupando lugar de destaque. Projeta-se o caminho de uma organização de rede educativa uniforme, homogênea e única, capaz de efetivar, de modo conveniente, a transmissão desses conhecimentos das primeiras letras. A realidade, entretanto, ainda não acompanhava o tom de proficiência com que se pretendia construir as representações mentais sobre a vida nas escolas. Sobre o lugar de Portugal em uma exposição que ocorreria em Viena de Áustria, em dezembro de 1872, Ramalho Ortigão recorda aos portugueses que pouco havia para ser mostrado em termos dos produtos didáticos nacionais. Compêndios aprovados de todas as áreas do conhecimento traziam noções errôneas, a despeito de haverem sido todos eles submetidos e aprovados pelos órgãos pedagógicos competentes. Assim, encontravam-se, com muita freqüência, obras que traziam inúmeras definições incorretas, envergonhando o país e o ensino. Em tom jocoso, o jornalista arremata:

\footnotetext{
"Pedimos sobretudo, que não esqueça de mandar, dentro de uma gaiola, para a seção de história natural, um dos nossos professores de instrução primária, que o Estado consegue sustentar com noventa mil réis por ano. Que se faça notar a todos os visitantes que a gaiola não tem comedouro e que o professor se alimenta exclusivamente com a leitura do Manual enciclopédico que tem debaixo do braço. Que principalmente não esqueça - a fim de podermos continuar a aproveitar no serviço público o professor que expusermos - afixar no recinto da exposição um rótulo em que se leia: 'pede-se ao público o obséquio de não comer nem mostrar comestíveis diante da gaiola do Sr. Professor português, para não despertar no objeto exposto idéias que o Governo de sua Majestade Fidelíssima julga incompatíveis com o exercício do magistério no território nacional.’”98
}

${ }_{97} \mathrm{Tal}$ apreciação também constava dos textos publicados n'As Farpas, particularmente em Junho de 1871. Destacando esse fastio da sociedade portuguesa daquele último quartel do XIX, Eça pontua o cenário que apresenta: "os cafés são soturnos. Meio deitados para cima das mesas, os homens tomam o café a pequenos goles, ou fumam calados. A conversação extinguiu-se. Ninguém possui idéias originais e próprias. Há quatro ou cinco frases, feitas de há muito, que se repetem. Depois boceja-se. Quatro pessoas reúnem-se: passados cinco minutos, murmuradas as trivialidades, o pensamento de cada um dos conversadores é poder-se livrar dos outros três." (EÇA DE QUEIRÓS, Uma campanha alegre / volume I, p. 34)

${ }^{98}$ Ramalho ORTIGĀO, As Farpas / XIII: crónica mensal da política, das letras e dos costumes (1872), p. 174. Ramalho Ortigão, em vários artigos d'As Farpas, destaca o problema dos maus compêndios como um dos grandes óbices ao aprendizado das crianças na escola. No excerto acima transcrito, a alusão feita ao Manual enciclopédico 
A instrução oferecida em Portugal, inadequada e ineficaz, levava a supor que a educação do povo era, na realidade, uma mentira alegada por um Estado que não teria sequer intenção de erradicar a ignorância. $\mathrm{O}$ mesmo Estado que em termos concretos investia em caminhos-de-ferro deixava a instrução ao relento. Falava-se, pois, de uma escola que se sabia não existir sequer nas mentes daqueles que proferiam laudatários discursos. Assim o que se fazia era apenas fingir que se ensinava... Assim como em Antero, também o discurso de Ramalho Ortigão tende a apontar a escola como um dos possíveis antídotos da decadência que assolava o país há alguns séculos. Para que isso viesse a ocorrer, tornava-se, entretanto, imprescindível modernizar e reestruturar o arcaico modelo de escola, que não atendia nem às exigências da época nem à urgência da crise.

A profundidade da ignorância coletiva do povo português não permitia que ele pudesse sequer usufruir de sua liberdade; e, acerca do tema, Ramalho Ortigão recorre a uma carta - escrita ainda por D. Pedro IV ao Marquês de Resende - quando o rei, tempos atrás, já identificava, em seu país, algo próximo dessa miséria intelectual de que há pouco se falava. Dizia D. Pedro: "a criação portuguesa é e tem sido sempre para a vida servil, Este povo está inteiramente apático. Eu vou constitucionalizá-lo contra a sua vontade". ${ }^{99} \mathrm{O}$ que o jornalista lamenta é que, passado meio século, a educação portuguesa permanecesse voltada ainda para essa vida servil.

A escola que não instrui, não educa, não faz nada, é - de acordo com o redator d'As Farpas - a escola do compêndio, a escola da repetição e da memorização vazia; a escola, enfim, que o século XIX português conseguira produzir. E os compêndios seriam, por sua vez, o comércio produtivo do Estado. Tanto isso seria verdade que nem as mais ásperas críticas eram capazes de sequer alterar a publicação, a distribuição ou mesmo a venda desses produtos do comércio que a escolarização havia criado - pelo menos, é o que diz Ramalho Ortigão. Portanto o tema da leitura escolar entra com a Geração de 70 na pauta da discussão sobre a escola, que, por coincidência, tomaria a partir dali outro rumo...

Eça de Queirós traça o retrato numérico do estado da instrução - também n’ As Farpas. Para ele, a situação das escolas era por si elucidativa da hostilidade dos governantes e, inclusive, da população para com a cultura letrada. No primeiro caso, sabidamente não se investia; no segundo, o povo realmente optava por mandar as crianças ao trabalho, mesmo que isso lhes fosse custar a oportunidade de instrução. De fato, das intenções aos atos, a escola não dava certo... Cursos eram, a todo o momento, abertos e fechados. O professor primário não tinha carreira estruturada e ganhava um salário miserável. Para aceitar essa remuneração, quem efetivamente concorria para as cadeiras de instrução primária eram indivíduos absolutamente desprovidos de habilitações literárias. Não havia inspeção organizada e, com esse

coincide, como veremos nos capítulos seguintes, com o depoimento de muitos outros protagonistas da época, que retratam esse livro de Monteverde como o grande livro da escola portuguesa na segunda metade do século XIX. Por aqui, somos tentados a indagar até que ponto muitas das obras aprovadas pela Junta Consultiva da Instrução Pública e adotadas nas escolas não eram dirigidas exatamente aos alunos, constituindo-se antes em guias e roteiros para que os professores, que andavam com esses livros "debaixo do braço" preparassem adequadamente a aula, que, na maior parte das vezes, não saberiam dar de outro modo. Estamos convencidos de que, no caso específico, o Manual enciclopédico cumpria essa função, como explicitaremos adiante, quando da análise específica dos textos escolares.

${ }_{99}^{9}$ D. Pedro IV de Portugal e I do Brasil, apud, Ramalho ORTIGÃO, As Farpas / XV, p. 34. 
abandono generalizado, o professor abandonava-se também, rendido a um entediante cotidiano, indolente perante a desesperança que pautava sua vida.

O grupo-geração do qual Eça de Queirós era um dos maiores protagonistas polemizava com a tese já corrente em Portugal segundo a qual, por parte das próprias famílias, não haveria interesse na escolarização das crianças. Haveria, ao contrário, rivalidade entre escola e família. Acreditar nisso seria mais confortável - observa o literato - embora não houvesse correspondência entre o mito que se criara e o plano das realidades materiais. O país como um todo e particularmente o Estado português não apostavam na instrução como uma estratégia de fortalecimento social. Aí residiria o coração do problema. Se não se pensasse em remediar o óbice da pobreza do camponês, havia ao menos de se pensar na adoção da alternativa de cursos noturnos, aos quais os mesmos homens do campo sem dúvida recorreriam.

\begin{abstract}
"Nos campos a família é hostil à escola, diz-se. Erro. A família não nega o filho à escola, requer o filho para o trabalho. A criança aí, de sete a dez anos, já conduz os bois, guarda o gado, apanha a lenha, acarreta, sacha, colabora na cultura. Tem a altura de uma enxada e a utilidade de um homem. Sai de madrugada, recolhe às trindades, com o seu dia rudemente trabalhado. Mandá-lo à escola, de manhã e de tarde, umas poucas de horas, é diminuir a força produtora do casal. Um aluno de mais na escola é assim um braço de menos na lavoura. Ora uma família de lavradores não pode luxuosamente diminuir as suas forças vivas. Não é por o filho saber soletrar a cartilha que a terra lhe dará mais pão. Portanto tiram a criança à escola para a empregar na terra.”100
\end{abstract}

Sendo assim, julgava-se que Portugal viveria, dentre os países civilizados, uma situação anômala, particularmente pelos perversos efeitos acarretados pelo trabalho infantil, que era, segundo consta, adotado em larga escala. Eça de Queirós, em outra oportunidade, relata ainda o drama de um pescador que fôra preso, juntamente com os seus filhos - crianças ainda, que o ajudavam - por ter usado redes de arrastar que haviam sido proibidas por alguma portaria, publicada no Diário de Governo - e que muito provavelmente o referido pescador desconhecia. Eça ridicuriza o fato de a punição estar calcada justamente no fato de o pescador não haver tomado conhecimento de uma lei que exigiria, para ser compreendida, o domínio da leitura e dos códigos escritos da informação. Nessa medida, o redator destaca que o crime daquele homem teria sido o de não ter sido capaz de ler as prescriçôes do Diário de Governo; condenado, por conseguinte, "por ousar ser pescador antes de ser bacharel formado" ${ }^{101}$.

Explícito o tom de crítica social expresso em sua crônica, Eça de Queirós também seria refratário ao modelo tradicionalista de ensino, personificado, segundo ele, na

${ }^{100}$ EÇA DE QUEIRÓS, Uma campanha alegre II, p. 77.

101 "Um pobre homem passa o seu dia remando, quebrado pela luta com o mar, para comer à noite, na promiscuidade da mesma gamela, com uns poucos de filhos, uma pouca de sardinha. Levou para isso a sua rede de arrastar com que trabalha há muito, que ele vê no barco de seu amigo, do seu vizinho, do seu patrão. Desembarca ao pôr do Sol, esfomeado, encharcado de água - e encontra pela frente o Senhor Regedor ! - E como existe a portaria de tantos de tal, revogada por uma portaria posterior, posta em vigor por outra, caida depois em desleixo, novamente revogada, alterada por uma diferente legislação, ultimamente anulada, e agora rediviva e ativa - ele, por ignorar completamente essa jurisprudência trapalhona, vai ser levado por aqueles soldados ao Porto e aferrolhado numa enxovia! O crime deste homem, portanto, é não ler o Diário do Governo! Esse homem está preso por não ser um jurisconsulto ! Esse homem será condenado por ousar ser pescador - antes de ser bacharel formado!" (EÇA DE QUEIRÓS, Uma campanha alegre I, p. 137) 
referência dos colégios. Era fundamental - dizia o escritor - repensar o tema da educação, tanto em sua variável política - discutindo o papel do Estado e a responsabilidade dos familiares em fazer cumprir a prescrição da obrigatoriedade - quanto nos aspectos atinentes ao método de que a própria escola se valia para proceder à desejada transmissão de conteúdos culturais. Em virtude da ausência de oportunidades escolares para a maioria das crianças portuguesas, mas também em função do fato de as escolas existentes não se mostrarem capazes de tornar o aluno pronto no final do ano - já que, em cada 50 alunos, apenas 1 era considerado preparado para a etapa seguinte - a escolarização primária portuguesa era falha e em completo desacordo com todas as tendências contemporâneas. Havia, pois, de se atentar para o problema do método e da superação dos entediantes processos que obstaculizavam o sucesso e a eficácia da vida escolar. Além de provocar o tédio, a instrução desenvolveria tendência à distração:

\begin{abstract}
“Será necessário que penetremos nos colégios? - Espreitemos só pela porta. - Um dos grandes males do colégio é o tédio. O tédio enfraquece, anula o espírito, a vontade, e só deixa viva e exigente a curiosidade. De quê? de tudo, do imprevisto, do que se não tem, do que está na rua quando nós estamos em casa, do que está no vício quando nós estamos no dever..”102
\end{abstract}

Seja como for, a profundidade crítica dos artífices da Geração de 70 tinha a ver com o estado de Portugal em uma época onde a crise cultural somava-se a problemas de ordem material. Quanto à escola, a tônica do discurso intelectual da época recairia sobre a problemática do método de ensino. Acreditava-se na possibilidade de se vir a desenvolver um método científico para se ensinar.

\title{
João de Deus, a Geração de 70 e a Cartilha Maternal
}

De algum modo, os intelectuais caracterizados como integrantes da chamada Geração de 70 pretenderam - como já expusemos - demarcar a diferença entre sua geração e todas as outras que lhe precederam. Procurando em tudo sinais de inovação, eles se consideravam transformadores. Fosse pelo estilo ou pelo conteúdo e vigor da crítica e dos juízos que proferiam, os protagonistas pareciam desejar demarcar os parâmetros da distinção. Julgavam-se à frente de seu tempo, por dialogar com o que este trazia de mais atual. Acreditavam romper com as tênues fronteiras de uma arte descompromissada, com o álibi de que a realidade social solicitava ser substantivamente alterada. Ao criarem eixos de interpretação social, pelo signo da criação artística que os envolvia, aqueles jovens desejavam intervir nesse cenário. Eram, pois, acima de tudo, militantes do que Antero qualificaria como 'ideal'... Porém, nesse caminho, "onde cada um desses mundos tem mil vidas" 103 , os jovens de 70 não estariam em absoluto sozinhos. A história não costuma apresentar questões que os contemporâneos não se disponham a ouvir. A recusa da tradição atingia naquela

\footnotetext{
${ }^{102}$ EÇA DE QUEIRÓS, Uma campanha alegre II, p. 91-2.
}

${ }^{103}$ Antero de QUENTAL, Vida, In: Odes modernas, p. 66. 
altura outros personagens, outros territórios; dentre eles, mais especificamente, havia quem buscasse modificar o roteiro da pedagogia.

A Geração de 70 - como já pudemos observar anteriormente - deslocou o problema pedagógico em Portugal, particularmente pelas críticas efetuadas à questão da autoridade e da tradição. Dessacralizando o universo do conhecimento e de sua produção, aqueles jovens teriam - como vimos - questionado profundamente a tônica dominante da história portuguesa. Julgava-se que os portugueses cultivavam a ignorância por não terem efetivamente lutado contra séculos de atraso nos quais se haveria criado uma mentalidade de intolerância e de dogmatismo intelectual. Para os jovens de 70, lutar contra tal força da inércia histórica tornava-se tarefa urgente. Mais do que nunca, a questão pedagógica adquiria nítida coloração política, histórica e mesmo filosófica. Se o problema português era identificado na ignorância das populações, fazia-se imperativo histórico ilustrar o povo e transformar a leitura, de atividade restrita e sacralizada, em atitude rotineira, trivial, dessacralizada, e, nessa medida, emancipadora. Ora, a expressão prática desse objetivo estaria dada nas esperanças depositadas no método de ensino da leitura e da escrita desenvolvido pelo poeta João de Deus ${ }^{104}$.

O último quartel do século XIX veria o desenvolvimento das correntes cientificistas, evolucionistas - dentre as quais se destacariam o marxismo e o positivismo - na tarefa de edificação de uma ciência da sociedade. Os sonhos e projetos deixados pelos revolucionários franceses adquiririam nova feição, na medida em que a acepção de perfectibilidade - tão cara aos homens do final do século XVIII e aos que a eles sucederam - deixaria de ser tomada no território da utopia, para ser apreendida enquanto modo efetivo de progresso e de ordenação evolutiva do tecido social. Consolidar o âmbito público era, portanto, evitar - pela via da ordem e do progresso - novas revoluçôes que abalassem o futuro. A capacidade científica dos povos estaria ligada a seu potencial de prosperidade material e humano e, portanto, seria fruto do desenvolvimento industrial. Era necessário e urgente, pois, encaminhar Portugal para esse avanço que a lei da evolução teria já traçado.

Teóphilo Braga, ao discorrer sobre a personalidade de João de Deus, aponta o poeta como representante do 'gênio nacional' naquilo que havia de emotividade lírica e espiritual do povo. Porém, mais do que a sua poesia, a Geração de 70 valorizaria a atuação do poeta na polêmica que este teria travado com Castilho a propósito do valor estético dos Lusíadas. Este, segundo a apreciação que, nos anos 50, havia feito Castilho, seria inferior ao seu D. Jayme, por pedagogicamente não ser recomendável como leitura escolar. Nos termos de Teóphilo Braga, isso teria proporcionado a visibilidade da intransigência intelectual de Castilho, particularmente diante do desprendimento da resposta dada por João de Deus: “- condenar os Lusíadas

${ }^{104}$ O Diccionario bibliographico portuguez compara João de Deus a Castilho, pela polêmica com que ambos os métodos teriam marcado a história do pensamento pedagógico em Portugal. Nascido em 1831, João de Deus teria - aos 30 anos - se formado bacharel em Direito pela Universidade de Coimbra. A primeira edição da Cartilha maternal ou arte da leitura data de 1876, tendo sido essa publicação organizada e providenciada pelo rev. Madureira, abade d' Arcozello. Em 1881, a cartilha já estava em sua 5 a edição. A força do debate que em torno desse método de leitura se travaria em Portugal teria sido estampada em jornais, que publicavam a polêmica entre os partidários do autor e seus adversários, no parlamento e nas revistas especializadas (INNOCENCIO Francisco da Silva, Diccionario bibliographico portuguez, tomo 10, p.23). 
porque não servem para Cartilha do Padre Ignácio é o mesmo que condenar a Cartilha do Padre Ignácio porque não serve para epopéia nacional" ${ }^{105}$. Os antigos membros da geração nova desejavam ver em João de Deus um aliado, talvez um cúmplice, indubitavelmente um precursor. É assim que Teófilo Braga se refere ao poeta:

\begin{abstract}
"Este fenômeno da chamada Questão de Coimbra, que significou simplesmente a dissolução final do romantismo (...) não será bem compreendido, sobretudo na transformação da poesia lírica moderna em Portugal, se se não estudar João de Deus como o seu precursor. Precedeu no movimento filosófico e crítico os Dissidentes de Coimbra, e, sem conhecer a renovação das doutrinas metafísicas nem as teorias sociais, nem a síntese monística das ciências físicas ou naturais, nem a indisciplina revolucionária; sem ter em vista romper com o passado nem proclamar novas afirmaçôes, como é que ele fecundou duplamente a poesia portuguesa, pela sua obra e por uma influência imediata?" 106
\end{abstract}

Em termos da história das idéias pedagógicas, João de Deus destaca-se por ter sido o autor de um método para o ensino das primeiras letras que traz notoriedade à polêmica acerca do tema, assim como o Método de Leitura Repentina fizera tempos atrás. $\mathrm{Na}$ verdade o método João de Deus e o método Castilho são apresentados por parte da bibliografia ainda recente na história da educação portuguesa como as grandes demarcações educacionais que pontuaram o século XIX. Não se trata, no presente capítulo, de averiguar o impacto que tais metodologias trouxeram à efetiva prática pedagógica - o que pretendemos fazer a seguir -, mas basicamente delimitar o papel de ambas no percurso das idéias e dos grupos acadêmicos que em torno delas se iam formando.

Estudar a proposta pedagógica de João de Deus representa muito mais do que a busca de compreensão de um método. Trata-se, como em Castilho, da tentativa de apreensão do fenômeno da aquisição da habilidade da leitura como um componente de um imaginário, de um universo simbólico mais amplo. Questionaremos adiante o significado da leitura para os intelectuais dessa geração e suas proximidades e distâncias perante aquela que imediatamente lhe antecedeu. Rômulo de Carvalho avalia, em seu trabalho, a Cartilha Maternal de João de Deus como "uma das obras mais notáveis da pedagogia portuguesa”. Para esse estudioso, João de Deus teria alcançado um dos "maiores êxitos na luta contra os processos tradicionais do aprendizado da leitura" 107. Os teóricos da educação portuguesa tendem, portanto, a acreditar que o debate gerado pelo método teria sido traduzido por uma real implementação da Cartilha Maternal nas práticas escolares portuguesas.

Segundo nos relata Teóphilo Braga, ainda em 1870, João de Deus fôra convidado pelo gerente da casa Rolland para elaboração de uma cartilha para o ensino das primeiras letras. A referida livraria posteriormente iria à falência, mas João de Deus se teria sentido desafiado e, em 1876, era publicada pela primeira vez aquela que se chamaria Cartilha Maternal ou Arte da Leitura. O título é já por si revelador do desejo

\footnotetext{
${ }^{105}$ Teóphilo BRAGA, João de Deus: esforço biographico por..., p. 20.

${ }^{106}$ Teóphilo BRAGA, João de Deus: um esforço biográphico por..., p. 21.

${ }^{107}$ Rômulo de CARVALHO, História do ensino em Portugal, p. 607.
} 
subliminar do autor quanto à proposição de uma aliança entre escola e família, em nome da instrução. Havia oposição entre o modelo educativo familiar e a tarefa civilizatória que, em tese, era especificamente a escola quem se propunha a cumprir. João de Deus pretendia pois cativar a confiança dos lares, pela homenagem prestada às mães. Partia do pressuposto segundo o qual a fala é a língua da família; quem se aparta do ambiente doméstico exerce simbolicamente a atividade da escrita, que - em si própria - prometia ser a língua social. Daí a relevância da escolarização, como o passaporte autorizado para o ingresso no sinuoso mundo da cultura letrada. O formato da Cartilha Maternal, inclusive na dinâmica da apresentação, parecia à primeira vista inovador. Todo o conteúdo do texto vinha impresso "em letras gordas, umas a negro, outras preenchidas a traço fino, com o fim de distinguir as sílabas entre si, imediatamente, pelo aspecto dos caracteres tipográficos" ${ }^{108}$.

Trazendo, já à partida, textos explicativos para servirem de orientação ao professor, dirigindo-o em sua atividade cotidiana, João de Deus divide a obra em vinte e cinco liçôes, a partir das quais o aluno estaria habilitado, em termos de competência cognitiva e de repertório linguístico, ao domínio e ao manejo da palavra escrita. Em termos de método, João de Deus recusa a antecedência do trabalho com a identificação das letras e das sílabas, cujo reconhecimento, a seu ver, seria, na margem oposta, decorrente da leitura da palavra. Provavelmente pela primeira vez, em Portugal, desafiava-se o primado da soletração e propunham-se, em seu lugar, procedimentos analíticos para o ensino da leitura, mediante aquilo que os teóricos da Escola Nova chamariam de método global. A justificativa do autor, nesse sentido, aproximava-se do discurso de Castilho: pretendia-se alcançar o êxito e a brevidade do aprendizado da leitura, bem como tornar a escola atraente...

\begin{abstract}
"Este sistema funda-se na língua viva. Não apresenta os seis ou oito abecedários do costume, senão um, do tipo mais frequente, e não todo, mas por partes, indo logo combinando esses elementos conhecidos em palavras que se digam, que se ouçam, que se entendam, que se expliquem; de modo que, em vez do principiante apurar a paciência numa repetição néscia, se familiarizasse com as letras e os seus valores na leitura animada de palavras inteligíveis. Assim ficamos também livres do silabário, em cuja interminável série de combinações mecânicas não há penetrar uma idéia! Esses longos exercícios de pura intuição visual constituem uma violência, uma amputação moral contrária à natureza." 109
\end{abstract}

A habilidade da leitura seria desenvolvida primeiramente pelo estudo das vogais, sem as quais - diz João de Deus - não poderia haver palavra escrita. As vogais representariam vozes, por meio das quais surgem os valores sonoros das palavras. Mas não se partia das vogais soltas em seus sons. Principiava-se, antes, pelo significado extraído da conjunção de mais de uma vogal - como em ai; ui; eu; ia. O princípio, para João de Deus, deveria ser sempre a inteligibilidade da palavra. Como antes dele já apontara Castilho, João de Deus dirá que a palavra falada está para a família assim

${ }^{108}$ Rômulo de CARVALHO, História do ensino em Portugal, p. 608.

${ }^{109}$ JOÃO DE DEUS, Cartilha Maternal ou arte da leitura por..., p. VII-VIII. Pelo próprio título e pela orientação das lições, percebe-se que explicitamente o autor desejava, para além da escola, atingir as mães e monitorá-las para o ensino da leitura. 
como a palavra escrita está para a escola. Porém, enquanto o aprendizado da fala acontece de maneira espontânea, natural, no ambiente familiar, o domínio progressivo da leitura requereria um percurso extremamente doloroso, atormentando, de maneira insuportável, mestres e discípulos. João de Deus, confiante na existência de um modelo alternativo de ensino da leitura, enfatiza a necessidade de se suprimir a etapa da soletração e da silabação como competências prévias e imprescindíveis para a alfabetização. O alfabeto, por ser assim, não seria apresentado logo à partida. Só se falaria nele, aliás, na vigésima quinta lição, quando o aluno já dominasse efetivamente o processo da língua, reconhecendo todo tipo de palavra, e podendo inclusive ler textos. Ao retirar o alfabeto do princípio do processo pedagógico, João de Deus pretendia, pelo encanto intrínseco da leitura, conferir ao aprendizado o mesmo fascínio exercido pela palavra escrita:

"Esse meio ou método não pode ser essencialmente diferente do método encantador, pelo qual
as mães nos ensinam a falar, que é falando, ensinando-nos palavras vivas, que entretêm o es-
pírito, e não letras e sílabas mortas, como fazem os mestres. Pois apressemo-nos também nós
a ensinar palavras, e acharemos a mesma amenidade. Com aquelas cinco letras já se escrevem
quatro palavras usuais, e que, por uma feliz coincidência, se lêm do mesmo modo, isto é, acen-
tuando a primeira voz. Lêde-as, e nunca soletreis; que mal sabeis como a soletração confunde
o principiante, e lhe deprava o raciocínio com somas falsas. Lêde-as acompanhando fielmente
com o ponteiro a letra que estais lendo; e vereis a facilidade, o gosto e a admiração com que o
aluno vos segue e vos imita, reconhecendo em sua consciência a palavra retratada no papel." 110

O aluno deveria ser, durante todo o processo da leitura, estimulado pelo professor. Para João de Deus, o aluno tem de ser entusiasmado em sua entrada no universo das letras. Ora, não sendo as letras, mas a junção delas quem desenvolveria o raciocínio analítico do estudante, recomenda-se na primeira lição o reconhecimento das vozes e dos sons correspondentes às seguintes expressóes: ai, ui, eu, ia. O aluno acompanha - ao reconhecer os sons pelos sinais e, pelos sinais, os significados a eles correlatos - o sentido intrínseco à palavra escrita, traduzido, enquanto tal, na sinalização da voz e da mensagem destinada a produzir comunicação entre os homens.

Aprofundando a crítica aos modelos de ensino da leitura comumente usados em Portugal, João de Deus não poupa recriminações àqueles que pretendiam começar o processo de ensino da leitura pela prática da silabação. No que concerne à leitura por sílabas, o escritor demonstra particular reticência quanto a um modelo de ensino que privilegiava o som, em detrimento do valor analítico dos caracteres, o que seria - segundo ele - "tão mal ou pior que soletrar"11. A Cartilha Maternal de João de Deus - ao grafar as diferentes sílabas com colorações destacadas umas das outras - depara-se com problemas trazidos pelos falares regionais e pelos diferentes sotaques. A escola e a língua eram, também aqui, tecidas pela tecla da uniformidade. A aquisição

${ }^{110}$ JOÃO DE DEUS, Cartilha Maternal ou arte da leitura por..., p. 2.

${ }^{111}$ JOÃO DE DEUS, Cartilha Maternal ou arte da leitura por..., p. 8. Na sequência, o educador prepara o leitor: "adiante exporemos claramente os elementos e condiçôes da linguagem, base de toda a arte de leitura. Se a letra representa um fato da linguagem, e o mestre não discrimina esse fato, como há de ensinar a ler?” (Id. Ibid., p. 8) 
da linguagem escrita teria uma correspondência no aprendizado da melodia dos termos, em um tipo de ouvir-falar aceitável para a linguagem oral e passível de ser superado mediante o estilo (por definição) único do ler-escrever. Nas lições de sua cartilha, pode ser conferida a estratégia de João de Deus para erradicar as variantes linguísticas regionais, mediante a unívoca e inconfundível norma da língua culta, a língua do impresso. Pretendia-se, pela Cartilha, trazer à tona uma forma diferente de ser escola:

"Costumamo-nos colocar a um canto da mesa, mais o aluno; ele dum lado à esquerda, e nós do outro. Pomo-lhes a lição diante convenientemente; e enquanto nas primeiras quatro liçóes percorremos com o ponteiro pela parte de cima as letras da palavra, imo-las simultaneamente lendo. Ora, como do intervalo da letra naturalmente se abstrai, nem esse intervalo é apreciável na marcha do ponteiro, a sílaba e a palavra afigura-se, aos olhos do principiante, como uma pequena escala cujas notas vibram na sua ordem natural. E o que é a leitura senão a interpretação sucessiva das letras simples e compostas, certas ou incertas da palavra escrita? Por isso é que a leitura é a verdadeira soletração; porque só na leitura se dá aos caracteres seu justo valor." 112

João de Deus polemiza com o método de Castilho, no concernente à criação que seu adversário fizera de palavras e sinais sonoros, destacando que a invenção de novos caracteres e nova fonética em nada contribui para a ortografia exata. O autor da Cartilha Maternal questiona a própria existência de uma ortografia exata posto que existam tantos modos de ler quantas forem as variações de ênfase na força relativa dos diferentes sons que compóem a palavra. Não haveria método algum passível de ser eficaz enquanto não se reconhecesse que não há correspondência direta entre ler e dizer o que se leu. Diante disso, João de Deus contrapõe-se aos críticos que argumentavam que de qualquer maneira se aprende a ler. De fato, em alguns casos - explicita o polemista - é possível aprender com qualquer método. Ocorre que, talvez na grande maioria das vezes, o indivíduo desiste, quer pelo excessivo tempo gasto para a operação da leitura, quer pelo tormento causado pelos rígidos, arcaicos e incorretos procedimentos escolares. João de Deus pretende, diante disso, tornar seu método nitidamente português e as instruções da própria cartilha são visivelmente um recado para os mestres de primeiras letras, ou para qualquer um que se pretenda aventurar pelo universo do ensino da leitura. Os procedimentos indicados são também dicas para permitir ao professor conhecer melhor sua língua maternal.

João de Deus qualifica o valor de cada letra, dando-lhe a entonação da leitura, a partir do modo pelo qual ela deveria ser pronunciada. Tal preocupaçáo fica exposta na seqüência de seu texto, quando classifica a fala em função não mais do critério binário das vogais e consoantes, mas pelo parâmetro quaternário que supunha vozes (as vogais puras e nasaladas), tons (v, z, j, r), sons (f, ç, x) e modos [ labiais (m,b,p) e linguais; divididos, por sua vez, em dentais $(\mathrm{d}, \mathrm{t})$, palatais $(\mathrm{r}, \mathrm{l}, \mathrm{lh})$ e guturais $(\mathrm{g}, \mathrm{q})]$.

A obra $A$ Cartilha Maternal e a imprensa, publicada em Lisboa no ano de 1877, é coletânea de artigos laudatórios. Trata-se de conjunto selecionado de textos publicados pela imprensa portuguesa. O método era elogiado, na maioria dos casos, por seu caráter inovador. Entendiam os partidários da Cartilha Maternal que João de Deus se

112 JOÃO DE DEUS, Cartilha Maternal ou arte da leitura por..., p. 28. 
pautara pela simplicidade, traduzida por excelentes resultados práticos já evidenciados pelos usos da Cartilha. O que havia de radicalmente distinto naquele novo modelo de ensinar a ler? Eficácia e rapidez decorrentes da inversão do trajeto da aprendizagem do aluno. O ponto de partida deixava de ser o entediante processo da soletração, ou a soletração carente de significado. Não mais se partia exclusivamente do som, mas buscava-se alcançar o significado das palavras; e por essa razão o ponto de partida da alfabetização era a palavra. Poderíamos mesmo dizer que João de Deus inventou para o caso português a alfabetização analítica. As palavras da Cartilha, grafadas com diferentes tonalidades, faziam dessa distinção tipográfica a chave para a posterior compreensão das partes sonoras de que se compóem os vocábulos. Finalmente, a uniformidade dos exercícios era apreciada pelos entusiastas do método como uma fonte de clareza lógica. Diante disso, havia quem classificasse o método como uma derivação pedagógica da corrente positivista; seja como for, o método procurava ser radicalmente moderno.

João de Deus inova por não acoplar seu método a questões fonéticas ou de sons, dado que, fazendo principiar o processo da leitura pela palavra, realmente torna a lógica do aprendizado da leitura semelhante à lógica da fala; em ambos os casos, o ponto de partida seria o significado. Diante disso, pode-se realmente entender que há uma lógica distinta no método de João de Deus; e que provavelmente a brevidade deixara de ser, como em Castilho e em Monteverde, uma meta, para se tornar um efeito do próprio percurso e da dinâmica da leitura. João de Deus, nessa medida, deve mesmo ser considerado como um antecedente ou até como um precursor do método global ou analítico desenvolvido por Decroly no princípio do século XX, particularmente desde 1906. O poeta defendia que o interesse da criança pela leitura é determinante no processo do aprendizado. Por sua vez, no tocante à alfabetização, o interesse não ocorreria pelo sinal sonoro, ou pela mecânica reprodução do sinal gráfico. O interesse era despertado fundamentalmente pelo sentido da palavra, por aquilo que ela designa e pela correspondência escrita entre os nomes e os objetos. Seria então a correspondência entre os objetos da realidade e os nomes que a linguagem humana dá para eles quem despertaria a curiosidade da infância para com a fala e posteriormente para com a transposição escrita dessa mesma fala.

Carvalho Junior atesta para o Jornal das Senhoras a eficácia do método, quando relata a prova pública a que a Cartilha Maternal fôra submetida. O teste ocorreu em um teatro de Lisboa e foi presenciado por pais e professores - além das autoridades do distrito - muitos deles descrentes quanto aos possíveis resultados positivos. O Abade de Arcozello foi o responsável pelo convite feito às pessoas que compunham o auditório. Diante daquele público, seriam entrevistadas crianças entre 5 e 8 anos, as quais haviam aprendido a ler pela Cartilha Maternal, cada uma com um número específico de lições: algumas tinham tido 12 aulas, outras 20, outras 30, ou mesmo 100 . O resultado comprovava que o ensino pelo método inventado por João de Deus se destacava de maneira singular particularmente porque às crianças eram apresentados textos extraídos de diversos livros, com os quais elas não teriam familiaridade, e em cuja leitura apresentavam notável fluência e desenvoltura. Salientava-se ainda a brevidade com que a maioria dos discípulos havia decifrado os enigmas da leitura. Contava-se sobre um menino - esse mais velho, de 12 ou 13 anos - que, tendo passado 4 anos na escola, havia aprendido apenas algumas letras. Quando foi introduzido na Cartilha Maternal, passou finalmente, em pouquíssimas lições dadas no decorrer de 
dois meses, a ser capaz de ler. O pai da criança e o mestre asseguravam o fato. Outros relatos publicados na mesma obra - A Cartilha Maternal e a imprensa - destacavam que João de Deus tomava como um desafio todas as crianças que lhe chegavam às mãos rotuladas pelos pais e mães como incapazes de aprender o bê-á-bá. Nesses casos - contava-se - João de Deus procurava convencer o discípulo e seus pais de que o culpado não era o menino, mas o martírio e o trauma que a escola, os castigos, as palmatoadas e principalmente a irracionalidade do método (ou mesmo a ausência de método) provocavam. Com tudo isso, João de Deus granjeava inúmeros adeptos e incontáveis admiradores entre os mestres que orientava e a população que o acompanhava. Acreditando piamente naquilo que fazia, o poeta aparecia, em sua época, como detentor dos segredos da didática da leitura. Em suas mãos, ensinava-se bem e em pouco tempo. Os incontáveis registros sobre o tema levam-nos realmente a acreditar na eficiência do método quanto àquilo que propunha. Mesmo assim, João de Deus defendia-se contra os que o acusavam de conferir prioridade à brevidade:

\begin{abstract}
"Assim, pois, as cartilhas escrevem-se para a infância; e a infância tem muito tempo a perder. Por isso a brevidade não pode prevalecer sobre nenhuma outra condição de um método. O que importa, principalmente e essencialmente é levar o principiante de degrau em degrau pelas dificuldades da arte; é não contrariar a natureza humana com processos e afirmações absurdas; é lisonjear, favorecer, desenvolver as nossas faculdades, em vez de as torcer e atrofiar. A brevidade pouco importa. Mas a quem pode ela prejudicar ? Que mal faz à criança ou ao adulto, aprender num mês aquilo que havia de aprender em dois, se o não molestam, se o não cansam, se o não enfastiam, antes o entretêm e deleitam ?"113
\end{abstract}

\title{
João de Deus: do método de leitura à leitura do método
}

Em muitos de seus escritos, João de Deus alude à sua preocupação com os efeitos da leitura, com a necessidade da leitura, com as intersecçôes entre cultura, civilização e leitura - essa leitura que vinha pelos trilhos do caminho de ferro... Havia, naquele último quartel do século XIX, reconhecida relação entre a prosperidade material e o âmbito do desenvolvimento das letras. Era como se a nova civilização que estava por vir exigisse a "forma escolar" como seu modelo básico. Por ser assim, o ler e escrever passam a ser apreendidos como armas competitivas, instrumentos de cuja posse dependeria o progresso das nações. A humanidade, no atual estágio por que passava, exigia o signo da escrita como condição imprescindível para seu desenvolvimento. O saber ler era, pois, condição de dignificação humana; aquilo que metodologicamente atribuía a distinção do homem cultivado.

A sacralização da atividade da leitura vem acoplada a uma percepção evolutiva da humanidade: a leitura decorre da palavra divina, aproxima o homem de seu Criador e favorece a partilha, a socialização e a circulação das idéias. $\mathrm{Na}$ acepção evolutiva desse modelo interpretativo, prosperariam os povos que melhor se fizessem capazes

${ }^{113}$ JOÃO DE DEUS, Carta lida pelo Abade de Arcozello - Cândido José Ayres de Madureira - no teatro Baquet em Lisboa, quando da reuniāo de avaliação do método de João de Deus, In: A Cartilha Maternal e a imprensa, p. 15-6. 
de aproveitar os benefícios trazidos pela distribuição da palavra escrita. A civilização, por tal dispositivo, acumula memória e sai vitoriosa do embate contra o obscurantismo popular. Transformar o povo era tarefa urgente... O ensino da leitura seria visto, por tal dimensão, como um projeto civilizatório, passível de se colocar ao alcance das camadas majoritárias da população. Espraiar a atitude leitora era o objetivo maior de João de Deus. Na verdade, tratava-se do esforço para trazer eficácia à instrução portuguesa, naquela escola que era, entretanto, rejeitada por seus usuários, como uma instituição incapaz de fazer cumprir o que promete.

Sucede que abordar analítica e historicamente o método de João de Deus é uma atitude intelectual que deve ser acompanhada da observação sobre o modo mediante o qual o poeta orientava os educadores da época para lidarem com as predisposiçôes mentais e emocionais dos estudantes. Em virtude da maneira dogmática e constritiva mediante a qual a escola estivera, desde remotas épocas, estruturada, o aluno que não era capaz de aprender, de modo geral, era um estudante espiritualmente bloqueado para o aprendizado. O aluno deveria ser, portanto, estimulado, motivado, a partir do entusiasmo com que o mestre o faria acreditar em sua capacidade de aprender. O processo de aprendizado suporia, pois, como condição primordial, que o estudante acreditasse nele mesmo. Talvez nem o próprio João de Deus tivesse consciência dessa sua estratégia, mas indubitavelmente ela agia como uma profecia auto-realizadora. Convencia-se o aluno de que sua dificuldade de aprender não era ocasionada por sua incapacidade, mas pela ineficácia da ação escolar. Dizia-se a ele que, em função disso, seria utilizado um método diferenciado dos procedimentos tradicionais já experimentados pelo mesmo aluno. Este, então, passaria a apostar na possibilidade da mudança e na ocorrência efetiva do aprendizado, ou seja: aberto para aprender, o jovem aprenderia... E assim criava-se um ciclo de estímulo, autoconfiança e sucesso escolar. João de Deus era confiante na possibilidade de desenvolução institucional da escola. Talvez por isso tenha sido bem-sucedido o seu método. Mas o mestre deveria, acima de tudo, ser capaz de apreender os mecanismos lógicos utilizados pelo aluno no percurso da aprendizagem. A arte da educação supunha, antes de qualquer coisa, uma linguagem comum. Cabia ao mestre decodificar a linguagem do estudante e ser capaz de torná-la mais complexa, aproximando-a da outra linguagem, a linguagem culta, a linguagem da escola, a linguagem socialmente recomendada. A arte do magistério exigiria ser estudada como se de uma ciência se tratasse:

"A arte da leitura é hoje uma ciência culta, um sistema, uma unidade lógica: todas as suas partes jogam entre si, e têm uma filosofia. O mestre deixou de ser um autômato que repetia ba, be, bi, bó, bu, a ser um intérprete, um explicador. Não conta com o grande auxiliar do tempo, que até gasta os mármores, nem ainda com o empenho do aluno. Conta consigo, com a arte, com a natural e irresistível simpatia da racionalidade do aluno, com a racionalidade do Método. Pode o discípulo não estudar, mas se prestou atenção, se ouviu, aprendeu a ler. Não há cabeças de burro. As cabeças de burro passaram das crianças para os homens, dos discípulos para os mestres. Ler é essencial a todos. Onde há um analfabeto, não há civilização." 114

${ }^{114}$ JOÃO DE DEUS, Cartas sobre o método de leitura, In: Prosas, p. 261-2. 
João de Deus, preocupado em ensinar os professores sobre sua arte, partia do pressuposto de que eles em geral não sabiam o que faziam, agindo por aproximações, por induções, mas sem um método claramente definido. António Gomes Ferreira relata a carência de método como uma concreta característica do ensino português no século XVIII. ${ }^{115}$ Os professores, também no XIX, praticamente desconheciam as matérias que ensinavam. Tampouco compreendiam a fisiologia e a psicologia de seus alunos. O magistério era ainda um fazer profissional, que se praticava, sem qualquer dimensão teórica. O trabalho de João de Deus evidentemente sofreu essa dificuldade. Nem sempre os professores compreendiam o que a Cartilha lhes propunha.

Ao procurar se contrapor ao método de João de Deus, Francisco do Amaral Cirne Jr. - tanto no relatório apresentado ao Comissário de Estudos do Distrito do Porto, sob o título Exame da Cartilha Maternal (1879), quanto em sua obra Resumo da História da Pedagogia (1881) - atenta para o fato de seu autor não haver conseguido e nem haver sequer acreditado no ensino da leitura e da escrita simultaneamente, como processos concomitantes. Esta seria, no parecer daquele crítico, uma das maiores falhas do método da Cartilha Maternal. Embora condenando as práticas escolares presas por práticas arcaicas de soletração e de silabação, João de Deus - mesmo assim - entendia que a leitura era processo cognitivo do qual dependia a posterior prontidão para a escrita. Anteriormente, porém, entre as décadas de 40 e 50, Caldas Aulete já havia publicado sua Cartilha Nacional, que se teria constituído na primeira tentativa em língua portuguesa de articular de maneira simultânea o ensino da leitura e da escrita sem haver precedência de um sobre o outro. Embora Cirne Jr. julgasse que até mesmo a cartilha de Caldas Aulete apresentasse problemas metodológicos, a despeito da larga utilização que teria conseguido nas escolas, o crítico reconhece que seu autor soubera decifrar o nó górdio do ensino português, ao propugnar um modelo simultâneo para o aprendizado dos saberes da escola primária. Em seu parecer, a cartilha de João de Deus provocara, em certo sentido, uma volta atrás, apesar de toda a louvação que lhe era feita; e que Cirne Jr. atribui à completa ausência em Portugal de uma ciência pedagógica à altura do século.

No texto em que examina a cartilha de João de Deus, Cirne Jr. conclama os leitores à prudência diante de novidades, declarando que o entusiasmo nunca deverá ser o primeiro alicerce da atitude de investigação e de crítica. Todo o debate posto em torno do método Castilho não teria sido suficiente - argumenta Cirne Jr. - para impedi-lo de cair por terra e ser submetido ao mais completo esquecimento. De maneira análoga, o crítico previa a redução gradativa do entusiasmo gerado pela Cartilha Maternal, e explica:

115 "Em geral, os mestres de ler, escrever e contar sabiam pouco sobre o que ensinavam e menos ainda sobre como o deviam fazer. Sem método, alguns terão perdido o controlo da aula ou permitido uma relação demasiado permissiva, situação que não podia deixar de desagradar às populaçôes e às autoridades, mas a maioria parece ter assumido ar grave e austero que ajudava a impor o respeito e manter a disciplina, o que estava mais de acordo com a mentalidade da época. Todavia, manter todos os alunos em silêncio e a trabalhar entregues a si mesmos ou a outros mais adiantados, enquanto se atendia uma criança de cada vez, dificilmente seria conseguido sem se recorrer a castigos. Então, se o grupo dos meninos que o mestre tinha sob a sua responsabilidade era não só muito numeroso como muito diversificado, tanto quanto a idades como a saberes e, ainda por cima, dados a travessuras ou a desmandos, que os mais velhos ardilosamente provocariam, o mais provável seria que ele se exasperasse com alguma frequência, punindo sem critério e com violência desmesurada todos aqueles que lhe pareciam estar envolvidos nas perturbaçôes." (António Gomes FERREIRA, A criança no Portugal do setecentos: contributo para o estudo da evolução dos cuidados e das atitudes para com a infância, p. 381-2). 
na verdade, os métodos só se fariam capazes de resistir ao crivo do tempo quando se mostrassem capazes de ser manuseados pelo professor no cotidiano da sala de aula.

Haveria uma tendência, por assim dizer, compreensível e quase natural, de se empregar a metodologia já conhecida, sobre cujo domínio e eficácia não pairassem quaisquer dúvidas; enfim aquilo que, posto à prova do tempo, deu certo. O método novo, descrito apenas nos livros, era, em geral, visto com reticência e desconfiança por parte dos protagonistas da educação: os professores, que hesitavam para pô-lo em prática. Pelas palavras de Cirne Jr., explicita-se a relutância quanto àquilo que é apenas projeto impresso nas teoria : “com efeito, um método só será eficazmente implantado numa escola quando teórica e praticamente for bem familiar ao professor. Prefere-se o método que melhor se conhece porque é aquele com que melhor nos ajeitamos."116 A lógica que presidia a aceitação e o otimismo para com o método de João de Deus estaria posta na carência de reformas efetivas capazes de aprimorar o ensino português. A própria imprensa periódica cobrira o tema de modo superficial, até porque havia reconhecida incapacidade técnica de avaliação da matéria. Nessa trilha, afirma-se que, de tudo o que se teria escrito à época acerca da Cartilha Maternal de João de Deus, a grande ênfase e realce eram colocados na dimensão da suposta brevidade do método, o que por si contrastaria com a lentidão e a inoperância da escola primária portuguesa naqueles tempos. Cirne Jr, desqualificando completamente os entusiastas do método de João de Deus, refere-se a eles como pedagogos improvisados: "publicam-se anúncios pomposos, promete-se aos pais rapidez assombrosa, chegando a afiançar-se que bastam quinze liçōes para uma criança aprender a ler corretamente."117 A Cartilha Maternal - no parecer daquele opositor - havia apenas reordenado o modo com que se dispunha o alfabeto, mas não representava avanço significativo; até porque se mantinha, disfarçado, o aprendizado tradicional, os procedimentos sintéticos de alfabetização e especialmente o descompasso entre o aprender a ler e o aprender a escrever.

$\mathrm{O}$ que parecia estar em jogo, pelas premissas de F. A. Cirne Jr., era a própria capacidade de resistência à inovação por parte da escola e do professorado. Essa aversão ao desconhecido e à mudança verificar-se-ia - como diz ele - no indisfarçável apego da escola a práticas e técnicas ultrapassadas. O embate do século XIX português é, por um lado, o discurso da inovação e, por outro, as representações da permanência secular daquilo que se criticava. A forma escolar em gestação passava também por inúmeras contradiçôes... Cada vez mais, a pedagogia do discurso buscava novas soluçôes. Esse era um tempo em que era bastante forte a cosmovisão evolucionista, mediante a qual o desenvolvimento da criança é apreendido apenas como uma revelação do anterior percurso da espécie.

Cirne Jr., em seu argumento, parecia defender os mesmos postulados do método que condenava: "no ensino da leitura o conhecido é a palavra falada ou a frase. Da adoção da palavra ou da frase para ponto de partida resultam duas variantes do mesmo método"118, a saber: decomposição das palavras em sílabas e depois em sons

\footnotetext{
${ }^{116}$ Francisco do Amaral CIRNE JR. , Exame da Cartilha Maternal: relatório apresentados ao Exmo snr Comisário d'Estudos do distrito do Porto, p. 7.

${ }^{117}$ Francisco do Amaral CIRNE JR., Exame da Cartilha Maternal..., p. 9.

${ }^{118}$ Id. Ibid., p. 19.
} 
elementares e irredutíveis. A partir do contato com esses elementos fonéticos da palavra é que seriam estudadas as letras (sinais) que os representam:

"Depois o aluno reconstrói a palavra (síntese reflexa) e fica completa, com este primeiro ensaio de leitura, a operação do método. Tomando a frase para ponto de partida, procede-se, ainda, da mesma forma: decomposição da frase em palavras, das palavras em sílabas, da sílaba nos elementos que a formam e assim sucessivamente como na outra variante. É este o único método racional de ensinar a ler, é o caminho que seguiu a raça na invenção da escrita. Ora, o Snr. João de Deus segue exatamente o caminho oposto porque toma, para ponto de partida, o ensino das letras que nada significam para uma criança, parte do desconhecido para o desconhecido." 119

Destacando que o método de João de Deus não se mostrara capaz de descobrir o segredo do ensino simultâneo da leitura e da escrita, Cirne Jr. resume a contribuição da Cartilha Maternal à idéia de apresentação do texto por matizes de tons de preto diferenciados para as sílabas. Era - segundo ele - a parte formal, (quando compunha a cartilha em letras distintas da cor preta, mais clara ou mais escura), a única coisa válida, computando-se todo o esforço de João de Deus... Além disso, a excessiva preocupação com a brevidade proporcinara retrocesso nos estudos sobre alfabetização, dado que o projeto de João de Deus, pelas razões expostas, havia se revelado aquém do de Caldas Aulete, de Ramos Paz e de Brito Aranha.

Ao rebater essa crítica, João de Deus enfatiza que, mais preocupado do que com o desenvolvimento da raça, ele estaria com o progresso civilizatório e com o papel da leitura no mesmo processo. E, enfaticamente, destaca que o saber ler seria, sob tal enfoque, muito mais premente do que o saber escrever. Era preciso ler, e, mais do que isso, ler o texto impresso. Parece-nos emblemático o embate dessa intelectualidade portuguesa sobre a estratégia e o segredo da alfabetização. Disso - supunham eles dependeria o futuro da escolarização primária, e, aqui estaria também contido o próprio futuro do país. O imaginário da leitura, mais do que nunca, permeava a acepção simbólica da escola.

\section{João de Deus: a regeneração social pelo método de ensino}

O sucesso de João de Deus parecia, para alguns, matéria inquestionável. Era o caso de Samuel Tito que entretece seu relato de maneira a apontar o poeta como o apogeu de um longo e árduo processo histórico, no qual inúmeras tentativas pregressas teriam tido seu ápice nos resultados dos estudos do poeta e em suas técnicas para ensinar a ler e a escrever. Outros destacavam a singeleza de sua concepção, muitos ainda apontam que seus exercícios de intuição visual seriam o caminho para interromper, de uma vez por todas, o interminável império da soletração. De qualquer modo, o próprio João de Deus - assim como Castilho já fizera há vinte e poucos anos atrás - não poupa elogios a si mesmo. Acreditava de fato ter tomado posse do segredo da didática da leitura. Julgava que a racionalidade do processo da

${ }^{119}$ Francisco do Amaral CIRNE JR., Exame da Cartilha Maternal..., p. 20. 
leitura vinha por analogia à racionalidade da fala e era imprescindível para orientar o aprendizado. A leitura escolar tornara-se algo repugnante pelo fato de não respeitar esse processo, mas antes contrariá-lo, opondo-se ao modo racional, e à natureza do aprendizado. $\mathrm{Na}$ ausência desses critérios, instaurar-se-ia a irracionalidade, a falsidade, a contradição. A leitura correta exigiria, por sua vez, princípios adequados, corretos, deduzidos gradual e metodicamente.

A leitura, para João de Deus, pretendia ser a confirmação da fala - nisso ele concordava com Castilho. A grande polêmica, aliás, que marcaria seu trajeto de debatedor foi com um seguidor de Castilho: Simões Raposo, vereador e professor oficial na chamada Casa Pia em Lisboa. No ano de 1879, Simões Raposo já havia publicado sua cartilha, adotada para uso dos alunos da Real Casa Pia de Lisboa ( $O$ primeiro livro da escola: cartilha de leitura preliminar e elementar - aprovado pelo Conselho Superior de Instrução Pública para ser usada em escolas primárias de $1^{\circ}$ grau). Tendo sido inspetor de instrução primária no Porto, Raposo tinha formação pela Escola Normal primária de Lisboa, e se destacava como especialista no assunto da educação. Em 7 de janeiro de 1879, carta de Simões Raposo dirigida ao redator do jornal Comércio de Lisboa, chamado Luciano Cordeiro, vinha a público. Nessa polêmica noticiada no mesmo veículo de imprensa, Raposo provocava João de Deus declarando que a Cartilha Maternal não era maternal, não tinha originalidade alguma, e, sobretudo, não havia trazido melhoramento à escola portuguesa. $\mathrm{O}$ crítico ainda acrescenta, dizendo que seu sucesso derivava, além de tudo, de uma mera exploração mercantil. Para Raposo, o que de mais ridículo havia nos apóstolos de João de Deus era o fato de entenderem a Cartilha Maternal como única alternativa - que não tivera nem precedente e nem sucessor - como se a história da educação pudesse assim ser resumida a um discurso de inauguração e encerramento. João de Deus era, à época, cultuado; e sua obra apontada como a grande descoberta de toda a história da pedagogia. Por ser isso - em sua opinião - uma inverdade, o crítico pretendia evidenciar a improcedência da tese. No primeiro semestre de 1879 , Simóes Raposo era o único vereador da Câmara de Lisboa a votar contra um projeto segundo o qual os professores deveriam ser, pela mesma Câmara, convidados para receber os conhecimentos teóricos do referido método João de Deus pelo próprio autor da Cartilha Maternal. A Câmara forneceria aos docentes os meios de transportes e lhes custearia as despesas. Raposo justifica sua rejeição a tal projeto, pelo fato de haver nele cláusula que dizia que esse estudo ocorreria a fim de que posteriormente o método fosse adotado nas escolas de Lisboa. Além disso, o projeto conteria juízo de valor antecipado ao crivo da investigação e da prática, expondo que o método por João de Deus desenvolvido era o que mais satisfazia às necessidades de aprendizado de crianças e adultos. Ocorre que, naquela altura, o método de João de Deus não teria ainda conseguido aprovação da junta consultiva de instrução pública e a objeção de Simões Raposo teria nesse obstáculo o amparo legal de que precisava. João de Deus, no calor daquela contenda, se enfurece: "seriamente será ainda necessário provas? Pois à vista do que vai no país com o método, qual será a pessoa sensata que duvide se há ali alguma coisa de extraordinário, uma nova luz, uma verdade desconhecida e utilíssima?”120

\footnotetext{
${ }^{120}$ JOÃO DE DEUS, Novidades, In: A Cartilha Maternal e a critica, p. 65-6.
} 
A não aprovação imediata da Cartilha Maternal se deveu - segundo seu autor - a algumas frases interpretadas como republicanas, como é o caso da expressão: "sombra espessa da monarquia”. Isso não impediu, entretanto, João de Deus de se sentir lesado quando outras obras - segundo ele menores e que constituíam apenas plagiato ou contrabando literário - foram aprovadas pela mesma junta consultiva, que tanto relutava no caso da unanimemente reconhecida Cartilha Maternal. Como se verá adiante, o mercado editorial do livro didático e a aprovação dos mesmos livros pelo órgão governamental competente eram peças de um jogo de poder e dinheiro bastante destacado em Portugal de meados do século XIX. Os critérios pedagógicos evidentemente subordinar-se-iam à questão do mercado e das relaçôes com a corte monárquica.

Foram muitas as polêmicas e inquietações que João de Deus teria com a apropriação que outros fariam de seu método. Entretanto, uma que certamente o incomodou foi a que relataremos a seguir. Ao tomar contato com o método de um dito Felizardo Lima, de Vila Meã, no concelho de Amarante, João de Deus se surpreenderia com a disputa que, desde o princípio, o autor da chamada Cartilha Infantil parecia desejar travar com a Cartilha Maternal. O método de Felizardo Lima, embora não fosse novo, dado que o autor tinha grande experiência anterior, parecia agora renovado, a partir de uma suposta metodologia sincrética, da qual o autor também se vangloriava, e que se dizia basear na fusão dos princípios de Castilho com os de João de Deus, na pretensão de, evidentemente, superar ambos. A nova cartilha no prelo era anunciada por vários jornais do Norte e prometia ser enviada pelo correio, além de dizer que ensinava a ler em 20 dias. Outro anúncio no jornal Penafidelense garantia que desde o ano de 1863 - há quinze anos, portanto, daquela publicação - o dito educador costumava ensinar a ler e a escrever em três meses. Nos últimos tempos, fazia até provas públicas para certificar que era capaz de levar trabalhadores do concelho de Torres Vedras, de Amarante, de Penafiel, a aprenderem a ler e escrever em 47 lições. Dizendo possuir significativa vantagem sobre os procedimentos de ensino desenvolvidos por João de Deus, Lima oferecia seus préstimos às Câmaras Municipais, "sem outra remuneração que o abono da despesa em jornadas, que só receberá depois de obtidos os resultados que promete" 121 . João de Deus - que, como realça Theóphilo Braga, era, nos debates diários que a imprensa lhe reservava, um polemista de extrema grandeza, destacado pela fina ironia - rebate imediatamente, dizendo que Felizardo Lima não havia entendido nada de seu método.

Felizardo Lima diz haver constatado que o método por ele próprio elaborado era melhor do que o de João de Deus. Pretendia provar isso. Desafia então os brios do poeta. Sugere que fossem reunidos alguns analfabetos de qualquer freguesia do país, metade para serem ensinados por João de Deus e a outra metade por ele, Lima; cada qual evidentemente com seu respectivo método. No final de 20 dias, os discípulos de ambos seriam apresentados em reunião pública para que o público decidisse qual dos dois dera o melhor resultado.

Durante todo aquele ano de 1879 , houve grande número de debates e requerimentos dirigidos à Câmara dos Deputados solicitando do governo os investimentos de recursos, quer com o estudo e o ensino do método de João de Deus, quer com sua

${ }^{121}$ PENAFIDELENSE, In: João de Deus, A Cartilha Maternal e a critica, p. 82. 
adoção. Havia, como contraponto, também uma representação de professores primários de Lisboa, solicitando do legislativo que, "no caso de ser votada a proposta com relação ao método de João de Deus, se estabeleçam cursos paralelos em que se pratiquem os outros métodos em uso, a fim de conhecer-se o que dá mais vantagens no ensino." ${ }^{122} \mathrm{O}$ método vencedor seria aquele que se deveria uniformemente utilizar por todo o território nacional. Naquela ocasião e a propósito disso, é João de Deus quem propóe um desafio a um daqueles professores que assinavam a carta, a quem ele, nesse momento, elege como crítico dileto. Ele, que sempre se recusara a aceitar desafios de outros opositores, aqui, provavelmente privilegiava o interlocutor. A 21-5-1879, João de Deus sugeria a M. J. Martins Contreiras que fosse feita uma disputa no ensino: um dos lados com seu método; o outro com um método qualquer. Cada facçaó teria um padrinho, e Theóphilo Braga, que, a princípio, deveria ser o padrinho de João de Deus, acaba por ser escolhido como árbitro da contenda. Contreiras opta por valer-se do método legográfico (de Caldas Aulete) que, na ocasião era verdadeiramente o que mais ameaçava João de Deus, pela promessa que fazia do ensino paralelo da leitura a da escrita. Contreiras não postulava a adoção oficial deste ou daquele método, mas defendia a liberdade de escolha do professor de acordo com o que ele mais se familiarizasse. Acreditava inclusive ser dever da escola normal ensinar a seus alunos-mestres diferentes métodos, diferentes procedimentos educativos, diferentes técnicas de ensino, de modo a verdadeiramente habilitá-los pelo conhecimento polivalente de seu ofício. Dizia então Contreiras que "desviar pois alunos mestres para o estudo especial dum método e para a prática do mesmo, seria expô-los a ficarem ignorando todos os outros, obstar a que adquirissem conhecimentos que lhe são igualmente necessários"123. Quando escolhe para o debate com João de Deus o método legográfico, provavelmente Contreiras desejasse, portanto, apenas provocar o oponente, por saber que a cartilha de Caldas Aulete assustava o poeta, como nenhuma outra o fazia.

Contreiras recorre até à sua própria experiência pessoal no ofício de professor:

"Pratiquei o método legográfico na aula anexa à normal, quando o meu falecido professor Caldas Aulete andava organizando a Cartilha Nacional, sob o plano de J. Halben. Estou convencido que embora a arte de ler e a de traçar caracteres sejam diferentes, a leitura e a escrita completam-se e auxiliam-se, porque têm a mesma base e o mesmo fim: a idéia. Um curso noturno, de 90 alunos, que lecionei em Oeiras, determinou pelos resultados práticos, a minha predileção pelo método legográfico, que usarei ao efetuar-se o nosso certamen. E aumenta a força da minha convicção, quando leio os jornais pedagógicos da Bélgica, e vejo que presentemente há uma luta entre os partidários deste método a que chamam o método do futuro e os seus adversários que não apresentam um argumento sério para o combater.!"124

${ }^{122}$ DIARIO DE NOTÍCIAS, 10-5-1879, In: João de Deus, A Cartilha Maternal e a crítica, p. 122.

${ }^{123}$ M. J. Martins CONTREIRAS, Democracia, 1-6-1879, In: João de Deus, A Cartilha Maternal e a crítica, p. 139.

${ }^{124}$ M. J. Martins CONTREIRAS, Democracia, 18-6-1879, In: João de Deus, a Cartilha Maternal e a crítica, p. 152. "Frequentava eu a escola normal de Marvilla, em 1869, quando o ilustre professor Caldas Aulete (...) apresentou a seus discípulos o manuscrito da Cartilha Nacional, fazendo na presença do curso alguns exercícios práticos. Nas conferências pedagógicas que, por esse tempo, se realizaram entre os alunos, presididos pelo distinto diretor da escola, 
Com o fito de convencer a opinião pública e particularmente a categoria dos professores, João de Deus - hábil e retoricamente - pretendia aproximar-se dela, pela simplicidade e pela excessiva valorização da prática de sala de aula em detrimento das teorias educacionais, às quais tantas vezes seus debatedores recorriam. Sobre o tema do método, dizia que o parecer de Contreiras defendia antes a liberdade da ignorância do que a liberdade de escolha. A estratégia do poeta - assim como ele fizera anteriormente com crianças que, com os métodos habituais da escola portuguesa, não teriam sido capazes de aprender a ler - pautava-se no esforço de devolver ao leitor e professor comum a confiança em seu trabalho e a auto-estima; o que serviria - para além de encontrar partidários - também para propagar, divulgar e impulsionar o uso escolar da Cartilha Maternal. Todo o argumento de Contreiras leva a crer que realmente havia um projeto embutido naquela movimentação parlamentar sobre a causa da instrução, cujo vértice seria o interesse de adoção do método de João de Deus nas escolas.

Contreiras recorre, em seu argumento, ao valor educativo da imprensa e à necessidade da educação para a leitura, voltada para capacitar as gerações mais jovens a fazerem melhor uso do jornal. Recorda que Caldas Aulete, quando da elaboração de sua obra, teria consultado e se referenciado por diferentes jornais e compêndios estrangeiros, o que havia evidentemente contribuído para o bom resultado que obtivera. Contreiras, por fim, desafia João de Deus, defendendo o mérito de sua cartilha, dizendo que não parece natural ensinar a interligação das vogais antes de se haver explicado às crianças quais são as vogais. Acrescenta que, em termos dos princípios positivos da linguística, mesmo a cartilha tradicional, ainda que caluniada, tinha mais razão de ser que a dita maternal. Sucede que, em um daqueles textos e cartas enviadas à imprensa, Contreiras remetera para o redator do jornal Democracia o método de leitura que acabara de concluir: Cartilha da Escola. Diante de tal oportunismo, João de Deus rescinde o desafio, acusando a cartilha de Contreiras de plágio da de Caldas Aulete e declarando que o único interesse daquele seu opositor seria o de promover seu método à custa da polêmica.

Em qualquer dos casos, todos pareciam concordar no seguinte: era necessário aprimorar a escola para capacitar o povo para o diálogo escrito. Realmente, a despeito ou por causa de toda a polêmica que o envolveu, o método de leitura preconizado por João de Deus teve um alcance ímpar na opinião pública portuguesa. Chegou-se a destacar o fato de a Cartilha Maternal adequar-se inclusive àquelas famílias que não desejavam para seus filhos a perda do tempo de trabalho com o estudo. $\mathrm{O}$ ensino rápido da leitura permitiria a conciliação entre o tempo do plantio e da colheita e o tempo da escola. E com isso, quem sabe, o país poderia mudar seu modo de olhar tão indiferente para a escola e para os benefícios da instrução.

discutiu-se e apreciou-se em todos os sentidos a cartilha, que vinha iniciar entre nós o método legográfico, os exercícios simultâneos de leitura e escrita. Pouco depois ela foi praticada na escola acadêmica, e muitos dos discípulos de Caldas Aulete, em cujo número me encontro, não deixaram de procurar praticamente também em suas escolas a confirmação das teorias que o ensino normal lhes apresentara. Provam-no as diversas ediçōes tiradas, apesar do elevado preço por que se vende a Cartilha Nacional." (M. J. Martins CONTREIRAS, Democracia, 8-12-1879, In: João de Deus, A Cartilha Maternal e a critica, p. 201). 


\section{Forma de escola, criminalidade e ciência}

João de Deus, nos últimos decênios da monarquia, teve seu método apropriado por inúmeros dos arautos republicanos em Portugal. Há naqueles anos intenso debate sobre o problema da instrução pública, e - talvez pela aproximação do final do século, talvez pelo rearranjo econômico e o rápido desenvolvimento de alguns países europeus - o atraso português parecia cada vez mais evidente. Em Coimbra de 1880, a Câmara Municipal fazia sessão solene para examinar alguns alunos da escola municipal regida pelo método João de Deus. O final de século tornava a educação um rito cada vez mais visível, destacado pelo acompanhamento incansável dos jornais. Por sua vez, congressos e conferências pedagógicas intensificar-se-iam a partir dos anos 80, coordenados em geral por integrantes da Liga Nacional de Instrução. Tais eventos impulsionavam a Associação das Escolas Móveis pelo método João de Deus, que, fundada em 1882, teria promovido - segundo dados de Catroga - "149 missões escolares, o que representava uma média de 7 missões anuais; em 1908, esse número foi de 18, que envolveram 1.153 alunos, o que perfez um total de 9.664, isto é, 420 alunos por ano; e, em 1909, a associação contava com 1.705 sócios” ${ }^{125}$. Em 1890, a Revista de Educação e Ensino trazia com freqüência comentários sobre a boa repercussão social ocasionada pelo Método João de Deus quando aplicado em escolas primárias. Ressaltava-se o valor social representado pela iniciativa das Escolas Móveis, as quais, por sua vez, propunham-se, adotando as técnicas de João de Deus, enfrentar o analfabetismo de jovens e adultos portugueses na época. Naquele ano de 1890, já havia 50 missões da Associação das Escolas Móveis João de Deus. O projeto de lei das Escolas Móveis supunha - como constava da mesma revista - o seguinte: 1) ensino da leitura, escrita e quatro operaçôes pelo método João de Deus; 2) envio de missões de atividades (por cinco meses) para os distritos que mais carecessem de instrução; 3) o ministro de Estado dos negócios da instrução pública e belas-artes era o responsável para o envio das escolas; 4) o local, dia e horário dos cursos seriam estabelecidos pelo Presidente da Câmara, conforme as conveniências locais; 5) a duração do curso seria inicialmente de três horas, podendo prolongar-se até quatro, no caso de haver um só; 6) após os 5 meses previstos para duração dos cursos seria realizado, em dia de feriado ou domingo, o exame dos alunos, cerimônia que contaria com a presença de todas as autoridades civis, eclesiásticas e militares da região, o que faria por supor uma solenidade festiva para se proceder ao encerramento do processo.

O objetivo declarado das Escolas Móveis era o de "tornar todos os portugueses iguais perante a palavra escrita. E pur si muove. Todo aquele que soubesse ler, escrever e contar, tendo massa cinzenta suficiente, saberia abrir novos horizontes à sua atividade" ${ }^{126}$. Com tais palavras, Casimiro Freire - fundador das Escolas Móveis - definia o objetivo daquela agremiação que militava pela causa do ensino, em nome da memória de João de Deus. Os cursos ambulantes, que preparariam para os rudimentos da leitura, da escrita e do cálculo, habilitariam, no decorrer de 4 ou de 6 meses, o

${ }^{125}$ Fernando CATROGA, O republicanismo em Portugal..., segunda parte, p. 397.

${ }^{126}$ Casimiro FREIRE, Por que se instituíram as Escolas Móveis, In: João de Deus RAMOS, A instrucção do povo..., III tomo, 2a série, no 1 , p. 3-4. 
indivíduo para que, no trabalho, ele pudesse depois adquirir os indispensáveis conhecimentos profissionais.

Os professores das Escolas Móveis chegavam às localidades e, durante alguns dias, encarregar-se-iam da matrícula dos alunos - crianças e adultos dos dois sexos- que pretendiam ser inscritos. Verificavam, na ocasião, se os alunos eram completamente analfabetos ou se teriam algum reconhecimento da escrita. O programa das atividades estaria contido no programa de leitura da Cartilha Maternal seguida pela leitura da tradução que João de Deus fizera da obra Deveres dos filhos. Além disso, os alunos deveriam ser avaliados com ditados e cópias feitas no quadro, no reconhecimento e desenvoltura nas quatro operações. Deveria haver inspeção sobre as atividades das Escolas Móveis por parte de reconhecidas autoridades locais na área da pedagogia.

Dizia João de Sousa Tavares - na sala de sessões da Câmara dos Deputados em Lisboa, no ano de 1908, quando finalmente se daria o reconhecimento oficial das Escolas Móveis - que, dos 13.115 analfabetos matriculados nelas, as Escolas Móveis teriam conseguido 36,2\% (ou 4.748 alunos) de aproveitamento. Mesmo assim, a partir daquela data, as Escolas Móveis haviam se tornado isentas de tributos pelas doações que recebessem e o governo mandaria imprimir seu Boletim Anual. ${ }^{127}$

O debate acerca do método de João de Deus, a exemplo do que acontecera anteriormente com Castilho, adquire aspecto institucionalizado, pelo fato de seus partidários desejarem e defenderem sua adoção uniforme como método oficial das escolas do país. Assim como no caso de Castilho, o culto ao redor da personagem João de Deus contribuiria para obscurecer a objetividade quanto ao tratamento da questão. Ainda no final do século, em muitas sessões do parlamento, seria proposta a adoção oficial do método de João de Deus, que, no confronto com outras cartilhas - dizia-se - havia demonstrado maior eficácia. ${ }^{128}$

A Reforma de 1836 estabelecia o seguinte quadro de matérias para a instrução primária: "ler, escrever e contar; civilidade, moral e doutrina cristã; gramática portuguesa; breves noções de história, geografia e constituição; desenho linear; exercícios ginásticos. A reforma concede a todo cidadão a liberdade de estabelecer escolas contanto que participe ao administrador do concelho qual o local da escola." ${ }^{129}$ Por sua vez, em 1844 a instrução obrigatória foi estabelecida para as crianças e jovens entre 7 e 15 anos de idade. A lei previa inclusive punição aos pais e tutores que não enviassem seus filhos à escola, prescrição essa que, durante todo o transcorrer da monarquia constitucional, ficou apenas como letra morta no papel, posto que não havia escolas em número e condiçōes suficientes, não havia quaisquer mecanismos de formação dos mestres, não havia interesse por parte da família pela instrução oferecida, não havia vontade política dos poderes públicos para dar prioridade efetiva às práticas de educação popular. A escola portuguesa, pensada e posta em lei

${ }^{127}$ José de Sousa TAVARES, O reconhecimento official das Escolas Móveis pelo Methodo João de Deus no Parlamento, In: João de Deus RAMOS, A intrucção do povo; boletim das Escolas Móveis pelo Methodo João de Deus, III anno, 2a série, no 1,1908 , p. 9-10.

${ }^{128}$ A INSTRUCÇÃO DO POVO e o methodo de João de Deus: representação á camara dos sns. deputados, publicada no Diario do Governo n 163 de 26 de Julho de 1897, p.10-11.

${ }^{129}$ F. A. do Amaral CIRNE JR., Resumo da história da pedagogia, p. 170. 
como uma necessidade, não existia como realidade necessária para o cotidiano das populaçôes. Talvez porque, presos aos segredos das soluçôes de gabinete, os homens que pensavam a pedagogia pouco conhecessem da realidade onde se inscrevia o aprendizado escolar.

Os anos 70, como vimos, transformaram a educação em ciência e, naquela época, o tema da pedagogia teve como eixo a questão dos métodos e procedimentos de um ensino eminentemente racional, eficaz, científico. Na recorrente comparação feita entre os destinos dos povos, das raças, e os percursos individuais, a preocupação educativa será tomada como estratégia privilegiada para superação do atraso, da constatada decadência. A tônica predominante nos autores do último quartel do século XIX era traduzida pela fé na ciência. A preocupação com o método cada vez mais ocupará o lugar anteriormente reservado à circunscrição política do objeto educativo. Tal inflexão, sem dúvida alguma, deixou sua marca, na medida em que ser educado deixa de ser escolha cultural, para passar a se constituir como destino inexorável das raças na caminhada da civilização. Sendo assim, o problema pedagógico será debatido à luz da denúncia dos equívocos de práticas toscas, reduzidas a tentativas inócuas de memorização. A carência de dispositivos educacionais adequados é compreendida como responsável pelo malogro da escolarização primária. Considera-se que a metodologia utilizada pelas escolas portuguesas estava em desacordo com as tendências do espírito do século..

A racionalidade do processo educativo, ao contrário do que se vinha fazendo até então, derivaria dessa sensibilidade pedagógica para a compreensão do raciocínio infantil, que, por sua vez, não se sujeitaria às orientaçôes do pensamento adulto. Caminhar por etapas era a tônica do discurso em prol de uma educação nova, radicalmente diferenciada do que até então se fazia. O debate pedagógico passa a advogar as "liçôes de coisas", como proposta alternativa à dogmática tradicional. De acordo com o que vem registrado nas edições e nos periódicos com que à época o tema seria abordado, a finalidade desse modelo de ensino intuitivo era primordialmente a condução das crianças para que, no processo de aprendizado, elas pudessem efetivamente observar as coisas, nomeá-las e compará-las com outras. O intuito das "liçôes de coisas" seria o de possibilitar um aprendizado decorrente do exercício dos sentidos e do amadurecimento das capacidades de observação. Com isso, pretendia-se inovar as orientaçôes usuais e os métodos corriqueiros na escola tradicional. Começava, aliás, o discurso contra o tradicional em educação, tradição essa que é comumente confundida com as técnicas das definições decoradas. São sugeridos, nos tratados pedagógicos da época, procedimentos intuitivos para o ensino e, com freqüência, apresentava-se a articulação entre educação física, moral e intelectual. A esse respeito, os autores referenciar-se-iam pela obra de Spencer, que tem por título - na tradução portuguesa efetuada por Ricardo Jorge - Educação intelectual, moral e física. No Directorio de sua Cartilha Nacional, pela qual pretendia ensinar simultaneamente a "ler, escrever, ortografar e desenhar", Júlio Caldas Aulete parte dessa tríplice classificação - sugerida por Spencer - acerca do percurso educativo. Os escritos, com isso, pretendiam ser contrapostos às rotinas da instrução e, com isso, contribuir para erradicar algumas das práticas autoritárias e opressoras da escola portuguesa a seu tempo, fosse o uso imoderado da palmatória, fosse a excessiva imobilidade a que eram obrigados os estudantes. Pelo contrário, sugere Caldas Aulete: 


\begin{abstract}
"Tratai sempre as crianças com benignidade. $\mathrm{O}$ terror atrofia a inteligência e não melhora o coração. Os castigos corporais são um crime e um grave atentado contra a moral (...) Na escola onde presidir a justiça não haverá necessidade nunca de recorrer a esses meios criminosos e imorais. Na escola onde houver injustiça existirá sempre a indisciplina e a confusão. O homem habituado na juventude a ser tratado com prepotência e força, mais tarde empregará os mesmos meios brutais para com os seus inferiores. E ei-los entrados no caminho do crime. E se é crime entre homens o praticar sevícias contra alguém, por que o não há de ser no recinto da escola, exercidas contra crianças? Pois não é juntar a covardia ao crime?”"130
\end{abstract}

A escola, agência moralizadora, teria por função capital desviar a criança do contato com o vício, mediante atitudes disciplinadoras, preventivas. Ocorre que o caminho do mal precisava ser mostrado, até para que ele viesse a ser temido. Reconhecia-se o mundo como território regido por leis, cuja transgressão exigiria por si a severidade da punição. O imaginário escolar apresentava-se, em última instância, como microcosmos dessa órbita maniqueísta; e a escola justificava com isso sua sinistra austeridade. De certo modo, utiliza-se crescentemente o recurso a práticas supostamente naturais para demonstrar a necessidade de firmar o domínio de uma normatividade social indeclinável e inquestionável, como se sua ordenação derivasse mesmo de fatores naturais. Além disso, a educação era vista como antídoto natural da desordem e da agitação social. $\mathrm{Na}$ organicidade do tecido social, a má educação seria, pois, ruína corruptora dos costumes, da ordem, das hierarquias pretensamente naturais. É possível verificar um duplo pensar em Portugal daquela época: de um lado, aqueles que pensavam os portugueses como uma raça e, de outro lado, os que preferiam encarar seu povo pela categoria da vocação. Como observa Catroga, o século XIX pautava-se pela ilusão de equacionar os dilemas sociais da humanidade a partir dos progressos efetuados no âmbito daquilo que supunha ser a Ciência.

\title{
A pedagogia do exame
}

A crítica à organização escolar torna-se bastante comum entre os pedagogos desse final de século, até porque eles constatavam a dissonância entre o descaso português e o êxito já europeu do modelo escolar. Em Portugal a escola falhara. Urgia encontrar as razões que, no conjunto, explicassem isso. Muitas vezes se recorria à ausência de atrativos da vida escolar, tendo em vista a necessidade prática de as famílias recorrerem ao trabalho infantil. Além disso - observam algumas obras pedagógicas da época - os professores muitas vezes não sabiam dar aulas e confundiam seu ofício com a memorização do compêndio. Era como se o livro escolar dirigisse a aula, como guia para

${ }^{130}$ Júlio CALDAS AULETE, Directorio, In: Cartilha nacional ou methodo legographico para aprender simultaneamente a ler, escrever, ortographar e desenhar, sem página. Sobre o método legográfico, pudemos constatar, como já indicamos anteriormente, que ele teve um papel bem mais destacado na história da educação portuguesa do século XIX do que faz crer a literatura pedagógica posterior. Eram inúmeros os tratados teóricos sobre o ensino, até o princípio deste nosso século XX - ainda que algumas vezes fosse para criticar - que dialogavam com essa referência (vide, por exemplo, João de Deus RAMOS, Guia prático e teórico da Cartilha Maternal ou arte da leitura de João de Deus, 1901, p. 75). A Cartilha Nacional: methodo legographico para aprender simultaneamente a ler, escrever, ortographar e desenhar - de Caldas Aulete - será analisada no último capítulo desta tese. 
o professor, não apenas em termos da abordagem dos conteúdos trabalhados, mas principalmente pela seleção do conteúdo. O abuso do compêndio levava a que houvesse casos em que a aula não existia: era substituída pela mera cópia do texto, a partir da qual os alunos estudavam, e o mestre viria depois para 'tomar a lição'; professores e alunos ignorando o modo coletivo de ensinar e aprender...

"Acentue-se bem que o professor que obriga a decorar nada ensina (...) é apenas matar o tempo e fazer cretinos. Relaciona-se muito este primeiro ponto com o segundo que apontamos: uso e abuso do compêndio; com efeito nada mais cômodo nem mais estúpido do que dizer: a lição é de páginas tantas a tantas e no dia conveniente 'tomar a lição'; este sistema de rotina ainda é tão vulgar quão pernicioso."131

Ocorre que, muitas vezes, a rejeição ao compêndio era acompanhada pela crítica ao livro de modo geral, como se a própria existência do impresso houvesse desviado a prática do professor. A desconfiança acerca do tema da leitura é ainda muito ilustrativa para se compreender os paradoxos do debate sobre a instrução naquele Portugal de final de século. À escola caberia regrar, vigiar, delimitar e circunscrever o território de uma leitura que, leiga, tornava-se cada vez mais profana e ameaçadora dos valores dominantes. A circulação do texto conformava práticas leitoras que, se fossem deixadas por si, contribuiriam para a indesejada e temida transformação dos costumes. Cabia à escola - porque o grupo social assim a escolheu - domesticar o rebelde gesto da leitura, que, através dessa operação, deveria deixar o campo da fruição, do prazer, para penetrar no 'científico' terreno da Pedagogia: conhecimentos úteis, morais... pedagógicos, enfim. Nessa direção, sugere-se por recorrência a Spencer:

"O professor não deve adotar compêndio, o compêndio é ele; o único ensino em harmonia com a dignidade profissional é o ensino oral; o aluno aprende assim a ouvir, o que é difícil, a refletir e a investigar. Escreve Ramalho Ortigão: 'os livros são lentes através das quais se observa o mundo; são necessários aos olhos fracos, cuja vista conservam e frutificam; mas será melhor poder passar-se sem eles.' A autoridade de Spencer sanciona isto mesmo: 'a função dos livros é uma função suplementar; os livros constituem um meio indireto de adquirir conhecimentos para quando faltam os meios diretos; um meio para ver, segundo a opinião dos outros homens, aquilo que não podemos ver pelos nossos próprios olhos." 132

O conhecimento por meio de livros deveria ser, sob tal aspecto, substituído pelo aprendizado que prescinde do livro, para que a leitura não criasse autonomia e distanciamento frente à palavra de mestre. Era como se o próprio princípio da autoridade tivesse vindo abaixo pelo primado do impresso vulgarizado e acessível, que dessacralizara, enquanto veículo material, todos os pensamentos secretos e as idéias perigosas. É o medo da força simbólica do livro, na concorrência com a disciplina das instituiçôes familiar e escolar, quem move determinados setores da intelectualidade a fazer a quase apologia da tranquila ignorância.

\footnotetext{
${ }^{131}$ José de SOUSA, Notas de pedagogia philosophica, p. 61-62.

${ }^{132}$ José de SOUSA, Notas de pedagogia philosophica, p. 63.
} 
A crítica àquela pedagogia do compêndio não deixava de ser também a proposição de um olhar de denúncia sobre algumas das sabidas mazelas da escola portuguesa. Uma das dificuldades levantadas diz respeito à questão dos exames de instrução primária, necessários para o ingresso nos liceus, e que se apresentavam como o tenebroso resultado da ausência de cuidados metodológicos e didáticos no âmbito da instrução. $\mathrm{Na}$ imensa maioria das vezes os alunos não eram sequer submetidos a exames e, quando o eram, falhavam. Os exames eram feitos nas próprias salas dos liceus e o júri era composto por um inspetor ou um professor que tivesse sido por ele designado, por um membro da junta escolar e por um professor de escola complementar. O professor dos alunos examinados também deveria estar presente, "sem voto, mas com a faculdade de os interrogar, dirigir, elucidar e fornecer as notas do seu aproveitamento." 133 O espaço da sala era reduzido e não comportava nada além de meia dúzia de cadeiras, onde se sentavam em geral as pessoas convidadas dos examinadores. Não eram admitidas pessoas em pé e, na maioria das vezes, os familiares dos alunos não obtinham assento, ficando no corredor, do lado de fora, muitas vezes sob os vigilantes olhares de um policial. A descrição feita por Domingos Tarrozo parece-nos bastante ilustrativa da representação dos exames de instrução primária, naquele contexto de final de século. Era medo, insegurança e recordação do compêndio:

“A criança não pode dizer o que aprendeu e o que sabe. Não tem licença de falar. Há de responder unicamente e em poucas palavras às perguntas que o examinador lhe faz. O pedagogo interroga pelo seu compêndio ou pelo dum amigo que lhe dá uma boa parte dos ganhos sobre as vendas feitas. Se o examinando estudou por outro livro e não repete mecanicamente as definiçôes e as asneiras do volume que dá interesse ao professor do liceu proprietário da respectiva cadeira, está, desde logo, perdido." ${ }^{134}$

A denúncia abarcaria inclusive - como fica exposto - aspectos concernentes ao mercado editorial e à sua interferência na escolha do compêndio adotado pelos examinadores; compêndio esse que, em tese, sequer era exigido, posto que apenas havia orientações explícitas quanto ao programa de estudos e não existia nenhuma prescrição de literatura didática obrigatória. Era como se toda a estrutura da escolarização primária estivesse voltada para aquela ocasião, à espera do momento em que o aprendiz fosse submetido a exame. Ali eram concentradas todas as manifestações do poder disciplinar e coercitivo exercido pela escolarização. Os examinadores deveriam pronunciar-se sobre uma prova escrita que constaria de um ditado de vinte linhas extraído de algum dos livros aprovados para as escolas, de operações aritméticas, de resolução de um problema para aplicação das operações simples, e de um desenho a lápis. Depois é que seria feita a prova oral. Aqui, o examinando poderia ser solicitado para classificação gramatical, conjugação oral de verbos regulares e irregulares, escrita e leitura de números no quadro, "leitura em voz alta e acentuada de uma página de livro de prosa aprovada para as escolas de ensino complementar e de duas ou três

\footnotetext{
${ }^{133}$ ENSINO obrigatório ou collecção completa da legislação sobre instrucção primaria, p. 13.

${ }^{134}$ Domingos TARROZO, O monopólio da sciencia official: discussão d'um problema politico, p. 95-96.
} 
estâncias do poema Os Lusíadas." ${ }^{135}$. Como vimos, se não soubessem recitar o compêndio decorado, os examinandos - que eventualmente poderiam ter até estudado por outros livros - seriam sumariamente reprovados; e nisso consistia a liturgia da escola. Acresce-se a isso que os professores, presos ao suposto conhecimento obtido com a leitura do livro escolar, se distanciavam da leitura dos clássicos da língua portuguesa. Eram também apenas leitores de compêndios...

A escola, distante de sua declarada missão de irradiadora do conhecimento, da ciência produzida, teria como resultado a conformação de espíritos dóceis, modelados pelo diapasão restritivo de maus compêndios que encerram por completo qualquer manifestação de criatividade por parte do postulante ao saber. Rejeitaria seus frutos mais valorosos e os bons estudantes, na maior parte das vezes, traduzir-se-iam em maus alunos. Sob tais restrições, o problema da escolarização adquiria, no caso português, tonalidade sombria, dado que parecia impossível o êxito de uma instituição enredada por certas mazelas que, por sua vez, estariam na origem de sua lógica. Reconhecer-se-ia, portanto, o aspecto dogmático da instituição que se apropria, põe e dispõe a seu modo de saberes produzidos no campo da ciência e da técnica. Ocorre que, contraditoriamente a essa feição escolar do conhecimento, o que há de específico no campo do saber é exatamente a oposição irredutível ao pressuposto dogmático. A escola, em sua atividade costumeira, trabalharia talvez com o oposto de seus objetivos declarados - fechada que estava a qualquer inovação.

A instituição escolar, tal como esta se pôe em nossa contemporaneidade, aparece como um dispositivo de mediação entre as iniciativas conservadoras do existente e os projetos de mudança social. A escola moderna, nem sempre adequada aparentemente à sociedade que a acolhe, é de fato agenciada como centro de irradiação cultural, cuja tarefa seria eminentemente a de transmissão dos valores, dos costumes, da tradição. Mas a escola também, contraditoriamente, pretende proceder à mudança. Como instituição, propóe-se a conservar e a criar. Desse modo, institucionalmente, o binômio tradição-inovação torna-se razão de ser da escolarização; daí, talvez, seus aparentes paradoxos, que teimam em resistir ao tempo... Como destacam os estudos acerca do tema, a educação escolar portuguesa, no decorrer de todo o século XIX, não havia chegado a ser uma aquisição, um bem, um valor efetivamente procurado pelas famílias, que, na maior parte das vezes, requisitavam precocemente o trabalho dos seus filhos, retirando-os da escola.

Custódio Dias Guerreiro ${ }^{136}$ declara em texto dedicado a comentar os Congressos Pedagógicos ocorridos em Lisboa e no Porto em 1898 - sob o título Aspiraçóes e protestos do professorado primário - que um dos maiores males da sociedade portuguesa de modo geral, e que se refletia intensamente na condição do magistério, era o indiferentismo. Ele, que era professor, membro e defensor da Associação do Professorado Primário Português, destacava que a própria vida associativa sofria desse mal da

${ }^{135}$ ENSINO obrigatório ou collecção completa da legislação sobre instrucção primaria, p. 66.

${ }^{136}$ António NÓVOA define o professor e dirigente associativo Custódio Dias Guerreiro como um entusiasta do movimento de associação dos docentes em Portugal. Defensor das Conferências Pedagógicas, Guerreiro supunha que elas agiriam no sentido de desenvolver um espírito de classe e de solidariedade corporativa no professorado português. (vide António NÓVOA, Le temps des professeurs / volume I, p. 494-5) 
descrença e da indiferença de seus associados para com os debates que, em última instância, diziam respeito à sua vida enquanto profissionais do ensino.

\begin{abstract}
"Para que serve a Associação? A quantos professores tenho ouvido dizer: 'Ora! vamos a ver no que é que isto pára; quem sabe? a mensalidade é carita: e depois, tenho fé que nunca precisarei de socorros da Associação e os mais que se arranjem... Não te rales...' Conseguida a realização do último Congresso Pedagógico com grande custo dos delegados que a ele assistiram e também dos que concorreram para as despesas, quantos professores diziam: 'Ora! Congresso! de que serve? Temos passado sem isso perfeitamente, e depois... os delegados é que vão por lá gozar as belezas da capital e nós aqui...Não te rales...”'137
\end{abstract}

Essa imagem de conformismo poderia também traduzir-se na pequena valorização que as famílias, de maneira geral, atribuíam ao aprendizado das letras. A indiferença com que era visto o tempo da escola por parte da população é, como temos visto, salientada por inúmeros autores. No entanto, mesmo entre os intelectuais do final do século, em alguns casos, não era nítida a defesa da escola como um valor irredutível. Havia quem desconfiasse da trilha tomada pela cultura das letras. A propósito, Francisco Adolpho Coelho, curiosamente, chegou um dia a argumentar que a crença irrestrita nos poderes civilizatórios da alfabetização conduziria inevitavelmente a apreciação de caráter discricionário assumido relativamente a povos e sujeitos ignorantes, que passavam, sob essa ótica, a ser encarados como inferiores ou incompletos. Ele, que era considerado por alguns, como um dos maiores especialistas nas origens da língua portuguesa, foi quem proferiu a quarta e última Conferência do Casino Lisbonense. Intitulou sua intervenção Questões de Ensino e - como nos atesta Rogério Fernandes - "no decorrer de uma sessão memorável motivou a indignação do mandarinato universitário." 138

Em um momento de menor otimismo cultural, Adolpho Coelho destacava o perigo de os meios de se conhecer confundirem-se com o próprio conhecimento e, nesse esquadro, a leitura e a escrita seriam antes estratégias, que, por isso mesmo, deveriam ser analisadas sem tanta paixão. O domínio dos relatos tradicionais, bem como a capacidade de memorização da história pátria, seriam, no parecer do autor, propriedades mais frequentemente encontradas entre pessoas analfabetas, posto que a habilidade escrita traria consigo a propensão para o esquecimento. Desse modo, Adolpho Coelho questiona algumas das certezas já estabelecidas naquele último quartel do XIX acerca das supostas propriedades benéficas intrínsecas à alfabetização.

O livro de leitura era o grande alvo revelador do atraso da instrução portuguesa. Adolpho Coelho toma sua referência também para revelar a evidência da necessidade de se adequar e inovar o conjunto de procedimentos pedagógicos de sala de aula. Para esse estudioso dos assuntos educacionais, a excessiva ênfase dada aos aspectos moralizadores da educação primária contribuía para que se perdesse o atrativo do aprendizado enquanto percurso intelectual do espírito. Supondo, como seus contemporâneos, que o desenvolvimento individual teria analogia com o desenvolvimento da espécie, Adolpho Coelho também condenava os compêndios que, além de não estimularem em nada a

\footnotetext{
${ }^{137}$ Custódio Dias GUERREIRO, Aspirações e protestos do professorado primario, p. 88.

${ }^{138}$ Rogério FERNANDES, O pensamento pedagógico em Portugal, p. 121-2.
} 
intuição e imaginação das crianças, exigiam delas uma capacidade de raciocínio que pressuporia maturidade maior do que a sua idade permitia. Para além disso, haveria obviedades e disparates, os quais, ao serem postos como saber de escola, traziam funestas conseqüências para o desenvolvimento do raciocínio lógico dos que a isto fossem submetidos.

Adolpho Coelho colocava entre as dificuldades para o aprendizado mecânico da leitura, a tônica moralizante dos textos escolares que, enquanto tal, pretendiam sem sucesso, instruir sem recrear. A criança - segundo o parecer do mesmo educador - não age por deduções de princípios. A criança, pelo contrário, só consegue chegar ao campo do conhecimento, da razão e da moral por uma trilha intuitiva e analógica. Em função disso, histórias mágicas, repletas de fantasia, deveriam passar a fazer parte do cotidiano infantil. Apresentadas à infância, tais histórias - vivas e ágeis, com movimento, ação e desenlace grandioso - combinam bem com o universo mágico a que os primeiros anos da vida humana necessariamente se prendem. O discurso escolar, ao contrário, invariavelmente premia a virtude e castiga o vício, e a criança não se reconhece nisso, porque sabe que a vida não é assim... Segundo Adolpho Coelho, os textos de escola deveriam ter direta consonância com o modo específico pelo qual a criança raciocina. Não se deveria exigir do estudante conhecimentos superiores aos que sua pouca idade lhe permitem. Não se poderia tampouco subestimar o modo particular do raciocínio infantil. Por isso os contos de fadas e as fábulas eram defendidos e recomendados para uso das escolas. Eles, ao mesmo tempo em que satisfazem o desejo infantil pelo maravilhoso, proporcionam a canalização da imaginação para matéria instrutiva.

Defende-se então o seguinte: até porque a criança reproduziria em seu desenvolvimento o caminho do homem primitivo, deveria ser dada a ela a possibilidade de se embrenhar pelo universo mágico, pelo campo metafísico do maravilhoso. Depois então ela evoluiria para se tornar adulta, como os povos um dia o fizeram. Adolpho Coelho julga que os elementos ditos tradicionais trariam aos meninos o prazer e a fruição da leitura espontânea, incentivando pelo interesse o contato da mesma meninice com o mundo do impresso, com o território da leitura.

\section{Ciência pedagógica recuperando a vocação nacional}

O último quartel do século XIX português - como vimos - considera a educação uma estratégia científica capaz de interagir com os fatores motrizes da decadência. A pedagogia passará a ser abordada como ciência; e o tema do ensino é mobilizado em discurso sobre métodos e técnicas pedagógicas, como se os autores quisessem regrar a até então 'arte' da educação. Bernardino Machado comenta a necessidade de se recuperar a vocação do povo português: "somos poucos e estamos quase inteiramente despercebidos". ${ }^{139}$ Machado recorda a consciência de Pombal acerca do paralelo entre a instrução da mocidade e a felicidade dos Estados. Para o analista político, que escrevia em 1882, há inclusive um sentido de felicidade pública na educação, quando esta atividade se coloca a serviço da nacionalidade. Falar e contar a nação era, em última

\footnotetext{
${ }^{139}$ Bernardino MACHADO, À nação portuguesa, o magistério primário, p. 1.
} 
instância, tarefa essencial para que os povos, reconhecendo cada um a identidade que lhes seria própria, pudessem escapar do domínio de outros povos talvez mais poderosos, mais capazes de expressar a vida nacional. A conquista do mundo, aos olhos de Bernardino Machado, teria cumprido apenas uma etapa da vocação nacional portuguesa. Não podendo viver de lembranças, a outra etapa estaria ainda por construir, sob a pena de se perder o que restara da própria tradição.

Em 23/10/1886, Bernardino Machado, em carta enviada a Oliveira Martins, apresentava o valor da instrução qualificando-o de capital, por ser capaz de desenvolver pelo crivo do conhecimento as faculdades criadoras do homem, produzindo, nessa atividade, a reprodução e o acúmulo do capital financeiro. A ciência, por ser assim, interagiria com as disposições naturais, inatas da espécie humana, conduzindo à eliminação de todos os fatores propensos à subversão da ordem. Nessa medida, os paradoxos inerentes ao ambiente democrático poderiam ter seu contraponto no esforço radicado no ofício pedagógico. A instrução é compreendida, nesse sentido, como estratégia privilegiada de conciliação entre as classes, em nome do quê, igualmente, se passa a defender um ensino profissionalizante para aquelas camadas da população que, tendo concluído a instrução primária, tivessem aptidão e desejo de prosseguir seus estudos, conciliando-os, porém, com a vida produtiva. Pelo estudo, sem grandes transtornos, se poderiam resolver pacificamente as sérias questôes trabalhistas que perturbavam aquele final de século. Arma política, a escola parecia necessária aos dirigentes... Instância de reprodução da desigualdade social, sem dúvida. Mas era talvez algo para além disso a tarefa da escola projetada.

Com a finalidade de obtenção de dispositivos que alcançassem o êxito do percurso educativo, os tratados pedagógicos, no limiar do século, irão apresentar com recorrência fórmulas e estratégias a serem cumpridas pelos professores, de maneira a garantirem o sucesso da ação educativa. Antes de qualquer coisa, propõe-se a disciplina do caráter e da vontade do estudante como etapas essenciais a obtenção de quaisquer objetivos pedagógicos. A preocupação tanto com o físico quanto com o meio deveria ser saciada pela educação física, que - desenvolvendo pelo exercício do corpo o caráter individual - aprimoraria a própria raça, no bojo de uma visão evolucionista referenciada pelo darwinismo social. Caracterizando a obra de Spencer como a nova 'catequese pedagógica', Ricardo Jorge - no prefácio que escreve para a tradução portuguesa de Educação intellectual moral e physica - declara estar confiante na possibilidade de as novas doutrinas da ciência da educação proporcionarem a "melhor cura do definhamento intelectual e até moral e físico da sociedade portuguesa" ${ }^{140}$. Acreditase que as novas gerações agem por imitação das ações alheias. Tal tendência imitativa seria natural e passível de ser aproveitada na ação educativa. No controle de seus instintos, impulsos e emoçôes, o aluno disciplinaria sua alma, mesmo que, a princípio, suas ações fossem apenas a reprodução de gestos impostos pelo ambiente do qual procede a educação. A educação moral teria por finalidade incutir na alma do educando certo número de princípios, que, por sua vez, estruturariam seu caráter. Alguns desses sentimentos eram apresentados como valores destinados a adequar o estudante a princípios sociais de convívio, pretendendo inclusive o aperfeiçoamento do ser

${ }^{140}$ Ricardo d'Almeida JORGE, Prefácio, In: SPENCER, Educação intellectual, moral e physica, p. XVI. 
humano, como se a educação fosse um instrumento modificador a partir do qual a espécie poderia ser melhorada; e, com a espécie, os povos.

Os ideais educativos apresentados por J. Augusto Coelho em seus tratados de Pedagogia Geral têm correspondência com esse imaginário cientificista e moralista. Deseja-se - acredita o pedagogo - formar referências simbólicas que afastem o homem do seu egoísmo natural, que o conduzam à capacidade de sacrificar uma porção de si próprio a uma causa, ao seu país. Não se trata apenas de valores cívicos, de formação específica para uma abstrata cidadania; é também isso. Mas é indubitavelmente mais do que isso. Trata-se de inventar a disponibilidade humana para o outro, a edificação de princípios de generosidade, uma ética que não é completamente burguesa porque passa por valores como a lealdade, a solidariedade, a honra - tão caras ao mundo medieval. Ao mesmo tempo, trata-se também de preparar, aí sim, o trabalhador tenaz, disciplinado e perseverante, capaz de dominar e conter suas pulsões, em uma disciplina que contempla o equilíbrio, a força de vontade, o poder de iniciativa e o autodomínio. É evidente que não se tratava de modo algum da escola que existia, mas daquela que deveria ser edificada para elevar Portugal à altura dos povos tidos por mais civilizados. Tal empreendimento coletivo deveria agenciar a educação com o fito de contribuir com sua parcela para a própria evolução da espécie, na busca de prover o futuro de um altruísmo derivado do próprio egoísmo do gênero humano. Modificar a raça e o indivíduo pela ação educativa torna-se anseio desde o final do século XIX. Para tanto, buscava-se compreender os processos e métodos que faziam do indivíduo um representante da sua raça em particular. Agir sobre o modo de ser de cada um seria, sob tal chave teórica, melhorar a própria espécie.

A busca de transformação do caráter individual através da educação teria, nessa medida, valor estratégico de modificação da raça no curso de um esforço coletivo desenvolvido intergerações. As aptidões cognitivas e morais dos povos seriam - no parecer de Augusto Coelho - passíveis de transformação, mediante o esforço equivalente a um deslocamento da energia da ação. Raças e naçôes seriam regeneradas dos desvios que a rota da história pudesse eventualmente ter trazido. O povo português é percebido por Augusto Coelho como uma raça mole, incapaz de trabalhar seu espírito aventureiro; daí a decadência. Era preciso deter e superar essa rota decadente. Pensar a educação, naquela fronteira de século, persistia sendo, de alguma forma, refletir sobre o decadentismo. Para Augusto Coelho, nem tudo que vale para a Europa, pode ser diretamente apropriado pelos portugueses, dado que nem o estilo étnico nem a vocação do povo permitiriam a simples permuta e transferência de técnicas e soluções. Para a compreensão da escola, era imprescindível dar a devida atenção às coisas e ao modo de ser da nacionalidade.

Recomenda então o autor que os portugueses procurassem uma forma de escolarização - em termos de conteúdos de ensino e métodos de aprendizagem - que se mostrasse absolutamente portuguesa, inclusive com o objetivo de disciplinar aquela população que, originariamente, primava pela inconstância. Desejava-se uma "forma escolar de socialização" - para usar a expressão de Vincent -, capaz de remediar os pontos fracos de toda a vida nacional. É por isso que se revelariam valorosos os incentivos escolares, a existência de exames e de todo um conjunto de verificações constantes do aprendizado que, nos povos do Norte, poderiam ser sumariamente 
dispensados, já que ali se aprendia pelo desejo exclusivo de saber, ao passo que nos povos do Sul - especialmente em Portugal - aprendia-se apenas quando a existência de exames a isso obrigava.

Cada raça - "moles ou enérgicas, frouxas ou constantes, tendentes para a superficialidade ou para a profundeza" ${ }^{141}$ - deveria, pois, aos olhos do pedagogo, ter a educação que seu caráter específico solicita. Em suma, isso significava a defesa intransigente de uma escola classificatória, uniformizadora, rígida, hierárquica, vigilante, onde se pudesse efetivamente driblar as propensões naturais, incutindo disciplina e força à vulnerável índole do caráter nacional português. Em qualquer hipótese, persiste - e é acrescida - a capacidade redentora e regeneradora atribuída à escolarização, enquanto estratégia política de conformação de um determinado modelo de Estado nacional.

Pensava-se aqui o cidadão, mas pensava-se também o trabalhador; pensava-se o sujeito ordeiro, disciplinado, mas, de alguma forma, desejava-se, pela 'reforma da infância', criar o homem novo: aquele que viria a construir o povo novo, capaz de conduzir Portugal aos caminhos do futuro.... Ainda que o futuro fosse sempre pautado pela incerteza, pela indeterminação, pela imponderabilidade do acaso, havia a firme crença na produção de um modo científico de olhar para diante. O imaginário educativo, que perfilha um feixe de significados sempre plural e conflitivo, hesita - sob tal impasse - entre a esperança da renovação e o conforto da permanência. Por mais que os pedagogos desejassem solucionar a hesitação, por discursos e por atos, ela se repunha, ainda que muitas vezes escondida.

Havia, entretanto, nítido descompasso entre aquilo que os intelectuais, pedagogos, literatos e mesmo alguns políticos vislumbravam como necessidade educativa do país e a realidade da situação das escolas portuguesas que, alheias às teorias que a seu respeito vinham sendo tecidas, continuavam a existir sob o signo da carência. Era como se o campo das idéias houvesse se antecipado, e a vida real da escola não correspondesse a tais projetos para ela traçados.

\section{A escola que vê entrar a República}

A escola que vê entrar a República em Portugal é ainda uma instituição primária que não logrou obter a desejada homogeneidade, a desejada unificação por todo o território do continente. É, muito aquém disso, uma instituição pobre, fragmentária, que atende populações as mais diversificadas e que não dispõe dos necessários recursos para seu papel educativo. Essa escola é responsável por uma prática desacreditada pelas populaçôes, incapaz que se revela de atender seus próprios objetivos declarados: as crianças não aprendem, em sua maioria, nem a ler, nem a escrever, nem a contar. O professor, na única sala de que se compõe a mesma escola, recebe 20 ou 30 crianças, número este que, entretanto, pode variar de acordo com a localidade do país, chegando a haver casos de 60 ou de 6 crianças compondo as classes. A mobília era composta, habitualmente, por cinco ou seis banquinhos, às vezes bancos-mesas, onde

141 "O aluno português, abandonado a si e sem o aguilhão do incentivo ou da fiscalização repetida efetuada por via de exames, deixa-se ficar atrás, esmorecendo no seio do tépido e úmido ambiente desta zona meridional e maritima em que se desenvolve." (J. Augusto COELHO, A reforma do ensino primário, p. 94-95) 
as crianças, sujeitas a deformações físicas, "passam horas e horas com o corpito feito num arco, mirando e remirando alguma gravura mais interessante dos seus livrinhos de estudo" ${ }^{142}$ Embora de variada superfície, o pé direito de algumas escolas mais precárias chegava a ser de dois metros e, à guisa de recursos didáticos, o professor contava, quando muito, com um quadro-negro em más condições e, por vezes, com um mapa de Portugal. O ensino, absolutamente teórico e árido, afastava a criança de qualquer contato com seu cotidiano, como se esse - na evidente tradição jesuítica - fosse, por princípio, fonte potencial de corruptibilidade. Alheios à experiência e mesmo à observação, os fenômenos naturais eram alguma coisa profundamente estranha à prática educativa das escolas primárias portuguesas no início do século XX. Alguma coisa na escola resistia ao novo; e a população, de algum modo, resistia à escola.

Mesmo assim, a escola - enquanto agência de moralização e civilização - era valorizada como estratégia privilegiada para elaboração do novo consenso nacional, de índole laica, secular e cívica. Criar a escola efetivamente nacional significaria, para os republicanos, dar vida e conteúdo à possibilidade de superar pela via da cultura os tempos de abatimento e de declínio nacional. Significaria dar suporte institucional e viabilidade ao propósito da regeneração. Significaria enfim caminhar, pela superação do passado, rumo à prospecção do futuro. Recriar-se-ia, pois, com a escola e com a República, a nacionalidade em sua acepção mais plena.

Portugal continuava a ser um país de analfabetos, muito embora o número de escolas houvesse aumentado significativamente. A tese de António Nóvoa revela, nesse sentido, que, entre os anos letivos de 1852/3 e 1899/90, o número de escolas primárias públicas no território português havia praticamente quadriplicado, o que não se verifica nos índices de alfabetização, que não conseguiam sequer alcançar a casa dos $30 \%$ nos primórdios do século. Nóvoa já destacava que as elevadíssimas taxas de analfabetismo em Portugal eram representativas do descompasso entre os textos das autoridades e dos intelectuais e as reais necessidades percebidas pela população como um todo.

Supunha-se que uma das tarefas prioritárias da distinção com que a ordem republicana deveria operar em relação aos tempos da monarquia era a instrução popular. Mais uma vez, aparece a crença do discurso quanto ao potencial presumidamente transformador posto no ofício da educação escolar. A república desenharia o homem do dia seguinte. E isso, para os políticos da época, parecia ser estratégia essencial. $\mathrm{Na}$ verdade, aquela República que começara pela política, havia de ser firmada pela formação das subjetividades e das consciências. Daí, mais uma vez, a confiança irrestrita que parece ser, por alguns dos atores do cenário político, depositada na instrução; instrução essa formadora de uma nova pátria, de um novo pacto social, de uma nova moral coletiva. Como destaca João de Barros, trata-se da "moral do esforço, da energia, da vontade, do trabalho"; aquela que efetivamente forma e conforma o corpo e o espírito do estudante para a disciplina da vida do trabalhador. Desejava-se explicitamente substituir o lugar da religiosidade da escola que viera com a Monarquia pelo espírito da constância, da tenacidade, da perseverança, da disciplina, necessário ao trabalhador do futuro republicano.

${ }^{142}$ Alfredo Filippe MATTOS, O passado, o presente e o futuro da escola primaria portugueza, p. 278. 
O propósito declarado da escolarização é o da confluência entre o preparo para a cidadania e a preparação para o mundo do trabalho. A escola é tida como instituição que disciplina o corpo e a mente, que conduz o homem ao controle de suas pulsões, que transforma os valores aceitos pelo grupo social em regras assumidas pelo caráter individual. $\mathrm{O}$ ato educativo agiria, portanto, como um mecanismo de educação da vontade - seja a vontade individual ou mesmo a vontade coletiva na fabricação do consenso social. Os educadores do final do XIX e princípio do século XX apresentam cada vez mais um conjunto de procedimentos que, aparentemente, surgiam como a revelação do segredo da pedagogia científica bem-sucedida. Buscavam-se mecanismos apropriados para aproximar as populaçóes da escola, populaçôes aquelas que eram - em tese - refratárias ao processo de escolarização. Até certo ponto, a recusa de enviar as crianças para a escola passava pelo descrédito provocado pelo fato de a instituição, não sendo capaz de alfabetizar, não cumprir efetivamente aquilo que, em princípio, prometia. As crianças em sua maioria deixavam a escola sem saber ler, sem saber escrever, sem saber contar... Custou para a família portuguesa efetivamente delegar à escolarização uma parcela de sua responsabilidade educativa. Por mais que fosse recomendada essa transferência de responsabilidades, na prática, vimos que não possuía grande ressonância a vida de escola; não havia, aliás, ressonância nem em termos de efetivo investimento estatal, nem no que diz respeito a - por assim dizer - crenças e expectativas das populações.

$\mathrm{O}$ que fazia com que os intelectuais e homens do Estado português visualizassem com costumeira simpatia aquela instituição sobre a qual não investiam? Que tipo de compreensão a sociedade lançava sobre a vida escolar e sobre seus resultados mais imediatos? A pequena alfabetização da sociedade portuguesa naquele período era ou não fruto da ação pedagógica da escola? O que de fato fazia aquela escola? Quem era ela? Quais os seus ritos e mitos? E quais as correlaçôes entre suas práticas cotidianas e as representações mentais criadas no seio da sociedade civil acerca das mesmas práticas? O caminho em busca do cotidiano virá na seqüência de algumas observações finais sobre esse imaginário da intelectualidade portuguesa acerca do temário da instrução pública.

A discussão das idéias, seja como for, não se confunde com a implementação de práticas a elas irredutivelmente acopladas. Tomar a história do ideário pedagógico, no nível de suas representaçôes, como se de práticas se tratasse, tem sido inequivocamente uma das mais sedutoras ilusões da história da educação. Veremos, em capítulos seguintes, que o cotidiano da sala de aula em Portugal tinha àquela altura uma autonomia própria e o que lá se fazia não coincidia exatamente com o teor caloroso do debate. A escolarização - como já se atentou inúmeras vezes - tem uma lógica própria, que compreende certos ritos, saberes e valores, tomados por apropriação do leque mais extenso da cultura social, mas apresentando inequivocamente uma fisionomia particular, muito específica, e que precisa ser estudada se pretendermos de fato obter dados brutos sobre a escola. O campo das idéias deverá ser, pois, acompanhado da procura dessa singularidade escolar, em seu movimento, naquilo que se apresentava como dinâmica e funcionamento interno à instituição, muitas vezes alheia ao que sobre ela se dizia ${ }^{143}$.

\footnotetext{
${ }^{143}$ O trabalho de Silvina GVIRTZ, acerca dos cadernos escolares da Argentina entre 1930 e 1990 destaca que uma das características do discurso escolar consistiria exatamente em sua capacidade de administrar outros discursos, estabelecidos, por sua vez, em inúmeros universos de linguagem: "o discurso escolar é diferente e irredutivel a outros discursos, e torna-se no mínimo difícil aproximar-se de sua estrutura a partir da ideía de uma redução ou transposiçãa de
} 
Poderíamos, aliás, a propósito do tema, recordar que são inúmeros os autores atuais que exploram essa vertente do que designam por modelo (António Nóvoa), forma (Guy Vincent), ou gramática escolar (David Tyach). Seria - dizem os especialistas da História da Educação - uma relação pedagógica inédita essa que, com a modernidade, se estruturará nos países europeus. A escola - ao se apropriar da tarefa educativa que anteriormente era reservada a outros setores sociais, particularmente à família - institui práticas inusitadas de formação do comportamento religioso e da conduta civil, de conformação de hábitos de obediência e de disciplina, de treino para submissão às autoridades e táticas visando o controle do corpo e dos impulsos. Haveria, sob tal perspectiva, regras impessoais que determinariam a dinâmica da instituição; sob tais regras, deveriam ser normalizadas as atitudes dos mestres e dos discípulos. Essa configuração da escola tende ao ensino simultâneo, embora não haja inequivocamente se confundido com ele, posto que, durante muito tempo, as práticas de ensino eram individualizadas. De todo modo, tratava-se fundamentalmente da transmissão e aquisição de aptidóes e habilidades, que, de modo algum, se reduziam ao domínio cognitivo, abarcando - por assim dizer - aspectos afetivos, motores, corporais e emocionais.

Acerca do tema, dirá Vincent:

"A emergência da forma escolar, forma que se caracteriza por um conjunto coerente de atributos, onde os primeiros que se devem citar são a constituição de um universo separado para a infância, a importância das regras no aprendizado, a organização racional do tempo, a multiplicação e a repetição de exercícios cuja única função é proporcionar o aprendizado e o aprendizado de acordo com regras, ou, dito de outro modo, tendo por fim seu próprio fim, que corresponde a um novo modo de socialização, o modo escolar de socialização. Este não cessa de se estender e de se generalizar para se tornar o modo de socialização dominante de nossas formaçōes sociais." 144

O interlocutor do mestre da escola primária é um só: o conjunto de seus discípulos. A escola, que transmite supostamente o saber, veiculará também o código das classificações e as teias de poder, tal como estas se dispõem na organização social. Faz isso - a escola - por palavras e por gestos, demarcando por sinais e por algum arbitrário conceitual e valorativo, aquilo que - revestido sob o signo da cultura - acredita preparar para a vida social, tal como esta se constitui: com seus desajustes, suas distribuições, suas hierarquias, as intenções prescritas e os resultados permitidos, suas interdiçôes, suas desigualdades; e até com suas injustiças...

outros discursos" (Silvina GVIRTZ, El discurso escolar a traves de los cuadernos de clase: Argentina 1930-1990, p. 213). Os saberes disciplinares na escola organizar-se-iam de modo muito particular, estabelecendo, entretanto, de maneira entrelaçada, competências e habilidades fundamentalmente eficazes para a inserção do homem adulto da sociedade massificada: "homogeneização, compartimentalização, classificação e hierarquização"(Id. Ibid., p. 193-194). A escola, apropriando-se a seu modo do mundo do poder e da cultura, agiria, então, até certo ponto, por conta própria.

${ }^{144}$ Guy VINCENT (org.), L'éducation prisonnière de la forme scolaire?, p. 39. No trabalho intitulado Tinkering toward utopia, David Tyack e Larry Cuban destacariam também a existência daquilo que eles qualificam como uma gramática própria que regula a vida da escola enquanto instituição. Para esses autores, essa gramática normativa e não redutível a quaisquer outras ordenações exteriores, tenderia a modelar esquemas muito particulares para a dinâmica da escolarização. De alguma forma, essa gramática possibilitaria o cumprimento do ritual cotidiano, tal como prevê o imaginário escolar em sua perspectiva histórica. Por tal razão, também no parecer desses dois autores, a escola tende a modificar intrinsecamente inclusive as reformas que são para ela projetadas. 


\title{
3. O MÉTODO DA ESCOLA E A ESCOLA COMO MÉTODO: VOZES DA IMPRENSA
}

\author{
"A história tem a propriedade de nos confundir; ela confronta-nos sem cessar com coisas estranhas \\ diante das quais a nossa reação mais natural é não ver; longe de constatar que não temos a boa \\ chave, não nos apercebemos mesmo que há uma fechadura para abrir" \\ (Paul VEYNE, Como se escreve a história, p.259).
}

\section{A escola e os ruídos da leitura}

Na verdade, o debate pedagógico português durante todo esse período compreendido entre 1820 e 1910 perpassa o objeto sobre o qual discorre a partir de variadas matrizes analíticas. Como já pudemos introduzir no capítulo anterior, houve três etapas que delinearam e marcaram as tendências do discurso sobre educação em Portugal do período que caminhava do liberalismo monárquico (1820) à República (1910). Em um primeiro momento, situado genericamente entre 1820 e 1850, a tônica foi colocada nos critérios e condições para a extensão, por parte do Estado, da escolarização às camadas populares. No período compreendido entre 1850 e 1870, passa-se a enfatizar o modelo de escola de Estado que se pretendia desde o princípio engendrar: qual seria o método indicado, como se processaria o ensino, quais os requisitos para a formação de um bom professor, etc. Acreditava-se já que discutir apenas a referência da escola, sem estabelecer estratégias pelas quais se daria seu funcionamento, era tarefa inócua, dado que a vida escolar, tal como se encontrava à época, não cumpria sequer aquilo a que se propunha. Finalmente, a educação passaria - particularmente entre 1870 e 1910 - a ser apreendida como se de uma ciência se tratasse. Deseja-se, a partir de então, conjugar o máximo de eficácia ao máximo de precisão na atividade do ensino, como se esta pudesse ser prevista e controlada, à luz de regras e de normatização científica. A pedagogia passaria, dali por diante, a ser entendida como uma vertente das ciências do homem que, ainda que emprestando repertório de outras áreas do conhecimento, mapearia o objeto da educação.

O tema da escola tinha alguma imbricação com a dinâmica política, posto que a grande questão intelectual para os teóricos do XIX português era a reflexão sobre a identidade de Portugal, compreendido o país quer como destino, quer como vocação, quer como vontade. O tema da escola era apresentado como estratégia para dinamizar e consolidar a nacionalidade. Ocorre que, durante o período em pauta, não houve a 
primazia da política educativa no contexto das políticas públicas. Isso não quer dizer, entretanto, que não houvesse debate acumulado e refletido nos próprios discursos políticos ou mesmo nos jornais da época sobre o referido tema. A instrução pública era apresentada, pelo menos desde os anos trinta, como motor privilegiado para a regeneração nacional, para a efetivação do progresso social e político e para possibilitar a prosperidade econômica.

De acordo com recenseamento efetuado no ano de 1838, havia em Portugal da época 34.869 alunos de instrução primária e 1.872 de instrução secundária. Isso significava, para os 3.300 .000 indivíduos que compunham a população portuguesa de então, uma correspondência equivalente a 1 estudante por 54 pessoas. De acordo com a situação verificada, a composição média de uma família portuguesa era, na ocasião, de 3,89 indivíduos; o que significava na prática que, em cada 14 famílias, apenas uma delas teria um indivíduo educado; entendendo-se aqui por educação diga-se de passagem - o cumprimento de alguns anos de escola, os quais, por sua vez, nem sempre podiam ser caracterizados como profícuos em termos da aquisição das habilidades básicas da leitura e da escrita.

Ocorre que, no decorrer dos primeiros anos do século XX, particularmente no período que imediatamente antecedeu a queda da monarquia, a situação do ensino persistia sendo denunciada pela imprensa periódica, que julgava o caso português sempre à luz de sua já sabida defasagem em relação a países mais desenvolvidos da Europa. A tabela abaixo, publicada pelo semanário $A$ Escola, que circulava em Coimbra no ano de 1905, vinha a propósito do debate que então se travava acerca do recenseamento escolar. Os números por si pareciam já revelar a urgência de se atentar para a gravidade da situação das escolas em Portugal, tendo em vista o próprio desenvolvimento cultural e econômico do país, à luz da comparação com a Europa ${ }^{145}$ :

\begin{tabular}{|l|l|l|l|}
\hline CONCELHO & ESCOLAS & POPULAÇÃO & $\begin{array}{l}\text { Número de escolas em relação à } \\
\text { população }\end{array}$ \\
\hline 1. Condeixa & 12 & 11.597 habitantes & 1 escola para 966 hab. \\
\hline 2. Figueira da Foz & 30 & 43.035 habitantes & 1 escola para 1434 hab. \\
\hline 3.Montemor-o-Velho & 22 & 22.050 habitantes & 1 escola para 1002 hab. \\
\hline 4.Penela & 10 & 10.354 habitantes & 1 escola para 1035 hab \\
\hline 5.Pombal & 14 & 34.516 habitantes & 1 escola para 2465 hab. \\
\hline 6.Soure & 14 & 20.380 habitantes & 1 escola para 1455 hab. \\
\hline 7.Total do Círculo & 102 & 141.932 habitantes & 1 escola para 1391 hab. \\
\hline 8. Total do Reino & 4886 & 5.000 .000 habitantes & 1 escola para 1023 hab. \\
\hline 9. Suissa & 7000 & 2.934 .075 habitantes & 1 escola para 419 hab. \\
\hline 10. Noruega & 6490 & 2.000 .000 habitantes & 1 escola para 308 hab. \\
\hline 11. Suécia & 9794 & 4.579 .115 habitantes & 1 escola para 467 hab. \\
\hline 12. Dinamarca & 2940 & 1.969 .039 habitantes & 1 escola para 669 hab. \\
\hline
\end{tabular}

Oferecer a instrução significava o Estado assumir verdadeiramente parcela da responsabilidade familiar e amparar a nação portuguesa para situá-la no rumo onde já estariam os demais países europeus; como diziam à época, a par de seu tempo.

${ }^{145}$ A ESCOLA; bi-semanário dedicado aos interesses da instrucção e do magistério, no 204, 23-9-1905. 
Na verdade, compreendia-se por educação mais do que o componente de desenvolvimento intelectual. A educação abrangeria uma dimensão de valores não redutível a quaisquer saberes de cunho propriamente científico. Através do gesto educativo, se estaria fortalecendo, por um lado, a inteligência; e, por outro, o caráter moral do indivíduo, para que seus bons atributos pudessem ser potencializados e desenvolvidos ao máximo e para que seus vícios ou suas perturbações fossem sanadas. Trabalhar com a categoria da desenvolução humana era, para aqueles portugueses da primeira metade do século XIX, enfrentar a prevenção do crime; era retirar as crianças e os jovens dos perigos e dos vícios da rua e do contato com seus iguais. Os seres humanos, educáveis, podem aprimorar os dons que lhes foram cedidos pela natureza. A educação era, assim, tanto domesticação quanto moralização.

O curioso é que, de alguma maneira, a sociedade e particularmente as suas elites viam no potencial educativo a ameaça da mudança e da revolta. Assim, os mesmos argumentos que eram usados para a defesa da causa da instrução eram utilizados para criticá-la. Para alguns, a escola contribuiria para a promoção dos vícios, dos crimes, da desordem da rebelião, enfim, de todos os espectros da transgressão do tecido social. ${ }^{146}$ Supunham essas pessoas que a instrução e o aprendizado da leitura teriam efeito nefasto sobre a moral e a religião populares, proporcionando ao homem contato com idéias perigosas, subversivas, transgressoras. Para o caso das meninas, o receio era ainda maior, dado que o conhecimento da escrita permitiria a correspondência livre com namorados e pretendentes, facilitando dessa maneira a fuga do controle paterno. Por vezes, acreditava-se que a ordem pública seria mais facilmente mantida com a manutenção da ignorância popular. Como a isso se somava o descrédito que, na maior parte das vezes, as famílias depositavam na escola, não havia grandes esforços para promover a escolarização. Havia temor de que o conhecimento viesse a agir no sentido oposto de seus objetivos declarados, incentivando revoltas e potencializando inquietações que ameaçavam o tecido social. Por seu turno, os partidários da causa educativa consideravam imprescindível o espraiar da instrução popular em função do fato de o homem ser apresentado como um ser moral. A escola era entendida, sob tal perspectiva, antes como uma agência de socialização - capaz de trazer ao estudante a compreensão da lógica e das hierarquias da sociedade adulta - e de moralização, por cuja experiência o indivíduo adquiriria os conteúdos e as atitudes socialmente prescritos e valorizados. A escola era então um rito. Envolvia todo um aprendizado com o manusear do impresso, cuja apreensão ou não também delimitaria lugares sociais, também insinuaria fronteiras de posição.

Sucede que, de algum modo, o tema da instrução permeava a própria acepção da política liberal, supondo a necessária correspondência entre a cidadania proclamada e a preparação do juízo crítico daqueles que deveriam exercitar a soberania nacional pelo sufrágio. Compreendendo a vida liberal e democrática como um processo em constante e progressivo aperfeiçoamento, destacava-se a urgência de se superar o estágio de "bestialidade" intrínseco à ignorância, de maneira a valorizar talentos e aperfeiçoar o percurso civilizatório, recuperando o que se acreditava ser a identidade portuguesa perdida na aventura das navegações. Oferecer instrução significaria, sob

${ }^{146}$ O PANORAMA, volume IV, 1840, página 391. 
essa ótica, capacitar as camadas populares ao apego à ordem instituída, até para que o clamor pela democracia não fosse mais longe.

Posto dessa forma, preparado para a nova civilidade eminentemente urbana, o indivíduo deveria ser habilitado para a familiarização com novos ofícios postos pela modernidade da fábrica industrial e das oficinas. Cabia, por um lado, cumprir com as exigências do Estado para o cumprimento integral da acepção mesma de cidadania; por outro lado, dever-se-ia construir a Pedagogia para novas funçôes a serem ainda desenhadas pelo Estado português. À Pedagogia caberia, então, não apenas acompanhar os tempos, mas fundamentalmente, adiantar-se a eles.

O discurso da educação em Portugal do XIX, muitas vezes, destacava que havia uma especificidade portuguesa a ser considerada em qualquer reforma institucional que viesse a ocorrer. A reforma da educação deveria fazer-se à portuguesa, por portugueses e para portugueses, distanciando-se dos modelos e referenciais externos. O discurso político definia as naçôes à luz do que seria sua específica índole. E esta, por sua vez, decorreria do conceito de vocação. Povos e pessoas seriam inscritos por suas especificas vocações. Contrariar a vocação era contrariar o talento e a própria possibilidade de êxito coletivo e individual. Descobrir e desenvolver em cada um sua vocação era a máxima finalidade da ação educativa.

O problema do conceito de vocação para a matéria pedagógica reside no facto de ele retirar da Pedagogia parte de suas potencialidades. Se, ao nascer, a pessoa traria inscrita consigo uma dada propensão natural para este ou aquele ofício, tornar-se-iam reduzidas as perspectivas de transformação individual pela ação educativa. Ao aplicar a idéia de vocação a uma dimensão coletiva, aí se cai necessariamente na dimensão da fatalidade, do cumprimento de um destino imanente inscrito de maneira teleológica no espírito do povo ou de cada nação em particular: destino esse que viria a se objetivar com o correr dos tempos, mas que permanecia e persiste sendo hoje o que fora outrora e sempre. Daí vêm também as noçôes de caráter nacional e talvez até de identidade de um país construído pela recordação das diferenças perante outros povos, outras culturas. A ilusão de uma feição portuguesa capaz de nacionalizar as idéias emprestadas do estrangeiro é uma tônica bastante presente no discurso pedagógico português do XIX. Cabia, sem dúvida, a inovação. A inovação - sabia-se - envolvia reformas institucionais. Por outro lado, não se aceita dissolver o velho para fundar e estrear o inteiramente novo; nem em política, nem em matéria pedagógica. Pretende-se antes revitalizar alguns aspectos, atualizar outros, para compor um mosaico que verdadeiramente expressasse para os portugueses sua própria índole nacional.

Não adiantaria incorporar, de modo mecânico, conteúdos e metodologias de ensino de outros povos. Não haveria nisso adequação, por faltar aquela correspondência entre índole coletiva e projeto desenhado. Tais saberes deveriam ser assimilados aos usos e aos costumes particulares e específicos de Portugal. Reconhecia-se haver um rumo comum para onde se dirigiam inevitavelmente todos os que se pretendessem em consonância com seu tempo; pois havia findado a época de nobreza guerreira, quando instrução cabia apenas aos considerados "espíritos fracos". O Estado moderno teria trazido para dentro de suas fronteiras novas posiçôes, novas necessidades, tanto de educação como requisito social - a envolver inclusive regras de urbanidade e cortesia quanto da instrução, do ponto de vista cognitivo, propriamente intelectual. Os demais países da Europa - e isso era constantemente recordado - já teriam inaugurado aquela 
desejada modernidade educativa. A propensão civilizatória pressuporia um dado grau de cultivo letrado. O próprio modelo escolar firmava-se intencionalmente perante códigos e sinais que dialogavam com uma única acepção de cultura, que, ao se colocar pelo caminho da instrução, destronaria as pretensas concorrentes de matriz popular. A irradiação da escola, naquele percurso do século XIX, firmaria, de uma vez por todas, a civilização do escrito. Além disso, havia de se erigir valores para cuja adesão as crianças e os jovens deveriam ser formados. Evidentemente, nesse rol valorativo vinha muito da memória histórica que se desejava efetivar. A memória coletiva seria produzida no relato da escolarização. Havia signos e indícios perante os quais a escolarização prepararia para o mundo do trabalho as gerações emergentes. A moral e a razão seriam, sob essa dinâmica, as duas âncoras sociais para sedimentar os projetos e as proposiçóes pedagógicas das mais variadas ordens.

O papel secular da escola combinaria, pois, ao ensino das habilidades técnicas da leitura, da escrita e do cálculo, o aprendizado das virtudes socialmente recomendáveis, bem como parâmetros de trato interpessoal; enfim, civismo e civilidade. Distinguindo-se pelo respeito à religião, ao rei e à pátria, o povo português teria na honra seu maior predicado. Cortesia, urbanidade, tolerância e hospitalidade eram caracterizados como atributos pertencentes à índole de uma nação que, por essência, teria na generosidade sua maior grandeza. Ocorre que tais virtudes, postas como vocação portuguesa, deveriam ser sempre atualizadas. Isso exigiria a correção de algumas mazelas e dificuldades no plano das condições econômicas do país. Portugal deveria - segundo entendiam os jornais - fomentar a indústria nacional de maneira a desenvolver recursos próprios que o tornasse independente da dinâmica colonial, particularmente em crise desde a independência do Brasil.

A instrução popular, se bem desenvolvida, poderia equipar o povo português para as habilidades que esse mundo moderno e industrial tanto necessitava, preparando, desse modo, uma nova versão da prosperidade nacional. Portugal perdera com a colonização que não soubera efetivar. Foi a colonização quem impediu o país de se voltar com maior ênfase para os recursos próprios do seu solo. Havia de se desenvolver um modelo de instrução popular especificamente voltado para regenerar esse erro histórico e recuperar a vocação de grandeza da pátria portuguesa. Formar pela ciência e organizar nessa direção um modelo combinado de instrução popular seria a tarefa máxima do Estado.

A idéia de regeneração pela trilha do ensino percorria também um imaginário extremamente preocupado com a possibilidade de emergência da desrazão. As crianças nasceriam todas com pendor para o bem e para o mal, e competiria à ação educativa reforçar ou eliminar tais propensões com que a natureza dota cada um em princípio. No decorrer do desenvolvimento humano, o indivíduo paulatinamente vai deixando o mundo da natureza para ingressar no território da cultura. Nessa trajetória, haveria, entretanto, alguns parâmetros pelos quais a vida da criança em seu desenvolvimento rumo à maturidade poderia ser qualificada como normal. Ser normal é algo posto como um dado; quaisquer desvios da ritualização prescrita poderiam ser compreendidos como vestígios de anormalidade. A educação - como prática social - requereria das crianças aprendizado da obediência, ancorada por atitudes de autoridade e não apenas pela ameaça da punição ou do castigo. A rotina da educação deveria ser criada antes pelo hábito do que pelo discurso e, até certo ponto, educar 
era justamente essa maneira de incutir atitudes socialmente recomendáveis às gerações mais jovens. ${ }^{147}$

Era muito comum os jornais denunciarem que a instrução jamais tinha sido tomada como prioridade no rol de políticas públicas em Portugal. Dados de Manoel Francisco de Medeiros Botelho oferecem sobre o ano de 1872 o seguinte quadro: "na Prússia há uma escola para 633 habitantes; na França, uma para 564; na Holanda, uma para 411; na Suíssa, uma para 349; nos Estados Unidos, uma para 185; em Portugal, uma para 1.156. A desproporção é imensa!" ${ }^{148}$ As escolas eram insuficientes em termos quantitativos e aquelas que existiam quase sempre funcionavam mal, o que induz os educadores e intelectuais da época a refletirem sobre o problema do método, dos procedimentos pedagógicos e das estratégias de aprendizagem.

Reconhece-se a necessidade de se estudar a infância, compreender sua especificidade, os passos de sua desenvolução orgânica, emocional e social para, a partir dela, proceder ao combate da indigência e da criminalidade futura, à prevenção de desvios, à retirada dos meninos da rua e ao controle das multidóes incautas. De algum modo, a excessiva preocupação com o tema do glorioso passado do país tendia a retirar as imagens mentais da construção do futuro. A infância era tida, nesse sentido, como fator estratégico porque - ausência de passado - personificava a prosperidade do país. Daí sua relevância social. Essa era a primordial tarefa da escola: encaminhar e fornecer suporte teórico e valorativo para que as gerações mais jovens pudessem trilhar a busca de um destino mais promissor. Assim como Portugal, à infância não é suposto o presente. Bastava o passado e o futuro...

Havia de se educar a pátria até para regenerá-la: assim entendiam Herculano, Castilho, a Geração de 70 e finalmente os republicanos. Mas assim entendiam também os jornais e as revistas da época que, dissertando sobre a matéria pedagógica, julgavam que o problema da leitura em expansão poderia abalar os próprios alicerces da nacionalidade. Não havia como lutar contra os perigosos e indomáveis efeitos de folhas redigidas que andavam por aí à solta... Urgia, então, orientar, ritmar, socializar e induzir modos e práticas de leitura que pudessem ajuizar simbolicamente os significados subversivos do mundo da tipografia. A escola era defendida para eleger e defender conteúdos culturais como se fossem os únicos autorizados e para controlar outros conteúdos espraiados pela proliferação do material impresso e por eventuais práticas espontâneas de leitura. Era essa a grande ameaça que se desejava combater quando se punha ênfase na tarefa civilizadora da escolarização.

A escola se apresentava, dessa forma, como estratégia de correção dos excessos da civilização, pela própria via da civilização; ou seja: através da ação escolar, haveria um percurso de aprimoramento na trilha civilizatória. A escola era a possibilidade institucional da mediação entre os valores do passado, as potencialidades do presente e as incertezas e indefinições do sempre indeterminado futuro. Por isso mesmo, alguns viam na escolarização a agenda de tempos por vir... A despeito desse fato, a escola era, sem qualquer dúvida, a instituição charneira para o diálogo com a leitura: dizemos diálogo porque não supomos que toda a leitura estivesse confinada ao

\footnotetext{
${ }^{147}$ O PANORAMA, volume III, 1839, p. 405-6.

${ }^{148}$ Manoel Francisco de Medeiros BOTELHO, O que é e o que deve ser a instrucção nacional, p. 18-9.
} 
domínio escolar; não acreditamos tampouco que a escola exercitasse prioritariamente a alçada da leitura. Haveria, sim, um intercâmbio, eivado, contudo, de tensôes, de contradições, de desconfiança. A leitura é, por si, prática autônoma que, levada ao extremo, pode negar a própria ação escolar. Por essa razão todo o discurso à volta desse tema abarca as vantagens e os perigos do ler: que tanto aproximam como ameaçam a instituição escolar. Nossa tese é a de que a escola se põe na sociedade portuguesa do período em tela principalmente para rivalizar com a atitude da leitura espontânea que, em si, é percebida como fonte de corrupção dos costumes e transgressão de tradições. Não se pretende que as novas gerações inventem nada; nem ao menos aquilo que foi para elas projetado. Caberia aos novos assegurar e perpetuar a herança dos que vieram antes; mesmo que tal herança fosse eivada de demarcações, hierarquias e desigualdades. Subverter a ordem não poderia ser tarefa da pedagogia; esta, por definição, preserva: daí tomar a leitura, o livro e o jornal como suas concorrentes...

\section{A ambiência educativa impressa em panorâmicas folhas periódicas}

\section{O Panorama; jornal litterario e instructivo da Sociedade Propagadora dos Conhecimentos} Uteis (1837) pretendia, como o próprio nome assinalava, derramar, por meio da criação do hábito da leitura, parâmetros cultivados de civilização e cultura. Como destaca Catroga, O Panorama teria sido o primeiro instrumento de divulgação das novas idéias, dos novos quadros mentais, da nova concepção de história e de mundo, veiculados, em Portugal, a partir da efetivação do regime liberal em 1834. Era uma revista que, fundada por Alexandre Herculano, pretendia atingir camadas médias e populares, ou - nas palavras de Catroga - um público interclassista. Para tanto, apresentava um formato inovador, enciclopédico e divulgava conhecimentos gerais e conquistas da ciência nas diferentes áreas do conhecimento. Havia nitidamente ali o intuito civilizador e a revista entendia a si própria com a missão de uma Pedagogia social formadora de hábitos e criadora de tradiçôes. Era assim que O Panorama falava de educação e do que se fazia nos povos estrangeiros; falava do modo de governar os homens e da Academia Real das Ciências; falava dos indígenas da América e do Marquês de Pombal... Consta que a tiragem da revista alcançaria, em alguns números, uma média de 5000 exemplares, "cifra que, mesmo exagerada, é, contudo, digna de registro numa época em que a taxa de analfabetismo se aproximava dos $90 \% " 149$. Muitas outras iniciativas teriam o sucesso d'O Panorama por referência. Castilho, com a Revista Universal Lisbonense, não denegaria a apropriação dessa herança. O século XIX vinha relatado por um conjunto de jornais e de revistas pretensamente voltados explicitamente para a educação popular, para a formação de pessoas leitoras. ${ }^{150}$ Há claramente um papel pedagógico, intencional e planejado

${ }^{149}$ Fernando CATROGA, Alexandre Herculano e o historicismo romântico, In: $A$ história através da história, p. 42.

${ }^{150}$ Maria Manuela Tavares RIBEIRO já assinalava o seguinte sobre as bases sociais da leitura no século XIX português: "num complexo e vasto conjunto de fatores estruturais, tendenciais e conjunturais - a alfabetização, a liberalização legislativa da imprensa, os diversos progressos técnicos, a constituição de um mercado editorial do livro, 
nessa leitura de formação, cuja finalidade explícita era, sobretudo, libertar, o leitor de possíveis armadilhas das situações cotidianas, preparando-o e habilitando-o, em uma direção enciclopédica, para temas dos quais se julgava necessário o domínio. Desejava-se pela imprensa formar a cultura geral. Compreender a intersecção entre tais iniciativas e a Pedagogia portuguesa propriamente dita é o que pretendemos fazer neste capítulo.

Já nos primeiros anos de existência do jornal, particularmente 1837 e 1838, o prólogo dirigido aos assinantes veicularia, com bastante frequência, a importância social da habilidade coletiva da leitura. O jornal dizia pretender "derramar a instrução, fazendo descer a literatura e a ciência ao nível das inteligências comuns." ${ }^{151}$ Segundo diziam os articulistas, o problema da leitura em Portugal consistia, antes de qualquer coisa, na ausência de interesse das populaçôes pelo ato de ler. A disposição de instruir, própria do jornal, deveria ser complementada pela disposição anterior de distrair, na ausência da qual o povo não procuraria instrução. $O$ mundo da cultura deveria ser, pois, apresentado sob essa dupla perspectiva: distrair instruindo. Mas, para além da instrução, o mundo da cultura deveria perfazer uma atitude formadora de hábitos e de valores socialmente prescritos. Desse modo, tratava-se, acima de tudo, de uma tarefa educativa. A leitura instrutiva era - como já observamos anteriormente - aquela que, de alguma forma, poderia controlar a leitura espontânea, prevenindo as populaçóes da atração por práticas leitoras desregradas, passíveis estas de ocasionar a corrupção dos costumes e dos padróes de moralidade.

A leitura é apontada - nos primeiros números d' O Panorama - como fonte de bons hábitos morais. $\mathrm{O}$ costume de ler estruturaria práticas de meditação, desenvolveria a perspicácia do raciocínio, a retidão nos modos de julgamento sobre os homens e sobre os fatos, o abandono de maus modos, ligados, na grande maioria das vezes, a práticas de sociabilidade de setores tidos por menos civilizados. Além de código moral, a leitura veiculava, sobretudo, normas de urbanidade e estratégias de controle das paixões. Ocorre que, paulatinamente, passa-se a diferenciar a ação da boa escola da atuação da má escola; do mesmo modo, distingue-se a boa e instrutiva leitura da má e corruptora leitura. ${ }^{152}$

Instruir o povo era missão do jornal. O desejo de saber se teria ampliado socialmente, em virtude do aperfeiçoamento da ciência e da técnica. E a vontade de adentrar o mundo da cultura letrada era tida por decorrência natural desse processo. Era o livro

\footnotetext{
o desenvolvimento concorrencial da imprensa, os problemas suscitados pelo acesso das classes médias aos bens culturais, a necessária educação das classes laboriosas, a reorganização de meios e formas de educação e de cultura, a autonomização dos intelectuais em relação à propriedade literária e às relaçôes do escritor com a sociedade - o livro é veículo importante de circulação de idéias, de comunicação de mensagens e sendo, ao mesmo tempo, um objeto de consumo da sociedade oitocentista portuguesa." (Maria Manuela Tavares RIBEIRO, Livros e leitura no século XIX , In: História da vida privada e do quotidiano em Portugal, p. 2).

${ }^{151}$ O PANORAMA; jornal litterario e instructivo da Sociedade Propagadora dos Conhecimentos Uteis, volume segundo, 6-1-1837 p. 36.

152 "A escola é um verdadeiro remédio do amor próprio; bem-entendido que falamos da boa escola; a má, além dos frutos detestáveis, que infelizmente produz, tem o inconveniente de não ensinar os meninos a conhecerem-se nem a corrigirem-se. A boa escola também desenvolve os sentimentos de modéstia, de sociabilidade, de ternura, de gratidão, de benevolência, que são todas excelsas virtudes. A má escola exercita uma influência contrária." (O PANORAMA..., no35, 30-12-1837, p. 276).
} 
quem criava a necessidade da escola e do aprendizado da leitura; e não o contrário. Os contemporâneos tinham isso muito claro. As publicações voltadas para a ilustração popular eram tributárias do fervilhar jornalístico. O impresso se havia firmado no mundo contemporâneo. Mais e mais, o homem do povo faria da leitura um hábito, uma prática. Era, então, imprescindível trazer e veicular, até para efeito pedagógico, bons e úteis conhecimentos, a serem irradiados a partir dos jornais e das revistas e dos folhetos que circulavam, fugindo a qualquer controle.

Quanto às escolas propriamente ditas, O Panorama encarregava-se de transmitir preceitos e regras para a conduta do mestre, com o fito de que a ação educativa fosse efetivamente levada a contento. As crianças deveriam ser orientadas para a obediência e os desvios deveriam ser punidos. Cabia, porém, ao educador explicitar com distinta clareza o porquê da punição, de modo a garantir a eficácia do eventual castigo. Saber bem recompensar e bem punir eram as verdadeiras artes que destacavam a ação do bom educador. Recomendava-se, a esse respeito, que o mestre não se enfurecesse, mas que se mostrasse capaz de manter o equilíbrio, a serenidade, a ponderação do julgamento. Mesmo o ato de castigar deveria ser realizado perante critérios objetivos, sempre mantida a equidade do educador. Consciente de que a juventude é muito propensa à imitação, recomenda-se que o professor seja capaz de se manter perante códigos irrepreensíveis de conduta moral e civil.

A iniciativa editorial de outros inúmeros jornais e revistas editados a partir do final dos anos 30 pretende atender - no modelo d'O Panorama - camadas variadas da população, tendo por propósito, como já pudemos observar, uma pedagogia do homem feito. Tratava-se de reformar a sociedade para depurá-la de seus elementos de risco, até para prevenir a ocorrência das revoluções. Os jornais são recorrentes na apresentação da pergunta: qual era, de facto, a vocação de Portugal? E por que, em seu caminho, pela história da civilização, esse povo obteve tantas glórias durante o tempo das descobertas para imediatamente depois ser relegado a tão profundo esquecimento? Quais eram as razões da decadência portuguesa? O tema da escola e a educação do povo são tomados, nessa perspectiva, como possíveis hipóteses explicativas. O país não teria sabido se colocar a par de seu tempo no desenvolvimento de um modelo de civilização que o aproximasse dos outros povos europeus naquilo que diz respeito à irradiação e à partilha das conquistas da ciência e da técnica.

Portugal estaria aquém dos demais países europeus na divulgação da parcela de conhecimento vista como essencial para todos os indivíduos. Havia - no parecer da maior parte desses formadores da opinião pública que escreviam para os jornais e para as revistas letradas em Portugal de meados do século - um nível fundamental de instrução necessário a todos os homens e que seria o mesmo, invariável e universal, independentemente de proveniências de classe ou de fortuna, não devendo, assim, ser pelas mesmas obstaculizado. Esse degrau primário corresponderia à etapa destinada a derrocar as crenças e superstiçóes populares. A cultura do escrito concorria e recusava as tradiçóes da oralidade, da memória, dos usos e dos costumes.

Os custos da escola primária pública, de acordo com dados da Revista Universal Lisbonense, eram os seguintes: 


\begin{tabular}{|c|c|c|c|c|c|c|c|c|}
\hline $\begin{array}{l}\text { DISTRITOS } \\
\text { ADMINIS- } \\
\text { TRATIVOS }\end{array}$ & PopUlaÇĀo & $\begin{array}{l}\text { CUSTO EM } \\
\text { RÉIS DA } \\
\text { INSTRUÇÃO } \\
\text { PRIMÁRIA }\end{array}$ & $\begin{array}{l}\text { ALUNOS } \\
\text { DA INS- } \\
\text { TRUÇĀO } \\
\text { PRIMÁRIA }\end{array}$ & $\begin{array}{l}\text { MESTRES } \\
\text { OU } \\
\text { CADEIRAS } \\
\text { PROVIDAS }\end{array}$ & $\begin{array}{l}\text { QUOTA } \\
\text { DOS } \\
\text { ALUNOS } \\
\text { PELA } \\
\text { POPULAÇĀO }\end{array}$ & $\begin{array}{l}\text { QUOTA } \\
\text { PELO } \\
\text { CUSTO }\end{array}$ & $\begin{array}{l}\text { QUOTA } \\
\text { ORDE- } \\
\text { NADOS } \\
\text { MESTRES }\end{array}$ & $\begin{array}{l}\text { QUOTA } \\
\text { DOS } \\
\text { ALUNOS } \\
\text { PELOS } \\
\text { MESTRES }\end{array}$ \\
\hline Viana & 179.112 & $3.506 \$ 666$ & 2.017 & 44 & $1 \mathrm{em} 84$ & $3 \$ 506$ & $79 \$ 696$ & 45 \\
\hline Braga & 292.486 & $6.836 \$ 666$ & 4.049 & 74 & $1 \mathrm{em} 73$ & $1 \$ 709$ & $92 \$ 387$ & 54 \\
\hline Porto & 349.848 & $7.310 \$ 000$ & 2.801 & 72 & $1 \mathrm{em} 116$ & $2 \$ 611$ & $101 \$ 527$ & 38 \\
\hline Vila Real & 178.144 & $5.216 \$ 666$ & 2.719 & 67 & $1 \mathrm{em} 65$ & $1 \$ 932$ & $77 \$ 860$ & 40 \\
\hline Bragança & 125.771 & $5.036 \$ 666$ & 1.993 & 56 & $1 \mathrm{em} 66$ & $2 \$ 518$ & $89 \$ 940$ & 35 \\
\hline Aveiro & 228.710 & $5.846 \$ 666$ & 2.978 & 63 & $1 \mathrm{em} 78$ & $2 \$ 016$ & $92 \$ 804$ & 47 \\
\hline Coimbra & 239.696 & $6.726 \$ 666$ & 1.857 & 67 & $1 \mathrm{em} 133$ & $3 \$ 737$ & $100 \$ 398$ & 27 \\
\hline Viseu & 294.703 & $9.636 \$ 666$ & 3.894 & 123 & $1 \mathrm{em} 77$ & $2 \$ 470$ & $78 \$ 346$ & 31 \\
\hline Guarda & 198.310 & $7.826 \$ 666$ & 2.678 & 86 & $1 \mathrm{em} 77$ & $3 \$ 010$ & $91 \$ 007$ & 31 \\
\hline $\begin{array}{l}\text { Cast. } \\
\text { Branco }\end{array}$ & 130.787 & $4.646 \$ 666$ & 1.238 & 43 & $1 \mathrm{em} 108$ & $3 \$ 872$ & $108 \$ 063$ & 28 \\
\hline Leiria & 126.862 & $3.776 \$ 666$ & 1.151 & 35 & $1 \mathrm{em} 115$ & $3 \$ 433$ & $107 \$ 904$ & 32 \\
\hline Santarém & 145.375 & $4.316 \$ 666$ & 935 & 43 & $1 \mathrm{em} 155$ & $4 \$ 616$ & $100 \$ 387$ & 21 \\
\hline Lisboa & 411.765 & $14.080 \$ 000$ & 2.936 & 108 & $1 \mathrm{em} 142$ & $4 \$ 855$ & $130 \$ 370$ & 27 \\
\hline Portalegre & 82.398 & $3.776 \$ 666$ & 861 & 36 & $1 \mathrm{em} 95$ & $4 \$ 385$ & $104 \$ 907$ & 23 \\
\hline Évora & 82.581 & $2.606 \$ 666$ & 784 & 22 & $1 \mathrm{em} 105$ & $3 \$ 324$ & $118 \$ 484$ & 35 \\
\hline Beja & 105.318 & $3.326 \$ 666$ & 828 & 33 & $1 \mathrm{em} 127$ & $4 \$ 017$ & $100 \$ 808$ & 25 \\
\hline \multirow[t]{2}{*}{ Faro } & 128.224 & $2.576 \$ 666$ & 415 & 16 & $1 \mathrm{em} 308$ & $6 \$ 207$ & $161 \$ 041$ & 26 \\
\hline & 3.300 .000 & $97049 \$ 990$ & 34.134 & 988 & $1 \mathrm{em} 97$ & $2 \$ 854$ & $98 \$ 238$ & 34 \\
\hline
\end{tabular}

O artigo em questão - redigido por C.A. Costa - revela preocupação com as disparidades regionais do investimento em escolas. Como demonstram os dados da tabela, de fato, se havia crise quanto ao oferecimento da instrução primária em todo o Reino, havia verdadeira falência quanto à sua distribuição. Naquele ano de 1843, "enquanto no Algarve há em cada 78 famílias 1 menino que aprende a ler à custa do Estado, há em Vila Real 1 por 15 famílias." ${ }^{153}$ Outra questão que frequentemente era destacada pelos artigos sobre a instrução pública residia no tema da escolha, da formação e da habilitação dos professores para o ensino primário. Em artigo publicado no ano de 1846, Silvestre Pinheiro Ferreira destacava a dificuldade do Estado na seleção de bons professores, inclusive em virtude já do péssimo salário que os candidatos ao magistério receberiam.

O tema da reforma pela educação ganhava corpo. Algumas premissas eram comuns: havia de se garantir a todos a instrução gratuita e obrigatória, posto que, se todos teriam direito de reclamá-la e exigi-la, todos teriam como contrapartida o dever de enviar suas crianças à escola, na medida em que os benefícios da instrução reverteriam necessariamente em benefício da sociedade. A regeneração da vida social portuguesa principiaria por aí: lentidão quanto ao aumento, à expansão e ao aperfeiçoamento da rede pública de escolas; pequena demanda por instrução primária por parte das comunidades locais; pouca aptidão e ausência de formação profissional

${ }^{153}$ Cláudio Adriano da COSTA, Instrucção Pública, In: Revista Universal Lisbonense, tomo II, ano de 1842 -1843, p.64. A tabela que acabamos de reproduzir encontra-se neste mesmo artigo, à página 63. 
dos docentes admitidos; má situação física e material das escolas; e o que era, no contexto, ainda pior - a incúria governamental, insensível perante as candentes necessidades de uma escola que, imóvel, persistia sendo a mesma, incapaz de engendrar mudanças.

\section{O modelo escolar e a persistência do arcaísmo no contexto da pretendida regeneração}

Os anos 50 presenciaram - como assegura Oliveira Marques - a expansão e a estabilidade da economia e da política em Portugal. Rómulo de Carvalho observou que a prosperidade desse período conviveu com o reconhecimento da insuficiência quanto a matrizes técnicas de conhecimentos, capazes de verdadeiramente alavancar os recursos econômicos, em termos mais competitivos. A escola, dali por diante, passou a ser pensada também como exigência tecnológica, condição para o aprimoramento material das sociedades, pelo fato de capacitar o indivíduo para habilidades exigidas pelo progresso. Os elos que uniam instrução e cidadania continuariam a povoar o discurso e o imaginário sobre a escola. Mas, cada vez com maior intensidade, será destacada a aliança entre a preparação que a escola oferece e a qualificação para o trabalho. Nessa direção, a escola projetada deverá ser uniforme, padronizada, controlada por órgãos nacionais de inspeção. Nas práticas, contudo, isso ainda não ocorria. O liberalismo convive, pois, com a persistência de um modelo escolar herdado do modelo pombalino: salas de aula esparsas, distantes uma das outras, muitas vezes abrigando crianças de mais de uma aldeia, cada escola com seu respectivo professor, sem haver diretrizes conscientemente assumidas. Na indefinição e na incerteza quanto ao método e ao conteúdo, o professor recorria ao compêndio. Estudando, ele - professor - pelo compêndio dirigido aos alunos, procurava, a partir daquilo, ensinar: a ler, a escrever e a contar. Ensinava também como os alunos deveriam aprender a se comportar. A vida escolar era, não apenas veículo eficiente de instrução, mas fundamentalmente agência de moralização; de inculcação de valores e de referências, de transmissão de códigos e de padrôes de conduta.

A extensão da escola para setores ampliados da população portuguesa passava também pelo medo da mendicidade e da indigência que ia, de certa maneira, ganhando força nos ambientes citadinos. Na verdade, a civilização exigiria a inserção do sujeito no ambiente da palavra, da correção gramatical - em termos tanto da morfologia quanto da sintaxe - exigida pelo convívio social, pela interação do homem com seus conterrâneos. Além disso, um ambiente cultural cada vez mais circunscrito sobre o referencial do impresso exigiria o domínio e o manejo do escrito: a leitura e a habilidade de escrever tornavam-se imperativos da nova sociabilidade desenhada pela civilização do texto, da técnica; em uma palavra, da modernidade. Talvez haja sido o sentimento e a consciência do tempo quem trouxe a escola. Um tempo que se queria apartado do presente: produzindo a memória escrita para recordar o passado e voltado, substantivamente, para a prospecção do futuro.

Mariano Guira era Comissário dos Estudos da cidade de Lisboa. Seus textos evidenciam a preocupação da época com a instrução. No ano de 1864, artigo intitulado 'Casas para Escolas' trazia o parecer de Mariano Guira sobre a necessidade de o Estado e os particulares atentarem para os aspectos físicos da vida escolar: 
"As condições materiais da casa escolar não são indiferentes ao professor e aos alunos. O professor, depois das fadigas do magistério, carece de encontrar o modesto conforto de uma habitação, posto que simples, decente e higiênica. A escola deve concorrer para conservar as crianças de bom humor, para lhes incutir o amor pelo estudo, pelo asseio e pela boa ordem. Se a casa de escola não estiver em condições convenientes, se os alunos estiverem constrangidos, apertados, e metidos em uma atmosfera viciada, não pode haver gosto pelo estudo, nem disciplina, nem saúde. O que a tal respeito se observa na grande maioria das escolas deste distrito é muito para lamentar. Se se quiser que a instrução primária seja uma realidade, é indispensável cuidar seriamente da construção de casas apropriadas para escolas. É neste intento que pedimos a atenção das autoridades administrativas, câmaras municipais, juntas de paróquia ou quaisquer outras corporações ou cidadãos que se interessem pelo assunto para os projetos de edificação que apresentamos. A primeira condição que se deve procurar para o estabelecimento de uma escola é um lugar central, de fácil acesso, bem ventilado. A escola deve ficar isolada de qualquer habitação insalubre, e afastada quanto possível dos lugares onde haja ruído ou qualquer outro objeto de distração que possa perturbar os exercícios escolares, ou desviar a atenção dos alunos." 154

A sala de aula deveria ainda contar com uma disposição própria. Os alunos ficariam em bancadas apropriadamente enfileiradas pelo espaço da sala de aula, defronte ao estrado e à cadeira destinados ao lugar do professor. É toda uma arquitetura que distribui lugares, configura e delimita padróes de espaço e estipula marcas de significados de poder institucional. A escola, já pela disposição física, classificaria e ordenaria os indivíduos. Há preocupação quanto à ventilação e à luz necessárias ao funcionamento rotineiro da classe. A época procura regrar a dinâmica da escolarização, como se fosse possível conferir a ela, por um ato de vontade, uma eficiência padronizada à luz da referência de um ensino simultâneo.

Em outro texto - intitulado 'Mobília para Escolas' - Mariano Guira discorria sobre o mobiliário de uma escola 'bem organizada'. A instituição, para bem funcionar, precisaria conter os seguintes objetos: estrado; quadro preto; bancadas para os alunos;

\begin{abstract}
"Além dos objetos mencionados, deve ter a escola: um crucifixo, em frente dos alunos, na parede superior ao estrado; o busto ou o retrato do rei; um contador mecânico com 100 esferas; um relógio; um mapa de Portugal; um quadro do novo sistema legal de pesos e medidas, como o metro, o litro, o quilograma, etc.; um pote com torneira para água e um copo ou um púcaro de metal; um lavatório; cabides numerados à entrada da escola para bonés, capas, etc.; livros para se emprestarem aos alunos mais pobres; exemplares para escrita e cadernos para escrita e para contas." 155
\end{abstract}

O estrado - de acordo com a recomendação do Comissário dos Estudos - deveria ter uma altura tal que o professor pudesse vigiar todos os alunos. Deveria ter ainda dois ou três degraus. Sobre o estrado, ficaria a mesa do mestre, com 2 metros de comprimento por 0,96 metros de largura. O quadro preto estaria situado à esquerda da mesa

\footnotetext{
${ }^{154}$ Mariano GUIRA, Archivo Pittoresco, $7^{\circ}$ anno, 1864, p. 164-5.

${ }^{155}$ Mariano GUIRA, Archivo Pittoresco, $7^{\circ}$ anno, 1864, p. 248.
} 
do professor, com 1 metro de largura e 0,66 metros de altura. As bancadas sugeridas por Guira eram compostas por duas peças - carteira e banco - ligadas entre si. Seriam feitas especialmente a partir das medidas médias das crianças e comportariam, cada uma, três alunos. A ligação entre a mesinha e o banco, como já observavam outros estudos, era importante para estipular a disciplina pretendida, posto que, com mesa e banco ligados, a mobilidade do aluno seria dificultada: ele não seria capaz de deixar sua carteira com tanta facilidade, estando por sua vez devidamente afastado dos colegas e companheiros. Guardava-se pelo estrado, a distância do professor; pela carteira, assegurava-se o espaço do aluno, que deveria, acima de tudo, conhecer o seu lugar; o lugar que os hierarquicamente superiores teriam reservado para ele. Isso seria o mundo e isso era também a escola. Haveria nas carteiras orifícios para tinteiros. Calcula-se todavia que nem todas as escolas poderiam contar com esse mobiliário ultra-moderno. Pensando nisso, o redator esclarece que, nas escolas onde não houvesse aquelas bancadas para os alunos, deveria existir pelo menos o seguinte:

“1) Que haja uma banca comprida para a escrita, de modo que um terço dos alunos possam aí escrever, a fim de serem divididos em três classes que ocupam por seu turno a banca. É conveniente que no ato da escrita cada aluno tenha um banco separado (mocho), em vez de estarem sentados uns poucos no mesmo quando escrevem. $2^{\circ}$ ) Que os bancos da aula não deixem de ter costas. É muitíssimo inconveniente e prejudicial à saúde conservar os alunos encostados às paredes úmidas e frias, ou curvados sobre os bancos por não terem onde se encostarem. $\mathrm{Na}$ escola de Queluz há uns bancos, mandados fazer há bastantes anos pela casa real (segundo nos constou), que reúnem as condições convenientes. Cada banco pode acomodar quatro ou cinco alunos; tem costas de madeira um pouco inclinadas e na parte inferior do assento há uma caixa onde os alunos guardam os livros, barretes, etc."156

Buscava-se uma padronização da estrutura física da sala de aula. Havia com frequência notícias sobre a venda de material escolar e principalmente sobre novas descobertas técnicas feitas nesse terreno. Propunham-se novos instrumentos, mais fáceis e mais baratos, novos materiais para fabricação do moderno mobiliário; todo ele voltado para uma boa capitalização comercial da própria idéia da sala de aula... O século XIX desenhava, assim, sua escola nas revistas.

Talvez a grande temática da educação e da escola no século XIX estivesse contida na nova percepção que os contemporâneos passavam a ter da infância. A criança passaria, ainda na primeira metade do século, a ser retratada como um ser específico, dotado de uma complexidade intrinseca, que pouco teria a ver com as características do adulto. Os adultos precisariam, por causa disso, refletir sobre a lógica que preside a razão infantil. Supunha-se que compreender o raciocínio da criança era uma das chaves para o êxito da prática educativa. Conclamavam-se os leitores para que eles passassem a prestar mais atenção às suas crianças. $\mathrm{O}$ estímulo para a descoberta da infância não era, porém, desinteressado: passava-se a querer reparar na criança do berço para que ela nos revelasse o que de nós, adultos, já estaria lá... Procurava-se acentuar o rol das obrigaçôes dos pais, obrigações estas que abarcariam a formação moral das gerações emergentes. Com

${ }^{156}$ Mariano GUIRA, Archivo Pittoresco, $7^{\circ}$ anno, 1864, p. 248. 
cuidado, falava-se do mau pai, daquele que não honra seu dever para com sua prole, atribuindo à má índole os maus tratos e eventualmente a própria falta de amor. Supunhase que, paralelamente à escola, cabia ao lar a tarefa civilizatória.

Ora, mas se a educação era assim compreendida, antes como a formação do coração humano do que dos aspectos concernentes à racionalidade, parecia fundamental atribuir ao mestre de instrução primária um lugar de destaque no cenário social. O mestre como enfaticamente observava António Feliciano de Castilho, em artigo datado de 1855 para o jornal coimbrão intitulado $A$ instrução e o povo - era de fato o 'instituidor' primário e, como tal, deveria ser tratado pela sociedade e particularmente pelos pais de família. Castilho - admitindo as lacunas da escola primária e particularmente de seus professores no cumprimento de sua missão - sublinhava no texto a necessidade de implantação de medidas de cunho pedagógico imprescindíveis para a construção de uma escola eficaz. Propõe a criação de um Ministério exclusivamente dedicado aos assuntos da instrução pública. Sugere, ainda, o incentivo à veiculação de folhas periódicas destinadas a instruir, complementando a ação da escola e voltadas também para a formação dos mestres. Esse último objetivo viria a ser consubstanciado - acreditava o educador - pela ação de jornais especificamente dirigidos à temática da instrução. $A$ instrução e o povo não era, como temos visto, o único órgão da imprensa que, à época, lidava com a finalidade didática de dirigir ensinamentos aos adultos. Podemos destacar que, na mesma direção, situavam-se as propostas d'O Panorama, da Revista Universal Lisbonense (que o mesmo Castilho fundou em 1840 e foi responsável pela redação dos primeiros quatro tomos) e d' $O$ Instituto - dado que todos eles traziam inúmeros textos e, por vezes, inclusive seções reservadas a apresentação de questôes de ensino. A imprensa era apresentada pelos intelectuais portugueses da época como dispositivo irradiador de suas idéias, com o propósito de consolidar novos quadros mentais acerca de temas considerados relevantes. Pressionar o governo era também fazer isso. Haveria de chegar o momento em que administradores de concelho, juntas de paróquia, governadores civis, todas as autoridades, enfim, se sensibilizariam para a urgência de tomar como prioridade das políticas públicas a formação da juventude nas escolas. Entendiam os intelectuais da época que o país precisava de educação escolar - ainda que ninguém acreditasse nisso: nem as autoridades nem mesmo as famílias. Competiria à instrução primária organizar, ordenar, classificar a cidade, preveni-la do crime, da desordem e particularmente das revoluçôes sociais, que pareciam ser a grande tentação daqueles tempos. A cidade, a vida mercantil, a concorrência de um mercado que, caótico, ia se estruturando, esse era o mundo para o qual se deveria dirigir a escolarização pública. A instituição escolar é compreendida como agência de prevenção dos desvios e do controle das multidóes. Para evitar a marginalidade, a indigência, a mendicidade e o crime, a escola deveria vir. Era a cidade quem a chamava; a cidade que toma aqui a voz daquele diretor da quase única escola de formação de professores que havia em Portugal de meados do século XIX.

\section{A escola que classifica, ordena, instrui}

Conclama-se a escola como estratégia de reforma que preveniria o país contra o fantasma da revolução. Desejava-se a mudança, mas a mudança contida, regrada e 
vigiada - que, não rompendo a ordenação do passado, fosse capaz de alterar apenas o necessário, passo a passo, sem violência e sem traumas. Quando todos tivessem instrução, julgava-se que não haveria mais perigo de abalos sociais, posto que haveria uma regulação natural para equilibrar a disparidade das fortunas através da equalização do direito de cada um explorar ao máximo suas capacidades e seus talentos. A desigualdade predominante no cômputo geral da sociedade é interpretada como diversidade de dons individuais: venceriam os melhores, os mais capazes, os mais talentosos. A sociedade estaria finalmente harmonizada com os princípios da justiça social. Os jornais contribuíam para difundir a idéia de que inteligência bem aproveitada poderia potencializar ao infinito a natureza do homem, conduzindo-o para a civilização, aprimorando essa mesma civilização e trazendo utilidade social ao mundo da propriedade e do trabalho. Por volta do último quartel do século, o socialismo era já uma doutrina a atormentar os contemporâneos que temiam a morte da individualidade e, por conseguinte, a crise da sociabilidade. A educação deveria cada vez mais ser apontada como mecanismo de controle das populaçôes, estratégia de inibição das leituras superficiais, dispositivo de regulação da vida na cidade ${ }^{157}$, estrutura de previsão e produção de disciplina social.

A Península Ibérica, que inventara com o Novo Mundo a Modernidade, ficara para trás por se haver atrasado no desenvolvimento técnico. Os intelectuais portugueses do XIX entendiam que tal empreendimento passava pelas fronteiras da escolarização universal e pelo desenvolvimento técnico e científico. O cultivo da inteligência traria por suposto a ponderação, o equilíbrio, a sensatez para a compreensão das dificuldades cotidianas. Acreditavam os partidários e 'amigos do estudo' que o conhecimento, além de capacitar para a destreza quanto ao enfrentamento de obstáculos do dia-a-dia, habilitaria o indivíduo para a felicidade familiar e para a virtude social. Por tal razão, o conhecimento é assinalado pela imprensa periódica corrente à época como obra civilizadora, imprescindível para o progresso nacional. Os jornalistas, ao reconhecerem a utilidade social da ciência, aventuram-se a determinar regras para o bom e eficaz aprendizado. Nessa medida, é comum encontrarmos, desde meados do século, reflexões intrigadas sobre problemas da Didática, de como melhor ensinar, dos procedimentos necessários para a obtenção do êxito. Uma das dicas desde logo assinaladas era a urgente necessidade de implantação do ensino paralelo da leitura e da escrita. O problema do método - como vimos - ocupará a meditação dos contemporâneos de maneira bastante acentuada naquele tempo, chegando nos anos 70 a ser entendido como chave da orientação pedagógica cientificamente refletida.

Inúmeras experiências educativas que pretendiam testar novos modelos e referenciais para o ensino das primeiras letras eram postas à prova por educadores que nem sempre passariam para a história. No princípio dos anos 50, A. Forjaz aplicara seu método ao Asilo da Infância de Coimbra, método feito, em parte, por uma nova ordenação do abecedário, com tábuas de palavras e frases que pretendiam - nas palavras do autor - estar em harmonia com a orientação do método ainda há pouco tempo desenvolvido por António Feliciano de Castilho. Dizia Forjaz na introdução

${ }^{157}$ Para o caso brasileiro, o trabalho de Marta Carvalho é exemplar sobre essa relação da escola com a cidade (CARVAlHO, Marta Maria Chagas de. A escola e a república. São Paulo: Brasiliense, 1989). 
de sua obra $O$ amigo dos meninos que, pelas manhãs, o Asilo seguia à risca todos os preceitos do Método Português; à tarde, porém - como parecia indispensável cuidar das classes mais adiantadas, trazendo-lhes elementos mais aprofundados de escrita, numeração, gramática, etc. -, os alunos menores ficariam sob o encargo de educadoras de infância cuja função era apenas recordar-lhes o que teriam aprendido no período da manhã. $\mathrm{O}$ abecedário escrito por Forjaz viria nessa direção, com o objetivo de tornar-se um roteiro alternativo, mais apropriado do que os tradicionais compêndios, todos eles considerados obsoletos relativamente aos procedimentos em voga nos demais países europeus. Resenha crítica, assinada por J. C. Harcourt - no periódico $A$ instrução e o povo - saudaria a publicação da obra de Forjaz, destacando a necessidade de publicações pedagógicas imbuídas de conhecimentos didáticos e metodológicos atualizados, em consonância com o próprio avanço da civilização, que, no caso português, se verificava ainda profundamente acanhado.

\begin{abstract}
"Mas deste abandono nascia igualmente a falta de homens que dedicassem a sua inteligência à confecção de livros próprios ao ensino. Entendia-se que escrever para crianças era uma missão pouco gloriosa e pouco digna de uma grande inteligência. Erro fatal, que condenava a instrução a nutrir-se de escritores raquíticos, magros de idéias, péssimos de forma, que, em vez de educar, carregavam a inteligência nada virgem de matérias áridas e pouco interessantes. A não ser o Manual enciclopédico, livro grande em volume, mas, para nós, incompleto e impróprio para escolas primárias, e que só pode dever a sua reputação à falta de outro, nenhum livro tinha ainda aparecido que preenchesse essa lacuna que nos países civilizados havia chamado a atenção dos homens iminentes. Um livro pueril e singelo julgava-se uma puerilidade e a instrução definhava-se lentamente pela influência destas e outras muitas causas, que a índole deste jornal nos obriga a calar. Felizmente, nestes últimos tempos tem-se cuidado deste ponto, o mais capital hoje para este país, e homens superiores se têm entregado a este tarefa verdadeiramente civilizadora. Entre esses homens que a história contemporânea deve apontar com cuidado, figura eminentemente o Sr. Dr. Adrião Forjaz. Professor distinto, ilustração conhecida na ciência econômica, espírito altamente pensador, e conhecendo as necessidades de sua época, não se esquivou a esta nobre missão de ilustrar o povo; o seu espírito, acostumado às meditaçôes profundas da ciência, não recuou perante os prejuízos, sacrificando a sua inteligência eminente às puerilidades de um livro de crianças. Além de muitas obras deste gênero, já conhecidas neste país, acaba de dotar a instrução primária com uma obra preciosa a todos os respeitos e digna de merecer uma séria atenção. É $O$ amigo dos meninos." 158
\end{abstract}

Em quê Forjaz pretendia inovar? Quais eram substantivamente os pontos que singularizavam sua obra? A introdução dirigida ao leitor já ensaiava tal explicação. $\mathrm{O}$ autor dizia pretender ensinar paralelamente as diferentes grafias das letras. Antes disso, sugeria que o reconhecimento do texto impresso deveria vir de modo concomitante ao reconhecimento da letra manuscrita (cujo aprendizado, na grande maioria das escolas da época, ainda antecedia o da letra de imprensa). Supunha-se ser recomendável que à criança fossem apresentados simultaneamente os diversos sinais

${ }^{158}$ J. C. HARCOURT, O amigo dos meninos, In: A instrução e o povo; jornal científico e literario da sociedade civilizadora, primeiro ano, 1855 , p. 48 . Como poderemos observar nos capítulos posteriores, a referência ao $M a-$ nual enciclopédico de Monteverde denotava a intensa utilização desse compêndio pelas escolas à época. 
tipográficos codificados para cada um dos símbolos gráficos. Mas, principalmente, defendia-se o ensino concomitante da leitura e da escrita. Acreditava-se que, ao proceder assim, as escolas teriam maior eficiência e agilidade no aprendizado das primeiras letras, a partir de novas orientações para a questão do método de ensino.

Em relato que, no ano de 1855 fazia a $O$ Instituto, o mesmo educador descreve a prática de ensino desenvolvida com os mesmos meninos do Asilo da Infância de Coimbra, que teria dado origem àquele compêndio partidário de se ensinar paralelamente a ler e a escrever. Forjaz pretendia ser um colaborador de Castilho, declarando-se defensor de uma jornada de ensino da leitura capaz de produzir grandes e significativos resultados. Para isso, entretanto, havia de se estruturar o método - organizado e pensado a partir de experiências bem-sucedidas de ensino, perante o pioneirismo que, sobretudo, Castilho teria trazido. Sobre os resultados da aplicação daquele modelo de ensino anteriormente descrito para o Asilo da Infância de Coimbra, Forjaz não tem qualquer dúvida. Era uma cruzada que deu certo e que poderia servir de exemplo para um novo modo de se proceder a prática do magistério.

Como assinalava o próprio Forjaz, no relato que propicia aos leitores sobre a experiência já efetuada com as crianças do asilo de Coimbra:

"No mesmo asilo, o ensino da leitura nos dois caracteres, redondo e manuscrito (ou letra
inglesa), e igualmente o da escrita e da numeração, principiam a um tempo; com o que ga-
nhamos em adiantamento e maior variedade de exercícios. Conhecidas as vogais nos caracteres
redondos, por que não se passar logo aos ingleses, ou vendo-os no livro, ou traçados na tábua
do professor? Por que não, por exemplo, lendo os alunos a palavra - a-i-a - nos primeiros, não
hão de fazê-lo igualmente nos segundos? Por que não se há de ir desde logo tentando a escrita
dos mesmos caracteres na tábua preta, sem contudo retardar a leitura à espera do aperfeiçoa-
mento que virá para o diante? (...) Satisfazendo ao desejo que nos tem sido comunicado algu-
mas vezes, damos finalmente um breve diretório da escola deste estabelecimento; no qual os
professores encontrarão informaçôes mais importantes acerca do plano total de suas liçôes"159

Tencionava-se, por assim dizer, que a escola fosse efetivamente desejada pela população. Sabia-se, no entanto, que isso só viria a ocorrer no momento em que os pais julgassem que a frequência à escola era realmente importante para a formação humana, coisa que ainda não acontecia em proporçôes significativas. A escola desejada é aquela que demonstra rápidos resultados. A escola desejada é também aquela capaz de fazer o que a família reconhece não saber. A escola socialmente desejada é, finalmente, aquela que, pelo trabalho que desempenha, capacita o ser humano para o dia de amanhã. Existiria essa escola em Portugal? Tornava-se moda dissertar, acerca do ensino, sobre questões metodológicas. Eram incansavelmente

${ }^{159}$ A apresentação ao leitor continua, com as seguintes palavras: "os primeiros exercícios de leitura dizem de si. São fórmulas doutrinais, contendo a santa e pura moral do Evangelho; pequenas e delicadas historietas, extraidas de alguns ótimos escritores estrangeiros; e o excelente pequeno catecismo desta Diocese, adotado igualmente nas de Viseu, Lamego, Bragança, e outras; estudo em variados caracteres. O abecedário da numeração, no qual também se contém as primeiras noçôes do sistema métrico das novas medidas, compreende igualmente o resumo das liçôes, que desde muito tempo se dão no asilo com bom resultado (A. FORJAZ, O amigo dos meninos; introdução compreendendo um abecdário de leitura e numeração e uns primeiros exercícios de leitura e nestes o pequeno catecismo de doutrina cristã da diocese de Coimbra em caracteres variados para uso especialmente do Asilo da Infância de Coimbra, p. 4-6)." 
propostas técnicas e recursos cuja aplicação traria a eficácia almejada. A partir dos anos 50, uma orientação de cunho didático - como já pudemos observar nos capítulos antecedentes - passaria a tomar conta dos debates educativos das revistas e jornais especializados. Era como se, no método, estivesse contido todo o segredo e a alquimia da matéria educativa. Só quando se aperfeiçoasse o método, a importância da escola viria a se fazer sentir.

Já se esboçava, na época, uma preocupação com a direção analítica do ensino da leitura, posto que, cada vez mais, o desdobramento da palavra parecia a receita mais eficaz para o pleno e ágil aprendizado; até porque é a palavra e não a sílaba quem representa verdadeiramente a unidade de sentido. No entanto, ao contrário do que preconizaria posteriormente João de Deus, para esses pedagogos dos anos 50 , não se toma a palavra como ponto de partida; há apenas o desdobramento e o reconhecimento dos sons das partes de uma palavra que o aprendiz não é ainda capaz de ler, dado que a leitura deveria vir por partes...

Procuram-se resultados práticos e isso requeria a explicitação do método de ensino preconizado. Nenhum passo deveria ser deixado de fora dessas prescrições metodológicas, sob o risco de comprometer todo o projeto. O conhecimento deveria vir de maneira fácil, quase trivial, amena, sutil, garantindo ao máximo a aplicação das faculdades de observação e as idéias concretas do aluno. Para tanto, porém, a lição deveria ser sempre acompanhada do exercício. O professor escreveria no quadro negro toda a palavra que o aluno já houvesse anteriormente decomposto e reduzido aos respectivos sons elementares. Assim o professor chamaria a atenção de toda a classe para a correspondência entre aquele sinal gráfico e os sons naturais que simbolizavam cada um de seus elementos fônicos. Depois, o mestre escreveria embaixo da palavra a primeira sílaba que a formava, solicitando que os alunos o imitassem com suas respectivas lousinhas.

Após ser copiada pelo aluno, cada uma das sílabas deveria ser falada pela classe, que então teria sua primeira oportunidade de leitura. O professor faria perguntas aos discípulos, que deveriam repetir cada uma das sílabas separadamente, para depois reencontrar o valor de todas elas unidas. Enfatizar-se-ia, em todo o processo, a voz e a articulação das palavras e das sílabas. $\mathrm{Na}$ verdade, com tudo isso, fica muito nítida a busca de construção de um modelo novo de escola, estruturado por meio de uma lógica de sinais e de rituais. A escola como instituição social teria seu êxito assegurado quanto melhor firmados os alicerces dos ritos organizadores do cotidiano institucional. Aos olhos da época, não se teria dúvida sobre isso. Outrossim, o bom aprendizado exigia a concentração de esforços em um percurso que tomasse significado aos olhos do estudante; e isso só poderia ocorrer se o aprendizado da escrita viesse concomitante ao da leitura. Conduzir o aprendiz a imitar os sinais gráficos era maximizar os esforços de concentração e de atenção despendidos durante a aula. Começar-se-ia pelo recurso à imitação, tido por fundamental para esse primeiro aprendizado dos passos iniciais da leitura. Supunha-se que o ensino paralelo possibilitaria uma maior fixação do aluno na atividade do ler, dado que o exercício da escrita fixaria seu interesse, concentraria sua atenção e consequentemente, permitiria um aprendizado mais eficaz.

Mendonça (1856) - em orientações redigidas para $O$ Instituto acerca dessa problemática do ensino paralelo da escrita e da leitura - apresentava como requisitos para o ensino bem sucedido o seguinte: 1) principiar o processo pela letra de mão, até que 
houvesse leitura corrente; 2) Começar pela decomposição das sílabas; 3) Só depois do reconhecimento de todas as sílabas, o aluno tomaria conhecimento do alfabeto manuscrito; 4) Quando enfim soubesse escrever bem o que lhe fosse ditado, lendo com desembaraço tudo o que, em letra de mão, lhe fosse apresentado, o educando deveria estudar o abecedário da letra impressa, confrontando o valor dos caracteres com aqueles que já conhecia; 5) "uma vez familiarizado com o abecedário da letra redonda, meta-se-lhe então na mão o primeiro livro impresso, e por ele se exercite na leitura, já lendo, já copiando da letra redonda para a manuscrita, já imitando a letra redonda. Só deste ponto em diante é que devem separar-se, e ser para ele como distintas, individualidades à parte, as disciplinas de ler e escrever." ${ }^{160}$

O século XIX português seria marcado pela procura do método pelos pedagogos e curiosamente pela ausência de ressonância de tal debate nas práticas rotineiras de sala de aula. Havia algum diálogo entre as inquietações dos políticos, intelectuais e estudiosos de Pedagogia e os mestres de ofício que lidavam com a confecção da escola todos os dias. A correspondência, contudo, não é certamente aquela que esperavam os arautos da Pedagogia das revistas e dos jornais. Seja como for, do meio para o fim do século, multiplicam-se as orientações de cunho técnico-pedagógico, que passariam, cada vez mais, a tomar o lugar do debate sobre a extensão ou não da escolarização pública. Desejava-se escola para todos; mas reivindicava-se a possibilidade de indagar e de arbitrar sobre os conteúdos e sobre os métodos dessa escola; sobre o que ela dizia e sobre o que ensinava: acerca do homem; a propósito do mundo; sobre as medidas decimais e sobre o sistema político... Desejava-se criar, cada vez mais ardorosamente, uma nova cosmovisão, capaz de engendrar o homem de amanhã. Este, paradoxalmente, deveria ser o digno representante dos valores de um Portugal do passado. Assim julgavam os que acreditavam nos caminhos da instituição escolar; instituição do Estado e para o Estado, mas que deveria estar a todo o instante em estreitas relações com o ambiente doméstico e comunitário de quem dependia e a quem, em última instância, iria servir.

De todo modo, passava-se a entender o problema da escolarização, cada vez mais, perante a chave valorativa da leitura. O final do século presencia, como vimos, a intensificação do debate sobre o tema da metodologia prescrita e recomendada para o processo de ensino-aprendizado da leitura e da escrita. Passa-se a compreender que a questão da leitura conformava antes uma habilidade proveniente do desejo do que uma árida atividade cognitiva. A leitura mais fácil é a da fruição; portanto, ensinar pelo e para o prazer poderia significar a recorrência a um novo modelo metodológico e didático, mais preciso, mais ágil, mais eficaz. O aprendizado também - supunha-se - fruiria com maior espontaneidade. Não era sem algum grau de inquietação que os contemporâneos avaliavam esse problema técnico e ideológico da leitura. Um problema que se confrontava com as orientações da moral vigente: de uma sociedade estamental, pautada pela correspondência entre as desigualdades de fortunas e as distinções de sangue; uma sociedade patriarcal, onde a religião e a família eram autoridades constritivas e inibidoras do novo; uma sociedade que não parecia, por fim, ter

${ }^{160}$ M. R. de MENDONÇA, Methodo do ensino paralelo da escripta e da leitura, In: O Instituto, vol.IV, $\mathrm{n} \circ 22$, p. 270 . 
vontade de se transformar. Mesmo assim, visualiza-se, a conviver com o modelo antigo e arcaico, um inaudito retrato sobre o aprendizado da leitura, pontuado também pela esfera da brincadeira e da distração, como estratégias a serem mobilizadas no ato de ensinar. Aprender a ler era, acima de tudo, desejar decifrar a imagem da palavra; decifrar a história, decifrar o mundo da cultura...

O Jornal da infância nos anos 80 recordava os leitores da emoção sentida por todos, quando pela primeira vez somos capazes de decifrar o mundo por escrito... Conclamava-se, nessa direção, pais e mães a incentivarem o gosto e a propensão da infância para a leitura como uma distração instrutiva. A escola prestaria o serviço de facultar a compreensão de uma técnica; técnica transposta por suposto para uma leitura mais arguta do mundo. Surgiam, com freqüência, no último quartel do século XIX, jornais e revistas destinados às próprias crianças e jovens. Cabia a esses periódicos a função de pedagogos. No Jornal da infância alguns artigos dirigidos às crianças tinham por narradores supostos alunos de instrução primária. O periódico apresentava a habilidade da leitura como a principal missão da instrução primária. Aproximando a criança de códigos comuns ao que se acreditava ser o mundo civilizado, escola e leitura deveriam fazer do estudo um substituto da rua. Ir à escola era sair da rua, afastar-se das más influências, precaver-se contra as tentaçôes da marginalidade. Colocar as crianças na escola, na proporção do país, era também impedir os abusos do trabalho infantil; e, nem que fosse só por isso, a escola passa a ser o salutar contraponto dos abusos da vida produtiva e da vida familiar.

A escolarização era tida por processo corretor de desvios de outras instâncias corroídas do tecido social. A institucionalização da educação escolar deveria, sob tal perspectiva, compreender a adoção de mecanismos de controle do uso que as famílias faziam de seus filhos, particularmente para abusar do trabalho das crianças. Na verdade, talvez subrepticiamente, insinuava-se acreditar que a atividade escolar poderia concorrer e assim relativizar, no contexto da sociedade, a primazia e o poder da agremiação familiar. Acontece que a criança idealizada pelo universo das revistas não era propriamente a criança real; e, sobretudo, faltava ao professor, mesmo àquele recém-formado em Escola Normal, os métodos, as técnicas, os instrumentos necessários para possibilitar o enfrentamento de uma realidade de analfabetismo e de descaso familiar pela escola, muito mais acentuada do que à época assinalavam os poucos e precários manuais de Pedagogia. Quando o então recém-formado mestre se via em meio a uma turma de rapazes analfabetos de escola rural, munido que estaria apenas dos parcos conhecimentos e do rol de definiçóes que sua instrução lhe haveria legado, o que fazia esse jovem docente? Em que medida sua formação lhe seria útil? Como ele equacionaria o contingente enorme de carência das crianças que lhe eram confiadas?

Havia nas últimas décadas do século XIX português - segundo dados levantados por António Nóvoa - Escolas de Habilitação para o Magistério Primário que, no ano letivo de 1896-7, eram 45 e em 1899-1900 seriam já 191. No ano seguinte (1900-1), elas passariam a ser 240 e, em 1902-3, havia 343 escolas que preparavam o que deveria ser o conjunto do professorado primário em Portugal. No parecer de Nóvoa, a segunda metade do século XIX foi um período fundamental no que concerne ao processo de construção da profissionalização do corpo de professores. As representações simbólicas sobre o mestre-escola do Antigo Regime - as quais, de alguma forma, 
persistiam ainda - concorreriam cada vez mais com o novo perfil a ser assumido pelos profissionais da educação, que, a partir de então, seriam dotados de uma nova consciência e de um repertório profissional cada vez mais tributário de sua formação específica, além de um reconhecimento que vinha se intensificando acerca da identidade própria do magistério enquanto categoria de trabalho. Tudo isso tornaria mais próximo do modelo científico o professor do novo tempo que vinha se afigurando: "o professor de instrução primária da era científica tomaria definitivamente o lugar do antigo mestre-escola. Essa evolução é fruto de uma ideologia do progresso e de uma fé nas potencialidades da escola, da qual as significações socio-políticas serão doravante claramente depreendidas" ${ }^{161}$.

Como atesta Nóvoa, o final do século XIX pode ser compreendido como o período de profissionalização do magistério, particularmente pela ação empreendida pela proliferação das Escolas de Habilitação do Magistério e pelas cinco Escolas Normais existentes em Portugal no mesmo período (Marvila, Angra, Calvário, Lisboa, Porto, Évora). A respeito da correlação entre a formação do professor e os saberes com que era estruturado o novo repertório da profissão, Nóvoa dirá o seguinte: "durante o século XIX a formação dos professores repousa essencialmente, não sobre a aquisição de um corpo de saberes e de saber-fazer, mas sobre a aprendizagem de um saber ensinar conhecimentos adquiridos antes de entrar nas escolas normais." ${ }^{162}$. É fato que, desde o início do último quartel do século XIX, particularmente a partir dos anos 70, acentua-se interesse da literatura pedagógica produzida em Portugal relativamente à busca de demarcações das fronteiras desejáveis para se estruturar o bom método de ensino. Supunha-se que o país não se desenvolvia por não ter sido capaz de fazer frente aos progressos tecnológicos constatados em outros países, tributários esses do aperfeiçoamento técnico, científico e educacional. A pretensão de realinhar Portugal à Europa passava pelo investimento na escola primária e pela erradicação do analfabetismo. Ocorre que, organizadas como estavam, as escolas primárias portuguesas não obtinham êxito. Mal estruturadas fisicamente, mal equipadas em seu mobiliário, as escolas eram casas frias e pouco atraentes, pela monotonia de seu ofício. Na maioria das vezes sem saber como agir, os professores eram orientados pela prescrição dos compêndios que, por sua vez, eram também pouco apropriados. A base daquele ensino seria, pois, o medo e o recurso à memória. Não havia nada que estimulasse, portanto, pais e alunos à valorização desse modelo escolar.

Os últimos anos do século contariam com a publicação de inúmeras brochuras sobre o temário pedagógico. Era como se os teóricos e particularmente os editores desejassem socializar a ciência da educação, dirigindo-se, para tanto, aos pais, às famílias e, em especial, aos professores e técnicos do ensino primário. Apresentavam-se princípios, métodos, e técnicas de ensino intuitivo como prescrição daquilo que os novos

${ }^{161}$ Continua o argumento de Nóvoa: "o nascimento do professor de instrução primária se faz em interação com a organização e difusão da escola popular e com o desenvolvimento dos grandes sistemas educativos escolares, tal qual nós ainda em nossos dias os conhecemos. A gênese do sistema de ensino de Estado e da profissäo de professor remonta ao fim do século XVIII, mas é somente no final do século XIX que a escola e o professor de instrução primária adquirem as caracteristicas que permanecem sendo as suas atualmente." (António NÓVOA, Le temps des professeurs, volume 1, p. 420).

162 "De acordo com os autores da época, é aí que reside a especificidade da ciência da educação e, portanto, da formação dos professores” (António NÓVOA, Le temps des professeurs, volume 1, p. 424-5). 
tempos pareciam exigir. Recomendava-se que os educadores, de modo geral, adotassem, em sua lide cotidiana, aquilo que a investigação científica atestara ser infalível. Conviria trazer para Portugal o fruto de pesquisas e investigações científicas que, em vários países, mostraram que a Pedagogia se tornara já uma ciência regulatória dos métodos e das técnicas para a viabilização da eficácia do processo da aprendizagem. Havia de se dotar os educadores familiares e escolares de um conjunto articulado e classificado de orientaçôes normativas para que a atividade docente pudesse ocorrer perante a aplicação cientificamente calculada de tais requisitos do que se supunha ser o ensino exitoso.

O problema do método e das técnicas pedagógicas conquistava, naquele final de século, seu espaço; e a partir daqui a Pedagogia portuguesa reivindicaria seu papel de ciência da educação. A Pedagogia cada vez mais ia, desse modo, se firmando como um conjunto sistemático de técnicas, métodos, saberes, conteúdos, valores e, sobretudo, linguagem, repertório. A educação passaria, cada vez com maior intensidade, a ser dita por uma língua muito particular, só sua. O vocabulário da Pedagogia - bem como provavelmente o das outras disciplinas constituídas naquele final do século XIX - procurava assumir coloração de ciência, estruturando-se, frente a outros discursos, pela distinção. Não era mais qualquer um que, desde então, estaria autorizado a falar o discurso da educação ${ }^{163}$. Nessa perspectiva, do final do século em diante, passa a haver uma profusão prescritiva de normas e regras para orientação do bom aprendizado. Entendia-se - como explicita António Nóvoa - que o firmamento de uma ciência da educação significava tomada de consciência perante valores, adesão a princípios, conhecimento de modos de ensinar e identificação dos conteúdos ensinados. A pedagogia se constituía, então, como um corpo de saberes específico, que compreendia em si mesmo um saber-fazer e um referencial valorativo que lhe seria próprio. Ser bom professor teria por requisito conhecer a didática e o conteúdo das disciplinas ensinadas. A mudança era - sob tal dimensão teórica anunciada. Ocorre que, nas atitudes e atividades rotineiras da sala de aula, lá onde ninguém entra, tudo parecia estar na mesma... A Revista das escolas (1895) anotaria, a esse respeito, o seguinte:

"A escola primária tem lá a sua geringonça ou jargão, mas que todos entendem, porque todos mais ou menos passaram por ali. Assim, dar lição é um ato mais do discípulo do que do mestre, quando parecia mais lógico ser o mestre quem desse e o discípulo quem tomasse ou recebesse as lições. Pois não, senhor; apesar do velho aforismo: 'ninguém dá o que não tem', é o discípulo quem dá e o mestre quem toma."164

Ocorre que as leituras que já se faziam à época sobre as articulações entre o desenvolvimento intelectual e físico não permitiam mais que a memória - e ela só continuasse a ser tida como a grande válvula da aprendizagem. Efetivamente, a entrada dos autores positivistas no cenário internacional, além da intensificação do intercâmbio

${ }^{163}$ Marilena CHAUÍ. Ideologia e Educação. Educação e Sociedade. Cortez Editora/Autores Associados/Cedes. Ano II. n5. Janeiro 1980. p.24.

${ }^{164}$ Luiz Filippe LEITE, Excertos d'um livro inédito, In: Revistas das escolas; publicação periodica quinzenal, anno $1, \mathrm{n}^{\circ} 4,1-3-1895$, p. 51. 
de obras acadêmicas no interior da comunidade européia - e a Geração de 70 tivera nesse processo um papel primordial - fez com que outros teóricos da educação também fossem lidos. Passara-se a conviver com Herbart, com Pestalozzi, com Spencer; e os pedagogos do final do século tiveram, também em Portugal, suas idéias irradiadas por veículos jornalísticos que, agora, eram dirigidos primordialmente para a figura do professor. Reconhecia-se no magistério resistência à mudança. Não bastava mudar as leis. Era necessário alterar mentalidades e atitudes dos professores. Intrigava aos intelectuais da educação o porquê de as crianças, tendo frequentado a escola primária, não serem aprovadas nos exames finais e nos exames dos liceus. Julgava-se que a razão para isso era o uso excessivo da memória nos procedimentos escolares, a ausência de formação dos professores e a carência de uma sólida rede de inspeção capaz de orientar os profissionais do magistério acerca dos métodos mais apropriados e de novas estratégias para se dar aula. Quando se abria uma escola - reconhecia-se - havia um ato político de inauguração, para o qual eram convidadas as pessoas mais importantes da localidade. Era um cenário com flores, discursos de exaltação. Enfim, as festas de abertura de escola, bem como seus aniversários comemorativos, costumavam encher de vida aquele território: ocorre que era uma vida artificial, incapaz de ser reproduzida no dia-a-dia, vazia de significado pedagógico; uma vida apenas de aparência.

A revista intitulada $O$ Ensino - que possuía, durante os anos oitenta, uma tiragem bastante considerável - buscava em seus artigos explicitar o que supunha ser o lugar da Pedagogia: um campo de estudos científico, centralizado pela disciplina Didática. Esta, por sua vez, era caracterizada como ciência que expõe as 'leis' da educação. A Didática seria complementada pela Metodologia do Ensino, a qual, por sua vez, era apresentada como arte que deverá "dirigir o ensino em conformidade com aquelas leis" ${ }^{165}$. Ora, o estado então vigente da civilização não admitiria mais que a missão do professor se reduzisse a obrigar a criança a decorar um conjunto de palavras extraído dos compêndios; e, como já pudemos observar, eles destacavam isso. A idéia de ensinar a ler pelo exercício da repetição monótona, entediante e improfícua daquilo que prescrevia o discurso do compêndio não poderia mais, face aos avanços da discussão da Pedagogia, continuar a ser adotada. Diante disso, a acepção do ensino intuitivo ganhava corpo como suposição básica de um referencial pedagógico que pretendia ser acima de tudo científico. A educação era encarada como ciência de cariz objetivo, de cujas regras poderiam ser desmembradas as orientaçôes para a sociedade do futuro. Compreender o processo de ensino como um caminho que passava antes pela intuição do que pela razão exigiria mudança nos processos utilizados para ensinar. Valorizava-se a faculdade da imaginação, como componente criativo imprescindível ao desenvolvimento infantil. Os estágios do desenvolvimento humano e a dinâmica do aprendizado que predominaria em cada um deles tornavam-se objeto da curiosidade intelectual da época. A leitura, por exemplo, era interpretada como veículo portador de inúmeros e inusitados significados, através dos quais - sabia-se - uma nova interpretação da realidade deveria advir. Tal constatação exigia que toda a leitura fosse explicada. Essa prática, por seu turno, embora não podendo ser qualificada como inovadora, estaria, muitas vezes, ausente das salas de aula, onde professores deixavam os livros falarem

${ }^{165}$ O ENSINO; revista de instrucção primária, 1º anno, 2a série, , volume I, no 7, 31-7-1885, p. 111. 
sozinhos - ou seja: contentavam-se com a cópia e com a reprodução dos termos do compêndio. Procurava-se, na contramão, firmar os alicerces de uma pedagogia da aula oralizada, centrada na palavra, na explicação e na narrativa do professor. Isso daria novo ritmo à escola. Mas nada poderia ser em excesso.

\begin{abstract}
"Em todo o caso, quer num ou noutro dos sistemas, é preciso sabermo-nos moderar. Não há muito ainda que ouvimos certo professor falar sobre a leitura longo tempo, e explicá-la ainda por cima. Querendo tirar da leitura tudo o que ela pode dar (e já notamos que pode dar muito e muito) sob o ponto de vista da educação moral e intelectual e em proveito desses ensinamentos, tanto fez que, dada a hora de passar a outro ponto, ainda os seus alunos não tinham lido nada. Isto é: ao princípio haviam eles escutado com interesse e respondido com vontade; depois foi-se-lhes esmorecendo a atenção, foi-se-lhes apagando o ardor e as atitudes bem demonstravam a fadiga e o aborrecimento. Aquele nosso caro colega abusa da explicação da leitura; desnatura o exercício; esquece que as crianças, sobretudo as das classes baixas, devem ler por ler e não para aprenderem moral, gramática, etc., a não ser incidentalmente e como por ocasião."166
\end{abstract}

Faltava, nos termos do redator, a prudência da aula expositiva centrada sobre o que havia de essencial em cada lição. Faltava, sobretudo, a distribuição do tempo, dos horários, na composição harmoniosa de uma grade curricular regrada, ritualizada, sistematizada.

Quando se discutia a pertinência ou não da escolarização primária, colocava-se nitidamente como alternativa a idéia de ensino doméstico ministrado por preceptor; e existia claramente quem fosse favorável a isso. Quando, naquela fronteira entre o século XIX e o XX, os jornalistas frisavam a ausência de interesse das famílias pelo tema da escolarização, era também às famílias ricas que eles se referiam, dado que, se no caso dos ambientes pobres havia recorrência ao trabalho infantil, as famílias abastadas muitas vezes optavam por valer-se de preceptores particulares, em grande parte das vezes, estrangeiros. Construir a escola de massas significava ultrapassar ambos os obstáculos: o do trabalho infantil e o da relutância das elites pela cultura do coletivo escolar. Aliás, o próprio desenvolvimento da agricultura no âmbito da técnica agrícola deveria contar com o aprimoramento da escola. Os jornais e revistas destinados ao debate pedagógico naquela época trabalhavam o problema, como vimos, imputando ao descaso dos familiares a falência daquele específico modelo de escola, incapaz de atrair crianças e famílias.

\title{
A distração, a criança anormal e o desenvolvimento infantil
}

A Pedagogia era constituída, no discurso, como um desdobramento ou mesmo uma aplicação científica das conquistas da Psicologia. Os temas recorrentes nas revistas pedagógicas do final de século XIX discutiam as bases psicológicas e, por vezes, biológicas do comportamento infantil. A criança era caracterizada pela inconstância, pela curiosidade e pela indisciplina, em contraste sempre com o universo da civilização. Haveria nela naturalmente um enorme desejo de conhecer tudo aquilo de que os adultos insistiam em

${ }^{166}$ LEITURA, In: Educação Nacional, 7 o anno, no 41, 7-12-1902, p. 173. 
deixá-la apartada. Nessa primordial apropriação do universo e particularmente do território da cultura, os órgãos dos sentidos, particularmente o tato, seriam os instrumentos principais. A criança era compreendida como um 'outro', balizada pela referência a um 'nós' anteriormente delimitado na identidade adulta. Tanto pela diferença quanto mesmo pela estranheza, apreende-se como essencial na composição infantil sua especificidade, que, em última instância, era exatamente sua incompletude, ou aquilo que lhe faltava para se tornar partícipe do universo adulto. Apresentada como um natural explorador dos mistérios que lhe eram antepostos, a criança organizaria uma particular leitura de mundo, apreendendo as contradições que a organização social lhe colocava, o que se evidencia em sua avidez por desvendar os "porquês" das coisas. A infância, ávida pela novidade, era, pois, ela mesma a representação do novo..

Os articulistas, frequentemente, atentavam para as conseqüências perigosas da distração e da imaginação infantis. Acreditava-se, aliás, que, muitas vezes, as crianças não aprendiam na escola porque ali se distraíam. E a escola não se mostrava capaz de prender atenção dessas crianças que nela se distraíam.

Alguns alunos empolgavam-se com extrema facilidade; mas se empolgavam pelos jogos, pelas brincadeiras, por quaisquer diversōes; jamais, porém, pelo estudo... Tentando-se nitidamente, com tal esforço classificatório, compreender o que de fato se passava no espírito de tais crianças e adolescentes, em momento algum se confessa a incapacidade da escola de prender a atenção. A ausência de atrativos do espaço escolar viria apenas sugerida pelo laconismo da interpretação...

\footnotetext{
"Vejamos agora o aluno que o jogo empolga. Quantas vezes o espírito se ausenta da aula! Pensa no que há de fazer durante o recreio, no divertimento para que convidará os colegas. Amanhã é dia feriado! Ao pensar nisso, o rosto do nosso estudante ilumina-se de felicidade, e esta alegria antecipada manifesta-se algumas vezes duma maneira intempestiva no meio do silêncio que reina na escola. Esquece que está no banco da classe, e vivamente, ao ouvido do vizinho, insinua a idéia luminosa que acabou de lhe penetrar no espírito. É mister que uma palavra severa do professor o chame à realidade; começa a trabalhar, muito perturbado com o acidente. Esta classe de crianças tem uma imaginação cujos rasgos os levam a praticar o que a boa disciplina lhes proíbe."167
}

Entendia-se que educar era, entre outras coisas, disciplinar o espírito. Ora, os contemporâneos sabiam que justamente por isso a distração no princípio do processo do aprendizado deveria estar pressuposta. Havia de se efetuar um esforço de mobilizar ao máximo a faculdade de imaginação, cujos resultados agiriam no sentido de capturar o interesse e a vivacidade infantis para o acompanhamento dos assuntos da aula. Para tal finalidade, parecia fundamental raptar do jogo o que ele teria de encanto e impulsionar o aluno a viver na aula a sua intuição, a sua fala, a sua compreensão de mundo. Era necessário chamar o aluno, conclamar sua palavra, valorizar suas intervençóes. Era urgente que a forma da aula pudesse ser transmutada, para que esta deixasse então de ser o entediante monólogo e viesse, com criatividade e com graça, a se constituir em diálogo entre professores e alunos; diálogo este mediado pela direção das duas partes rumo à relação com o conhecimento. Não era, pois, o castigo quem remediaria

${ }^{167}$ DISTRAÇÃO da criança, In: Educação Nacional, 16-4-1899, nº 134. 
o problema da distração na escola. A instrução era percebida como aquisição de uma dada linguagem; e, para que fosse eficaz esse processo de configuração lingüística, o aluno deveria também ser capaz de compreender o que dizia o professor. Instruir não significava, portanto, exibir com vigor qualquer particular "talento oratório" ${ }^{168}$. Instruir significava trazer elementos para que a criança se aproximasse também em sua fala do mundo das letras e da cultura letrada.

Nessa exortação ao potencial da Pedagogia, eram proclamadas estratégias para ativar o interesse infantil. Lutar contra a distração escolar supunha o entrelaçamento do movimento físico e do movimento intelectual, já que ambos são igualmente necessários - supõem-se e chamam-se um ao outro. Pela mesma razão, parecia imperioso renovar a escola, com o propósito de que o ensino deixasse de se calcar apenas em abstrações para recorrer às coisas concretas; em consonância com as etapas do raciocínio infantil. Não se entendia, aliás, como a criança pensa; mas sabia-se - os clássicos da Pedagogia já haviam observado esse ponto - que o raciocínio infantil era pautado pela compreensão do mundo sensível, antes de abstrair a realidade.

O final do século XIX presenciaria, em termos da investigação teórica, a consagração das questões pedagógicas. Reputava-se a um determinismo biológico e cultural as diferenças entre as pessoas, tomando cada um pela particularidade de seu feitio, sua personalidade, suas especificidades decorrentes, em última instância, do gênero, da cor e da raça. Assim como se supunha que o meio determinava a conduta, acreditava-se na superioridade biológica de uns sobre outros, o que acarretaria, por si, efeitos tidos por naturais no âmbito do próprio comportamento humano. Ora, educar era, destarte, intervir nessa trajetória.

Artigo de Ferreira-Deusdado escrito para a Revista de Educação e Ensino, em 1897, sob o título "A sugestão hipnótica na educação", defendia a prática da hipnose aplicada ao ensino, desde que esta fosse dirigida para eliminar más inclinaçôes. Sob a referência teórica emprestada da doutrina de Comte, o autor discorria naquela oportunidade sobre as interfaces entre os caracteres congênitos e os que são produto dos hábitos. Ora, sendo que o ensino pode ser também considerado uma sugestão, sua estrutura - no parecer de Ferreira-Deusdado - poderia ser assim definida: "ato pelo qual uma idéia ou um sentimento é insinuado ou imposto ao espírito e aceite por ele sem deliberação prévia." ${ }^{69}$ Acreditava-se que, mesmo antes de compreender os porquês, a criança poderia e deveria ser induzida a agir.

A capacidade de adaptação do indivíduo ou da espécie é qualificada pelo autor como "alicerce de educabilidade". Ferreira-Deusdado entendia que à predominância do instinto se oporia o hábito, o qual, por sua vez, capacitava as aptidóes do entendimento. A moralidade teria, portanto, alguma coisa a ver com a conformação dos costumes, pela criação de hábitos postos como dever imperativo da coletividade social. O hábito tornar-se-ia segunda natureza do gênero humano, influindo, assim, nas determinações da herança genética. Acoplado a tal idéia vem evidentemente o desejo de normalização, de produção de uma suposta regularidade que ordenaria, não apenas

${ }^{168}$ DISTRAÇÃO da criança, In: Educação Nacional, 16-4-1899, nº 134.

${ }^{169}$ FERREIRA-DEUSDADO, A sugestão hipnótica na educação, In: Revista de Educação e Ensino, volume XII, 1897, p. 485. 
a compreensão, mas principalmente o controle da infância por parte dos adultos. Essa construção discursiva calcada no apelo a padrōes de comportamento unânimes discorria também, como não poderia deixar de ser, sobre a essência da normalidade; e, como decorrência da mesma preocupação, teorizava sobre a acepção da subentendida criança anormal. A idéia de anormalidade era bastante cara aos estudos que se debruçavam sobre o problema pedagógico à luz das determinaçôes étnicas e das limitaçôes provenientes da hereditariedade. A pedagogia - que, cada vez com maior intensidade, pretendia encarar a si própria como matéria indiscutível da ciência - dissertava com muita frequência sobre o tema da anormalidade. Revistas e jornais especializados - particularmente no período compreendido entre 1890 e 1910 - destacavam as características instrínsecas à criança anormal. A anormalidade era percebida, nesses escritos, invariavelmente como um prejuízo de origem hereditária - que poderia, entretanto, pelo efeito da educação, ser amortecido.

Texto de José de Vasconcelos publicado no periódico O Ensino do dia 28/5/1910 destacava o anormal como um ser destituído de certas referências intelectuais e morais impressas no padrão médio da "humanidade civilizada". Classificado como idiota, como imbecil, ou como débil, em função do grau de sua anomalia, o anormal era tido, já em princípio, como um ser atípico, devendo a sociedade encetar esforços no sentido de regenerá-lo. $\mathrm{Na}$ verdade, supunha-se que o anormal seria dependente do meio, encontrando-se com maior frequência entre os ambientes das camadas populares, a partir dos quais eles se dirigiriam para o mundo do crime. Haveria de se envidar esforços com o fito de afastar o jovem de seu meio original corruptor, contrabalançando pela educação o pernicioso efeito daquilo que se entendia ser a hereditariedade.

Mas o pensamento sobre a anormalidade apenas ilustra a preocupação de um tempo que encara o desenvolvimento cognitivo do ser humano como se ele fosse regrado por leis que, enquanto tal, poderiam ser desvendadas, apreendidas, e até controladas. Não se compreende a criança no modo pelo qual ela se desenvolve; na maneira como ela expressa emoções; na desenvoltura pela qual ela se apercebe do mundo que circula ao seu redor; na espontaneidade com que ela manifesta seus desejos e suas contrariedades. Julgava-se que nada se entendia da criança; mas supunha-se que, ao observá-la, o estudioso estaria no caminho para ajuizá-la e ajustá-la. Descobrir as leis que regulariam o desenvolvimento humano requereria controlar etapas, regrar o tempo, dominar a história.

$\mathrm{Na}$ mesma época era publicado no jornal republicano A Federação Escolar (com data de 16/7/1910), em sua Seção Pedagógica, artigo assinado pela professora Alzira Cardoso, intitulado Crianças Anormais, onde eram expostas as diferentes "patologias" da mente infantil, contrapondo-as explicitamente àquilo que se considerava "estado são e normal". Supunha-se que o educador deveria ser atento para a tipologia abaixo explicitada:

1) No caso da criança triste, parte-se, desde o princípio, do patamar comparativo em relação a seus colegas 'alegres', corados, risonhos, integrados em jogos e com o coraçãa a bater mais depressa. A condição de criança triste, entretanto, não era circunstancial, mas orgânica, devendo ser tratada assim como uma patologia. A criança alegre - seu mais nítido contrário - toma parte das aulas, demonstra interesse, vivacidade e rapidez de raciocínio. 
"Na aula, interessa-se pelas explicações do professor, pelas respostas dos condiscípulos, gosta delas e nelas toma parte. É às vezes turbulenta e distraída, mas é cheia de valentia e entusiasmo. É franca e confia nos outros. A criança triste tem o olhar morno, o rosto descorado; as trepidações do seu coração são lentas; receia os movimento e os jogos, não é sociável, procura o isolamento. Não se ri, não grita. $\mathrm{Na}$ aula está tranquila, mas não se interessa pelo que vê nem pelo que ouve. Está constrangida. O seu pensamento está visivelmente afastado. A menor censura tanto a pode deixar indiferente como magoá-la. É reservada, desconfiada e às vezes sonsa." ${ }^{170}$

Acredita-se que uma disfunção biológica acarretaria esse sofrimento crônico da criança. Sendo assim, por conseguinte, supõe-se que o sofrimento moral teria sua origem radicada no mau funcionamento da estrutura orgânica da criança. Havendo diminuição do "tônus vital", dar-se-ia a depressão, geradora da tristeza. Além dos fatores físicos, a tristeza teria também, entretanto, causas morais, que potencializariam a dor transformando-a em fonte de permanente infelicidade. A inação física e intelectual, bem como a fraqueza da imaginação e o isolamento, produziriam o contínuo aborrecimento e a alteração nos padrões do humor... Vê-se nitidamente o avanço quanto à sinalização do peso da biologia na determinação do comportamento humano, tendência esta que seria, décadas depois, substituída por um vetor que preferiria encontrar na psicologia, e não mais na fisiologia, a origem dos traços crônicos das emoções de tristeza. A idéia da variável orgânica da depressão ganharia, como podemos constatar, novo impulso revigorante neste final de século XX. Mas, ainda naquele princípio, visualizava-se, a título de alerta:

"São, enfim, crianças francamente doentes e que, possuídas duma tara hereditária, não pensam senão em morrer. MALES: É suficiente descrever a criança triste e apontar as causas deste estado mórbido para ver imediatamente todos os males. A tristeza reage sobre o organismo e agrava o estado doentio donde ela deriva. Torna a criança inapta para todo o progresso físico, mental ou moral. Não vive, vegeta, arrasta-se. É um incômodo para os seus camaradas, um deplorável exemplo. REMÉDIOS: A criança triste é um doente. É ao médico que compete indicar o regime apropriado. Os pais e os educadores não devem intervir, senão para assinalar os sintomas e observar o tratamento (...) O educador tem um importante papel a desempenhar nestas curas. Pode e deve fazer-se um auxiliar inteligente da família e do médico. O exemplo duma cura deste gênero levada a bom termo será dum excelente efeito sobre todos os camaradas do pequeno melancólico, sobretudo se eles forem discretamente empregados como auxiliares para a consecução do êxito." ${ }^{171}$

2) A criança nervosa, por sua vez, caracterizar-se-ia pela instabilidade mental, ocasionada, também neste caso, por fatores de origem orgânica - sistema nervoso desequilibrado, mal funcionamento dos órgãos de nutrição, etc. - aliados a determinações ambientes, que poderiam, sem dúvida, exacerbar a tendência já presente no organismo. Os sintomas da criança nervosa seriam a agitação permanente, a inconstância no humor e a transformação abrupta de um grande entusiasmo em uma inexplicável melancolia. Isso faria com que a criança nervosa fosse caracterizada por um comportamento imprevisível, do qual a

\footnotetext{
${ }^{170}$ Alzira CARDOSO, Creanças anormais, In: A Federação Escolar, no 79, 16-7-1910.

${ }^{171}$ Alzira CARDOSO, Creanças anormais, In: A Federação Escolar, no 79, 16-7-1910.
} 
distração era a principal pista. Adverte-se que a criança que frequentemente presenciava espetáculos e brigas domésticas entre seus pais seria propensa, por essa razão, a desenvolver comportamento destemperado:

"A criança nervosa é, sobretudo, um agitado que passa, sem razão aparente, dum extremo a outro: ora está alegre, ora triste; ora exuberante, ora melancólico; ora dócil, ora intratável; ora paciente, ora altercador; ora amável, ora caturra; ora polido, ora insolente; ora atento, ora distraído (...) A criança nervosa é incapaz da atenção seguida. É necessário recomeçar tudo, dia a dia, e submete a paciência do professor a uma rude prova. Se não se cuidar muito dela sairá da escola como entrou: agitada, ignorante, impotente, insuportável.” 172

3) Finalmente, a criança muito sensivel seria afetada por uma suposta doença constituída pelo excesso de sensibilidade. Nesses casos, a criança grita, chora e incomoda permanentemente seus pais, que, em geral cedem-lhe as vontades, deixando-a livre para fazer o que bem quiser. Esse tipo de criança tem tendência a devaneios prolongados, chorando aparentemente por qualquer coisa. Esse tipo de criança costuma ser egoísta e auto-centrada.

$\mathrm{Na}$ verdade a classificação pretendia explicar aos professores as anomalias facilmente verificáveis em seus alunos que, sendo tratados à luz da ciência, poderiam, sem tantos traumas, conseguir sucesso na escolarização. O problema, então, não estaria mais na escola, na família ou na educação em si. Estaria - pelo contrário - na própria criança, que deveria ser, então, dirigida à luz das recomendações pedagógicas e psicológicas determinadas a partir dos padrôes de normalidade que o jornal republicano contava para os educadores.

\section{Impasses da hereditariedade e a nova pedagogia}

A Pedagogia firmara-se como ramo do saber dotado de competência científica e repertório específico. Suas conquistas não chegaram assim tão tarde a Portugal, embora o atraso fosse sempre motivo de queixa entre os contemporâneos. Sabia-se que trazer cientificidade ao campo da educação era, sobretudo, conjugar a ação disciplinar da escola com sua tarefa civilizadora: despojar a criança daquilo que seria sua animalidade; torná-la polida e prudente; moralizar seu sentimento e sua percepção; e, com todos esses requisitos preenchidos, cultivar sua inteligência com a transmissão de conteúdos culturais julgados relevantes. Educar era trazer ao indivíduo uma razão autônoma, uma ética autônoma; tudo isso passava pela erradicação de alguma crença, de algum costume, de alguma tradição. A educação escolar era aculturação. A despeito disso, os contemporâneos julgavam imprescindível que as escolas, ao ensinar, recorressem às narrativas da boa tradição portuguesa.

Escrevendo naqueles tempos imediatamente antecedentes à República, Ferreira-Deusdado indagava sobre a legitimidade intelectual da Pedagogia em um mundo que

${ }^{172}$ Alzira CARDOSO, Creanças Anormaes, In: A Federação Escolar, no 79, 16-7-1910. 
parecia ser todo ele regulado por leis do campo da biologia. Havia inúmeras outras iniciativas nessa direção. A Encyclopedia das Famílias; revista illustrada de instrucção e recreio pretendia ter uma explícita função educativa: "instruir, educar, recrear" ${ }^{173}$. Tratava-se, na verdade, de um almanaque que abarcava universo bastante vasto de assuntos: da agricultura ao teatro, passando por anatomia, mineralogia, botânica, química, mecânica, música, engenharia, e - obviamente - educação. Os temas deveriam ser todos apresentados em linguagem acessível, de modo a que o leitor menos informado pudesse verdadeiramente tomar contato com distintas áreas, cujo conjunto formaria um leque razoável da cultura geral para as camadas populares e médias da população. A leitura popular tinha por finalidade construir um repertório comum, uma base de cultura pública. Era - digamos assim - o rol dos conhecimentos autorizados. Podemos constatar nesse tipo de periódicos a crença ilimitada nos poderes da ciência da educação.

Tornavam-se cada vez mais fortes, em Portugal daquele princípio de século, os ideários da Educação Nova e do movimento que, à volta da Pedagogia Experimental, mundialmente ganharia corpo. Tratava-se da aplicação mais direta dos preceitos científicos e positivistas ao campo da educação. Supunha-se que a educação tradicional desconhecia as teorias da aprendizagem e que, por ser assim, priorizava a ação docente e não o aprendizado do aluno; que não diferenciava o ato de instruir do gesto de educar; que não conhecia efetivamente os parâmetros de observação capazes de levar a criança a refazer em seu processo educativo as etapas cognitivas pelas quais historicamente a humanidade teria passado. A nova escola pretendia mensurar cientificamente as faculdades cognitivas de cada um dos estudantes. Ela deveria se comportar, nos termos do que diziam as revistas do princípio do século XX, como uma "escola por medida", exatamente talvez por fazer da experimentação a chave do processo de ensino. De algum modo, existe aqui a ilusão de conferir à Pedagogia o estatuto de uma ciência exata ${ }^{174}$.

Havia quem enfatizasse a necessidade de a instrução portuguesa passar a se referenciar mediante as necessidades, as aspirações e as expectativas das populaçóes locais. Isso significava que as localidades, os municípios, as câmaras, as juntas de paróquia, deveriam investir no edifício escolar, na mobília, nos utensílios da escola. Deveria haver esse esforço conjugado que resultaria na prática de afastamento dos professores interinos, à medida que se aperfeiçoasse o controle das comunidades sobre a escola.

Era muito comum, naquelas revistas do princípio do século, matérias voltadas para a prevenção pedagógica de alguns dos males com os quais a sociedade se defrontava,

${ }^{173}$ No $24^{\circ}$ ano de publicação a Revista vinha com a seguinte propaganda na sua contracapa: "A Enciclopédia mais útil que se publica em Portugal! Única no seu gênero que conseguiu atingir o $24^{\circ}$ ano! O livro indispensável às famílias! A grande aceitação que a Enciclopedia das Famílias tem conseguido obter é única e exclusivamente devido ao fiel cumprimento do seu programa, que encerra as mais levantadas idéias, mas que se resume a instruir, educar, recrear." (ENCYCLOPEDIA das Famílias, no 287, 24ㅇ ano, 1910).

174 "É isto que vem confirmar uma psicologia mais perfeita, propriamente experimental e que pensa ser bem sucedida por processos cada vez mais perfeitos e rigorosos, medindo as faculdades intelectuais ou morais. De modo que se poderão tomar as medidas do espírito como do corpo, e notificá-las em cifras sobre uma ficha psicométrica. Assim precisada, a psicologia reclama uma educação adaptada a cada criança, ou, segundo o termo do Dr. Claparède, a escola por medida. É preciso conceder a maior atenção a este esforço, que tende a constituir uma ciência exata da criança e a renovar ou até a transformar, por uma verdadeira revolução, toda a Pedagogia." (A ESCOLA POR MEDIDA, In: A Federação Escolar, no 86, 3-9-1910) 
particularmente a embriaguez dos povos das aldeias. Acreditava-se que a instrução e os benefícios dela decorrentes poderiam ser antídotos eficazes do alcoolismo. Educar o povo trabalhador era, também, sob tal perspectiva, conferir hábitos de moderação, capazes de extirpar-lhe a tentação do vício. A recomendação de exercícios ginásticos nas escolas ia exatamente por aí. O condicionamento corporal seria análogo ao condicionamento da alma; quer no tocante à propensão para o vício, quer no cultivo de bons e saudáveis costumes.

Entendia-se à época que os requisitos necessários para o bom desempenho da tarefa do magistério pautavam-se no domínio de algumas habilidades e na posse de alguns atributos, que vêm assim arrolados: 1). Capacidade de captar a admiração de seus discípulos; 2). Domínio da relação com o discípulo, mediante autoridade construída sobre três bases: moralidade; domínio do conteúdo da aula; habilidade didática 3). Capacidade de despertar a inteligência do aluno, levando-o a apaixonar-se pelo conhecimento a ser adquirido; 4). Entusiasmo, criatividade e habilidade de inovação perante a rotina do trabalho. Aí estariam, pois, arrolados os requisitos para se criar um bom professor.

Não se pode dizer, contudo, que os educadores da época não houvessem se esforçado para sensibilizar a sociedade civil portuguesa, bem como os poderes instituídos para o temário pedagógico. As revistas faziam isso, com competência; para quem quisesse ouvir... O princípio do século traria um novo estatuto para o professor primário. Nem sempre, porém, os intelectuais conseguiam convencer as populações; e aqui não se tratava de uma exceção. Artigo de Cesário Tavares publicado na Educação Nacional de 23-11-1902, sob o título "Mestre-escola e professor primário", identificava as dificuldades de reconhecimento efetivo do valor social de uma profissão carente de prestígio. A própria utilização ainda em voga da expressão mestre-escola parecia suficiente para evidenciar o menosprezo, a zombaria, e principalmente o não reconhecimento do estatuto profissional daqueles "funcionários da primeira instrução". Na verdade, supunha-se que o "escárnio das multidões" pelo mestre-escola decorria de sua tarefa de apóstolo da civilização, ainda que, muitas vezes, se dedicasse a ela sem vontade nem entusiasmo. Séculos de ignorância - recorda o referido articulista - fizeram por induzir o descaso e o desprezo justamente pelas mais elevadas das profissões, dado que, em coro com os professores, os médicos e os escritores eram também reputados em baixa consideração na escala social. $\mathrm{Na}$ verdade, o desprezo pela escola e muito particularmente pelas letras era identificado como um dos mais perniciosos males da sociedade portuguesa. A mesma sociedade que desdenhava os mestres repudiava as letras.

A escola a que se referiam os contemporâneos era o resultado incontornável do percurso civilizatório que, ao unificar territórios, deveria uniformizar os símbolos, os valores; em uma palavra, a cultura. Na verdade, entendia-se o temário da escrita como um território à parte que, se, por um lado, negava, por outro, concorria com o âmbito da oralidade. Sob outra perspectiva, a memória de Portugal, julgava-se dever engrandecê-la, até para esboçar prospecçōes de grandeza também para o futuro. A escola veicula a memória do passado, mas sempre faz isso tomando por interlocutor o futuro. A escola então denega apenas o tempo presente. A marca mais visível da escolarização estaria assim posta nessa dupla temporalidade, no intervalo colocado entre passado e futuro, no espaço vazio do dia de hoje.

Frequentemente apontado como a grande alavanca da instrução pública, reconhece-se no professor primário a verdadeira esperança de motivação das populações para 
o estudo. Tendo herdado do mestre-escola atributos como modéstia, escrúpulo, caráter, decoro, lisura e decência, o professor primário é tomado como arauto das virtudes cívicas, civis e sociais e, talvez nessa qualidade, residisse grande parte do segredo do respeito que desfrutava. Ressalta-se, ainda, que o professor primário era, frequentemente, um sujeito estudioso, gastando, a despeito de sua baixa remuneração, vultosas quantias para a aquisição de livros e assinatura de jornais. Primeiro apóstolo da causa da instrução, o professor primário seria, acima de tudo, um militante convicto, que, entusiasmado, convenceria os relutantes sobre os benefícios da escola, sobre a validade do aprendizado escolar. A educação, para o professor da escola primária, deveria ser primeiramente uma aposta; uma aposta em nome do futuro - aposta pela qual ele teria empenhado a própria vida. 


\section{Das Representaçóes Às Práticas, a Vida cotidiana das escolas}

"Evitemos retirar à nossa ciência o seu quinhão de poesia. Evitemos sobretudo corar por isso, coisa que já surpreendi em alguns. Seria espantosa tolice julgar que, pelo fato de exercer sobre a nossa sensibilidade um apelo tão poderoso, a história fosse menos capaz de satisfazer também a nossa inteligência."

(Marc Bloch, Introdução à História)

\section{Rotina e inovação: a geografia da escola passada}

O ritual da escolarização - em sua rotina, seus usos seus costumes - não condizia exatamente com as prescrições do discurso que tematizava a questão. A situação do professor era, por exemplo, muito mais miserável do que apontavam os debates sobre o ofício do magistério. Os professores régios eram pobres e, passando a vida a lecionar, muitas vezes chegavam à sua aposentadoria sem obtenção de meios razoáveis para prover a subsistência. Diz-se comumente que a população portuguesa, durante o curso do século XIX, rejeitava a alternativa escolar e não se sensibilizava com os benefícios que, em tese, poderiam ser trazidos pela instrução. Há, inclusive, uma variação considerável de registros que indicam tal tendência à perpetuação de uma cultura pautada exclusivamente pelos limites da oralidade. Tanto nos debates político-ideológicos quanto nos acervos que retratam a prática da inspeção, há indícios que nos permitem efetivamente acreditar na existência de uma parcela considerável das famílias portuguesas que se recusava a transferir sua competência educativa para a responsabilidade dos mestres de Primeiras Letras. Havia nitidamente uma certa dose de desconfiança quanto ao potencial subversivo posto por aquilo que Guy Vincent caracterizou como forma escolar de socialização ${ }^{175}$. Por outro lado, são também frequentes as cartas, os ofícios, os abaixo-assinados dirigidos a autoridades que solicitavam escola, que reclamavam um direito que a constituição assegurava, que balizavam sua reivindicação pelo argumento segundo o qual o não-oferecimento da instrução pública teria como principal prejudicado o país.

\footnotetext{
${ }^{175}$ Para Guy Vincent, no trabalho intitulado L'école primaire française: etude sociologique, a escola seria tomada como uma forma dominante do processo de socialização em nossas sociedades modernas e contemporâneas. Tratar-se-ia, no parecer deste autor, de uma maneira historicamente circunscrita, no sentido de proceder a um dado modelo de interação entre adultos e crianças. Haveria, nessa dimensão, uma gramática própria que instaura uma normatividade específica. Vincent procura estudar a escola (e, nela, a forma escolar) pela maneira como a instituição age a fim de proceder à transmissão dos saberes e do saber-fazer. Ao efetuar esse papel, que é a sua razão de existir, a escola delimita seguramente relações claras de poder.
} 
Podemos, portanto, acreditar que havia, sim, quem desejasse a escola para seus filhos; havia, sim, quem acreditasse que o conhecimento escolar poderia ser tomado como instrumento de intervenção mais pronta no processo civilizatório. E havia, também, como via de mão-dupla, quem rejeitasse ou fosse indiferente à tarefa da instituição escolar. O século XIX arbitrou esse conflito sem dar ganho de causa à primeira posição.

O século XIX foi o século da escola. Esta deveria representar as novas conquistas da cidade, da técnica, da informação, dos meios novos de comunicação, dos transportes ferroviários. A escola deveria vir para ensinar o menino sobre o mundo. Mas, a par dessa modernidade, havia o ambiente tradicional, memórias locais, do cotidiano da vida aldeã. Esse outro mundo também deveria estar composto na escola. Por tal razão, há uma dupla face no tema da escolarização; naquilo que ele traz de reformador e no que ele, sem dúvida, carrega em termos de conservação. Mesmo que, no caso de Portugal do XIX, o problema da escola tenha sido um vencido e não um vencedor no que tange a prioridades das políticas públicas, devemos ter em mente, ao estudá-lo, que - até onde pudemos constatar - havia intenso e movimentado debate sobre a validade ou não da universalização da instrução. Esse debate revelava distintos e, por vezes, contraditórios modos de ver o problema. Entregava-se à instrução a tarefa de divulgar um conjunto de conhecimentos tidos como úteis, ensinamentos socialmente adequados - tudo aquilo que a sociedade julgava apropriado veicular. A escola era a instância que declarava a cultura oficial, com tudo o que deveria ser nela - ou em nome dela - reconhecido. A cultura passaria, por sua vez, a ser compreendida mediante grade conceitual hermética, cuja chave pertenceria exclusivamente àqueles que fossem capazes de transcorrer o itinerário da escolarização....

Para compreender representações e práticas correspondentes à escola portuguesa do século XIX, deveremos também recorrer ao debate educativo expresso pelos congressos e pelas conferências pedagógicas que, a partir dos 70, passariam a ter lugar em Portugal. Tais reuniōes dos profissionais da educação, à semelhança do que já existia em outros países europeus, pretendiam efetuar permuta das idéias, pelo confronto do que a experiência prática e o aprofundamento teórico haveria trazido aos educadores individualmente. Isso significaria, pois, transformar o ganho particular de cada professor em aproveitamento coletivo da categoria profissional. No ano de 1872, em texto intitulado $O$ que é e o que deve ser a instrucção nacional, Manuel Francisco de Medeiros Botelho propugnava o estabelecimento sistemático de Conferências Pedagógicas, à guisa de estímulo para construção de parâmetros escolares mais uniformes, mais racionais, mais organizados... Nos termos daquele educador, tais reuniōes terão por objeto "especialmente a organização e a disciplina escolares, a confrontação e apreciação dos diferentes métodos, as lacunas que é necessário prencher ainda nas coisas do ensino, as dificuldades que é preciso remover; em suma: as reformas que julguem convenientes" 176 .

As conferências e os congressos pedagógicos eram frequentemente citados como elementos propulsores, que impulsionavam a melhoria do ensino. E melhorar o ensino era auxiliar o próprio progresso civilizatório. A preocupação com a conquista dos

${ }^{176}$ Manuel Francisco de Medeiros BOTELHO, O que é e o que deve ser a instruç̧ão nacional, p. 55. 
segredos do método mais eficaz tornar-se-ia nota predominante para isso. Sobre as conferências, dizia Simões Lopes:

\begin{abstract}
"São uma escola em que os professores mais aptos, tendo este meio de incitamento ao estudo, vêm apresentar o resultado das suas observações e experiências, e discutir os princípios em que deve assentar a melhor norma de ensino, o melhor meio de educar as faculdades do espírito, e finalmente a melhor organização escolar. Os menos aptos vêm aprender e tirar estímulos para o seu próprio aperfeiçoamento. São uma escola em que a comunicação recíproca de idéias, de experiências, de observações e de estudos concorre poderosamente para que do trabalho do professorado resulte maior utilidade social." ${ }^{\text {177 }}$
\end{abstract}

Procuravam-se experiências exitosas no campo do ensino, para delas tirar deduçôes, recomendações e generalizações. Buscava-se trazer à escola sua configuração uniforme, homogênea. Mas basear em quê essa forma? Um dos caminhos, supunha-se ser este: a partilha e a irradiação de experiências daqueles que, por estudarem mais, por refletirem mais detidamente sobre a própria prática, haviam se tornado profissionais de ponta no magistério. As vantagens dos congressos de professores estariam dadas tanto pela exposição de trabalhos escolares quanto pelo efeito de irradiação de métodos e técnicas bem-sucedidos em sala de aula. ${ }^{178}$ Sublinhavam-se, naquelas reuniões, procedimentos inovadores de aprendizado: o princípio do ensino ativo, a necessidade de observação e de experimentação. Para tanto, era comum os conferencistas defenderem o estímulo pedagógico a excursōes escolares, criação de museus educativos, fundação de jornais, exposiçôes escolares e tudo quanto, além disso, pudesse ser caracterizado como inovador da dinâmica do ensino escolar.

Simōes Lopes, na Conferência Pedagógica realizada no Porto em 1883, recordava o destacado papel demonstrado por pessoas que, não sendo educadoras, eram, todavia, verdadeiras beneméritas da instrução. O exemplo grandioso do Conde Ferreira - que, ao falecer, deixara legado vultoso para a construção de escolas - é aqui enfatizado como um modelo do quanto a sociedade como um todo, e não apenas os órgãos governamentais, poderiam contribuir para a causa do ensino.

Quando se pronunciavam sobre o segredo do método, os professores reunidos nas conferências não se limitavam a enaltecer inovaçōes. Em debate sobre o ofício que profissionalmente os unia, destacavam que as falhas na escolarização eram decorrentes de não se saber ensinar: nem todas as crianças deixavam a escola tendo apreendido os preceitos mínimos da leitura e da escrita enquanto habilidades necessárias para a vida moderna. Outrossim, mesmo as que, a custo de enorme esforço, se mostravam capazes de aprender, muitas vezes esqueciam, logo a seguir, o que, há pouco, a escola

177 A. Simões LOPES, Conferencias pedagógicas do Porto em 1883: relatorios, programmas, horarios, actas, resoluções e mais trabalhos do primeiro congresso de professores primarios reunidos no Porto, sob a direcção de..., p. 23 (3-10-1883).

${ }^{178}$ A propósito do lugar pedagógico das Conferências e Congressos de professores, recordaríamos o trabalho de António Nóvoa, que situa esse esforço associativo como um marco primordial na constituição do alicerce profissional dos docentes. Nóvoa destaca, a tal respeito, que as Conferências Pedagógicas teriam conhecido a seu tempo um verdadeiro sucesso em Portugal no tocante à formação do corpo de professores primários (António NÓVOA, Le temps des professeurs, volume I, p. 493-4). 
havia ensinado. Na verdade, em geral, não se mobilizava o conhecimento aprendido para o trato cotidiano. Não se requisitava a competência da leitura e, quando eventualmente isso ocorria, já se teriam esquecido do que recentemente haviam aprendido. Os professores reunidos sabiam muito bem que à escola caberia ensinar a "falar com clareza e a escrever com correção" ${ }^{179}$. Tratava-se, fundamentalmente, de ensinar a criança a pensar corretamente, à luz do universo da escrita. Em nome do que julgavam ser a "ciência da pedagogia", ${ }^{180}$ defendiam o ensino intuitivo e a necessidade de se partir do mais simples, do mais próximo, do mais concreto, para posteriormente ousar generalizaçóes que somente por analogia as crianças poderiam compreender.

Nas conferências, um dos temas mais intensamente debatidos era o da disciplina e sua relação com a organização geral da instituição educativa. Desejava-se regrar pela uniformidade a instituição escolar. Afinal, julgava-se habitualmente a escola como o elemento de transição que possibilitava ao indivíduo a passagem da vida familiar para a vida social. Nessa dimensão, procuravam-se alicerces comuns para as práticas escolares, à luz do que se supunham ser as expectativas da mesma vida social. Para tanto, a disciplina era, de fato, um imperativo: disciplina para o aluno e para o professor; disciplina que apresenta, organiza, estrutura, conforma e distribui lugares sociais, demarcando, com isso, posições; disciplina, enfim, que habitua ao exercício combinado entre poderes e obediências...

No cumprimento de seus deveres, o professor era caracterizado como exemplo de humildade, obediência, dever, trabalho, honra, virtude. Subordinado perante seus superiores - inspetores, câmaras municipais, juntas escolares -, o professor dever-se-ia destacar pelas maneiras decentes, pelo traje discreto, pela disposição constante para o recebimento das normas que dirigiriam a vida da rede escolar, vista como um todo. A própria organização institucional - e ele, professor, deveria saber disso - dependia de sua regularidade, pontualidade e fidelidade. O professor que cometesse abandonos da sala de aula, ainda que provisórios e casuais, teria mais dificuldade - como parecia aos congressistas evidente - quanto à cobrança da constância e da regularidade de seus alunos.

Recordando que a ausência do professor levava, por vezes, os alunos a danificarem o mobiliário da sala de aula, destaca-se que o bom resultado do ensino depende, em grande parte, da presença da autoridade do mestre. Este, por sua vez, deveria mostrar-se capaz de manter "digna e prudentemente as suas relaçôes com os pais de seus alunos, para o que evitará a demasiada familiaridade com eles, não se mostrando altivo e desdenhoso" ${ }^{\text {”181. }}$.

${ }^{179}$ António Ferreira de JESUS (e outros da comissão), Detalhe do programa da língua materna, In: Conferencias pedagógicas do Porto em 1883: relatorios, programmas, horarios, actas, resoluçôes e mais trabalhos do primeiro congresso de professores primarios reunidos no Porto, sob a direç̧ão de..., p. 35.

${ }^{180}$ António de Padua Souza LOBO (e outros, representando a comissão), 3a Sessão da Conferência, In: Conferencias pedagógicas do Porto em 1883: relatorios, programmas, horarios, actas, resoluçôes e mais trabalhos do primeiro congresso de professores primarios reunidos no Porto, sob a direç̧ão de..., p. 50 . O terceiro ponto trabalhado naquela terceira sessão da Conferência Pedagógica do Porto debatia o tema da disciplina escolar. "O ponto é este: utilidade da disciplina no corpo docente do magistério primário; quais os atos por que se afirma; fará parte dos deveres do professorado primário?” (Id. Ibid., p. 50).

${ }^{181}$ António de Padua Souza LOBO (e outros, representando a comissão), 3a Sessão da Conferência, In: Conferencias pedagógicas do Porto em 1883: relatorios, programmas, horarios, actas, resoluçôes e mais trabalhos do primeiro congresso de professores primarios reunidos no Porto, sob a direç̧ão de..., p. 55. 
Isso permitiria o resguardo de sua relativa independência moral, em nome da qual deveria também se preservar afastado de reuniōes públicas e das próprias autoridades locais.

Portador de conduta irrepreensível, caberia ao professor "o fazer compreender a seus alunos a afeição, a estima e o respeito que dedica a seus superiores, despertando-lhes, destarte, a obediência refletida, fazendo-lhes crer que ninguém impõe deveres por prazer, mas sim em virtude de uma lei, além de que o homem tem muitas vezes necessidade de ser mandado por outro que seja mais sábio e mais experiente" ${ }^{182}$.

Devendo fazer crer que o seu trabalho (que, como missão, assemelhava-se ao sacerdócio) the despertaria, acima de tudo, prazer, do professor esperava-se religiosidade, sensatez, discernimento, circunspecção, devoção... Quanto ao método de ensino prescrito para as escolas primárias, em geral, os professores reunidos em suas Conferências Pedagógicas indicavam o modo de ensino simultâneo como o mais apropriado, o mais eficiente, o mais moderno, enfim. Ocorre que, para se adotar verdadeiramente esse modelo de ensino coletivo, seria imprescindível providenciar mobiliário apropriado e padronizado para compor a disposição das salas de aula. Além disso, era cada vez mais urgente a uniformização dos compêndios didáticos utilizados em classe. Como dar um ensino coletivo e geral se os livros dos alunos são diferentes? Como homogeneizar o momento dos exercícios escolares se não houver unidade nas leituras? Todos esses obstáculos eram percebidos como óbices ao próprio êxito da escolarização portuguesa. Portugal, tal como estava, não alcançaria, ainda, os requisitos modernos para erigir a escola nacional.

Com o propósito de organização de critérios genéricos para a nova escola que se pretendia traçar, os professores enfatizavam a urgência de se cumprir a prescrição legal, dividindo a escola em três classes. Enquanto uns estivessem concentrados em exercícios que o mestre lhes ministrasse, o professor ocupar-se-ia dos outros. Por essa razão, o modo simultâneo era visto como estratégia para regular o bom aproveitamento do tempo e do espaço escolar. Inovaçóes à parte, o grande segredo da aula estaria na capacidade de o carisma do professor cativar a atenção de seus discípulos. Para isso, conferir prioridade para a exposição, para a aula - com o recurso do quadro-negro e do giz... Era esperado do professor que soubesse explicar a matéria.

O tempo das lições era dividido perante organização criteriosa do horário escolar (que, geralmente também não existia), de modo que professores e alunos não se distraíssem e se dispersassem após 4 ou 5 minutos de aula. Para o bom emprego do tempo, dever-se-ia manter o aluno continuamente ocupado, não se contentando com o dar a ele o conhecimento do alfabeto e as habilidades motoras para o traçado na ardósia. Havia de se proceder na escola à mais completa possível iniciação no campo intelectual. Para tanto, o professor devia ser dedicado e, a tal dedicação, o aluno deveria corresponder com a 'obediência de um filho'.

Para formação da disciplina escolar, a mesma Conferência Pedagógica do Porto (1883) solicitava dos poderes centrais a uniformização dos procedimentos e da forma da escola. Reivindicavam-se carteiras-bancos padrão, com dois lugares cada uma; a adoção paulatina do modo simultâneo de ensino, que, a princípio, contaria com o auxílio de

${ }^{182}$ António de Padua Souza LOBO (e outros, representando a comissão), 3a Sessão da Conferência, In: Conferencias pedagógicas do Porto em 1883: relatorios, programmas, horarios, actas, resoluçôes e mais trabalhos do primeiro congresso de professores primarios reunidos no Porto, sob a direcção de..., p. 56. 
dois monitores; os exercícios escolares sempre divididos entre manhã e tarde, com horários padronizados; a estrutura da distribuição das matérias pela grade do horário escolar, alternando as disciplinas que exigissem maior concentração (leitura, língua materna, cálculo) com outras, que requisitavam menor esforço (desenho, ginástica, lições educativas). Pelo visto, então, nas representaçôes perfilhadas por corações e por mentes, quer na literatura, quer nos debates dos especialistas, a "forma escolar" vinha se configurando, cada vez mais uniforme, homogênea, única e global, quase eterna...

\section{A escola como signo de poder local: rivalidade comunitária}

Em sua dimensão concreta, entretanto, o problema da escola passava indubitavelmente por outras variáveis. Voltando atrás na linha do tempo, no ano letivo de 1826, em Tomar, a população das freguesias de São Silvestre dos Chãos e de Nossa Senhora da Graça, consultada pelo procurador Thomaz da Silva Teixeira, reclamava da inexistência de uma cadeira de Primeiras Letras em um daqueles dois lugares, posto que, somados, eles contavam com quase duzentos meninos entre 7 e 12 anos. Existia na ocasião uma cadeira na Vila das Pias, que ficava, entretanto, a duas léguas de distância daquelas duas freguesias, caminho que era além do mais entrecortado por montes e ribeiras, com dificuldades naturais para a travessia e o trânsito, particularmente no decorrer do inverno.

Naquele mesmo ano de 1827, um ofício do Juiz relata que a Câmara do Couto de Barrô, na comarca de Aveiro, tinha sua população estendida por mais de 260 fogos, com 900 indivíduos do sexo masculino, sendo muitos deles menores de 12 anos, sem saber nem ler nem escrever, dado que inexistia naquela localidade a função e o cargo de um mestre de Primeiras Letras.

A justificativa do subsídio literário, em sua 'avultada quantia', demonstra a convicção dos suplicantes quanto ao direito que deveriam ter assegurado pelo poder público mediante pagamento de tributo. Nos últimos anos, recordam os requerentes que a colheita havia sido maior e que, por essa razão, teria crescido também a parcela referente ao imposto. Sublinhando a exclusividade de tal tributo para com a conservação e o aumento das escolas menores, na forma da lei de 10 de Abril de 1772, a população julgava absolutamente legítimo e natural a solicitação que fazia para que fosse providenciada pelos orgãos competentes a urgente criação de uma escola naquela localidade.

Naqueles tempos, também o vigário de Ribeiradio na comarca de Viseu, José Batista de Niza, seguido de mais 18 signatários - dentre eles o vigário de Arcozello, o boticário e outros moradores de Ribeiradio e Arcozello das Maias - escreviam ofício à infanta regente do governo de D. Pedro IV. Pedia-se à princesa que ela intercedesse para que viesse a ser criada naquela freguesia de Ribeiradio uma cadeira de Primeiras Letras capaz de atender à formação da mocidade dos povos daquela região. Segundo os signatários, a despeito da elevada proporção da população em idade escolar, a cadeira de Primeiras Letras mais próxima distava quase três léguas daquele povoado. Isso justificava o fato de as famílias deixarem de mandar seus filhos à escola. Por escassez de meios, as crianças seriam, nessa medida, relegadas ao silêncio e às trevas da ignorância, nas quais rotineiramente deviam ser sepultados verdadeiros talentos, os quais, se as condições houvessem sido outras, poderiam - quem sabe 
- se haver sobressaído na propagação e no adiantamento das ciências e das letras. Declarando-se cônscios de que a Carta Constitucional promulgada por D. Pedro em 1826 garantia a instrução primária e gratuita a todos os cidadãos, os súditos solicitavam o que julgavam ser dever coletivo e direito individual.

Também 31 moradores da freguesia de São Cristóvão de Mafamude, no concelho de Gaia, fazem o mesmo: solicitam escola, com a argumentação de que a freguesia era extremamente populosa e a criação de uma cadeira régia de Primeiras Letras poderia por tal razão contribuir para diminuir os elevados índices de indigência e de pobreza daquela povoação e da de outras freguesias próximas. Nesse caso específico, eles inclusive indagavam o nome do eventual professor, um tal José de Freitas Lima Júnior que, no parecer dos signatários, reuniria as condições postas como necessárias para lecionar naquele povoado.

A 8 de fevereiro de 1828, moradores da vila e do concelho de Melres, na comarca do Porto, solicitavam a criação de uma escola de Primeiras Letras, argumentando que não havia nas imediações "até muito mais de uma légua mestre algum"183. Havia ainda outros casos, como o de Nicolau António Ferreira Guimarães, do lugar de Miradouro na freguesia de São Miguel de Creixomil, cujo requerimento pela abertura de escola dirigido à infanta D. Maria em 21 de janeiro de 1828 continha a sugestão de que fosse ele próprio nomeado professor. O requerente - natural da vila de Guimarães - obteve baixa do serviço militar por moléstias, prestando concurso para tabelião, depois para ajudante de escrivão da provedoria de sua comarca, tendo exercido, portanto, ambas as funçōes para as quais fora aprovado. Solicitando a regência da cadeira, o proponente ressalta o bom desempenho que sempre demonstrou nos ofícios que exercera, destacando, para além de seu próprio interesse, a conveniência da criação de uma cadeira de Primeiras Letras para o ensino dos meninos de São Miguel do Creixomil e de mais 6 freguesias que dela seriam próximas e que não contavam - nenhuma delas - com escolas primárias.

De qualquer maneira, era comum que o requerente demarcasse os contornos da geografia, optando por sua respectiva freguesia. É o que faz António Cardeira Sanches, do lugar de Mareco na provedoria de Viseu quando, a 4 de fevereiro de 1828, solicita às autoridades a criação de uma cadeira específica de Primeiras Letras naquela povoação, cujas proximidades também careciam de bons e qualificados mestres. $\mathrm{Na}$ verdade, o lugar de Mareco é apresentado como o mais central, o que conduziria à inferência de que a obtenção de uma cadeira efetivamente suprimiria a dificuldade de muitas crianças dos vilarejos ao redor, as quais, tendo algum interesse em frequentar a instrução primária, não eram capazes de enfrentar caudalosos rios e ribeiras sem pontes, "medonhas colinas e matas agrestes" ${ }^{184}$, cuja travessia era necessária, sendo entretanto quase intransitável, para facultar o caminho da escola.

Essas razões de ordem topográfica pareciam ser as mais fortes para sensibilizar as autoridades competentes a criarem cadeiras de Primeiras Letras. Poder-se-ia, porém, dizer que havia, muitas vezes, outros dispositivos que motivavam o pedido de escola,

${ }^{183}$ Coleção de Manuscritos da Biblioteca Geral da Universidade de Coimbra, códice 2533, caderno de documentos 55 .

${ }^{184}$ Coleção de Manuscritos da Biblioteca Geral da Universidade de Coimbra, códice 2533, caderno de documentos no 56 . 
em virtude do fato de os requerimentos e abaixo-assinados, extremamente comuns à época, reafirmarem o direito legal que as populações teriam sobre a instrução de seus filhos, como se, de fato, essa instrução fosse desejada porque percebida como fonte de alguma possibilidade de emancipação. Eles acreditavam nisso...

Em 5-4-1819, o provedor da Comarca da Guarda (que abrangia a povoação de Pinhanços), António Delgado da Silva, solicitava dos poderes públicos a criação de uma cadeira de Primeiras Letras naquele vilarejo. Para tanto, o provedor afirmava haver recorrido ao depoimento de testemunhas variadas, e todas elas confirmavam o fato de não existir qualquer possibilidade de escolarização para as crianças, a não ser em lugares próximos, como a Vila de Santa Marinha, que distava dali meia légua e Seia que se localizava à distância de uma légua, "ficando por meio o ribeirão, que de inverno impede a passagem aos meninos" ${ }^{185}$. Diante dessa constatação de geográfico obstáculo à instrução, sugere-se a criação de uma cadeira de Primeiras Letras no povoado de Pinhanços. Na verdade, enquanto provedor da comarca da Guarda, António Delgado da Silva havia sido, por designação da Coroa, responsabilizado por averiguar a situação das crianças daquela região, sendo que, por tal atribuição, dele dependia a criação ou não da referida cadeira. Com tal objetivo, em nome do referido provedor, o ouvidor António Hortencio Mendes Cardozo informava que, depois de haver obtido o certificado de idoneidade das pessoas a serem ouvidas no caso, confirmou com elas a localização exata de Pinhanços e verificou que aquele lugar era mesmo próximo de inúmeras outras terras onde existiria população em idade escolar que não possuía nenhum estabelecimento de ensino para poder frequentar. Havia - com mais exatidão - seis povos que distavam cada um cerca de meia légua de Pinhanços: Lagarinhos, Gache, Passarela, Novellâens, Lages e Santa-Comba. Os caminhos que os conduziam a Pinhanços eram, por seu turno, facilmente transitáveis, mesmo no inverno mais rigoroso, pelo fato de não serem cortados por montes, despenhadeiros, rios ou ribeiras. Ocorre que, somando as crianças de todas essas localidades, haveria cerca de 150 meninos que, para aprenderem a ler e a escrever, teriam de se deslocar para Santa- Marinha, Vila Nova do Casal ou Vila de Seia, que ficavam - cada uma das referidas vilas - a meia ou a uma légua de Pinhanços, caminho que entretanto era cortado por grandes ribeiros (o rio de Seia, a ribeira de Arrifana), o que muitas vezes impedia a passagem em épocas de chuvas abundantes. Era por isso - conclui a investigação - que poucas pessoas de Pinhanços e arredores sabiam ler e escrever. Ora, tendo em vista que todas aquelas populaçóes eram ligadas à cultura do vinho, evidentemente o subsídio literário seria ali recolhido. A escola era, pois, no parecer daquelas gentes, um direito que lhes estaria sendo sonegado.

Luís Albuquerque, que (em trabalho publicado em 1960) havia estudado esse caso, revela que teria sido em 1818 - a partir de um "requerimento de homens qualificados da povoação de Pinhanços para que fosse instituída uma cadeira de Primeiras Letras naquela localidade" 186 - que o referido processo tivera lugar. Ocorre que, no ano de 1829, há outro processo contíguo àquele outrora exposto por Albuquerque, e que

\footnotetext{
${ }^{185}$ Coleção de Manuscritos da Biblioteca Geral da Universidade de Coimbra, códice 1341, folha 91.

${ }^{186}$ Luís ALBUQUERQUE, Notas para a história do ensino em Portugal, p. 236-7.
} 
constava de queixa dos habitantes da Vila de Santa Maria - também pertencente, como vimos, à comarca da Guarda - quanto à remoção sem substituição de um professor Manuel Dias Profírio - daquele lugarejo para o local de Pinhanços. O Presidente da Câmara de Santa Marinha, o juiz, o mais velho e o mais novo dentre os vereadores, o procurador, o bacharel, e outras lideranças locais reivindicavam o regresso da cadeira de Primeiras Letras que havia pertencido àquela localidade e vinham expressar em abaixo-assinado seu descontentamento para com tal situação.

$\mathrm{Na}$ verdade, constava que se pretendia suprimir a cadeira daquela vila, e que subsistiria a cadeira de Pinhanços, considerada pelos signatários uma aldeia fraca e menor. Percebe-se nitidamente, em virtude da própria construção do texto, que se tratava de uma sinuosa disputa local. Entendia-se que a ausência de escola enfraqueceria a regiāo, fortalecendo a outra, que então passaria a ocupar um lugar de destaque nas redondezas. A marca da escola é aqui nítido objeto de disputa, como se ela proporcionasse um certo status, ambicionado particularmente pelos homens de posse da região. Sobre o tema, aliás, os signatários destacavam que a Vila de Santa Marinha se projetava como a "primeira de maior esplendor na Comarca" ${ }^{187}$, composta que era, além de tudo, por homens nobres, que, por essa condição, não deveriam ser obrigados a enviar seus filhos para uma aldeia distante, quando estes poderiam ser educados na própria vila se fosse mantida a cadeira régia. Segundo consta ainda do documento, a Vila de Santa Marinha era extremamente concorrida, posto que os próprios magistrados da Comarca iam nela residir durante meses e meses, o que jamais ocorrera - diziam eles - na aldeia de Pinhanços.

"Na mesma vila sempre houve Mestre das Primeiras Letras, isto sem memória em contrário, ele ensinou muitos Meninos, que passaram a ser clérigos, religiosos, doutores, ministros de letras e homens de caráter, e não seriam tantos como o são, e muitos existem, se não fossem educados nas Primeiras Letras na dita Vila, por lhes ficar penoso irem fora dela. Logo, para que não se corte este séquito de Homens Grandes, a dita Cadeira deve subsistir na dita Vila; útil ainda aos povos vizinhos, e ela tem aí subsistido depois que Vossa Magestade se dignou criar cadeiras tais, não havendo motivo para que deixe de continuar." 188

A Vila de Santa Marinha era composta por mais de quinhentos vizinhos, ao passo que - como comentavam os signatários - a aldeia de Pinhanços possuía apenas cento e trinta. Em termos de vizinhança, aparentemente, a Vila aglutinaria um contigente bastante maior de meninos de outros lugares que iriam para lá estudar. No ano anterior, quando lecionava em Santa Marinha, o professor contara com 45 discípulos; desde que fora efetuada a sua transferência para Pinhanços, esse número caiu para menos de 20. Diante do exposto, o abaixo-assinado - que, como já comentamos, era subscrito por personalidades da região - pretende servir como um alerta às autoridades.

${ }^{187}$ Coleção de manuscritos da Biblioteca Geral da Universidade de Coimbra, Papéis do Arquivo da Junta da Diretoria Geral dos Estudos, códice 1341, folhas 73, 74, 75.

${ }^{188}$ Coleção de Manuscritos da B.G.U.C., Papéis do Arquivo da Junta da Diretoria Geral dos Estudos, códice 1341 , folhas $73,74,75$. 
“O lugar de Pinhanços, no tempo de inverno, não dá pronta passagem, não só por dias, mas por semanas e meses para se ir ao mesmo lugar, pois as muitas águas dos ribeiros a ele próximos, impossibilitam a passagem, que é penosa ainda a homens fortes e valentes, pois as águas ainda chegam a cobrir algumas fracas pontes que há e passam ao lugar os prédios vizinhos; estes inundando-se; por consequiência é impossível que aí possam transitar os Meninos a irem à dita Aldeia, à aula de Primeiras Letras; logo, deve subsistir a cadeira na dita vila; e, de outra sorte, é ruína nos presentes e futuros, ficam privados de saberem ler, escrever e contar, que por uma parte alguns Pais de famílias não têm com que paguem a um Mestre, quando são nos seus coletados para o Subsídio Literário; e, por outra parte, os que têm com que pague a um Mestre, este o não há em pronto, e muito mais em razão d'ele dever ser aprovado por Vossa Magestade." 189

Há nitidamente contraposição entre a condição dos habitantes da vila e a situação supostamente precária dos habitantes de aldeia. Os habitantes da vila insistem em frisar a diferença. De qualquer modo, a crença na escolarização parece - na documentação - evidente. A escola não cria, mas consolida e reitera o percurso civilizatório. Os notáveis da localidade, os homens de ciência, os líderes políticos e religiosos, os legisladores, todos esses precisavam da instrução; e um maior número de homens instruídos era prova visível do adiantamento e dos progressos da localidade.

Os signatários reconhecem que, quando as aulas de Primeiras Letras eram ministradas pelo antigo professor - José Correia de Castro -, era pequeno o afluxo dos estudantes. Mas isso era porque o mestre, velho, doente e cansado de ensinar, não mostrava mais disposição para o exercício da profissão. Desde que, entretanto, a cadeira fora provida pelo sobredito professor Profírio, as aulas teriam passado a ser concorridas inclusive por meninos de aldeias vizinhas. A aldeia de Pinhanços distava, como já se pôde observar, meia légua de Santa Marinha. Na verdade, o processo nada tinha a ver com quaisquer interesses do próprio docente que - como diz o abaixo-assinado - havia requerido a sua transferência, que era, entretanto rejeitada e repudiada pelos pais de seus alunos. Os pais de família habitantes daquela vila diziam pois no referido documento que não se deveria, em hipótese alguma, atender tal desejo do professor, em prejuízo dos interesses prioritários do conjunto daquela população local.

Os requerentes, ao escreverem isso, ou não procuraram o professor buscando estabelecer acordo com ele, ou não tiveram sucesso ao fazê-lo; não se sabe. Poder-se-ia indagar se as açôes escolares eram consoantes aos interesses das famílias (e, nesse caso, quais famílias); em que medida elas representavam os interesses dos professores; e se haveria correspondência entre esses dois universos de interesse. A hipótese que aqui levantamos faz por entrever um certo nível de tensão e de conflito entre a ação docente e as lógicas de regulação familiar, como se essa escola criada pelo mundo moderno se situasse a si própria, parcialmente pela complementaridade, parcialmente pela adesão, parcialmente pela contraposição ao equilíbrio institucional da família nuclear típica.

Como fica explícito, recorre-se à participação desigual de duas comunidades no conflito por escola. Por outro lado, ainda que acenando para a possibilidade de

${ }^{189}$ Coleção de Manuscritos da B.G.U.C., Papéis do Arquivo da Junta da Diretoria Geral dos Estudos, códice 1341 , folhas $73,74,75$. 
abertura de concurso para a cadeira que ficara vaga, os proponentes sugerem - inclusive com uma certa veemência - o regresso do professor que partira por livre vontade para a aldeia de Pinhanços. Tal ênfase justifica-se exclusivamente pela eficácia daquele mestre no ensino da leitura e da escrita. É, portanto, em nome exclusivamente de sua competência técnica que a presença do antigo professor é defendida. A população, nessa disputa local, exige um direito: o direito de as crianças irem à escola para aprender.

\section{Escola e família, público e particular}

Compreender a lógica da escolarização supōe identificar algumas intersecções entre escola e família, entre comunidade local e poderes públicos, entre a criança e o adulto, entre as classes sociais e as classes escolares. O estudo da escolarização como variável histórica e social tem algumas regularidades passíveis de serem apreendidas. Há, contudo, variantes, especificidades, diferenças, deslocamentos... Na identidade, percebe-se o lugar do outro. Desse modo, ao percorrer esse imaginário que dialoga com a acepção de escola pública em Portugal no período compreendido entre 1820 e 1910, verificaremos inúmeros paradoxos; coisas que se punham de um modo e subitamente apareciam de outro. Temos por exemplo motivos para acreditar que a população portuguesa, no período em pauta, valorizava e desprezava a escola; queriam-na e rejeitavam-na. Depende da clave por onde olhemos... De qualquer maneira, talvez, em história, as grandes generalizaçôes sejam, ao fim e ao cabo, somente mesmo uma força de expressão, um recurso para possibilitar o relato coerente. A ambigüidade se mantém. Havia indiferença pela escola; mas havia, na outra margem, quem lutasse por ela.

A averiguação feita a 20-7-1822 pelo Comissário dos Estudos de Lisboa - António da Costa - decorria de uma situação, tida por anômala, do professor António dos Santos Albano Gonçalves Lima. Por que esse indivíduo tinha apenas 14 discípulos? Era ou não verdade aquilo que dizia a vizinhança: que ele não queria ter mais alunos? Comentava-se, de fato, que, desde que se havia proibido que os mestres aceitassem dinheiro de seus alunos, a escola - que anteriormente andara cheia - teria perdido consideravelmente os alunos que tinha. $\mathrm{Na}$ verdade, entre os anos 1816-17, o rei promulga uma determinação que impedia os mestres de receberem dinheiro por lições em escolas públicas, prevendo inclusive pena de suspensão para punir quem desrespeitasse essa prescrição. O professor em tela, segundo o parecer do Comissário dos Estudos, ficou bastante descontente; e o número de seus discípulos foi, a pouco e pouco, diminuindo. Isso porque o professor faltava muito às aulas e, além do mais, tratava as crianças com aspereza; e, por isso,

“o número dos Discípulos se reduzia cada vez a menos. Assim chegou a não ter o ano passado mais do que esses 14 que apontam no Mapa do ano letivo próximo passado, segundo diz a referida Régia Provisão. E deve notar-se que os dito 14 Discípulos foram os que por todo o decurso do dito ano passado entraram e por algum tempo, frequentaram aquela Escola; porque, sucedendo de ordinário, mui principalmente nas escolas de Primeiras Letras, em todo o decurso do ano despedirem-se delas muitos dos Discípulos que as frequentam, passando-se 
delas para outras, ou seguindo outros destinos; aqueles que atualmente a frequentavam ao mesmo tempo nunca naquele ano chegarão a $14 .{ }^{\prime 190}$

Procurando tecer algumas considerações suplementares sobre a situação do professor e do ensino, o Comissário recorda que a casa de escola havia sido alterada pela altura do Natal. Ele resolve, então, fazer uma visita às novas instalaçôes no dia 8 de janeiro. Chega lá mais ou menos às 10 da manhã. A escola contava, naquele dia, com apenas duas crianças. O mestre disse-lhe que eram aqueles dois meninos os únicos alunos que tinha. Ao ser questionado sobre as razões de tão diminuta freqüência, atribui esse fato à mudança das instalações da escola. Mas o Comissário não se convence, cônscio que estava de outros casos onde a mudança de endereço não teria trazido tanto prejuízo à freqüência escolar. Em geral, ao mudar o estabelecimento para outro sítio, os professores costumavam de imediato perder um ou dois alunos, mas logo adquiriam outros, provenientes das novas redondezas. Insatisfeito, portanto, com o estado em que encontrara a escola, o Comissário dos Estudos regressa lá em 27 e 28 de março. Chegando ali por volta das 9 h30 havia 7 discípulos, que lhe pareceram todos 'mui meninos'. O mestre esclarece que faltavam às aulas naquela ocasião apenas 2 , sendo que ambos eram também - como reconhecia o docente - principiantes. O Comissário é assim levado a crer que os meninos não eram efetivamente capazes de aturar a permanência na escola, desaconselhados que, ainda por cima, seriam tanto por seus pais quanto pelo próprio professor.

"Que este homem nenhum cuidado tem da Escola, e só trata de desfrutar o Ordenado, tudo
quanto tenho observado nele desde o fim de 1816, em que comecei a servir, m’o confirma.
No princípio, até ele tratava de desfrutar os pais dos discípulos, pagando-se deles. Se algum
não pagava, não o tinha com os outros, mas em uma casinha pequena próxima à da Escola, e
pouco clara, à qual na Escola se chamava segredo. Um homem, que lhe era mui vizinho,
e ali mandava um afilhado, e que no princípio (por ser a Escola Pública) não estipulou preço
com o Mestre, referiu-me que, vendo um dia sair da escola uns poucos de rapazes, lhes pergun-
tava como ia lá o que era seu afilhado. Reponderam dizendo: esse está no segredo. Informado
do que isso queria dizer, e conhecendo que era preciso pagar, procurou falar com o Mestre, per-
guntou-lhe quanto se dava, e ficou pagando 600 réis por mês, enquanto de lá o não tirou." 191

A mulher do professor era - como anota o Comissário António de Castro - mestra de uma escola de meninas que funcionava na mesma freguesia. Atrevidamente, a senhora havia - por sua vez - repelido uma intimação que lhe havia sido feita pelas autoridades, pelo fato de ela também costumar cobrar proventos aos pais dos alunos pelos seus serviços em escola pública. $\mathrm{Na}$ ocasiāo, ela teria agido de maneira extremamente grosseira, tendo desafiado o próprio Comissário, alardeando que não aturaria mais aquilo. António de Castro estava, porém, convencido de que, apesar das ameaças em contrário, tanto ele como ela não deixariam por livre vontade o magistério público, dado que recebiam ele $140 \$ 000$ réis e ela $100 \$ 000$ réis. Além do exercício da

\footnotetext{
${ }^{190}$ Coleção de Manuscritos da Biblioteca Geral da Universidade de Coimbra, códice 1341, folha 119.

${ }^{191}$ Coleção de Manuscritos da Biblioteca Geral da Universidade de Coimbra, códice 1341, folha 119.
} 
docência, o professor António dos Santos Albano Gonçalves Lima era também empregado em uma Contadoria do Tesouro Público, onde deveria comparecer todos os dias também às 9 h00 da manhã. Se estava na escola, faltava a esse outro serviço. Como poderia ele estar nos dois lugares ao mesmo tempo? Mesmo assim, o tempo corria e a situação anômala era, pela inércia, mantida e assegurada:

A oposição escola-família curiosamente aparecia até nos registros variados de abaixoassinados por populaçôes locais e aldeãs que vinham solicitar dos poderes públicos o oferecimento de escolas primárias que permitissem às crianças o contato particularmente importante com a habilidade da leitura, da escrita e do cálculo. Muitas vezes, até quando o professor pretendia a mudança da escola, a população não aceitava e procurava impedi-lo. Em nome da escolarização, não se via mal algum em brigar com o próprio mestre-escola. Aparentemente não se supunha, nem sequer se reivindicava, que a juventude pudesse aprofundar seus estudos, obtendo acesso ao ensino de liceus, por exemplo. Não se esperava que a maior parte das crianças fosse mais do que alfabetizada e moralizada pela ação escolar. Desejava-se exclusivamente que houvesse a possibilidade do conhecimento de habilidades rudimentares para a civilização do escrito, o que possibilitaria desenvoltura do jovem no mundo e nas atividades citadinas. Além disso, solicitava-se da escola que ela impregnasse o estudante de atitudes e roteiros de conduta social considerados como moral e religiosamente adequados. Nesse sentido, podemos ler a carta subscrita em 18 de Março de 1857 por 61 pessoas da freguesia de Vallongo no concelho de Águeda. Os signatários haviam se surpreendido e manifestavam na ocasião sua perplexidade diante do então recente edital do Conselho Superior de Instrução Pública de Coimbra, que mandava pôr a concurso a cadeira de instrução primária de primeiro grau estabelecida no lugar de Arrancada daquela mesma freguesia. Na verdade, os signatários recordavam que a referida cadeira, desde que havia sido há oito anos deixada pelo Professor Padre José Pinheiro dos Santos, tinha tido por volta de cinco professores - uns após outros, transferidos sempre -, de modo que os alunos não conseguiam ter qualquer aproveitamento significativo em função mesmo da diferença dos métodos de ensino entre os vários e sucessivos professores. A cadeira estava então preenchida e finalmente ocupada pelo mestre Joaquim Daniel de Oliveira Araújo, considerado muito digno, sendo sua conduta pedagógica apreciada por aqueles conterrâneos. Esse professor efetivamente parecia satisfazer as expectativas dos pais que viam, pela primeira vez em muito tempo, seus filhos se aperfeiçoando no rol de saberes que constituíam o conhecimento especificamente escolar.

Os abaixo-assinados - estudantes, proprietários, negociantes, escrivãos, juízes, regedores, professores e outros habitantes - optaram por não declarar seu vínculo profissional. Seriam talvez empregados em um ofício qualquer e não propriamente profissionais liberais como os anteriores? Solicitavam o cancelamento da mudança do atual professor - mudança essa que, aliás, estava ainda em vias de se realizar - com a pretensão de impedir que a cadeira de Arrancada viesse a ser ocupada por aquele outro indivíduo que, por sua vez, enquanto ocupara há tempos atrás a função de professor interino naquela mesma localidade, pôde ficar já conhecido pelos habitantes como alguém pouco recomendável em termos de costumes e de responsabilidade pelo ofício que então exercia. $\mathrm{Na}$ verdade, cometia muitas faltas, como aliás parecia continuar a cometer, posto que, ocupando o lugar de professor em uma freguesia próxima, diziam os requerentes que passava semanas inteiras sem sair de sua terra, 
faltando às aulas que deveria estar ministrando. $\mathrm{O}$ pedido revela indubitavelmente o desejo da instrução, mas uma instrução controlada e fiscalizada pela comunidade familiar, que não pretende delegar, mas apenas provisoriamente emprestar uma parcela de sua responsabilidade educativa à instituição escolar. Os registros revelam inúmeras vezes a perspectiva de pais e de familiares como considerando a si e a seus filhos mais importantes do que os próprios professores, sobre os quais propunham tantas vezes que fosse centrada a educação das crianças. Os mestres da infância não pareciam ser tomados, na grande maioria das vezes, pelo valor intrínseco que revelavam na tarefa educativa, mas antes pelo valor instrumental que possuíam na serventia das populações e das teias familiares.

Não eram eram poucas as acusações contra professores que, lecionando em estabelecimentos públicos, mesmo assim cobravam pelo trabalho, exigindo pagamento das famílias que lhes confiavam seus filhos. Alguns desses processos haviam sido impetrados por parte das comunidades locais contra os docentes. Percebe-se que tal problema acompanha o século e muitas vezes o professor primário era assim encarado sob o prisma da suspeita. Bento d'Oliveira Pereira era professor público primário da cidade de Braga desde o ano de 1852 e foi apenas em 1871 - 18 anos depois de seu ingresso no magistério - que requereu pela primeira vez uma licença que lhe foi concedida pelo Comissário dos Estudos, em atenção ao seu significativo tempo de serviço (19 anos) e ao modo dedicado com que ele sempre lidara com o exercício do magistério. $\mathrm{Na}$ verdade, o professor alegava que desejaria aproveitar a possibilidade de obtenção de licença para ter aulas de alemão no Liceu de Braga, bem como para habilitar-se e aprimorar seus conhecimentos em agricultura e em economia rural. O gosto pelo estudo era apontado como característica desse docente, cujas curiosidade intelectual e erudição haviam já se manifestado nos próprios exames de instrução primária que prestara em 20-12-1856 para conseguir lugar de opositor da primeira cadeira de Braga, sob a responsabilidade do então Comissário dos Estudos António Maria Pinheiro.

$\mathrm{O}$ professor Pereira tinha começado sua carreira regendo a cadeira de Boticas no distrito de Vila Real, onde ainda recebia provimentos temporários. Nas férias de 1856 ele adoeceu e como conseqüência pediu exoneração, deixando a função de professor em Boticas. Naquele mesmo ano - como já pudemos observar - presta concurso para professor primário da cidade de Braga e destaca-se a tal ponto no resultado de seus exames que o Comissário dos Estudos, sobre o caso, chegou a ter comentado que, embora o outro concorrente não fosse destituído de habilidades, "poucos são os opositores a cadeiras desta disciplina que possam com ele [Bento d'Oliveira Pereira] competir." 192 Naquela ocasião, o próprio Bento d'Oliveira Pereira dirigia ofício ao presidente e aos vereadores da Câmara de Boticas, solicitando deles um atestado onde se registrasse alguns dados a propósito de sua conduta docente na cidade.

“(...) qual é a sua conduta moral, civil e política; qual o seu Método de ensino; aproveitamento de seus alunos, e se nisso tinha o maior zelo e brio, pelo que se tornasse digno de louvor, bem

${ }^{192}$ Arquivo Geral das Secretarias do Estado constantes dos Arquivos Nacionais da Torre do Tombo, MINISTÉRIO DO REINO Mç 3882. 
assim se afluíam à sua escola estudantes de diversos concelhos e mesmo fregueisas deste; como tudo o mais que V. Sas. tenham propriamente observado não só em seus Meninos; mas também aos pais de alunos que têm sido educados por este professor (...)"

A resposta - datada de 8-11-1856 - absolutamente induzida, veio, como era de se esperar, nos conformes, de acordo evidentemente com a expectativa do proponente:

"Atestamos para constar onde convier em como Bento de Oliveira Pereira é de boa conduta Moral, Civil e Política, bem como desde 1852 (...) mostrou-se sempre, pelo seu bom método de ensinar, grande aproveitamento aos seus discípulos, por cujo motivo afluíam a esta cadeira alunos de diversas partes tanto de fora do Concelho como das freguesias deste mesmo Concelho (...)"

Quando terminou o ano letivo de 1863-64, o professor Bento d'Oliveira Pereira teve problemas: um jornal local - a 7-7-1864 - efetuara acusaçôes contra sua prática docente, o que conduz a um processo administrativo no qual foi averiguada a legitimidade das seguintes acusaçōes: 1) que o professor cometia muitas faltas e se fazia substituir, em tais ocasiōes, por pessoa pouco habilitada; 2) que exigia pagamento de seus alunos pelas aulas ministradas, não se preocupando em promover o adiantamento dos que nada lhe pagavam; 3) que costumava praticar abusos, vexações e extorsões contra professores seus colegas por ocasião dos concursos às cadeiras de instrução primária em que servia de examinador.

Inquirido para que respondesse àquelas três acusações, o professor Pereira, em 23-10-1864, responde ao ofício que lhe fora encaminhado a 17-10-1864 pelo administrador do Concelho de Braga. Acerca do que qualifica como calúnias de que teria sido vítima, o professor declara ser público e notório que tais acusaçôes eram falsas e promovidas por "dois ou três indivíduos, meus inimigos declarados." 193 Mas, pelo fato de ser julgado perante a Direção Geral de Instrução Pública, ele anexava à sua resposta documentos e atestados de boa conduta moral e civil provenientes do Administrador do Concelho e da Câmara Municipal, do Comissário dos Estudos e do Governador Civil do distrito, do inspetor das escolas, da Junta de Paróquia da cidade de Braga e de seus antigos alunos. Incluía ainda no processo um abaixo-assinado de professores e candidatos a professores de vários distritos, do Minho e de Trás-os-Montes, protestando contra aquelas anônimas acusações que o jornal se dispusera a fazer. Todos, nesse caso unidos, desmentiam a falsa acusação feita no referido periódico e, segundo o professor, já devidamente respondida. $\mathrm{O}$ acusado, sentindo-se ultrajado, solicitava então que o caso fosse levado aos tribunais, de maneira que a calúnia de que fora vítima fosse efetivamente punida. Os integrantes do Conselho Superior de Instrução Pública - reunidos em 4-7-1865 - absolveram o acusado. $\mathrm{O}$ caso foi assim encerrado, com o reconhecimento de que se tratara apenas de uma intriga motivada por excusos interesses e desavenças pessoais. Aliás, a solidariedade que, por vezes, parecia existir entre o professor de escola e as comunidades aldeãs era, em muitos casos, atrapalhada pela presença de mestres livres, que ministravam lições particulares. A presença de tais indivíduos era frequentemente encarada como sintoma

${ }^{193}$ Arquivo Central das Secretarias de Estado, constante dos Arquivos Nacionais da Torre do Tombo, MINISTÉRIO DO REINO Mç 3882. 
de possível desequilíbrio, fundamentalmente em virtude de - conhecendo maneiras alternativas de proceder ao ensino - as famílias que dispunham de razoáveis condiçōes financeiras pagarem para que os filhos fossem à escola. Na verdade, era habitual haver queixas, por parte de antigos professores régios, quanto aos métodos e aos procedimentos de ensino daqueles que lhes faziam explícita concorrência.

Ao experimentar outros códigos de comportamento e diferentes padrôes normativos para suas atitudes escolares, os alunos habituavam-se, de acordo com o redator, à indisciplina, à irregularidade no comportamento cotidiano e à desobediência às autoridades. Os alunos, muitas vezes, ao regressarem para a escola pública, não mostravam sequer disposição para acatar seus princípios e as regras que determinam a dinâmica da sua rotina escolar. Isso tornava-se um problema de grandes proporçóes para todos os que, de um modo ou de outro, dedicavam-se ao ofício do magistério nas escolas oficiais: os alunos não eram capazes de extirpar vícios contraídos. Ainda de acordo com esse depoimento, tal situação levava mesmo ao descontrole quanto ao tempo e à duração da aprendizagem. Os pais mudavam os filhos de escola; depois enviavam-nos de volta para o professor régio. Nessa oportunidade, as crianças já haviam sido mal habituadas e custavam muito mais a obedecer. Não obedecendo, evidentemente, não aprendiam com a mesma prontidão. Havia, enfim, por causa disso, uma diminuição do aproveitamento dos discípulos na aquisição das habilidades da leitura, da escrita e do cálculo. O proponente sugeria uma reforma alfabética e silábica, pautada por noções que teriam sido por ele mesmo desenvolvidas em um opúsculo que havia publicado e que, na mesma ocasião, enviava como anexo. Verificamos já que a procura pela uniformização era um dos traços dessa modernidade educativa que Portugal pretendia efetivar. A homogeneidade escolar, que passava pelos conteúdos e pelos compêndios, na configuração de uma única grade curricular, parecia ter como finalidade última a eficácia dos padrōes de ensino-aprendizado. Estávamos no tempo da invenção do método: nele eram postas - como se pôde observar pelo discurso de Castilho - todas as esperanças de redenção e de regeneração da escola portuguesa. Havia de se descobrir uma teia entretecida de significados, de rituais, de colorações simbólicas e pedagógicas que construíssem não apenas o rol de conhecimentos de que a escola se encarregaria de transmitir, mas fundamentalmente o conjunto de técnicas pedagógicas que permitiria efetivamente a incorporação de tais saberes e de tais valores por parte daqueles que eram por excelência o objeto e o alvo da ação escolar: os educandos.

Nóvoa ressalta, para o caso português, a relevância dos processos de profissionalização do professorado como critério socio-histórico de análise, elucidativo da dinâmica que teria pontuado o percurso da escolarização. Para Nóvoa, compreender a história da rede escolar tem por suposto a apreensão desse 'tempo dos professores', ou da constituição de um corpo valorativo de normas específicas da profissão docente. Tal repertório, conjugado a um conjunto de saberes e de técnicas, demarcaria a nascença de um saber pedagógico, reservado apenas aos que se consagrassem no campo da instrução como especialistas. A história da pedagogia é, então, percebida pelo referido autor por um filtro muito específico: a história da profissão-professor ${ }^{194}$. Ocorre que

\footnotetext{
${ }^{194}$ No parecer de António Nóvoa: "a elaboração de um corpo de saberes e de técnicas é a consequência lógica do interesse renovado que a Era Moderna consagra ao porvir da infância e à intencionalidade educativa. Trata-se mais de um saber técnico do que de um conhecimento fundamental, na medida em que se organiza preferencialmente em torno
} 
- como também recorda o trabalho de Nóvoa - historicamente a codificação dos saberes, do saber-fazer, do conteúdos, das técnicas e das estratégias de ensino; enfim de tudo o que pode ser classificado como critério constitutivo da atitude docente, não teria sido pensado, de maneira geral, pelo próprio professor, sendo antes uma imposição heterônoma proveniente da Igreja, do Estado, das classes e setores dominantes. Não havendo, pois, formulado sua regra de ação, o professor se apropria desse referencial que a pedagogia lhe oferece e passa a agir em nome dele. A pedagogia torna-se, nessa medida, a invocação teórica de uma rede de práticas, em princípio, frequentes em sala de aula. Qualquer generalização tende, todavia, a elidir a particularidade dos fatos e dos eventos, posto que apreende apenas a regularidade da questão. Admitindo que todas as regras comportam exceçôes, constataremos que existiram professores que desejaram estabelecer eles mesmos as regras, acreditando estar com isso a inventar novos procedimentos, mais apropriados e adequados à sua prática docente. Teriam sido esses professores que pensaram seus próprios métodos e maneiras de ensinar melhores do que aquele que não se importavam com isso? Voltemos um pouco atrás...

\section{A composição dos saberes escolares sob o signo da memória}

O professor régio Jacob Lopes d'Almeida escreveu em Novembro de 1826 um regulamento para ser adotado em suas aulas de modo que seus discípulos viessem a utilizá-lo, a respeitá-lo, a segui-lo, tendo em vista o pleno cumprimento das orientações e das regras escolares. Com a frequente leitura para os alunos das prescrições contidas no regulamento, o professor supunha que o trabalho escolar viria naturalmente a se organizar com maior eficácia e que os possíveis castigos por não cumprimento das normas poderiam vir, consequentemente, a diminuir, visto que os interessados teriam mais elementos para recordar, de modo sistemático, o rol de deveres que regia o dia-a-dia da escola. Tratava-se na verdade, de uma tentativa sistematizada por parte do docente para inserir no cotidiano escolar um conjunto de ritos e de símbolos distribuídos ordenadamente pelo tempo e pelos horários. Isso criaria uma rotina capaz de dar o tom das atividades do espaço e do tempo escolar. A busca pelo ensino simultâneo parecia também ser perseguida por esse professor. Poderíamos suspeitar da existência de uma intenção normativa nessa procura de conferir ao cotidiano uma regularidade sistêmica.

A escola deveria ser aberta no verão às 7 da manhã e à tarde às 3 . No inverno, a abertura da escola ocorreria às 8 pela manhã e às $2 \mathrm{da}$ tarde. Todo o estudante que não chegasse nesse horário estabelecido receberia 2 palmatoadas.

"Os que vierem antes daquele tempo nunca se aproximarão da Escola sem que o Professor dê sinal de que são chegadas as horas para nela deverem entrar; e se fora estiverem fazendo

\footnotetext{
dos princípios e das estratégias de ensino. A pedagogia introduz uma relação ambígua entre os professores e o saber, a qual atravessa toda a sua história profissional: assinale-se, a título de exemplo, que a hierarquia interna à profissão docente tem como critério um saber geral e não um saber específico (isto é, um saber pedagógico). Por outro lado, é importante sublinhar que este corpo de saberes e de técnicas foi quase sempre produzido no exterior do 'mundo dos professores', por teóricos e especialistas vários (António M.S.S. da Nóvoa, História da educação, p. 203) .”
} 
gritarias, algazarras, ou outras ações indignas, que mostram o pouco respeito que têm ao Mestre - o qual devem supor que os está ouvindo e vigiando - e que também não receiam o castigo o terão de 3 palmatoadas. Quando entrarem na Escola, ou saírem dela, o farão 2 a 2, e nunca de montão nem encontrando-se uns aos outros; ao primeiro passo que puserem dentro dela dirão em voz que bem se ouça seja com a cabeça descoberta e o chapéu na mão direita caído pela perna do mesmo lado: 'Louvado Seja Nosso Senhor Jesus Cristo'. E assim mesmo, 2 a 2, chegarão respeitosamente a seu Mestre, a quem saudarão, com os bons dias, sendo de manhã, e depois do jantar com as boas tardes, e tendo ele recebido a benção com a cabeça um pouco inclinada, irão com o mesmo sossego, tomar os seus lugares, assentando-se em boa figura, corpo direito e pés bem postos, e principiarão a estudar sem que lhes importe mais nada; o que faltar a isto tem a pena de 2 palmatoadas." 195

O professor entendia que a principal obrigação dos educadores da infância e da juventude era instruir a mocidade nas máximas religiosas e em tudo o que fosse relativo ao culto de Deus e à salvação da alma. Para essa meta, os alunos eram ordenados a se confessar periodicamente - ao menos de 2 em 2 meses - e a apresentar à escola declaração comprobátoria redigida pelo sacerdote, assegurando a confissão. Quem não cumprisse esse dever, deveria, como castigo, sentar-se no chão por 3 dias, além de ' 6 grandes palmatoadas'. Era também expressamentee proibido aos alunos subirem à torre para tocar o sino da igreja, nas festas ou em qualquer ocasião. Tal atitude seria considerada grave contravenção e estaria sujeita por tal razão a ser punida com 2 palmatoadas. Entrar na Igreja exigiria, por sua vez, o cumprimento de um dado ritual de devoção, que passava pelo toque da água benta, levemente, sem desperdício, sem jogá-la no chão, mas de modo sereno, com as pontas dos dedos da mão direita. Depois, o estudante deveria seguir com a cabeça inclinada para dirigir-se em direção do altar, para ajoelhar-se e rezar o ato de contrição, bem como outras oraçôes. Faltar com esse cerimonial produziria pena de 4 palmatoadas.

Percebe-se a pressuposição de que os delitos nomeados efetivamente ocorriam e faziam parte do universo de tentaçôes do qual a criança deveria buscar fugir. A distração é vista com um grande mal, assim como os chistes e os gracejos da infância. A própria brincadeira, é aceita com reticência. A alegria, o espontâneo, as travessuras, devem ser, sistematicamente, substituídas por práticas rituais reveladoras de auto-domínio - o que passa pelo recurso ao medo, ao temor: dos pais, dos professores, mas também do padre que confessa, do ato de contrição que delata, e, em especial, de Deus, que tudo vê. Para a disciplinarização dos gestos, para a arquitetura de controle de corpos e de coraçôes, viria a narrativa escolar; uma toada ancorada em recursos da Igreja e da religião e que deveria conduzir as crianças a aceitarem o mundo tal qual ele é. Pela âncora da religiosidade, povoar o mundo adulto exigiria do estudante treinos constantes de conduta. Para adestrar o mundo infantil, no perigo da dispersão que poderia, aos seus olhos, vir a corrompê-lo, o professor recomenda práticas de civilidade:

"Todo o meu discípulo que for apanhado ou visto a tomar qualquer coisa em casa ou fazenda alheia, ou danificar alguma pessoa com ações ou palavras decompostas e menos decentes, tem,

\footnotetext{
${ }^{195}$ Coleção de Manuscritos da Biblioteca Geral da Universidade de Coimbra, códice 2523, documento nº 22.
} 
indo depois a dobrar, o castigo, pela primeira vez, de 6 grandes palmatoadas. Na vinda e ida da Escola, e assim ao deitar e levantar da cama, e também todas as vezes que comerem, os meus discípulos pedirão e tomarão a benção de seus pais ou superiores sempre de joelhos; e nunca se cobrirão diante deles, nem se apresentarão em público na sua presença, mas, em toda a ocasião ou lugar, os tratarão com muito respeito, amor e obediência; como pessoas a quem mais devem depois de Deus." 196

Dever-se-ia, como recomenda a Bíblia, amar a Deus sobre todas as coisas e desse amor a Deus seria desmembrado o amor ao Rei, como se a monarquia tivesse sua justificativa ainda no direito divino do monarca soberano. Vassalos de Deus e do Rei, em primeira instância, os estudantes teriam a "filial obrigação" de obedecer a suas "paternais determinaçôes", sem fazer qualquer oposição aos poderes da Coroa, por ações ou por palavras; mantida a obrigação moral de delatar todo aquele que conspirasse contra a autoridade constituída. Ao fazer isso, a escola prepararia o súdito obediente, cioso, respeitoso e fiscalizador dos riscos da transgressão. A escola teria como prioridade em seu currículo o ensino do lugar simbólico da autoridade: autoridade que supunha fidelidade; fidelidade esta superior ao próprio dever de lealdade, já que competia ao jovem denunciar qualquer companheiro que houvesse se pronunciado contra a ordem das coisas.

$\mathrm{Na}$ saída da escola, os estudantes deveriam dirigir-se imediatamente para suas casas. A saída e entrada eram inequivocamente os momentos do perigo, deixando inquietos pais e educadores. Lá concentrar-se-ia o tempo das tentações. $\mathrm{Na}$ fronteira entre o muro da escola e a porta para o mundo, os estudantes teriam no grupo um poder; o poder coletivo que os mestres e os pais não conseguiam controlar, não eram capazes de deter. $\mathrm{Na}$ entrada e na saída das aulas, imperava o reinado absoluto da juventude escolar, sem, entretanto, a constrição do dever e da disciplina impostos pelos adultos da escola, adultos esses que são, nesses fortuitos e fugazes minutos, objeto de troça e diversão. Mais do que nunca, é na entrada e na saída da escola que essa juventude, essa meninice, reconhece e explora um poder que lhe é dado pelo pouco que viveu. Parece-lhe sempre que há a vida toda pela frente, que essa vida será tão longa quanto eterna, que todo o poder será um dia dos meninos... Por essa razão talvez é tão frequente o tom de indiferença com que a juventude lida com a experiência dos mais velhos; essa juventude que, ao entrar e ao sair da escola, deseja intensamente viver à prova da aventura. Um poder que não é visto dificilmente pode ser fiscalizado. Nesse momento acontecem, com maior freqüência, as conversas mais soltas, mais atrevidas, mais irreverentes. Nesses minutos de transição entre a família e a escola - a entrada e a saída das aulas - não haveria autoridade que detivesse a força, a imaginação, a aliança, a agilidade, o buliço... da rua. Nessa ocasião, fortalecida pela senha que lhe oferece o espírito de grupo, a infância é solidária apenas aos códigos que lhe são próprios, que lhe são específicos, em um território onde adulto definitivamente não entra. A força do grupo era o medo da escola. Temia-se o momento da saída: as crianças, sem olhar para trás, sem olharem-se umas às outras, deveriam dirigir-se rapidamente para seus lares. Lá estariam protegidas por seus pais.

${ }^{196}$ Coleção de Manuscritos da Biblioteca Geral da Universidade de Coimbra, códice 2532, documento nº22. 
Lá, os adultos também estariam delas protegidos. Não se demore, pois, o discípulo no caminho, "e não molestarão uns aos outros com pancadas, empurrões, palavras ou açôes injuriosas e malsoantes, e nem a outra alguma pessoa." ${ }^{197}$ Do contrário, quatro palmatoadas era o castigo aplicado.

Do dever de amar a Deus sobre todas as outras coisas, escola tira como ilação, o incondicional amor a ser prestado aos pais. ${ }^{198}$ Não se questiona em hipótese alguma o tipo de relação mantida entre pais e filhos, nem as relações de poder que estariam postas na dinâmica familiar. Enquanto prolongamento da estrutura divina, a família é vista como a célula primeira, a partir da qual a reprodução do mundo e do homem é possibilitada. Daí serem naturalizadas as interações entre os diferentes sujeitos no campo familiar e, no caso, a criança tem - não importa sob que condições - o dever imprescritível de ser grata eternamente a seus pais, mesmo que estes eventualmente não demonstrem grande correspondência a esse amor. Do amor aos pais são desmembrados feixes de patriotismo devoto, como se a nação fosse, em sua essência, um prolongamento da família. A obrigatoriedade do respeito e da obediência incondicional aos pais é talvez a primeira grande constrição sofrida pelo gênero humano. A escolarização da modernidade traz justificativa teórica para esse dever e, assim, a criança - cada vez que manifesta algum pensamento ou sentimento destoante - imediatamente sofre o sentido da culpa, dado que há um Deus que a tudo observa e a todos os faltantes deverá punir. O amor irrestrito pelos pais é, além de tudo, um grande álibi para justificar a necessidade de dependência e obediência que, como é óbvio, revela-se o corolário natural dessa natureza do amor filial. É álibi por justificar a sujeição. Obedientes, por seu turno, as crianças tornar-se-iam mais controláveis...

\begin{abstract}
"Depois de estarem dentro da Escola, não brincarão, rirão, olharão para fora, nem lhes importará quem passar defronte, o que obrar o contrário e se distrair com outras coisas tem a pena a dobrar de 2 palmatoadas. Quando entrar qualquer pessoa na Escola, todos se levantarão imediatamente e ficarão de pé até que o Professor os mande assentar, e em todo este tempo darão mostras de boa educação, respeito e civilidade, estando quietos e bem concertados; o que assim não obrar tem a pena de 4 palmatoadas. Espirrando o mestre, todos se erguerão dizendo: viva! E se assentarão ao responder ele: obrigado." 199
\end{abstract}

As minúcias do regulamento visavam o controle total do estudante por parte do vigilante olhar de seu mestre. A instituição escolar, que furta a criança do convívio familiar, isola-a dos maus modos, mediante o treino contínuo - que possibilita a ulterior incorporação - de toda uma política do detalhe, de um código de atitudes de polidez. Enquanto isso, os olhares, os gestos, as palavras, os sons, os movimentos, tudo isso é estritamente controlado pelo professor, que - para usar a qualificação de

${ }^{197}$ Coleção de Manuscritos da Biblioteca Geral da Universidade de Coimbra, códice 2532, documento nº 22.

${ }^{198}$ A esse respeito, vale lembrar que Rogério Fernandes já observava em seu trabalho sobre as práticas da escola primária em Portugal do Antigo Regime que "uma das concretizações do dever de obediência residia na subordinação total dos filhos à vontade dos pais. O normativo social impunha a obediência incondicional à hierarquia familiar (Rogério FERNANDES, Os caminhos do ABC: sociedade portuguesa e ensino de Primeiras Letras, p. 483) ."

${ }^{199}$ Coleção de Manuscritos da Biblioteca Geral da Universidade de Coimbra, códice 2532, documento nº22. 
Foucault - "marca lugares e indica valores" 200 . Tratava-se efetivamente de uma organização do múltiplo, do disforme; mas significava também agendar a previsibilidade daquilo que é, por definição, o fortuito, o indeterminado, o incerto. Acreditava-se, por meio disso, na possibilidade de regrar o futuro. $\mathrm{O}$ ensino simultâneo - aquele em que o professor trata o coletivo da classe como se se tratasse de um único aluno - é aqui almejado, não enquanto modalidade de instrução, mas como uma forma educativa mais eficaz para a obtenção do controle geral sobre o conjunto dos estudantes. A escola desse regulamento, como temos visto, parece um estabelecimento voltado antes para a reza do que para as letras. As crianças deveriam sim frequentar aquela instituição, mas com a finalidade precípua de introjeção de hábitos e de atitudes postos como adequados para uma ordeira e pacata vida social. O controle do corpo era, para tanto, tarefa primordial:

\begin{abstract}
"Não lhes é permitido bocejar, espreguiçar-se, nem estarem-se arranhando indecentemente, com todas as unhas, na Cabeça ou outras partes do corpo; por serem açôes estas que bem podem deixar de fazer-se sem prejudicar a saúde; e que pelo tempo adiante se tornarão viciosas, além de serem nojentas e pecaminosas, no meio de uma sociedade bem educada; a quem igualmente escandaliza e ofende muito o meter a mão na braguilha ou outras partes desonestas. Todo o meu discípulo deve evitar estes defeitos, e não o fazendo tem por cada vez a pena de 2 palmatoadas. Quando se lhes abrir a boca involuntariamente, por ser isso uma ação a que não pode obstar-se, acudirão logo a cobri-la com a palma da mão que estiver desocupada, para assim encobrirem o que esta ação tem de nojenta e feia; o que assim não fizer tem a pena, por cada vez, de duas palmatoadas. Escarrarão brandamente entre os seus pés, e com estes, sem fazer grande estrondo, esfregarão os escarros de forma que nada se veja deles; o que assim não praticar tem a pena de 2 palmatoadas. Todos trarão seus lenços ou paninhos nas algibeiras para se assoarem e limparem, quando disso necessidade tiverem; o que devem fazer sem estrépito nem olharem para o que tiram do nariz; pois que lhes não é permitido assearem-se as mãos, por ser esta uma ação em si muito porca e nojenta; o que não cumprir este artigo em tudo tem a pena por cada vez de duas palmatoadas." ${ }^{201}$
\end{abstract}

Qualquer falta à escola, ainda que em casos de justa causa, deveria ser acompanhada ou por um bilhete ou pela justificativa efetuada por alguém que, com responsabilidade, desculpasse a criança. Se o aluno aparecesse na escola depois de um dia em que não pudera ir sem o bilhete e sem o acompanhante para justificar a ausência, receberia de imediato quatro palmatoadas. Todas as semanas, os alunos recebiam oraçôes de doutrina para decorarem em casa. Quando não eram capazes, na segunda-feira logo a seguir, de recitar a oração da semana anterior, mostrando que não fizeram caso em aprendê-la - mesmo que tentassem (nos termos do regulamento) enganar seus mestres, alegando que haviam perdido o papel escrito -, receberiam três palmatoadas, devendo pemanecer por um dia em pé na escola; além evidentemente de serem novamente encarregados da mesma tarefa de decorar a oração prevista. $\mathrm{Na}$ mesma direção, todo aquele que não soubesse a lição após um ou dois dias de feriados receberia quatro palmatoadas.

\footnotetext{
${ }^{200}$ Michel FOUCAULT, Vigiar e punir, p. 135.

${ }^{201}$ Coleção de Manuscritos da Biblioteca Geral da Universidade de Coimbra, códice 2532, documento n²2.
} 
O estudante não era um qualquer e deveria afastar-se de toda companhia de garotos que não estivessem frequentando alguma aula. Entendia-se, na verdade, que havia o risco de, em excessivo e frequente contato com o mundo exterior à escola, os alunos desistirem da vida escolar. A ritualização da escola, de algum modo, constituía um prefácio para o mundo dos adultos e uma prevenção quanto à possibilidade do contágio perante os vícios, as mesquinhezas, os perigos e a obscuridade do imprevisível mundo exterior.

\section{O porteiro, o professor e o gaiato}

A escolarização pretende estruturar-se como aquilo que possibilita tirar a criança da rua. Seja pelo tempo que ocupa na vida da infância, seja pela responsabilidade que incute através de um conjunto articulado de saberes que contam do mundo, a escola põe a criança eternamente em dívida: dívida para com Deus, para com seus pais, mestres e superiores. Através dessa culpa imposta sob o signo do medo, julga-se que a criança mais facilmente se subordinará aos ditames da vida social. A instituição escolar produz a prática da obediência e da aceitação como pressupostos - transformando a ordenação social em reino de natureza. A escola convém à família, na medida em que é à família que o culpado-criança irá servir. Ocorre que a própria dinâmica da escolarização perpassa algumas contradições que devem estar postas na análise do objeto.

Em carta dirigida ao Rei, em 17 de julho de 1823, o Comissário dos Estudos de Lisboa António de Castro declara que havia sido informado que um estudante de nome Francisco Silva Ramos, da aula de Gramática Latina do bairro de Alfama comportava-se muito mal. Desrespeitava o culto às imagens místicas, tinha desprezo pela doutrina católica e chegou a dizer impropérios e ofensas diante de símbolos religiosos. Disse que as imagens eram apenas estampas e que serviriam para.... A partir daí, passa a usar uma linguagem chula e indecente. Seus colegas - continua o Comissário - ao ouvirem tais absurdos se teriam escandalizado e reprenderam o companheiro por falar daquela maneira. $\mathrm{O}$ menino, porém, não lhes deu qualquer atenção e continuou com aquele desenrolar de disparates e de ofensas. A insistência do colega motivou - segundo constava do documento - os demais rapazes do grupo a relatarem o que ouviam ao porteiro da escola, queixando-se daquela atitude que lhes "parecia intolerável". O porteiro, por sua vez, relatou o caso diretamente àquele Comissário dos Estudos, que dirige um ofício ao Padre Ramos, onde solicita informaçôes sobre o aproveitamento pedagógico do menino Francisco Silva Ramos, bem como quanto à sua conduta em termos de comportamento e costumes. O Comissário destacava, no referido ofício, que, se o professor não tivesse os elementos necessários para fornecer um relato fiel e confiável, que os procurasse, como fosse possível, para participar às instâncias superiores.

O professor então responde - em ofício dirigido em 3/7/1823 ao Comissário António de Castro - que nada existia para desabonar a conduta de seu discípulo, tanto em sua frente como fora dela. O aluno Silva Ramos tinha poucas faltas e não apresentava problemas de comportamento. Outrossim, o professor assegurava que tirara informaçóes junto à vizinhança onde ele morava, ao que fora informado que o menino era bem quisto e que se comportava bem. Finalmente, o mestre frisa que: "por isso, como eu só posso conhecer a conduta dos meus Discípulos, que praticam na minha ausência, 
sendo má, pelas queixas que se me fazem, e estas ainda não chegaram, só posso informar na verdade o que acabo de dizer." 202 Pelo texto, há veladamente a sugestão de que o Padre Ramos sabia já do que se tratava, sem, todavia, tocar no assunto, posto que o Comissário também ainda não o havia feito. Este último, entretanto, não parece acreditar na palavra do professor e levanta dúvidas quanto à veracidade das supostas informaçôes que, sobre o comportamento do estudante, haviam sido obtidas. Nitidamente, o Comissário declara duvidar das informações prestadas pelo docente, ilustrando nesse caso a complexa teia da microfísica do poder escolar. A hierarquia aqui perpassava nitidamente relações pessoais e de confiança, não apenas entre o mestre e seus discípulos, mas entre o porteiro e os alunos, e, finalmente - ou talvez principalmente - entre o porteiro e o Comissário dos Estudos responsável pela supervisão daquela escola, o qual, por sua vez, arrematava com o seguinte:

\begin{abstract}
"Mas duvido que seja assim: porque afirma o porteiro que apenas soube as expressóes escandalosas do estudante, lhe dera conta delas, e do como as sabia; e que ele, ouvindo-as com desprezo, lhe respondera que o estudante na sua presença sempre se portara bem e que não devia fazer caso do que diziam rapazes. Fazendo ao mesmo tempo mais alguma averiguação, falei com dois estudantes daquela aula e que conhecia por mais fidedignos; e também falei com o pai de um deles, e com o tio do outro; e o que por este modo alcancei, me confirmou o que me tinha referido, e achei em tudo conforme o que soube dos estudantes, com o que eles contaram em suas próprias casas, mostrando-se os mencionados pai e tio inquietos, considerando, um que seu filho, o outro que seu sobrinho andasse numa aula que também frequentava semelhante indivíduo. E como ao mesmo tempo vi que o que me dizia o Professor não justificava o Estudante, nem me podia fazer duvidar sobre o que acerca dele se me referia; pois que só o abonava no modo com que se portava na sua presença e no mais se dava por ignorante: não pude deixar de acreditar o que me constava; e assentei que devia d'alguma sorte proceder." ${ }^{203}$
\end{abstract}

Sucede que - continua o relato do Comissário - quando o estudante Silva Ramos teve notícias de que as autoridades poderiam vir a ser informadas pelo porteiro sobre sua conduta, tratou logo de pedir desculpas, dizendo-se arrependido e prometendo não mais dizer "semelhantes coisas", o que - nas palavras do Comissário - era um sinal comprobatório do delito, porque, assegurando que não mais falaria tais coisas, o estudante traía-se; "por conseguinte, reconhecendo tê-las dito" 204 . Entretanto, o menino

${ }^{202}$ A resposta do Padre Ramos, professor da referida turma de alunos, vem nos seguintes termos, datada de Lisboa, 3 de Julho de 1823: "em cumprimento da Ordem de Vossa Senhoria em que me determina que informe tanto a respeito do comportamento como do aproveitamento literário do meu discípulo Francisco Silva Ramos, o que posso informar a Vossa Senhoria é: que o seu comportamento na minha presença tanto na aula como fora tem sido excelente: a sua frequência com poucas faltas e não pouca aplicação e aproveitamento; e ontem mesmo, tirando informaçôes na vizinhança onde ele mora, me disseram que se comportava bem; por isso, como eu só posso conhecer a conduta dos meus discípulos, que praticam na minha ausência, sendo má, pelas queixas que se me fazem, e estas ainda me não chegaram, só posso informar na verdade o que acabo de dizer." (Manoel Joaquim Pires RAMOS, Coleção de Manuscritos da Biblioteca Geral da Universidade de Coimbra, códice 1339, folha 81).

${ }^{203}$ António de CASTRO, Coleção de Manuscritos da Biblioteca Geral da Universidade de Coimbra, códice 1339, folhas 77-80.

204 "Mas antes de fazer coisa alguma, tendo provavelmente o estudante alguma notícia de que eu poderia ser informado pelo porteiro acerca do seu comportamento, e temendo algum resultado; foi-se ter com o porteiro e, dizendo-lhe 
solicitou encarecidamente ao porteiro que nada relatasse sobre o ocorrido. Imediatamente depois, mal se fechavam as aulas, o porteiro dirige-se ao Comissário para denunciar o que acabara de ouvir. O Comissário remete o caso à Real Junta, com a nítida sugestão de que providências pudessem ser tomadas para proceder ao castigo do trangressor, o que ao menos serviria como exemplo para aqueles que eventualmente pudessem vir a tomar tais atitudes por modelo. O Comissário declara, de antemão, que não se satisfazia com os arrependimentos e com as promessas de emenda, posto que o estudante agia daquele modo exclusivamente por medo do castigo e não por verdadeira convicção. Além disso, enquanto aguardavam a resposta final da Junta da Diretoria Geral dos Estudos, o menino deveria ser "despedido interinamente" da aula, o que foi exigido em ofícios datados de 8/7/1823 e dirigidos ao professor e ao porteiro, para que não mais consentissem na entrada daquele rapaz no estabelecimento.

Constrangido o professor Padre Ramos com a possibilidade de se suspeitar ser ele quem estava a sonegar informações, antes mesmo que chegasse às suas mãos o ofício do Comissário, ele escreve outro, em que dizia que, após ter recebido e respondido aquela solicitação quanto a informações sobre o comportamento do estudante, ele havia ficado sabendo... Mas o Comissário não esmorece...

"Receoso, quanto me parece, o Padre Ramos, de que, apesar de nada me ter dito no seu
ofício contra o estudante, eu procedesse sempre de algum modo contra ele, no seguinte dia 9
pelo meio dia, não tendo ainda recebido o meu ofício de 8 por não o ter levado o contínuo,
senão na tarde de 9 , dirigiu-me outro ofício ( ${ }^{\circ}$ 2) em que com efeito disse que depois de
ter respondido ao meu (do dia 2) tinha sabido por dito de alguns estudantes que Francisco
Silva Ramos, estando junto com outros muitos no pátio do Estabelecimento, falara algumas
coisas indecentes. Julgo que se deve logo notar aqui, $1^{\circ}$ ) que não declara que coisas indecentes
fossem essas que o estudante falara, podendo-se dizer indecentes coisas mui diversas e que se
possam e devam classificar mui variadamente; $2^{\circ}$ ) que não exprimindo a menor dúvida sobre
a verdade do fato de ter o estudante falado coisas tais, parece que o reconhece como certo. Não
parece verossímil que, sabendo o professor ter o estudante falado coisas indecentes, não sou-
besse quais elas tinham sido. E se o soube, por que m’o não declarou? Não posso conjecturar
outra razão mais de que querer favorecer o Estudante, dissimulando como pode a sua culpa.
E, mostrando ter o fato verdadeiro, nada vale nem vem a propósito o que depois ajunta. Ajunta
ele imediatamente: Mas que falariam muitos dos outros que estavam com ele? Que falaram
eles, e que foi o que disseram, lhe perguntarei eu: e se d'alguma sorte o sabe, porque o não diz
se lhe constou que Francisco Silva Ramos na sua culpa teve cúmplices ou conselheiros, que,

que não soubera o que dissera; protestando estar mui arrependido, e prometendo nunca mais dizer semelhantes coisas (por conseguinte, reconhecendo tê-las dito); pediu-lhe encarecidamente me não referisse nada. Apenas se fecharam as aulas, vejo imediatamente o porteiro dar-me conta disto mesmo. Refletindo porém sobre o caso, pareceu-me mui grave e melindroso para o tomar sobre mim e decidi-lo por mim mesmo. E não me satisfazendo semelhantes mostras de arrependimento e promessas de emenda, que o medo do castigo maior provavelmente extorquia a um rapaz de 14 anos; julguei que nem devia tomar sobre mim o perigo que resultaria aos condiscipulos de o terem consigo, entretanto que eu desse conta e baixasse da Real Junta a Decisāo. Por isso me resolvi a fazê-lo despedir interinamente da aula, por oficio, que enviei ao professor na data de 8 do corrente, e outro na mesma data ao porteiro, para que o não consentisse no estabelecimento, declarando em ambos que assim se executaria enquanto a Junta da Diretoria Geral dos Estudos, a quem dava conta, não tivesse decidido a seu respeito (António de CASTRO, Coleção de Manuscritos da Biblioteca Geral da Universidade de Coimbra, códice 1339, folhas 77-80)." 
ou o igualassem na culpa, ou de qualquer sorte dessem a ela causa; por que o não declara? Se considerado o caráter e costume deles, que melhor que ninguém deve conhecer quem é o seu Mestre, julga que assim se deve supor; por que não declara isso mesmo? Que falariam muitos dos outros que estavam com ele? Eu respondo francamente a esta pergunta: talvez falassem tão mal, e pior ainda que Silva Ramos; assim é possível que sucedesse. Mas não se quer saber o que é possível; quer-se saber o que foi. O caso é que, tendo feito as averiguações que disse, tenho assaz fundamento para me persuadir que a culpa foi só desse, que ele mostra proteger, e, não podendo de outro modo, querendo fazer passar por suspeitos os que foram inocentes. Não lhe concilia isto crédito de bom Professor." 205

O professor, como aqui se evidencia, teria na ocasiāo aconselhado o porteiro a não fazer caso daquele tipo de conversa dos meninos, até para que o conflito pudesse terminar por ali. De algum modo, ao contrário do porteiro e do Comissário dos Estudos, o professor não incentiva a prática de delação entre seus alunos. Efetivamente, o que fariam os outros enquanto aquele menino se comportava com maus modos, dizendo palavrōes? Qual a verdadeira razão que os teria motivado a falar? Em que medida a palavra daquelas crianças poderia ser considerada verdadeira, se não havia nenhum adulto que estivesse lá na ocasiāo? Para o professor, sem dúvida nenhuma, o melhor teria sido esquecer o caso. Aconselhou o porteiro; mas este agiu na direção diametralmente contrária, indo relatar ao Comissário todo o ocorrido.

O professor atribuía ao porteiro aquelas desordens, devido ao fato de os alunos estarem sendo, pela sua autorização, admitidos no estabelecimento antes da hora de entrada, quando a orientação dada ao mesmo porteiro era a de que a porta não fosse aberta em hipótese alguma antes dos cinco minutos que antecediam o toque. Contrariando habitualmente tal prescrição, o porteiro alegava que era necessário evitar que as crianças pudessem lá fora fazer alguma coisa má, que eventualmente a vizinhança pudesse dar queixa.

O Comissário refuta a argumentação do professor, ao destacar que, se a reunião dos estudantes não houvesse ocorrido da porta para dentro, certamente ela seria mais perigosa da porta para fora, onde nem porteiro, nem professor, nem pais, nem ninguém poderia controlá-los e retirá-los do pernicioso caminho da rua. Aliás, nesse caso, certamente caberia à vizinhança dar a queixa ou apenas dizer mal dos rapazes... O intuito do Comissário era, sem reservas, o de contradizer o professor, solicitando da Corte Real a decisão que efetivamente viria a ser tomada pela Junta da Diretoria Geral dos Estudos a 4-8-1823 - qual seja a expulsão do menino. A esse respeito o Comissário nem sequer disfarça; para ele, o caso tornara-se já um duelo: ele, que pretendia ser o grande e maior juiz da instituição, que deveria tudo saber, tudo escutar, tudo deliberar... $\mathrm{Na}$ verdade, o caso ilustra o conflito e o confronto entre as diferentes instâncias da instituição quanto a uma aparente superposição da competência e dos critérios de punição: entre porteiros, professores, inspetores e alunos delatores. A quem cabe vigiar, zelar pela ordem e defender os bons costumes no domínio da escola? Seja como for, o desejo de poder do Comissário é, nessa situação, indisfarçável.

${ }^{205}$ António de CASTRO, Coleção de Manuscritos da Biblioteca Geral da Universidade de Coimbra, códice 1339, folhas 77-80. 
O relato ilustra a correlação de forças na escola, onde o professor é apenas uma das variáveis envolvidas, entre inúmeras outras. Aliás, especificamente neste caso, não se poderia dizer que foi dele que partiu a arbitrariedade e o abuso do poder. Teria sido, antes, do Comissário e do próprio porteiro, que levava e trazia informações... Três anos depois, teria ocorrido mais uma contenda envolvendo esses três personagens: o professor Padre Ramos, o Comissário dos Estudos António de Castro e o porteiro da escola.

No dia 17/6/1826 uma carta do Comissário António de Castro de Lisboa principia por declarar que, pela Régia Provisão de 23/9/1812, ordenara-se aos porteiros dos Estabelecimentos de Estudos a incumbência, entre outras coisas, de fiscalização das faltas diárias e horárias dos professores e dos estudantes. Os apontamentos do porteiro deveriam ser, por tal orientação, entregues diretamente ao Comissário da Junta da Diretoria Geral dos Estudos. Ocorre que não havia sido estipulada qualquer previsão de descontos quanto aos vencimentos atinentes a faltas horárias e, sendo assim, quando os professores entravam mais tarde ou saíam mais cedo, nenhuma medida costumava ser tomada. Esse problema se havia intensificado nos últimos anos, posto que se tornava cada vez mais comum os porteiros registrarem ausência dos mestres por algumas horas dos dias letivos, sem que isso fosse sequer computado pela falta de regulamentação legal para arbitrar sobre a matéria. Os professores vinham - na opinião do Comissário António de Castro - relaxando sua assiduidade, deixando por vezes a escola durante longos períodos, frequentemente 20,30, às vezes 60 minutos antes do horário previsto. Segundo ainda esse relato do Comissário, Joaquim Pires Ramos era, em seu entender, o mais grave dos casos.

Expondo, na seqüência, dias e minutos, de Janeiro a Maio, o Comissário calculou 521 minutos de faltas do Professor, o que prejudicaria evidentemente o andamento das liçôes. O cômputo dos minutos de ausência do professor corresponderia a 8 horas e 41 minutos, sendo que a carga diária estipulada era de cinco horas, faltando-lhe, portanto, uma hora $\mathrm{e}$ 19 minutos para que o docente perfilhasse um período de ausência que, no total, equivaleria a dois dias. De acordo com o pronunciamento do Comissário dos Estudos, isso propiciava uma situação de extrema gravidade:

"E, sendo este o estado a que as coisas têm chegado, que será daqui em diante? E que detrimento não resulta daqui à mocidade, não só pela falta de explicação, doutrina e exercício, que receberia naquele espaço de tempo, mas pela desenvoltura a que nele se entregará, não sendo o seu costume aparecerem em casa dos pais, senão depois da hora de dever acabar a aula? Tenho por vezes dito aos Porteiros e a alguns dos Professores e ao mestre Padre Ramos, o muito que estranho semelhante abuso: mas emenda nenhuma, antes cada vez a pior. A única causa, que ao que parece poderia justificar uma saída antes da hora, seria uma indisposição violenta, como uma dor de cabeça que, acometendo de súbito o Professor, lhe impedisse o prosseguir no exercício do Magistério. Mas isto sucede uma ou outra vez e não tantas quantas são as saídas antecipadas que se lhe fazem. Tem o Padre Ramos dado por causa o ser então a hora da Missa no Oratório de que se tem incumbido: mas justamente pode dizer-se que a Cadeira nada tem com o Oratório, nem se admite o princípio de que o Professor só é obrigado à sua Aula quando não tem outra coisa que fazer." ${ }^{206}$

206 António de CASTRO, Coleção de Manuscritos da Biblioteca Geral da Universidade de Coimbra, códice 1339, folhas 91 e 96. 
Sucede que o caso não se encerra aí. António de Castro, em 4/7/1826 dirige outro ofício à Junta da Diretoria Geral dos Estudos, onde recorda que já enviara o mapa das faltas dos professores e onde reitera sua expectativa de urgentes providências daquele órgão central quanto ao problema. O Comissário destaca que já expusera anteriormente o caso, a relaxação a que as escolas vinham sendo submetidas pelas constantes faltas horárias de docentes menos responsáveis. Ao salientar que já enviara o mapa das faltas referentes aos meses anteriores - que, aliás, lhe fôra fornecido pelo Porteiro do estabelecimento, Manuel Ribeiro Carvalho -, o Comissário declara haver julgado procedente o envio da relação das ausências constatadas no próprio mês de Junho, relação esta que o mesmo porteiro lhe remetera no dia anterior. Abaixo, trancreve-se o quadro d'onde constam as faltas horárias do referido Padre Ramos, expostas e comentadas na seqüência da correspondência do Comissário dos Estudos.

"Em 16 de manhã 60 minutos ou 1 hora; Em 16 de tarde 15 minutos; Em 17 de tarde 120 minutos ou 2 horas; Em 21 de manhã 45 minutos ; Em 30 de manhã 60 minutos ou 1 hora.

Somam pois as referidas faltas horárias, que o sobredito Professor fez só no passado mês de Junho, 5 horas justas, o que equivale ao tempo que ele é obrigado a dar aula um dia inteiro. E bem se vê pela dita soma o como a desordem vai em aumento. Na verdade parecem-me semelhantes faltas, cometidas com tanta freqüência, causassem muito maior dano e davam muito maior escândalo, do que se o Professor faltasse à Aula um ou dois dias. Poderá pois para mais pleno conhecimento desta matéria juntar-se esta Conta à sobredita de 17 do passado.”207

O professor, por seu turno, relata que havia sido em 20/7/1826 convocado na presença do Comissário de Estudos e ali lhe teria sido lida uma Régia Provisão pela qual o Rei tinha mandado o mesmo Comissário repreendê-lo por ele não vir regularmente cumprindo suas obrigaçôes relativas ao horário escolar. Na verdade a Régia Provisão ordenara inclusive o desconto das horas em que foi constatada a ausência. O Padre Ramos diz julgar que aqueles poucos minutos em que deixava o serviço do magistério deveriam ser considerados equivalentes ao direito que os professores desfrutavam para abonar duas faltas mensais. No tocante às razões alegadas para cometer aquelas faltas, ele procura justificar-se, expondo que sempre foi obediente ao Comissário e que não costumava sequer valer-se das faltas abonadas a que tinha direito. Ocorre que, a dada altura, ele foi chamado para dizer Missa no oratório de uma família que, por seus costumes, era - no dizer do professor - reputada exemplar naquela localidade. Essa família, que - segundo ele - tinha o hábito de ouvir missa e comungar em dias de semana (que não eram feriados), havia pedido ao Padre Ramos que ele lhes fosse rezar missa. O padre disse não ter podido recusar pelo fato de a mesma família costumar ajudá-lo muitas vezes, sempre que atrasava o pagamento de seu ordenado.

${ }^{207}$ António de CASTRO, Coleção de Manuscritos da Bibliteca Geral da Universidade de Coimbra, códice 1339, folhas 94-95. 
As faltas horárias passariam, então, a ocorrer quando o período letivo da escola coincidia em alguns poucos minutos com o tempo da missa que o professor precisaria celebrar, já que, pelas razões acima expostas, ele se via na "precisão de servir".

Algum tempo depois, o mesmo problema volta a ocorrer e a referida escola presencia novamente a contraposição entre o poder do porteiro e do Comissário dos Estudos de um lado e o lugar social desempenhado pelo professor da turma de outro lado. Em 16 de janeiro de 1829, o Professor Manoel Joaquim Pires Ramos declara em carta endereçada ao Rei ignorar a causa pela qual o Comissário dos Estudos lhe havia suspendido o pagamento do terceiro quartel do ano de 1828. O professor afirma não haver cometido um maior número de faltas do que aquele que lhe era facultado pela lei e, ao informar o contrário, o Comissário dos Estudos estaria faltando com a verdade, já que não ia nunca ao estabelecimento e, por tal razão, nada saberia dizer, a não ser o que o porteiro lhe informava. Aliás, o porteiro costumava gabar-se do fato de que "o Comissário o tem por muito certo no serviço e por isso não vai visitar aquele estabelecimento". Muitas vezes - conta o Padre Ramos - podia haver algum atraso por parte dos professores à medida que o sino não era tocado na hora certa. Nas palavras do professor: "e se eu me demorava alguma vez em entrar para a aula era esperando que o Porteiro tocasse o sino porque eu muitas vezes ia mais cedo, supondo que ele tocava o sino pelo tempo e ele tocava pelo sol e vice-versa." ${ }^{208} \mathrm{O}$ professor relata, então, que o porteiro era, de fato, seu inimigo desde aquele princípio do ano de 1823 , a partir de quando nada mais fazia a não ser entretecer intrigas capazes de prejudicar a todos os que considerasse seus adversários, gabando-se, ainda para mais, da alta reputação de que usufruía perante o Comissário dos Estudos. A conduta daquele porteiro, aos olhos do docente, chegava a ser perigosa, em virtude de criar o ambiente de descofiança, mal estar e intriga - com um levar e trazer de falsas informações...

“(...) porque o porteiro dá ao Comissário ótimas infomações daqueles que lhe pagam jantares e merendas ou lhe dão dinheiro, e dá péssimas informações daqueles que não lhe fazem o mesmo, e o Comissário dá a Vossa Magestade as mesmas informações que dele recebe, ou por estar iludido, ou não sei porque, e não quer informar-se com pessoas honradas para informar com verdade a Vossa Magestade, e por isso o Porteiro gaba-se que dá e tira cadeiras em Lisboa a quem quer, e me disse a mim no dia 31 de Outubro que, se eu era Professor, era por ele querer e no mês de Novembro, antes de me ser intimada a suspensão do exercício do Magistério, disse que eu ia ser expulso da cadeira por causa dele, e diz que o seu filho estudante há-de ser Professor de Gramática e Língua Grega porque o Comissário já lhe prometeu isso mesmo e por isso estão os professores e mestres de Primeiras Letras gemendo debaixo de insultos, calúnias e acusações falsas e se Vossa Magestade mandasse devassar sobre a conduta do Comissário, sendo ouvidos não só os Professores mas também a vizinhança dele, talvez pareceria muito diferente do que tem inculcado a Vossa Magestade."209

${ }^{208}$ Manoel Joaquim Pires RAMOS, Coleção de Manuscritos da Biblioteca Geral da Universidade de Coimbra, códice 1339 , folha 70 .

${ }^{209}$ Manoel Joaquim Pires RAMOS, Coleção de Manuscritos da Biblioteca Geral da Universidade de Coimbra, códice 1339, folha 69. Este ofício havia sido escrito pelo docente a 23/1/1829. No ofício anterior, datado, como vimos de 16/1/1829, o mesmo professor qualificaria do seguinte modo as intenções do porteiro: “(...) nada mais 
Em um último ofício do professor, o Padre Ramos finalmente explicita suas suspeitas, expondo o caso do princípio ao final. Diz então - dirigindo-se na verdade à Junta da Diretoria Geral dos Estudos - que o Comissário dos Estudos António de Castro ou não pode ou não quer visitar os estabelecimentos de ensino e as escolas de Primeiras Letras. Para, no entanto, exercer sua tarefa de fiscalização - e ele já havia dito isso em carta anterior - servia-se dos porteiros das mesmas instituiçóes como "espias para indagar da vida particular a pública dos professores e dos Mestres de Primeiras Letras" ${ }^{210}$. Por tal razão, dando o porteiro informaçōes falsas ao Comissário, este daria também informaçóes falsas ao Rei. O porteiro, na verdade, daria ótimas informações acerca dos que lhe pagassem jantares, merendas ou talvez lhe dessem mesmo dinheiro, dando péssimas referências dos demais, que porventura se recusassem a tal suborno. Sendo que o Comissário dava-se por satisfeito com as informações do porteiro, sem tirar quaisquer possíveis dúvidas com pessoas honradas da região, o porteiro excedia-se todos os dias um pouco mais.

A hierarquia do tecido escolar é mais entrecruzada do que à primeira vista possa parecer. Na verdade, o que parecia ocorrer é que entre o Padre Ramos - professor daquela turma de estudantes - e o Comissário dos Estudos responsável pela inspeção da referida escola havia nítida diferença quanto à compreensão da tarefa educativa. Para o Comissário, a ênfase estaria posta no cumprimento do horário, na ritualização da vida escolar perante regras bem delimitadas, na obediência por parte de todos os agentes institucionais a essas prescrições e às classificaçōes delas decorrentes. Assim, a escolarização seria um processo de ordenamento das próprias hierarquias e do senso de autoridade que, em outra dimensão, preside a própria estrutura da sociedade. Com essa percepção do processo, o Comissário sequer se constrangia por eleger o porteiro como seu informante, já que supunha ser seu direito e seu dever o conhecimento integral de tudo quanto se passava no recinto do estabelecimento. O cumprimento de regras seria, a partir dessa estratégia, estritamente vigiado. Já para o professor, no contexto de uma pedagogia derivada explicitamente de preceitos religiosos, a formação de um leque valorativo era essencial para a garantia de uma salutar formação. A educação é compreendida como consolidação de um conjunto de normas, valores e atitudes que deveriam compor não apenas a racionalidade mas fundamentalmente a formação do caráter e do espírito infantil. Por essa razão é que o professor não teria visto, de fato, com bons olhos a delação do menino que, ao acusar o companheiro, tinha faltado com seu dever de lealdade. O Padre Ramos, por seu turno, também nisso diferenciando-se do Comissário dos Estudos, não julgava haver qualquer problema em deixar a aula um pouco mais cedo para rezar missa para uma família honrada da região. Afinal, para ele, tudo resumia-se, ao fim e ao cabo, a uma tarefa catequética.

tem feito senão excogitar crimes para me imputar e para o Comissário dar conta a Vossa Magestade a meu respeito (...) mas não sabe o Comissário nem quer saber para dar conta a Vossa Magestade que o Porteiro, quando os professores entram para as aulas começa a contar e a perguntar novidades, e a dizer que podem conversar antes de entrar para a aula, porque o Comissário o tem muito por certo no serviço e por isso não vai visitar aquele estabelecimento (...)" (Manoel Joaquim Pires RAMOS, coleção de Manuscritos da Biblioteca Geral da Universidade de Coimbra, códice 1339, folha 70).

${ }^{210}$ Coleção de Manuscritos da Biblioteca Geral da Universidade de Coimbra, códice 1339, folha 69. 
Outrossim, em virtude dos votos religiosos que fizera, seu magistério não poderia ser profissão a tempo inteiro ${ }^{211}$.

\section{Um professor 'de moral estragada': suas testemunhase e seus adversários}

Acerca da estrutura de poder na escola, poderíamos citar outro exemplo, onde a ação do professor era objeto da queixa contra a escola. Sugere-se a abertura de um concurso para o cargo que ele ocupava. O proponente era José Manoel de Campos Fea da Vila de Alter do Chão, que envia para o rei uma representação em cujo ofício destaca o estado de abandono em que se encontrava a instrução primária daquela vila por causa da permanência do professor em exercício, Balthazar Correa do Inço. Era 24-1-1854. A atuação daquele professor no magistério primário era desaprovada porque absolutamente imprópria - diz o relator. Os alunos em nada aproveitavam suas liçóes e, como conseqüência, a permanência de tal indivíduo como regente de classes apenas significaria um ônus a mais para o Estado.

Além de ignorante e incapaz de ensinar, o professor teria, na ocasião, conduta duvidosa e uma moral 'muito estragada', segundo os termos do autor da queixa. Isso reforçaria a convicção dos pais no sentido de não lhes enviarem os filhos. Após quinze dias de escola, as crianças que frequentavam aquelas aulas passavam a utilizar em casa expressões grosseiras e termos chulos, sendo que tal linguajar, não podendo ser caracterizado como pertencente aos hábitos das famílias, só poderia ser - acreditavam todos - obra do professor. Para o relator, os fatos e escândalos públicos eram tão notórios que já nada precisaria ser a isso acrescido. Sugere-se então que o docente fosse destituído da cadeira que ocupava e que a escola fosse provida por um professor substituto, realmente capaz de proceder com habilidade e dignidade, "que ensine rima pelo Método Castilho, pois só assim bem dirão os Pais de famílias e autoridades que para isso cooperam." 212

Alguns meses depois, em 20-5-1854, por parte da administração do concelho, foi encaminhado ao Governador Civil ofício correspondente a uma averiguação que supostamente teria sido encaminhada pelo mesmo Governo Civil de Portalegre, com o propósito de verificar se tinham ou não procedência as críticas que haviam sido imputadas ao professor primário Balthazar Correa do Inço naquele aqui caracterizado 'requerimento acusatório'. O relator - José Maria da Silva Leal - declarava ter estado na Vila de Alter, a 17 de julho, sem haver entretanto dado conhecimento disso ao Administrador do Concelho. Seu objetivo - como ele próprio destacaria - era aferir a

${ }^{211}$ De acordo com o trabalho de António Nóvoa, a idéia de a atividade docente constituir-se em exercício a tempo inteiro seria a primeira etapa do processo de profissionalização do professorado português. As etapas seguintes seriam o estabelecimento de um suporte legal para o exercício da atividade docente, a criação de instituições encarregadas da formação dos profissionais do ensino e a consolidação de um associativismo que daria, àqueles professores, espírito de corpo, de pertença a uma dada categoria profissional. (António M. S. S. NÓVOA, História da educação, p. 207).

${ }^{212}$ Id. Ibid. Como constataremos no capítulo seguinte, concernente a processos de inspeção às escolas públicas e particulares, de acordo com um relativo senso comum da mentalidade portuguesa de então, o bom professor era antes de mais nada o que tornava o ensino atraente e conduzia o aluno ao desejo de aprender. Talvez por aí se justifique essa solicitação de ver aplicado, ao invés dos procedimentos rotineiros da prática escolar, o método Castilho. 
justiça ou injustiça das acusaçôes. E, de fato, perguntando em Alter sobre a capacidade literária do referido professor, teria efetivamente constatado que aquele indivíduo era motivo de execração pelos pais de família e de riso para todos.

"Aquele homem poderá ser bom logista, bom Seiareiro, porque esta é a vida a que se entrega; mas bom professor de ensino primário jamais o será porque não tem habilitações para isso, nem procura adquiri-las. Falando da sua eficácia, terei dito tudo, asseverando a Vossa Excelência que se passam semanas e semanas em que ele não aparece à aula, para lecionar os seus discípulos, não obstante ser esta em sua própria casa e o número deles não exceder a três: sendo todavia certo que Alter tem hoje mais de cem crianças nas circunstâncias de frequentarem a escola, e que, sem dúvida a frequentariam com aproveitamento se o professor de instrução pública daquela vila fosse um homem com os necessários predicados de um diretor da mocidade. Já disse que se passam semanas sem que este apareça à aula; (...) mas não disse ainda que ele encarrega a direção dela a um filho de quatorze a quinze anos, discípulo de tal mestre, que logo que se vê só, mais trata de folgar do que estudar (....) E eu digo: se em Alter não há um jovem que saiba ler e escrever, é disso causa o atual professor, Balthazar Correa do Inço."213

Em 27-5-1854, em ofício dirigido ao Conselho Superior na pessoa do Ministro e Secretário de Estado e Negócios do Reino, o Governador Civil Diogo António Palmin Pinto relata, a princípio, que procedeu à investigação sobre a situação do ensino primário na localidade de Alter do Chão, tomando "informações particulares e confidenciais sobre as graves acusações que ali se fazem, e soube, por pessoas sérias daquela Vila, e ainda por outras do Crato, mui relacionadas em Alter, que efetivamente as arguições em geral são fundadas; e que em conseqüência a instrução pública corre naquela Vila quase abandonada e pessimamente dirigida." ${ }^{214} \mathrm{Na}$ seqüência, o Governador Civil explica que, se o comportamento moral e civil do professor não podia ser qualificado de escandaloso, como fazia crer a queixa do advogado José Manoel de Campos Feo, não era, em hipótese alguma, o que se poderia considerar exemplar ou mesmo regular. O expositor não explicita, contudo, o que pretende dizer com isso. Mas conclui expondo que, em função do ocorrido, sentia a necessidade urgente de que alguma providência fosse tomada para alterar aquele quadro: não cabia a ele dissimular a gravidade da situação, tendo em vista sua responsabilidade no cargo que ocupava e a importância da povoação de Alter.

Procedeu-se, então, a partir do mês de Agosto a uma autuação, na qual testemunhas seriam inquiridas para averiguar formalmente a veracidade dos fatos que constavam da acusação contra a pessoa do professor. Por ordem do Governador Civil de Portalegre, as testemunhas escolhidas deveriam ser pais de família e principais proprietários daquela localidade. Esse escrúpulo quanto à escolha das testemunhas é, na ocasião, justificado pelo pressuposto de que se tratava de um caso melindroso, por envolver a figura do professor de instrução primária nos aspectos de sua conduta moral, civil e profiisional. Depois de confeccionado o auto de investigação, o acusado deveria dele

${ }^{213}$ José Maria da Silva LEAL, Caderno de Documentos 47, Coleção de Manuscritos da Biblioteca Geral da Universidade de Coimbra, códice 2531.

${ }^{214}$ Diogo António Palmin PINTO, Caderno de Documentos 47, Coleção de Manuscritos da Biblioteca Geral da Universidade de Coimbra, códice 2531. 
tomar conhecimento - devendo ainda responder por escrito aos artigos da arguição que lhe seria feita. Os autos do processo, bem como a resposta do acusado, seriam finalmente remetidos pelo administrador do concelho de Fronteira ao Governador

Civil. Este, por sua vez, recomendava que fossem mantidas, naquele caso específico, a ponderação, a serenidade e a imparcialidade. Ainda por ordem do Governador Civil, as testemunhas seriam inquiridas pelo Administrador do Concelho de Fronteira no Concelho de Alter do Chão. Deu-se encaminhamento ao processo e, em 9-8-1854, o professor foi autuado na vila de Alter do Chão na Sala de Administração do Concelho. De acordo com o Secretário Geral do Concelho de Fronteira (Portalegre), os artigos da acusação contra o professor compreendiam os seguintes delitos:

“1) Que ele não cumpre com os deveres do Magistério faltando semanas inteiras à escola que deixa entregue a um seu filho de 14 anos pouco mais ou menos, que mais trata de folgar do que estudar e lecionar os alunos; $2^{\circ}$ ) Que é de uma conduta moral e civil estragada, usando na escola, bem como seus filhos, de expressões impróprias e que pervertem; 30) Que por tudo e pela incapacidade notória do professor, os pais de família têm retirado seus filhos da escola, que hoje se acha frequentada por três alunos, para os entregarem a mestres particulares a quem pagam." 215

No mesmo dia (9-8-1854), o professor responde aos artigos da acusação, desmentindo os três tópicos perante os quais devia explicitar inocência. Antes de mais nada, o docente alegava que só deixara de ministrar suas aulas por motivos de força maior, quando realmente estava de algum modo impedido. Nessas raras ocasiōes - segundo o réu -, deixava a cadeira sob responsabilidade de seu filho, um jovem de 17 anos que, já há 4 anos, andava como estudante na cadeira de Filosofia Racional com o Padre Diogo Joaquim Sardinha - anexando documento comprobatório desse dado, com assinatura do mesmo padre.

Por fim, tendo exercido a tarefa do magistério por 29 anos, admira-se o acusado de, sendo há 22 anos o responsável pela mesma cadeira da qual o desejavam tirar, pairar sobre ele, pela primeira vez e depois de tanto tempo, suspeitas tão graves quanto à aptidão para o ofício ao qual dedicara toda sua vida. A respeito da opção de alguns pais de família por mestres particulares, o professor diz que não pode ser responsabilizado pela conduta de "certas desinteligências". Aliás, o acusado arremata declarando que seus discípulos eram em número de 12 e não de 3 como mentirosamente havia sido afirmado.

$\mathrm{O}$ administrador do concelho de Fronteira efetua em 9 de agosto de 1854 um inquérito, que tem lugar na própria vila de Alter, onde testemunhas seriam, então, ouvidas a propósito do processo. Foram no total oito as testemunhas inquiridas, que trariam novos elementos para o prosseguimento da investigação.

A primeira testemunha ouvida foi Valério dos Santos Pinto, de 51 anos de idade, casado, exercendo a profissão de boticário, residente na vila de Alter, "testemunha jurada aos Santos Evangelhos para dizer a verdade e só a verdade do que souber e lhe for perguntado" 216 . Ele declarou ser verdade que o professor, às vezes, faltava e, em tais

${ }^{215}$ Cadernos de Documentos 47, Coleção de Manuscritos da Biblioteca Geral da Universidade de Coimbra, códice 2531.

${ }^{216}$ Cadernos de Documentos 47, Papéis relativos á Instrucção Pública destes Reinos, Coleção de Manuscritos da Biblioteca Geral da Universidade de Coimbra, códice 2531. 
ocasióes, deixava com os encargos do magistério o filho de 14 anos, o que, efetivamente, causava insatisfação e por vezes transtorno às famílias, levando inúmeros pais a retirarem os filhos da escola para encaminhá-los para a instrução de mestres particulares. Já Joaquim da Costa Callado - a segunda testemunha ouvida - com 50 anos, casado e lavrador - não sabia dizer se o professor faltava ou não às aulas. Não tinha também conhecimento do fato de o mestre utilizar expressões impróprias em sala de aula. Julga apenas que muito daquilo que se atribuía à incapacidade ou à ausência de zelo do professor derivava na verdade da proliferação de mestres particulares naquela região. Francisco Inácio Gonçalves, de 39 anos, casado, escrivão do Juízo Ordinário, também opta por não se pronunciar sobre as faltas e sobre a conduta do docente, mas reitera que eram tão concorridas as aulas dos "mestres particulares a quem se paga" que o próprio professor Balthazar teria encarregado a um deles a instrução de seu filho.

Pelo relato de Crispino Jorge Alves - de 45 anos, casado, sapateiro e quarta testemunha inquirida -, algumas vezes, de fato, o professor confiava as aulas a seu filho, que, entretanto, cumpria com muita dignidade essa tarefa. Sobre as expressões que o professor usaria, nada pode dizer a respeito, "mas disse que há, como sempre houve, mestres particulares a quem pagam mas que não obstante tudo isso a escola do dito Balthazar é frequentada por mais de uma dúzia de alunos e mais não disse" 217 . Victor José tinha 36 anos, era casado e também exercia o ofício de sapateiro. Para ele as denúncias tinham razões de existir; o professor não cumpria os deveres do magistério como seria de se esperar, os alunos tinham poucas aulas e nada aprendiam. Ele mesmo - a testemunha - pretendia tirar o filho da escola e levá-lo para um mestre pago.

Conforme Francisco Lopes - casado, 40 anos, carpinteiro-, Balthazar cumpria, sim, todos os requisitos necessários a um professor de instrução primária; e, como prova disso, destacava o fato de seus dois filhos, com idade de 8 e 5 anos, sendo alunos do referido docente, serem já capazes de ler "em livro", tendo ambos, além da pouca idade, apenas um ano de freqüência à escola. Para essa sexta testemunha, a própria recorrência das famílias a mestres particulares jamais poderia ser atribuída à má conduta pessoal ou pedagógica daquele professor. Por outro lado, mesmo o filho, a quem o mestre algumas vezes confiava a tarefa de substituí-lo, tinha já 16 anos e era, acima de tudo, "rapaz bastante esperto".

O depoimento de Joaquim da Costa, de 49 anos de idade, também foi peremptório na defesa do professor. Consta do manuscrito o seguinte:

“(...) respondendo ao primeiro artigo da acusação, sabe que Balthazar Correa do Inço, professor primário desta vila, que além de exercer o seu magistério, tem outras coisas mais em que se ocupa e é de opinião dele declarante e reconhecido por todos que um professor primário não pode subsistir com um ordenado tão módico que atualmente vencem todos, que nas algumas faltas que se diz cometer no exercício de seus deveres, é substituído por um seu filho de idade de dezessete anos, o qual se dedica à vida eclesiástica e que (...) já fizera o exame de Gramática Latina na Cabeça do Bispado donde consta ter ficado aprovado. Respondendo ao segundo artigo disse que há muito tempo não frequenta a casa do dito professor e nem sabe se ele usa

${ }^{217}$ Cadernos de Documentos 47, Papéis...., Coleção de Manuscritos da Biblioteca Geral da Universidade de Coimbra, códice 2531 . 
ou deixa de usar expressões impróprias a uma casa de educação; e sobre a sua moral, não acha que tenha um procedimento que cause mais escândalo nesta vila, que diz maus exemplos a seus filhos ou seus discípulos. Respondendo ao terceiro, disse que sabe que o professor primário há vinte e nove anos exerce esta ocupação e que nos exames que tem feito tanto em Lisboa como na Cabeça do Distrito tem sido aprovado convenientemente e, quanto à freqüência dos rapazes, tem ouvido dizer que são poucos e mais não disse e depois de lhe ser lido o seu depoimento o achou conforme e assinou (...)"218

Como se pode constatar, algumas das testemunhas pareciam convictas da inocência do referido professor, embora pudessem também parecer constragidas para assumir explicitamente tal parecer. Talvez, de algum modo, tivessem receio de represálias. Consta ainda do processo a certidão de batismo de Augusto, o filho do professor Balthazar, nascido em 23-12-1837, contando, portanto, com aproximadamente 17 anos em 1854. Havia, contudo, outros depoimentos que acusam o mestre-escola:

"Como homem, não é melhor a sua conduta. Nos primeiros tempos do magistério, viveu em público e escandaloso concubinato com a mulher com quem depois casou, advertido para isso por alguns amigos que, naquela época, o protegiam: ultimamente, há um ou dois anos, separou-se dela, expulsando-a de casa. Não encontrei das pessoas por mim consultadas quem soubesse se na aula usava de expressóes torpes e impróprias, como se diz no $2^{\circ}$ artigo da acusação. Mas vários me disseram que se não peja de soltar palavras que revelam uma péssima educação, diante não só de estranhos, mas de seus próprios filhos, propalando mesmo opiniões anti-religiosas na presença destes, e da gente rude dos campos que emprega no serviço da lavoura. Por todos estes motivos e principalmente pelo nenhum aproveitamento dos alunos que ensina, os chefes de família vêm-se obrigados a mandar seus filhos a aulas de mestres particulares, a quem pagam 300 a 400 réis mensalmente, deixando outros muitos de aprender, por não terem seus pais meios bastantes para lhes pagarem a instrução." 219

Finalmente tudo levava a crer que o professor era, pela vida pública e por razóes concernentes a sua vida particular, extremamente mal conceituado naquela terra. $\mathrm{Na}$ verdade, para finalizar, parecia ser o próprio Governador Civil do distrito de Portalegre - Diogo António P. Pinto - quem queria a substituição do docente Balthazar. No dia 20 de dezembro de 1854, ele dirige um ofício ao Conselho Superior de Instrução Pública - do qual era conselheiro -, onde dá o resultado oficial do inquérito que havia sido efetuado a partir da Portaria de 13/6, acerca da apreciação do bom ou mau fundamento das acusaçóes efetuadas contra o mestre régio daquela vila. O Governador Civil reconhece haver contradições nos testemunhos daquelas 7 pessoas preliminarmente inquiridas; ao que se acrescia a dúvida quanto à própria lisura do Administrador do Concelho na condução do referido processo. O Governador explica que, por tais razões, encarregara o bacharel Vicente Pereira Gomes de Carvalho de obter informações e esclarecimentos de pessoas 'independentes e graves'. Disso resultou que as informações

${ }^{218}$ Cadernos de Documentos 47, Papeis...., Coleção de Manuscritos da Biblioteca Geral da Universidade de Coimbra, códice 2531 .

${ }^{219}$ Cadernos de Documentos 47, Coleção de Manuscritos da Biblioteca Geral da Universidade de Coimbra, códice 2531. 
obtidas foram, em sua grande maioria, desfavoráveis ao professor; daí a "necessidade de substituí-lo por outro, que preste mais proveito ao importante serviço da instrução pública." 220

Ocorre que a morosidade dos trâmites do Conselho Superior de Instrução Pública ajudara o professor. Nada acontecendo no ano que se seguiu, o provimento temporário de Balthazar terminou. Ele deveria, por causa disso, se inscrever em concurso público se desejasse continuar no magistério. Interessado em prejudicá-lo, o Governador Civil de Portalegre interfere quando, no ano seguinte, o mesmo professor procurava regularizar sua situação pelo caminho do concurso. Através de ofício de seu secretário, o Administrador do Concelho de Alter escrevia em 16-11-1855 ao governo de Portalegre, explicitando as razôes de ordem moral e civil para que alguns postulantes ao cargo particularmente o professor Balthazar - não fossem admitidos no concurso.

\begin{abstract}
"O professor desta vila Balthazar Correa do Inço não tem idoneidade alguma porque, além de não saber escrever nem contar, não tem método de ensinar; é casado e não vive em companhia de sua mulher, sendo voz constante que se acha amancebado com uma cunhada; trata os discípulos com demasiada aspereza, pelo que os pais lhes têm tirado da aula e dirigido-me muitas queixas e faltas que tem cometido no desempenho de suas obrigaçóes. O professor da vila de Sêda, António Máximo de Brito, acha-se nas mesmas razões, de não saber, de faltar, e de escândalo público, porque, sendo casado, se apartou de sua mulher, para estar vivendo amigado com uma mulher solteira, de quem há pouco teve uma filha de que se tomou conta por essa administração e ele assinou termo de responsabilidade para a criar e educar à sua custa e pelo que tive várias representações dos moradores daquela vila." ${ }^{221}$
\end{abstract}

$\mathrm{Na}$ verdade, os obstáculos sobre a conduta pessoal e os hábitos e preferências afetivas dos professores pareciam ocupar mais espaço na decisão do que as considerações a propósito da capacidade literária e didática dos mesmos docentes. Ao mestre, não caberia apenas a instrução. Ele precisaria ser também modelo de lisura, exemplo de urbanidade; referenciado, enfim, por padrôes de moral e de conduta irrepreensíveis. O caso de Balthazar ilustra, com precisão, a interferência dos assuntos privados na esfera pública da profissão docente. Ao pretender tornar-se professor, o postulante deveria ser, antes de tudo, obediente aos interesses e às autoridades estabelecidas. O papel do Governador Civil de Portalegre é provavelmente maior do que quer fazer acreditar o laconismo da documentação.

Diogo António Pinto, já em 17-11-1855, informava o Conselho Superior de Instrução Pública sobre o ofício que lhe fora remetido pelo Administrador do Concelho de Alter do Chão. De acordo com os termos deste texto, ele reitera a crítica quanto à capacidade literária e moral dos dois professores, recordando ainda que os provimentos temporários de ambos venciam naquela ocasião. As cadeiras seriam, por tudo isso, postas a concurso. O Governador, diante do fato, sugere então a destituição dos dois aqui qualificados 'empregados' por terem ambos revelado péssima conduta moral,

${ }^{220}$ Cadernos de Documentos 47, coleção de Manuscritos da Biblioteca Geral da Universidade de Coimbra, códice 2531.

${ }^{221}$ Cadernos de Documentos 47, Coleção de Manuscritos da Biblioteca Geral da Universidade de Coimbra, códice 2531. 
sendo também 'relaxados' no desempenho de suas tarefas docentes. Na carta que remete ao Conselho Superior de Instrução Pública, o Governador Civil diz o seguinte:

\begin{abstract}
“Tendo-me dirigido o Administrador do Concelho de Alter do Chão o ofício (cópia inclusa) sobre a incapacidade literária e moral dos professores de ensino primário da dita vila, Balthazar Correa do Inço, e da freguesia de Sêda António Máximo de Brito; julgo do meu dever prevenir a Vossa Excelência, informando que, por forma alguma, convém ao Serviço de Instrução Pública que os ditos dois professores sejam novamente providos nas cadeiras que atualmente regem, postas agora a concurso por terem findado os respectivos provimentos temporários. Aqueles dois empregados, além de inábeis, inteiramente faltos de instrução, e de péssima conduta moral, são escandalosamente relaxados no cumprimento de seus deveres, como por vezes tenho levado a conhecimento de Vossa Excelência, e nomeada e ultimamente nas observações do Mapa de Instrução Pública junto ao Relatório que por cópia acompanhou o meu ofício n ${ }^{\circ}$ 330 de 9 do corrente, e por isso considero da maior urgência a sua destituição."222
\end{abstract}

Balthazar Correa do Inço era nascido na Galiza, e se naturalizara português em 1816 por ser filho de pais portugueses. José da Cunha e Silva, secretário do Liceu Nacional do distrito de Portalegre, em nome do Comissário dos Estudos, relata que Balthazar fizera seu exame como opositor à cadeira de ensino primário, estabelecida na Vila de Alter do Chão. Trouxe, na ocasião, atestados do pároco, do administrador do concelho e da Câmara Municipal da referida vila, para provar que nada depunha contra si em termos de conduta moral e civil e que não padecia de qualquer moléstia contagiosa. Alguns professores de instrução secundária e primária compuseram o júri do concurso de Balthazar. Examinado - nos termos do relator, que de algum modo se opunha ao parecer que havia sempre sido expresso pelo Governador Civil do distrito - "com imparcialidade e retidão", o postulante foi aprovado no concurso.

$\mathrm{Na}$ ocasião, Balthazar declara, com testemunhas, que lecionava naquela vila há 24 anos, ensinando com regularidade e mostrando conduta civil e religiosa apropriada. Antes disso, lecionara em Assumar, onde esteve até que a Junta da Diretoria Geral dos Estudos o transferisse para essa vila de Alter. A mulher lhe havia roubado e fugido, deixando ao seu exclusivo encargo cinco filhos menores para cuidar. Tinha sido aprovado em todos os concursos de instrução primária que havia prestado. Há doze anos havia uma queixa na justiça contra ele, processo pelo qual era acusado de atirar em Gaspar José de Morais, crime que, entretanto, nunca se provou. A escola de instrução primária, que deveria engendrar símbolos, valores e territórios, também era composta por contradições como essa.

A procura pela instrução, ao longo do período investigado (1820-1910), pareceu-nos bastante presente e consoante com a complexificação de uma racionalidade progressiva imposta à vida escolar. No princípio, não havia sequer regularidade naquelas escolas. O raio de ação dos órgãos superiores encarregados da instrução era pequeno, a formação do corpo docente praticamente não existia. No último quartel

${ }^{222}$ Caderno de Documentos 47, Coleção de Manuscritos da Biblioteca Geral da Universidade de Coimbra, códice 2531 . 
do XIX, inegavelmente, a situação era já outra. Havia, bem ou mal, um esforço de inspecionar as escolas e a profusão de compêndios didáticos publicados e aprovados todos os anos traziam certa padronização quanto aos conteúdos didáticos que faziam a rotina da sala de aula. A profissão do magistério passa a ser, cada vez mais, ambicionada pelas mulheres; se não para si, ao menos como possibilidade para que suas filhas desfrutassem de uma posição que minimamente as protegeria das tiranias do serviço doméstico. Podemos depreender isso da carta dirigida ao Rei de Portugal no ano de 1874, onde uma mãe de família solicitava, a título exclusivamente pessoal, instrução para sua pequenina filhinha. Consta, assim, dos antigos papéis do Arquivo Central das Secretarias de Estado o seguinte pedido:

"Senhor,

Ignacia da Conceição de 42 anos de idade, casada, com três filhos menores, doente e falta de meios, vem respeitosamente à presença de Vossa Magestade solicitar a graça de ser admitida na Escola Normal sua filha Maria Dalgisa de 7 anos. Certa de que Vossa Magestade, como Pai e como Rei, se dignará escutar o pedido justificado de uma Mãe pobre e aflita, que ambiciona a educação de seus filhos, pede e espera lhe seja deferido pela maneira requerida." 223

Agência de moralização, a escola fabrica o profissional com que pretende lidar. Ao professor de instrução primária, cabia a tarefa que anteriormente pertencera ao pároco: confessor e guia de populaçóes. Para isso, os cuidados perante a conduta individual deveriam ultrapassar as fronteiras da própria escola. Havia uma dimensão do sagrado a ser aqui fabricada. Ocorre que, permeada por conflitos e confrontos entre os diversos agentes que compunham sua teia, a instituição convive com universos simbólicos e valorativos multifacetados. Isso leva a crer que, embora reproduzindo um conjunto de códigos e de saberes produzidos pela sociedade de que faz parte, a escola também inventa novos significados, recria pela apropriação o leque da cultura com que trabalha. Pensar a escola é pensar a interação entre a comunidade familiar, os alunos, professores, inspetores, porteiros.... Há dissonância entre essas vozes; há ruídos; mas há também melodias entrecruzadas, há harmonia. A forma ou "gramática da escola” - para emprestar as expressões de Vincent e Tyack ${ }^{224}$ - só poderá ser compreendida mediante a análise conjugada dessas diferentes vozes, que traçam, no panorama geral, distintas versões acerca do lugar social ocupado efetivamente pela escolarização. Nessa medida, em seu traçado cotidiano, a escola institui o território do inédito e inventa algo de novo, ao procurar cumprir uma incumbência que acredita ser sua vocação institucional.

${ }^{223}$ Arquivo Central das Secretarias de Estado MINISTÉRIO DO REINO Maço 3882. Na margem do canto abaixo à direita, alguém assina, com data de 20 de junho de 1874 , e atesta que a requerente é pobre.

224 Em Tinkering toward utopia, David Tyack e Larry Cuban procuram questionar o alcance da resistência à mudança que as práticas escolares demonstram ter, mediante a indagação de alguns pressupostos básicos: "Por que os americanos acreditaram no progresso da educação por mais de um século e têm-no colocado em dúvida nos útlimos anos? O quanto é acurada a percepção de que as reformas educacionais vêm em ciclos; e como isso pode ser reconciliado com a noção de progresso? Qual a relação entre o discurso político, a ação política e os mecanismos instituicionais? Como a escola tem mudado as reformas, opondo-se à tese de que as reformas mudam a escola? O que constitui o sucesso na reforma da escola? Por que esses sucessos tornam-se invisiveis? Por que a gramática da escolarização - a forma organizacional que preside a instrução - persiste (...)?” (David TYACK e Larry CUBAN, Tinkering toward utopia, p. 5). 
A escola que vive o dia-a-dia da sala de aula não corresponde exatamente à escola reclamada por políticos, criticada por jornais, ressaltada por pedagogos. Entretanto, também não é alheia a todos esses discursos. Compreender a sala de aula exige, pois, essa sintonia com o tempo: tempo dos professores, sim, mas também tempo de alunos, de inspetores, de Comissários de Estudos, de porteiros; tempo das famílias e do liberalismo; tempo da máquina a vapor e da industrialização; tempo, enfim, da comemoração do estado nacional.... Vivia-se um tempo onde cada vez mais se firmaria o lugar dos compêndios na escola. Por sua vez, as intençốes dos autores de compêndios não correspondem exatamente ao uso que o professor faz desses conteúdos que procura transmitir. Por sua vez, o aluno fará uma triagem daquilo que a escola efetivamente lhe traz em termos de significado; as famílias interpretarão esse conjunto. Parece evidente que, nesse contracanto, há conflito, há disputa de representaçôes, há confronto, há concorrências, há contradições. Por tudo isso, a ação escolar interage com a história, é filha de seu tempo. A construção da escola parece-nos, nessa medida, um diálogo dos atores educativos com sua época, com seu país, com sua região, com os poderes locais e globais (políticos e econômicos), com seus semelhantes, consigo próprios... 


\title{
5. Tempo E ESPaÇo de ENSino: o TRAÇAdo do Currículo (INSPEÇÃO ÀS ESCOLAS EM I 867)
}

\author{
"Porque conhecer é como nunca ter \\ visto pela primeira vez, e nunca ter visto pela \\ primeira vez é só ter ouvido contar"
}

(Fernando Pessoa)

\section{Inspeção estatística, rotinas escolares e roteiros de aprendizado}

O presente capítulo abarcará o tema da inspeção às escolas, lidando com alguns Relatórios de inspetores, entre as décadas de 50 e 70 do século XIX português. Na verdade, pretendemos reconstruir, pelo levantamento de discursos, de dados e de inferências estatísticas, alguns aspectos da vida cotidiana da escolarização primária. Pudemos, sob tal perspectiva, averiguar o quanto o debate sobre a educação estaria ancorado em práticas efetivas de sala de aula. Partimos da hipótese segundo a qual, para se compreender o que, de fato, era realizado em cada classe, havia de se questionar o próprio espaço físico, as condições materiais da aula, o mobiliário, os utensílios pedagógicos utilizados. Mais do que isso, era preciso articular o lugar social de tais objetos, averiguando seus usos. E finalmente seria imprescindível compreender os atores que atuavam naquele cenário. Pudemos indagar quais os pontos de intersecção e quais as distâncias entre a escola dita e apregoada e a escola efetivamente vivida, tanto em termos dos procedimentos relativos à instrução propriamente dita, quanto no tangente aos castigos, às repreensões, eventualmente às recompensas, ou ainda no que concerne à interação que aquela vida escolar mantinha com a comunidade que a ela acorria. $\mathrm{O}$ que, de fato, as famílias esperavam da escola? Pela voz dos inspetores, pudemos rastrear muitos dos indícios que o passado escolar nos legou. Para tanto, propusemo-nos a uma abordagem combinada entre os necessários aspectos quantitativos e a imprescindível interpretação qualitativa dos recortes de cotidianos pela estatística obtidos.

Ao tomar em mãos a documentação concernente aos registros de inspeção efetuados nos anos de 1867 e 1875 em todos os distritos do território português, optamos por trabalhar o material recorrendo à estatística, ainda que não mantivéssemos qualquer pretensão de alcançar uma suposta totalidade, crença muitas vezes subjacente a usos de procedimentos quantitativos de investigação. Certeau adverte que, ao classificar unidades léxicas, a estatística produz um tipo de significado que lhe é específico. Será 
necessário criar uma nova categorização do real; já que o caminho da estatística "baliza os elementos utilizados e não o fraseado devido à bricolagem, à inventividade artesanal, à discursividade" 225 . Ao enveredar por tal opção metodológica, acreditamos que reconstituir alguns parâmetros médios da sala de aula portuguesa seria uma estratégia interessante para se obter revelaçôes do cotidiano escolar. A estatística propicia a média, tal como esta pode ser depreendida das informaçóes constantes dos Relatórios de inspeção. Ao fazer isso, evidentemente deixamos de encontrar muito do que procurávamos, dado que a multiplicidade das salas de aula não se reconstrói facilmente. De qualquer maneira, os Relatórios, ainda que detalhados, não nos trazem de volta a dinâmica, o movimento, as vozes infantis ou o buliço de sala de aula, resgatando apenas as notas, por vezes, lacônicas, estanques, do modo pelo qual se pretendeu talvez contar à posteridade o modo de ser da escola primária à moda portuguesa. Procuramos assinalar, dos dados contidos nos Relatórios (fundamentalmente o de 1867), pistas quantitativas, passíveis de fornecer um cruzamento de informações. Especialmente para o caso dos Relatórios de Inspeção de 1875, procuramos desenvolver critérios interpretativos de base qualitativa. Dessa maneira, procuramos percorrer o duplo caminho da pesquisa, com grandezas diferentes: entre a quantidade e a qualidade no tratamento dos dados e das informações.

Para melhor aproveitamento de nosso material primário, optamos por preliminarmente trazer alguns recortes, extraídos da coletânea organizada em 1984 por Joaquim Ferreira Gomes, que abarca - como consta do próprio título - os relatórios do Conselho Superior de Instrução Pública entre os anos 1844 e 1859. Com esta documentação, passamos a falar da materialidade da escolarização. A instrução primária é apresentada, já no Relatório do ano letivo de 1844-1845, como modalidade de ensino que mais interferirá na felicidade dos povos, sendo, em sua própria essência, um gênero nacional, pelo fato de dispor o homem para os "usos mais ordinários da vida". Mesmo assim, reconhece-se que foi esse ramo de ensino o último que entrou no quadro das preocupaçôes do estado português, precedido pelos níveis secundário e superior ${ }^{226}$. No que dizia respeito à situação então reinante naquelas tardias escolas de instrução primária, os problemas da origem teriam sido agravados pelos elevados níveis de absenteísmo escolar, de crianças que principiavam a escolarização para depois abandoná-la, ou mesmo aquelas que, apoiadas por seus pais - ao desespero das doutrinas pedagógicas e dos discursos entusiastas -, sequer adentravam o recinto escolar.

Nos termos do Relatório do ano letivo de 1844-1845, eram 1116 as escolas públicas do Continente sustentadas pelo Estado, sendo que haveria certa margem de imprecisão decorrente da transferência de algumas e de outras, que haviam estado

\footnotetext{
${ }^{225}$ Michel DE CERTEAU, $A$ invenção do cotidiano; artes de fazer, p. 45-46.

226 "A instrução primária, apesar de ser a que influi mais diretamente na felicidade dos povos e que, por isso, é denominada por excelência nacional, porque dispõe o homem para os usos mais ordinários da vida, foi contudo a última que entrou no quadro da administração do Estado. Quando já a secundária e superior se achavam contempladas na universidade, fundada pelo sr. D. Dinis, ainda a instrução primária andava abandonada aos cuidados dos particulares e pelos claustros dos cabidos e conventos, a quem o estado pagava, quando muito, alguma pensão para o sustento de alguma cadeira. "(RELATÓRIOS do Conselho Superior de Instrução Pública, p.26).
} 
vagas, terem sido providas. Cerca de 45.500 alunos do sexo masculino e 1.641 do sexo feminino frequentavam essas escolas públicas que, por sua vez, concorriam com outras 1.084 escolas particulares, frequentadas por 18.776 alunos de ambos os sexos. A população de Portugal era estimada, na época, em 3.412.500, sendo portanto a proporção de escolas avaliada em 1 para 53 habitantes. Havia - como se pode observar - distinção também no que diz respeito ao gênero, pelo fato de as escolas femininas serem em número bastante diminuto em relação às masculinas. $\mathrm{O}$ Relatório salientava que, no ano de 1844 , teria havido uma reestruturação do ensino primário, mediante o acréscimo do $2^{\circ}$ Grau, que viria a supostamente aprimorar o sistema de instrução. Supunha-se que um dos modos de melhorar a escola seria o de tornar mais complexo esse sistema de ensino. Destaca-se a necessidade de favorecer o investimento na formação dos professores, embora o projeto de estruturação de Escolas Normais necessitasse de um ensaio prévio, posto na experiência a ser efetuada em escola modelo, em Lisboa. Nunca é demais lembrar que, para essa época, quando se diz escola, o que se pretende dizer é uma classe aberta em funcionamento, com um grupo de alunos, sob responsabilidade de um professor. A essa realidade herdeira do pombalismo era dado o nome de escola.

Note-se que se considerava como adepta do ensino simultâneo a maioria das escolas portuguesas daquela época. No mesmo período, temos a defesa do ensino simultâneo levada a cabo por autores como Castilho, que pareciam, naquela altura, sonhar com esse modo combinado e ritmado de ensinar as primeiras letras. Por outro lado, verificaremos que, nos Relatórios concernentes à inspeção de 1866-67 e 1875, constata-se uma maioria de professores que tinham profunda dificuldade de estruturar seu ensino por outro tipo de metodologia que não fosse o modo individual. Por aí, julgamos que, naquele ano de 1845, compreendia-se por 'ensino simultâneo' antes um ato de vontade do que uma prática efetivamente implementada. É de se supor que houvesse níveis bastante elevados de transmissão individual do conhecimento escolar na escola portuguesa do século XIX. Temos razóes para suspeitar que o discurso da inspetoria carece de rigor terminológico, até no que diz respeito à sistematização das informaçôes, que, grande parte das vezes, vinham impressas por um tom demasiado idealista e vago ${ }^{227}$. Ao defender, por exemplo, o aumento dos ordenados dos professores, o Relatório discorre sobre a relevância do papel social desses profissionais, que, pela força da precariedade reinante, não se veriam estimulados ao esforço para obtenção de melhoria e promoção. Sugere-se uma escala de três graus como plano de carreira para os profissionais da educação, de modo a favorecer a difícil emulação para uma profissão pouco valorizada em termos dos proventos recebidos. A esse respeito, consta do Relatório o seguinte juízo: "está geralmente reconhecido que o progresso somente se pode esperar da carreira aberta ao talento:

${ }^{227}$ Os próprios Relatórios eram reconhecidamente imperfeitos, pelo fato de não haver dispositivos que permitissem a cobertura de todo o Reino, sem exceção. Sobre esse aspecto, consta do texto relativo ao ano letivo de 1844-1845 o seguinte: "a falta de muitos Relatórios parciais não permite fazer este geral mais circunstanciado e regular, nem deduzir dele combinaçôes e resultados práticos, em que consiste a maior utilidade de tais obras. Com a prática, é natural que se vá emendando aquele defeito, sendo essa a sorte de todas as instituiçôes nascentes começarem imperfeitas; $e$, quando o Conselho tiver elementos estatísticos em que se possa firmar com segurança, poderá então expor com maior regularidade o estado da instrução pública e propor as providências que ele reclamar". (RELATÓRIOS do Conselho Superior de Instrução Pública, p. 39). 
enquanto os ordenados e recompensas, por maiores que sejam, não o despertam, se se lhe tira a sedutora perspectiva de um futuro mais feliz." 228

Pelo fato de se assumir no texto o olhar iluminista, para o qual a instrução pública é caracterizada como alicerce do desenvolvimento e da prosperidade das nações, reclama-se a necessidade de colocar todas as escolas públicas em edifícios do Estado, padronização esta que serviria aos interesses de uma rede escolar disciplinadamente homogênea, padronizada e uniforme. Sendo que basicamente cada escola correspondia a uma única classe, a maioria desses estabelecimentos funcionava, ainda, nos velhos moldes herdados do Antigo Regime, nas próprias casas em que habitavam os professores, em proporção que veremos adiante.

Ao reiterar os já conhecidos índices sobre a proporção de escolas públicas em relação aos alunos matriculados, o Relatório do ano letivo de 1846-1847 explicita que tais dados podem não corresponder à realidade das escolas, pelo fato de haver inúmeras crianças que, embora matriculadas, em nada aproveitam a instrução e abandonam frequentemente a escola. Mesmo assim, o Conselho reconhece progressos na situação das escolas primárias, expressos inclusive no zelo e na assiduidade de professores. O Conselho manifesta sua preocupação quanto à superintendência e vigilância das escolas por Comissários qualificados para tal função, de modo a que as visitas às escolas se fizessem regulares e periódicas e que pudesse efetivamente existir avaliação "com a nota de merecimento, assim literário e moral, como pedagógico dos professores, recomendando-lhes a escolha e a indicação dos melhores métodos e o estímulo de sociedades que promovessem nas aldeias o gosto e o zelo pela instrução" 229 .

Teria sido, pelos padrões legais, a orientação do Decreto de 20 de Setembro de 1845 que criou para todo o território português o ensino primário de $2^{\circ}$ grau, que, nos termos do Relatório da inspeção referente ao ano letivo de 1846-47, "não diferem das do $1^{\circ}$ senão em ensinar-se nelas o ensino primário em toda a sua latitude e com mais perfeição." 230 $\mathrm{Na}$ verdade, esse degrau da escolarização voltava-se fundamentalmente para classes pertencentes a povoações urbanas, comerciais e industriais - diz o mesmo texto - "cujos habitantes querem seus filhos habilitados para manejarem com inteligência as suas profissōes, sem os passar ao ensino secundário"231. Era como se houvesse a possibilidade de ilustrar as camadas médias e inferiores da população, sem com isso proceder à temida subversão do tecido social, em sua grade hierárquica e estamental. A orientação curricular parecia, desse modo, ancorada na orientação de classe social. O conhecimento desejado deveria ser, antes de tudo, contido e graduado; do contrário, poderia vir a se constituir como arma indesejada e perigosa. Percebe-se, a esse respeito, a intensa preocupação em relação a atitudes de inculcação de hábitos morais, tidas como mais necessárias ao professor do que a própria capacidade de ensino.

Reclamando da ausência de escolas normais que efetivamente preparassem o magistério, o Conselho pondera sobre os verdadeiros efeitos da multiplicação das escolas primárias enquanto aquelas não existissem, recordando, em função disso, a pouca

\footnotetext{
${ }^{228}$ Id. Ibid., p. 30.

${ }^{229}$ RELATÓRIOS do Conselho Superior de Instrução Pública, p. 46.

${ }^{230}$ RELATÓRIOS..., p. 46.

${ }^{231}$ RELATÓRIOS..., p. 47.
} 
frequência e o diminuto número de crianças que ao ensino acorriam. Mesmo assim, sugere-se a criação de escolas em freguesias rurais, recomendando que o ensino nesses estabelecimentos fosse confiado aos próprios párocos das aldeias. No ano letivo de 1847-1848, o Conselho manifesta sua preocupação com o problema do material didático em uso nas escolas. O Relatório diz que "o Conselho tem coligido, dos livros elementares nacionais, os mais adaptados ao ensino de instrução primária e, anualmente, tem comunicado ao governo de V. Magestade a coleção adotada" ${ }^{232}$. O atraso da instrução primária em Portugal, em relação aos demais países europeus, preocupa os especialistas. Desse modo a multiplicação das escolas primárias apresenta-se como prioridade primeira dos planos do Conselho. A escolarização primária, sendo a única que se supóe efetivamente universal, é aquela que deverá ser "levada à porta de todos, porque é a de que todos precisam" 233 . Os registros de inspeção começam já a procurar mapear o estado do analfabetismo em todo país, e reparam que, no cômputo geral, as províncias do Norte do Tejo têm níveis intelectuais mais elevados que as outras do Sul, o que se manifesta também no aproveitamento da instrução primária em cada região do Continente. A crença no método, como âncora infalível da escolarização, também surge bastante acentuada aqui. Recomenda-se que se ensaiem as metodologias de ensino preconizadas por Pestalozzi, Jacotot e Kley. Supõe-se que a inovação didática será capaz de trazer vantagens e facilidades para o ensino. E, ao lado disso, sugere-se que a utilização de bons livros escolares poderá vir a se tornar a pedra de toque da melhoria do ensino português. Aparece, assim acentuada, a crença nas técnica e nos instrumentos como o fator determinante do êxito da educação ministrada.

O Relatório anual de 1848-1849 destaca, já no princípio, a precariedade dos esforços educativos, sentida fundamentalmente a partir das resistências do magistério à mudança, às reformas e às inovaçôes ${ }^{234}$. O texto apresenta como outros obstáculos ao progresso da civilização a insuficiência dos professores, o reduzido número de escolas de instrução primária e a pequena afluência dos alunos a muitas delas. Recorda o Relatório que, em Bragança, alguns párocos se teriam disposto a reger gratuitamente algumas cadeiras de instrução primária, tendo havido, por meio desse auxílio das irmandades, um aumento no número de escolas da região. O Conselho aplaude e recomenda tal iniciativa.

Naquela época, o Conselho Superior de Instrução Pública, preocupado que estava com a busca de bons métodos para impulsionar os progressos da instrução, tomava a peito a tarefa de avaliar a utilização de obras experimentais; era o caso da Leitura Repentina de Castilho - como vimos, aliás, em capítulo anterior. Procurava-se emitir julgamento acerca da validade das obras em observação, como critério para sua recomendação e possível generalização. A escola portuguesa caminhava para a busca da padronização. Toda diversidade era assim considerada improdutiva e defeituoso seria o ensino ministrado enquanto não se fizesse capaz de superá-la. Projetava-se uma nova materialidade escolar, que supunha a introdução de técnicas pedagógicas e utensílios didáticos em consonância com o que vinha sendo experimentado nos demais países da

\footnotetext{
${ }^{232}$ RELATÓRIOS do Conselho Superior de Instrução Pública, p. 59.

${ }^{233}$ RELATÓRIOS... p. 71.

${ }^{234}$ RELATÓRIOS do Conselho Superior de Instrução Pública, p. 75.
} 
Europa. A leitura escolar passava a ser prioridade do discurso técnico-pedagógico, pelo fato de se traduzir quase como contraponto à leitura espontânea.

Zelo, moral, civilidade docente e aproveitamento dos alunos

O século que reconhece a leitura como sua marca matricial pretende dela se apropriar para poder transformá-la. A atitude do leitor escolar conformaria regras que regulariam o gesto de ler, disciplinando a curiosidade intelectual e tornando-se, pela prática de uma rotina heterônoma, arte do previsível. A preocupação com o livro escolar, muito cara desde essa segunda metade do século XIX, tem a ver com o desejo, que os teóricos da escolarização e as classes letradas de uma maneira geral possuem, de atribuir à escola o monopólio do ensino da leitura. A escola de ler, escrever e contar é também a instância de regulação social do ato de ler. Há nítido propósito de controle da leitura espontânea por meio do que se compreendia ser a missão da leitura escolar. $\mathrm{O}$ intento de padronização é, a esse respeito, expresso diretamente no discurso dos inspetores. Teria havido melhoramento na instrução primária exatamente em decorrência da uniformização de algum material didático. A estrutura da grade curricular de modo sistematizado teria sido efetuada exatamente a partir dos compêndios. O método, então, era tributário da substituição do ensino manuscrito pelo livro. Nisso estaria a marca da modernidade desse estilo escolar.

Percebe-se a explicitação do desejo de uniformidade como pauta para a atuação do órgão central da administração pedagógica. Ao Conselho Superior de Instrução Pública caberia proceder a essa homogeneização da rede das escolas primárias portuguesas, mediante a consolidação de estratégias de formação e de supervisão dos docentes, mediante inclusive a organização de visitas regulares dos inspetores às escolas, com o objetivo de auxiliar o conjunto dos professores a observar as regulamentaçóes legais e os procedimentos didáticos sugeridos para o magistério. Através desse esforço, supunha-se que a instrução portuguesa estaria no caminho do progresso da civilização. $\mathrm{Na}$ sequência do mesmo Relatório de 1850-1851, reconhece o Conselho a precariedade da situação da maioria das escolas, que ainda sofria pelo abandono e absenteísmo da população matriculada, provocando disparidade entre os números oficiais e a realidade escolar em sua dinâmica concreta. Destaca o texto que a população portuguesa não estaria, ainda, convencida da necessidade social de enviar os filhos à escola. Pelo contrário: as famílias pareciam resistir à escolarização de seus filhos, fosse pelas debilidades da vida escolar, fosse por necessidade do trabalho infantil. Seja como for, a despeito do entusiasmo com que aparecia a complexidade aparente dos currículos em vigor na escola primária, o Relatório aqui é menos otimista perante o futuro da instituição.

Recorda-se, também, que, frequentemente, as populaçōes rurais viam prejudicada a rota da escola pela precariedade dos caminhos ou pela excessiva distância entre a habitação e o prédio escolar. Com medo dos perigos do trajeto ou pela necessidade do trabalho na lavoura, os pais optavam por não mandarem os filhos à escola. O Relatório de 1854-1855 chega a propôr que os párocos das aldeias contribuíssem na tarefa de persuasão dos pais de família para que confiassem seus filhos à instrução. Era preciso melhorar a formação oferecida na escola para que ela pudesse fazer sentido para as populações; que, por enquanto, ainda não faziam caso 
do ler e do escrever. Havia de se aprimorar métodos e modos de ensino; mas urgia, sobretudo, encontrar soluções para as dificuldades materiais postas na vida escolar e que englobavam do salário do professor às condições e à localização do próprio prédio da escola.

O comissário José Maria d'Almeida e Araújo Corrêa de Lacerda, em 24-12-1855, assina o Relatório dirigido ao rei, relatando a situação em que se encontravam as escolas do distrito de Lisboa naquele período. Tal obrigação de prestar contas ao rei em tal Relatório circunstanciado teria sua origem no decreto datado de 10-11-1845. Além de Comissário de Estudos do distrito de Lisboa, o relator era Reitor do Liceu Nacional de Lisboa. Ele queixava-se das dificuldades de proceder à investigação que lhe fôra confiada, considerando a escassez de informaçôes provenientes de averiguaçóes anteriores, além da falta de tempo e de recursos necessários. O relator denuncia a prática, usual entre professores de escolas públicas, de recebimento do que entendiam ser "subsídios pecuniários" de seus discípulos, o que fraudaria o compromisso mútuo entre Estado e docentes, já que cumpria ao primeiro a indeclinável obrigação de custear gratuitamente, a todas as camadas da sociedade, a instrução elementar. Para o relator, em virtude dos baixos salários recebidos pelo magistério, era difícil penalizar tais professores. Além disso, apesar da prescrição legal quanto ao estabelecimento de edifícios públicos a serem utilizados como casas de educação, notava-se que, à época, na grande maioria dos casos, a casa de escola era ainda alugada pelo próprio professor, com o objetivo de poder ministrar suas aulas - na ausência de ação mais efetiva por parte dos poderes centrais.

O relator sublinha também a necessidade de as escolas fortalecerem o espírito do catolicismo, mediante a introdução de uma cadeira específica de religião nas escolas primárias, já que o estudo de doutrina cristã, por ser excessivamente complexo para a cognição infantil, não cumpriria por si só esse intento de reforçar a religiosidade. Ignorando a religião - pondera o texto -, os homens desconheceriam "as razões da consciência que nos obrigam ao fiel desempenho dos deveres sociais”. A criação de uma cadeira específica para o ensino religioso seria a forma de trazer solidez aos preceitos da doutrina católica professada e deles deduzir as implicações no sentido da conformação de hábitos e de açôes necessários ao bom cumprimento dos deveres para com Deus. Isso seria por si só pedagógico e não cabia à escolarização furtar-se da função eminentemente moralizadora, derivada da "exata observância da sua moral divina". ${ }^{235}$ Além disso, o Comissário de Estudos sugere a uniformização dos compêndios utilizados nas escolas primárias e secundárias públicas e particulares. Essa seria fundamentalmente uma estratégia endereçada a padronizar os recursos e os temas postos como específicos da instrução primária:

“(...) venho suplicar com a maior instância, a Vossa Magestade, que se digne fazer apresentar, porque pertence exclusivamente ao corpo legislativo, um projeto de lei, em virtude do qual fique pertencendo ao Conselho Superior a escolha dos compêndios; e que, por compêndios idênticos hajam de ser lidas as diferentes disciplinas (...) perante o Conselho Superior

\footnotetext{
${ }^{235}$ Id. Ibid., p. 7.
} 
de Instrução Pública poderão disputar preferências, simultânea ou sucessivamente, os autores ou introdutores dos novos compêndios"236

O Comissário de Estudos reservou um item específico intitulado "Método português e de leitura repentina”. Consistia ele - como já elucida o título - em um parecer circunstanciado sobre a aplicação do Método de ensino das primeiras letras desenvolvido por José Feliciano de Castilho em algumas escolas - e o resultado decorrente desse procedimento. Teria sido o próprio rei quem - por portaria expedida pelo Conselho Superior de Instrução Pública - ordenara que do Relatório constasse parecer a respeito das vantagens do método de Leitura Repentina. O relator explica que, para proceder a tal investigação com o devido rigor, dirigiu-se a professores de escolas públicas e particulares, obtendo, no final, 96 respostas, das quais 18 referiam-se a classes de ensino feminino. Pela leitura dos documentos, que teriam sido arquivados na Comissão de Estudos, algumas deduções faziam-se já cabíveis: 71 reprovavam o método (dentre um total de 96); 6 aprovavam-no, sendo que, desses, 4 o praticavam sem alterações, 1 com alterações e o outro aprovava sem, entretanto, praticá-lo; 19 desconheciam por completo o método; 16, dentre os 71 que reprovavam o método, haviam-no ensaiado.

A rejeição ao Método Português-Castilho viria então acompanhada por variadas razões, arroladas a seguir como decorrentes das justificativas apresentadas pelos professores:

1) Dificuldade, em Lisboa, de os alunos começarem o curso regular na idade apropriada. Isso dificultaria quaisquer processos de ensino simultâneo. A polêmica em torno da adoção da metodologia desenvolvida por Castilho vinha, nesse caso, mais uma vez, acoplada à idéia de outro modelo de aula a referenciar a atuação do professor. Parecia mesmo que o que então se buscava era o ensino coletivo simultâneo. A esse respeito, o Relatório explicitava o seguinte:

"O método português, para produzir as vantagens que promete, requer essencialmente que o ensino seja comum; mas, como pela razão dada não o pode ser, torna-se impraticável ou inútil. Os arbítrios empregados diversamente por diversos professores para atenuar os inconvenientes da irregularidade das matrículas (irregularidade, aliás, invencível, porquanto a não se permitir, ficariam de pronto desertas as escolas, mormente fora das grandes cidades) sendo de fácil e proveitosa adoção, quando os professores empregam o método simultâneo individual, contrariam diretamente o da leitura repentina, porque o tornam mais moroso e menos eficaz." ${ }^{237}$

2) Haveria descaso pelo estilo individual dos professores, como comenta o trecho abaixo transcrito:

"Porque desconsidera os professores, porquanto, obrigando-os a cantar, a bater palmas, e como que a fazer esgares para bem exprimir, cantando, os diferentes valores de algumas letras, etc., quando acontece que o professor é de figura desastrada, ou disforme de rosto, ou tem defeito

\footnotetext{
${ }^{236}$ José Maria d'Almeida e Araújo Corrêa de LACERDA, Relatório do Commissário dos Estudos do districto de Lisboa pertencente ao anno de 1854, 1855, 1856, p. 8.

${ }^{237}$ Id. Ibid., p. 10.
} 
na boca ou na toada desafina, o expõe à mofa ou ao riso dos discípulos. É certo, em todo caso, que a pouca idade ousa desenvolta o que não deve e, como vulgarmente se diz, toma confiança demasiada e inconveniente com quem com ela como que se desenlaça; e é certo igualmente que não fica fácil ao professor, que necessariamente há-de usar de tais meios para chegar ao seu fim, manter-se com a gravidade própria e indispensável de quem ensina, e educa." ${ }^{238}$

3) Considera-se que as impressões obtidas por tal método apresentariam enormes dificuldades de memorização por parte dos alunos, além do fato de a introdução de ritmos e de toadas dispersar a atenção da criança, confundindo o processo de aprendizado com um momento de entretenimento. As crianças tropeçam a cada passo e entremeiam, sem êxito, o canto com as tentativas de ler.

4) Com a alfabetização pelos procedimentos previstos por Castilho, os educandos adquiririam vícios dificilmente extirpáveis. A leitura cadenciada conduziria a criança a decorar a lição, mesmo sem dominar o processo da leitura, o que dificultaria o processo posterior de proceder à leitura sem cadência. Além de problemas relativos à pronúncia, as crianças teriam adquirido tiques no rosto, pela contínua tentativa de imitar, entoar e cantar.

5) Além das objeçôes anteriores, considera-se que o método destrói a ortografia etimológica, usualmente aceita pelos literatos. A rejeição da nova ortografia decorreria do fato de sua utilização vir a contrariar o que aqui se denomina "índole da língua portuguesa, que não pode renegar as de que descende, sem que se transforme numa algaravia ininteligível”239. Tal modificação dos códigos linguísticos tradicionais agiria no sentido de dificultar o estudo das línguas estrangeiras, além de exigir a tradução de todos os livros publicados até então em língua portuguesa.

6) O método não ensinaria a escrever, o que induzia os professores a recorrerem a outras metodologias de ensino, que, ensinando a escrita, se sobrepusessem ao modelo de Castilho, o que por sua vez produziria o que se caracterizava aqui como nefasto sincretismo.

7) Os alunos desse método não teriam qualquer tipo de destaque nos exames de instrução primária.

8) Pondera-se, ainda, o aumento das despesas do Estado e dos particulares, dificultando a "instrução geral que, aliás, em proveito comum, deve facilitar-se quanto for possível" 240 .

Apesar de todas essas dificuldades assinaladas pelo corpo docente, o Comissário de Estudos do Distrito de Lisboa José Maria d'Almeida e Araújo Corrêa de Lacerda defende o Método Português-Castilho, identificando-o como um instrumento alternativo adequado para proceder a uma melhoria real no ensino da leitura. Convencido de que as inovaçôes produzidas pelo poeta Castilho representariam vantagens significativas para

\footnotetext{
${ }^{238}$ Id. Ibid., p. 10.

${ }^{239}$ José Maria d'Almeida e Araíjo Corrêa de LACERDA, Relatório do Commissário dos Estudos do districto de Lisboa pertencente ao anno de 1854, 1855, 1856, p. 11.

${ }^{240}$ José Maria d' Almeida e Araújo Corrêa de LACERDA, Relatório do Commissário dos Estudos do districto de Lisboa pertencente ao anno de 1854, 1855, 1856, p. 11
} 
o domínio da habilidade da leitura, o relator conclui - contrariando a imensa maioria de pareceres de que se valeu - que "não se apresentam razões bastantes nas quais haja de fundamentar-se a condenação do método português" ${ }^{241}$. Contudo, ele não poderia deixar de minimamente ouvir o eco dos vestígios de sala de aula. Por causa deles, observa também que "tampouco por hora se dão as [razôes] que se precisam para [o método português] haver de ser adotado exclusivamente, como seu ilustre autor parece desde já desejar" ${ }^{242}$. A proposta do Comissário de Estudos é a de que, por todas as razões que, por um lado, favorecem, e, por outro, depreciam o Método Português, continuasse a haver um "ensaio" sobre a aplicação do mesmo método, de modo a que a análise pudesse vir a ser apurada; e, se possível, acompanhada pelo aperfeiçoamento da reflexão prática e teórica dos professores, que - a propósito do tema, segundo o Comissário - não pareciam ter razão.

Preocupado com os níveis elevadíssimos de abandono escolar, o Relatório de Correa de Lacerda, no final do ano 1855, sugere procedimentos para diminuição dos níveis de evasão, os quais, em grande parte dos casos, decorriam mais da família e das opções dos pais pelo trabalho das crianças do que da própria vontade das crianças. As escolas primárias, para se tornarem verdadeiramente atraentes, deveriam, por seu turno, ser providas com equipamentos, mobiliários e utensílios adequados, de maneira a permitir uma vida escolar estruturada em termos de exercícios e de liçóes - sem que, para tanto, faltassem quadro-negro e tabelas para tabuadas, papel, tintas e penas. Sugere-se, ainda, o auxílio pecuniário a todos os professores que tivessem consigo um número superior a 100 discípulos. Reconhecia-se, entretanto, ser a pobreza a principal causa da permanência da ignorância da ignorância popular.

O Relatório do Conselho Superior de Instrução Pública datado do ano letivo de 1856-57 propõe, para melhorar a situação do magistério, um aumento de ordenados, e também o fornecimento por parte das Câmaras Municipais ou Juntas de Paróquias, de utensílios e de casa apropriada para as escolas, a criação de um corpo de inspeção regular tendo em vista a obtenção da uniformidade do ensino e a criação de escolas normais. ${ }^{243}$

O lugar da escola na construção de uma sociedade mais desenvolvida, mais civilizada, mais próspera, enfim, passaria antes pelos hábitos de civilidade que a escola introduz do que por quaisquer saberes letrados. A esperança dos especialistas consiste na possibilidade de que - nos termos do Relatório referente ao ano letivo de 1853-4 -"em todas as classes vá penetrando o respeito às leis, os sentimentos honestos que acompanham sempre as idéias justas, o gosto do trabalho e o conhecimento dos bens que ele procura, a moderação dos desejos e este amor esclarecido de ordem que é hoje o único sacrifício dos povos". ${ }^{244}$

${ }^{241}$ José Maria d'almeida e Araújo Corrêa de LACERDA, Relatório do Commissário dos Estudos do districto de Lisboa pertencente ao anno de 1854, 1855, 1856, p. 12.

${ }^{242}$ Id.Ibid.

${ }^{243}$ O Relatório referente ao ano letivo de 1857-8 acentua a incompetência da maior parte dos professores que concorria às cadeiras de ensino primário. Alegava-se que os atestados de bons costumes eram passados sem rigor, que os docentes não possuíam o conjunto das necessárias habilidades literárias e que a própria prática do ensino não favoreceria qualquer aprimoramento. Pelo contrário, os baixos salários contribuiriam para a efetiva degradação da função docente (RELATÓRIOS do Conselho Superior de Instrução Pública, p. 262).

${ }^{244}$ RELATÓRIOS do Conselho Superior de Instrução Pública, p. 172. 
Nota-se que se espera da escola não apenas a reprodução pela via da cultura dos dispositivos de dominação e de desigualdade social, mas, mais do que isso, a criação, pelo patamar da cultura, de instrumentos de domínio simbólico, mais efetivos do que a coerção. A escola deverá apresentar-se como instância produtora do consensos, de fabricação e consolidação dos iguais na ordem desigual. Pelo imaginário da nação projetada, a escola surge como o veículo de sustentação e de perpetuação social. A sociedade que pretendia mudar deveria alterar sua dinâmica escolar e produzir, dessa maneira, novo imaginário, novo consenso. Por um lado, a constatação da inutilidade da existência de escolas a que a população não acorria. Por outro lado, a conclamação da necessidade de se criarem mais escolas primárias, em virtude do processo civilizatório. Cabe lembrar que, nessa altura, era já obrigatória a instrução primária, pela legislação portuguesa, embora não houvessem evidentemente quaisquer mecanismos de efetivo controle desse preceito legal. Havia, como óbices para o desenvolvimento da instrução, falta de bons edifícios e de material escolar, conjugada à má formação e péssima remuneração do professorado.

\section{Os relatórios de inspeção às escolas públicas do ano letivo de 1866-67: abordagem preliminar}

Os Relatórios da Inspeção de 1867 possibilitam o tratamento estatístico das informaçôes escolares, com o propósito de obter regularidades reveladoras do quadro em que se encontrava a escola portuguesa no período em tela. Procurou-se dar um tratamento quantitativo aos dados sempre a partir de perguntas claramente formuladas, com o fito de estabelecer correlações e aproximaçôes entre variáveis e entre regiōes. Havia, nesse período, em comparação com os anos 40 e 50 anteriormente referidos, a utilização de mais livros escolares, uma inspeção mais profissionalizada, informações, portanto, mais precisas. Em virtude disso, ao consultar a documentação, percebemos que haveria a possibilidade de efetuar, aqui, algumas perguntas mais concretas. Pretendemos descobrir, por exemplo, se havia alguma relação entre o número de livros da biblioteca do professor e o aproveitamento escolar de seus alunos; qual era o número médio de alunos em sala de aula; qual a idade média dos alunos da escola primária e quais os índices de repetência e evasão; quais as estratégias de ensino usuais, seja quanto aos métodos de alfabetização, seja quanto aos castigos e punições adotados; de que se compunha o mobiliário escolar e os materiais pedagógicos de sala de aula; qual a habilitação dos professores para a prática do magistério... Essas e outras indagaçôes perfilhavam a inquietação inicial, quando nos propusemos a utilizar como amostra cinco concelhos de quase todos os distritos de Portugal. Mediante cópia do texto impresso no Relatório anual referente a 1874-5, pudemos reproduzir os dados manuscritos, de modo a possibilitar o tratamento estatístico. Nessa etapa seguinte, questôes novas surgiram, inúmeras hipóteses preliminares ficaram pelo caminho. Os aspectos que viremos a abordar são considerados indícios de vidas cotidianas, dos usos ordinários da escola em uma tão singela quanto significativa subjetividade pedagógica. À partida, o intuito que nos movia era o de obtenção do máximo de informaçôes extraídas pela via da estatística, o que nos permitiria dela sair - ainda que para posteriormente a ela regressar, com maior solidez de informações, trazidas por 
outros registros de análise. Havia, por detrás daqueles dados, uma realidade profunda, aparentemente intangível, inacessível, submersa: a 'parte oculta do iceberg' ${ }^{245}$.

Passamos a averiguar a distribuição de dados acerca do que se poderia chamar de demografia escolar, especialmente tomando como fonte o Relatório da inspeção de 1867.

Acerca desse Relatório de 1867, especificamente, destacamos que tivemos algumas limitaçôes do acesso às fontes, o que nos impossibilitou espeficamente de trabalharmos os dados da região do Porto. Mesmo assim, esforçamo-nos por estabelecer uma organização do universo estudado por meio de amostragem por distritos, acompanhada pelo número de escolas situadas em cada concelho dos respectivos distritos - excetuado o Porto.

\section{Amostra utilizada e caracterização das escolas}

Tabela 1: Número de escolas por distrito e concelho na amostra:

\begin{tabular}{|c|c|c|}
\hline Distritos & CONCELHo & No. DE ESCOLAS \\
\hline \multirow[t]{5}{*}{ Aveiro } & Águeda & 8 \\
\hline & Aveiro & 8 \\
\hline & Mealhada & 5 \\
\hline & Oliveira d'Azemeis & 8 \\
\hline & Oliveira do Bairro & 7 \\
\hline \multirow[t]{4}{*}{ Coimbra } & Coimbra & 16 \\
\hline & Cantanhede & 8 \\
\hline & Arganil & 8 \\
\hline & Condeixa-a-Nova & 6 \\
\hline \multirow[t]{5}{*}{ Castello Branco } & Idanha a Nova & 8 \\
\hline & Castello Branco & 8 \\
\hline & Belmonte & 3 \\
\hline & Certã & 8 \\
\hline & Covilhã & 8 \\
\hline \multirow[t]{5}{*}{ Guarda } & Almeida & 8 \\
\hline & Cea & 8 \\
\hline & Gouvêa & 8 \\
\hline & Guarda & 8 \\
\hline & Pinhel & 8 \\
\hline \multirow[t]{5}{*}{ Évora } & Mora & 4 \\
\hline & Alandroal & 4 \\
\hline & Évora & 8 \\
\hline & Montemor o Novo & 7 \\
\hline & Redondo & 3 \\
\hline \multirow[t]{4}{*}{ Lisboa } & Cintra & 7 \\
\hline & Belém & 8 \\
\hline & Alenquer & 9 \\
\hline & AldeIa Galega do Ribatejo & 3 \\
\hline
\end{tabular}

${ }^{245}$ A propósito dessa terminologia que Foucault introduz à guisa de referencial analítico, vide L’ordre du discours. 


\begin{tabular}{|c|c|c|}
\hline & S.Thiago do Cacém & 3 \\
\hline & Setúbal & 5 \\
\hline & Olivaes & 8 \\
\hline & Mafra & 8 \\
\hline & Bairro d'Alfama & 8 \\
\hline & Bairro d'Alcântara & 8 \\
\hline \multirow[t]{5}{*}{ Portalegre } & Marvão & 4 \\
\hline & Portalegre & 8 \\
\hline & Souzel & 2 \\
\hline & Alter do Chão & 5 \\
\hline & Elvas & 6 \\
\hline \multirow[t]{5}{*}{ Villa Real } & Villa Real & 8 \\
\hline & Villa Pouca d'Aguiar & 8 \\
\hline & Monte Alegre & 8 \\
\hline & Chaves & 8 \\
\hline & Alijó & 7 \\
\hline \multirow[t]{5}{*}{ Vizeu } & Vizeu & 8 \\
\hline & Tondella & 8 \\
\hline & Resende & 7 \\
\hline & Oliveira de Frades & 8 \\
\hline & Lamego & 8 \\
\hline \multirow[t]{5}{*}{ Vianna do Castello } & Vianna do Castello & 9 \\
\hline & Ponte de Lima & 10 \\
\hline & Monção & 8 \\
\hline & Caminha & 6 \\
\hline & Arcos de Valderez & 8 \\
\hline Total & & 386 \\
\hline
\end{tabular}

O tratamento estatístico a que foram submetidos os dados disponíveis do Relatório da Inspeção de 1867 trazem-nos algumas pistas relevantes para a reconstituição da atmosfera cotidiana da vida escolar portuguesa naquela época. Em relação aos valores estipulados para aferir o aproveitamento dos alunos (0-12), a qualificação média para amostra de todos os distritos selecionados foi de 5,9, sendo que a média mais baixa foi encontrada no distrito da Guarda $(5,0)$ e Villa Real $(5,0)$, e a mais alta corresponde aos distritos de Coimbra $(7,3)$ e Évora $(7,0)$. Tais valores - cabe explicitar - eram apresentados no formulário padrão dos Relatórios, como instrumentos parciais de medida para calcular o mérito do professor. Acerca disso, pudemos verificar que o mérito docente era calculado a partir de critérios variados, que percorriam o comportamento moral e civil do professor, seu zelo para com a atividade do magistério e o aproveitamento pedagógico dos alunos. Para cada um desses quatro quesitos, eram atribuídas notas, computadas entre 0 e 12 , sendo que a distribuição desse patamar avaliatório era feita na seguinte proporção: $0-3=$ medíocre; $4-6=$ suficiente; $7-9=$ bom; 10-12 = muito bom. Como pudemos observar acima, além da análise acerca do aproveitamento dos alunos, procedia-se à mensuração de outros quesitos reputados essenciais para a condição docente e o exercício do magistério: a conduta moral, civil e o zelo. Quanto ao zelo do professor, a média para toda amostra foi de 6,9, sendo que, mais uma vez, o distrito da Guarda recebe o mais baixo valor $(5,6)$, sendo Villa 
Real e Évora destacadas com os pontos mais altos (8,0 e 7,8, respectivamente). Em geral, as notas atribuídas pelo inspetor em relação aos itens 'moral' e 'civil' foram mais elevadas do que aquelas referentes ao 'zelo' docente e ao 'aproveitamento dos alunos'. As máximas qualificações de moral situaram-se nos distritos de Villa Real $(9,2)$ e Lisboa $(9,2)$ e a máxima de civil foi tomada de Lisboa $(9,4)$. Para toda amostra, as médias quanto à conduta moral e civil foram de 8,3 .

Tabela 2: Qualificações médias do inspetor, por escola, sobre o mérito do professor por distrito e para o total da amostra:

\begin{tabular}{|l|l|l|l|l|l|l|l|l|l|l|l|}
\hline & \multicolumn{9}{|l|}{ Distrito } & & \\
\hline Critério & Total & Aveiro & Coimbra & $\begin{array}{l}\text { Castello } \\
\text { Branco }\end{array}$ & Guarda & Évora & Lisboa & Portalegre & $\begin{array}{l}\text { Villa } \\
\text { Real }\end{array}$ & $\begin{array}{l}\text { Vizeu } \\
\text { Vianna } \\
\text { do } \\
\text { Castello }\end{array}$ \\
\hline Moral & 8.3 & 7.4 & 8.6 & 7.6 & 8.3 & 8.6 & 9.2 & 8.4 & 9.2 & 7.4 & 7.8 \\
\hline Civil & 8.3 & 7.6 & 8.4 & 7.7 & 8.2 & 9.0 & 9.4 & 8.4 & 9.0 & 7.4 & 7.6 \\
\hline Zelo & 6.9 & 7.1 & 7.6 & 6.2 & 5.6 & 7.8 & 7.2 & 6.8 & 8.0 & 6.3 & 6.6 \\
\hline $\begin{array}{l}\text { Aprovei- } \\
\text { tamento }\end{array}$ & 5.9 & 5.4 & 7.3 & 5.7 & 5.0 & 7.0 & 6.2 & 5.8 & 5.0 & 5.8 & 5.6 \\
\hline
\end{tabular}

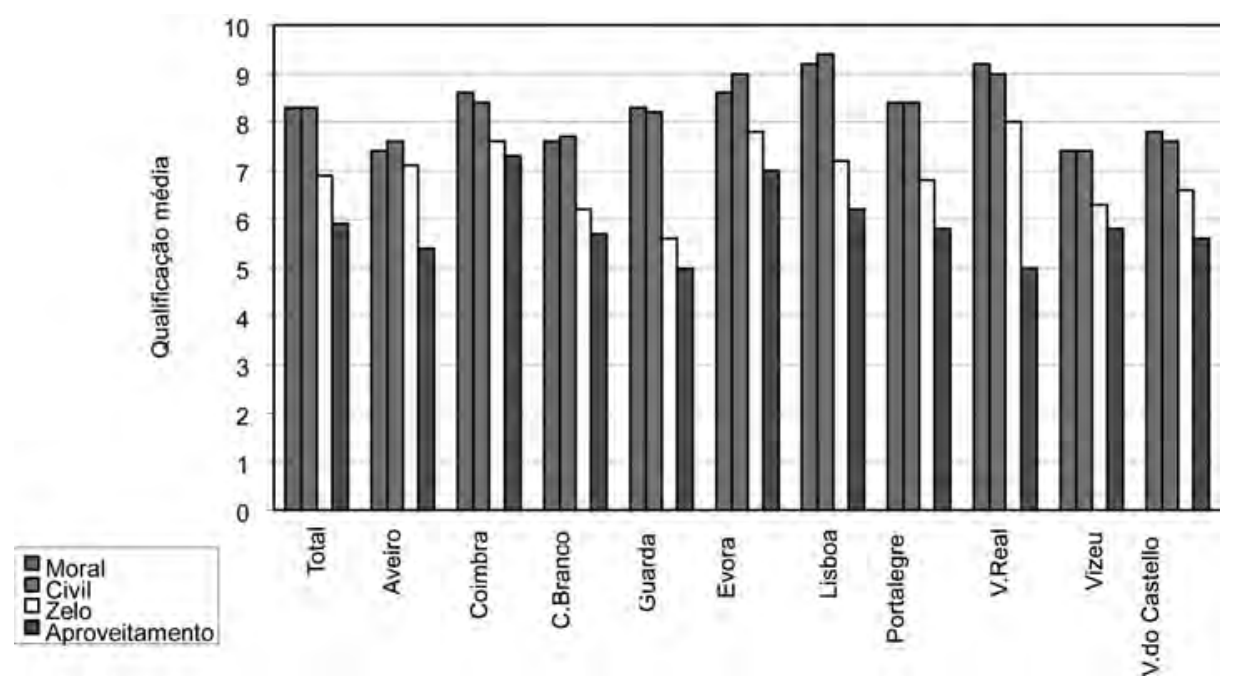

Figura 1: Qualificaçōes médias do inspetor, por escola, sobre o mérito do professor por distrito e para o total da amostra. Portugal, 1867

Ainda no que tange ao mérito do professor, podem ser observadas associações lineares entre os itens moral e civil $(\mathrm{r}=0,96)$; moral e zelo $(\mathrm{r}=0,81)$; moral e aproveitamento dos alunos $(\mathrm{r}=0,72)$; civil e zelo $(\mathrm{r}=0,83)$; civil e aproveitamento dos alunos $(r=0,73)$; zelo e aproveitamento dos alunos $(r=0,85)$. Isso significa dizer que, quando um valor era maior, o outro a ele associado também crescia; e, no caso 
de ser menor, o outro também o seria ${ }^{246}$. Por outro lado, não foram constatadas associações lineares entre os quatro critérios de observação do mérito do professor e o número de livros, mapas ou tabelas de primeira leitura constantes a escola.

Tabela 3: Coeficientes de correlação de Pearson e níveis descritivos (p) entre parênteses.

\begin{tabular}{|l|l|l|l|l|l|l|l|l|l|l|}
\hline & CIVIL & ZELO & $\begin{array}{l}\text { APROVEI- } \\
\text { TAMENTO }\end{array}$ & $\begin{array}{l}\text { VOLUMES } \\
\text { PROFESSOR }\end{array}$ & $\begin{array}{l}\text { VOLUMES } \\
\text { ESCOLA }\end{array}$ & MAPAS & $\begin{array}{l}\text { TABE- } \\
\text { LAS 1A. } \\
\text { LEITURA }\end{array}$ & $\begin{array}{l}\text { DICIO- } \\
\text { NÁRIOS }\end{array}$ & $\begin{array}{l}\text { No. } \\
\text { ALUNOS } \\
\text { EM } \\
1866\end{array}$ & $\begin{array}{l}\text { No. } \\
\text { ALUNOS } \\
\text { PRESENTES } \\
1867\end{array}$ \\
\hline Moral & $\begin{array}{l}0.96 \\
(0.00)\end{array}$ & $\begin{array}{l}0.81 \\
(0.00)\end{array}$ & $\begin{array}{l}0.72 \\
(0.00)\end{array}$ & $\begin{array}{l}0.28 \\
(0.04)\end{array}$ & $\begin{array}{l}0.21 \\
(0.12)\end{array}$ & $\begin{array}{l}0.08 \\
(0.57)\end{array}$ & $\begin{array}{l}-0.11 \\
(0.42)\end{array}$ & $\begin{array}{c}0.41 \\
(0.00)\end{array}$ & $\begin{array}{c}0.47 \\
(0.00)\end{array}$ & $\begin{array}{c}0.42 \\
(0.00)\end{array}$ \\
\hline Civil & & $\begin{array}{l}0.83 \\
(0.00)\end{array}$ & $\begin{array}{l}0.73 \\
(0.00)\end{array}$ & $\begin{array}{l}0.32 \\
(0.02)\end{array}$ & $\begin{array}{l}0.26 \\
(0.06)\end{array}$ & $\begin{array}{l}0.08 \\
(0.55)\end{array}$ & $\begin{array}{l}-0.12 \\
(0.40)\end{array}$ & $\begin{array}{c}0.41 \\
(0.00)\end{array}$ & $\begin{array}{c}0.47 \\
(0.00)\end{array}$ & $\begin{array}{l}0.43 \\
(0.00)\end{array}$ \\
\hline Zelo & & & $\begin{array}{l}0.85 \\
(0.00)\end{array}$ & $\begin{array}{l}0.32 \\
(0.02)\end{array}$ & $\begin{array}{l}0.06 \\
(0.67)\end{array}$ & $\begin{array}{l}0.09 \\
(0.53)\end{array}$ & $\begin{array}{l}-0.13 \\
(0.36)\end{array}$ & $\begin{array}{c}0.35 \\
(0.01)\end{array}$ & $\begin{array}{c}0.40 \\
(0.00)\end{array}$ & $\begin{array}{c}0.43 \\
(0.00)\end{array}$ \\
\hline $\begin{array}{l}\text { Aprovei- } \\
\text { tamento }\end{array}$ & & & & $\begin{array}{l}0.33 \\
(0.00)\end{array}$ & $\begin{array}{l}0.13 \\
(0.34)\end{array}$ & $\begin{array}{l}0.24 \\
(0.08)\end{array}$ & $\begin{array}{l}-0.12 \\
(0.39)\end{array}$ & $\begin{array}{c}0.45 \\
(0.00)\end{array}$ & $\begin{array}{c}0.46 \\
(0.00)\end{array}$ & $\begin{array}{c}0.58 \\
(0.00)\end{array}$ \\
\hline
\end{tabular}

Observamos que existem altas associações lineares entre moral e civil $(\mathrm{r}=0.96)$, moral e zelo $(r=0.81)$, moral e aproveitamento dos alunos $(r=0.72)$, civil e zelo $(\mathrm{r}=0.83)$, civil e aproveitamento $(\mathrm{r}=0.73)$, e zelo do professor com aproveitamento dos alunos $(r=0.85)$; do que se depreende que, quanto maior o zelo do professor, maior o aproveitamento dos alunos.

Não existe associação linear entre mérito do professor (moral, civil, zelo, aproveitamento) e volumes da escola, mérito e número de mapas na escola, mérito e número de tabelas para a primeira leitura. Também foram feitos gráficos (diagramas de dispersão) que mostram as ditas associações. Nesses gráficos, para cada par de observações é desenhado um ponto; quanto mais alinhados aparecem os pontos, maior é a associação entre as variáveis.

${ }^{246}$ Para toda amostra foi calculado o coeficiente de correlação de Pearson entre o mérito do professor assinado pelo inspetor (moral, civil, zelo) e o aproveitamento dos alunos; entre o mérito do professor e o número de alunos presentes no ano de 1867; entre o mérito do professor e o número de livros na biblioteca do professor; entre o mérito do professor e o número de mapas e de dicionários da escola. O coeficiente de correlação de Pearson mede se existe ou não associação linear entre duas variáveis. Este coeficiente varia entre -1 e 1 . Se o coeficiente é igual a zero (ou próximo de zero) significa que não existe associação linear entre as variáveis. Foi este o caso - embora contrariando as nossas expectativas e talvez o nosso desejo inconfesso - da suposta correlação, que não se verificou, entre mérito de professor e número de livros na biblioteca. $\mathrm{Na}$ outra margem, um valor do coeficiente igual a 1 significa associação linear direta perfeita entre as variáveis (ou seja, a valores baixos de uma delas correspondem valores baixos também da outra, e a valores altos de uma, correspondem valores altos de outra). Quanto mais próximo de um (1) se encontra o valor do coeficiente, maior é a associação linear direta entre elas. Um valor de coeficiente igual a -1 (ou próximo de -1) indica associação linear perfeita inversa (forte associação linear inversa) entre as variáveis: ou seja, para valores baixos de uma das variáveis correspondem valores altos da outra, e vice-versa (para valores altos de uma das variáveis correspondem valores baixos da outra). O valor entre parênteses corresponde ao nível descritivo (p) do teste de hipótese de que o coeficiente de correlação na população é nulo; um valor de $\mathrm{p}<0,05$ significa que é rejeitada a hipótese nula de que o coeficiente de correlação é nulo (ou seja: existe associação entre as duas variáveis) ; e um valor de p maior ou igual a 0,05 indica que se aceita a hipótese de que as variáveis não estão associadas entre si. 


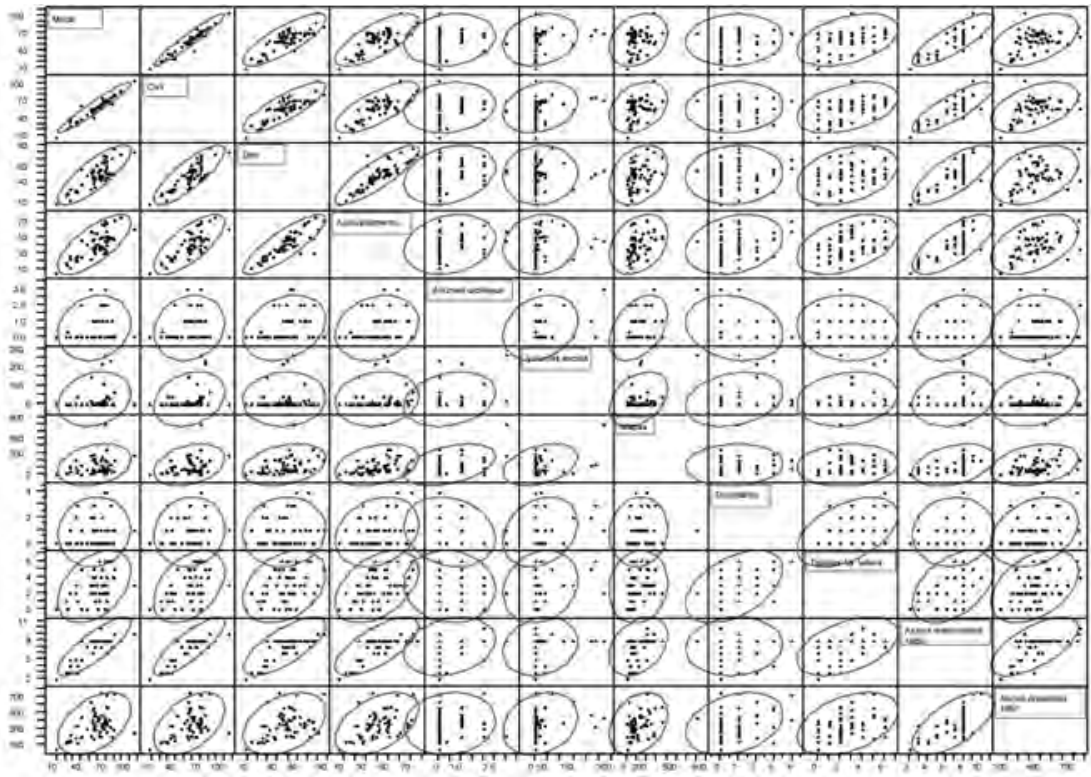

Figura 2 : Diagrama de dispersão para Moral, Civil, Zelo, Aproveitamento, Número de volumes do professor, Número de volumes da escola, Mapas, Tabelas de primeira leitura, Dicionários, Alunos matriculados em 1866 e presentes em 1867.

Também a respeito do mérito do trabalho docente, não eram poucos os inspetores que faziam considerações de ordem qualitativa para deixar registrado em seu Relatório um rol completo de observações. Nessa condição, podemos situar o caso do concelho de Águeda no distrito de Aveiro. As oito freguesias onde se situavam escolas regidas por diferentes professores tiveram seus mestres assim classificados:

"1 1aescola: Consta-me que o professor é exato, mas é pouco hábil e tem mau método de ensino; $2^{a}$ escola: $\mathrm{O}$ professor é muito hábil e instruído, mas o serviço de repartição de fazenda e do tesouro da Comarca Municipal rouba-lhe o zelo que devia empregar no serviço da escola; $3^{a}$ escola: O professor é muito hábil e zeloso, tornando-se credor de bem merecido louvor; 4a escola: O professor é zeloso e satisfaz convenientemente; $5^{a}$ escola: $O$ professor não tem zelo nem vocação para o magistério, além de que acha-se envolvido em um processo crime de tiros e ferimentos praticados na localidade. Deve ser transferido; $\sigma^{a}$ escola: Suspendi o professor pela sua irregular conduta, apresentar alunos supostos, não ter documento algum de matrícula ou relação de faltas e muitas queixas que geralmente contra ele me fizeram; 7a escola: É um professor medíocre o que rege a cadeira, e com péssima letra, mas zeloso; $8^{\circ}$ escola: $\mathrm{O}$ professor é mui hábil, instruído e zeloso, acrescendo haver levantado uma casa para a escola à sua custa, que não só é atualmente a melhor do distrito, mas otimamente colocada, com todas as condições morais, pedagógicas e higiênicas, pelo que, e por todas as mais circunstâncias que nele concorrem, é digno de elogio." ${ }^{247}$

${ }^{247}$ Inspector José António da Silva, MINISTÉRIO DO REINO - $N^{\circ} 1046$, Manuscritos transferidos do 
No Bairro d'Alcântara, em Lisboa, o inspetor teceu algumas anotações sobre a escola de Santa Catarina: "a mestra está cansada e doente. Precisa de ser aposentada quanto antes. Nas costuras é que há mais aproveitamento: três alunas bordam suficientemente e quase todas cosem." ${ }^{248} \mathrm{Na}$ sequência, relata que as duas escolas situadas na freguesia de São Paulo "poderão ser suprimidas sem inconveniente pela qualidade dos professores, que não são susceptíveis de se tornarem melhores." 249

Sobre as escolas situadas no Concelho de Cintra (distrito de Lisboa), o inspetor revela o lugar de onde fala, explicitando a origem das informações de que dispôs: "o mérito moral e civil dos professores é baseado na informação do administrador e dos párocos respectivos, e quanto ao zelo é segundo a informação da mesma autoridade e segundo o que pude observar nos dias em que visitei a escola." 250

Os inspetores, muitas vezes, notavam que o zelo do professor era afrouxado após a obtenção da propriedade da cadeira. Sobre as cinco escolas constantes no concelho da Mealhada, do distrito de Aveiro, o inspetor faz as seguintes observaçôes:

"1a Barcouço) Havendo o professor tomado posse da cadeira em Maio, não o posso bem avaliar, mas parece ser zeloso; $2^{a}$ Casal Comba) O professor é hábil, porém depois que obteve a cadeira de propriedade tem afrouxado sucessivamente de zelo. Carece de ser repreendido ou transferido; $3^{a}$ Luso) O professor está há um ano de posse da cadeira. É hábil, quer mostrar-se zeloso; e com a prática poderá tornar-se mais metódico; $4^{a}$ Pompilhosa) $\mathrm{O}$ professor tem próximo d'um ano de exercício e parece que há de servir otimamente; $5^{a}$ Mealhada) Tem um professor hábil e que se emprega no serviço com reconhecido zelo e muita força de vontade, pelo que o julgo digno de merecido louvor." ${ }^{251}$

As observações acrescidas denotam intensa preocupação quanto aos aspectos concernentes ao zelo profissional, o qual era, não raras vezes, aferido por informaçôes fornecidas - como vimos - por notários da localidade. Não havia, nos comentários dos inspetores, muita informação acerca do desempenho dos alunos enquanto uma variável alternativa para apreender de fato o tal zelo com o qual tanto eles se preocupavam. Algumas vezes, era no decorrer da própria visita de inspeção que se preenchiam os mapas das escolas que apresentavam deficiência nos registros. Era esse o caso, por exemplo, de Barbacena, no concelho de Elvas, distrito de Portalegre.

O segundo dado aferido pelo Relatório dos inspetores dizia respeito ao número dos alunos matriculados no ano letivo de 1866-67 e sua correlação com os alunos presentes à visita da inspeção. Para o total da amostra, os 24,1 alunos de sexo masculino presentes à visita do inspetor correspondem a 56\% dos 43 alunos matriculados, sendo que as 5,2 meninas presentes à visita representam $69 \%$ das 7,5 alunas que, em média, estavam matriculadas na ano de 1866-67. Tais dados indicam que talvez os índices de abandono e deserção escolar fossem maiores entre os meninos, sendo a presença das meninas, ainda

Ministério do Interior - Relação elaborada pelo Dr. Alcino Manuel Silva / Inspecção extraordinária às escolas públicas e particulares...1867.

${ }^{248}$ MINISTÉRIO DO REINO - N 1055.

${ }^{249}$ MINISTÉRIO DO REINO - N 1055.

${ }^{250} M R$ 1055. A partir daqui passaremos a abreviar por $M R$ o conjunto de documentação procedente do Ministério do Reino.

${ }^{251}$ MR 1046. Distrito: Aveiro; Concelho: Mealhada. 
que proporcionalmente muito menor, mais constante. A propósito, nota-se que, para todos os distritos, o número de alunos do sexo feminino é invariavelmente menos da metade em relação à quantidade dos alunos do sexo masculino. Se, em todo Portugal, as escolas tinham em média 24 alunos do sexo masculino e 5 do sexo feminino no momento da visita do inspetor, as diferenças regionais revelam, por vezes, dados relevantes quanto a certas distinções, por distritos, no que diz respeito à população escolar. Sendo assim, Vianna do Castello apresentou o maior número médio de alunos do sexo masculino $(37,5)$ na visita do inspetor, seguida por Coimbra $(32,7)$ e Castello Branco $(30,7)$. Lisboa mostrou a maior média de alunas $(9,4)$, seguida por Castello Branco $(8,8)$ e por Portalegre $(5,6)$.

Tabela 4: Número médio de alunos por escola em 1866 e presentes na visita do inspetor à escola em 1867 , por distritos e para o total da amostra.

\begin{tabular}{|c|c|c|c|c|c|c|c|c|c|c|c|}
\hline & & \multicolumn{10}{|c|}{ DISTRITO } \\
\hline $\begin{array}{l}\text { Matrícula e } \\
\text { presença }\end{array}$ & Total & Aveiro & Coimbra & $\begin{array}{l}\text { Castello } \\
\text { Branco }\end{array}$ & Guarda & Évora & Lisboa & Portalegre & $\begin{array}{l}\text { Villa } \\
\text { Real }\end{array}$ & Vizeu & $\begin{array}{l}\text { Vianna } \\
\text { do } \\
\text { Castello }\end{array}$ \\
\hline $\begin{array}{l}\text { Masculino } \\
\text { matriculados }\end{array}$ & 42.9 & 45.3 & 51.8 & 46.9 & 41.6 & 28.5 & 40.3 & 31.8 & 31.8 & 36.8 & 67.1 \\
\hline $\begin{array}{l}\text { Feminino } \\
\text { matriculados }\end{array}$ & 7.5 & 6.9 & 2.5 & 11.9 & 9.2 & 8.2 & 12.5 & 9.9 & 4.2 & 3.1 & 4.4 \\
\hline $\begin{array}{l}\text { Masculino } \\
\text { presentes }\end{array}$ & 24.1 & 22.2 & 32.7 & 30.7 & 19.9 & 13.2 & 20.0 & 19.0 & 18.1 & 25.2 & 37.5 \\
\hline $\begin{array}{l}\text { Feminino } \\
\text { presentes }\end{array}$ & 5.2 & 5.2 & 2.9 & 8.8 & 4.7 & 4.5 & 9.4 & 5.6 & 3.2 & 1.9 & 3.3 \\
\hline
\end{tabular}

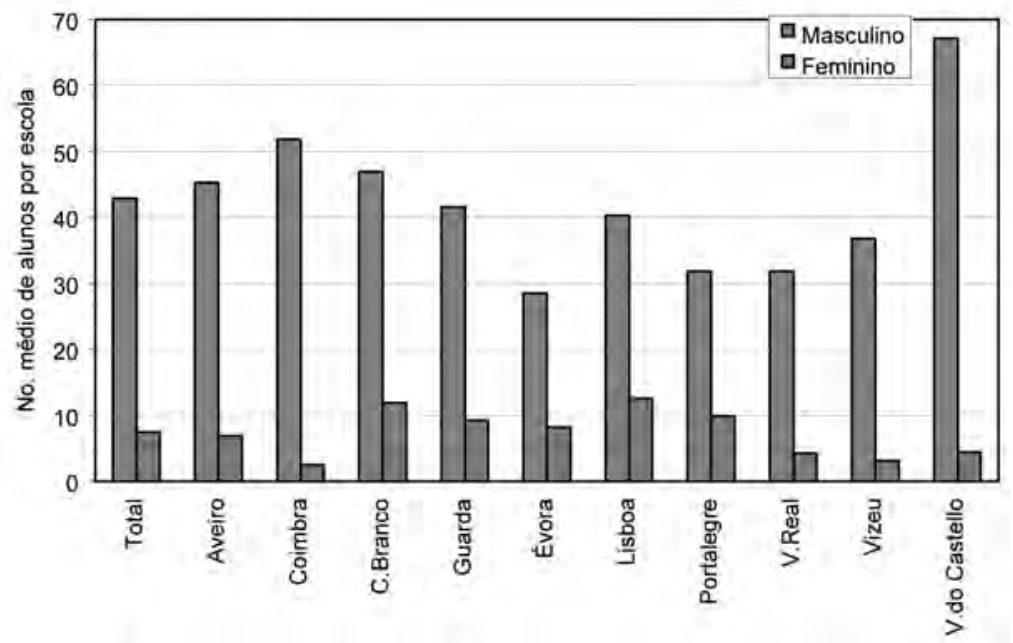

Figura 3: Número médio de alunos matriculados por escola, por sexo, por distrito e para o total da amostra. Portugal, 1866-7. 


\section{O espaço físico da escola e o funcionamento de sua estrutura administrativa}

Pelos registros, podem-se obter dados acerca do espaço físico da escola, seja em termos de qualidade do edifício, seja no que diz respeito à estrutura administrativa de seu funcionamento. Sobre, por exemplo, a distribuição dos proprietários do edifício da escola, perguntava-se se o imóvel pertencia ao Estado, Câmara Municipal, Junta de Paróquia, Irmandade ou Confraria, Professor ou outro particular. O levantamento demonstrou que, para toda a amostra, a maior porcentagem dos proprietários dos edifícios das escolas situou-se na categoria de "outro particular" $(58,3 \%)$, diferente do professor, seguido do próprio professor $(16,4 \%)$, da Junta de Paróquia (12,6\%) e da Câmara Municipal (7,3\%), o que leva a supor que o prédio em que funcionava a escola era, na maior parte das vezes, alugado ao professor por uma terceira pessoa.

Tabela 5: Distribuição dos proprietários do edifício da escola, por distritos e para o total da amostra.

Portugal, 1867

\begin{tabular}{|c|c|c|c|c|c|c|c|c|c|c|c|}
\hline & & DISTRIT & & & & & & & & & \\
\hline $\begin{array}{l}\text { Proprie- } \\
\text { tário do } \\
\text { edifício }\end{array}$ & Total & Aveiro & Coimbra & $\begin{array}{l}\text { Castello } \\
\text { Branco }\end{array}$ & Guarda & Évora & Lisboa & Portalegre & $\begin{array}{l}\text { Villa } \\
\text { Real }\end{array}$ & Vizeu & $\begin{array}{l}\text { Vianna } \\
\text { do } \\
\text { Castello }\end{array}$ \\
\hline $\begin{array}{l}\text { Particular } \\
\text { (diferente } \\
\text { do pro- } \\
\text { fessor) }\end{array}$ & $\begin{array}{l}224 \\
(58.3 \\
\%)\end{array}$ & $\begin{array}{l}19 \\
(52.8 \\
\%)\end{array}$ & $\begin{array}{l}23(60.5 \\
\%)\end{array}$ & $\begin{array}{l}17 \\
(48.6 \\
\%)\end{array}$ & $\begin{array}{l}18 \\
(45.0 \%)\end{array}$ & $\begin{array}{l}13 \\
(56.6 \%)\end{array}$ & $\begin{array}{l}53 \\
(79.1 \\
\%)\end{array}$ & $\begin{array}{l}15 \\
(60.0 \%)\end{array}$ & $\begin{array}{l}22 \\
(53.7 \%)\end{array}$ & $\begin{array}{l}21 \\
(55.2 \%)\end{array}$ & $\begin{array}{l}23 \\
(56.0 \\
\%)\end{array}$ \\
\hline Professor & $\begin{array}{l}63 \\
(16.4 \\
\%)\end{array}$ & $\begin{array}{l}8(22.2 \\
\%)\end{array}$ & $\begin{array}{l}6(15.8 \\
\%)\end{array}$ & $\begin{array}{l}9(25.6 \\
\%)\end{array}$ & $\begin{array}{l}10 \\
(25.0 \%)\end{array}$ & $\begin{array}{l}1(4.3 \\
\%)\end{array}$ & $\begin{array}{l}4(6.0 \\
\%)\end{array}$ & $1(4.0 \%)$ & $\begin{array}{l}10 \\
(24.4 \%)\end{array}$ & $\begin{array}{l}10 \\
(26.3 \%)\end{array}$ & $\begin{array}{l}4(9.8 \\
\%)\end{array}$ \\
\hline $\begin{array}{l}\text { Junta } \\
\text { Paróquia }\end{array}$ & $\begin{array}{l}48 \\
(12.6 \\
\%)\end{array}$ & $\begin{array}{l}6(16.7 \\
\%)\end{array}$ & $\begin{array}{l}2(5.3 \\
\%)\end{array}$ & $\begin{array}{l}7(20.0 \\
\%)\end{array}$ & $\begin{array}{l}11 \\
(27.5 \%)\end{array}$ & $\begin{array}{l}1(4.3 \\
\%)\end{array}$ & $\begin{array}{l}0(0.0 \\
\%)\end{array}$ & $\begin{array}{l}3 \\
(12.0 \%)\end{array}$ & $\begin{array}{l}7 \\
(17.1 \%)\end{array}$ & $\begin{array}{l}3(7.9 \\
\%)\end{array}$ & $\begin{array}{l}8 \\
(19.5 \\
\%)\end{array}$ \\
\hline $\begin{array}{l}\text { Câmara } \\
\text { Munici- } \\
\text { pal }\end{array}$ & $\begin{array}{l}28(7.3 \\
\%)\end{array}$ & $\begin{array}{l}2(5.6 \\
\%)\end{array}$ & $\begin{array}{l}4 \\
(10.5 \%)\end{array}$ & $\begin{array}{l}1(2.9 \\
\%)\end{array}$ & $\begin{array}{l}1(2.5 \\
\%)\end{array}$ & $\begin{array}{l}6 \\
(26.2 \%)\end{array}$ & $\begin{array}{l}2(3.0 \\
\%)\end{array}$ & $\begin{array}{l}6 \\
(24.0 \%)\end{array}$ & $\begin{array}{l}1(2.4 \\
\%)\end{array}$ & $\begin{array}{l}3(7.9 \\
\%)\end{array}$ & $\begin{array}{l}2(4.9 \\
\%)\end{array}$ \\
\hline Estado & $\begin{array}{l}13(3.4 \\
\%)\end{array}$ & $\begin{array}{l}1(2.8 \\
\%)\end{array}$ & $\begin{array}{l}2(5.3 \\
\%)\end{array}$ & $\begin{array}{l}0(0.0 \\
\%)\end{array}$ & $\begin{array}{l}0(0.0 \\
\%)\end{array}$ & $\begin{array}{l}1(4.3 \\
\%)\end{array}$ & $\begin{array}{l}5(7.5 \\
\%)\end{array}$ & $0(0.0 \%)$ & $\begin{array}{l}1(2.4 \\
\%)\end{array}$ & $\begin{array}{l}1(2.6 \\
\%)\end{array}$ & $\begin{array}{l}2(4.9 \\
\%)\end{array}$ \\
\hline $\begin{array}{l}\text { Irmanda- } \\
\text { de ou } \\
\text { Confraria }\end{array}$ & $\begin{array}{l}8(2.0 \\
\%)\end{array}$ & $\begin{array}{l}0(0.0 \\
\%)\end{array}$ & $\begin{array}{l}1(2.6 \\
\%)\end{array}$ & $\begin{array}{l}1(2.9 \\
\%)\end{array}$ & $\begin{array}{l}0(0.0 \\
\%)\end{array}$ & $\begin{array}{l}1(4.3 \\
\%)\end{array}$ & $\begin{array}{l}3(4.4 \\
\%)\end{array}$ & $0(0.0 \%)$ & $\begin{array}{l}0(0.0 \\
\%)\end{array}$ & $\begin{array}{l}0(0.0 \\
\%)\end{array}$ & $\begin{array}{l}2(4.9 \\
\%)\end{array}$ \\
\hline Total & $\begin{array}{l}384 \\
(100 \%)\end{array}$ & $\begin{array}{l}36 \\
(100 \%)\end{array}$ & $\begin{array}{l}38 \\
(100 \%)\end{array}$ & $\begin{array}{l}35 \\
(100 \%)\end{array}$ & $\begin{array}{l}40 \\
(100 \%)\end{array}$ & $\begin{array}{l}23 \\
(100 \%)\end{array}$ & $\begin{array}{l}67 \\
(100 \%)\end{array}$ & $\begin{array}{l}25 \\
(100 \%)\end{array}$ & $\begin{array}{l}41 \\
(100 \%)\end{array}$ & $\begin{array}{l}38 \\
(100 \%)\end{array}$ & $\begin{array}{l}41 \\
(100 \%)\end{array}$ \\
\hline
\end{tabular}




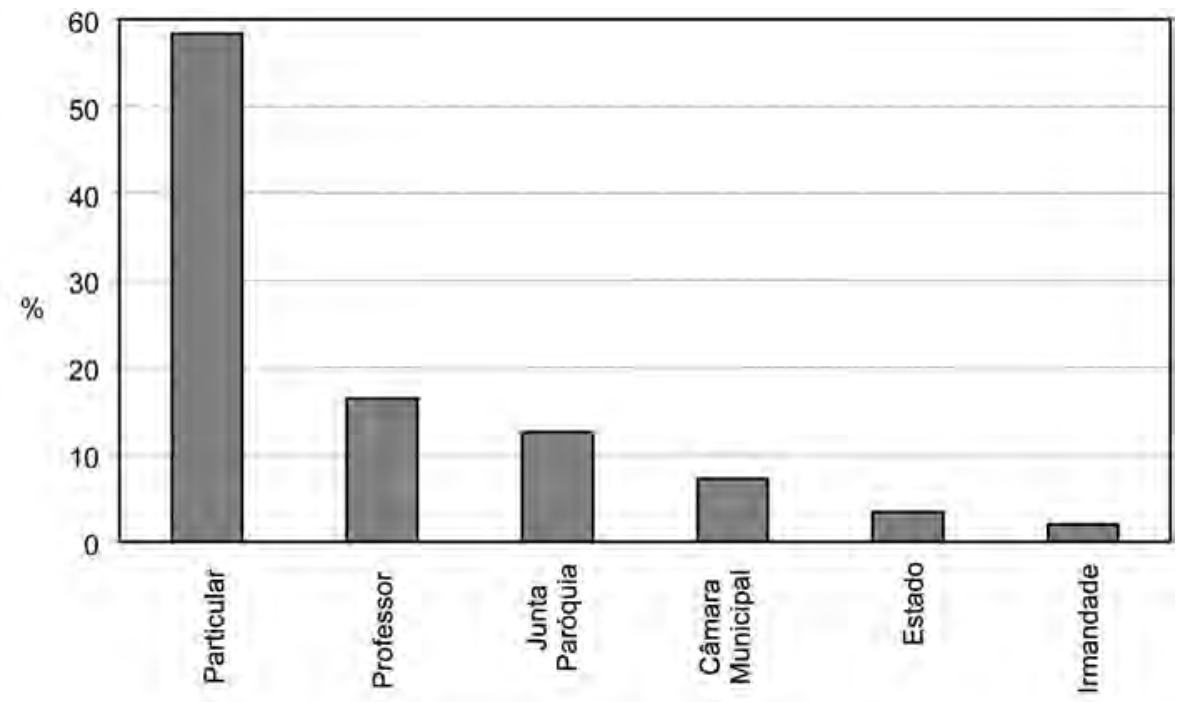

Proprietário do edificio da escola

Figura 4: Distribuição percentual dos proprietários do edifício da escola para o total da amostra. Portugal, 1867.

As escolas possuíam em média uma sala de 28 metros quadrados de superfície com duas janelas. Coimbra e Vianna do Castello apresentavam superfície maior (respectivamente 34,4 e 34,1 metros quadrados) seguidas por Lisboa, com 31,6 metros quadrados. Cada escola tinha em média três mesas, com sete bancos e menos de cinco cadeiras. Havia, aqui também, variaçôes distritais: Lisboa e Vianna do Castello tiveram o maior número de bancos por escola (9,4 e 8,6 respectivamente); Lisboa e Portalegre apresentaram a maior média de cadeiras por escola (9,2 e 6,6 respectivamente), ao passo que Vianna do Castello e Villa Real não chegaram a ter sequer duas cadeiras por cada escola.

A profunda diversidade regional quanto aos dados analisados dificulta parâmetros de generalização pela média. Torna-se, pois, difícil dizer que, em média, cada professor contava com 2,1 tinteiros e cada escola tinha 8,2 tinteiros dos alunos. Isso porque, ao observar as especificidades de cada distrito, deparamo-nos no caso de Coimbra com 3,0 tinteiros por professor e 13,5 tinteiros de alunos; sendo que em Évora havia, no mesmo período, uma média de 0,8 tinteiros por professor e 2,1 tinteiros de alunos. Tais disparidades nos levam a acreditar que, se a média representa, sem dúvida, um parâmetro relevante para a análise, ele jamais poderá ser tomado como único posto que mostra regularidades, escondendo, entretanto, especificidades. Nota-se, na tabela abaixo, o cálculo de quantos alunos recebiam da escola papel e livros de graça. Quase não havia tabelas para a primeira leitura. 
Tabela 6: Superfície média da aula principal, número médio de janelas, mobília e utensílios da escola, por distritos e para o total da amostra. Portugal, 1867

\begin{tabular}{|c|c|c|c|c|c|c|c|c|c|c|c|}
\hline & & \multicolumn{10}{|c|}{ DisTRITO } \\
\hline $\begin{array}{l}\text { Área e } \\
\text { utensílios }\end{array}$ & Total & Aveiro & Coimbra & $\begin{array}{l}\text { Castello } \\
\text { Branco }\end{array}$ & Guarda & Évora & Lisboa & Portalegre & $\begin{array}{l}\text { Villa } \\
\text { Real }\end{array}$ & Vizeu & $\begin{array}{l}\text { Vianna } \\
\text { do } \\
\text { Castello }\end{array}$ \\
\hline $\begin{array}{l}\text { Superfície } \\
(\mathrm{m} 2)\end{array}$ & 28.0 & 30.7 & 34.4 & 18.2 & 23.1 & 19.2 & 31.6 & 28.8 & 27.2 & 27.0 & 34.1 \\
\hline Janelas & 2.0 & 1.6 & 2.3 & 2.0 & 1.6 & 1.8 & 2.2 & 2.0 & 1.7 & 1.9 & 2.3 \\
\hline Mesas & 2.8 & 2.0 & 2.6 & 2.1 & 1.8 & 1.4 & 5.0 & 2.8 & 2.3 & 2.2 & 3.9 \\
\hline Bancos & 6.8 & 5.4 & 6.5 & 7.1 & 5.8 & 4.1 & 9.4 & 7.2 & 5.5 & 6.1 & 8.6 \\
\hline Cadeiras & 4.3 & 2.7 & 2.6 & 2.6 & 4.6 & 5.4 & 9.2 & 6.6 & 1.8 & 3.5 & 1.7 \\
\hline $\begin{array}{l}\text { Tinteiros } \\
\text { escola }\end{array}$ & 1.9 & 0.7 & 3.2 & 0.5 & 0.9 & 1.2 & 3.7 & 2.9 & 0.1 & 1.2 & 3.0 \\
\hline $\begin{array}{l}\text { Tinteiros } \\
\text { prof. }\end{array}$ & 2.1 & 1.5 & 3.0 & 1.5 & 1.7 & 0.8 & 3.5 & 1.4 & 1.9 & 1.8 & 2.3 \\
\hline $\begin{array}{l}\text { Tinteiros } \\
\text { alunos }\end{array}$ & 8.2 & 11.9 & 13.5 & 8.7 & 4.1 & 2.1 & 3.4 & 5.6 & 11.3 & 11.0 & 11.8 \\
\hline $\begin{array}{l}\text { Quadros } \\
\text { pretos }\end{array}$ & 0.8 & 0.3 & 1.3 & 0.4 & 0.3 & 0.3 & 1.4 & 1.0 & 0.2 & 0.3 & 1.4 \\
\hline $\begin{array}{l}\text { Lousas } \\
\text { escola }\end{array}$ & 2.2 & 1.2 & 1.1 & 2.9 & 1.1 & 2.5 & 2.5 & 5.8 & 0.1 & 1.8 & 3.9 \\
\hline $\begin{array}{l}\text { Lousas } \\
\text { professor }\end{array}$ & 1.4 & 0.8 & 1.3 & 1.1 & 0.9 & 0.3 & 1.6 & 0.6 & 1.2 & 1.4 & 4.1 \\
\hline $\begin{array}{l}\text { Lousas } \\
\text { alunos }\end{array}$ & 8.5 & 6.9 & 6.0 & 9.8 & 4.1 & 5.2 & 15.0 & 7.0 & 8.2 & 5.6 & 10.8 \\
\hline $\begin{array}{l}\text { Papel de } \\
\text { graça }\end{array}$ & 4.5 & 2.1 & 3.6 & 4.7 & 0.8 & 1.2 & 14.7 & 2.6 & 0.4 & 1.7 & 4.4 \\
\hline $\begin{array}{l}\text { Livros de } \\
\text { graça }\end{array}$ & 3.0 & 1.3 & 4.1 & 3.3 & 1.7 & 6.0 & 4.7 & 1.1 & 1.2 & 1.1 & 4.4 \\
\hline $\begin{array}{l}\text { Vols. da } \\
\text { escola }\end{array}$ & 3.5 & 0.0 & 1.7 & 7.9 & 1.8 & 1.6 & 11.2 & 2.2 & 0.1 & 0.7 & 1.6 \\
\hline $\begin{array}{l}\text { Vols. } \\
\text { Professor }\end{array}$ & 17.8 & 19.4 & 16.1 & 9.3 & 16.5 & 10.6 & 29.3 & 18.1 & 11.1 & 15.7 & 20.4 \\
\hline Mapas & 0.1 & 0.1 & 0.1 & 0.1 & 0.0 & 0.0 & 0.3 & 0.2 & 0.0 & 0.1 & 0.1 \\
\hline Dicionários & 0.4 & 0.3 & 0.3 & 0.3 & 0.4 & 0.1 & 0.6 & 0.2 & 0.4 & 0.4 & 0.5 \\
\hline Tabelas & 0.4 & 0.0 & 0.3 & 0.2 & 0.4 & 2.3 & 0.3 & 0.9 & 0.1 & 0.1 & 0.5 \\
\hline
\end{tabular}




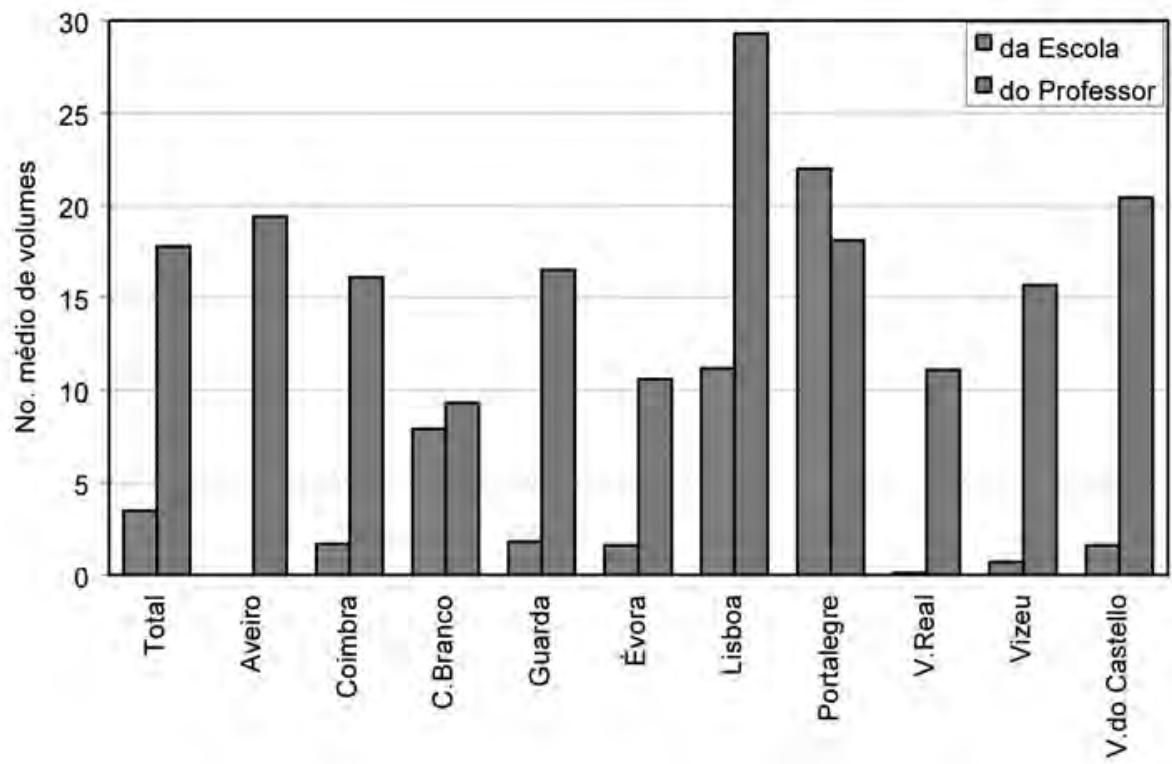

Figura 5: Número médio de volumes da escola e do professor por escola, para o total da amostra e por distrito. Portugal, 1867.

Como vimos, fazia parte do Relatório do inspetor a informação sobre quantas crianças, por escola, recebiam de graça papel, tintas, penas e livros. O inspetor do Bairro d'Alcântara em Lisboa faz uma ressalva diante da anotação em que havia declarado que 214 alunos teriam, naquele dito Concelho, recebido de graça papel, tinta, e penas. Diz ele: "o papel geralmente não é dado pelos professores; ou trazem-no os alunos ou lhes é vendido pelo mestre. É porém costume da maioria dos professores dizerem que dão tudo." ${ }^{252}$ Por outro lado, dos 79 alunos que nas 8 escolas do Concelho de Certã em Castello Branco recebiam de graça os livros, 76 pertenciam a uma única escola, distribuindo-se os restantes 3 livros pelas outras 7 instituições escolares. Tudo isso dificulta uma distribuição pela média que, de qualquer maneira, ficava abaixo de 5 no caso dos alunos que recebiam papéis, tinta e penas de graça e por volta de 3 os que recebiam livros.

Verifica-se dificuldade semelhante quando se buscam dados acerca dos volumes que constavam da livraria de cada escola. Por exemplo, dos 132 livros que constam das livrarias dos professores das 8 escolas do Concelho de Águeda em Aveiro, 100 livros pertencem a apenas uma escola. A mesma escola de Certã - distrito de Castelo Branco - que doava livros a 76 alunos - e da qual falamos acima - contava com uma biblioteca de 102 volumes (sendo que o total para as 8 escolas do mesmo Concelho era de 110 volumes). Também uma escola de Alandroal - distrito de Évora - concentrava quase todos os volumes da livraria do professor - 103, dentre os 114 distribuídos por 4 escolas. Tais ponderações pontuais relativizam os dados englobados na média

${ }^{252}$ MR 1055. (Inspecção extraordinaria às escolas... 1867 / Distrito de Lisboa ,Concelho: Bairro d'Alcântara) 
de 3,5 volumes de livros por escola e 17,8 volumes do professor. Note-se ainda que as bibliotecas dos agentes do magistério eram maiores nos distritos de Lisboa $(29,3)$, Aveiro $(19,4)$ e Vianna $(20,4)$. Castello Branco, pelo contrário, destacou-se também da média geral por ser o distrito com menor número médio de livros na biblioteca do professor $(9,3)$. Praticamente não havia mapas, não havia dicionários, não havia tabelas de primeira leitura nas escolas portuguesas; muitas vezes as cadeiras eram pequenos assentos de cortiça. Com exceção dos distritos de Coimbra, Lisboa, Portalegre e Vianna do Castello, a média de quadros-negros por escola não chegava a uma unidade. As lousas existentes pertenciam, em sua maioria, aos alunos $(8,5)$, seguidos da própria escola $(2,2)$ e do professor $(1,4$ em média).

O inspetor do concelho de Redondo, do distrito de Évora, acrescenta em seu Relatório que, em sessão da Câmara, fizera requisição, como parte do material escolar, de coleção de pesos e medidas "para cada escola da capital do concelho, depois de lhe mostrar a conveniência dela para o ensino prático do sistema métrico. Tenciono fazer o mesmo em todos os concelhos. Na sessão da Junta de Paróquia fiz também a mesma requisição. Tenciono proceder assim em todas as freguesias rurais." Ele também requisitara à Câmara e à Junta de Paróquia um mapa de Portugal, para cada escola da capital do concelho, acreditando que se não deixaria de atender a "tão justo pedido, depois de conhecer a conveniência do mapa para o estudo da corografia e da história pátria”. ${ }^{253}$

Sobre a ventilação em sala de aula, os dados revelam que foi considerada suficiente por $61,5 \%$ dos Relatórios, deficiente em $23,9 \%$ e incômoda para 14,6\%. Lisboa e Évora foram os distritos com maior percentual de ventilação suficiente (80,9\% e 79,2\% respectivamente). A avaliação de Vianna do Castello, Coimbra e Portalegre revela maiores proporçôes dos que caracterizam a ventilação de deficiente (respectivamente 46,3\%; $39,5 \% ; 36,0 \%)$. Já as maiores porcentagens de ventilação incômoda situaram-se em Castello Branco $(25,7 \%)$ e Viseu (21,4\%), como podemos confirmar pelos dados da tabela a seguir:

Tabela 7: Distribuição das escolas conforme a qualidade da ventilação da sala de aula, de acordo com o critério do inspetor por distritos e para o total da amostra. Portugal, 1867.

\begin{tabular}{|c|c|c|c|c|c|c|c|c|c|c|c|}
\hline \multirow[b]{2}{*}{ Ventilação } & \multirow[b]{2}{*}{ Total } & \multicolumn{10}{|c|}{ Distrito } \\
\hline & & Aveiro & Coimbra & $\begin{array}{l}\text { Castello } \\
\text { Branco }\end{array}$ & Guarda & Évora & Lisboa & Portalegre & Villa Real & Vizeu & $\begin{array}{l}\text { Vianna } \\
\text { do } \\
\text { Castello }\end{array}$ \\
\hline Suficiente & $\begin{array}{l}240 \\
(61.5 \\
\%) \\
\end{array}$ & $\begin{array}{l}19 \\
(50.0 \\
\%)\end{array}$ & $\begin{array}{l}19 \\
(50.0 \%)\end{array}$ & $\begin{array}{l}19 \\
(54.3 \%)\end{array}$ & $\begin{array}{l}28 \\
(70.0 \%)\end{array}$ & $\begin{array}{l}19 \\
(79.2 \%)\end{array}$ & $\begin{array}{l}55 \\
(80.9 \%)\end{array}$ & $\begin{array}{l}12 \\
(48.0 \%)\end{array}$ & $\begin{array}{l}24 \\
(61.6 \%)\end{array}$ & $\begin{array}{l}28 \\
(66.7 \\
\%) \\
\end{array}$ & $\begin{array}{l}17 \\
(41.5 \%)\end{array}$ \\
\hline Deficiente & $\begin{array}{l}93 \\
(23.9 \\
\%) \\
\end{array}$ & $\begin{array}{l}12 \\
(31.6 \\
\%) \\
\end{array}$ & $\begin{array}{l}15 \\
(39.5 \%)\end{array}$ & $\begin{array}{l}7 \\
(20.0 \%)\end{array}$ & $\begin{array}{l}7 \\
(17.5 \%)\end{array}$ & $\begin{array}{l}2 \\
(8.3 \%)\end{array}$ & $\begin{array}{l}9 \\
(13.2 \%)\end{array}$ & $\begin{array}{l}9 \\
(36.0 \%)\end{array}$ & $\begin{array}{l}8 \\
(20.5 \%)\end{array}$ & $\begin{array}{l}5 \\
(11.9 \\
\%) \\
\end{array}$ & $\begin{array}{l}19 \\
(46.3 \%)\end{array}$ \\
\hline Incómoda & $\begin{array}{l}57 \\
(14.6 \\
\%) \\
\end{array}$ & $\begin{array}{l}7 \\
(18.4 \\
\%) \\
\end{array}$ & $\begin{array}{l}4 \\
(10.5 \%)\end{array}$ & $\begin{array}{l}9 \\
(25.7 \%)\end{array}$ & $\begin{array}{l}5 \\
(12.5 \%)\end{array}$ & $\begin{array}{l}3 \\
(12.5 \%)\end{array}$ & $\begin{array}{l}4 \\
(5.9 \%)\end{array}$ & $\begin{array}{l}4 \\
(16.0 \%)\end{array}$ & $\begin{array}{l}7 \\
(17.9 \%)\end{array}$ & $\begin{array}{l}9 \\
(21.4 \\
\%) \\
\end{array}$ & $\begin{array}{l}5 \\
(12.2 \%)\end{array}$ \\
\hline Total & $\begin{array}{l}390 \\
(100 \\
\%)\end{array}$ & $\begin{array}{l}38 \\
(100 \\
\%)\end{array}$ & $\begin{array}{l}38 \\
(100 \%)\end{array}$ & $\begin{array}{l}35 \\
(100 \%)\end{array}$ & $\begin{array}{l}40 \\
(100 \%)\end{array}$ & $\begin{array}{l}24 \\
(100 \%)\end{array}$ & $\begin{array}{l}68 \\
(100 \%)\end{array}$ & $\begin{array}{l}25 \\
(100 . \%)\end{array}$ & $\begin{array}{l}39 \\
(100 \%)\end{array}$ & $\begin{array}{l}42 \\
(100 \\
\%)\end{array}$ & $\begin{array}{l}41 \\
(100 \%)\end{array}$ \\
\hline
\end{tabular}

${ }^{253}$ MR 1050. (Inspecção extraordinária às escolas../ Distrito:Évora; Concelho: Redondo). 


\section{Incómoda}

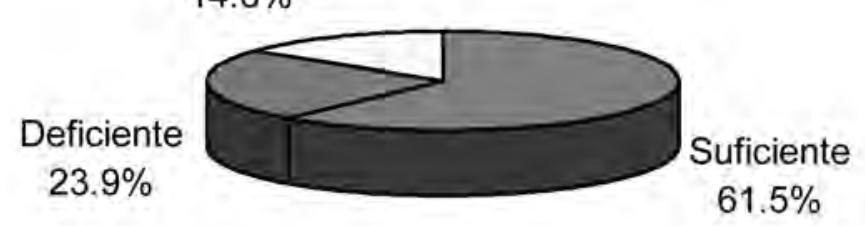

Figura 6: Distribuição das escolas conforme a qualidade da ventilação na sala de aula de acordo com o critério do inspetor para o total da amostra. Portugal, 1867.

Em relação à situação higiênica das escolas averiguadas pela inspeção, a maior porcentagem de toda a amostra - correspondente a $62,7 \%$ - relatava condições satisfatórias, seguidas da categoria 'pouco satisfatórias'- equivalente a $32,9 \%$ e finalmente havia $4,4 \%$ das escolas caracterizadas como 'insalubres'. Como nos demais quesitos, a distribuição dessa média pelos diferentes distritos está longe de ser equilibrada. Temos, por exemplo, Castello Branco e Évora, com elevadas taxas de condiçôes insalubres (respectivamente 14,2\% e 12,5\%). Por outro lado, Guarda e Lisboa apresentam 79,5\% e 74,6\% de condiçôes de higiene avaliadas pela inspeção como satisfatórias. Portalegre é o distrito que traz maior percentual de condiçôes pouco satisfatórias $(48,0 \%)$, o que se pode detectar até por algumas caracterizações de ordem qualitativa. Não possuindo nenhuma janela, a escola situada na freguesia de Conceição do concelho de Elvas (distrito de Portalegre) foi assim caracterizada pelo registro do inspetor: "na 5a escola, a superfície luminosa é a da porta da rua. A aula é também cozinha. As cadeiras são pequenos assentos de cortiça, da forma mais primitiva." ${ }^{254}$ Duas outras instituiçōes situadas no concelho de Cintra em Lisboa também receberam, por parte da inspeção, anotações suplementares. Para trazer o retrato da escola da Villa de Collares, diz o inspetor: "há próximo o matadouro e alguns currais. Há por baixo um açougue" 255 . Os dados levam-nos a crer que as escolas situadas em grandes centros urbanos eram privilegiadas em relação àquelas existentes nas aldeias ou povoados mais distantes.

${ }^{254}$ MR 1056. (Inspecção extraordinária às escolas.../ Distrito: Portalegre; Concelho:Elvas)

${ }^{255}$ MR-1055. (Inspecção extraordinaria às escolas.../ Distrito: Lisboa; Concelho:Cintra). Sobre outra escola situada naquele mesmo concelho, o inspetor comenta o seguinte: "A casa da escola é em uma loja junto à estrada real que é de muitíssimo trânsito." (Idem Ibidem) 
Tabela 8: Distribuição das escolas conforme suas condiçôes higiênicas de acordo com o critério do inspetor por distritos e para o total da amostra. Portugal, 1867

\begin{tabular}{|c|c|c|c|c|c|c|c|c|c|c|c|}
\hline & & DISTRI & & & & & & & & & \\
\hline $\begin{array}{l}\text { Condiçôes } \\
\text { higiências }\end{array}$ & Total & Aveiro & Coimbra & $\begin{array}{l}\text { Castello } \\
\text { Branco }\end{array}$ & Guarda & Évora & Lisboa & Portalegre & $\begin{array}{l}\text { Villa } \\
\text { Real }\end{array}$ & Vizeu & $\begin{array}{l}\text { Vianna } \\
\text { do } \\
\text { Castello }\end{array}$ \\
\hline $\begin{array}{l}\text { Satisfató- } \\
\text { rias }\end{array}$ & $\begin{array}{l}240 \\
(62.7 \\
\%)\end{array}$ & $\begin{array}{l}20 \\
(55.6 \\
\%)\end{array}$ & $\begin{array}{l}25 \\
(65.8 \%)\end{array}$ & $\begin{array}{l}15 \\
(42.9 \%)\end{array}$ & $\begin{array}{l}31 \\
(79.5 \%)\end{array}$ & $\begin{array}{l}14 \\
(58.3 \%)\end{array}$ & $\begin{array}{l}50 \\
(74.6 \%)\end{array}$ & $\begin{array}{l}12 \\
(48.0 \%)\end{array}$ & $\begin{array}{l}24 \\
(61.5 \%)\end{array}$ & $\begin{array}{l}24 \\
(61.5 \\
\%)\end{array}$ & $\begin{array}{l}25 \\
(61.0 \%)\end{array}$ \\
\hline $\begin{array}{l}\text { Pouco } \\
\text { satisfató- } \\
\text { rias }\end{array}$ & $\begin{array}{l}126 \\
(32.9 \\
\%)\end{array}$ & $\begin{array}{l}14 \\
(38.9 \\
\%)\end{array}$ & $\begin{array}{l}13 \\
(34.2 \%)\end{array}$ & $\begin{array}{l}15 \\
(42.9 \%)\end{array}$ & $\begin{array}{l}7 \\
(17.9 \%)\end{array}$ & $\begin{array}{l}7 \\
(29.2 \%)\end{array}$ & $\begin{array}{l}15 \\
(22.4 \%)\end{array}$ & $\begin{array}{l}12 \\
(48.0 \%)\end{array}$ & $\begin{array}{l}14 \\
(35.9 \%)\end{array}$ & $\begin{array}{l}14 \\
(35.9 \\
\%)\end{array}$ & $\begin{array}{l}15 \\
(36.6 \%)\end{array}$ \\
\hline Insalubres & $\begin{array}{l}17 \\
(4.4 \\
\%)\end{array}$ & $\begin{array}{l}2 \\
(5.5 \\
\%)\end{array}$ & $\begin{array}{l}0 \\
(0.0 \%)\end{array}$ & $\begin{array}{l}5 \\
(14.2 \%)\end{array}$ & $\begin{array}{l}1 \\
(2.6 \%)\end{array}$ & $\begin{array}{l}3 \\
(12.5 \%)\end{array}$ & $\begin{array}{l}2 \\
(3.0 \%)\end{array}$ & $\begin{array}{l}1 \\
(4.0 \%)\end{array}$ & $\begin{array}{l}1 \\
(2.6 \%)\end{array}$ & $\begin{array}{l}1 \\
(2.6 \\
\%)\end{array}$ & $\begin{array}{l}1 \\
(2.4 \%)\end{array}$ \\
\hline Total & $\begin{array}{l}383 \\
(100 \\
\%)\end{array}$ & $\begin{array}{l}36 \\
(100 \\
\%)\end{array}$ & $\begin{array}{l}38 \\
(100 \%)\end{array}$ & $\begin{array}{l}35 \\
(100 \%)\end{array}$ & $\begin{array}{l}39 \\
(100 \%)\end{array}$ & $\begin{array}{l}24 \\
(100 \%)\end{array}$ & $\begin{array}{l}67 \\
(100 \%)\end{array}$ & $\begin{array}{l}25 \\
(100 \%)\end{array}$ & $\begin{array}{l}39 \\
(100 \%)\end{array}$ & $\begin{array}{l}39 \\
(100 \\
\%)\end{array}$ & $\begin{array}{l}41 \\
(100 \%)\end{array}$ \\
\hline
\end{tabular}

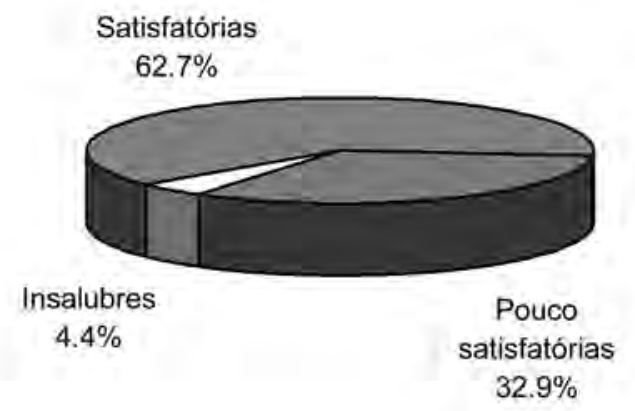

Figura 7: Distribuição das escolas conforme suas condições higiênicas de acordo com o critério do inspetor para o total da amostra. Portugal, 1867

\section{O perfil do professor e suas condições físicas, morais e pedagógicas}

Buscando traçar o desenho completo do funcionamento da escola, os Relatórios traziam ainda informações sobre a condição pessoal do corpo de professores, informando o Estado sobre seus rendimentos, condição civil, faixa etária, etc... Acerca da idade dos docentes, os Relatórios, então, possibilitam o cálculo para o quadro do magistério de modo geral. Havia na amostra toda 374 professores, com idade média 
de 41 anos; o valor da idade mais frequente foi de 28 anos. Os professores mais jovens eram os de Évora e Viseu (com 21 anos) e os mais velhos (2 professores) eram de Vianna do Castello (70 anos).

Tabela 9: Média, moda, mediana, mínimo, máximo e desvio padrão da idade dos professores das escolas, por distrito e para o total da amostra. Portugal, 1867

\begin{tabular}{|l|l|l|l|l|l|l|l|l|l|l|l|}
\hline & \multicolumn{2}{|l|}{ DISTRITO } \\
& Total & Aveiro & Coimbra & $\begin{array}{l}\text { Castello } \\
\text { Branco }\end{array}$ & Guarda & Évora & Lisboa & Portalegre & $\begin{array}{l}\text { Villa } \\
\text { Real }\end{array}$ & $\begin{array}{l}\text { Vizeu } \\
\text { Vianna } \\
\text { do } \\
\text { Castello }\end{array}$ \\
\hline Média & 41 & 42 & 39 & 42 & 39 & 40 & 45 & 38 & 37 & 42 & 43 \\
\hline Mediana & 40 & 40 & 34 & 41 & 34 & 39 & 45 & 33 & 34 & 39 & 43 \\
\hline Moda & 28 & 43 & 28 & 36 & 33 & 23 & 55 & 26 & 28 & 30 & 50 \\
\hline Mínimo & 21 & 26 & 24 & 24 & 25 & 21 & 22 & 23 & 23 & 21 & 27 \\
\hline Máximo & 70 & 66 & 58 & 61 & 61 & 60 & 68 & 67 & 68 & 64 & 70 \\
\hline $\begin{array}{l}\text { Desvio } \\
\text { Padrão }\end{array}$ & 11.6 & 10.8 & 10.8 & 11.0 & 10.1 & 12.9 & 11.7 & 12.1 & 11.6 & 13.5 & 10.5 \\
\hline
\end{tabular}

Obs: A mediana é aquele valor que fica na metade, depois de ordenar todas as idades de menor a maior (ou seja, aquele valor da idade tal que a metade das idades são menores do que ele, e a metade das idades são maiores do que ele). A moda é o valor mais frequente

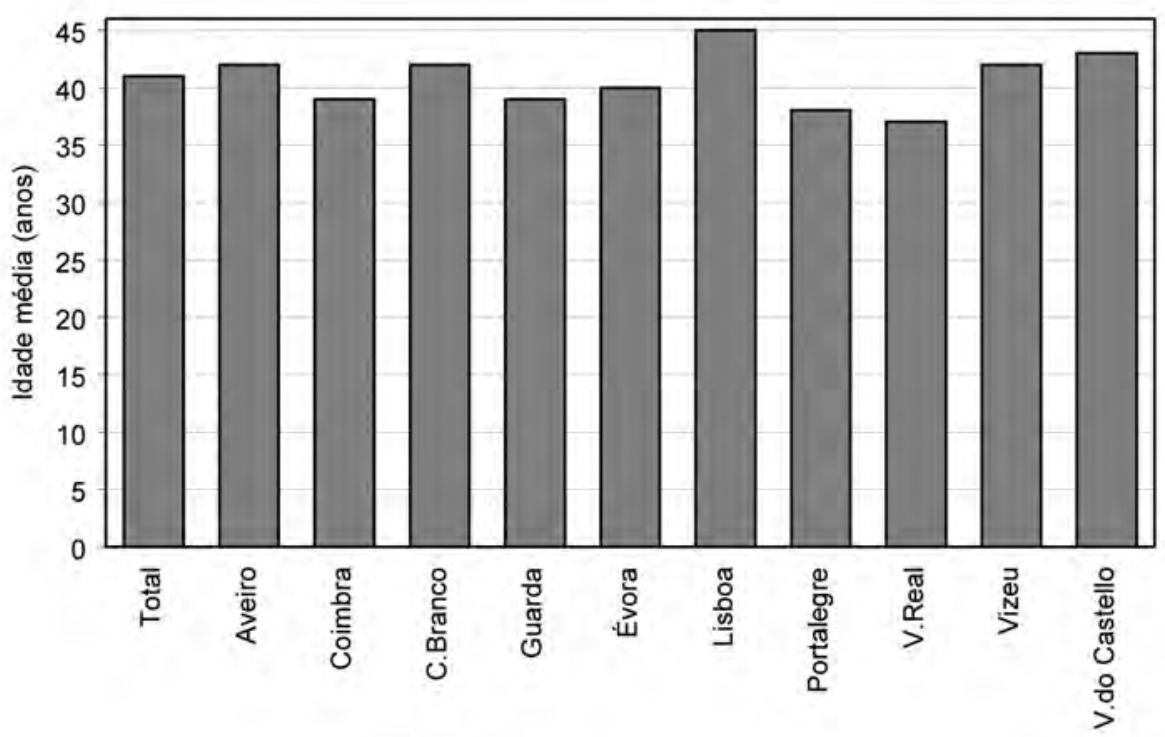

Figura 8: Idade média dos professores por distrito e para o total da amostra. Portugal, 1867 


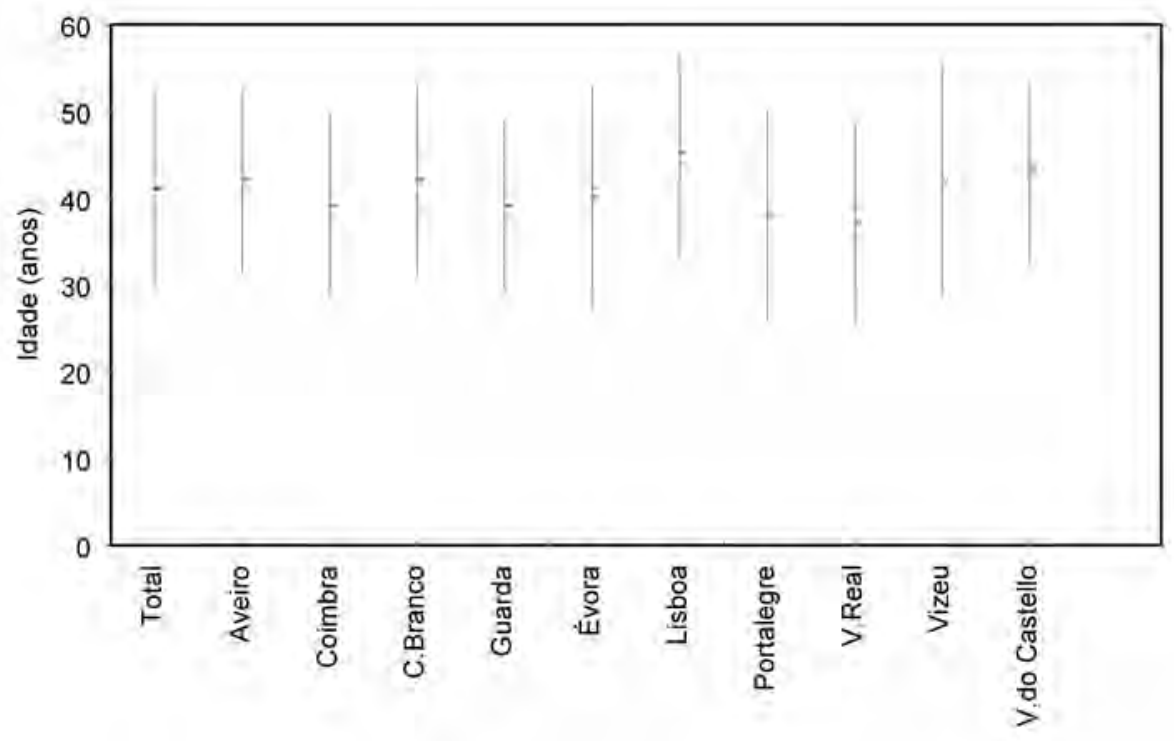

Figura 9: Média e desvio padrão da idade dos professores por distrito e para o total da amostra. Portugal, 1867

No que concerne à apreciação feita pelos inspetores a propósito das condições morais e pedagógicas da rede escolar como um todo, a média para toda a amostra corresponde a $61,6 \%$ de condições consideradas boas; $37,1 \%$ de suficientes; e $12,7 \%$ de condiçôes medíocres. Observando-se a tabela abaixo por distritos, percebe-se que Coimbra, Portalegre e Lisboa foram, pela ordem, os três melhores colocados quanto ao referido item, apresentando respectivamente 76,3\%, 72\%, $71,6 \%$ de condiçóes morais e pedagógicas avaliadas como boas. Aveiro e Vianna do Castello foram, por seu turno, os distritos com maior percentual de condiçóes morais e pedagógicas suficientes (37,1\% e 35,7\% respectivamente). Castello Branco e Évora sobressaem-se por trazer maior porcentagem de condiçōes medíocres $(25,7 \%$ e $25 \%$ respectivamente). A partir da análise desses dados, permitimo-nos questionar a homogeneidade dos critérios utilizados para avaliação do inspetor. Dada a proximidade geográfica entre Portalegre e Évora e, considerando o fato de ser Évora naquela altura um dos grandes centros de Portugal, custa a crer que Portalegre apresentasse escolas e professores melhor qualificados moral e pedagogicamente. Talvez o rigor da análise diferisse de acordo com cada inspetor ou apresentasse mesmo variações regionais que, numa estatística como esta, infelizmente, não temos instrumentos para considerar. 
Tabela 10: Distribuição das escolas conforme as condições morais e pedagógicas da rede escolar para o total da amostra e por distrito. Portugal, 1867

\begin{tabular}{|c|c|c|c|c|c|c|c|c|c|c|c|}
\hline & & Distritc & & & & & & & & & \\
\hline $\begin{array}{l}\text { Condiç̧̄es } \\
\text { morais e } \\
\text { pedagó- } \\
\text { gicas }\end{array}$ & Total & Aveiro & Coimbra & $\begin{array}{l}\text { Castello } \\
\text { Branco }\end{array}$ & Guarda & Évora & Lisboa & Portalegre & $\begin{array}{l}\text { Villa } \\
\text { Real }\end{array}$ & Vizeu & $\begin{array}{l}\text { Vianna } \\
\text { do } \\
\text { Castello }\end{array}$ \\
\hline Boas & $\begin{array}{l}228 \\
(61.6 \\
\%)\end{array}$ & $\begin{array}{l}19 \\
(54.3 \%)\end{array}$ & $\begin{array}{l}29 \\
(76.3 \%)\end{array}$ & $\begin{array}{l}14 \\
(40.0 \%)\end{array}$ & $\begin{array}{l}24 \\
(70.6 \%)\end{array}$ & $\begin{array}{l}8 \\
(50.0 \\
\%)\end{array}$ & $\begin{array}{l}48 \\
(71.6 \%)\end{array}$ & $\begin{array}{l}18 \\
(72.0 \%)\end{array}$ & $\begin{array}{l}25 \\
(64.1 \\
\%)\end{array}$ & $\begin{array}{l}23 \\
(59.0 \%)\end{array}$ & $\begin{array}{l}20 \\
(47.6 \%)\end{array}$ \\
\hline Suficientes & $\begin{array}{l}95 \\
(25.7 \\
\%)\end{array}$ & $\begin{array}{l}13 \\
(37.1 \%)\end{array}$ & $\begin{array}{l}6 \\
(15.8 \%)\end{array}$ & $\begin{array}{l}12 \\
(34.3 \%)\end{array}$ & $\begin{array}{l}7 \\
(20.6 \%)\end{array}$ & $\begin{array}{l}4 \\
(25.0 \\
\%)\end{array}$ & $\begin{array}{l}14 \\
(20.9 \%)\end{array}$ & $\begin{array}{l}3 \\
(12.0 \%)\end{array}$ & $\begin{array}{l}9 \\
(23.1 \\
\%)\end{array}$ & $\begin{array}{l}12 \\
(30.8 \%)\end{array}$ & $\begin{array}{l}15 \\
(35.7 \%)\end{array}$ \\
\hline Medíocres & $\begin{array}{l}47 \\
(12.7 \\
\%)\end{array}$ & $\begin{array}{l}3 \\
(8.6 \%)\end{array}$ & $\begin{array}{l}3 \\
(7.9 \%)\end{array}$ & $\begin{array}{l}9 \\
(25.7 \%)\end{array}$ & $\begin{array}{l}3 \\
(8.8 \%)\end{array}$ & $\begin{array}{l}4 \\
(25.0 \\
\%)\end{array}$ & $\begin{array}{l}5 \\
(7.5 \%)\end{array}$ & $\begin{array}{l}4 \\
(16.0 \%)\end{array}$ & $\begin{array}{l}5 \\
(12.8 \\
\%)\end{array}$ & $\begin{array}{l}4 \\
(10.2 \%)\end{array}$ & $\begin{array}{l}7 \\
(16.7 \%)\end{array}$ \\
\hline Total & $\begin{array}{l}370 \\
(100 \\
\%)\end{array}$ & $\begin{array}{l}35 \\
(100 \%)\end{array}$ & $\begin{array}{l}38 \\
(100 \%)\end{array}$ & $\begin{array}{l}35 \\
(100 \%)\end{array}$ & $\begin{array}{l}34 \\
(100 \%)\end{array}$ & $\begin{array}{l}16 \\
(100 \\
\%)\end{array}$ & $\begin{array}{l}67 \\
(100 \%)\end{array}$ & $\begin{array}{l}25 \\
(100 \%)\end{array}$ & $\begin{array}{l}39 \\
(100 \\
\%)\end{array}$ & $\begin{array}{l}39 \\
(100 \%)\end{array}$ & $\begin{array}{l}42 \\
(100 \%)\end{array}$ \\
\hline
\end{tabular}

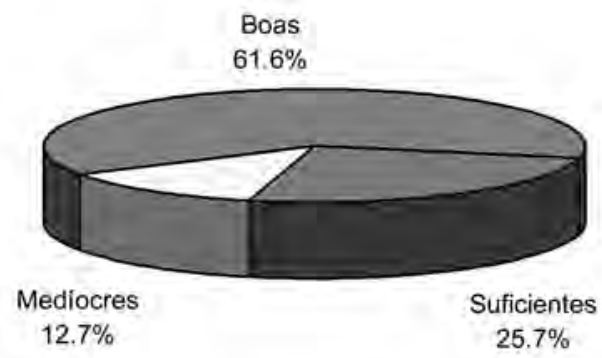

Figura 10: Distribuição das escolas conforme as condiçôes morais e pedagógicas de acordo com o critério do inspetor para o total da amostra. Portugal, 1867.

O Professor António Figueiredo, da freguesia de Bemfeita, tinha uma elevada taxa de alunos presentes no dia da visita do inspetor. De fato, compareceram 33 dos seus 39 alunos. Tal indicador não tem correspondência, entretanto, com a apreciação efetuada quanto ao zelo e aproveitamento dos alunos, cujos valores se mantiveram próximos dos da média de sua freguesia. O Professor António Figueiredo, como muitos de seus colegas, aliás, municiou ele próprio a mobília e os utensílios escolares, tal como ocorria em $37 \%$ da escolas portuguesas. Em alguns casos - como Vianna do Castello e Viseu - esse percentual elevava-se a quase 50\%. Por outro lado, constata-se em outros distritos a presença forte da Junta de Paróquia. 
Tanto na Guarda quanto em Villa Real, quase metade das escolas tinham mobílias e utensílios ministrados pela Junta de Paróquia, ainda que, em média, as escolas portuguesas recebessem $24,4 \%$ da sua mobília e de seus utensílios escolares da Junta de Paróquia. Nota-se também a presença das Câmaras Municipais: eram elas que, em 27,2\% dos casos para todo o país forneciam as mobílias e utensílios escolares. No Alentejo, a Câmara exercia ação quase tutelar: em Évora, 68,8\% dos casos e em Portalegre 55,6\% recebiam mobiliário dessa fonte. Uma pequena proporção era, ain$\mathrm{da}$, fornecida por irmandades ou confrarias $(2,6 \%)$ e pelo Estado $(2,1 \%)$. Curioso é que Lisboa e Coimbra apresentassem percentuais aproximados de distribuição do material e do mobiliário escolar entre o professor e a Câmara Municipal, sendo, no caso de Coimbra, o equivalente a 31,2\% para cada um e em Lisboa aproximadamente $40 \%$, como podemos observar pela tabela abaixo:

Tabela 11: Distribuição das escolas conforme a origem da mobília e utensílios por distritos e para o total da amostra. Portugal, 1867

\begin{tabular}{|c|c|c|c|c|c|c|c|c|c|c|c|}
\hline \multirow[b]{2}{*}{$\begin{array}{l}\text { Origem da } \\
\text { mobília }\end{array}$} & \multirow[b]{2}{*}{ Total } & \multicolumn{10}{|c|}{ DISTRITO } \\
\hline & & Aveiro & Coimbra & $\begin{array}{l}\text { Castello } \\
\text { Branco }\end{array}$ & Guarda & Évora & Lisboa & Portalegre & $\begin{array}{l}\text { Villa } \\
\text { Real }\end{array}$ & Vizeu & $\begin{array}{l}\text { Vianna } \\
\text { do } \\
\text { Castello }\end{array}$ \\
\hline Professor & $\begin{array}{l}159 \\
(37 . \\
0 \%)\end{array}$ & $\begin{array}{l}15 \\
(39.5 \%)\end{array}$ & $\begin{array}{l}15 \\
(31.2 \%)\end{array}$ & $\begin{array}{l}15 \\
(32.6 \%)\end{array}$ & $\begin{array}{l}17 \\
(36.2 \%)\end{array}$ & $\begin{array}{l}2 \\
(12.5 \\
\%)\end{array}$ & $\begin{array}{l}29 \\
(40.3 \\
\%)\end{array}$ & $\begin{array}{l}7 \\
(25.9 \%)\end{array}$ & $\begin{array}{l}13 \\
(30.2 \\
\%)\end{array}$ & $\begin{array}{l}22 \\
(48.9 \\
\%)\end{array}$ & $\begin{array}{l}24 \\
(50.0 \%)\end{array}$ \\
\hline $\begin{array}{l}\text { Câmara } \\
\text { Municipal }\end{array}$ & $\begin{array}{l}117 \\
(27.2 \\
\%)\end{array}$ & $\begin{array}{l}9 \\
(23.7 \%)\end{array}$ & $\begin{array}{l}15 \\
(31.2 \%)\end{array}$ & $\begin{array}{l}11 \\
(23.9 \%)\end{array}$ & $\begin{array}{l}5 \\
(10.6 \%)\end{array}$ & $\begin{array}{l}11 \\
(68.8 \\
\%)\end{array}$ & $\begin{array}{l}30 \\
(41.7 \\
\%)\end{array}$ & $\begin{array}{l}15 \\
(55.6 \%)\end{array}$ & $\begin{array}{l}4 \\
(9.4 \\
\%)\end{array}$ & $\begin{array}{l}6 \\
(13.3 \\
\%)\end{array}$ & $\begin{array}{l}11 \\
(22.9 \%)\end{array}$ \\
\hline $\begin{array}{l}\text { Junta de } \\
\text { paróquia }\end{array}$ & $\begin{array}{l}105 \\
(24.4 \\
\%)\end{array}$ & $\begin{array}{l}10 \\
(26.3 \%)\end{array}$ & $\begin{array}{l}9 \\
(18.7 \%)\end{array}$ & $\begin{array}{l}16 \\
(34.8 \%)\end{array}$ & $\begin{array}{l}23 \\
(48.9 \%)\end{array}$ & $\begin{array}{l}3 \\
(18.7 \\
\%)\end{array}$ & $\begin{array}{l}1 \\
(1.4 \\
\%)\end{array}$ & $\begin{array}{l}3 \\
(11.1 \%)\end{array}$ & $\begin{array}{l}21 \\
(48.8 \\
\%)\end{array}$ & $\begin{array}{l}12 \\
(26.7 \\
\%)\end{array}$ & $\begin{array}{l}7 \\
(14.6 \%)\end{array}$ \\
\hline Particular & $\begin{array}{l}29 \\
(6.7 \\
\%)\end{array}$ & $\begin{array}{l}3 \\
(7.9 \%)\end{array}$ & $\begin{array}{l}5 \\
(10.4 \%)\end{array}$ & $\begin{array}{l}2 \\
(4.3 \%)\end{array}$ & $\begin{array}{l}0 \\
(0.0 \%)\end{array}$ & $\begin{array}{l}0 \\
(0.0 \\
\%)\end{array}$ & $\begin{array}{l}4 \\
(5.6 \\
\%)\end{array}$ & $\begin{array}{l}2 \\
(7.4 \%)\end{array}$ & $\begin{array}{l}5 \\
(11.6 \\
\%)\end{array}$ & $\begin{array}{l}4 \\
(8.9 \\
\%)\end{array}$ & $\begin{array}{l}4 \\
(8.3 \%)\end{array}$ \\
\hline $\begin{array}{l}\text { Irmandade } \\
\text { ou } \\
\text { Confraria }\end{array}$ & $\begin{array}{l}11 \\
(2.6 \\
\%)\end{array}$ & $\begin{array}{l}0 \\
(0.0 \%)\end{array}$ & $\begin{array}{l}4 \\
(8.3 \%)\end{array}$ & $\begin{array}{l}1 \\
(2.2 \%)\end{array}$ & $\begin{array}{l}2 \\
(4.3 \%)\end{array}$ & $\begin{array}{l}0 \\
(0.0 \\
\%)\end{array}$ & $\begin{array}{l}3 \\
(4.1 \\
\%)\end{array}$ & $\begin{array}{l}0 \\
(0.0 \%)\end{array}$ & $\begin{array}{l}0 \\
(0.0 \\
\%)\end{array}$ & $\begin{array}{l}0 \\
(0.0 \\
\%)\end{array}$ & $\begin{array}{l}1 \\
(2.1 \%)\end{array}$ \\
\hline Estado & $\begin{array}{l}9 \\
(2.1 \\
\%)\end{array}$ & $\begin{array}{l}1 \\
(2.6 \%)\end{array}$ & $\begin{array}{l}0 \\
(0.0 \%)\end{array}$ & $\begin{array}{l}1 \\
(2.2 \%)\end{array}$ & $\begin{array}{l}0 \\
(0.0 \%)\end{array}$ & $\begin{array}{l}0 \\
(0.0 \\
\%)\end{array}$ & $\begin{array}{l}5 \\
(6.9 \\
\%)\end{array}$ & $\begin{array}{l}0 \\
(0.0 \%)\end{array}$ & $\begin{array}{l}0 \\
(0.0 \\
\%)\end{array}$ & $\begin{array}{l}1 \\
(2.2 \\
\%)\end{array}$ & $\begin{array}{l}1 \\
(2.1 \%)\end{array}$ \\
\hline Total & $\begin{array}{l}430 \\
(100 \\
\%)\end{array}$ & $\begin{array}{l}38 \\
(100 \%)\end{array}$ & $\begin{array}{l}48 \\
(100 \%)\end{array}$ & $\begin{array}{l}46 \\
(100 \%)\end{array}$ & $\begin{array}{l}47 \\
(100 \%)\end{array}$ & $\begin{array}{l}16 \\
(100 \\
\%)\end{array}$ & $\begin{array}{l}72 \\
(100 \\
\%)\end{array}$ & $\begin{array}{l}27 \\
(100 \%)\end{array}$ & $\begin{array}{l}43 \\
(100 \\
\%)\end{array}$ & $\begin{array}{l}45 \\
(100 \\
\%)\end{array}$ & $\begin{array}{l}48 \\
(100 \%)\end{array}$ \\
\hline
\end{tabular}




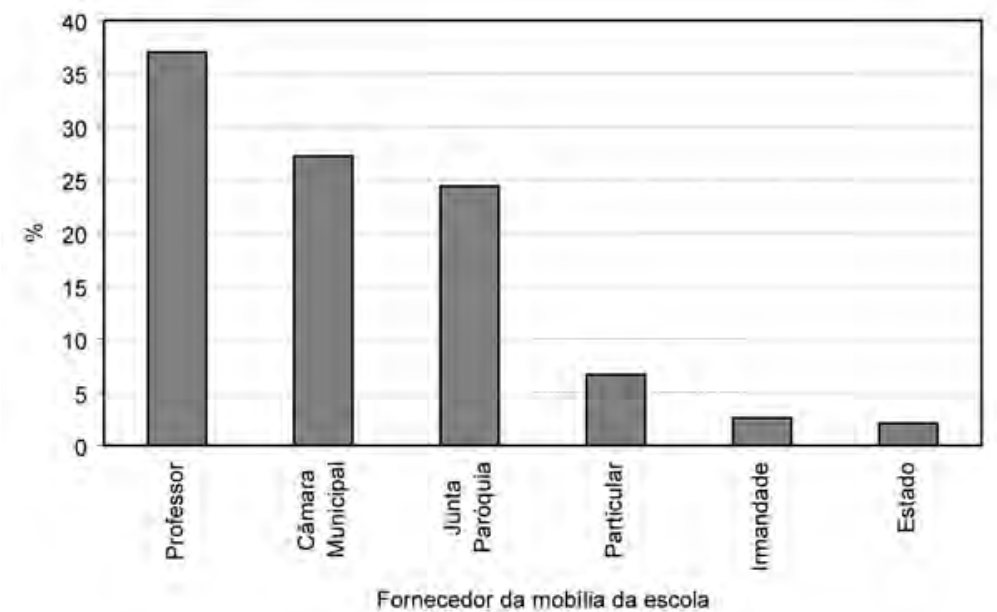

Figura 11: Distribuição das escolas conforme a origem da mobília e utensílios para o total da amostra. Portugal, 1867

\section{Formação dos professores, estado civil, situação funcional e tempo de serviço}

Talvez as diferenças regionais pudessem ser aqui apreendidas mediante o envolvimento maior ou menor da comunidade local para com sua escola, mas isso fica apenas como hipótese. Para a amostra toda, a maior parte dos professores são casados - 43,1\% -, sendo os solteiros $30,5 \%$. Havia $4,4 \%$ de viúvos e $22 \%$ de eclesiásticos.

Tabela 12: Distribuição dos professores conforme o estado civil do professor por distritos e para o total da amostra. Portugal, 1867

\begin{tabular}{|c|c|c|c|c|c|c|c|c|c|c|c|}
\hline \multirow[b]{2}{*}{$\begin{array}{l}\text { Estado } \\
\text { civil do } \\
\text { professor }\end{array}$} & \multirow[b]{2}{*}{ Total } & \multicolumn{10}{|c|}{ DisTRITO } \\
\hline & & Aveiro & Coimbra & $\begin{array}{l}\text { Castello } \\
\text { Branco }\end{array}$ & Guarda & Évora & Lisboa & Portalegre & $\begin{array}{l}\text { Villa } \\
\text { Real }\end{array}$ & Vizeu & $\begin{array}{l}\text { Vianna } \\
\text { do } \\
\text { Castello }\end{array}$ \\
\hline Casado & $\begin{array}{l}167 \\
(43.1 \\
\%)\end{array}$ & $\begin{array}{l}14 \\
(38.9 \%)\end{array}$ & $\begin{array}{l}12 \\
(31.6 \%)\end{array}$ & $\begin{array}{l}17 \\
(48.6 \%)\end{array}$ & $\begin{array}{l}16 \\
(40.0 \%)\end{array}$ & $\begin{array}{l}10 \\
(34.5 \\
\%)\end{array}$ & $\begin{array}{l}30 \\
(44.8 \%)\end{array}$ & $\begin{array}{l}10 \\
(40.0 \%)\end{array}$ & $\begin{array}{l}16 \\
(42.1 \%)\end{array}$ & $\begin{array}{l}16 \\
(42.1 \%)\end{array}$ & $\begin{array}{l}26 \\
(63.4 \%)\end{array}$ \\
\hline Solteiro & $\begin{array}{l}118 \\
(30.5 \\
\%) \\
\end{array}$ & $\begin{array}{l}9 \\
(25.0 \%)\end{array}$ & $\begin{array}{l}18 \\
(47.4 \%)\end{array}$ & $\begin{array}{l}8 \\
(22.9 \%)\end{array}$ & $\begin{array}{l}7 \\
(17.5 \%)\end{array}$ & $\begin{array}{l}16 \\
(55.2 \\
\%)\end{array}$ & $\begin{array}{l}23 \\
(34.3 \%)\end{array}$ & $\begin{array}{l}6 \\
(24.0 \%)\end{array}$ & $\begin{array}{l}16 \\
(42.1 \%)\end{array}$ & $\begin{array}{l}6 \\
(15.8 \%)\end{array}$ & $\begin{array}{l}9 \\
(22.0 \%)\end{array}$ \\
\hline Eclesiástico & $\begin{array}{l}85 \\
(22.0 \\
\%) \\
\end{array}$ & $\begin{array}{l}13 \\
(36.1 \%)\end{array}$ & $\begin{array}{l}7 \\
(18.4 \%)\end{array}$ & $\begin{array}{l}9 \\
(25.7 \%)\end{array}$ & $\begin{array}{l}16 \\
(40.0 \%)\end{array}$ & $\begin{array}{l}0 \\
(0.0 \\
\%) \\
\end{array}$ & $\begin{array}{l}9 \\
(13.4 \%)\end{array}$ & $\begin{array}{l}7 \\
(28.0 \%)\end{array}$ & $\begin{array}{l}5 \\
(13.2 \%)\end{array}$ & $\begin{array}{l}14 \\
(36.8 \%)\end{array}$ & $\begin{array}{l}5 \\
(12.2 \%)\end{array}$ \\
\hline Viúvo & $\begin{array}{l}17 \\
(4.4 \\
\%)\end{array}$ & $\begin{array}{l}0 \\
(0.0 \%)\end{array}$ & $\begin{array}{l}1 \\
(2.6 \%)\end{array}$ & $\begin{array}{l}1 \\
(2.9 \%)\end{array}$ & $\begin{array}{l}1 \\
(2.5 \%)\end{array}$ & $\begin{array}{l}3 \\
(10.3 \\
\%) \\
\end{array}$ & $\begin{array}{l}5 \\
(7.5 \%)\end{array}$ & $\begin{array}{l}2 \\
(8.0 \%)\end{array}$ & $\begin{array}{l}1 \\
(2.6 \%)\end{array}$ & $\begin{array}{l}2 \\
(5.3 \%)\end{array}$ & $\begin{array}{l}1 \\
(2.4 \%)\end{array}$ \\
\hline Total & $\begin{array}{l}387 \\
(100 \\
\%)\end{array}$ & $\begin{array}{l}36 \\
(100 \%)\end{array}$ & $\begin{array}{l}38 \\
(100 \%)\end{array}$ & $\begin{array}{l}35 \\
(100 \%)\end{array}$ & $\begin{array}{l}40 \\
(100 \%)\end{array}$ & $\begin{array}{l}29 \\
(100 \\
\%)\end{array}$ & $\begin{array}{l}67 \\
(100 \%)\end{array}$ & $\begin{array}{l}25 \\
(100 \%)\end{array}$ & $\begin{array}{l}38 \\
(100 \%)\end{array}$ & $\begin{array}{l}38 \\
(100 \%)\end{array}$ & $\begin{array}{l}41 \\
(100 \%)\end{array}$ \\
\hline
\end{tabular}




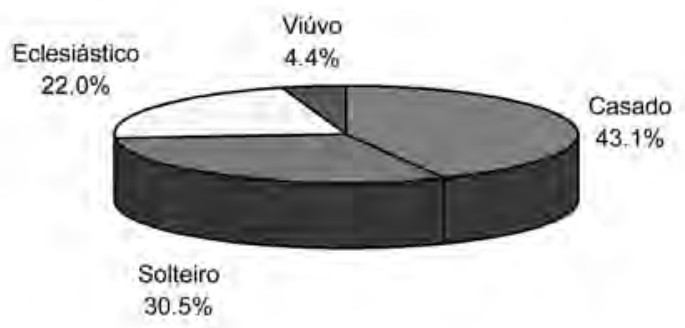

Figura 12: Distribuição dos professores conforme estado civil para o total da amostra. Portugal, 1867

O Relatório de inspeção de 1867 dava lugar também para informações quanto a habilitações e exames dos professores. Da lista de matérias arroladas, constava o curso de Português, desenho linear, francês ou inglês, matemáticas, introdução à história natural, geografia e história, latim, filosofia racional, eloquência e, finalmente, curso da Escola Normal. As mais altas porcentagens correspondem a Latim (28,1\%), Filosofia Racional (20,5\%) e Eloquência (15,7\%). Évora e Lisboa foram os distritos com mais altas porcentagens de cursos de Português (23,8\% e 18,9\%, respectivamente), seguidas por Coimbra e Villa Real (que apresentavam respectivamente 11,7\% e 9,7\% de professores com cursos de Português). Com habilitações em Francês e Inglês, Lisboa também se destacou com 21,7\%. Vianna do Castelo, Villa Real e Castello Branco foram os distritos com maiores valores referentes à capacitação em Latim $(37,8 \%, 35,4 \%, 32,3 \%$ e $31,4 \%$ respectivamente). A formação dos professores era - como revela o quadro abaixo - bastante precária, havendo, porém, destaque para disciplinas que compunham o mosaico eclesiástico da cultura: a filosofia, o latim, a eloquência - heranças do medievo trivium.

Tabela 13: Distribuição dos professores conforme habilitação e exames por distritos e para o total da amostra. Portugal, 1867

\begin{tabular}{|l|l|l|l|l|l|l|l|l|l|l|l|}
\hline & \multicolumn{9}{|l|}{ Distrito } \\
\hline $\begin{array}{l}\text { Formação } \\
\text { dos } \\
\text { professores }\end{array}$ & Total & Aveiro & Coimbra & $\begin{array}{l}\text { Castello } \\
\text { Branco }\end{array}$ & Guarda & Évora & Lisboa & Portalegre & $\begin{array}{l}\text { Villa } \\
\text { Real }\end{array}$ & \multicolumn{2}{l|}{$\begin{array}{l}\text { Vizeu } \\
\text { Vianna } \\
\text { do } \\
\text { Castello }\end{array}$} \\
\hline Latim & $\begin{array}{l}159 \\
(28.1 \%)\end{array}$ & $\begin{array}{l}23 \\
(35.4 \%)\end{array}$ & $\begin{array}{l}22 \\
(23.4 \%)\end{array}$ & $\begin{array}{l}16 \\
(31.4 \%)\end{array}$ & $\begin{array}{l}18 \\
(28.6 \%)\end{array}$ & $\begin{array}{l}5 \\
(23.8 \\
\%)\end{array}$ & $\begin{array}{l}15 \\
(20.3 \%)\end{array}$ & $\begin{array}{l}10 \\
(25.7 \%)\end{array}$ & $\begin{array}{l}10 \\
(32.3 \\
\%)\end{array}$ & $\begin{array}{l}26 \\
(28.9 \\
\%)\end{array}$ & $\begin{array}{l}14 \\
(37.8 \%)\end{array}$ \\
\hline $\begin{array}{l}\text { Filosofía } \\
\text { racional }\end{array}$ & $\begin{array}{l}115 \\
(20.5 \%)\end{array}$ & $\begin{array}{l}18 \\
(27.7 \%)\end{array}$ & $\begin{array}{l}13 \\
(13.8 \%)\end{array}$ & $\begin{array}{l}14 \\
(27.4 \%)\end{array}$ & $\begin{array}{l}12 \\
(19.0 \%)\end{array}$ & $\begin{array}{l}2 \\
(9.5 \\
\%)\end{array}$ & $\begin{array}{l}7 \\
(9.5 \%)\end{array}$ & $\begin{array}{l}9 \\
(23.0 \%)\end{array}$ & $\begin{array}{l}9 \\
(29.0 \\
\%)\end{array}$ & $\begin{array}{l}21 \\
(23.3 \\
\%)\end{array}$ & $\begin{array}{l}10 \\
(27.0 \%)\end{array}$ \\
\hline $\begin{array}{l}\text { Eloquên- } \\
\text { cia }\end{array}$ & $\begin{array}{l}89 \\
(15.7 \%)\end{array}$ & $\begin{array}{l}15 \\
(23.2 \%)\end{array}$ & $\begin{array}{l}12 \\
(12.9 \%)\end{array}$ & $\begin{array}{l}13 \\
(25.4 \%)\end{array}$ & $\begin{array}{l}12 \\
(19.0 \%)\end{array}$ & $\begin{array}{l}2 \\
(9.5 \\
\%)\end{array}$ & $\begin{array}{l}2 \\
(2.7 \%)\end{array}$ & $\begin{array}{l}5 \\
(12.8 \%)\end{array}$ & $\begin{array}{l}3 \\
(9.7 \%)\end{array}$ & $\begin{array}{l}(21.1 \\
\%)\end{array}$ & $\begin{array}{l}6 \\
(16.2 \%)\end{array}$ \\
\hline $\begin{array}{l}\text { Francês ou } \\
\text { inglês }\end{array}$ & $\begin{array}{l}63 \\
(11.2 \%)\end{array}$ & $\begin{array}{l}4 \\
(6.1 \%)\end{array}$ & $\begin{array}{l}13 \\
(13.8 \%)\end{array}$ & $\begin{array}{l}3 \\
(5.9 \%)\end{array}$ & $\begin{array}{l}6 \\
(9.5 \%)\end{array}$ & $\begin{array}{l}2 \\
(9.5 \\
\%)\end{array}$ & $\begin{array}{l}16 \\
(21.7 \%)\end{array}$ & $\begin{array}{l}5 \\
(12.8 \%)\end{array}$ & $\begin{array}{l}2 \\
(6.4 \%)\end{array}$ & $\begin{array}{l}9 \\
(10.0 \\
\%)\end{array}$ & $\begin{array}{l}3 \\
(8.2 \%)\end{array}$ \\
\hline
\end{tabular}




\begin{tabular}{|c|c|c|c|c|c|c|c|c|c|c|c|}
\hline Português & $\begin{array}{l}43 \\
(7.6 \%)\end{array}$ & $\begin{array}{l}3 \\
(4.6 \%)\end{array}$ & $\begin{array}{l}11 \\
(11.7 \%)\end{array}$ & $\begin{array}{l}0 \\
(0.0 \%)\end{array}$ & $\begin{array}{l}3 \\
(4.8 \%)\end{array}$ & $\begin{array}{l}5 \\
(23.8 \\
\%)\end{array}$ & $\begin{array}{l}14 \\
(18.9 \%)\end{array}$ & $\begin{array}{l}1 \\
(2.6 \%)\end{array}$ & $\begin{array}{l}3 \\
(9.7 \%)\end{array}$ & $\begin{array}{l}2 \\
(2.2 \\
\%)\end{array}$ & $\begin{array}{l}1 \\
(2.7 \%)\end{array}$ \\
\hline $\begin{array}{l}\text { Geo- } \\
\text { grafia e } \\
\text { História }\end{array}$ & $\begin{array}{l}37 \\
(6.5 \\
\%)\end{array}$ & $\begin{array}{l}1 \\
(1.5 \\
\%)\end{array}$ & $\begin{array}{l}10 \\
(10.6 \\
\%)\end{array}$ & $\begin{array}{l}3 \\
(5.9 \\
\%)\end{array}$ & $\begin{array}{l}7 \\
(11.2 \\
\%)\end{array}$ & $\begin{array}{l}1 \\
(4.8 \\
\%)\end{array}$ & $\begin{array}{l}5 \\
(6.8 \\
\%)\end{array}$ & $\begin{array}{l}4 \\
(10.3 \%)\end{array}$ & $\begin{array}{l}0 \\
(0.0 \\
\%)\end{array}$ & $\begin{array}{l}6 \\
(6.7 \\
\%)\end{array}$ & $\begin{array}{l}0 \\
(0.0 \\
\%)\end{array}$ \\
\hline $\begin{array}{l}\text { Matemá- } \\
\text { ticas }\end{array}$ & \begin{tabular}{|l|}
34 \\
$(6.0$ \\
$\%)$
\end{tabular} & $\begin{array}{l}1 \\
(1.5 \\
\%)\end{array}$ & $\begin{array}{l}8 \\
(8.5 \\
\%)\end{array}$ & $\begin{array}{l}1 \\
(2.0 \\
\%)\end{array}$ & $\begin{array}{l}5 \\
(7.9 \%)\end{array}$ & $\begin{array}{l}1 \\
(4.8 \\
\%)\end{array}$ & $\begin{array}{l}8 \\
(10.8 \\
\%)\end{array}$ & $\begin{array}{l}2 \\
(5.1 \%)\end{array}$ & $\begin{array}{l}1 \\
(3.2 \\
\%)\end{array}$ & $\begin{array}{l}6 \\
(6.7 \\
\%)\end{array}$ & $\begin{array}{l}1 \\
(2.7 \\
\%)\end{array}$ \\
\hline $\begin{array}{l}\text { Desenho } \\
\text { linear }\end{array}$ & $\begin{array}{l}13 \\
(2.3 \\
\%)\end{array}$ & $\begin{array}{l}0 \\
(0.0 \\
\%)\end{array}$ & $\begin{array}{l}2 \\
(2.1 \\
\%)\end{array}$ & $\begin{array}{l}0 \\
(0.0 \\
\%)\end{array}$ & $\begin{array}{l}0 \\
(0.0 \\
\%)\end{array}$ & $\begin{array}{l}2 \\
(9.5 \\
\%)\end{array}$ & $\begin{array}{l}5 \\
(6.8 \\
\%)\end{array}$ & $\begin{array}{l}1 \\
(2.6 \%)\end{array}$ & $\begin{array}{l}3 \\
(9.7 \\
\%)\end{array}$ & $\begin{array}{l}0 \\
(0.0 \\
\%)\end{array}$ & $\begin{array}{l}0 \\
(0.0 \\
\%)\end{array}$ \\
\hline $\begin{array}{l}\text { Escola } \\
\text { Normal }\end{array}$ & $\begin{array}{l}8 \\
(1.4 \\
\%)\end{array}$ & $\begin{array}{l}0 \\
(0.0 \\
\%)\end{array}$ & $\begin{array}{l}0 \\
(0.0 \\
\%)\end{array}$ & $\begin{array}{l}1 \\
(2.0 \\
\%)\end{array}$ & $\begin{array}{l}0 \\
(0.0 \\
\%)\end{array}$ & $\begin{array}{l}1 \\
(4.8 \\
\%)\end{array}$ & $\begin{array}{l}1 \\
(1.3 \\
\%)\end{array}$ & $\begin{array}{l}2 \\
(5.1 \%)\end{array}$ & $\begin{array}{l}0 \\
(0.0 \\
\%)\end{array}$ & $\begin{array}{l}1 \\
(1.1 \\
\%)\end{array}$ & $\begin{array}{l}2 \\
(5.4 \\
\%)\end{array}$ \\
\hline $\begin{array}{l}\text { História } \\
\text { natural }\end{array}$ & $\begin{array}{l}4 \\
(0.7 \\
\%)\end{array}$ & $\begin{array}{l}0 \\
(0.0 \\
\%)\end{array}$ & $\begin{array}{l}3 \\
(3.2 \\
\%)\end{array}$ & $\begin{array}{l}0 \\
(0.0 \\
\%)\end{array}$ & $\begin{array}{l}0 \\
(0.0 \\
\%)\end{array}$ & $\begin{array}{l}0 \\
(0.0 \\
\%)\end{array}$ & $\begin{array}{l}1 \\
(1.3 \\
\%)\end{array}$ & $\begin{array}{l}0 \\
(0.0 \%)\end{array}$ & $\begin{array}{l}0 \\
(0.0 \\
\%)\end{array}$ & $\begin{array}{l}0 \\
(0.0 \\
\%)\end{array}$ & $\begin{array}{l}0 \\
(0.0 \\
\%)\end{array}$ \\
\hline Total & $\begin{array}{l}565 \\
(100 \\
\%)\end{array}$ & $\begin{array}{l}65 \\
(100 \\
\%)\end{array}$ & $\begin{array}{l}94 \\
(100 \\
\%)\end{array}$ & $\begin{array}{l}51 \\
(100 \\
\%)\end{array}$ & $\begin{array}{l}63 \\
(100 \\
\%)\end{array}$ & $\begin{array}{l}21 \\
(100 \\
\%)\end{array}$ & $\begin{array}{l}74 \\
(100 \\
\%)\end{array}$ & $\begin{array}{l}39 \\
(100 \%)\end{array}$ & $\begin{array}{l}31 \\
(100 \\
\%)\end{array}$ & $\begin{array}{l}90 \\
(100 \\
\%)\end{array}$ & $\begin{array}{l}37 \\
(100 \\
\%)\end{array}$ \\
\hline
\end{tabular}

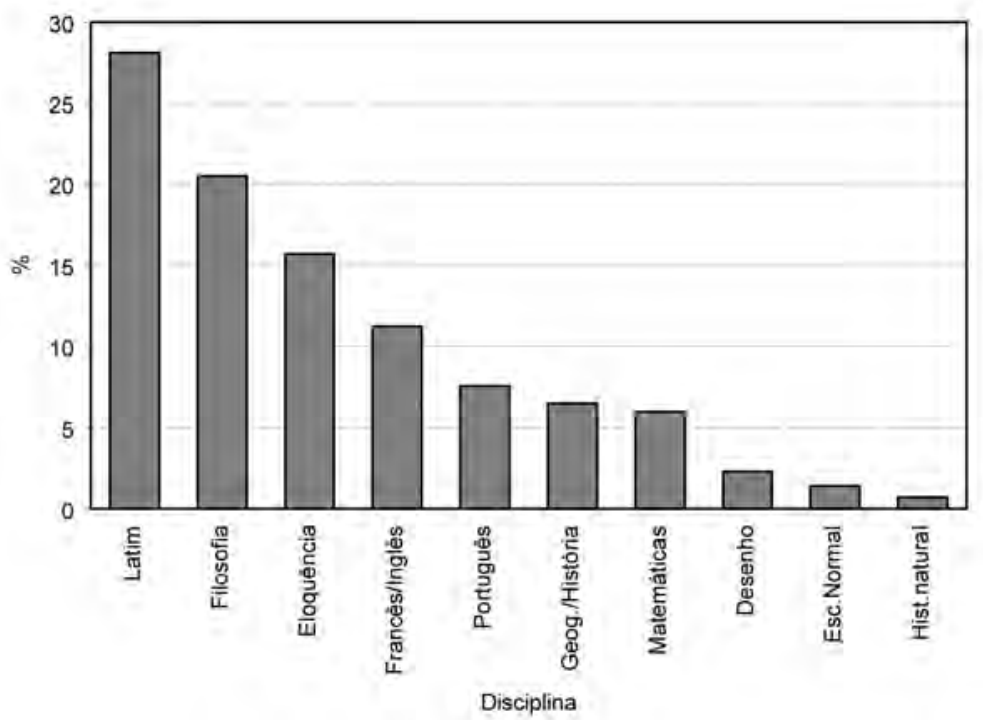

Figura 13: Distribuição dos cargos dos professores conforme a habilitação e exames para o total da amostra. Portugal, 1867. 
Quanto ao provimento dos cargos do magistério, a maior parte dos professores encontrava-se na condição de vitalícios - 52,4\% -; sendo que, dos demais, 40, 2\% eram temporários e apenas $7,4 \%$ estavam na categoria de interinos. ${ }^{256}$ Vianna do Castello e Lisboa foram os distritos com mais elevado percentual de professores vitalícios (63,4\% e 63\% respectivamente), seguidas de Castello Branco (57,2\%), Évora $(53,3 \%)$, Viseu e Coimbra (ambas com 47,4\%). As porcentagens maiores de professores na condição de temporários foram encontradas nos distritos de Portalegre e Villa Real (64\% e 60\% respectivamente). Em relação aos interinos, a maior proporção deles concentrava-se no distrito da Guarda (17,8\%). Vianna do Castello e Aveiro foram os distritos com mais baixas porcentagens de professores interinos $(2,4 \%$ e $2,8 \%$ respectivamente).

Tabela 14: Distribuição dos professores conforme provimento dos cargos por distritos e para o total da amostra. Portugal, 1867

\begin{tabular}{|c|c|c|c|c|c|c|c|c|c|c|c|}
\hline \multirow[b]{2}{*}{ Cargo } & \multirow[b]{2}{*}{ Total } & \multicolumn{10}{|c|}{ Distritos } \\
\hline & & Aveiro & Coimbra & $\begin{array}{l}\text { Castello } \\
\text { Branco }\end{array}$ & Guarda & Évora & Lisboa & Portalegre & $\begin{array}{l}\text { Villa } \\
\text { Real }\end{array}$ & Vizeu & $\begin{array}{l}\text { Vianna } \\
\text { do } \\
\text { Castello }\end{array}$ \\
\hline Vitalício & $\begin{array}{l}197 \\
(52.4 \%)\end{array}$ & $\begin{array}{l}22 \\
(61.1 \%)\end{array}$ & $\begin{array}{l}18 \\
(47.4 \%)\end{array}$ & $\begin{array}{l}20 \\
(57.2 \%)\end{array}$ & $\begin{array}{l}21 \\
(46.6 \%)\end{array}$ & $\begin{array}{l}8 \\
(53.3 \\
\%)\end{array}$ & $\begin{array}{l}46 \\
(63.0 \%)\end{array}$ & $\begin{array}{l}7 \\
(28.0 \%)\end{array}$ & $\begin{array}{l}11 \\
(36.7 \\
\%)\end{array}$ & $\begin{array}{l}18 \\
(47.4 \%)\end{array}$ & $\begin{array}{l}26 \\
(63.4 \%)\end{array}$ \\
\hline $\begin{array}{l}\text { Tempo- } \\
\text { rário }\end{array}$ & $\begin{array}{l}151 \\
(40.2 \%)\end{array}$ & $\begin{array}{l}13 \\
(36.1 \%)\end{array}$ & $\begin{array}{l}18 \\
(47.4 \%)\end{array}$ & $\begin{array}{l}13 \\
(37.1 \%)\end{array}$ & $\begin{array}{l}16 \\
(35.6 \%)\end{array}$ & $\begin{array}{l}6 \\
(40.0 \\
\%)\end{array}$ & $\begin{array}{l}19 \\
(26.0 \%)\end{array}$ & $\begin{array}{l}16 \\
(64.0 \%)\end{array}$ & $\begin{array}{l}18 \\
(60.0 \\
\%)\end{array}$ & $\begin{array}{l}18 \\
(47.4 \%)\end{array}$ & $\begin{array}{l}14 \\
(34.2 \%)\end{array}$ \\
\hline Interino & $\begin{array}{l}28 \\
(7.4 \%)\end{array}$ & $\begin{array}{l}1 \\
(2.8 \%)\end{array}$ & $\begin{array}{l}2 \\
(5.2 \%)\end{array}$ & $\begin{array}{l}2 \\
(5.7 \%)\end{array}$ & $\begin{array}{l}8 \\
(17.8 \%)\end{array}$ & $\begin{array}{l}1 \\
(6.7 \\
\%)\end{array}$ & $\begin{array}{l}8 \\
(11.0 \%)\end{array}$ & $\begin{array}{l}2 \\
(8.0 \%)\end{array}$ & $\begin{array}{l}1 \\
(3.3 \\
\%)\end{array}$ & $\begin{array}{l}2 \\
(5.2 \%)\end{array}$ & $\begin{array}{l}1 \\
(2.4 \%)\end{array}$ \\
\hline Total & $\begin{array}{l}376 \\
(100 \%)\end{array}$ & $\begin{array}{l}36 \\
(100 \%)\end{array}$ & $\begin{array}{l}38 \\
(100 \%)\end{array}$ & $\begin{array}{l}35 \\
(100 \%)\end{array}$ & $\begin{array}{l}45 \\
(100 \%)\end{array}$ & $\begin{array}{l}15 \\
(100 \\
\%)\end{array}$ & $\begin{array}{l}73 \\
(100 \%)\end{array}$ & $\begin{array}{l}25 \\
(100 \%)\end{array}$ & $\begin{array}{l}30 \\
(100 \\
\%)\end{array}$ & $\begin{array}{l}38 \\
(100 \%)\end{array}$ & $\begin{array}{l}41 \\
(100 \%)\end{array}$ \\
\hline
\end{tabular}

${ }^{256}$ O trabalho de Nóvoa abarca o mesmo cálculo em relação aos tipos de provimento dos cargos docentes, mas utiliza como fonte o Relatório de 1875 . Há coincidência em relação aos 7,4\% de professores interinos, mas ele calcula $30,5 \%$ de temporários e $62,1 \%$ de vitalícios para aquele ano de 1875 . Acerca do tema, comenta o referido autor: "Em 1874-5 os resultados do Relatório de inspeção confirmam que a profissão de professor representa uma atividade segura e estável para aqueles que decidem abraçá-la: quase 2/3 dos professores de instrução primária são nomeados vitalícios. Por outro lado, os professores temporários (que representam 30\% do corpo de professores primários) são, em sua maioria, jovens que se consagram ao ensino há um, dois ou três anos e têm todas as razões para esperar que a sua nomeação como vitalícios não lhes acarrete problemas. Finalmente, os professores de instrução primária que fazem do ensino uma atividade provisória representam apenas $7,4 \%$ do corpo do ensino primário. Sem querer negar a importância relativa dessa porcentagem, é incontestável que, em 1874-5, a grande maioria dos professores portugueses faziam de sua profissão, não apenas a ocupação principal de um período de sua vida, mas sobretudo a atividade para a qual eles consagram o melhor de seu percurso profissional." (António NÓVOA, Le temps des professeurs, volume I, p. 383). 


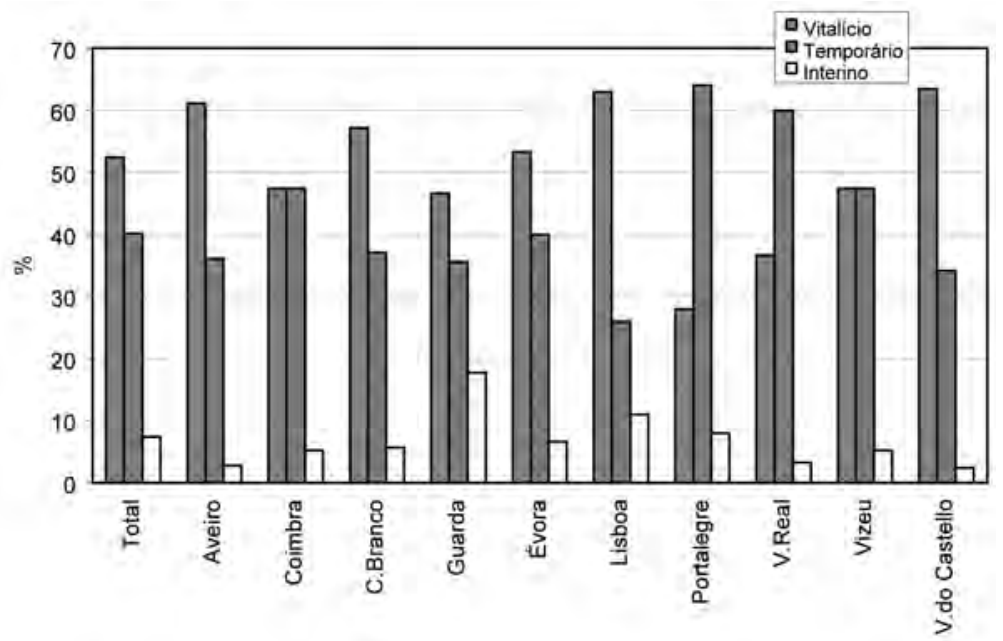

Figura 14: Distribuição dos professores conforme provimento dos cargos por distritos e para o total da amostra. Portugal, 1867.

Tabela 15: Tempo médio de serviço dos professores no magistério público para o total da amostra. Portugal, 1867

\begin{tabular}{|c|c|c|c|c|c|c|c|c|c|c|}
\hline & \multicolumn{10}{|c|}{ Distrito } \\
\hline Total & Aveiro & Coimbra & $\begin{array}{l}\text { Castello } \\
\text { Branco }\end{array}$ & Guarda & Évora & Lisboa & Portalegre & $\begin{array}{l}\text { Villa } \\
\text { Real }\end{array}$ & Vizeu & $\begin{array}{l}\text { Vianna } \\
\text { do } \\
\text { Castello }\end{array}$ \\
\hline $\begin{array}{l}8 \text { anos } \\
11 \text { meses }\end{array}$ & $\begin{array}{l}10 \text { anos } \\
7 \text { meses }\end{array}$ & $\begin{array}{l}8 \text { anos } \\
1 \text { mes }\end{array}$ & $\begin{array}{l}10 \text { anos } \\
7 \text { meses }\end{array}$ & $\begin{array}{l}7 \text { anos } \\
11 \text { meses }\end{array}$ & $\begin{array}{l}2 \text { anos } \\
1 \text { mes }\end{array}$ & $\begin{array}{l}10 \text { anos } \\
9 \text { meses }\end{array}$ & $\begin{array}{l}5 \text { anos } 6 \\
\text { meses }\end{array}$ & $\begin{array}{l}7 \text { anos } \\
1 \text { mes }\end{array}$ & $\begin{array}{l}11 \text { anos } \\
5 \text { meses }\end{array}$ & $\begin{array}{l}10 \text { anos } \\
5 \text { meses }\end{array}$ \\
\hline
\end{tabular}

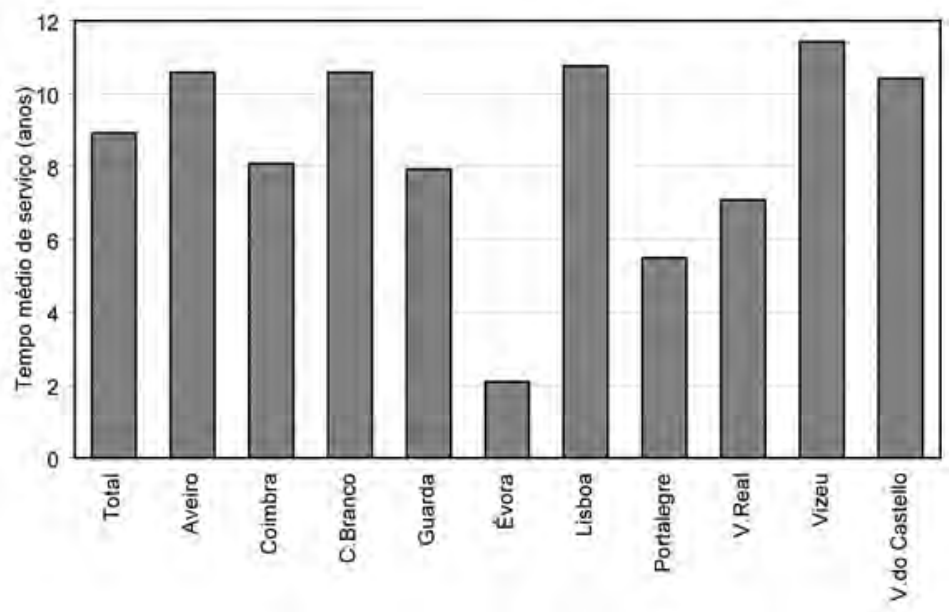

Figura 15: Tempo médio de serviço por distrito e para o total da amostra. Portugal, 1867. 
No concernente ao tempo de serviço do magistério público, em média, constata-se que os professores tinham 8 anos e 11 meses de serviço, havendo, como revela o quadro acima, diferenças distritais.

O Relatório de Inspeção aferia também a origem dos rendimentos do magistério, detectando que $69 \%$ dos mesmos eram, para toda a amostra, provenientes do ordenado do Estado. Em todos os distritos, guardadas as devidas especificidades regionais, mais de $60 \%$ dos rendimentos dos professores provinha da receita do pagamento do Estado, o que nos permite afirmar que já vinha ganhando terreno a perspectiva do magistério como uma "profissão a tempo inteiro", para usar uma expressão que é cara a António Nóvoa, embora houvesse ainda regência de outras cadeiras, lições particulares e fundamentalmente o exercício concomitante de outras atividades, estranhas ao magistério, na proporção exposta pelo quadro abaixo:

Tabela 16: Rendimentos dos professores (por mil réis) conforme origem por distritos e para o total da amostra. Portugal, 1867

\begin{tabular}{|c|c|c|c|c|c|c|c|c|c|c|c|}
\hline & & Distrite & & & & & & & & & \\
\hline $\begin{array}{l}\text { Origem } \\
\text { dos } \\
\text { rendi- } \\
\text { mentos }\end{array}$ & Total & Aveiro & Coimbra & $\begin{array}{l}\text { Castello } \\
\text { Branco }\end{array}$ & Guarda & Évora & Lisboa & Portalegre & $\begin{array}{l}\text { Villa } \\
\text { Real }\end{array}$ & Vizeu & $\begin{array}{l}\text { Vianna } \\
\text { do } \\
\text { Castello }\end{array}$ \\
\hline Estado & $\begin{array}{l}32267.6 \\
(68.7 \%)\end{array}$ & $\begin{array}{l}3081.3 \\
(68.6 \%)\end{array}$ & $\begin{array}{l}2951.8 \\
(74.2 \%)\end{array}$ & $\begin{array}{l}2968.2 \\
(69.9 \%)\end{array}$ & $\begin{array}{l}3212.5 \\
(68.7 \%)\end{array}$ & $\begin{array}{l}1221.2 \\
(70.0 \\
\%)\end{array}$ & $\begin{array}{l}6694.2 \\
(62.9 \%)\end{array}$ & $\begin{array}{l}2166.4 \\
(60.5 \%)\end{array}$ & $\begin{array}{l}2922.6 \\
(76.9 \%)\end{array}$ & $\begin{array}{l}3377.5 \\
(68.2 \\
\%)\end{array}$ & $\begin{array}{l}3671.9 \\
(75.5 \%)\end{array}$ \\
\hline $\begin{array}{l}\text { Regência } \\
\text { cadeiras }\end{array}$ & $\begin{array}{l}7441.9 \\
(15.8 \%)\end{array}$ & $\begin{array}{l}814.7 \\
(18.1 \%)\end{array}$ & $\begin{array}{l}640.0 \\
(10.1 \%)\end{array}$ & $\begin{array}{l}565.2 \\
(13.3 \%)\end{array}$ & $\begin{array}{l}828.3 \\
(17.7 \%)\end{array}$ & $\begin{array}{l}290.0 \\
(16.6 \\
\%)\end{array}$ & $\begin{array}{l}1423.6 \\
(13.4 \%)\end{array}$ & $\begin{array}{l}520.0 \\
(14.5 \%)\end{array}$ & $\begin{array}{l}735.7 \\
(19.4 \%)\end{array}$ & $\begin{array}{l}680.0 \\
(13.7 \\
\%)\end{array}$ & $\begin{array}{l}944.3 \\
(19.4 \%)\end{array}$ \\
\hline $\begin{array}{l}\text { Profissão } \\
\text { estranha } \\
\text { ao ma- } \\
\text { gistério }\end{array}$ & $\begin{array}{l}5470.0 \\
(11.6 \%)\end{array}$ & $\begin{array}{l}592.0 \\
(13.2 \%)\end{array}$ & $\begin{array}{l}300.0 \\
(7.5 \%)\end{array}$ & $\begin{array}{l}658.0 \\
(15.5 \%)\end{array}$ & $\begin{array}{l}603.0 \\
(12.9 \%)\end{array}$ & $\begin{array}{l}77.0 \\
(4.4 \\
\%)\end{array}$ & $\begin{array}{l}1427.0 \\
(13.4 \%)\end{array}$ & $\begin{array}{l}632.0 \\
(17.7 \%)\end{array}$ & $\begin{array}{l}140 \\
(3.7 \%)\end{array}$ & $\begin{array}{l}848.0 \\
(17.1 \\
\%)\end{array}$ & $\begin{array}{l}193.0 \\
(4.0 \%)\end{array}$ \\
\hline $\begin{array}{l}\text { Licôes } \\
\text { particu- } \\
\text { lares }\end{array}$ & $\begin{array}{l}1239.0 \\
(2.6 \%)\end{array}$ & $\begin{array}{l}6.0 \\
(0.1 \%)\end{array}$ & $\begin{array}{l}83.0 \\
(2.1 \%)\end{array}$ & $\begin{array}{l}0.0 \\
(0.0 \%)\end{array}$ & $\begin{array}{l}0.0 \\
(0.0 \%)\end{array}$ & $\begin{array}{l}32.0 \\
(1.8 \\
\%)\end{array}$ & $\begin{array}{l}819.0 \\
(7.7 \%)\end{array}$ & $\begin{array}{l}249.0 \\
(7.0 \%)\end{array}$ & $\begin{array}{l}0.0 \\
(0.0 \%)\end{array}$ & $\begin{array}{l}50.0 \\
(1.0 \\
\%)\end{array}$ & $\begin{array}{l}0.0 \\
(0.0 \%)\end{array}$ \\
\hline $\begin{array}{l}\text { Cursos } \\
\text { noctur- } \\
\text { nos }\end{array}$ & $\begin{array}{l}563.4 \\
(1.3 \%)\end{array}$ & $\begin{array}{l}0.0 \\
(0.0 \%)\end{array}$ & $\begin{array}{l}3.0 \\
(0.1 \%)\end{array}$ & $\begin{array}{l}56.0 \\
(1.3 \%)\end{array}$ & $\begin{array}{l}32.2 \\
(0.7 \%)\end{array}$ & $\begin{array}{l}124.3 \\
(7.1 \\
\%)\end{array}$ & $\begin{array}{l}281.8 \\
(2.6 \%)\end{array}$ & $\begin{array}{l}12.0 \\
(0.3 \%)\end{array}$ & $\begin{array}{l}0.0 \\
(0.0 \%)\end{array}$ & $\begin{array}{l}0.0 \\
(0.0 \\
\%)\end{array}$ & $\begin{array}{l}54.1 \\
(1.1 \%)\end{array}$ \\
\hline Total & $\begin{array}{l}46981.9 \\
(100 \%)\end{array}$ & $\begin{array}{l}4494.0 \\
(100 \%)\end{array}$ & $\begin{array}{c}3977.8 \\
(100 \%)\end{array}$ & $\begin{array}{l}4247.4 \\
(100 \%)\end{array}$ & $\begin{array}{l}4676.0 \\
(100 \%)\end{array}$ & $\begin{array}{l}1744.5 \\
(100 \\
\%)\end{array}$ & $\begin{array}{l}10645.6 \\
(100 \%)\end{array}$ & $\begin{array}{l}3579.4 \\
(100 \%)\end{array}$ & $\begin{array}{l}3798.3 \\
(100 \%)\end{array}$ & $\begin{array}{l}4955.5 \\
(100 \\
\%)\end{array}$ & $\begin{array}{l}4863.3 \\
(100 \%)\end{array}$ \\
\hline Média & 121.7 & 124.8 & 104.7 & 121.4 & 116.9 & 67.1 & 158.9 & 143.2 & 97.4 & 127.1 & 118.6 \\
\hline
\end{tabular}




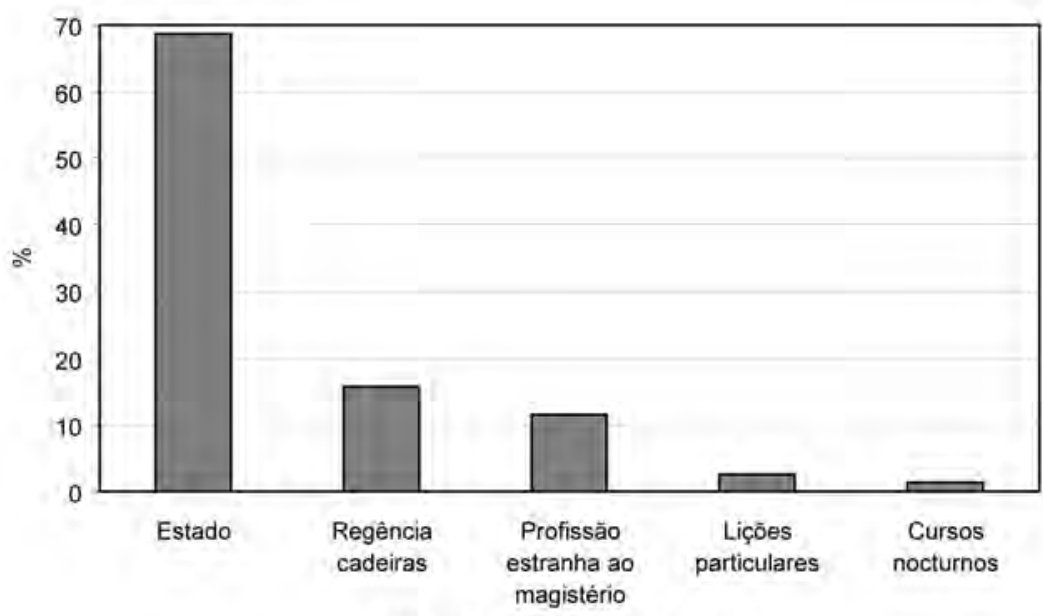

Origem dos rendimentos do professor

Figura 16: Distribuição dos rendimentos dos professores conforme sua origem para o total da amostra. Portugal, 1867.

Aproximadamente $69 \%$ dos rendimentos foram provenientes do ordenado do Estado para toda a amostra. Observando por distrito, também a categoria "ordenado do Estado" foi aquela que concentrou a maior parte dos rendimentos. Em segundo lugar aparece a categoria "regência de cadeiras" (15.8\%) e depois "profissão estranha ao magistério" (11.6\%). Para o total da amostra, as menores porcentagens corresponderam a "cursos noturnos"(1.3\%) e "liçôes particulares"(2.6\%).

Havia, no relato, solicitação de dados concernentes ao número de pessoas sustentadas por cada professor, o que levou à constatação de que Castello Branco era o distrito com maior número médio de pessoas da família sustentadas pelo professor (5 pessoas), sendo Évora aquele com menor número médio (1.5 pessoas). O número médio de pessoas sustentadas pelo professor, para a amostra toda, foi 3.7, como revela o quadro a seguir:

Tabela 17: Número médio de pessoas sustentadas por cada professor por distrito e para o total da amostra. Portugal, 1867

\begin{tabular}{|c|c|c|c|c|c|c|c|c|c|c|}
\hline & DisTRIT & & & & & & & & & \\
\hline Total & Aveiro & Coimbra & $\begin{array}{l}\text { Castello } \\
\text { Branco }\end{array}$ & Guarda & Évora & Lisboa & Portalegre & $\begin{array}{l}\text { Villa } \\
\text { Real }\end{array}$ & Vizeu & $\begin{array}{l}\text { Vianna } \\
\text { do } \\
\text { Castello }\end{array}$ \\
\hline 3.7 & 4.4 & 3.3 & 5.0 & 4.4 & 1.5 & 3.1 & 4.0 & 3.7 & 3.2 & 4.5 \\
\hline
\end{tabular}




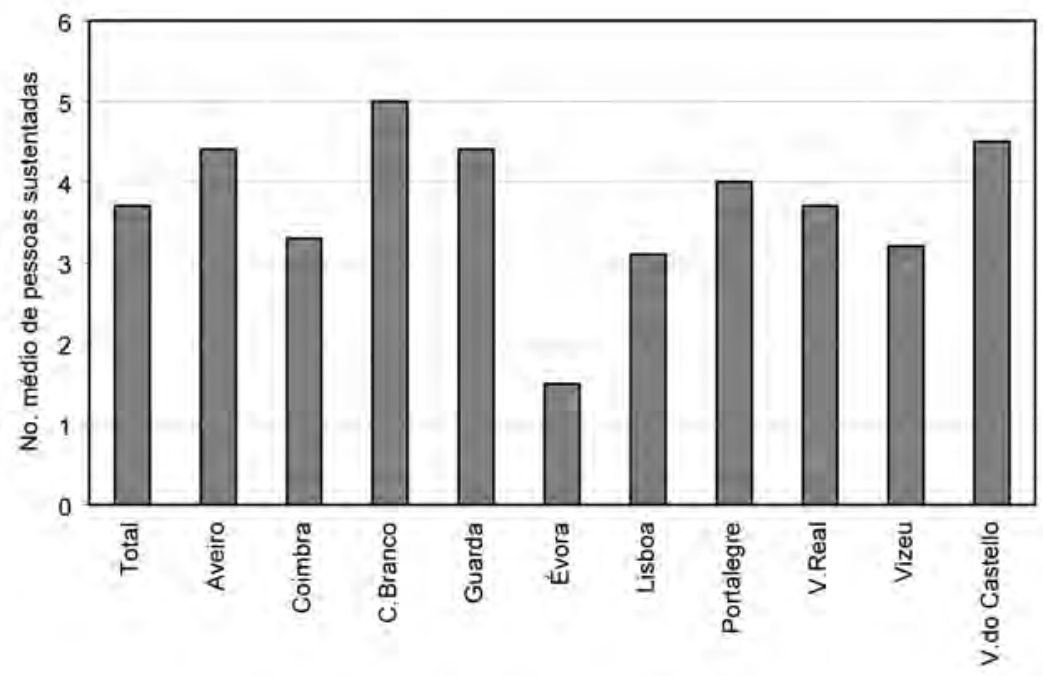

Figura 17: Número médio de pessoas sustentadas por cada professor por distrito e para o total da amostra. Portugal, 1867.

\section{A prática da sala de aula: o rotineiro, o repetitivo, o fugaz...}

O caminho da sala de aula deve necessariamente pontuar, de modo prioritário, qualquer estudo que pretenda abarcar a compreensão de práticas escolares concretas. A exigência de abandono de generalizações prévias, de desapego de quaisquer tipologias, teria como contrapartida o esforço de reconstituição da rotina escolar mediante os indícios e vestígios que foram nesse rastro deixados. O escrutínio desse dia-a-dia da sala de aula possibilitará a emergência daquilo que Azanha caracteriza como "pequenos episódios sem cor, marcados pela monotonia das repetiçōes" ${ }^{257}$. Aquilo, então, que parece, à primeira vista, insignificante pela obviedade da repetição converte-se em pista imprescindível para apreensão daquilo que, de fato, é fundamental: "o pano de fundo incolor da cotidianidade" ${ }^{258}$. Para compreender, no entanto, como esse 'fugidio território do mesmo' pode ser tomado como o prelúdio da interrupção, tomemos as palavras de Azanha:

"É comum imaginar-se que, na vida cotidiana, apenas os eventuais episódios fugazes escapam ao rotineiro e ao repetitivo. Como se o cotidiano fosse sempre uma paradoxal mescla de coisas que não se alteram e de novidades instantâneas que desaparecem. Sem examinar agora o fundo de verdade que pode haver nessa imagem, convém assinalar que essa dicotomização da duração de aspectos da vida cotidiana é também uma simplificação. Sem dúvida nenhuma, o cenário da vida cotidiana inclui coisas duradouras e coisas fugazes, mas

\footnotetext{
${ }^{257}$ José Mário Pires AZANHA, Uma idéia de pesquisa educacional, p. 62.

${ }^{258}$ José Mário Pires AZANHA, Uma idéia de pesquisa educacional, p. 63.
} 
isso não significa que nela a temporalidade assuma uma ou outra de apenas duas duraçôes possíveis: a breve e a longa. Aliás, essas expressōes são ambíguas, e é nessa ambiguidade que reside todo o seu valor heurístico. Não importa, e talvez, nem seja possível, uma criteriosa elucidação abstrata do que seja tempo breve ou a longa duração, mesmo porque serão coisas sempre diferentes em relação a diferentes objetos sócio-culturais. No estudo de como o tempo afeta a vida cotidiana, o interessante é imaginar que entre o efêmero e a permanência há uma pluralidade de durações." 259

Muito provavelmente não haverá, no âmbito da história da educação, nenhum território tão reticente à mudança quanto aquele que configura as práticas escolares da sala de aula. Com sua disposição material protocolada em termos de disposição do espaço físico, seja pelos utensílios, seja fundamentalmente pelos usos, pelas partilhas e distribuições, o que se vê ali é um tipo de organização do espaço e do tempo com uma especificidade própria. O cotidiano escolar - com seus banquinhos, tinteiros, mesinhas, livros e lousas - é revelador de uma forma de escola impregnada pela longa duração. Pensar o repertório das práticas escolares em seu dia-a-dia leva-nos a tangenciar o imaginário pedagógico de uma rotina que sempre nos parece familiar, porque, até certo ponto, foi experimentada na infância.

Os métodos de ensino arrolados pelo Relatório dos inspetores eram os seguintes, assim distribuídos pela frequência com que apareciam em todo o país: mútuo $=1,6 \%$; simultâneo $=17,3 \%$; individual $=20,0 \%$; misto, em que predomina o elemento mútuo $=7,7 \% ;$ misto, em que predomina o elemento simultâneo $=27,8 \%$; misto, em que predomina o elemento individual $=25,6 \%$.

De acordo com os dados obtidos, haveria a predominância do considerado ensino misto, embora outros registros nos permitam averiguar a proeminência com que, muitas vezes, se destacava o rastro do modo de ensino individual. Aliás, há alguns distritos, como a Guarda, em que 40,7 \% dos professores declaram adotar o modo individual, como sendo aquele que maior resultado teria oferecido, em termos de êxito do processo de alfabetização. Na verdade, particularmente para esse tópico, a análise fica confinada à declaração do professor ao inspetor, bem como a tópicas observações daquele dia específico da visita. Podemos suspeitar que tanto professores quanto inspetores preferiam definir como modo misto de aprendizado as estratégias de ensino que costumavam adotar. Seja como for, em linhas gerais, nos Relatórios predominava o método misto com destaque para o elemento simultâneo como o mais adotado pelo magistério, representando, de acordo com o levantamento efetuado, 48\% das escolas de Portalegre e 48,9\% das de Viseu. O modo de ensino misto, em que predomina o elemento individual, correspondia no total como vimos- a $25,6 \%$, havendo entretanto elevada proporção dessa modalidade pedagógica nos distritos de Évora $(45,7 \%)$ e Aveiro (48,5\%). O ensino mútuo, apesar de ter sido talvez o mais propagado em termos de debate pedagógico, foi, indiscutivelmente, o menos utilizado na época, com apenas 1,6\% da estatística a seu favor. Observe-se a tabela a seguir, de maneira a identificar as proporções e variações regionais:

\footnotetext{
${ }^{259}$ José Mário Pires AZANHA, Uma idéia de pesquisa educacional, p. 117.
} 
Tabela 18: Distribuição das escolas conforme o método de ensino adotado por distritos e para o total da amostra. Portugal, 1867

\begin{tabular}{|c|c|c|c|c|c|c|c|c|c|c|c|}
\hline & & \multicolumn{10}{|c|}{ Distrito } \\
\hline $\begin{array}{l}\text { Método de } \\
\text { ensino }\end{array}$ & Total & Aveiro & Coimbra & $\begin{array}{l}\text { Castello } \\
\text { Branco }\end{array}$ & Guarda & Évora & Lisboa & Portalegre & $\begin{array}{l}\text { Villa } \\
\text { Real }\end{array}$ & Vizeu & $\begin{array}{l}\text { Vianna } \\
\text { do } \\
\text { Castello }\end{array}$ \\
\hline $\begin{array}{l}\text { Misto } \\
\text { simultâneo }\end{array}$ & $\begin{array}{l}122 \\
(27.8 \%)\end{array}$ & $\begin{array}{l}11 \\
(33.3 \\
\%)\end{array}$ & $\begin{array}{l}14 \\
(36.8 \%)\end{array}$ & $\begin{array}{l}9 \\
(25.7 \%)\end{array}$ & $\begin{array}{l}1 \\
(1.7 \%)\end{array}$ & $\begin{array}{l}9 \\
(25.7 \\
\%)\end{array}$ & $\begin{array}{l}15 \\
(20.0 \%)\end{array}$ & $\begin{array}{l}12 \\
(48.0 \%)\end{array}$ & $\begin{array}{l}13 \\
(25.5 \%)\end{array}$ & $\begin{array}{l}23 \\
(48.9 \%)\end{array}$ & $\begin{array}{l}15 \\
(36.6 \%)\end{array}$ \\
\hline $\begin{array}{l}\text { Misto } \\
\text { individual }\end{array}$ & $\begin{array}{l}112 \\
(25.6 \%)\end{array}$ & $\begin{array}{l}16 \\
(48.5 \\
\%)\end{array}$ & $\begin{array}{l}4 \\
(10.6 \%)\end{array}$ & $\begin{array}{l}8 \\
(22.8 \%)\end{array}$ & $\begin{array}{l}14 \\
(23.7 \%)\end{array}$ & $\begin{array}{l}16 \\
(45.7 \\
\%)\end{array}$ & $\begin{array}{l}13 \\
(17.3 \%)\end{array}$ & $\begin{array}{l}7 \\
(28.0 \%)\end{array}$ & $\begin{array}{l}15 \\
(29.4 \%)\end{array}$ & $\begin{array}{l}7 \\
(14.9 \%)\end{array}$ & $\begin{array}{l}12 \\
(29.4 \%)\end{array}$ \\
\hline Individual & $\begin{array}{l}88 \\
(20.0 \%)\end{array}$ & $\begin{array}{l}2 \\
(6.1 \\
\%)\end{array}$ & $\begin{array}{l}5 \\
(13.2 \%)\end{array}$ & $\begin{array}{l}12 \\
(34.3 \%)\end{array}$ & $\begin{array}{l}24 \\
(40.7 \%)\end{array}$ & $\begin{array}{l}2 \\
(5.7 \\
\%)\end{array}$ & $\begin{array}{l}24 \\
(32.0 \%)\end{array}$ & $\begin{array}{l}3 \\
(12.0 \%)\end{array}$ & $\begin{array}{l}7 \\
(13.7 \%)\end{array}$ & $\begin{array}{l}4 \\
(8.6 \%)\end{array}$ & $\begin{array}{l}5 \\
(12.2 \%)\end{array}$ \\
\hline $\begin{array}{l}\text { Simultâ- } \\
\text { neo }\end{array}$ & $\begin{array}{l}76 \\
(17.3 \%)\end{array}$ & $\begin{array}{l}0 \\
(0.0 \\
\%)\end{array}$ & $\begin{array}{l}13 \\
(34.2 \%)\end{array}$ & $\begin{array}{l}5 \\
(14.3 \%)\end{array}$ & $\begin{array}{l}18 \\
(30.5 \%)\end{array}$ & $\begin{array}{l}4 \\
(11.5 \\
\%)\end{array}$ & $\begin{array}{l}16 \\
(21.3 \%)\end{array}$ & $\begin{array}{l}1 \\
(4.0 \%)\end{array}$ & $\begin{array}{l}7 \\
(13.7 \%)\end{array}$ & $\begin{array}{l}6 \\
(12.9 \%)\end{array}$ & $\begin{array}{l}6 \\
(14.6 \%)\end{array}$ \\
\hline $\begin{array}{l}\text { Misto } \\
\text { mútuo }\end{array}$ & $\begin{array}{l}34 \\
(7.7 \%)\end{array}$ & $\begin{array}{l}3 \\
(9.1 \\
\%)\end{array}$ & $\begin{array}{l}1 \\
(2.6 \%)\end{array}$ & $\begin{array}{l}0 \\
(0.0 \%)\end{array}$ & $\begin{array}{l}2 \\
(3.4 \%)\end{array}$ & $\begin{array}{l}4 \\
(11.4 \\
\%)\end{array}$ & $\begin{array}{l}7 \\
(9.4 \%)\end{array}$ & $\begin{array}{l}2 \\
(8.0 \%)\end{array}$ & $\begin{array}{l}8 \\
(15.7 \%)\end{array}$ & $\begin{array}{l}5 \\
(10.6 \%)\end{array}$ & $\begin{array}{l}2 \\
(4.8 \%)\end{array}$ \\
\hline Mútuo & $\begin{array}{l}7 \\
(1.6 \%)\end{array}$ & $\begin{array}{l}1 \\
(3.0 \\
\%)\end{array}$ & $\begin{array}{l}1 \\
(2.6 \%)\end{array}$ & $\begin{array}{l}1 \\
(2.8 \%)\end{array}$ & $\begin{array}{l}0 \\
(0.0 \%)\end{array}$ & $\begin{array}{l}0 \\
(0.0 \\
\%)\end{array}$ & $\begin{array}{l}0 \\
(0.0 \%)\end{array}$ & $\begin{array}{l}0 \\
(0.0 \%)\end{array}$ & $\begin{array}{l}1 \\
(2.0 \%)\end{array}$ & $\begin{array}{l}2 \\
(4.2 \%)\end{array}$ & $\begin{array}{l}1 \\
(2.4 \%)\end{array}$ \\
\hline Total & $\begin{array}{l}439 \\
(100 \%)\end{array}$ & $\begin{array}{l}33 \\
(100 \\
\%)\end{array}$ & $\begin{array}{l}38 \\
(100 \%)\end{array}$ & $\begin{array}{l}35 \\
(100 \%)\end{array}$ & $\begin{array}{l}59 \\
(100 \%)\end{array}$ & $\begin{array}{l}35 \\
(100 \\
\%)\end{array}$ & $\begin{array}{l}75 \\
(100 \%)\end{array}$ & $\begin{array}{l}25 \\
(100 \%)\end{array}$ & $\begin{array}{l}51 \\
(100 \%)\end{array}$ & $\begin{array}{l}47 \\
(100 \%)\end{array}$ & $\begin{array}{l}41 \\
(100 \%)\end{array}$ \\
\hline
\end{tabular}

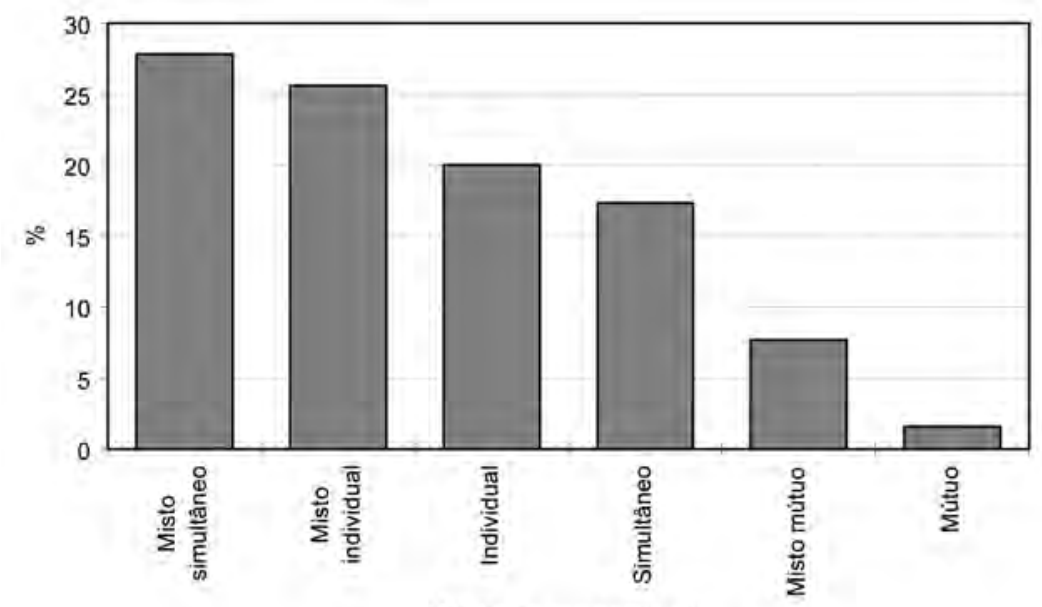

Método de ensino adotado

Figura 18: Distribuição das escolas conforme o método de ensino adotado. Total da amostra. Portugal, 1867 
Acerca das diferenças entre os três modos básicos de orientar o ensino em seu estado puro, tomemos a explicação que nos é dada por Simões Lopes, que era, como vimos, inspetor escolar nos anos 70, havendo sido também diretor de liceu, entusiasta e organizador das Conferências Pedagogicas. Em sua cartilha e seleta de manuscritos para uso escolar, Simões Lopes demonstrava - pela maneira como se dirigia aos professores primários no prefácio - preocupação quanto ao modo de ensino predominante na escola portuguesa. Quanto ao método, ele entendia que o elemento básico da palavra eram as sílabas e não as letras; daí orientar seus trabalhos didáticos para a recorrência metodológica da silabação fônica. Acreditava ter então inovado, pelo fato de suprimir de seu ensino a enfadonha e inócua soletração. Sobre o tipo de ensino recomendado para a primeira leitura, o autor defende, não sem alguma dificuldade, o modo simultâneo: aquele no qual o professor ensina todas as crianças como se elas fossem um único aluno. Ocorre que sobreviviam, com significativa intensidade, práticas de ensino individual, muitas vezes consideradas mais apropriadas para as crianças mais novas; ou ainda sobrevivências do ensino mútuo - herança jeusítica - que era a divisão das classes por pequenos grupos de alunos, coordenados, cada um, por um respectivo decurião. De acordo, pois, com Simões Lopes, passamos a falar dos modos de ensino elementar:

\begin{abstract}
"Ora, dos três modos - mútuo, individual e simultâneo - é preferível este último pelos prodigiosos resultados que dá, e é o que no país está geralmente adotado. (...) Além disto desaparecerão os inconvenientes do professor gastar um tempo precioso em tomar as lições individualmente aos pequenos, ou, o que ainda é pior, mandar-lhas tomar pelos decuriōes. Há, por exemplo, seis horas letivas por dia, e a escola tem seis classes, tocará a cada classe duas horas por dia; as classes em que se observa o modo simultâneo, essas aproveitam bastante, porque cada aluno aproveitará as duas horas que essa classe tem de exercícios. Mas suponhamos que a classe infantil tem doze alunos; calculando pelo baixo teremos duas horas divididas pelos doze alunos, o que dá dez minutos a cada um, isto é, o professor só pode dispôr por dia dez minutos para cada uma dessas crianças que entram na escola cheias de sorrisos inocentes., como quem entra num mundo novo. Neste tempo, que pode fazer-se? Que explicações se podem dar? Que demonstraçōes se podem fazer?’”260
\end{abstract}

Poder-se-ia mesmo dizer que o século XIX foi para Portugal uma contínua e progressiva conquista da uniformidade escolar, cujo primeiro sinal parecia ser a procura do caminho simultâneo para o ensino da leitura. Acerca do tema, os educadores se debatem, mas buscam compor um movimento eficaz, cuja chave estaria posta na orientação metodológica. O ensino que, feito no coletivo, partiria do conjunto, reordenando a suposta unidade, e transformando a todos em um. A propósito do método de ensino de primeiras letras, constata-se que o mais utilizado em Portugal foi o da soletração moderna, abarcando $62,2 \%$ das escolas, seguido pela soletração antiga, que apanhava $24,4 \%$. Apenas 4,9\% utilizavam a silabação fônica, 4,6\% o método legográfico e 3,9\% o método português.

${ }^{260}$ A. SIMÕES LOPES, Cartilha infantil: parte um ou quadros de leitura para as escolas populares (método de leitura sem soletração), p. 2. 
Tabela 19: Distribuição das escolas conforme o método de ensino da primeira leitura utilizado por distritos e para o total da amostra. Portugal, 1867

\begin{tabular}{|c|c|c|c|c|c|c|c|c|c|c|c|}
\hline & & DISTRI & TOS & & & & & & & & \\
\hline $\begin{array}{l}\text { Método de } \\
\text { ensino }\end{array}$ & Total & Aveiro & Coimbra & $\begin{array}{l}\text { Castello } \\
\text { Branco }\end{array}$ & Guarda & Évora & Lisboa & Portalegre & $\begin{array}{l}\text { Villa } \\
\text { Real }\end{array}$ & Vizeu & $\begin{array}{l}\text { Vianna } \\
\text { do } \\
\text { Castello }\end{array}$ \\
\hline $\begin{array}{l}\text { Soletração } \\
\text { moderna }\end{array}$ & $\begin{array}{l}255 \\
(62,2 \%)\end{array}$ & $\begin{array}{l}30 \\
(85.7 \\
\%)\end{array}$ & $\begin{array}{l}34 \\
(72.3 \%)\end{array}$ & $\begin{array}{l}30 \\
(83.3 \%)\end{array}$ & $\begin{array}{l}34 \\
(85.0 \%)\end{array}$ & $\begin{array}{l}15 \\
(62.6 \\
\%)\end{array}$ & $\begin{array}{l}18 \\
(26.2 \%)\end{array}$ & $\begin{array}{l}14 \\
(45.2 \%)\end{array}$ & $\begin{array}{l}29 \\
(60.4 \\
\%)\end{array}$ & $\begin{array}{l}35 \\
(87.5 \\
\%)\end{array}$ & $\begin{array}{l}16 \\
(40.0 \%)\end{array}$ \\
\hline $\begin{array}{l}\text { Soletração } \\
\text { antiga }\end{array}$ & $\begin{array}{l}100 \\
(24.4 \%)\end{array}$ & $\begin{array}{l}0 \\
(0.0 \\
\%)\end{array}$ & $\begin{array}{l}2 \\
(4.2 \%)\end{array}$ & $\begin{array}{l}4 \\
(11.1 \%)\end{array}$ & $\begin{array}{l}4 \\
(10.0 \%)\end{array}$ & $\begin{array}{l}5 \\
(20.8 \\
\%)\end{array}$ & $\begin{array}{l}44 \\
(63.8 \%)\end{array}$ & $\begin{array}{l}11 \\
(35.5 \%)\end{array}$ & $\begin{array}{l}10 \\
(20.8 \\
\%)\end{array}$ & $\begin{array}{l}4 \\
(10.0 \\
\%)\end{array}$ & $\begin{array}{l}16 \\
(40.0 \%)\end{array}$ \\
\hline $\begin{array}{l}\text { Silabação } \\
\text { fônica }\end{array}$ & $\begin{array}{l}20 \\
(4.9 \%)\end{array}$ & $\begin{array}{l}2 \\
(5.7 \\
\%)\end{array}$ & $\begin{array}{l}1 \\
(2.2 \%)\end{array}$ & $\begin{array}{l}2 \\
(5.6 \%)\end{array}$ & $\begin{array}{l}1 \\
(2.5 \%)\end{array}$ & $\begin{array}{l}2 \\
(8.3 \\
\%)\end{array}$ & $\begin{array}{l}5 \\
(7.2 \%)\end{array}$ & $\begin{array}{l}0 \\
(0.0 \%)\end{array}$ & $\begin{array}{l}1 \\
(2.1 \\
\%)\end{array}$ & $\begin{array}{l}1 \\
(2.5 \\
\%)\end{array}$ & $\begin{array}{l}5 \\
(12.5 \%)\end{array}$ \\
\hline Legográfico & $\begin{array}{l}19 \\
(4.6 \%)\end{array}$ & $\begin{array}{l}0 \\
(0.0 \\
\%)\end{array}$ & $\begin{array}{l}10 \\
(21.3 \%)\end{array}$ & $\begin{array}{l}0 \\
(0.0 \%)\end{array}$ & $\begin{array}{l}0 \\
(0.0 \%)\end{array}$ & $\begin{array}{l}0 \\
(0.0 \\
\%)\end{array}$ & $\begin{array}{l}1 \\
(1.4 \%)\end{array}$ & $\begin{array}{l}6 \\
(19.3 \%)\end{array}$ & $\begin{array}{l}1 \\
(2.1 \\
\%)\end{array}$ & $\begin{array}{l}0 \\
(0.0 \\
\%)\end{array}$ & $\begin{array}{l}1 \\
(2.5 \%)\end{array}$ \\
\hline Português & $\begin{array}{l}16 \\
(3.9 \%)\end{array}$ & $\begin{array}{l}3 \\
(8.6 \\
\%)\end{array}$ & $\begin{array}{l}0 \\
(0.0 \%)\end{array}$ & $\begin{array}{l}0 \\
(0.0 \%)\end{array}$ & $\begin{array}{l}1 \\
(2.5 \%)\end{array}$ & $\begin{array}{l}2 \\
(8.3 \% \\
)\end{array}$ & $\begin{array}{l}1 \\
(1.4 \%)\end{array}$ & $\begin{array}{l}0 \\
(0.0 \%)\end{array}$ & $\begin{array}{l}7 \\
(14.6 \\
\%)\end{array}$ & $\begin{array}{l}0 \\
(0.0 \\
\%)\end{array}$ & $\begin{array}{l}2 \\
(5.0 \%)\end{array}$ \\
\hline Total & $\begin{array}{l}410 \\
(100 \%)\end{array}$ & $\begin{array}{l}35 \\
(100 \\
\%)\end{array}$ & $\begin{array}{l}47 \\
(100 \%)\end{array}$ & $\begin{array}{l}36 \\
(100 \%)\end{array}$ & $\begin{array}{l}40 \\
(100 \%)\end{array}$ & $\begin{array}{l}24 \\
(100 \\
\%)\end{array}$ & $\begin{array}{l}69 \\
(100 \%)\end{array}$ & $\begin{array}{l}31 \\
(100 \%)\end{array}$ & $\begin{array}{l}48 \\
(100 \\
\%)\end{array}$ & $\begin{array}{l}40 \\
(100 \\
\%)\end{array}$ & $\begin{array}{l}40 \\
(100 \%)\end{array}$ \\
\hline
\end{tabular}

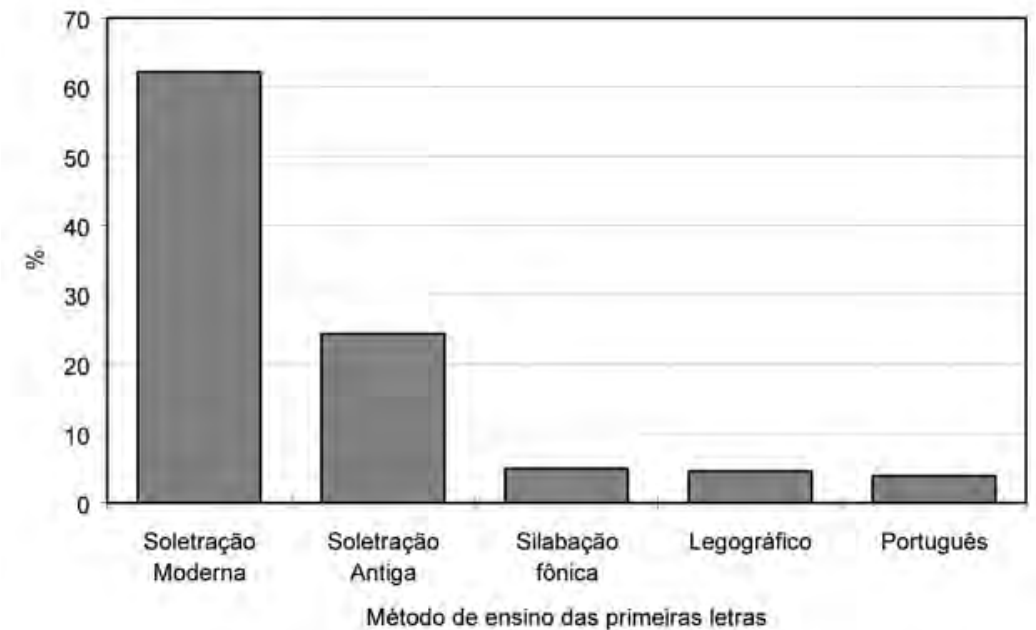

Figura 19: Distribuição das escolas conforme o método de ensino da primeira leitura utilizado para o total da amostra. Portugal, 1867. 
De acordo com a introdução do compêndio de Monteverde - Methodo facillimo para aprender a ler - que, como poderemos deduzir da estatística dos livros didáticos deste mesmo relatório de inspeção - era a obra infantil mais utilizada em Portugal, o método de soletração antiga consistiria em fazer da letra o ponto de partida da alfabetização; cada letra conservando, aqui, o seu nome clássico em língua portuguesa. Parte-se do alfabeto, nomeando sua sequência antes da sílaba que virá posteriormente como agregação das letras de que se compõe. No contraponto entre esse método e os que os inspetores qualificavam por silabação moderna, Monteverde explicita, ainda na introdução de seu manual:

"Conquanto este método seja aquele que ainda está quase geralmente seguido, não só em Portugal, mas em vários outros países, há muitos autores que o condenam como vicioso. Fundam a sua opinião em não existir nenhuma relação entre o modo de pronunciar as letras de que a sílaba se compõe e os sons que essas letras representam na realidade, como se vê das sílabas: fa, la, ma, ra, etc., as quais, soletradas segundo aquele método, dão: éfe á, éfá , éle á éla, éme á émá , érre é érrá. Pelo novo método de soletração, as consoantes ou articulações pronunciam-se como se fossem seguidas de e mudo: b be, c ce, ou ke, d de, ffe, g je ou gue, h he, j, je, k, ke, 1 le, $m$ me, $n$ ne, p pe, q ke, $r$ re, ou rre, s se ou ze, $t$ te, v, ve, $x$ che, ze, es ce z ze, etc. Assim, a palavra fato, há de soletrar-se: fe a fa, te o to. Pretendem alguns autores que este método é preferível ao primeiro; muitos outros há porém que lhe são contrários, sustentando que o melhor é o método sem soletração." 261

A estratégia de ensino dos princípios elementares da leitura e da escrita que consta do Relatório da inspeção de 1867 como silabação fônica seria aquela que se pretendia constituir como alternativa ao tradicional estilo de se ensinar a ler e escrever em Portugal, preso - quase de modo exclusivo - a procedimentos de soletração. Carreada, ainda, do elemento sintético, não podendo ser caracterizada como método global, a silabação traria, no entanto, para o cenário pedagógico alguns elementos analíticos. Estes se davam pela apresentação da sílaba - e não mais da letra - como ponto de partida do percurso do ensino. Pela sílaba, o som seria reconhecido como elemento primeiro, vivo e límpido na palavra da qual se desmembrou, composto com outros sinais sonoros que, se reconhecidos na formação das palavras, possibilitariam a rápida leitura pela lógica natural do sentido e do encadeamento sonoro.

De qualquer maneira, ensinar a ler persistia sendo partir do reconhecimento da analogia entre sons e sinais gráficos associados. Nos termos do que dizia à época o pedagogo Augusto Coelho, não se pensava na correlação entre o termo escrito e seu significado, remetendo-o antes ao registro do som. Com o progresso da ciência da educação, veríamos que o ato da leitura era apreendido como se apenas de neurologia se tratasse. Acreditando que a criança aprende por imitação tanto no caso da fala quanto no ato da escrita, Augusto Coelho procurava caracterizar os elementos científicos que poderiam ser desmembrados dessa transposição da linguagem falada para a escrita. A conferência proferida em 27-12-1897 por Augusto Coelho, sob o título

${ }^{261}$ E. A. MONTEVERDE, Methodo facillimo para aprender a ler..., p. 6. 
O ensino inicial da leitura, de certa maneira, configurava-se como síntese do pensamento corrente entre os educadores acerca do tema ali proposto. Acreditava Augusto Coelho que o ponto de partida do processo de aprendizagem era a impressão auditiva produzida no ouvido, e que despertaria no cérebro modificações em um específico conjunto de células. Por outro lado, haveria um conjunto de sinais gráficos, os quais despertariam no aparelho ocular uma dada impressão visual, que atuaria, de maneira análoga, sobre outras células cerebrais.

As cartilhas também procuravam, muitas delas, firmar seus específicos pareceres sobre o entendimento da transposição escrita da fala. Foi nesse sentido que, como já expusemos anteriormente, permitimo-nos recorrer à caracterização metodológica formulada por prefácios de autores, como Monteverde. De acordo com todos os dados disponíveis, o Methodo facillimo era obra encontrada em profusão nas escolas portuguesas. Os dados que analisaremos adiante revelarão que, enquanto autor de obras didáticas, Monteverde era o mais bem sucedido dentre os pedagogos portugueses. Seu Manual enciclopédico foi a seu tempo o grande livro da juventude que, por sua vez, havia majoritariamente aprendido a ler nas páginas do Methodo facillimo. Supusemos então que a obra de Monteverde era representativa por haver sido indubitavelmente manuseada pelo professor. Além disso, trazia explicações concernentes ao método, indicando, nessa medida, a orientação do autor tanto para o gesto da leitura quanto para os procedimentos metodológicos adotados em sala de aula. Podemos realmente acreditar que a introdução da cartilha de Monteverde - sob o título "diversos métodos ou modos do ensino elementar" - seria um referencial mobilizado pelos professores de primeiras letras. A despeito de serem inevitavelmente recriadas por cada leitor, essas astúcias do texto didático fariam parte das representaçôes simbólicas para o ensino da leitura em Portugal do século XIX.

O Método Português de António Feliciano de Castilho e o Método Legográfico de Júlio Caldas Aulete serão abordados em capítulo específico sobre os compêndios didáticos para o ensino da leitura. Ressalte-se aqui, porém, as exceções que vêm a confirmar a regra: $21,3 \%$ das escolas do distrito de Coimbra e 19,3\% das escolas de Portalegre utilizavam o método legográfico; 14,6\% das escolas de Villa Real valiam-se do método Português-Castilho. Na verdade, a grande questão e o maior desafio da escolarização portuguesa à época era exatamente posta no tema da eficácia de uma escola alfabetizadora. A escola portuguesa era mal sucedida naquilo a que se propunha fazer. Em sua grande maioria, lá entravam e de lá saiam alunos que não tinham efetivamente obtido o domínio das habilidades da leitura, da escrita e do cálculo. Entrava-se e saía-se da escola sem saber ler, escrever nem contar. Por essa razão, a questão de método do ensino torna-se a indagação primeira. Para que efetivamente se pudesse advogar a escola como veículo da civilização, havia de se superar os óbices de uma instrução tão arcaica quanto inoperante. Chega, por vezes, a parecer que o grande objetivo dos educadores desse período referia-se exclusivamente ao domínio e à prática do modo de ensino simultâneo, onde todos os alunos pudessem, a um só tempo, aprender pela lição do professor. Entendia-se, com isso, que, do modo simultâneo, seriam pois derivados os demais procedimentos e dispositivos de engendramento da uniformidade, da homogeneização, da padronização, enfim, daquele projetado desenho escolar. Ao que indica toda nossa 
documentação, essa era uma das finalidades da reinvenção metodológica proposta pelos pedagogos portugueses no decorrer do século XIX. Porém, como destaca Rogério Fernandes em seu trabalho sobre $O s$ caminhos do $A B C$, durante muito tempo, a ausência de textos impressos acessíveis ao professor conformou um determinado tipo de prática pedagógica que prescinde quase por completo dos manuais escolares, os quais, na grande maioria das vezes, quando existiam, eram de posse exclusiva do professor. Este, por sua vez, optava em geral por ensinar a partir da leitura de manuscritos. Já nesse último quartel do século XIX, podemos dizer que o texto didático tornara-se muito mais acessível - o que é nítido até pela tiragem editorial por eles apresentadas ${ }^{262}$. Cabe indagar até que ponto o professor de fato se vale desse recurso e como o fará.

\section{Frequência, recompensas e castigos: dispositivos do poder escolar}

Do Relatório da inspeção de 1867 constavam, ainda, tópicos relativos ao "método de ensinar gramática" e ao "método de ensinar o sistema métrico". Ambos estavam classificados pelas seguintes opções: teórico e prático. Para o ensino da gramática, o método mais utilizada era o teórico, com $65,7 \%$ para toda a amostra, sendo que, enquanto os distritos de Coimbra e Vianna do Castello declaravam recorrer na mesma proporção a ambas as abordagens metodológicas, os distritos mais ao Sul, fundamentalmente Castello Branco e Portalegre reconheciam que utilizavam em cerca de $80 \%$ o trabalho de ordem teórica. Em relação a um quesito assim subjetivo, julgamos que teria havido significativo prejuízo da objetividade, posto que as variaçôes regionais - a nosso ver - são aqui excessivamente marcadas. O Relatório não traz quaisquer informações acerca do que compreende por cada uma das referidas modalidades de ensino de gramática, o que também ocorrerá a propósito do ensino do sistema métrico de medidas. Também nesse caso, há evidente predomínio do referido modelo de ensino teórico, que, para o conjunto da amostra, chega a 77,4\%. Com maior ou menor variação, todos os distritos revelavam acentuada predominância nessa suposta estratégia teórica de se ensinar a medir. Em escolas do distrito de Évora, havia a seguinte anotação nos Relatórios em que o professor declarava ensinar o sistema métrico pelo método prático: “- com que utensílios?”263. Tal questionamento pode ser tomado quer como desconfiança da autoridade em face das informaçôes recebidas, quer como evidências das precaríssimas condições das escolas portuguesas no que concerne aos objetos da sala de aula e aos utensílios educativos. O mesmo inspetor de Évora faz algumas consideraçôes sobre o tópico a seguir, que solicitava informações acerca do "emprego do método heurístico para o desenvolvimento das faculdades intelectuais”. Nesse quesito, um professor do Alandroal responde que sim, ao que replica o inspetor em comentário exposto no próprio impresso do referido

\footnotetext{
${ }^{262}$ De acordo com dados do Diccionário bibliographico portuguez - pelo estudo de Innocencio F. da SILVA - entre 1836 e 1866 foram editados 414.350 exemplares do Methodo facillimo para aprender a ler tanto a letra redonda quanto a manuscripta, cartilha a que já nos referimos, de autoria de Emílio Achilles MONTEVERDE. Isso por si já revela que o livro didático havia se tornado uma realidade nesse percurso do XIX.

${ }^{263}$ MR 1050, Distrito: Évora; Concelhos: Mora e Montemor-o-Novo.
} 
Relatório: “-Achei o contrário. É parvo!”264 Ainda que possamos duvidar da coincidência entre tais respostas e aquilo que efetivamente tinha assento na realidade cotidiana da instituição, reconhece-se, no cômputo geral, 45\% dos professores declarando usar o referido "método heurístico", sendo que a maior proporção de sua dita utilização pode ser verificada justamente em Évora, distrito onde 68\% dos entrevistados respondeu afirmativamente, seguida por Aveiro - 58,3\% -, Portalegre - 56\%-, Villa Real - 50\% - e Lisboa - 49,2\%.

Tabela 20: Distribuição das escolas conforme o método de ensino de gramática utilizado por distritos e para o total da amostra. Portugal, 1867

\begin{tabular}{|l|l|l|l|l|l|l|l|l|l|l|l|}
\hline & \multicolumn{9}{|l|}{ Distrito } \\
\hline $\begin{array}{l}\text { Método } \\
\text { ensino } \\
\text { da } \\
\text { gramática }\end{array}$ & Total & Aveiro & Coimbra & $\begin{array}{l}\text { Castello } \\
\text { Branco }\end{array}$ & Guarda & Évora & Lisboa & Portalegre & $\begin{array}{l}\text { Villa } \\
\text { Real }\end{array}$ & \multicolumn{2}{l|}{$\begin{array}{l}\text { Vizeu } \\
\text { Vianna } \\
\text { do } \\
\text { Castello }\end{array}$} \\
\hline Teórico & $\begin{array}{l}217 \\
(65.7 \%)\end{array}$ & $\begin{array}{l}21 \\
(75.0 \%)\end{array}$ & $\begin{array}{l}16 \\
(45.7 \%)\end{array}$ & $\begin{array}{l}14 \\
(82.3 \%)\end{array}$ & $\begin{array}{l}14 \\
(60.9 \%)\end{array}$ & $\begin{array}{l}13 \\
(68.4 \\
\%)\end{array}$ & $\begin{array}{l}52 \\
(67.5 \%)\end{array}$ & $\begin{array}{l}24 \\
(82.8 \%)\end{array}$ & $\begin{array}{l}23 \\
(63.9 \\
\%)\end{array}$ & $\begin{array}{l}25 \\
(67.6 \%)\end{array}$ & $\begin{array}{l}15 \\
(51.7 \%)\end{array}$ \\
\hline Prático & $\begin{array}{l}113 \\
(34.3 \%)\end{array}$ & $\begin{array}{l}7 \\
(25.0 \%)\end{array}$ & $\begin{array}{l}19 \\
(54.3 \%)\end{array}$ & $\begin{array}{l}3 \\
(27.7 \%)\end{array}$ & $\begin{array}{l}9 \\
(39.1 \%)\end{array}$ & $\begin{array}{l}6 \\
(31.6 \\
\%)\end{array}$ & $\begin{array}{l}25 \\
(22.5 \%)\end{array}$ & $\begin{array}{l}5 \\
(17.2 \%)\end{array}$ & $\begin{array}{l}13 \\
(36.1 \\
\%)\end{array}$ & $\begin{array}{l}12 \\
(32.4 \%)\end{array}$ & $\begin{array}{l}14 \\
(48.3 \%)\end{array}$ \\
\hline Total & $\begin{array}{l}330 \\
(100 \%)\end{array}$ & $\begin{array}{l}28 \\
(100 \%)\end{array}$ & $\begin{array}{l}35 \\
(100 \%)\end{array}$ & $\begin{array}{l}17 \\
(100 \%)\end{array}$ & $\begin{array}{l}23 \\
(100 \%)\end{array}$ & $\begin{array}{l}19 \\
(100 \\
\%)\end{array}$ & $\begin{array}{l}77 \\
(100 \%)\end{array}$ & $\begin{array}{l}29 \\
(100 \%)\end{array}$ & $\begin{array}{l}36 \\
(100 \\
\%)\end{array}$ & $\begin{array}{l}37 \\
(100 \%)\end{array}$ & $\begin{array}{l}29 \\
(100 \%)\end{array}$ \\
\hline
\end{tabular}

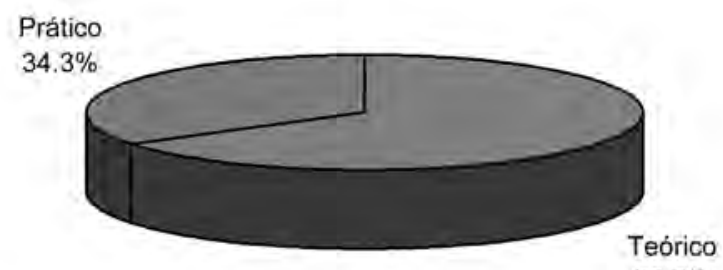

$65.7 \%$

Figura 20: Distribuição das escolas conforme o método de ensino da gramática utilizado para o total da amostra. Portugal, 1867.

${ }^{264}$ MR 1050, Distrito: Évora; Concelho: Alandroal. 
Tabela 21: Distribuição das escolas conforme o método de ensino do sistema métrico utilizado por distritos e para o total da amostra. Portugal, 1867

\begin{tabular}{|l|l|l|l|l|l|l|l|l|l|l|l|}
\hline & \multicolumn{9}{|l|}{ Distrito } \\
\hline $\begin{array}{l}\text { Método } \\
\text { de ensino } \\
\text { do Sistema } \\
\text { Métrico }\end{array}$ & Total & Aveiro & Coimbra & $\begin{array}{l}\text { Castello } \\
\text { Branco }\end{array}$ & Guarda & Évora & Lisboa & Portalegre & $\begin{array}{l}\text { Villa } \\
\text { Real }\end{array}$ & \multicolumn{2}{l|}{$\begin{array}{l}\text { Vizeu } \\
\text { Vianna } \\
\text { do } \\
\text { Castello }\end{array}$} \\
\hline Teórico & $\begin{array}{l}323 \\
(77.4 \%)\end{array}$ & $\begin{array}{l}29 \\
(69.0 \%)\end{array}$ & $\begin{array}{l}27 \\
(62.8 \%)\end{array}$ & $\begin{array}{l}28 \\
(87.5 \%)\end{array}$ & $\begin{array}{l}25 \\
(89.3 \%)\end{array}$ & $\begin{array}{l}22 \\
(84.6 \%)\end{array}$ & $\begin{array}{l}62 \\
(71.3 \\
\%)\end{array}$ & $\begin{array}{l}25 \\
(89.3 \%)\end{array}$ & $\begin{array}{l}34 \\
(97.1 \%)\end{array}$ & $\begin{array}{l}35 \\
(81.4 \\
\%)\end{array}$ & $\begin{array}{l}36 \\
(67.9 \%)\end{array}$ \\
\hline Prático & $\begin{array}{l}94 \\
(22.6 \%)\end{array}$ & $\begin{array}{l}13 \\
(31.0 \%)\end{array}$ & $\begin{array}{l}16 \\
(37.2 \%)\end{array}$ & $\begin{array}{l}4 \\
(12.5 \%)\end{array}$ & $\begin{array}{l}3 \\
(10.7 \%)\end{array}$ & $\begin{array}{l}4 \\
(15.4 \%)\end{array}$ & $\begin{array}{l}25 \\
(28.7 \\
\%)\end{array}$ & $\begin{array}{l}3 \\
(10.7 \%)\end{array}$ & $\begin{array}{l}1 \\
(2.9 \%)\end{array}$ & $\begin{array}{l}8 \\
(18.6 \\
\%)\end{array}$ & $\begin{array}{l}17 \\
(32.1 \%)\end{array}$ \\
\hline Total & $\begin{array}{l}417 \\
(100 \%)\end{array}$ & $\begin{array}{l}42 \\
(100 \%)\end{array}$ & $\begin{array}{l}43 \\
(100 \%)\end{array}$ & $\begin{array}{l}32 \\
(100 \%)\end{array}$ & $\begin{array}{l}28 \\
(100 \%)\end{array}$ & $\begin{array}{l}26 \\
(100 \%)\end{array}$ & $\begin{array}{l}87 \\
(100 \\
\%)\end{array}$ & $\begin{array}{l}28 \\
(100 \%)\end{array}$ & $\begin{array}{l}35 \\
(100 \%)\end{array}$ & $\begin{array}{l}43 \\
(100 \\
\%)\end{array}$ & $\begin{array}{l}53 \\
(100 \%)\end{array}$ \\
\hline
\end{tabular}

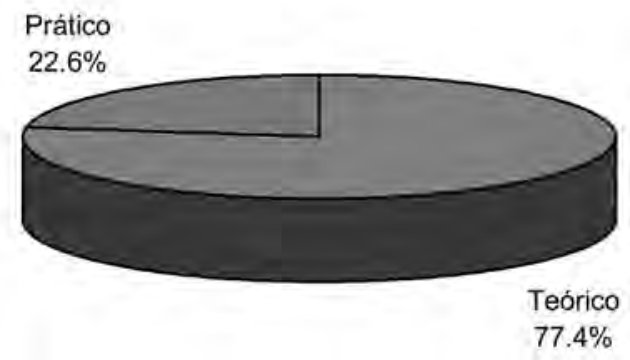

Figura 21: Distribuição das escolas conforme o método de ensino do Sistema Métrico utilizado para o total da amostra. Portugal, 1867.

Tabela 22: Distribuição das escolas conforme uso ou não do método heurístico para o desenvolvimento das faculdades intelectuais por distritos e para o total da amostra. Portugal, 1867

\begin{tabular}{|l|l|l|l|l|l|l|l|l|l|l|l|}
\hline & \multicolumn{9}{|l|}{ Distrito } \\
\hline $\begin{array}{l}\text { Método } \\
\text { heurístico }\end{array}$ & Total & Aveiro & Coimbra & $\begin{array}{l}\text { Castello } \\
\text { Branco }\end{array}$ & Guarda & Évora & Lisboa & Portalegre & $\begin{array}{l}\text { Villa } \\
\text { Real }\end{array}$ & \multicolumn{2}{l|}{$\begin{array}{l}\text { Vizeu } \\
\text { Vianna } \\
\text { do } \\
\text { Castello }\end{array}$} \\
\hline Sim & $\begin{array}{l}173 \\
(45.1 \%)\end{array}$ & $\begin{array}{l}21 \\
(58.3 \\
\%)\end{array}$ & $\begin{array}{l}12 \\
(31.6 \%)\end{array}$ & $\begin{array}{l}13 \\
(37.1 \%)\end{array}$ & $\begin{array}{l}16 \\
(40.0 \%)\end{array}$ & $\begin{array}{l}17 \\
(68.0 \\
\%)\end{array}$ & $\begin{array}{l}33 \\
(49.2 \%)\end{array}$ & $\begin{array}{l}14 \\
(56.0 \%)\end{array}$ & $\begin{array}{l}19 \\
(50.0 \%)\end{array}$ & $\begin{array}{l}18 \\
(46.1 \%)\end{array}$ & $\begin{array}{l}10 \\
(24.4 \%)\end{array}$ \\
\hline Não & $\begin{array}{l}211 \\
(54.9 \%)\end{array}$ & $\begin{array}{l}15 \\
(41.7 \\
\%)\end{array}$ & $\begin{array}{l}26 \\
(68.4 \%)\end{array}$ & $\begin{array}{l}22 \\
(62.9 \%)\end{array}$ & $\begin{array}{l}24 \\
(60.0 \%)\end{array}$ & $\begin{array}{l}18 \\
(32.0 \\
\%)\end{array}$ & $\begin{array}{l}34 \\
(50.8 \%)\end{array}$ & $\begin{array}{l}11 \\
(44.0 \%)\end{array}$ & $\begin{array}{l}19 \\
(50.0 \%)\end{array}$ & $\begin{array}{l}21 \\
(53.9 \%)\end{array}$ & $\begin{array}{l}31 \\
(75.6 \%)\end{array}$ \\
\hline Total & $\begin{array}{l}384 \\
(100 \%)\end{array}$ & $\begin{array}{l}36 \\
(100 \\
\%)\end{array}$ & $\begin{array}{l}38 \\
(100 \%)\end{array}$ & $\begin{array}{l}35 \\
(100 \%)\end{array}$ & $\begin{array}{l}40 \\
(100 \%)\end{array}$ & $\begin{array}{l}25 \\
(100 \\
\%)\end{array}$ & $\begin{array}{l}67 \\
(100 \%)\end{array}$ & $\begin{array}{l}25 \\
(100 \%)\end{array}$ & $\begin{array}{l}38 \\
(100 \%)\end{array}$ & $\begin{array}{l}39 \\
(100 \%)\end{array}$ & $\begin{array}{l}41 \\
(100 \%)\end{array}$ \\
\hline
\end{tabular}




\section{Método heurístico}

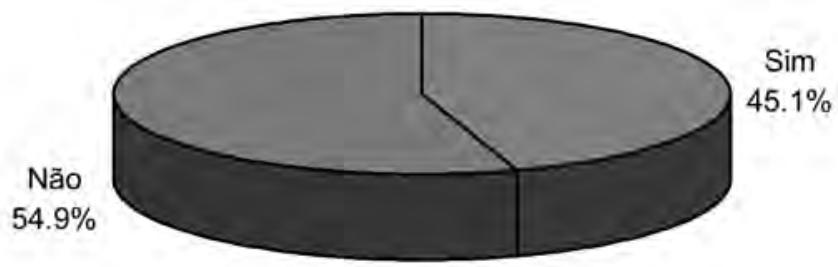

Figura 22: Distribuição das escolas em relação ao uso do método heurístico para o total da amostra. Portugal, 1867.

Quanto ao tipo de recompensas utilizadas pelo professor, nota-se que, destes, a maior parte - 74,5\% - declara utilizar "recompensas morais", sendo que 25,5\% afirmavam recorrer a "recompensas materiais", explicitando, por vezes, que os objetos entregues à guisa de prêmios para os estudantes mais destacados eram frequentemente livros.

Tabela 23: Distribuição das escolas conforme o tipo de recompensas utilizadas pelo professor por distritos e para o total da amostra. Portugal, 1867

\begin{tabular}{|c|c|c|c|c|c|c|c|c|c|c|c|}
\hline & & \multicolumn{10}{|c|}{ Distrito } \\
\hline $\begin{array}{l}\text { Recom- } \\
\text { pensas }\end{array}$ & Total & Aveiro & Coimbra & $\begin{array}{l}\text { Castello } \\
\text { Branco }\end{array}$ & Guarda & Évora & Lisboa & Portalegre & $\begin{array}{l}\text { Villa } \\
\text { Real }\end{array}$ & Vizeu & $\begin{array}{l}\text { Vianna } \\
\text { do } \\
\text { Castello }\end{array}$ \\
\hline Morais & $\begin{array}{l}216 \\
(74.5 \\
\%)\end{array}$ & $\begin{array}{l}1 \\
(33.3 \%)\end{array}$ & $\begin{array}{l}28 \\
(54.9 \%)\end{array}$ & $\begin{array}{l}27 \\
(67.5 \%)\end{array}$ & $\begin{array}{l}31 \\
(88.6 \%)\end{array}$ & $\begin{array}{l}11 \\
(78.6 \%)\end{array}$ & $\begin{array}{l}23 \\
(56.1 \%)\end{array}$ & $\begin{array}{l}16 \\
(88.9 \%)\end{array}$ & $\begin{array}{l}31 \\
(55.2 \%)\end{array}$ & $\begin{array}{l}25 \\
(86.2 \%)\end{array}$ & $\begin{array}{l}23 \\
(95.8 \%)\end{array}$ \\
\hline Materiais & $\begin{array}{l}74 \\
(25.5 \\
\%)\end{array}$ & $\begin{array}{l}2 \\
(66.7 \%)\end{array}$ & $\begin{array}{l}23 \\
(45.1 \%)\end{array}$ & $\begin{array}{l}13 \\
(32.5 \%)\end{array}$ & $\begin{array}{l}4 \\
(11.4 \%)\end{array}$ & $\begin{array}{l}3 \\
(21.4 \%)\end{array}$ & $\begin{array}{l}18 \\
(43.9 \%)\end{array}$ & $\begin{array}{l}2 \\
(11.1 \%)\end{array}$ & $\begin{array}{l}4 \\
(44.8 \%)\end{array}$ & $\begin{array}{l}4 \\
(13.8 \%)\end{array}$ & $\begin{array}{l}1 \\
(4.2 \%)\end{array}$ \\
\hline Total & $\begin{array}{l}290 \\
(100 \\
\%)\end{array}$ & $\begin{array}{l}3 \\
(100 \%)\end{array}$ & $\begin{array}{l}51 \\
(100 \%)\end{array}$ & $\begin{array}{l}40 \\
(100 \%)\end{array}$ & $\begin{array}{l}35 \\
(100 \%)\end{array}$ & $\begin{array}{l}14 \\
(100 \%)\end{array}$ & $\begin{array}{l}41 \\
(100 \%)\end{array}$ & $\begin{array}{l}18 \\
(100 \%)\end{array}$ & $\begin{array}{l}35 \\
(100 \%)\end{array}$ & $\begin{array}{l}29 \\
(100 \%)\end{array}$ & $\begin{array}{l}24 \\
(100 \%)\end{array}$ \\
\hline
\end{tabular}




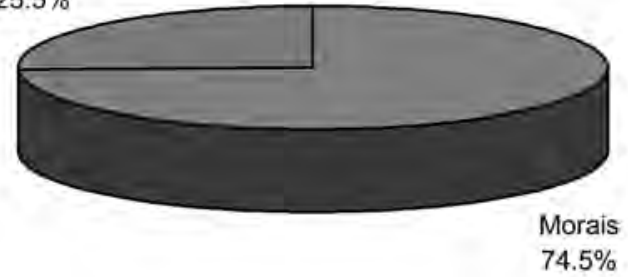

Figura 23: Distribuição das escolas conforme o tipo de recompensas utilizadas pelo professor para o total da amostra. Portugal, 1867.

No que diz respeito aos castigos aplicados pelo professor, estes, segundo o Relatório, dividiam-se também nas duas modalidades: morais e materiais. Os castigos materiais, por sua vez, podiam ser a palmatória ou outros, sendo que, no caso da palmatória, solicitava-se esclarecimento quanto ao modo de sua utilização: moderadamente ou imoderadamente. A palmatória teria, assim, seu uso assumido por $45,7 \%$ dos consultados de toda a amostra, dos quais $44,2 \%$ declaravam utilizá-la moderadamente e $1,5 \%$ afirmavam utilizá-la imoderadamente. Essa informação, por vezes proveniente de fontes da própria comunidade local, entrava, de qualquer modo, no cômputo do inspetor. Evidentemente, porém, nem todos declaravam o uso que faziam dos castigos físicos, deixando alguma dúvida quanto aos números explicitados na sequência:

Tabela 24: Distribuição das escolas em relação aos tipos de castigos aplicados pelo professor por distritos e para o total da amostra. Portugal, 1867

\begin{tabular}{|l|l|l|l|l|l|l|l|l|l|l|l|}
\hline & \multicolumn{9}{|l|}{ Distrito } \\
\hline Castigos & Total & Aveiro & Coimbra & $\begin{array}{l}\text { Castello } \\
\text { Branco }\end{array}$ & Guarda & Évora & Lisboa & Portalegre & $\begin{array}{l}\text { Villa } \\
\text { Real }\end{array}$ & \multicolumn{2}{l|}{$\begin{array}{l}\text { Vizeu } \\
\text { Vianna } \\
\text { do } \\
\text { Castello }\end{array}$} \\
\hline $\begin{array}{l}\text { Materiais } \\
\text { Modera- } \\
\text { damente }\end{array}$ & $\begin{array}{l}315 \\
(44.2 \%)\end{array}$ & $\begin{array}{l}33 \\
(50.8 \%)\end{array}$ & $\begin{array}{l}25 \\
(36.1 \%)\end{array}$ & $\begin{array}{l}35 \\
(43.2 \%)\end{array}$ & $\begin{array}{l}32 \\
(37.6 \%)\end{array}$ & $\begin{array}{l}11 \\
(34.4 \\
\%)\end{array}$ & $\begin{array}{l}43 \\
(48.9 \%)\end{array}$ & $\begin{array}{l}11 \\
(26.2 \%)\end{array}$ & $\begin{array}{l}38 \\
(55.1 \%)\end{array}$ & $\begin{array}{l}37 \\
(45.7 \\
\%)\end{array}$ & $\begin{array}{l}40 \\
(55.6 \%)\end{array}$ \\
\hline Morais & $\begin{array}{l}272 \\
(38.2 \%)\end{array}$ & $\begin{array}{l}30 \\
(46.1 \%)\end{array}$ & $\begin{array}{l}32 \\
(33.0 \%)\end{array}$ & $\begin{array}{l}26 \\
(32.1 \%)\end{array}$ & $\begin{array}{l}32 \\
(37.6 \%)\end{array}$ & $\begin{array}{l}13 \\
(40.6 \\
\%)\end{array}$ & $\begin{array}{l}34 \\
(38.6 \%)\end{array}$ & $\begin{array}{l}23 \\
(54.8 \%)\end{array}$ & $\begin{array}{l}31 \\
(44.0 \%)\end{array}$ & $\begin{array}{l}28 \\
(34.6 \\
\%)\end{array}$ & $\begin{array}{l}23 \\
(31.9 \%)\end{array}$ \\
\hline $\begin{array}{l}\text { Materiais } \\
\text { Imodera- } \\
\text { damente }\end{array}$ & $\begin{array}{l}11.5 \%) \\
(0.0 \%)\end{array}$ & $\begin{array}{l}2.0 \%) \\
(2.0 \%)\end{array}$ & $\begin{array}{l}0 \\
(0.0 \%) \\
(4.8 \%)\end{array}$ & $\begin{array}{l}2 \\
(6.2 \\
\%)\end{array}$ & $\begin{array}{l}2 \\
(2.3 \%)\end{array}$ & $\begin{array}{l}0 \\
(0.0 \%)\end{array}$ & $\begin{array}{l}0 \\
(0.0 \%)\end{array}$ & $\begin{array}{l}0 \\
(0.0 \\
\%)\end{array}$ & $\begin{array}{l}1 \\
(1.4 \%)\end{array}$ \\
\hline $\begin{array}{l}\text { Outros } \\
\text { Castigos }\end{array}$ & $\begin{array}{l}114 \\
(16.1 \%)\end{array}$ & $\begin{array}{l}2 \\
(3.1 \%)\end{array}$ & $\begin{array}{l}28 \\
(28.9 \%)\end{array}$ & $\begin{array}{l}20 \\
(24.7 \%)\end{array}$ & $\begin{array}{l}17 \\
(20.0 \%)\end{array}$ & $\begin{array}{l}6 \\
(18.8 \\
\%)\end{array}$ & $\begin{array}{l}9 \\
(10.2 \%)\end{array}$ & $\begin{array}{l}8 \\
(19.0 \%)\end{array}$ & $\begin{array}{l}0 \\
(0.0 \%)\end{array}$ & $\begin{array}{l}16 \\
(19.7 \\
\%)\end{array}$ & $\begin{array}{l}8 \\
(11.1 \%)\end{array}$ \\
\hline $\begin{array}{l}\text { Total } \\
(112 \\
(100 \%)\end{array}$ & $\begin{array}{l}65 \\
(100 \%)\end{array}$ & $\begin{array}{l}87 \\
(100 \%)\end{array}$ & $\begin{array}{l}81 \\
(100 \%)\end{array}$ & $\begin{array}{l}85 \\
(100 \%)\end{array}$ & $\begin{array}{l}32 \\
(100 \\
\%)\end{array}$ & $\begin{array}{l}88 \\
(100 \%)\end{array}$ & $\begin{array}{l}42 \\
(100 \%)\end{array}$ & $\begin{array}{l}69 \\
(100 \%)\end{array}$ & $\begin{array}{l}81 \\
(100 \\
\%)\end{array}$ & $\begin{array}{l}72 \\
(100 \%)\end{array}$ \\
\hline
\end{tabular}




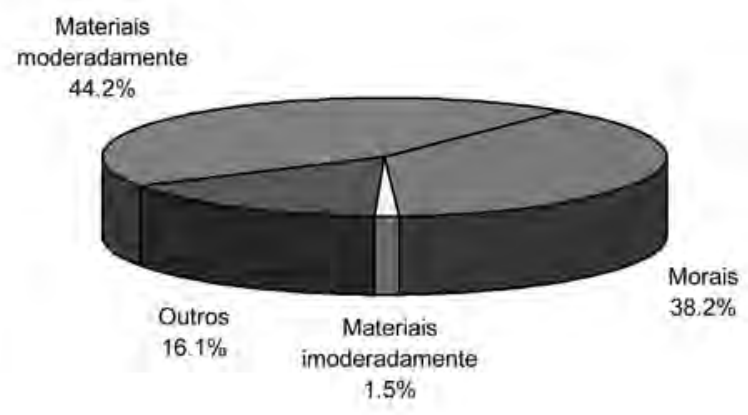

Figura 24: Distribuição das escolas em relação ao tipo de castigo utilizado pelo professor, para o total da amostra. Portugal, 1867.

Em nota de pé de página, o inspetor responsável pelo Concelho de Arganil em Coimbra destaca que soubera - por informações fornecidas pelos vizinhos - da utilização imoderada de castigos físicos por parte de um professor da região ${ }^{265}$. Por sua vez, teria havido também - segundo consta do Relatório concernente ao Concelho de Redondo no Distrito de Évora - um professor que assumia espontaneamente a utilização imoderada da palmatória. Tratava-se de João Moreira de Mattos, que lecionava na escola situada na Praça Nova no Edifício da Câmara na Freguesia de N. S. Anunciação. Curiosamente, embora tendo ficado aquém da média no que dizia respeito ao aproveitamento de seus alunos, o referido professor obteve média suficiente quanto ao zelo. Teve nota máxima quanto a seu comportamento moral e civil. Isso não refreou, porém, a indignação do inspetor que - diante da confissão desse uso imoderado do castigo físico - faria a lápis a seguinte anotação no impresso do Relatório: “- precisa-se tomar providências a respeito deste Herodes." 266

Por "outros castigos", entendia-se ficar de pé em um canto, ajoelhado, privado dos momentos de intervalo das lições, ou coisas que o valham. Eram aplicados em 16,1\% para toda a amostra, sem que houvesse, entretanto, maiores explicações quanto a essas outras modalidades de admoestação. Por fim, 38,2\% dos consultados utilizavam repreensôes tidas por 'morais' - nos termos do que consta do gráfico acima reproduzido.

Há significativa disparidade entre regiōes. Provavelmente havia também mais castigos físicos do que aqueles declarados explicitamente. Quanto aos registros de matrícula e de faltas, dividiam-se cada um mediante três alternativas: perfeitos, regulares, irregulares. Somente $7,7 \%$ dos registros de matrículas eram, do cômputo total, considerados perfeitos; a maior parte - $65,1 \%$ - era regular; e $27,2 \%$ consideravam-se irregulares. No caso das faltas, dá-se situação análoga: 5,5\% dos registros eram tidos por perfeitos; 43\% encontravam-se em condiçôes regulares; e 35,8\% eram considerados irregulares (um percentual ligeiramente maior do que o das matrículas irregulares). Há distinções distritais. No caso das matrículas, Portalegre (16,7\%), seguido por

\footnotetext{
${ }^{265}$ MR 1049. Distrito: Coimbra; Concelho: Arganil.

${ }^{266}$ MR 1050. Distrito: Évora; Concelho:Redondo.
} 
Aveiro (11,4\%), apresentaram o maior índice de registros tomados por perfeitos. Paradoxalmente, após Villa Real (54,1\%), Portalegre é também o distrito com maior proporção de registros de matrículas irregulares (45,8\%). As escolas de Villa Real surgem junto com as de Évora no registro de faltas: são aquelas que não apresentam nenhum registro perfeito. Note-se que, em Villa Real, 34,4\% das escolas sequer possuíam registros de faltas. Portalegre tem $16 \%$ de registros de faltas perfeitos - mais uma vez a mais elevada porcentagem. Encontravam-se, no entanto, em Portalegre outros $16 \%$ das escolas que não apresentavam nenhum tipo de registro, além de $44 \%$ de escolas com registros irregulares. Para o total, eram 14,9\% das escolas da amostra as que não possuíam quaisquer registros de faltas, sendo que a proporção caía consideravelmente no distrito de Lisboa (6,7\%), que tinha maior concentração percentual nos registros regulares $(56,6 \%)$ e irregulares $(30 \%)$, com apenas $6,7 \%$ de registros perfeitos, como se pode notar pelos quadros abaixo expostos:

Tabela 25: Distribuição das escolas de acordo com a qualidade dos registros de matrículas por distritos e para o total da amostra. Portugal, 1867

\begin{tabular}{|c|c|c|c|c|c|c|c|c|c|c|c|}
\hline \multirow[b]{2}{*}{$\begin{array}{l}\text { Registros } \\
\text { de matrí- } \\
\text { culas }\end{array}$} & \multirow[b]{2}{*}{ Total } & \multicolumn{10}{|c|}{ DisTRITO } \\
\hline & & Aveiro & Coimbra & $\begin{array}{l}\text { Castello } \\
\text { Branco }\end{array}$ & Guarda & Évora & Lisboa & Portalegre & $\begin{array}{l}\text { Villa } \\
\text { Real }\end{array}$ & Vizeu & $\begin{array}{l}\text { Vianna } \\
\text { do } \\
\text { Castello }\end{array}$ \\
\hline Regulares & $\begin{array}{l}237 \\
(65.1 \%)\end{array}$ & $\begin{array}{l}22 \\
(62.9 \%)\end{array}$ & $\begin{array}{l}29 \\
(78.4 \%)\end{array}$ & $\begin{array}{l}22 \\
(62.8 \%)\end{array}$ & $\begin{array}{l}23 \\
(60.5 \%)\end{array}$ & $\begin{array}{l}13 \\
(81.2 \\
\%)\end{array}$ & $\begin{array}{l}45 \\
(71.4 \%)\end{array}$ & $\begin{array}{l}9 \\
(37.5 \%)\end{array}$ & $\begin{array}{l}17 \\
(45.9 \%)\end{array}$ & $\begin{array}{l}27 \\
(71.1 \\
\%)\end{array}$ & $\begin{array}{l}30 \\
(73.2 \%)\end{array}$ \\
\hline Irregulares & $\begin{array}{l}99 \\
(27.2 \%)\end{array}$ & $\begin{array}{l}9 \\
(25.7 \%)\end{array}$ & $\begin{array}{l}5 \\
(13.5 \%)\end{array}$ & $\begin{array}{l}10 \\
(28.6 \%)\end{array}$ & $\begin{array}{l}12 \\
(31.6 \%)\end{array}$ & $\begin{array}{l}3 \\
(18.8 \\
\%)\end{array}$ & $\begin{array}{l}12 \\
(19.1 \%)\end{array}$ & $\begin{array}{l}11 \\
(45.8 \%)\end{array}$ & $\begin{array}{l}20 \\
(54.1 \%)\end{array}$ & $\begin{array}{l}7 \\
(18.4 \\
\%)\end{array}$ & $\begin{array}{l}10 \\
(24.4 \%)\end{array}$ \\
\hline Perfeitos & $\begin{array}{l}28 \\
(7.7 \%)\end{array}$ & $\begin{array}{l}4 \\
(11.4 \%)\end{array}$ & $\begin{array}{l}3 \\
(8.1 \%)\end{array}$ & $\begin{array}{l}3 \\
(8.6 \%)\end{array}$ & $\begin{array}{l}3 \\
(7.9 \%)\end{array}$ & $\begin{array}{l}0 \\
(0.0 \\
\%)\end{array}$ & $\begin{array}{l}6 \\
(9.5 \%)\end{array}$ & $\begin{array}{l}4 \\
(16.7 \%)\end{array}$ & $\begin{array}{l}0 \\
(0.0 \%)\end{array}$ & $\begin{array}{l}4 \\
(10.5 \\
\%)\end{array}$ & $\begin{array}{l}1 \\
(2.4 \%)\end{array}$ \\
\hline Total & $\begin{array}{l}364 \\
(100 \%)\end{array}$ & $\begin{array}{l}35 \\
(100 \%)\end{array}$ & $\begin{array}{l}37 \\
(100 \%)\end{array}$ & $\begin{array}{l}35 \\
(100 \%)\end{array}$ & $\begin{array}{l}38 \\
(100 \%)\end{array}$ & $\begin{array}{l}16 \\
(100 \\
\%)\end{array}$ & $\begin{array}{l}63 \\
(100 \%)\end{array}$ & $\begin{array}{l}24 \\
(100 \%)\end{array}$ & $\begin{array}{l}37 \\
(100 \%)\end{array}$ & $\begin{array}{l}38 \\
(100 \\
\%)\end{array}$ & $\begin{array}{l}41 \\
(100 \%)\end{array}$ \\
\hline
\end{tabular}

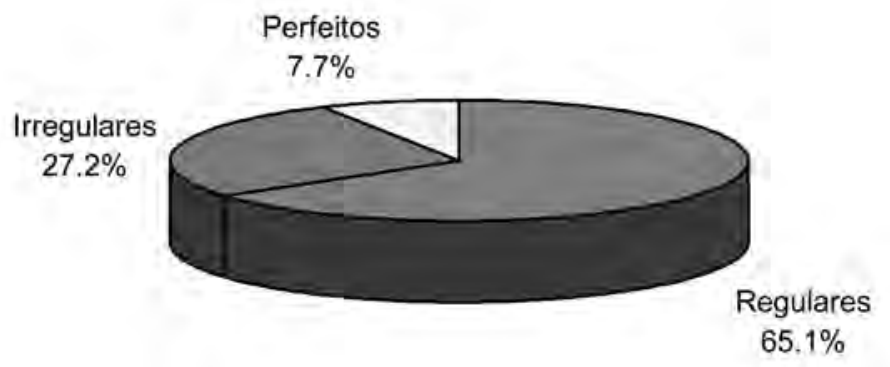

Figura 25: Distribuição das escolas de acordo com a qualidade dos registros de matrículas, para o total da amostra. Portugal, 1867 
Tabela 26: Distribuição das escolas de acordo com a qualidade dos registros de faltas por distritos e para o total da amostra. Portugal, 1867

\begin{tabular}{|c|c|c|c|c|c|c|c|c|c|c|c|}
\hline \multirow[b]{2}{*}{$\begin{array}{l}\text { Registros } \\
\text { de faltas }\end{array}$} & \multirow[b]{2}{*}{ Total } & \multicolumn{10}{|c|}{ Distrito } \\
\hline & & Aveiro & Coimbra & $\begin{array}{l}\text { Castello } \\
\text { Branco }\end{array}$ & Guarda & Évora & Lisboa & Portalegre & $\begin{array}{l}\text { Villa } \\
\text { Real }\end{array}$ & Vizeu & $\begin{array}{l}\text { Vianna } \\
\text { do } \\
\text { Castello }\end{array}$ \\
\hline Regulares & $\begin{array}{l}153 \\
(43.8 \%)\end{array}$ & $\begin{array}{l}19 \\
(54.3 \\
\%)\end{array}$ & $\begin{array}{l}18 \\
(48.7 \%)\end{array}$ & $\begin{array}{l}14 \\
(46.7 \%)\end{array}$ & $\begin{array}{l}14 \\
(37.8 \\
\%) \\
\end{array}$ & $\begin{array}{l}6 \\
(37.5 \%)\end{array}$ & $\begin{array}{l}34 \\
(56.6 \%)\end{array}$ & $\begin{array}{l}6 \\
(24.0 \%)\end{array}$ & $\begin{array}{l}9 \\
(28.1 \%)\end{array}$ & $\begin{array}{l}12 \\
(33.3 \%)\end{array}$ & $\begin{array}{l}21 \\
(51.3 \%)\end{array}$ \\
\hline Irregulares & $\begin{array}{l}125 \\
(35.8 \%)\end{array}$ & $\begin{array}{l}12 \\
(34.3 \\
\%) \\
\end{array}$ & $\begin{array}{l}7 \\
(18.9 \%)\end{array}$ & $\begin{array}{l}10 \\
(33.3 \%)\end{array}$ & $\begin{array}{l}15 \\
(40.5 \\
\%) \\
\end{array}$ & $\begin{array}{l}7 \\
(43.7 \%)\end{array}$ & $\begin{array}{l}18 \\
(30.0 \%)\end{array}$ & $\begin{array}{l}11 \\
(44.0 \%)\end{array}$ & $\begin{array}{l}12 \\
(37.5 \%)\end{array}$ & $\begin{array}{l}15 \\
(41.7 \%)\end{array}$ & $\begin{array}{l}18 \\
(43.9 \%)\end{array}$ \\
\hline Perfeitos & $\begin{array}{l}19 \\
(5.5 \%)\end{array}$ & $\begin{array}{l}1 \\
(2.9 \\
\%)\end{array}$ & $\begin{array}{l}4 \\
(10.8 \%)\end{array}$ & $\begin{array}{l}1 \\
(3.3 \%)\end{array}$ & $\begin{array}{l}2 \\
(5.4 \\
\%)\end{array}$ & $\begin{array}{l}0 \\
(0.0 \%)\end{array}$ & $\begin{array}{l}4 \\
(6.7 \%)\end{array}$ & $\begin{array}{l}4 \\
(16.0 \%)\end{array}$ & $\begin{array}{l}0 \\
(0.0 \%)\end{array}$ & $\begin{array}{l}2 \\
(5.6 \%)\end{array}$ & $\begin{array}{l}1 \\
(2.4 \%)\end{array}$ \\
\hline Nenhum & $\begin{array}{l}52 \\
(14.9 \%)\end{array}$ & $\begin{array}{l}3 \\
(8.5 \\
\%) \\
\end{array}$ & $\begin{array}{l}8 \\
(21.6 \%)\end{array}$ & $\begin{array}{l}5 \\
(16.7 \%)\end{array}$ & $\begin{array}{l}6 \\
(16.3 \\
\%) \\
\end{array}$ & $\begin{array}{l}3 \\
(18.8 \%)\end{array}$ & $\begin{array}{l}4 \\
(6.7 \%)\end{array}$ & $\begin{array}{l}4 \\
(16.0 \%)\end{array}$ & $\begin{array}{l}11 \\
(34.4 \%)\end{array}$ & $\begin{array}{l}7 \\
(19.4 \%)\end{array}$ & $\begin{array}{l}1 \\
(2.4 \%)\end{array}$ \\
\hline Total & $\begin{array}{l}349 \\
(100 \%)\end{array}$ & $\begin{array}{l}35 \\
(100 \\
\%)\end{array}$ & $\begin{array}{l}37 \\
(100 \%)\end{array}$ & $\begin{array}{l}30 \\
(100 \%)\end{array}$ & $\begin{array}{l}37 \\
(100 \\
\%)\end{array}$ & $\begin{array}{l}16 \\
(100 \%)\end{array}$ & $\begin{array}{l}60 \\
(100 \%)\end{array}$ & $\begin{array}{l}25 \\
(100 \%)\end{array}$ & $\begin{array}{l}32 \\
(100 \%)\end{array}$ & $\begin{array}{l}36 \\
(100 \%)\end{array}$ & $\begin{array}{l}41 \\
(100 \%)\end{array}$ \\
\hline
\end{tabular}

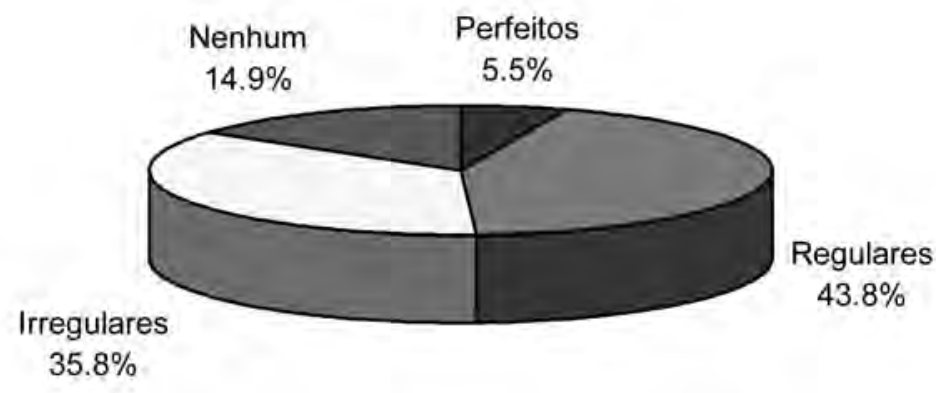

Figura 26: Distribuição das escolas de acordo com a qualidade dos registros de faltas, para o total da amostra. Portugal, 1867.

Sobre escolas das freguesias de Santa Eulália e Barbacena situadas no Concelho de Elvas, distrito de Portalegre, o inspetor relata a dificuldade apresentada para a organização dos dados acerca do próprio funcionamento da escola. Diz ele, então, em nota avulsa: "na $3^{a}$ escola [Santa Eulália] havia registro de faltas regulares e até perfeitos, mas o professor disse que perdera o de 1866 e por isso não pude confeccionar o mapa de um modo satisfatório. $\mathrm{Na} 4^{\mathrm{a}}$ escola [Barbacena] o antigo professor não deixou os registros se os tinha." ${ }^{267}$

Já o inspetor do Concelho do Redondo, no distrito de Évora, sobre os registros de faltas, todos imperfeitos, daquele professor que, por bater 'imoderadamente' em

${ }^{267}$ MR 1056. Distrito: Portalegre; Concelho: Elvas. 
seus alunos, havia sido por ele próprio caracterizado anteriormente como um Herodes, relata o seguinte sobre o procedimento adotado no caso: "dei um modelo deste mapa ao professor, em harmonia com as exigências do mapa escolar. Desejo que, de futuro, o professor esteja mais habilitado para responder bem a tantos livros." 268

$\mathrm{Na}$ maior parte das escolas que integram a amostra - 68\% -, a limpeza foi considerada suficiente, de acordo com esta inspeção. Apenas 3,3\% não apresentaram nenhuma limpeza. Os distritos de Évora (87,5\%), Lisboa (83,6\%) e Portalegre (80\%) são os que apresentam maiores índices de "suficiente limpeza". A "pouca limpeza" destaca-se nos distritos de Vianna do Castello (56,1\%) e Viseu (44,7\%). Resta saber se, por parte dos inúmeros inspetores espalhados pelo país, havia de fato homogeneidade de critérios para aferir uma uniforme acepção de limpeza, que facultasse desse modo a comparação.

Tabela 27: Distribuição das escolas conforme a qualidade da limpeza por distritos e para o total da amostra. Portugal, 1867

\begin{tabular}{|c|c|c|c|c|c|c|c|c|c|c|c|}
\hline \multirow[b]{2}{*}{$\begin{array}{l}\text { Qualidade } \\
\text { da Limpeza }\end{array}$} & \multirow[b]{2}{*}{ Total } & \multicolumn{10}{|c|}{ Distrito } \\
\hline & & Aveiro & Coimbra & $\begin{array}{l}\text { Castello } \\
\text { Branco }\end{array}$ & Guarda & Évora & Lisboa & Portalegre & $\begin{array}{l}\text { Villa } \\
\text { Real }\end{array}$ & Vizeu & $\begin{array}{l}\text { Vianna } \\
\text { do } \\
\text { Castello }\end{array}$ \\
\hline Suficiente & $\begin{array}{l}251 \\
(68.0 \\
\%) \\
\end{array}$ & $\begin{array}{l}19 \\
(57.5 \%)\end{array}$ & $\begin{array}{l}27 \\
(73.0 \%)\end{array}$ & $\begin{array}{l}25 \\
(71.4 \%)\end{array}$ & $\begin{array}{l}31 \\
(79.5 \%)\end{array}$ & $\begin{array}{l}14 \\
(87.5 \%)\end{array}$ & $\begin{array}{l}56 \\
(83.6 \%)\end{array}$ & $\begin{array}{l}20 \\
(80.0 \%)\end{array}$ & $\begin{array}{l}24 \\
(63.1 \\
\%) \\
\end{array}$ & $\begin{array}{l}18 \\
(47.4 \%)\end{array}$ & $\begin{array}{l}17 \\
(41.5 \%)\end{array}$ \\
\hline Pouca & $\begin{array}{l}106 \\
(28.7 \\
\%) \\
\end{array}$ & $\begin{array}{l}13 \\
(39.5 \%)\end{array}$ & $\begin{array}{l}10 \\
(27.0 \%)\end{array}$ & $\begin{array}{l}10 \\
(28.6 \%)\end{array}$ & $\begin{array}{l}8 \\
(20.5 \%)\end{array}$ & $\begin{array}{l}2 \\
(12.5 \%)\end{array}$ & $\begin{array}{l}10 \\
(14.9 \%)\end{array}$ & $\begin{array}{l}3 \\
(12.0 \%)\end{array}$ & $\begin{array}{l}10 \\
(26.3 \\
\%) \\
\end{array}$ & $\begin{array}{l}17 \\
(44.7 \%)\end{array}$ & $\begin{array}{l}23 \\
(56.1 \%)\end{array}$ \\
\hline Nenhuma & $\begin{array}{l}12 \\
(3.3 \\
\%) \\
\end{array}$ & $\begin{array}{l}1 \\
(3.0 \%)\end{array}$ & $\begin{array}{l}0 \\
(0.0 \%)\end{array}$ & $\begin{array}{l}0 \\
(0.0 \%)\end{array}$ & $\begin{array}{l}0 \\
(0.0 \%)\end{array}$ & $\begin{array}{l}0 \\
(0.0 \%)\end{array}$ & $\begin{array}{l}1 \\
(1.5 \%)\end{array}$ & $\begin{array}{l}2 \\
(8.0 \%)\end{array}$ & $\begin{array}{l}4 \\
(10.6 \\
\%)\end{array}$ & $\begin{array}{l}3 \\
(7.9 \%)\end{array}$ & $\begin{array}{l}1 \\
(2.4 \%)\end{array}$ \\
\hline Total & $\begin{array}{l}369 \\
(100 \\
\%)\end{array}$ & $\begin{array}{l}33 \\
(100 \%)\end{array}$ & $\begin{array}{l}37 \\
(100 \%)\end{array}$ & $\begin{array}{l}35 \\
(100 \%)\end{array}$ & $\begin{array}{l}39 \\
(100 \%)\end{array}$ & $\begin{array}{l}16 \\
(100 \%)\end{array}$ & $\begin{array}{l}67 \\
(100 \%)\end{array}$ & $\begin{array}{l}25 \\
(100 \%)\end{array}$ & $\begin{array}{l}38 \\
(100 \\
\%)\end{array}$ & $\begin{array}{l}38 \\
(100 \%)\end{array}$ & \begin{tabular}{|l}
41 \\
$(100 \%)$
\end{tabular} \\
\hline
\end{tabular}

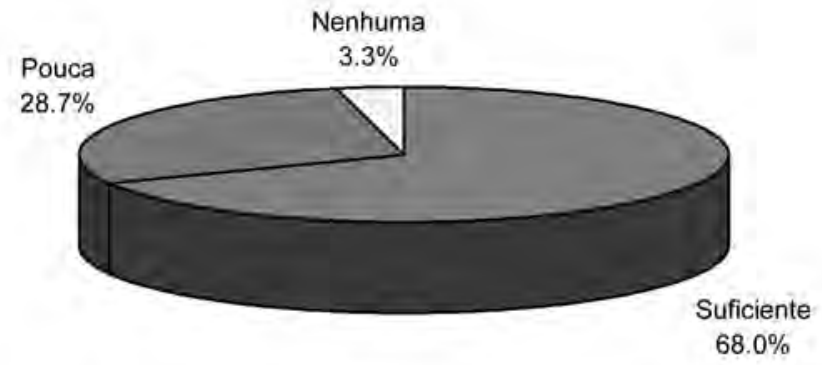

Figura 27: Distribuição das escolas conforme a qualidade da limpeza, para o total da amostra. Portugal, 1867.

${ }^{268}$ MR 1050. Distrito: Évora; Concelho: Redondo. 


\section{Meninos e meninas de diferentes idades}

O Relatório cuida de averiguar a classificação dos alunos meninos que frequentaram a escola segundo o ano em que começaram a estudar. A grande maioria, 31,7\%, começara naquele mesmo ano letivo (1866-1867), havendo, como sempre, significativa variação de acordo com os diferentes distritos. Dessa forma, teremos em Portalegre um índice de $47,2 \%$ de alunos ingressantes. Na outra ponta do Alentejo, Évora apresentará 46,4\% dos alunos nessa mesma condição. Mais a Norte, Coimbra, Aveiro, Vila Real e Vianna apontam para um percentual menor do que a média estabelecida para todo o país, revelando que as crianças do Alentejo sairiam precocemente da escola, mais cedo do que o restante dos meninos portugueses. Como podemos ler pela tabela abaixo, 18,8\% dos meninos que frequentavam a escola em Portugal haviam começado a estudar no ano letivo imediatamente anterior (1865-1866), sendo que 13,3\% dos alunos entraram na escola em 1864; 10,4\% em 1863 e assim por diante...

Tabela 28: Número e porcentagens de alunos do sexo masculino que frequentaram a escola segundo o ano em que começaram a estudar por distritos e para o total da amostra. Portugal, 1867

\begin{tabular}{|c|c|c|c|c|c|c|c|c|c|c|c|}
\hline \multirow[b]{2}{*}{$\begin{array}{l}\text { Ano } \\
\text { começo } \\
\text { estudo }\end{array}$} & \multirow[b]{2}{*}{ Total } & \multicolumn{10}{|c|}{ DisTRITO } \\
\hline & & Aveiro & Coimbra & $\begin{array}{l}\text { Castello } \\
\text { Branco }\end{array}$ & Guarda & Évora & Lisboa & Portalegre & $\begin{array}{l}\text { Villa } \\
\text { Real }\end{array}$ & Vizeu & $\begin{array}{l}\text { Vianna } \\
\text { do } \\
\text { Castello }\end{array}$ \\
\hline $\begin{array}{l}\text { Antes } \\
\text { de } 1857\end{array}$ & $\begin{array}{l}140 \\
(0.9 \%)\end{array}$ & $\begin{array}{l}3 \\
(0.2 \%)\end{array}$ & $\begin{array}{l}1 \\
(0.1 \%)\end{array}$ & $\begin{array}{l}0 \\
(0.0 \%)\end{array}$ & $\begin{array}{l}64 \\
(3.6 \%)\end{array}$ & $\begin{array}{l}22 \\
(3.1 \%)\end{array}$ & $\begin{array}{l}5 \\
(0.2 \%)\end{array}$ & $\begin{array}{l}0 \\
(0.0 \%)\end{array}$ & $\begin{array}{l}0 \\
(0.0 \%)\end{array}$ & $\begin{array}{l}2 \\
(0.1 \%)\end{array}$ & $\begin{array}{l}43 \\
(1.6 \%)\end{array}$ \\
\hline 1857 & $\begin{array}{l}70 \\
(0.4 \%)\end{array}$ & $\begin{array}{l}3 \\
(0.2 \%)\end{array}$ & $\begin{array}{l}14 \\
(0.8 \%)\end{array}$ & $\begin{array}{l}4 \\
(0.3 \%)\end{array}$ & $\begin{array}{l}13 \\
(0.7 \%)\end{array}$ & $\begin{array}{l}7 \\
(1.0 \%)\end{array}$ & $\begin{array}{l}6 \\
(0.2 \%)\end{array}$ & $\begin{array}{l}3 \\
(0.4 \%)\end{array}$ & $\begin{array}{l}1 \\
(0.1 \%)\end{array}$ & $\begin{array}{l}5 \\
(0.3 \%)\end{array}$ & $\begin{array}{l}14 \\
(0.5 \%)\end{array}$ \\
\hline 1858 & $\begin{array}{l}123 \\
(0.8 \%)\end{array}$ & $\begin{array}{l}5 \\
(0.3 \%)\end{array}$ & $\begin{array}{l}11 \\
(0.7 \%)\end{array}$ & $\begin{array}{l}7 \\
(0.4 \%)\end{array}$ & $\begin{array}{l}29 \\
(1.6 \%)\end{array}$ & $\begin{array}{l}7 \\
(1.0 \%)\end{array}$ & & $\begin{array}{l}2 \\
(0.2 \%)\end{array}$ & $\begin{array}{l}5 \\
(0.4 \%)\end{array}$ & $\begin{array}{l}18 \\
(1.1 \%)\end{array}$ & $\begin{array}{l}28 \\
(1.0 \%)\end{array}$ \\
\hline 1859 & $\begin{array}{l}243 \\
(1.5 \%)\end{array}$ & $\begin{array}{l}21 \\
(1.4 \%)\end{array}$ & $\begin{array}{l}22 \\
(1.3 \%)\end{array}$ & $\begin{array}{l}29 \\
(1.8 \%)\end{array}$ & $\begin{array}{l}44 \\
(2.5 \%)\end{array}$ & $\begin{array}{l}13 \\
(1.7 \%)\end{array}$ & $\begin{array}{l}33 \\
(1.2 \%)\end{array}$ & $\begin{array}{l}1 \\
(0.1 \%)\end{array}$ & $\begin{array}{l}19 \\
(1.4 \%)\end{array}$ & $\begin{array}{l}18 \\
(1.1 \%)\end{array}$ & $\begin{array}{l}43 \\
(1.6 \%)\end{array}$ \\
\hline 1860 & $\begin{array}{l}424 \\
(2.6 \%)\end{array}$ & $\begin{array}{l}15 \\
(1.0 \%)\end{array}$ & $\begin{array}{l}27 \\
(1.6 \%)\end{array}$ & $\begin{array}{l}54 \\
(3.4 \%)\end{array}$ & $\begin{array}{l}43 \\
(2.4 \%)\end{array}$ & $\begin{array}{l}19 \\
(2.7 \%)\end{array}$ & $\begin{array}{l}53 \\
(2.0 \%)\end{array}$ & $\begin{array}{l}4 \\
(0.5 \%)\end{array}$ & $\begin{array}{l}71 \\
(5.4 \%)\end{array}$ & $\begin{array}{l}57 \\
(3.7 \%)\end{array}$ & $\begin{array}{l}81 \\
(2.9 \%)\end{array}$ \\
\hline 1861 & $\begin{array}{l}567 \\
(3.5 \%)\end{array}$ & $\begin{array}{l}31 \\
(2.1 \%)\end{array}$ & $\begin{array}{l}64 \\
(3.9 \%)\end{array}$ & $\begin{array}{l}44 \\
(2.8 \%)\end{array}$ & $\begin{array}{l}55 \\
(3.1 \%)\end{array}$ & $\begin{array}{l}19 \\
(2.7 \%)\end{array}$ & $\begin{array}{l}92 \\
(3.4 \%)\end{array}$ & $\begin{array}{l}10 \\
(1.2 \%)\end{array}$ & $\begin{array}{l}49 \\
(3.7 \%)\end{array}$ & $\begin{array}{l}42 \\
(2.7 \%)\end{array}$ & $\begin{array}{l}161 \\
(5.9 \%)\end{array}$ \\
\hline 1862 & $\begin{array}{l}994 \\
(6.1 \%)\end{array}$ & $\begin{array}{l}132 \\
(9.1 \%)\end{array}$ & $\begin{array}{l}60 \\
(3.6 \%)\end{array}$ & $\begin{array}{l}88 \\
(5.6 \%)\end{array}$ & $\begin{array}{l}102 \\
(5.8 \%)\end{array}$ & $\begin{array}{l}37 \\
(5.1 \%)\end{array}$ & $\begin{array}{l}132 \\
(5.0 \%)\end{array}$ & $\begin{array}{l}28 \\
(3.4 \%)\end{array}$ & $\begin{array}{l}104 \\
(7.9 \%)\end{array}$ & $\begin{array}{l}76 \\
(4.9 \%)\end{array}$ & $\begin{array}{l}235 \\
(8.6 \%)\end{array}$ \\
\hline 1863 & $\begin{array}{l}1688 \\
(10.4 \%)\end{array}$ & $\begin{array}{l}120 \\
(8.3 \%)\end{array}$ & $\begin{array}{l}138 \\
(8.4 \%)\end{array}$ & $\begin{array}{l}101 \\
(6.4 \%)\end{array}$ & $\begin{array}{l}343 \\
(19.4 \%)\end{array}$ & $\begin{array}{l}68 \\
(9.5 \%)\end{array}$ & $\begin{array}{l}206 \\
(7.7 \%)\end{array}$ & $\begin{array}{l}56 \\
(6.9 \%)\end{array}$ & $\begin{array}{l}153 \\
(11.6 \%)\end{array}$ & $\begin{array}{l}174 \\
(11.2 \%)\end{array}$ & $\begin{array}{l}329 \\
(12.0 \%)\end{array}$ \\
\hline 1864 & $\begin{array}{l}2163 \\
(13.3 \%)\end{array}$ & $\begin{array}{l}164 \\
(11.3 \%)\end{array}$ & $\begin{array}{l}361 \\
(21.9 \%)\end{array}$ & $\begin{array}{l}199 \\
(12.7 \%)\end{array}$ & $\begin{array}{l}202 \\
(11.4 \%)\end{array}$ & $\begin{array}{l}79 \\
(11.8 \%)\end{array}$ & $\begin{array}{l}324 \\
(12.3 \%)\end{array}$ & $\begin{array}{l}129 \\
(15.9 \%)\end{array}$ & $\begin{array}{l}150 \\
(11.3 \%)\end{array}$ & $\begin{array}{l}197 \\
(12.7 \%)\end{array}$ & $\begin{array}{l}358 \\
(13.0 \%)\end{array}$ \\
\hline 1865 & $\begin{array}{l}3054 \\
(18.8 \%)\end{array}$ & $\begin{array}{l}396 \\
(27.3 \%)\end{array}$ & $\begin{array}{l}216 \\
(13.2 \%)\end{array}$ & $\begin{array}{l}327 \\
(20.8 \%)\end{array}$ & $\begin{array}{l}315 \\
(17.8 \%)\end{array}$ & $\begin{array}{l}88 \\
(12.4 \%)\end{array}$ & $\begin{array}{l}562 \\
(21.1 \%)\end{array}$ & $\begin{array}{l}134 \\
(16.5 \%)\end{array}$ & $\begin{array}{l}196 \\
(14.8 \%)\end{array}$ & $\begin{array}{l}240 \\
(15.5 \%)\end{array}$ & $\begin{array}{l}580 \\
(21.0 \%)\end{array}$ \\
\hline 1866 & $\begin{array}{l}5151 \\
(31.7 \%)\end{array}$ & $\begin{array}{l}420 \\
(28.9 \%)\end{array}$ & $\begin{array}{l}392 \\
(23.8 \%)\end{array}$ & $\begin{array}{l}562 \\
(35.9 \%)\end{array}$ & $\begin{array}{l}434 \\
(24.6 \%)\end{array}$ & $\begin{array}{l}328 \\
(46.4 \%)\end{array}$ & $\begin{array}{l}1062 \\
(39.9 \%)\end{array}$ & $\begin{array}{l}383 \\
(47.2 \%)\end{array}$ & $\begin{array}{l}371 \\
(28.0 \%)\end{array}$ & $\begin{array}{l}521 \\
(33.5 \%)\end{array}$ & $\begin{array}{l}678 \\
(24.7 \%)\end{array}$ \\
\hline $\begin{array}{l}\text { Desco- } \\
\text { nhecido }\end{array}$ & $\begin{array}{l}1626 \\
(10.0 \%)\end{array}$ & $\begin{array}{l}143 \\
(9.9 \%)\end{array}$ & $\begin{array}{l}339 \\
(20.7 \%)\end{array}$ & $\begin{array}{l}156 \\
(9.9 \%)\end{array}$ & $\begin{array}{l}123 \\
(7.1 \%)\end{array}$ & $\begin{array}{l}19 \\
(2.6 \%)\end{array}$ & $\begin{array}{l}177 \\
(6.6 \%)\end{array}$ & $\begin{array}{l}62 \\
(7.7 \%)\end{array}$ & $\begin{array}{l}204 \\
(15.4 \%)\end{array}$ & $\begin{array}{l}206 \\
(13.2 \%)\end{array}$ & $\begin{array}{l}197 \\
(7.2 \%)\end{array}$ \\
\hline Total & $\begin{array}{l}16243 \\
(100 \%)\end{array}$ & $\begin{array}{l}1453 \\
(100 \%)\end{array}$ & $\begin{array}{l}1645 \\
(100 \%)\end{array}$ & $\begin{array}{l}1571 \\
(100 \%)\end{array}$ & $\begin{array}{l}1767 \\
(100 \%)\end{array}$ & $\begin{array}{l}706 \\
(100 \%)\end{array}$ & $\begin{array}{l}2663 \\
(100 \%)\end{array}$ & $\begin{array}{l}812 \\
(100 \%)\end{array}$ & $\begin{array}{l}1323 \\
(100 \%)\end{array}$ & $\begin{array}{l}1556 \\
(100 \%)\end{array}$ & $\begin{array}{l}2747 \\
(100 \%)\end{array}$ \\
\hline
\end{tabular}


Sobre as meninas que iam à escola, temos que 34,3\% começaram a estudar naquele mesmo ano letivo (1866-1867); 21,4\% em 1865; 11,5\% em 1864; e 11,2\% em ano desconhecido.

Tabela 29: Número e porcentagens de alunos do sexo feminino que frequentaram a escola segundo o ano em que começaram a estudar por distritos e para o total da amostra. Portugal, 1867

\begin{tabular}{|c|c|c|c|c|c|c|c|c|c|c|c|}
\hline & & Distrite & & & & & & & & & \\
\hline $\begin{array}{l}\text { Ano } \\
\text { começo } \\
\text { estudo }\end{array}$ & Total & Aveiro & Coimbra & $\begin{array}{l}\text { Castello } \\
\text { Branco }\end{array}$ & Guarda & Évora & Lisboa & Portalegre & $\begin{array}{l}\text { Villa } \\
\text { Real }\end{array}$ & Vizeu & $\begin{array}{l}\text { Vianna } \\
\text { do } \\
\text { Castello }\end{array}$ \\
\hline $\begin{array}{l}\text { Antes de } \\
1857\end{array}$ & $\begin{array}{l}8 \\
(0.3 \%)\end{array}$ & $\begin{array}{l}3 \\
(1.2 \%)\end{array}$ & $\begin{array}{l}0 \\
(0.0 \%)\end{array}$ & $\begin{array}{l}0 \\
(0.0 \%)\end{array}$ & $\begin{array}{l}0 \\
(0.0 \%)\end{array}$ & $\begin{array}{l}0 \\
(0.0 \%)\end{array}$ & $\begin{array}{l}0 \\
(0.0 \%)\end{array}$ & $\begin{array}{l}0 \\
(0.0 \%)\end{array}$ & $\begin{array}{l}0 \\
(0.0 \%)\end{array}$ & $\begin{array}{l}2 \\
(2.4 \%)\end{array}$ & $\begin{array}{l}3 \\
(1.5 \%)\end{array}$ \\
\hline 1857 & $\begin{array}{l}5 \\
(0.2 \%)\end{array}$ & $\begin{array}{l}1 \\
(0.4 \%)\end{array}$ & $\begin{array}{l}0 \\
(0.0 \%)\end{array}$ & $\begin{array}{l}0 \\
(0.0 \%)\end{array}$ & $\begin{array}{l}0 \\
(0.0 \%)\end{array}$ & $\begin{array}{l}0 \\
(0.0 \%)\end{array}$ & $\begin{array}{l}0 \\
(0.0 \%)\end{array}$ & $\begin{array}{l}0 \\
(0.0 \%)\end{array}$ & $\begin{array}{l}0 \\
(0.0 \%)\end{array}$ & $\begin{array}{l}3 \\
(3.6 \%)\end{array}$ & $\begin{array}{l}1 \\
(0.5 \%)\end{array}$ \\
\hline 1858 & $\begin{array}{l}12 \\
(0.4 \%)\end{array}$ & $\begin{array}{l}1 \\
(0.4 \%)\end{array}$ & $\begin{array}{l}0 \\
(0.0 \%)\end{array}$ & $\begin{array}{l}0 \\
(0.0 \%)\end{array}$ & $\begin{array}{l}0 \\
(0.0 \%)\end{array}$ & $\begin{array}{l}0 \\
(0.0 \%)\end{array}$ & $\begin{array}{l}7 \\
(0.8 \%)\end{array}$ & $\begin{array}{l}0 \\
(0.0 \%)\end{array}$ & $\begin{array}{l}0 \\
(0.0 \%)\end{array}$ & $\begin{array}{l}2 \\
(2.4 \%)\end{array}$ & $\begin{array}{l}2 \\
(1.0 \%)\end{array}$ \\
\hline 1859 & $\begin{array}{l}42 \\
(1.5 \%)\end{array}$ & $\begin{array}{l}9 \\
(3.6 \%)\end{array}$ & $\begin{array}{l}0 \\
(0.0 \%)\end{array}$ & $\begin{array}{l}4 \\
(0.9 \%)\end{array}$ & $\begin{array}{l}0 \\
(0.0 \%)\end{array}$ & $\begin{array}{l}0 \\
(0.0 \%)\end{array}$ & $\begin{array}{l}20 \\
(2.3 \%)\end{array}$ & $\begin{array}{l}7 \\
(2.8 \%)\end{array}$ & $\begin{array}{l}1 \\
(0.6 \%)\end{array}$ & $\begin{array}{l}0 \\
(0.0 \%)\end{array}$ & $\begin{array}{l}1 \\
(0.5 \%)\end{array}$ \\
\hline 1860 & $\begin{array}{l}55 \\
(1.9 \%)\end{array}$ & $\begin{array}{l}12 \\
(4.7 \%)\end{array}$ & $\begin{array}{l}0 \\
(0.0 \%)\end{array}$ & $\begin{array}{l}14 \\
(3.1 \%)\end{array}$ & $\begin{array}{l}0 \\
(0.0 \%)\end{array}$ & $\begin{array}{l}7 \\
(3.4 \%)\end{array}$ & $\begin{array}{l}9 \\
(1.0 \%)\end{array}$ & $\begin{array}{l}1 \\
(0.4 \%)\end{array}$ & $\begin{array}{l}0 \\
(0.0 \%)\end{array}$ & $\begin{array}{l}4 \\
(4.8 \%)\end{array}$ & $\begin{array}{l}8 \\
(4.0 \%)\end{array}$ \\
\hline 1861 & $\begin{array}{l}83 \\
(2.9 \%)\end{array}$ & $\begin{array}{l}8 \\
(3.2 \%)\end{array}$ & $\begin{array}{l}0 \\
(0.0 \%)\end{array}$ & $\begin{array}{l}13 \\
(2.8 \%)\end{array}$ & $\begin{array}{l}1 \\
(0.4 \%)\end{array}$ & $\begin{array}{l}4 \\
(1.9 \%)\end{array}$ & $\begin{array}{l}29 \\
(3.3 \%)\end{array}$ & $\begin{array}{l}19 \\
(7.6 \%)\end{array}$ & $\begin{array}{l}1 \\
(0.6 \%)\end{array}$ & $\begin{array}{l}0 \\
(0.0 \%)\end{array}$ & $\begin{array}{l}8 \\
(4.0 \%)\end{array}$ \\
\hline 1862 & $\begin{array}{l}173 \\
(6.1 \%)\end{array}$ & $\begin{array}{l}26 \\
(10.3 \%)\end{array}$ & $\begin{array}{l}0 \\
(0.0 \%)\end{array}$ & $\begin{array}{l}25 \\
(5.5 \%)\end{array}$ & $\begin{array}{l}23 \\
(11.6 \%)\end{array}$ & $\begin{array}{l}20 \\
(9.7 \%)\end{array}$ & $\begin{array}{l}27 \\
(3.1 \%)\end{array}$ & $\begin{array}{l}19 \\
(7.6 \%)\end{array}$ & $\begin{array}{l}2 \\
(1.1 \%)\end{array}$ & $\begin{array}{l}16 \\
(19.0 \%)\end{array}$ & $\begin{array}{l}15 \\
(7.4 \%)\end{array}$ \\
\hline 1863 & $\begin{array}{l}234 \\
(8.3 \%)\end{array}$ & $\begin{array}{l}27 \\
(10.7 \%)\end{array}$ & $\begin{array}{l}0 \\
(0.0 \%)\end{array}$ & $\begin{array}{l}49 \\
(10.7 \%)\end{array}$ & $\begin{array}{l}17 \\
(8.2 \%)\end{array}$ & $\begin{array}{l}32 \\
(15.4 \%)\end{array}$ & $\begin{array}{l}57 \\
(6.5 \%)\end{array}$ & $\begin{array}{l}26 \\
(10.4 \%)\end{array}$ & $\begin{array}{l}4 \\
(2.3 \%)\end{array}$ & $\begin{array}{l}10 \\
(11.9 \%)\end{array}$ & $\begin{array}{l}12 \\
(5.9 \%)\end{array}$ \\
\hline 1864 & $\begin{array}{l}325 \\
(11.5 \%)\end{array}$ & $\begin{array}{l}40 \\
(15.8 \%)\end{array}$ & $\begin{array}{l}1 \\
(0.8 \%)\end{array}$ & $\begin{array}{l}39 \\
(8.5 \%)\end{array}$ & $\begin{array}{l}46 \\
(22.2 \%)\end{array}$ & $\begin{array}{l}34 \\
(16.4 \%)\end{array}$ & $\begin{array}{l}87 \\
(9.9 \%)\end{array}$ & $\begin{array}{l}35 \\
(14.0 \%)\end{array}$ & $\begin{array}{l}3 \\
(1.7 \%)\end{array}$ & $\begin{array}{l}9 \\
(10.7 \%)\end{array}$ & $\begin{array}{l}31 \\
(15.3 \%)\end{array}$ \\
\hline 1865 & $\begin{array}{l}607 \\
(21.4 \%)\end{array}$ & $\begin{array}{l}47 \\
(18.6 \%)\end{array}$ & $\begin{array}{l}14 \\
(11.7 \%)\end{array}$ & $\begin{array}{l}119 \\
(26.0 \%)\end{array}$ & $\begin{array}{l}37 \\
(17.9 \%)\end{array}$ & $\begin{array}{l}49 \\
(23.7 \%)\end{array}$ & $\begin{array}{l}185 \\
(21.0 \%)\end{array}$ & $\begin{array}{l}76 \\
(30.4 \%)\end{array}$ & $\begin{array}{l}17 \\
(9.6 \%)\end{array}$ & $\begin{array}{l}10 \\
(11.9 \%)\end{array}$ & $\begin{array}{l}53 \\
(26.2 \%)\end{array}$ \\
\hline 1866 & $\begin{array}{l}973 \\
(34.3 \%)\end{array}$ & $\begin{array}{l}63 \\
(24.8 \%)\end{array}$ & $\begin{array}{l}105 \\
(87.5 \%)\end{array}$ & $\begin{array}{l}162 \\
(35.4 \%)\end{array}$ & \begin{tabular}{|l|}
38 \\
$(18.4 \%)$
\end{tabular} & $\begin{array}{l}61 \\
(29.5 \%)\end{array}$ & $\begin{array}{l}319 \\
(36.3 \%)\end{array}$ & $\begin{array}{l}67 \\
(26.8 \%)\end{array}$ & $\begin{array}{l}62 \\
(35.2 \%)\end{array}$ & $\begin{array}{l}28 \\
(33.3 \%)\end{array}$ & $\begin{array}{l}68 \\
(33.7 \%)\end{array}$ \\
\hline $\begin{array}{l}\text { Desco- } \\
\text { nhecido }\end{array}$ & $\begin{array}{l}317 \\
(11.2 \%)\end{array}$ & $\begin{array}{l}16 \\
(6.3 \%)\end{array}$ & $\begin{array}{l}0 \\
(0.0 \%)\end{array}$ & $\begin{array}{l}32 \\
(7.0 \%)\end{array}$ & $\begin{array}{l}44 \\
(21.3 \%)\end{array}$ & $\begin{array}{l}0 \\
(0.0 \%)\end{array}$ & $\begin{array}{l}139 \\
(15.8 \%)\end{array}$ & $\begin{array}{l}0 \\
(0.0 \%)\end{array}$ & $\begin{array}{l}86 \\
(48.9 \%)\end{array}$ & $\begin{array}{l}0 \\
(0.0 \%)\end{array}$ & $\begin{array}{l}0 \\
(0.0 \%)\end{array}$ \\
\hline Total & $\begin{array}{l}2834 \\
(100 \%)\end{array}$ & $\begin{array}{l}253 \\
(100 \%)\end{array}$ & $\begin{array}{l}120 \\
(100 \%)\end{array}$ & $\begin{array}{l}457 \\
(100 \%)\end{array}$ & $\begin{array}{l}206 \\
(100 \%)\end{array}$ & $\begin{array}{l}207 \\
(100 \%)\end{array}$ & $\begin{array}{l}879 \\
(100 \%)\end{array}$ & $\begin{array}{l}250 \\
(100 \%)\end{array}$ & $\begin{array}{l}176 \\
(100 \%)\end{array}$ & $\begin{array}{l}84 \\
(100 \%)\end{array}$ & $\begin{array}{l}202 \\
(100 \%)\end{array}$ \\
\hline
\end{tabular}

As idades dos escolares - como facilmente se constata - eram bastante variadas e bem distribuídas principalmente entre os 7 e os 13 anos, havendo queda gradativa daqueles que se encontravam com faixa etária acima dos 14 anos. Havia, na escola primária, constituindo um grupo de 5,4\% dos alunos pertencentes ao sexo masculino, crianças com seis anos ou menos $(3,8 \%+1,3 \%+0,3 \%)$ e $4,7 \%$ dos meninos tinham já mais de 17 anos de idade. Também entre os alunos meninos, $60 \%$ pertenciam ao grupo distribuído entre 8 e 12, quase com as mesmas porcentagens para cada uma das idades mencionadas (em torno de $10 \%$ para cada idade). Aparentemente, as meninas entravam um pouco mais cedo na rotina escolar. Os percentuais mais elevados 
de meninas segundo o ano de nascimento são $12,4 \%$ e $12,3 \%$ para as idades de 8 e 9 anos respectivamente - considerando-se o ano de 1867, quando é efetuada a inspeção; seguem-se $11,3 \%$ e $11,1 \%$ para alunas de 7 e 10 anos respectivamente. $O$ percentual de $9,1 \%$ correspondia à faixa dos 11 anos e $8,2 \%$ tinham 6 anos de idade. Havia 4,5\% de alunas com apenas 5 anos de idade e 1,7\% de meninas ainda menorzinhas, como revela o quadro a seguir:

Tabela 30: Alunos do sexo feminino que frequentaram a escola segundo suas idades, por distritos e para o total da amostra. Portugal, 1867

\begin{tabular}{|c|c|c|c|c|c|c|c|c|c|c|c|}
\hline \multirow[b]{2}{*}{$\begin{array}{l}\text { Idade } \\
\text { (anos) }\end{array}$} & \multirow[b]{2}{*}{ Total } & \multicolumn{10}{|c|}{ Distrito } \\
\hline & & Aveiro & Coimbra & $\begin{array}{l}\text { Castello } \\
\text { Branco }\end{array}$ & Guarda & Évora & Lisboa & Portalegre & $\begin{array}{l}\text { Villa } \\
\text { Real }\end{array}$ & Vizeu & $\begin{array}{l}\text { Vianna } \\
\text { do } \\
\text { Castello }\end{array}$ \\
\hline $\begin{array}{l}4 \text { ou } \\
\text { menos }\end{array}$ & $\begin{array}{l}51 \\
(1.7 \%)\end{array}$ & $\begin{array}{l}2 \\
(0.6 \%)\end{array}$ & $\begin{array}{l}2 \\
(1.3 \%)\end{array}$ & $\begin{array}{l}0 \\
(0.0 \%)\end{array}$ & $\begin{array}{l}1 \\
(0.5 \%)\end{array}$ & $\begin{array}{l}0 \\
(0.0 \%)\end{array}$ & $\begin{array}{l}39 \\
(4.5 \%)\end{array}$ & $\begin{array}{l}0 \\
(0.0 \%)\end{array}$ & $\begin{array}{l}6 \\
(3.6 \%)\end{array}$ & $\begin{array}{l}0 \\
(0.0 \%)\end{array}$ & $\begin{array}{l}1 \\
(0.5 \%)\end{array}$ \\
\hline 5 & $\begin{array}{l}132 \\
(4.5 \%)\end{array}$ & $\begin{array}{l}9 \\
(2.9 \%)\end{array}$ & $\begin{array}{l}7 \\
(4.4 \%)\end{array}$ & $\begin{array}{l}6 \\
(1.3 \%)\end{array}$ & $\begin{array}{l}4 \\
(2.0 \%)\end{array}$ & $\begin{array}{l}10 \\
(4.1 \%)\end{array}$ & $\begin{array}{l}58 \\
(6.7 \%)\end{array}$ & $\begin{array}{l}21 \\
(8.5 \%)\end{array}$ & $\begin{array}{l}2 \\
(1.2 \%)\end{array}$ & $\begin{array}{l}5 \\
(4.6 \%)\end{array}$ & $\begin{array}{l}10 \\
(4.9 \%)\end{array}$ \\
\hline 6 & $\begin{array}{l}241 \\
(8.2 \%)\end{array}$ & $\begin{array}{l}25 \\
(8.2 \%)\end{array}$ & $\begin{array}{l}17 \\
(10.8 \%)\end{array}$ & $\begin{array}{l}21 \\
(4.6 \%)\end{array}$ & $\begin{array}{l}8 \\
(4.0 \%)\end{array}$ & $\begin{array}{l}16 \\
(6.5 \%)\end{array}$ & $\begin{array}{l}83 \\
(9.7 \%)\end{array}$ & $\begin{array}{l}29 \\
(11.6 \%)\end{array}$ & $\begin{array}{l}7 \\
(4.2 \%)\end{array}$ & $\begin{array}{l}8 \\
(7.2 \%)\end{array}$ & $\begin{array}{l}27 \\
(13.3 \%)\end{array}$ \\
\hline 7 & $\begin{array}{l}332 \\
(11.3 \%)\end{array}$ & $\begin{array}{l}23 \\
(7.5 \%)\end{array}$ & $\begin{array}{l}17 \\
(10.8 \%)\end{array}$ & $\begin{array}{l}52 \\
(11.4 \%)\end{array}$ & $\begin{array}{l}41 \\
(20.8 \%)\end{array}$ & $\begin{array}{l}25 \\
(10.2 \%)\end{array}$ & $\begin{array}{l}97 \\
(11.3 \%)\end{array}$ & $\begin{array}{l}21 \\
(8.5 \%)\end{array}$ & $\begin{array}{l}18 \\
(10.8 \%)\end{array}$ & $\begin{array}{l}13 \\
(11.7 \%)\end{array}$ & $\begin{array}{l}25 \\
(12.3 \%)\end{array}$ \\
\hline 8 & $\begin{array}{l}365 \\
(12.4 \%)\end{array}$ & $\begin{array}{l}40 \\
(13.1 \%)\end{array}$ & $\begin{array}{l}21 \\
(13.3 \%)\end{array}$ & $\begin{array}{l}53 \\
(11.6 \%)\end{array}$ & $\begin{array}{l}28 \\
(14.2 \%)\end{array}$ & $\begin{array}{l}29 \\
(11.8 \%)\end{array}$ & $\begin{array}{l}110 \\
(12.8 \%)\end{array}$ & $\begin{array}{l}24 \\
(9.7 \%)\end{array}$ & $\begin{array}{l}17 \\
(10.2 \%)\end{array}$ & $\begin{array}{l}14 \\
(12.6 \%)\end{array}$ & $\begin{array}{l}29 \\
(14.3 \%)\end{array}$ \\
\hline 9 & $\begin{array}{l}362 \\
(12.3 \%)\end{array}$ & \begin{tabular}{|l|}
27 \\
$(8.8 \%)$
\end{tabular} & $\begin{array}{l}21 \\
(13.3 \%)\end{array}$ & $\begin{array}{l}50 \\
(10.9 \%)\end{array}$ & $\begin{array}{l}21 \\
(10.7 \%)\end{array}$ & $\begin{array}{l}38 \\
(15.5 \%)\end{array}$ & $\begin{array}{l}94 \\
(10.9 \%)\end{array}$ & $\begin{array}{l}50 \\
(20.2 \%)\end{array}$ & $\begin{array}{l}23 \\
(13.9 \%)\end{array}$ & $\begin{array}{l}9 \\
(8.1 \%)\end{array}$ & $\begin{array}{l}29 \\
(14.3 \%)\end{array}$ \\
\hline 10 & $\begin{array}{l}327 \\
(11.1 \%)\end{array}$ & \begin{tabular}{|l|}
30 \\
$(9.8 \%)$
\end{tabular} & $\begin{array}{l}16 \\
(10.1 \%)\end{array}$ & $\begin{array}{l}49 \\
(10.7 \%)\end{array}$ & $\begin{array}{l}23 \\
(11.7 \%)\end{array}$ & $\begin{array}{l}37 \\
(15.1 \%)\end{array}$ & $\begin{array}{l}80 \\
(9.3 \%)\end{array}$ & $\begin{array}{l}32 \\
(12.9 \%)\end{array}$ & $\begin{array}{l}21 \\
(12.8 \%)\end{array}$ & $\begin{array}{l}13 \\
(11.7 \%)\end{array}$ & $\begin{array}{l}26 \\
(12.8 \%)\end{array}$ \\
\hline 11 & $\begin{array}{l}270 \\
(9.1 \%)\end{array}$ & $\begin{array}{l}25 \\
(8.2 \%)\end{array}$ & $\begin{array}{l}13 \\
(8.2 \%)\end{array}$ & $\begin{array}{l}57 \\
(12.5 \%)\end{array}$ & $\begin{array}{l}11 \\
(5.6 \%)\end{array}$ & $\begin{array}{l}35 \\
(14.3 \%)\end{array}$ & $\begin{array}{l}61 \\
(7.1 \%)\end{array}$ & $\begin{array}{l}25 \\
(10.1 \%)\end{array}$ & $\begin{array}{l}16 \\
(9.7 \%)\end{array}$ & $\begin{array}{l}9 \\
(8.1 \%)\end{array}$ & $\begin{array}{l}18 \\
(8.9 \%)\end{array}$ \\
\hline 12 & $\begin{array}{l}219 \\
(7.4 \%)\end{array}$ & $\begin{array}{l}15 \\
(4.9 \%)\end{array}$ & $\begin{array}{l}10 \\
(6.3 \%)\end{array}$ & $\begin{array}{l}51 \\
(11.2 \%)\end{array}$ & $\begin{array}{l}18 \\
(9.1 \%)\end{array}$ & $\begin{array}{l}20 \\
(8.2 \%)\end{array}$ & $\begin{array}{l}52 \\
(6.0 \%)\end{array}$ & $\begin{array}{l}22 \\
(8.9 \%)\end{array}$ & $\begin{array}{l}11 \\
(6.6 \%)\end{array}$ & $\begin{array}{l}7 \\
(6.3 \%)\end{array}$ & $\begin{array}{l}13 \\
(6.3 \%)\end{array}$ \\
\hline 13 & $\begin{array}{l}184 \\
(6.2 \%)\end{array}$ & $\begin{array}{l}29 \\
(9.6 \%)\end{array}$ & $\begin{array}{l}9 \\
(5.7 \%)\end{array}$ & $\begin{array}{l}47 \\
(10.3 \%)\end{array}$ & $\begin{array}{l}14 \\
(7.2 \%)\end{array}$ & $\begin{array}{l}13 \\
(5.3 \%)\end{array}$ & $\begin{array}{l}29 \\
(3.4 \%)\end{array}$ & $\begin{array}{l}10 \\
(4.0 \%)\end{array}$ & $\begin{array}{l}15 \\
(9.0 \%)\end{array}$ & $\begin{array}{l}13 \\
(11.7 \%)\end{array}$ & $\begin{array}{l}5 \\
(2.4 \%)\end{array}$ \\
\hline 14 & $\begin{array}{l}148 \\
(5.0 \%)\end{array}$ & $\begin{array}{l}9 \\
(2.9 \%)\end{array}$ & $\begin{array}{l}13 \\
(8.2 \%)\end{array}$ & $\begin{array}{l}40 \\
(8.8 \%)\end{array}$ & $\begin{array}{l}13 \\
(6.6 \%)\end{array}$ & $\begin{array}{l}9 \\
(3.7 \%)\end{array}$ & $\begin{array}{l}22 \\
(2.6 \%)\end{array}$ & $\begin{array}{l}9 \\
(3.6 \%)\end{array}$ & $\begin{array}{l}12 \\
(7.2 \%)\end{array}$ & $\begin{array}{l}9 \\
(8.1 \%)\end{array}$ & $\begin{array}{l}12 \\
(6.0 \%)\end{array}$ \\
\hline 15 & $\begin{array}{l}67 \\
(2.3 \%)\end{array}$ & $\begin{array}{l}9 \\
(2.9 \%)\end{array}$ & $\begin{array}{l}5 \\
(3.2 \%)\end{array}$ & $\begin{array}{l}13 \\
(2.8 \%)\end{array}$ & $\begin{array}{l}9 \\
(4.6 \%)\end{array}$ & $\begin{array}{l}8 \\
(3.3 \%)\end{array}$ & $\begin{array}{l}7 \\
(0.8 \%)\end{array}$ & $\begin{array}{l}4 \\
(1.6 \%)\end{array}$ & $\begin{array}{l}9 \\
(5.4 \%)\end{array}$ & $\begin{array}{l}0 \\
(0.0 \%)\end{array}$ & $\begin{array}{l}3 \\
(1.5 \%)\end{array}$ \\
\hline 16 & $\begin{array}{l}28 \\
(0.9 \%)\end{array}$ & $\begin{array}{l}7 \\
(2.3 \%)\end{array}$ & $\begin{array}{l}2 \\
(1.3 \%)\end{array}$ & $\begin{array}{l}8 \\
(1.8 \%)\end{array}$ & $\begin{array}{l}2 \\
(1.0 \%)\end{array}$ & $\begin{array}{l}2 \\
(0.8 \%)\end{array}$ & $\begin{array}{l}1 \\
(0.1 \%)\end{array}$ & $\begin{array}{l}0 \\
(0.0 \%)\end{array}$ & $\begin{array}{l}3 \\
(1.8 \%)\end{array}$ & $\begin{array}{l}0 \\
(0.0 \%)\end{array}$ & $\begin{array}{l}3 \\
(1.5 \%)\end{array}$ \\
\hline 17 & $\begin{array}{l}14 \\
(0.5 \%)\end{array}$ & $\begin{array}{l}1 \\
(0.3 \%)\end{array}$ & $\begin{array}{l}1 \\
(0.6 \%)\end{array}$ & $\begin{array}{l}9 \\
(2.0 \%)\end{array}$ & $\begin{array}{l}1 \\
(0.5 \%)\end{array}$ & $\begin{array}{l}1 \\
(0.4 \%)\end{array}$ & $\begin{array}{l}0 \\
(0.0 \%)\end{array}$ & $\begin{array}{l}0 \\
(0.0 \%)\end{array}$ & $\begin{array}{l}1 \\
(0.6 \%)\end{array}$ & $\begin{array}{l}0 \\
(0.0 \%)\end{array}$ & $\begin{array}{l}0 \\
(0.0 \%)\end{array}$ \\
\hline$>17$ & $\begin{array}{l}15 \\
(0.5 \%)\end{array}$ & $\begin{array}{l}6 \\
(2.0 \%)\end{array}$ & $\begin{array}{l}3 \\
(1.9 \%)\end{array}$ & $\begin{array}{l}0 \\
(0.0 \%)\end{array}$ & $\begin{array}{l}3 \\
(1.5 \%)\end{array}$ & $\begin{array}{l}2 \\
(0.8 \%)\end{array}$ & $\begin{array}{l}0 \\
(0.0 \%)\end{array}$ & $\begin{array}{l}0 \\
(0.0 \%)\end{array}$ & $\begin{array}{l}1 \\
(0.6 \%)\end{array}$ & $\begin{array}{l}0 \\
(0.0 \%)\end{array}$ & $\begin{array}{l}0 \\
(0.0 \%)\end{array}$ \\
\hline $\begin{array}{l}\text { Desco- } \\
\text { nhecida }\end{array}$ & $\begin{array}{l}196 \\
(6.6 \%)\end{array}$ & $\begin{array}{l}49 \\
(16.0 \%)\end{array}$ & $\begin{array}{l}1 \\
(0.6 \%)\end{array}$ & $\begin{array}{l}1 \\
(0.2 \%)\end{array}$ & $\begin{array}{l}0 \\
(0.0 \%)\end{array}$ & $\begin{array}{l}0 \\
(0.0 \%)\end{array}$ & $\begin{array}{l}127 \\
(14.8 \%)\end{array}$ & $\begin{array}{l}1 \\
(0.4 \%)\end{array}$ & $\begin{array}{l}4 \\
(2.4 \%)\end{array}$ & $\begin{array}{l}11 \\
(9.9 \%)\end{array}$ & $\begin{array}{l}2 \\
(1.0 \%)\end{array}$ \\
\hline Total & $\begin{array}{l}2951 \\
(100 \%)\end{array}$ & $\begin{array}{l}306 \\
(100 \%)\end{array}$ & $\begin{array}{l}158 \\
(100 \%)\end{array}$ & $\begin{array}{l}457 \\
(100 \%)\end{array}$ & $\begin{array}{l}197 \\
(100 \%)\end{array}$ & $\begin{array}{l}245 \\
(100 \%)\end{array}$ & $\begin{array}{l}860 \\
(100 \%)\end{array}$ & $\begin{array}{l}248 \\
(100 \%)\end{array}$ & $\begin{array}{l}166 \\
(100 \%)\end{array}$ & $\begin{array}{l}111 \\
(100 \%)\end{array}$ & $\begin{array}{l}203 \\
(100 \%)\end{array}$ \\
\hline
\end{tabular}


Tabela 31: Alunos do sexo masculino que frequentaram a escola segundo suas idades por distritos e para o total da amostra. Portugal, 1867

\begin{tabular}{|c|c|c|c|c|c|c|c|c|c|c|c|}
\hline \multirow[b]{2}{*}{$\begin{array}{l}\text { Idade } \\
\text { (anos) }\end{array}$} & \multirow[b]{2}{*}{ Total } & \multicolumn{10}{|c|}{ Distritos } \\
\hline & & Aveiro & Coimbra & $\begin{array}{l}\text { Castello } \\
\text { Branco }\end{array}$ & Guarda & Évora & Lisboa & Portalegre & $\begin{array}{l}\text { Villa } \\
\text { Real }\end{array}$ & Vizeu & $\begin{array}{l}\text { Vianna } \\
\text { do } \\
\text { Castello }\end{array}$ \\
\hline $\begin{array}{l}4 \text { ou } \\
\text { menos }\end{array}$ & $\begin{array}{l}52 \\
(0.3 \%)\end{array}$ & $\begin{array}{l}0 \\
(0.0 \%)\end{array}$ & $\begin{array}{l}13 \\
(0.7 \%)\end{array}$ & $\begin{array}{l}0 \\
(0.0 \%)\end{array}$ & $\begin{array}{l}1 \\
(0.1 \%)\end{array}$ & $\begin{array}{l}0 \\
(0.0 \%)\end{array}$ & $\begin{array}{l}18 \\
(0.7 \%)\end{array}$ & $\begin{array}{l}3 \\
(0.4 \%)\end{array}$ & $\begin{array}{l}17 \\
(1.4 \%)\end{array}$ & $\begin{array}{l}0 \\
(0.0 \%)\end{array}$ & $\begin{array}{l}0 \\
(0.0 \%)\end{array}$ \\
\hline 5 & $\begin{array}{l}213 \\
(1.3 \%)\end{array}$ & $\begin{array}{l}5 \\
(0.3 \%)\end{array}$ & $\begin{array}{l}30 \\
(1.7 \%)\end{array}$ & $\begin{array}{l}19 \\
(1.2 \%)\end{array}$ & $\begin{array}{l}13 \\
(0.7 \%)\end{array}$ & $\begin{array}{l}10 \\
(1.2 \%)\end{array}$ & $\begin{array}{l}58 \\
(2.1 \%)\end{array}$ & $\begin{array}{l}22 \\
(2.7 \%)\end{array}$ & $\begin{array}{l}15 \\
(1.3 \%)\end{array}$ & $\begin{array}{l}13 \\
(0.9 \%)\end{array}$ & $\begin{array}{l}28 \\
(1.0 \%)\end{array}$ \\
\hline 6 & $\begin{array}{l}623 \\
(3.8 \%)\end{array}$ & $\begin{array}{l}46 \\
(2.6 \%)\end{array}$ & $\begin{array}{l}57 \\
(3.2 \%)\end{array}$ & $\begin{array}{l}74 \\
(4.5 \%)\end{array}$ & $\begin{array}{l}75 \\
(4.6 \%)\end{array}$ & $\begin{array}{l}36 \\
(4.3 \%)\end{array}$ & $\begin{array}{l}149 \\
(5.5 \%)\end{array}$ & $\begin{array}{l}46 \\
(5.6 \%)\end{array}$ & $\begin{array}{l}27 \\
(2.3 \%)\end{array}$ & $\begin{array}{l}36 \\
(2.6 \%)\end{array}$ & $\begin{array}{l}77 \\
(2.9 \%)\end{array}$ \\
\hline 7 & $\begin{array}{l}1420 \\
(8.6 \%)\end{array}$ & $\begin{array}{l}126 \\
(7.0 \%)\end{array}$ & $\begin{array}{l}117 \\
(6.7 \%)\end{array}$ & $\begin{array}{l}218 \\
(13.4 \%)\end{array}$ & $\begin{array}{l}165 \\
(10.2 \%)\end{array}$ & $\begin{array}{l}46 \\
(5.5 \%)\end{array}$ & $\begin{array}{l}264 \\
(9.7 \%)\end{array}$ & $\begin{array}{l}103 \\
(12.6 \%)\end{array}$ & $\begin{array}{l}87 \\
(7.3 \%)\end{array}$ & $\begin{array}{l}115 \\
(8.4 \%)\end{array}$ & $\begin{array}{l}179 \\
(6.8 \%)\end{array}$ \\
\hline 8 & $\begin{array}{l}1967 \\
(12.0 \%)\end{array}$ & $\begin{array}{l}184 \\
(10.3 \%)\end{array}$ & $\begin{array}{l}190 \\
(10.8 \%)\end{array}$ & $\begin{array}{l}247 \\
(15.1 \%)\end{array}$ & $\begin{array}{l}150 \\
(9.3 \%)\end{array}$ & $\begin{array}{l}87 \\
(10.3 \%)\end{array}$ & $\begin{array}{l}385 \\
(14.2 \%)\end{array}$ & $\begin{array}{l}99 \\
(12.1 \%)\end{array}$ & $\begin{array}{l}105 \\
(8.8 \%)\end{array}$ & $\begin{array}{l}163 \\
(11.9 \%)\end{array}$ & $\begin{array}{l}357 \\
(13.3 \%)\end{array}$ \\
\hline 9 & $\begin{array}{l}1900 \\
(11.6 \%)\end{array}$ & $\begin{array}{l}174 \\
(9.7 \%)\end{array}$ & $\begin{array}{l}203 \\
(11.6 \%)\end{array}$ & \begin{tabular}{|l|}
222 \\
$(13.6 \%)$
\end{tabular} & $\begin{array}{l}167 \\
(10.3 \%)\end{array}$ & $\begin{array}{l}53 \\
(6.3 \%)\end{array}$ & \begin{tabular}{|l|}
347 \\
$(12.8 \%)$
\end{tabular} & $\begin{array}{l}96 \\
(11.7 \%)\end{array}$ & $\begin{array}{l}113 \\
(9.4 \%)\end{array}$ & $\begin{array}{l}172 \\
(12.5 \%)\end{array}$ & $\begin{array}{l}353 \\
(13.2 \%)\end{array}$ \\
\hline 10 & $\begin{array}{l}1787 \\
(10.9 \%)\end{array}$ & $\begin{array}{l}171 \\
(9.5 \%)\end{array}$ & $\begin{array}{l}204 \\
(11.6 \%)\end{array}$ & $\begin{array}{l}157 \\
(9.6 \%)\end{array}$ & $\begin{array}{l}146 \\
(9.0 \%)\end{array}$ & $\begin{array}{l}69 \\
(8.2 \%)\end{array}$ & $\begin{array}{l}326 \\
(12.0 \%)\end{array}$ & $\begin{array}{l}72 \\
(8.8 \%)\end{array}$ & $\begin{array}{l}107 \\
(8.9 \%)\end{array}$ & $\begin{array}{l}163 \\
(11.9 \%)\end{array}$ & $\begin{array}{l}372 \\
(13.9 \%)\end{array}$ \\
\hline 11 & $\begin{array}{l}1680 \\
(10.2 \%)\end{array}$ & $\begin{array}{l}148 \\
(8.2 \%)\end{array}$ & $\begin{array}{l}173 \\
(9.8 \%)\end{array}$ & $\begin{array}{l}148 \\
(9.1 \%)\end{array}$ & $\begin{array}{l}162 \\
(10.0 \%)\end{array}$ & $\begin{array}{l}61 \\
(7.2 \%)\end{array}$ & $\begin{array}{l}255 \\
(9.4 \%)\end{array}$ & $\begin{array}{l}76 \\
(9.3 \%)\end{array}$ & $\begin{array}{l}122 \\
(10.2 \%)\end{array}$ & $\begin{array}{l}159 \\
(11.6 \%)\end{array}$ & \begin{tabular}{|l}
376 \\
$(14.0 \%)$
\end{tabular} \\
\hline 12 & $\begin{array}{l}1502 \\
(9.2 \%)\end{array}$ & $\begin{array}{l}171 \\
(95 \%)\end{array}$ & $\begin{array}{l}145 \\
(8.2 \%)\end{array}$ & $\begin{array}{l}160 \\
(9.8 \%)\end{array}$ & $\begin{array}{l}145 \\
(9.0 \%)\end{array}$ & $\begin{array}{l}66 \\
(7.8 \%)\end{array}$ & $\begin{array}{l}206 \\
(7.6 \%)\end{array}$ & $\begin{array}{l}53 \\
(6.5 \%)\end{array}$ & $\begin{array}{l}111 \\
(9.3 \%)\end{array}$ & $\begin{array}{l}142 \\
(10.4 \%)\end{array}$ & $\begin{array}{l}303 \\
(11.3 \%)\end{array}$ \\
\hline 13 & $\begin{array}{l}1309 \\
(8.0 \%)\end{array}$ & $\begin{array}{l}109 \\
(6.1 \%)\end{array}$ & $\begin{array}{l}171 \\
(9.7 \%)\end{array}$ & $\begin{array}{l}128 \\
(7.9 \%)\end{array}$ & $\begin{array}{l}137 \\
(8.5 \%)\end{array}$ & $\begin{array}{l}63 \\
(7.5 \%)\end{array}$ & $\begin{array}{l}189 \\
(7.0 \%)\end{array}$ & $\begin{array}{l}57 \\
(7.0 \%)\end{array}$ & $\begin{array}{l}100 \\
(8.3 \%)\end{array}$ & $\begin{array}{l}123 \\
(9.0 \%)\end{array}$ & $\begin{array}{l}232 \\
(8.7 \%)\end{array}$ \\
\hline 14 & $\begin{array}{l}974 \\
(5.9 \%)\end{array}$ & $\begin{array}{l}96 \\
(5.4 \%)\end{array}$ & $\begin{array}{l}120 \\
(6.8 \%)\end{array}$ & $\begin{array}{l}91 \\
(5.6 \%)\end{array}$ & $\begin{array}{l}104 \\
(6.4 \%)\end{array}$ & $\begin{array}{l}66 \\
(7.8 \%)\end{array}$ & $\begin{array}{l}133 \\
(4.9 \%)\end{array}$ & $\begin{array}{l}33 \\
(4.0 \%)\end{array}$ & $\begin{array}{l}69 \\
(5.8 \%)\end{array}$ & $\begin{array}{l}87 \\
(6.4 \%)\end{array}$ & $\begin{array}{l}175 \\
(6.5 \%)\end{array}$ \\
\hline 15 & $\begin{array}{l}682 \\
(4.2 \%)\end{array}$ & $\begin{array}{l}58 \\
(3.2 \%)\end{array}$ & $\begin{array}{l}115 \\
(6.5 \%)\end{array}$ & $\begin{array}{l}64 \\
(3.9 \%)\end{array}$ & $\begin{array}{l}62 \\
(3.8 \%)\end{array}$ & $\begin{array}{l}47 \\
(5.5 \%)\end{array}$ & $\begin{array}{l}71 \\
(2.6 \%)\end{array}$ & $\begin{array}{l}33 \\
(4.0 \%)\end{array}$ & $\begin{array}{l}79 \\
(6.6 \%)\end{array}$ & $\begin{array}{l}64 \\
(4.7 \%)\end{array}$ & $\begin{array}{l}89 \\
(3.3 \%)\end{array}$ \\
\hline 16 & $\begin{array}{l}455 \\
(2.8 \%)\end{array}$ & $\begin{array}{l}48 \\
(2.7 \%)\end{array}$ & $\begin{array}{l}58 \\
(3.3 \%)\end{array}$ & $\begin{array}{l}25 \\
(1.5 \%)\end{array}$ & $\begin{array}{l}50 \\
(3.1 \%)\end{array}$ & $\begin{array}{l}50 \\
(5.9 \%)\end{array}$ & $\begin{array}{l}47 \\
(1.7 \%)\end{array}$ & $\begin{array}{l}24 \\
(2.9 \%)\end{array}$ & $\begin{array}{l}62 \\
(5.2 \%)\end{array}$ & $\begin{array}{l}42 \\
(3.1 \%)\end{array}$ & $\begin{array}{l}49 \\
(1.8 \%)\end{array}$ \\
\hline 17 & $\begin{array}{l}328 \\
(2.0 \%)\end{array}$ & $\begin{array}{l}28 \\
(1.6 \%)\end{array}$ & $\begin{array}{l}35 \\
(2.0 \%)\end{array}$ & $\begin{array}{l}10 \\
(0.6 \%)\end{array}$ & $\begin{array}{l}46 \\
(2.8 \%)\end{array}$ & $\begin{array}{l}46 \\
(5.5 \%)\end{array}$ & $\begin{array}{l}41 \\
(1.5 \%)\end{array}$ & $\begin{array}{l}20 \\
(2.4 \%)\end{array}$ & $\begin{array}{l}45 \\
(3.7 \%)\end{array}$ & $\begin{array}{l}30 \\
(2.2 \%)\end{array}$ & $\begin{array}{l}27 \\
(1.0 \%)\end{array}$ \\
\hline$>17$ & $\begin{array}{l}764 \\
(4.7 \%)\end{array}$ & $\begin{array}{l}62 \\
(3.4 \%)\end{array}$ & $\begin{array}{l}68 \\
(3.9 \%)\end{array}$ & $\begin{array}{l}16 \\
(1.0 \%)\end{array}$ & $\begin{array}{l}148 \\
(9.2 \%)\end{array}$ & $\begin{array}{l}99 \\
(11.7 \%)\end{array}$ & $\begin{array}{l}152 \\
(5.6 \%)\end{array}$ & $\begin{array}{l}55 \\
(6.7 \%)\end{array}$ & $\begin{array}{l}82 \\
(6.8 \%)\end{array}$ & $\begin{array}{l}30 \\
(2.2 \%)\end{array}$ & $\begin{array}{l}52 \\
(1.9 \%)\end{array}$ \\
\hline $\begin{array}{l}\text { Desco- } \\
\text { nhecida }\end{array}$ & $\begin{array}{l}759 \\
(4.5 \%)\end{array}$ & $\begin{array}{l}367 \\
(20.5 \%)\end{array}$ & $\begin{array}{l}57 \\
(3.2 \%)\end{array}$ & $\begin{array}{l}49 \\
(3.0 \%)\end{array}$ & $\begin{array}{l}44 \\
(2.7 \%)\end{array}$ & $\begin{array}{l}45 \\
(5.3 \%)\end{array}$ & $\begin{array}{l}74 \\
(2.7 \%)\end{array}$ & $\begin{array}{l}26 \\
(3.3 \%)\end{array}$ & $\begin{array}{l}57 \\
(4.7 \%)\end{array}$ & $\begin{array}{l}30 \\
(2.2 \%)\end{array}$ & $\begin{array}{l}10 \\
(0.4 \%)\end{array}$ \\
\hline Total & $\begin{array}{l}16415 \\
(100 \%)\end{array}$ & $\begin{array}{l}1793 \\
(100 \%)\end{array}$ & $\begin{array}{l}1756 \\
(100 \%)\end{array}$ & $\begin{array}{l}1628 \\
(100 \%)\end{array}$ & $\begin{array}{l}1615 \\
(100 \%)\end{array}$ & $\begin{array}{l}844 \\
(100 \%)\end{array}$ & $\begin{array}{l}2715 \\
(100 \%)\end{array}$ & $\begin{array}{l}818 \\
(100 \%)\end{array}$ & $\begin{array}{l}1198 \\
(100 \%)\end{array}$ & $\begin{array}{l}1369 \\
(100 \%)\end{array}$ & $\begin{array}{l}2679 \\
(100 \%)\end{array}$ \\
\hline
\end{tabular}

Houve alguma dificuldade para tabulação desses dados concernentes às idades da vida escolar, posto que muitos dos Relatórios consultados revelavam problemas quanto à classificação dos alunos conforme o ano em que começaram a estudar e segundo o ano em que nasceram. No primeiro caso, a tomar o exemplo de Elvas, os dados vieram já reconhecidamente imprecisos, acompanhados por um ponto de interrogação. Os professores de Alenquer, por seu turno, teriam preenchido erroneamente os mapas. Para corrigir o equívoco, o inspetor traçava a correção a lápis por cima do original, 
escrevendo os índices supostamente corretos de classificação dos alunos de acordo com os verdadeiros anos de seu nascimento. Já em Coimbra, havia escola feminina no Concelho de Condeixa-a-Nova, em cujo Relatório, entretanto, não havia quaisquer informações sobre o ensino de meninas. Desse modo, não teriam sido computadas suas idades, seus anos de estudo, como se as meninas nem sequer existissem enquanto alunas, sem que o inspetor fizesse, a tal respeito, qualquer comentário. No caso das escolas de Cintra, particularmente naquela sitiada na vila de Collares, queixa-se o inspetor: "quanto à escola de Collares, não é exato este capítulo, nem pôde apurar-se por não constar ao certo os alunos que frequentaram no ano de 1866, isto apesar do registro de matrícula estar regular; por confusão, o professor notou os alunos que se matricularam naqueles anos, alguns dos quais já haviam deixado a escola em 1866." ${ }^{269}$ O trecho é elucidativo da incerteza da época quanto ao próprio mapeamento da correlação entre alunos matriculados, índices de abandono e alunos realmente frequentadores da rotineira sala de aula.

\section{Inspetor e professor avaliam leitura, escrita, contas e doutrina cristã}

Os tópicos seguintes propunham a investigação das condições pedagógicas dos alunos no rol das matérias elementares da escola primária: leitura, escrita, contas, doutrina cristã. A avaliação, no caso, era efetuada tanto pelo professor como pelo inspetor, permitindo de tal modo a correlação entre ambos os critérios. Em termos do que constava como "classificação dos alunos presentes segundo o estado em que o inspetor os achou em leitura", temos para os alunos do sexo masculino um percentual médio para toda a amostra de $15,9 \%$ na categoria bom, 36\% na categoria suficiente e $48,1 \%$ nos considerados medíocres. Para as alunas meninas ${ }^{270}$, encontrar-se-ia respectivamente 20,7\% (bom), 37,2\% (suficiente), 42,1\% (medíocre), o que revela um desempenho algo superior para escolares do sexo feminino.

Teremos - como já pudemos observar - o ítem relativo à "classificação que o professor fez dos alunos que teve em todo o ano de 1866, segundo o estado em que se achavam no leitura no fim do dito ano". Comparativamente, obteremos que a porcentagem dos alunos bons segundo o inspetor é levemente inferior à porcentagem estabelecida pela avaliação do professor, havendo, nesse sentido, uma variação dos critérios, mediante a qual o aluno seria favorecido pelos dados de seu mestre. Sendo assim, enquanto os dados do inspetor consideram que havia, no total, 15,9\% de alunos meninos e $20,7 \%$ de alunas meninas com boa leitura, os relatos dos professores indicam que - segundo o parecer destes - haveria $24,9 \%$ de alunos meninos bons em leitura e $27,9 \%$ de alunas meninas boas em leitura. Para o caso dos alunos considerados medíocres na habilidade da leitura, evidentemente a relação se inverte,

\footnotetext{
${ }^{269}$ MR 1055. Distrito: Lisboa; Concelho: Cintra.
}

${ }^{270}$ Sabemos que poderá ser considerado um pleonasmo falar em alunos meninos e em alunas meninas. Ocorre que optamos por tal explicitação particularmente porque, quando estivermos tratando do conjunto dos estudantes, sem distinção de gênero, falaremos dos alunos. Por outro lado, se pudéssemos - para identificar o masculino - apenas meninos, pareceria que estávamos antes nos referenciando por uma condição etária do que por um critério institucional. Por essa razão mantivemos o pleonasmo alunos meninos e alunas meninas. 
havendo, na avaliação do inspetor, $48,1 \%$ de meninos e $42,1 \%$ de meninas consideradas medíocres, sendo que, no cômputo do professor, seriam 37,9\% de meninos e $36,8 \%$ de meninas o total dos medíocres em leitura. Para cada um e em todos os distritos, a porcentagem de alunos do sexo masculino qualificados pelo inspetor como bons em leitura é inequivocamente inferior ao percentual que o professor estabelecera sobre os 'seus' bons em leitura. A maior diferença a esse respeito estava posta no distrito de Aveiro, onde apenas 5,8\% dos alunos foram caracterizados como bons pelo inspetor, ao passo que o professor considerava bons $24,8 \%$ dos elementos da amostra.

Observando por distritos, verificamos que, para as boas alunas, manter-se-ia a mesma relação do total da amostra, exceto no que respeita Coimbra e Évora, onde o percentual de boas alunas na habilidade da leitura era maior na avaliação do inspetor do que no cálculo do professor. Especificamente no caso de Coimbra, como podemos constatar na tabela abaixo, havia para o inspetor $28,4 \%$ de boas alunas em leitura, enquanto os professores só conseguiam mapear $17,9 \%$ de alunas que liam bem. Em Évora, há também disparidade nesse critério, posto que seriam 45,2\% de boas alunas em leitura no parecer da inspeção, ao passo que os professores só conseguiam enxergar 23,6\%. Inversamente, também são Coimbra e Évora os únicos distritos nos quais a proporção de alunas tidas por medíocres pelo inspetor é menor do que aquela apresentada pelo professor. Para o caso de Coimbra, de 62,1\% medíocres, de acordo com o relato do professor, haveria, no cômputo da inspeção, apenas $35,8 \%$ de meninas medíocres no quesito da leitura. Em Évora, para aquilo que os professores julgavam ser 36,8\% de alunas medíocres, a inspeção calcula em apenas $25,7 \%$. Havia, entretanto, também coincidências entre o parecer do inspetor e o julgamento dos professores, como é o caso dos bons alunos meninos em leitura no distrito de Portalegre (entre os $21,5 \%$ e os $22,6 \%$ ) e como revelam também as proporções encontradas em Aveiro para as alunas meninas ditas medíocres (que ficavam entre os $34,5 \%$ do inspetor e os $35,7 \%$ do professor).

Tabela 32: Distribuição dos alunos do sexo masculino conforme se achavam em leitura de acordo com o critério do inspetor, por distritos e para o total da amostra. Portugal, 1867

\begin{tabular}{|l|l|l|l|l|l|l|l|l|l|l|l|}
\hline & \multicolumn{9}{|l|}{ Distrito } \\
\hline $\begin{array}{l}\text { Qualifi- } \\
\text { cação do } \\
\text { inspetor } \\
\text { em Leitura }\end{array}$ & Total & Aveiro & Coimbra & $\begin{array}{l}\text { Castello } \\
\text { Branco }\end{array}$ & Guarda & Évora & Lisboa & Portalegre & $\begin{array}{l}\text { Villa } \\
\text { Real }\end{array}$ & \multicolumn{2}{l|}{$\begin{array}{l}\text { Vizeu } \\
\text { Vianna } \\
\text { do } \\
\text { Castello }\end{array}$} \\
\hline Medíocre & $\begin{array}{l}4491 \\
(48.1 \%)\end{array}$ & $\begin{array}{l}351 \\
(46.2 \%)\end{array}$ & $\begin{array}{l}534 \\
(42.9 \%)\end{array}$ & $\begin{array}{l}476 \\
(44.4 \%)\end{array}$ & $\begin{array}{l}403 \\
(51.6 \%)\end{array}$ & $\begin{array}{l}217 \\
(48.1 \\
\%)\end{array}$ & $\begin{array}{l}597 \\
(43.9 \%)\end{array}$ & $\begin{array}{l}214 \\
(45.1 \%)\end{array}$ & $\begin{array}{l}344 \\
(48.9 \%)\end{array}$ & $\begin{array}{l}474 \\
(47.8 \\
\%)\end{array}$ & $\begin{array}{l}881 \\
(58.2 \%)\end{array}$ \\
\hline Suficiente & $\begin{array}{l}3371 \\
(36.0 \%)\end{array}$ & $\begin{array}{l}364 \\
(48.0 \%)\end{array}$ & $\begin{array}{l}439 \\
(35.3 \%)\end{array}$ & $\begin{array}{l}424 \\
(39.6 \%)\end{array}$ & $\begin{array}{l}260 \\
(33.3 \%)\end{array}$ & $\begin{array}{l}167 \\
(36.9 \\
\%)\end{array}$ & $\begin{array}{l}508 \\
(37.4 \%)\end{array}$ & $\begin{array}{l}158 \\
(33.4 \%)\end{array}$ & $\begin{array}{l}215 \\
(30.5 \%)\end{array}$ & $\begin{array}{l}369 \\
(37.3 \\
\%)\end{array}$ & $\begin{array}{l}467 \\
(30.8 \%)\end{array}$ \\
\hline Bom & $\begin{array}{l}1489 \\
(15.9 \%)\end{array}$ & $\begin{array}{l}44 \\
(5.8 \%)\end{array}$ & $\begin{array}{l}271 \\
(21.8 \%)\end{array}$ & $\begin{array}{l}172 \\
(16.0 \%)\end{array}$ & $\begin{array}{l}118 \\
(15.1 \%)\end{array}$ & $\begin{array}{l}68 \\
(15.0 \\
\%)\end{array}$ & $\begin{array}{l}255 \\
(18.7 \%)\end{array}$ & $\begin{array}{l}102 \\
(21.5 \%)\end{array}$ & $\begin{array}{l}145 \\
(20.6 \%)\end{array}$ & $\begin{array}{l}148 \\
(14.9 \\
\%)\end{array}$ & $\begin{array}{l}166 \\
(11 \%)\end{array}$ \\
\hline Total & $\begin{array}{l}9351 \\
(100 \%)\end{array}$ & $\begin{array}{l}759 \\
(100 \%)\end{array}$ & $\begin{array}{l}1244 \\
(100 \%)\end{array}$ & $\begin{array}{l}1072 \\
(100 \%)\end{array}$ & $\begin{array}{l}781 \\
(100 \%)\end{array}$ & $\begin{array}{l}452 \\
(100 \\
\%)\end{array}$ & $\begin{array}{l}1360 \\
(100 \%)\end{array}$ & $\begin{array}{l}474 \\
(100 \%)\end{array}$ & $\begin{array}{l}704 \\
(100 \%)\end{array}$ & $\begin{array}{l}991 \\
(100 \\
\%)\end{array}$ & $\begin{array}{l}1514 \\
(100 \%)\end{array}$ \\
\hline
\end{tabular}


Tabela 33: Distribuição dos alunos do sexo masculino conforme se achavam em leitura de acordo com o critério do professor, por distritos e para o total da amostra. Portugal, 1867

\begin{tabular}{|l|l|l|l|l|l|l|l|l|l|l|l|}
\hline & \multicolumn{9}{|l|}{ Distrito } \\
\hline $\begin{array}{l}\text { Qualifi- } \\
\text { cação do } \\
\text { professor } \\
\text { em Leitura }\end{array}$ & Total & Aveiro & Coimbra & $\begin{array}{l}\text { Castello } \\
\text { Branco }\end{array}$ & Guarda & Évora & Lisboa & Portalegre & $\begin{array}{l}\text { Villa } \\
\text { Real }\end{array}$ & \multicolumn{2}{l|}{$\begin{array}{l}\text { Vizeu } \\
\text { Vianna } \\
\text { do } \\
\text { Castello }\end{array}$} \\
\hline Medíocre & $\begin{array}{l}6173 \\
(37.9 \%)\end{array}$ & $\begin{array}{l}545 \\
(36.3 \\
\%)\end{array}$ & $\begin{array}{l}741 \\
(40.4 \%)\end{array}$ & $\begin{array}{l}621 \\
(40.4 \%)\end{array}$ & $\begin{array}{l}601 \\
(36.3 \%)\end{array}$ & $\begin{array}{l}306 \\
(41.3 \%)\end{array}$ & $\begin{array}{l}996 \\
(36.8 \%)\end{array}$ & $\begin{array}{l}294 \\
(37.2 \%)\end{array}$ & $\begin{array}{l}473 \\
(36.7 \%)\end{array}$ & $\begin{array}{l}654 \\
(39.2 \\
\%)\end{array}$ & $\begin{array}{l}942 \\
(36.5 \%)\end{array}$ \\
\hline Suficiente & $\begin{array}{l}6065 \\
(37.2 \%)\end{array}$ & $\begin{array}{l}585 \\
(38.9 \\
\%)\end{array}$ & $\begin{array}{l}670 \\
(36.5 \%)\end{array}$ & $\begin{array}{l}494 \\
(32.1 \%)\end{array}$ & $\begin{array}{l}618 \\
(37.3 \%)\end{array}$ & $\begin{array}{l}269 \\
(36.3 \%)\end{array}$ & $\begin{array}{l}1015 \\
(37.6 \%)\end{array}$ & $\begin{array}{l}317 \\
(40.1 \%)\end{array}$ & $\begin{array}{l}446 \\
(34.6 \%)\end{array}$ & $\begin{array}{l}603 \\
(36.2 \\
\%)\end{array}$ & $\begin{array}{l}1048 \\
(40.6 \%)\end{array}$ \\
\hline Bom & $\begin{array}{l}4067 \\
(24.9 \%)\end{array}$ & $\begin{array}{l}373 \\
(24.8 \\
\%)\end{array}$ & $\begin{array}{l}423 \\
(23.1 \%)\end{array}$ & $\begin{array}{l}422 \\
(27.5 \%)\end{array}$ & $\begin{array}{l}436 \\
(26.4 \%)\end{array}$ & $\begin{array}{l}166 \\
(22.4 \%)\end{array}$ & $\begin{array}{l}693 \\
(25.6 \%)\end{array}$ & $\begin{array}{l}179 \\
(22.6 \%)\end{array}$ & $\begin{array}{l}371 \\
(28.7 \%)\end{array}$ & $\begin{array}{l}411 \\
(24.6 \\
\%)\end{array}$ & $\begin{array}{l}593 \\
(22.9 \%)\end{array}$ \\
\hline Total & $\begin{array}{l}16305 \\
(100 \%)\end{array}$ & $\begin{array}{l}1503 \\
(100 \\
\%)\end{array}$ & $\begin{array}{l}1834 \\
(100 \%)\end{array}$ & $\begin{array}{l}1537 \\
(100 \%)\end{array}$ & $\begin{array}{l}1655 \\
(100 \%)\end{array}$ & $\begin{array}{l}741 \\
(100 \%)\end{array}$ & $\begin{array}{l}2704 \\
(100 \%)\end{array}$ & $\begin{array}{l}790 \\
(100 \%)\end{array}$ & $\begin{array}{l}1290 \\
(100 \%)\end{array}$ & $\begin{array}{l}1668 \\
(100 \\
\%)\end{array}$ & $\begin{array}{l}2583 \\
(100 \%)\end{array}$ \\
\hline
\end{tabular}

Tabela 34: Distribuição dos alunos do sexo feminino conforme se achavam em leitura de acordo como o critério do inspetor, por distritos e para o total da amostra. Portugal, 1867

\begin{tabular}{|c|c|c|c|c|c|c|c|c|c|c|c|}
\hline \multirow[b]{2}{*}{$\begin{array}{l}\text { Qualifi- } \\
\text { caçāo do } \\
\text { inspetor } \\
\text { em Leitura }\end{array}$} & \multirow[b]{2}{*}{ Total } & \multicolumn{10}{|c|}{ DistRITO } \\
\hline & & Aveiro & Coimbra & $\begin{array}{l}\text { Castello } \\
\text { Branco }\end{array}$ & Guarda & Évora & Lisboa & Portalegre & $\begin{array}{l}\text { Villa } \\
\text { Real }\end{array}$ & Vizeu & $\begin{array}{l}\text { Vianna } \\
\text { do } \\
\text { Castello }\end{array}$ \\
\hline Medíocre & $\begin{array}{l}838 \\
(42.1 \%)\end{array}$ & $\begin{array}{l}60 \\
(34.5 \%)\end{array}$ & $\begin{array}{l}19 \\
(35.8 \%)\end{array}$ & $\begin{array}{l}117 \\
(39.5 \%)\end{array}$ & $\begin{array}{l}81 \\
(56.2 \%)\end{array}$ & $\begin{array}{l}67 \\
(25.7 \%)\end{array}$ & $\begin{array}{l}270 \\
(43.1 \%)\end{array}$ & $\begin{array}{l}78 \\
(55.3 \%)\end{array}$ & $\begin{array}{l}40 \\
(34.8 \%)\end{array}$ & $\begin{array}{l}31 \\
(51.6 \%)\end{array}$ & $\begin{array}{l}75 \\
(62.5 \%)\end{array}$ \\
\hline Suficiente & $\begin{array}{l}741 \\
(37.2 \%)\end{array}$ & $\begin{array}{l}98 \\
(56.3 \%) \\
\end{array}$ & $\begin{array}{l}19 \\
(35.8 \%) \\
\end{array}$ & $\begin{array}{l}119 \\
(40.2 \%) \\
\end{array}$ & $\begin{array}{l}41 \\
(28.5 \%) \\
\end{array}$ & $\begin{array}{l}76 \\
(29.1 \%) \\
\end{array}$ & $\begin{array}{l}241 \\
(38.5 \%)\end{array}$ & $\begin{array}{l}44 \\
(31.2 \%) \\
\end{array}$ & $\begin{array}{l}39 \\
(33.9 \%)\end{array}$ & $\begin{array}{l}22 \\
(36.7 \%) \\
\end{array}$ & $\begin{array}{l}42 \\
(35.0 \%) \\
\end{array}$ \\
\hline Bom & $\begin{array}{l}411 \\
(20.7 \%)\end{array}$ & $\begin{array}{l}16 \\
(9.2 \%)\end{array}$ & $\begin{array}{l}15 \\
(28.4 \%)\end{array}$ & $\begin{array}{l}60 \\
(20.3 \%) \\
\end{array}$ & \begin{tabular}{l|}
22 \\
$(15.3 \%)$
\end{tabular} & \begin{tabular}{|l|}
118 \\
$(45.2 \%)$
\end{tabular} & $\begin{array}{l}15 \\
(18.4 \%)\end{array}$ & $\begin{array}{l}19 \\
(13.5 \%)\end{array}$ & $\begin{array}{l}36 \\
(31.3 \%)\end{array}$ & $\begin{array}{l}7 \\
(11.7 \%)\end{array}$ & $\begin{array}{l}3 \\
(2.5 \%) \\
\end{array}$ \\
\hline Total & $\begin{array}{l}1990 \\
(100 \%)\end{array}$ & $\begin{array}{l}174 \\
(100 \%)\end{array}$ & $\begin{array}{l}53 \\
(100 \%)\end{array}$ & $\begin{array}{l}296 \\
(100 \%)\end{array}$ & $\begin{array}{l}144 \\
(100 \%)\end{array}$ & $\begin{array}{l}261 \\
(100 \%)\end{array}$ & $\begin{array}{l}626 \\
(100 \%)\end{array}$ & $\begin{array}{l}141 \\
(100 \%)\end{array}$ & $\begin{array}{l}115 \\
(100 \%)\end{array}$ & $\begin{array}{l}60 \\
(100 \%)\end{array}$ & $\begin{array}{l}120 \\
(100 \%)\end{array}$ \\
\hline
\end{tabular}

Tabela 35: Distribuição dos alunos do sexo feminino conforme se achavam em leitura de acordo com o critério do professor, por distrito e para o total da amostra. Portugal, 1867

\begin{tabular}{|c|c|c|c|c|c|c|c|c|c|c|c|}
\hline \multirow[b]{2}{*}{$\begin{array}{l}\text { Qualifi- } \\
\text { caçáo do } \\
\text { professor } \\
\text { em Leitura }\end{array}$} & \multirow[b]{2}{*}{ Total } & \multicolumn{10}{|c|}{ DistRITO } \\
\hline & & Aveiro & Coimbra & $\begin{array}{l}\text { Castello } \\
\text { Branco }\end{array}$ & Guarda & Évora & Lisboa & Portalegre & $\begin{array}{l}\text { Villa } \\
\text { Real }\end{array}$ & Vizeu & $\begin{array}{l}\text { Vianna } \\
\text { do } \\
\text { Castello }\end{array}$ \\
\hline Medíocre & $\begin{array}{l}933 \\
(36.8 \%)\end{array}$ & $\begin{array}{l}75 \\
(35.7 \%)\end{array}$ & $\begin{array}{l}87 \\
(62.1 \%)\end{array}$ & $\begin{array}{l}114 \\
(26.5 \%)\end{array}$ & $\begin{array}{l}71 \\
(33.2 \%)\end{array}$ & $\begin{array}{l}78 \\
(36.8 \%)\end{array}$ & $\begin{array}{l}240 \\
(37.9 \%)\end{array}$ & $\begin{array}{l}110 \\
(44.0 \%)\end{array}$ & $\begin{array}{l}48 \\
(33.1 \%)\end{array}$ & $\begin{array}{l}30 \\
(24.8 \%)\end{array}$ & $\begin{array}{l}80 \\
(44.2 \%)\end{array}$ \\
\hline Suficiente & $\begin{array}{l}897 \\
(35.3 \%)\end{array}$ & $\begin{array}{l}69 \\
(32.9 \%)\end{array}$ & $\begin{array}{l}28 \\
(20.0 \%)\end{array}$ & $\begin{array}{l}195 \\
(45.2 \%)\end{array}$ & $\begin{array}{l}77 \\
(36.0 \%)\end{array}$ & $\begin{array}{l}84 \\
(39.6 \%)\end{array}$ & $\begin{array}{l}215 \\
(33.9 \%)\end{array}$ & $\begin{array}{l}73 \\
(29.2 \%)\end{array}$ & $\begin{array}{l}48 \\
(33.1 \%)\end{array}$ & $\begin{array}{l}42 \\
(34.7 \%)\end{array}$ & $\begin{array}{l}66 \\
(36.5 \%)\end{array}$ \\
\hline Bom & $\begin{array}{l}708 \\
(27.9 \%)\end{array}$ & $\begin{array}{l}66 \\
(31.4 \%)\end{array}$ & $\begin{array}{l}25 \\
(17.9 \%)\end{array}$ & $\begin{array}{l}122 \\
(28.3 \%)\end{array}$ & $\begin{array}{l}66 \\
(30.8 \%)\end{array}$ & $\begin{array}{l}50 \\
(23.6 \%)\end{array}$ & $\begin{array}{l}179 \\
(28.2 \%)\end{array}$ & $\begin{array}{l}67 \\
(26.8 \%)\end{array}$ & $\begin{array}{l}49 \\
(33.8 \%)\end{array}$ & $\begin{array}{l}49 \\
(40.5 \%)\end{array}$ & $\begin{array}{l}35 \\
(19.3 \%)\end{array}$ \\
\hline Total & $\begin{array}{l}2538 \\
(100 \%)\end{array}$ & $\begin{array}{l}210 \\
(100 \%)\end{array}$ & $\begin{array}{l}140 \\
(100 \%)\end{array}$ & $\begin{array}{l}431 \\
(100 \%)\end{array}$ & $\begin{array}{l}214 \\
(100 \%)\end{array}$ & $\begin{array}{l}212 \\
(100 \%)\end{array}$ & $\begin{array}{l}634 \\
(100 \%)\end{array}$ & $\begin{array}{l}250 \\
(100 \%)\end{array}$ & $\begin{array}{l}145 \\
(100 \%)\end{array}$ & $\begin{array}{l}121 \\
(100 \%)\end{array}$ & $\begin{array}{l}181 \\
(100 \%)\end{array}$ \\
\hline
\end{tabular}


Quanto à aquisição da escrita, verifica-se que o retrato apontado pelo professor está mais próximo da apreciação efetuada acerca da leitura. Já o quadro da inspeção revela que, naquela circunstância, nem todos os alunos que escreviam eram capazes de ler o escrito. A rigidez e o elevado nível de exigência e expectativa demasiada entre os professores de Coimbra, mais uma vez, se notabilizam, posto que, comparativamente, o registro do inspetor detecta um número maior de meninos considerados bons e suficientes ao escrever, acompanhados por uma diminuição do índice de alunos caracterizados como medíocres. A tendência, porém, persiste não sendo essa. Para a amostragem de todo o país, a porcentagem de alunos do sexo masculino considerados bons em escrita segundo o inspetor é menor do que o percentual expresso pelo professor. Inversamente, aumenta em média, no caso das anotações da inspeção, a proporção dos alunos qualificados como medíocres. No caso de Portalegre, dá-se por sua vez a ocorrência de praticamente metade dos alunos serem classificados pelo inspetor como "suficientes" na habilidade da escrita, contrastando com a outra quase metade, que seria a dos "medíocres". Para o conjunto da amostra, professores e inspetores aproximariam suas avaliações basicamente no atributo concernente ao conjunto de alunos tomados como suficientes. Em Vianna do Castello, o percentual do professor equivale praticamente ao do inspetor no que diz respeito à avaliação dos considerados bons alunos perante a capacidade da escrita, havendo, entretanto, no mesmo distrito, significativa variação quanto àqueles que eram adjetivados como suficientes e medíocres. Em Aveiro, Portalegre e Viseu, a quantificação dos alunos julgados medíocres em escrita foi semelhante entre os registros dos professores e os dos inspetores.

Tabela 36: Distribuição dos alunos do sexo masculino conforme se achavam em escrita de acordo com o critério do inspetor, por distritos e para o total da amostra. Portugal, 1867

\begin{tabular}{|c|c|c|c|c|c|c|c|c|c|c|c|}
\hline & & \multicolumn{10}{|c|}{ Distrito } \\
\hline $\begin{array}{l}\text { Qualifi- } \\
\text { cação do } \\
\text { inspetor } \\
\text { em Escrita }\end{array}$ & Total & Aveiro & Coimbra & $\begin{array}{l}\text { Castello } \\
\text { Branco }\end{array}$ & Guarda & Évora & Lisboa & Portalegre & $\begin{array}{l}\text { Villa } \\
\text { Real }\end{array}$ & Vizeu & $\begin{array}{l}\text { Vianna } \\
\text { do } \\
\text { Castello }\end{array}$ \\
\hline Medíocre & $\begin{array}{l}2572 \\
(44.2 \%)\end{array}$ & $\begin{array}{l}138 \\
(38.5 \\
\%)\end{array}$ & $\begin{array}{l}287 \\
(37.2 \%)\end{array}$ & $\begin{array}{l}207 \\
(34.4 \%)\end{array}$ & $\begin{array}{l}173 \\
(49.1 \%)\end{array}$ & $\begin{array}{l}122 \\
(43.3 \\
\%)\end{array}$ & $\begin{array}{l}602 \\
(47.7 \%)\end{array}$ & $\begin{array}{l}154 \\
(46.7 \%)\end{array}$ & $\begin{array}{l}177 \\
(56.0 \%)\end{array}$ & $\begin{array}{l}227 \\
(38.5 \%)\end{array}$ & $\begin{array}{l}485 \\
(50.9 \%)\end{array}$ \\
\hline Suficiente & $\begin{array}{l}2393 \\
(41.2 \%)\end{array}$ & $\begin{array}{l}191 \\
(53.4 \\
\%)\end{array}$ & $\begin{array}{l}308 \\
(39.9 \%)\end{array}$ & $\begin{array}{l}301 \\
(50.0 \%)\end{array}$ & $\begin{array}{l}127 \\
(36.1 \%)\end{array}$ & $\begin{array}{l}132 \\
(46.8 \\
\%)\end{array}$ & $\begin{array}{l}491 \\
(38.9 \%)\end{array}$ & $\begin{array}{l}158 \\
(47.9 \%)\end{array}$ & $\begin{array}{l}104 \\
(32.9 \%)\end{array}$ & $\begin{array}{l}268 \\
(45.4 \%)\end{array}$ & $\begin{array}{l}313 \\
(32.9 \%)\end{array}$ \\
\hline Bom & $\begin{array}{l}851 \\
(14.6 \%)\end{array}$ & $\begin{array}{l}29 \\
(8.1 \\
\%)\end{array}$ & $\begin{array}{l}177 \\
(22.9 \%)\end{array}$ & $\begin{array}{l}94 \\
(15.6 \%)\end{array}$ & $\begin{array}{l}52 \\
(14.8 \%)\end{array}$ & $\begin{array}{l}28 \\
(9.9 \\
\%)\end{array}$ & $\begin{array}{l}169 \\
(13.4 \%)\end{array}$ & $\begin{array}{l}18 \\
(5.4 \%)\end{array}$ & $\begin{array}{l}35 \\
(11.1 \%)\end{array}$ & $\begin{array}{l}95 \\
(16.1 \%)\end{array}$ & $\begin{array}{l}154 \\
(16.2 \%)\end{array}$ \\
\hline Total & $\begin{array}{l}5816 \\
(100 \%)\end{array}$ & $\begin{array}{l}358 \\
(100 \\
\%)\end{array}$ & $\begin{array}{l}772 \\
(100 \%)\end{array}$ & $\begin{array}{l}602 \\
(100 \%)\end{array}$ & $\begin{array}{l}352 \\
(100 \%)\end{array}$ & $\begin{array}{l}282 \\
(100 \\
\%)\end{array}$ & $\begin{array}{l}1262 \\
(100 \%)\end{array}$ & $\begin{array}{l}330 \\
(100 \%)\end{array}$ & $\begin{array}{l}316 \\
(100 \%)\end{array}$ & $\begin{array}{l}590 \\
(100 \%)\end{array}$ & $\begin{array}{l}952 \\
(100 \%)\end{array}$ \\
\hline
\end{tabular}


Tabela 37: Distribuição dos alunos do sexo masculino conforme se achavam em Escrita de acordo com o critério do professor, por distritos e para o total da amostra.

Portugal, 1867

\begin{tabular}{|c|c|c|c|c|c|c|c|c|c|c|c|}
\hline & & DISTRIT & & & & & & & & & \\
\hline $\begin{array}{l}\text { Qualifi- } \\
\text { cação do } \\
\text { professor } \\
\text { em Escrita }\end{array}$ & Total & Aveiro & Coimbra & $\begin{array}{l}\text { Castello } \\
\text { Branco }\end{array}$ & Guarda & Évora & Lisboa & Portalegre & $\begin{array}{l}\text { Villa } \\
\text { Real }\end{array}$ & Vizeu & $\begin{array}{l}\text { Vianna } \\
\text { do } \\
\text { Castello }\end{array}$ \\
\hline Suficiente & $\begin{array}{l}4380 \\
(40.9 \%)\end{array}$ & $\begin{array}{l}424 \\
(45.7 \%)\end{array}$ & $\begin{array}{l}416 \\
(35.2 \%)\end{array}$ & $\begin{array}{l}334 \\
(40.2 \%)\end{array}$ & $\begin{array}{l}403 \\
(43.8 \%)\end{array}$ & $\begin{array}{l}182 \\
(39.7 \\
\%)\end{array}$ & $\begin{array}{l}901 \\
(40.2 \\
\%)\end{array}$ & $\begin{array}{l}183 \\
(35.7 \%)\end{array}$ & \begin{tabular}{|l|}
315 \\
$(40.1 \%)$
\end{tabular} & $\begin{array}{l}397 \\
(39.5 \%)\end{array}$ & $\begin{array}{l}825 \\
(44.6 \%)\end{array}$ \\
\hline Medíocre & $\begin{array}{l}4055 \\
(37.8 \%)\end{array}$ & $\begin{array}{l}352 \\
(37.9 \%)\end{array}$ & $\begin{array}{l}571 \\
(48.2 \%)\end{array}$ & $\begin{array}{l}251 \\
(30.3 \%)\end{array}$ & $\begin{array}{l}325 \\
(35.3 \%)\end{array}$ & $\begin{array}{l}174 \\
(37.9 \\
\%)\end{array}$ & $\begin{array}{l}761 \\
(33.9 \\
\%)\end{array}$ & $\begin{array}{l}235 \\
(45.9 \%)\end{array}$ & $\begin{array}{l}252 \\
(32.1 \%)\end{array}$ & $\begin{array}{l}384 \\
(38.3 \%)\end{array}$ & $\begin{array}{l}750 \\
(40.6 \%)\end{array}$ \\
\hline Bom & $\begin{array}{l}2279 \\
(21.3 \%)\end{array}$ & $\begin{array}{l}152 \\
(16.4 \%)\end{array}$ & $\begin{array}{l}197 \\
(16.6 \%)\end{array}$ & $\begin{array}{l}245 \\
(29.5 \%)\end{array}$ & $\begin{array}{l}192 \\
(20.9 \%)\end{array}$ & $\begin{array}{l}103 \\
(22.4 \\
\%)\end{array}$ & $\begin{array}{l}582 \\
(25.9 \\
\%)\end{array}$ & $\begin{array}{l}94 \\
(18.4 \%)\end{array}$ & $\begin{array}{l}218 \\
(27.8 \%)\end{array}$ & $\begin{array}{l}223 \\
(22.2 \%)\end{array}$ & $\begin{array}{l}273 \\
(14.8 \%)\end{array}$ \\
\hline Total & $\begin{array}{l}10714 \\
(100 \%)\end{array}$ & $\begin{array}{l}928 \\
(100 \%)\end{array}$ & $\begin{array}{l}1184 \\
(100 \%)\end{array}$ & $\begin{array}{l}830 \\
(100 \%)\end{array}$ & $\begin{array}{l}920 \\
(100 \%)\end{array}$ & $\begin{array}{l}459 \\
(100 \\
\%)\end{array}$ & $\begin{array}{l}2244 \\
(100 \\
\%)\end{array}$ & $\begin{array}{l}512 \\
(100 \%)\end{array}$ & $\begin{array}{l}785 \\
(100 \%)\end{array}$ & $\begin{array}{l}1004 \\
(100 \%)\end{array}$ & $\begin{array}{l}1848 \\
(100 \%)\end{array}$ \\
\hline
\end{tabular}

Também no caso das alunas meninas, verifica-se a exceção do distrito de Coimbra como aquele em que notoriamente a avaliação do professor era mais rígida do que a do inspetor. Para toda a amostra e por distritos, a proporção de alunas consideradas boas em escrita pelo inspetor era menor do que o conjunto arrolado por parte do professor sobre suas boas alunas - excetuados os casos de Coimbra (com 26,9\% e $8,6 \%$ de alunas consideradas boas por inspetor e professor respectivamente) e Évora (com $36,7 \%$ e $21 \%$ para respectivamente inspetor e professor). Entretanto, no quadro geral, o percentual de alunas tidas por suficientes aumenta na avaliação dos inspetores, se o compararmos àquela avaliação efetuada pelos próprios professores $-46,4 \%$ e $38,5 \%$ respectivamente. Em geral, verifica-se também uma certa elevação da porcentagem de alunas medíocres quanto à habilidade da escrita - para os inspetores, elas constituíam 39,8\% e para os professores, somavam 33,7\%. Aliás, a avaliação da competência intelectual da escrita apresenta-se sob variados critérios, muitas vezes díspares entre si, em algumas regióes do país: Vianna do Castello destaca-se por ter um percentual de 77,6\% de alunas medíocres - de acordo com o parecer da inspeção - em um universo onde era praticamente inexistente o número de alunas boas. Para o mesmo distrito, os professores pensam completamente diferente dos inspetores. Segundo esse professorado, haveria em Vianna um contingente de $13,6 \%$ de alunas boas em escrita, e 86,4\% igualmente divididas entre suficientes e medíocres. 
Tabela 38: Distribuição dos alunos do sexo feminino conforme se achavam em Escrita de acordo com o critério do inspetor, por distritos e para o total da amostra. Portugal, 1867

\begin{tabular}{|c|c|c|c|c|c|c|c|c|c|c|c|}
\hline \multirow[b]{2}{*}{$\begin{array}{l}\text { Qualifi- } \\
\text { caçāo do } \\
\text { inspetor } \\
\text { em Escrita }\end{array}$} & \multirow[b]{2}{*}{ Total } & \multicolumn{10}{|c|}{ Distrito } \\
\hline & & Aveiro & Coimbra & $\begin{array}{l}\text { Castello } \\
\text { Branco }\end{array}$ & Guarda & Évora & Lisboa & Portalegre & $\begin{array}{l}\text { Villa } \\
\text { Real }\end{array}$ & Vizeu & $\begin{array}{l}\text { Vianna } \\
\text { do } \\
\text { Castello }\end{array}$ \\
\hline Suficiente & $\begin{array}{l}544 \\
(46.4 \%)\end{array}$ & $\begin{array}{l}26 \\
(50.0 \%)\end{array}$ & $\begin{array}{l}20 \\
(38.5 \%)\end{array}$ & $\begin{array}{l}63 \\
(63.6 \%)\end{array}$ & $\begin{array}{l}24 \\
(43.6 \%)\end{array}$ & $\begin{array}{l}64 \\
(35.6 \%)\end{array}$ & $\begin{array}{l}277 \\
(52.3 \%)\end{array}$ & $\begin{array}{l}32 \\
(39.6 \%)\end{array}$ & $\begin{array}{l}18 \\
(32.7 \%)\end{array}$ & $\begin{array}{l}9 \\
(47.4 \%)\end{array}$ & $\begin{array}{l}11 \\
(22.4 \%)\end{array}$ \\
\hline Medíocre & $\begin{array}{l}467 \\
(39.8 \%)\end{array}$ & $\begin{array}{l}24 \\
(46.2 \%)\end{array}$ & $\begin{array}{l}18 \\
(34.6 \%)\end{array}$ & $\begin{array}{l}26 \\
(26.3 \%)\end{array}$ & $\begin{array}{l}24 \\
(43.6 \%)\end{array}$ & $\begin{array}{l}50 \\
(27.7 \%)\end{array}$ & $\begin{array}{l}216 \\
(40.7 \%)\end{array}$ & $\begin{array}{l}33 \\
(40.7 \%)\end{array}$ & $\begin{array}{l}30 \\
(54.5 \%)\end{array}$ & $\begin{array}{l}8 \\
(42.1 \%)\end{array}$ & $\begin{array}{l}38 \\
(77.6 \%)\end{array}$ \\
\hline Bom & $\begin{array}{l}161 \\
(13.8 \%)\end{array}$ & $\begin{array}{l}2 \\
(3.8 \%)\end{array}$ & $\begin{array}{l}14 \\
(26.9 \%)\end{array}$ & $\begin{array}{l}10 \\
(10.1 \%)\end{array}$ & $\begin{array}{l}7 \\
(12.8 \%)\end{array}$ & $\begin{array}{l}66 \\
(36.7 \%)\end{array}$ & $\begin{array}{l}37 \\
(7.0 \%)\end{array}$ & $\begin{array}{l}16 \\
(19.7 \%)\end{array}$ & $\begin{array}{l}7 \\
(12.7 \%)\end{array}$ & $\begin{array}{l}2 \\
(10.5 \%)\end{array}$ & $\begin{array}{l}0 \\
(0.0 \%)\end{array}$ \\
\hline Total & $\begin{array}{l}1172 \\
(100 \%)\end{array}$ & $\begin{array}{l}52 \\
(100 \%)\end{array}$ & $\begin{array}{l}52 \\
(100 \%)\end{array}$ & $\begin{array}{l}99 \\
(100 \%)\end{array}$ & $\begin{array}{l}55 \\
(100 \%)\end{array}$ & $\begin{array}{l}180 \\
(100 \%)\end{array}$ & $\begin{array}{l}530 \\
(100 \%)\end{array}$ & $\begin{array}{l}81 \\
(100 \%)\end{array}$ & $\begin{array}{l}55 \\
(100 \%)\end{array}$ & $\begin{array}{l}19 \\
(100 \%)\end{array}$ & $\begin{array}{l}49 \\
(100 \%)\end{array}$ \\
\hline
\end{tabular}

Tabela 39: Distribuição dos alunos do sexo feminino conforme se achavam em Escrita de acordo com o critério do professor, por distritos e para o total da amostra. Portugal, 1867

\begin{tabular}{|c|c|c|c|c|c|c|c|c|c|c|c|}
\hline \multirow[b]{2}{*}{$\begin{array}{l}\text { Qualifi- } \\
\text { cação do } \\
\text { professor } \\
\text { em Escrita }\end{array}$} & \multirow[b]{2}{*}{ Total } & \multicolumn{10}{|c|}{ DistRITO } \\
\hline & & Aveiro & Coimbra & $\begin{array}{l}\text { Castello } \\
\text { Branco }\end{array}$ & Guarda & Évora & Lisboa & Portalegre & $\begin{array}{l}\text { Villa } \\
\text { Real }\end{array}$ & Vizeu & $\begin{array}{l}\text { Vianna } \\
\text { do } \\
\text { Castello }\end{array}$ \\
\hline Suficiente & $\begin{array}{l}588 \\
(38.5 \%)\end{array}$ & $\begin{array}{l}47 \\
(39.5 \%)\end{array}$ & $\begin{array}{l}14 \\
(40.0 \%)\end{array}$ & $\begin{array}{l}64 \\
(39.3 \%)\end{array}$ & \begin{tabular}{|l|}
56 \\
$(57.1 \%)$ \\
\end{tabular} & \begin{tabular}{|l|}
78 \\
$(54.5 \%)$ \\
\end{tabular} & $\begin{array}{l}195 \\
(34.1 \%)\end{array}$ & $\begin{array}{l}59 \\
(31.7 \%)\end{array}$ & \begin{tabular}{|l|}
29 \\
$(34.5 \%)$ \\
\end{tabular} & $\begin{array}{l}11 \\
(22.0 \%) \\
\end{array}$ & $\begin{array}{l}35 \\
(43.2 \%)\end{array}$ \\
\hline Medíocre & $\begin{array}{l}516 \\
(33.7 \%) \\
\end{array}$ & $\begin{array}{l}35 \\
(29.4 \%)\end{array}$ & $\begin{array}{l}18 \\
(51.4 \%)\end{array}$ & $\begin{array}{l}47 \\
(28.8 \%) \\
\end{array}$ & \begin{tabular}{|l|}
19 \\
$(19.4 \%)$ \\
\end{tabular} & \begin{tabular}{|l|}
35 \\
$(24.5 \%)$ \\
\end{tabular} & \begin{tabular}{l|}
196 \\
$(34.3 \%)$
\end{tabular} & $\begin{array}{l}86 \\
(46.2 \%)\end{array}$ & \begin{tabular}{|l}
30 \\
$(35.7 \%)$ \\
\end{tabular} & $\begin{array}{l}15 \\
(30.0 \%) \\
\end{array}$ & $\begin{array}{l}35 \\
(43.2 \%)\end{array}$ \\
\hline Bom & $\begin{array}{l}426 \\
(27.8 \%)\end{array}$ & $\begin{array}{l}37 \\
(31.1 \%)\end{array}$ & $\begin{array}{l}3 \\
(8.6 \%)\end{array}$ & $\begin{array}{l}52 \\
(31.9 \%)\end{array}$ & \begin{tabular}{|l|}
23 \\
$(23.5 \%)$ \\
\end{tabular} & \begin{tabular}{|l|}
30 \\
$(21.0 \%)$ \\
\end{tabular} & $\begin{array}{l}180 \\
(31.6 \%)\end{array}$ & $\begin{array}{l}41 \\
(22.1 \%)\end{array}$ & $\begin{array}{l}25 \\
(29.8 \%) \\
\end{array}$ & $\begin{array}{l}24 \\
(48.0 \%)\end{array}$ & $\begin{array}{l}11 \\
(13.6 \%)\end{array}$ \\
\hline Total & $\begin{array}{l}1530 \\
(100 \%)\end{array}$ & $\begin{array}{l}119 \\
(100 \%)\end{array}$ & $\begin{array}{l}35 \\
(100 \%)\end{array}$ & $\begin{array}{l}163 \\
(100 \%)\end{array}$ & $\begin{array}{l}98 \\
(100 \%)\end{array}$ & \begin{tabular}{|l|}
143 \\
$(100 \%)$
\end{tabular} & $\begin{array}{l}571 \\
(100 \%)\end{array}$ & $\begin{array}{l}186 \\
(100 \%)\end{array}$ & $\begin{array}{l}84 \\
(100 \%)\end{array}$ & $\begin{array}{l}50 \\
(100 \%)\end{array}$ & $\begin{array}{l}81 \\
(100 \%)\end{array}$ \\
\hline
\end{tabular}

Através da consulta aos Relatórios, verificam-se, de imediato, determinadas distorções pontuais, como é o caso da escola de São Bartolomeu em Coimbra, dirigida pela professora Perpétua Serra. Consta do formulário que, das 90 meninas ali matriculadas, 22 estariam presentes à visita do inspetor. Porém, quando da classificação por matérias, apenas 3 meninas foram avaliadas em leitura; em escrita, foram 16. Os dados revelam, então, que, provavelmente, teria havido mais de uma visita do inspetor para a elaboração do Relatório. Alguns inspetores, com o fito de elucidar e melhor explicitar os dados nele contidos, fazem algumas anotações suplementares no formulário impresso. Ao recorrer a tal recurso, o inspetor do concelho de Mora, em Évora, tece o seguinte comentário, talvez para justificar a apreciação negativa que fizera acerca da capacidade dos estudantes para a escrita: "os outros 15 não escrevem por não haver lousas."271

Por sua vez, o inspetor responsável pelo concelho de Alenquer dirá, ao pé da página, sobre as suas classes de leitura, especificamente sobre aquela dirigida pelo professor António de Mattos, em Pereiro, que não fizera corretamente os mapas: "não

${ }^{271} M R$ 1050. Distrito: Évora; Concelho: Mora. 
foi possível averiguar-se porque o professor incorporou-os, não compreendendo os quesitos e estando inexatas as respostas a alguns dos mesmos, e a escrituração pouco podia esclarecer." ${ }^{772}$ Também o Relatório concernente ao concelho de Cintra menciona a dificuldade que alguns professores teriam manifestado para o preenchimento apropriado dos mapas de inspeção. Acopladas a este obstáculo, viriam outras dificuldades, quanto à própria lisura do registro. Sobre a escola de Queluz, pondera assim o inspetor: "vão também classificadas algumas escritas de alunos que não estavam presentes. Apesar das escritas que vi, e o professor me afirmou serem dos discípulos da escola noturna, tenho razões para duvidar que o curso noturno fosse tão frequentado. A escola noturna havia sido encerrada no fim de março." 273

Também em contas, a porcentagem de alunos do sexo masculino bons segundo o inspetor foi menor do que aquela proveniente do critério do professor, para toda a amostra e nos diferentes distritos, à exceção da Guarda, onde ambas as avaliações consideraram uma média de aproximadamente $25 \%$ para os meninos classificados como bons alunos.

Tabela 40: Distribuição dos alunos do sexo masculino conforme se achavam em Contas de acordo com o critério do inspetor, por distritos e para o total da amostra. Portugal, 1867

\begin{tabular}{|c|c|c|c|c|c|c|c|c|c|c|c|}
\hline \multirow[b]{2}{*}{$\begin{array}{l}\text { Qualifi- } \\
\text { caçāo do } \\
\text { inspetor } \\
\text { em Contas }\end{array}$} & \multirow[b]{2}{*}{ Total } & \multicolumn{10}{|c|}{ Distrito } \\
\hline & & Aveiro & Coimbra & $\begin{array}{l}\text { Castello } \\
\text { Branco }\end{array}$ & Guarda & Évora & Lisboa & Portalegre & $\begin{array}{l}\text { Villa } \\
\text { Real }\end{array}$ & Vizeu & $\begin{array}{l}\text { Vianna } \\
\text { do } \\
\text { Castello }\end{array}$ \\
\hline Medíocre & $\begin{array}{l}2291 \\
(44.3 \%)\end{array}$ & $\begin{array}{l}89 \\
(32.5 \%) \\
\end{array}$ & $\begin{array}{l}220 \\
(40.6 \%)\end{array}$ & $\begin{array}{l}240 \\
(38.8 \%) \\
\end{array}$ & \begin{tabular}{|l|}
140 \\
$(44.2 \%)$ \\
\end{tabular} & $\begin{array}{l}79 \\
(36.1 \%)\end{array}$ & $\begin{array}{l}493 \\
(43.6 \%)\end{array}$ & $\begin{array}{l}137 \\
(51.7 \%)\end{array}$ & $\begin{array}{l}159 \\
(44.2 \%)\end{array}$ & $\begin{array}{l}304 \\
(45.3 \%)\end{array}$ & $\begin{array}{l}430 \\
(55.5 \%)\end{array}$ \\
\hline Suficiente & $\begin{array}{l}2013 \\
(38.9 \%)\end{array}$ & $\begin{array}{l}171 \\
(62.4 \%)\end{array}$ & $\begin{array}{l}221 \\
(40.8 \%)\end{array}$ & $\begin{array}{l}264 \\
(42.7 \%)\end{array}$ & \begin{tabular}{|l|}
91 \\
$(28.7 \%)$
\end{tabular} & $\begin{array}{l}117 \\
(53.4 \%)\end{array}$ & $\begin{array}{l}391 \\
(34.6 \%)\end{array}$ & $\begin{array}{l}101 \\
(38.1 \%)\end{array}$ & $\begin{array}{l}126 \\
(35.0 \%)\end{array}$ & $\begin{array}{l}275 \\
(41.0 \%)\end{array}$ & $\begin{array}{l}256 \\
(33.0 \%)\end{array}$ \\
\hline Bom & $\begin{array}{l}868 \\
(16.8 \%)\end{array}$ & $\begin{array}{l}14 \\
(5.1 \%)\end{array}$ & $\begin{array}{l}101 \\
(18.6 \%)\end{array}$ & $\begin{array}{l}114 \\
(18.5 \%)\end{array}$ & \begin{tabular}{l|}
86 \\
$(27.1 \%)$
\end{tabular} & $\begin{array}{l}23 \\
(10.5 \%)\end{array}$ & $\begin{array}{l}247 \\
(21.8 \%)\end{array}$ & $\begin{array}{l}27 \\
(10.2 \%)\end{array}$ & $\begin{array}{l}75 \\
(20.8 \%)\end{array}$ & $\begin{array}{l}92 \\
(13.7 \%)\end{array}$ & $\begin{array}{l}89 \\
(11.5 \%)\end{array}$ \\
\hline Total & $\begin{array}{l}5172 \\
(100 \%)\end{array}$ & $\begin{array}{l}274 \\
(100 \%)\end{array}$ & $\begin{array}{l}542 \\
(100 \%)\end{array}$ & $\begin{array}{l}618 \\
(100 \%)\end{array}$ & $\begin{array}{l}317 \\
(100 \%)\end{array}$ & $\begin{array}{l}219 \\
(100 \%)\end{array}$ & $\begin{array}{l}1131 \\
(100 \%)\end{array}$ & $\begin{array}{l}265 \\
(100 \%)\end{array}$ & $\begin{array}{l}360 \\
(100 \%)\end{array}$ & $\begin{array}{l}671 \\
(100 \%)\end{array}$ & $\begin{array}{l}775 \\
(100 \%)\end{array}$ \\
\hline
\end{tabular}

Tabela 41: Distribuição dos alunos do sexo masculino conforme se achavam em Contas de acordo com o critério do professor, por distritos e para o total da amostra. Portugal, 1867

\begin{tabular}{|l|l|l|l|l|l|l|l|l|l|l|l|}
\hline & \multicolumn{2}{|l|}{ Distrito } \\
\hline $\begin{array}{l}\text { Qualifi- } \\
\text { caçáo do } \\
\text { professor } \\
\text { em Contas }\end{array}$ & Total & Aveiro & Coimbra & $\begin{array}{l}\text { Castello } \\
\text { Branco }\end{array}$ & Guarda & Évora & Lisboa & Portalegre & $\begin{array}{l}\text { Villa } \\
\text { Real }\end{array}$ & Vizeu & $\begin{array}{l}\text { Vianna } \\
\text { do } \\
\text { Castello }\end{array}$ \\
\hline Suficiente & $\begin{array}{l}3840 \\
(40.1 \%)\end{array}$ & $\begin{array}{l}340 \\
(40.9 \%)\end{array}$ & $\begin{array}{l}353 \\
(40.0 \%)\end{array}$ & $\begin{array}{l}306 \\
(34.3 \%)\end{array}$ & $\begin{array}{l}331 \\
(43.6 \%)\end{array}$ & $\begin{array}{l}226 \\
(44.8 \%)\end{array}$ & $\begin{array}{l}790 \\
(38.8 \%)\end{array}$ & $\begin{array}{l}182 \\
(42.8 \%)\end{array}$ & $\begin{array}{l}282 \\
(40.5 \%)\end{array}$ & $\begin{array}{l}346 \\
(41.1 \%)\end{array}$ & $\begin{array}{l}684 \\
(40.2 \%)\end{array}$ \\
\hline Medíocre & $\begin{array}{l}3150 \\
(32.9 \%)\end{array}$ & $\begin{array}{l}275 \\
(33.0 \%)\end{array}$ & $\begin{array}{l}299 \\
(33.9 \%)\end{array}$ & $\begin{array}{l}350 \\
(39.2 \%)\end{array}$ & $\begin{array}{l}236 \\
(31.1 \%)\end{array}$ & $\begin{array}{l}185 \\
(36.6 \%)\end{array}$ & $\begin{array}{l}621 \\
(30.5 \%)\end{array}$ & $\begin{array}{l}142 \\
(33.3 \%)\end{array}$ & $\begin{array}{l}208 \\
(29.9 \%)\end{array}$ & $\begin{array}{l}226 \\
(26.9 \%)\end{array}$ & $\begin{array}{l}608 \\
(35.8 \%)\end{array}$ \\
\hline Bom & $\begin{array}{l}2579 \\
(27.0 \%)\end{array}$ & $\begin{array}{l}217 \\
(26.1 \%)\end{array}$ & $\begin{array}{l}230 \\
(26.1 \%)\end{array}$ & $\begin{array}{l}237 \\
(26.5 \%)\end{array}$ & $\begin{array}{l}192 \\
(25.3 \%)\end{array}$ & $\begin{array}{l}94 \\
(18.6 \%)\end{array}$ & $\begin{array}{l}624 \\
(30.7 \%)\end{array}$ & $\begin{array}{l}102 \\
(23.9 \%)\end{array}$ & $\begin{array}{l}206 \\
(29.6 \%)\end{array}$ & $\begin{array}{l}269 \\
(32.0 \%)\end{array}$ & $\begin{array}{l}408 \\
(24.0 \%)\end{array}$ \\
\hline Total & $\begin{array}{l}9569 \\
(100 \%)\end{array}$ & $\begin{array}{l}832 \\
(100 \%)\end{array}$ & $\begin{array}{l}882 \\
(100 \%)\end{array}$ & $\begin{array}{l}893 \\
(100 \%)\end{array}$ & $\begin{array}{l}759 \\
(100 \%)\end{array}$ & $\begin{array}{l}505 \\
(100 \%)\end{array}$ & $\begin{array}{l}2035 \\
(100 \%)\end{array}$ & $\begin{array}{l}426 \\
(100 \%)\end{array}$ & $\begin{array}{l}696 \\
(100 \%)\end{array}$ & $\begin{array}{l}841 \\
(100 \%)\end{array}$ & $\begin{array}{l}1700 \\
(100 \%)\end{array}$ \\
\hline
\end{tabular}

\footnotetext{
${ }^{272}$ MR 1055. Distrito: Lisboa; Concelho: Alenquer.

${ }^{273} M R$ 1055. Distrito: Lisboa; Concelho: Cintra.
} 
Como podemos conferir na tabela acima, para o total da amostra, o inspetor caracterizou $16,8 \%$ dos meninos como bons alunos, seguidos por $38,9 \%$ de alunos suficientes e $44,3 \%$ de alunos medíocres. No parecer dos professores, seriam, para o cômputo total, $27 \%$ de bons alunos, $40,1 \%$ de alunos considerados suficientes e, finalmente, $32,9 \%$ de alunos medíocres. Os valores relativos das classificaçôes dos inspetores e dos professores para alunos do sexo masculino considerados suficientes em contas não apresentam grandes diferenças, se tomarmos como referência o total de distritos (representando para inspetores e professores respectivamente $38,9 \%$ e $40,1 \%$ ).

No caso das meninas, havia também proximidade entre os índices de alunas qualificadas como suficientes em contas pelo inspetor - 38,7\% - e pelo professor - 37, $1 \%$. Em ambos os casos - meninos e meninas - aumentaria substancialmente a proporção de estudantes medíocres nas quatro operações aritméticas, quando se tomam comparativamente as avaliaçōes do inspetor e do professor. Para inspetores, haveria um total de $44,3 \%$ de meninos e $43,9 \%$ de meninas medíocres em contas. Já os professores entendiam que eram $32,9 \%$ do total de meninos os que podiam ser taxados de medíocres; a proporção das meninas seria para os professores $31,5 \%$ do total de alunas. Como notamos no quadro acima, em Aveiro, Castello Branco e Évora, houve relativa coincidência nas avaliaçôes de inspetores e professores no que respeita à proporção dos alunos caracterizados como medíocres. Também no caso das alunas - como retrata a tabela abaixo - pode-se dizer que, em alguns distritos, como Portalegre, houve concordância de critérios para detecção das, no caso específico, $40 \%$ de meninas medíocres na habilidade de contar.

Tabela 42: Distribuição dos alunos do sexo feminino conforme se achavam em Contas de acordo com o critério do inspetor, por distritos e para o total da amostra. Portugal, 1867

\begin{tabular}{|c|c|c|c|c|c|c|c|c|c|c|c|}
\hline & & DISTRI & & & & & & & & & \\
\hline $\begin{array}{l}\text { Qualifi- } \\
\text { caçāo do } \\
\text { inspetor } \\
\text { em } \\
\text { Contas }\end{array}$ & Total & Aveiro & Coimbra & $\begin{array}{l}\text { Castello } \\
\text { Branco }\end{array}$ & Guarda & Évora & Lisboa & Portalegre & $\begin{array}{l}\text { Villa } \\
\text { Real }\end{array}$ & Vizeu & $\begin{array}{l}\text { Vianna } \\
\text { do } \\
\text { Castello }\end{array}$ \\
\hline Medíocre & $\begin{array}{l}418 \\
(43.9 \%)\end{array}$ & $\begin{array}{l}7 \\
(38.9 \\
\%)\end{array}$ & $\begin{array}{l}11 \\
(52.4 \%)\end{array}$ & $\begin{array}{l}30 \\
(34.1 \%)\end{array}$ & $\begin{array}{l}16 \\
(39.0 \%)\end{array}$ & $\begin{array}{l}21 \\
(15.6 \%)\end{array}$ & $\begin{array}{l}211 \\
(49.8 \\
\%)\end{array}$ & $\begin{array}{l}30 \\
(40.0 \%)\end{array}$ & $\begin{array}{l}31 \\
(51.6 \%)\end{array}$ & $\begin{array}{l}12 \\
(42.9 \%)\end{array}$ & $\begin{array}{l}49 \\
(80.3 \%)\end{array}$ \\
\hline Suficiente & $\begin{array}{l}368 \\
(38.7 \%)\end{array}$ & $\begin{array}{l}10 \\
(55.6 \\
\%)\end{array}$ & $\begin{array}{l}10 \\
(47.6 \%)\end{array}$ & $\begin{array}{l}43 \\
(48.9 \%)\end{array}$ & $\begin{array}{l}20 \\
(48.8 \%)\end{array}$ & $\begin{array}{l}49 \\
(36.3 \%)\end{array}$ & $\begin{array}{l}168 \\
(39.6 \\
\%)\end{array}$ & $\begin{array}{l}24 \\
(32.0 \%)\end{array}$ & $\begin{array}{l}19 \\
(31.7 \%)\end{array}$ & $\begin{array}{l}13 \\
(46.4 \%)\end{array}$ & $\begin{array}{l}12 \\
(19.7 \%)\end{array}$ \\
\hline Bom & $\begin{array}{l}165 \\
(17.4 \%)\end{array}$ & $\begin{array}{l}1 \\
(5.5 \\
\%)\end{array}$ & $\begin{array}{l}0 \\
(0.0 \%)\end{array}$ & $\begin{array}{l}15 \\
(17.0 \%)\end{array}$ & $\begin{array}{l}5 \\
(12.2 \%)\end{array}$ & $\begin{array}{l}65 \\
(48.1 \%)\end{array}$ & $\begin{array}{l}45 \\
(10.6 \\
\%)\end{array}$ & $\begin{array}{l}21 \\
(28.0 \%)\end{array}$ & $\begin{array}{l}10 \\
(16.7 \%)\end{array}$ & $\begin{array}{l}3 \\
(10.7 \%)\end{array}$ & $\begin{array}{l}0 \\
(0.0 \%)\end{array}$ \\
\hline Total & $\begin{array}{l}951 \\
(100 \%)\end{array}$ & $\begin{array}{l}18 \\
(100 \\
\%)\end{array}$ & $\begin{array}{l}21 \\
(100 \%)\end{array}$ & $\begin{array}{l}88 \\
(100 \%)\end{array}$ & $\begin{array}{l}41 \\
(100 \%)\end{array}$ & $\begin{array}{l}135 \\
(100 \%)\end{array}$ & $\begin{array}{l}424 \\
(100 \\
\%)\end{array}$ & $\begin{array}{l}75 \\
(100 \%)\end{array}$ & $\begin{array}{l}60 \\
(100 \%)\end{array}$ & $\begin{array}{l}28 \\
(100 \%)\end{array}$ & $\begin{array}{l}61 \\
(100 \%)\end{array}$ \\
\hline
\end{tabular}


Tabela 43: Distribuição dos alunos do sexo feminino conforme se achavam em Contas de acordo com o critério do professor, por distritos e para o total da amostra. Portugal, 1867

\begin{tabular}{|c|c|c|c|c|c|c|c|c|c|c|c|}
\hline \multirow[b]{2}{*}{$\begin{array}{l}\text { Qualifi- } \\
\text { caçāo do } \\
\text { professor } \\
\text { em Contas }\end{array}$} & \multirow[b]{2}{*}{ Total } & \multicolumn{10}{|c|}{ Distrito } \\
\hline & & Aveiro & Coimbra & $\begin{array}{l}\text { Castello } \\
\text { Branco }\end{array}$ & Guarda & Évora & Lisboa & Portalegre & $\begin{array}{l}\text { Villa } \\
\text { Real }\end{array}$ & Vizeu & $\begin{array}{l}\text { Vianna } \\
\text { do } \\
\text { Castello }\end{array}$ \\
\hline Suficiente & $\begin{array}{l}448 \\
(37.1 \%)\end{array}$ & $\begin{array}{l}35 \\
(39.3 \%)\end{array}$ & $\begin{array}{l}5 \\
(71.4 \%)\end{array}$ & $\begin{array}{l}50 \\
(46.2 \%)\end{array}$ & $\begin{array}{l}30 \\
(31.2 \%)\end{array}$ & $\begin{array}{l}34 \\
(21.2 \%)\end{array}$ & $\begin{array}{l}188 \\
(41.4 \%)\end{array}$ & $\begin{array}{l}28 \\
(18.6 \%)\end{array}$ & $\begin{array}{l}35 \\
(66.0 \%)\end{array}$ & $\begin{array}{l}12 \\
(20.0 \%)\end{array}$ & $\begin{array}{l}31 \\
(100 \%)\end{array}$ \\
\hline Medíocre & $\begin{array}{l}380 \\
(31.5 \%)\end{array}$ & $\begin{array}{l}27 \\
(30.4 \%)\end{array}$ & $\begin{array}{l}1 \\
(14.3 \%)\end{array}$ & $\begin{array}{l}29 \\
(26.9 \%)\end{array}$ & $\begin{array}{l}33 \\
(34.4 \%)\end{array}$ & $\begin{array}{l}63 \\
(39.4 \%)\end{array}$ & $\begin{array}{l}133 \\
(29.3 \%)\end{array}$ & $\begin{array}{l}61 \\
(40.7 \%)\end{array}$ & $\begin{array}{l}9 \\
(17.0 \%)\end{array}$ & $\begin{array}{l}24 \\
(40.0 \%)\end{array}$ & $\begin{array}{l}0 \\
(0.0 \%)\end{array}$ \\
\hline Bom & $\begin{array}{l}380 \\
(31.4 \%)\end{array}$ & $\begin{array}{l}27 \\
(30.3 \%)\end{array}$ & $\begin{array}{l}1 \\
(14.3 \%)\end{array}$ & $\begin{array}{l}29 \\
(26.9 \%)\end{array}$ & $\begin{array}{l}33 \\
(34.4 \%)\end{array}$ & $\begin{array}{l}63 \\
(39.4 \%)\end{array}$ & $\begin{array}{l}133 \\
(29.3 \%)\end{array}$ & $\begin{array}{l}61 \\
(40.7 \%)\end{array}$ & $\begin{array}{l}9 \\
(17.0 \%)\end{array}$ & $\begin{array}{l}24 \\
(40.0 \%)\end{array}$ & $\begin{array}{l}0 \\
(0.0 \%)\end{array}$ \\
\hline Total & $\begin{array}{l}1208 \\
(100 \%)\end{array}$ & $\begin{array}{l}89 \\
(100 \%)\end{array}$ & $\begin{array}{l}7 \\
(100 \%)\end{array}$ & $\begin{array}{l}108 \\
(100 \%)\end{array}$ & $\begin{array}{l}96 \\
(100 \%)\end{array}$ & $\begin{array}{l}160 \\
(100 \%)\end{array}$ & $\begin{array}{l}454 \\
(100 \%)\end{array}$ & $\begin{array}{l}150 \\
(100 \%)\end{array}$ & $\begin{array}{l}53 \\
(100 \%)\end{array}$ & $\begin{array}{l}60 \\
(100 \%)\end{array}$ & $\begin{array}{l}31 \\
(100 \%)\end{array}$ \\
\hline
\end{tabular}

Em Doutrina Cristã, foram bastante semelhantes as distribuições nas categorias bom, suficiente e medíocre, obtidas, segundo o inspetor e o professor, tanto no caso dos meninos quanto na avaliação das meninas. Para o total do país, no julgamento acerca dos meninos, ultrapassa a casa dos $45 \%$ o percentual dos considerados medíocres tanto por professores quanto por inspetores. Para as meninas, aproxima-se da faixa dos $40 \%$ a proporção das alunas medíocres, fosse no parecer da inspeção ou do professor. Tudo isso revela, até certo ponto, a rigidez da escola perante os conteúdos programáticos eleitos como saberes elementares dessa pedagogia aplicada. No caso específico da Doutrina Cristã, percebe-se que, em alguns distritos, os professores eram mais exigentes na avaliação do que os próprios inspetores. A esse respeito, note-se para o caso das escolas masculinas - a situação de Portalegre, Castello Branco e, principalmente, Évora.

Tabela 44: Distribuição dos alunos do sexo masculino conforme se achavam em Doutrina Cristã de acordo com o critério do inspetor, por distritos e para o total da amostra. Portugal, 1867

\begin{tabular}{|l|l|l|l|l|l|l|l|l|l|l|l|}
\hline & \multicolumn{9}{|l|}{ Distrito } \\
\hline $\begin{array}{l}\text { Qualifi- } \\
\text { cação do } \\
\text { inspetor } \\
\text { Doutrina } \\
\text { Cristā }\end{array}$ & Total & Aveiro & Coimbra & $\begin{array}{l}\text { Castello } \\
\text { Branco }\end{array}$ & Guarda & Évora & Lisboa & Portalegre & $\begin{array}{l}\text { Villa } \\
\text { Real }\end{array}$ & $\begin{array}{l}\text { Vizeu } \\
\text { Vianna } \\
\text { do } \\
\text { Castello }\end{array}$ \\
\hline Medíocre & $\begin{array}{l}3713 \\
(46.5 \%)\end{array}$ & $\begin{array}{l}267 \\
(45.5 \%)\end{array}$ & $\begin{array}{l}433 \\
(47.3 \%)\end{array}$ & $\begin{array}{l}449 \\
(45.5 \%)\end{array}$ & $\begin{array}{l}298 \\
(45.1 \%)\end{array}$ & $\begin{array}{l}122 \\
(32.4 \\
\%)\end{array}$ & $\begin{array}{l}636 \\
(49.8 \%)\end{array}$ & $\begin{array}{l}144 \\
(37.1 \%)\end{array}$ & $\begin{array}{l}336 \\
(55.5 \\
\%)\end{array}$ & $\begin{array}{l}362 \\
(42.5 \\
\%)\end{array}$ & $\begin{array}{l}666 \\
(49.8 \%)\end{array}$ \\
\hline Suficiente & $\begin{array}{l}2652 \\
(33.2 \%)\end{array}$ & $\begin{array}{l}183 \\
(31.2 \%)\end{array}$ & $\begin{array}{l}312 \\
(34.0 \%)\end{array}$ & $\begin{array}{l}316 \\
(32.0 \%)\end{array}$ & $\begin{array}{l}230 \\
(34.7 \%)\end{array}$ & $\begin{array}{l}138 \\
(36.7 \\
\%)\end{array}$ & $\begin{array}{l}381 \\
(29.9 \%)\end{array}$ & $\begin{array}{l}125 \\
(32.1 \%)\end{array}$ & $\begin{array}{l}164 \\
(27.2 \\
\%)\end{array}$ & $\begin{array}{l}326 \\
(38.2 \\
\%)\end{array}$ & $\begin{array}{l}477 \\
(35.7 \%)\end{array}$ \\
\hline Bom & $\begin{array}{l}1624 \\
(20.3 \%)\end{array}$ & $\begin{array}{l}137 \\
(23.3 \%)\end{array}$ & $\begin{array}{l}172 \\
(18.7 \%)\end{array}$ & $\begin{array}{l}222 \\
(22.5 \%)\end{array}$ & $\begin{array}{l}134 \\
(20.2 \%)\end{array}$ & $\begin{array}{l}116 \\
(30.9 \\
\%)\end{array}$ & $\begin{array}{l}259 \\
(20.3 \%)\end{array}$ & $\begin{array}{l}120 \\
(30.8 \%)\end{array}$ & $\begin{array}{l}105 \\
(17.3 \\
\%)\end{array}$ & $\begin{array}{l}165 \\
(19.3 \\
\%)\end{array}$ & $\begin{array}{l}194 \\
(14.5 \%)\end{array}$ \\
\hline Total & $\begin{array}{l}7989 \\
(100 \%)\end{array}$ & $\begin{array}{l}587 \\
(100 \%)\end{array}$ & $\begin{array}{l}917 \\
(100 \%)\end{array}$ & $\begin{array}{l}987 \\
(100 \%)\end{array}$ & $\begin{array}{l}662 \\
(100 \%)\end{array}$ & $\begin{array}{l}376 \\
(100 \\
\%)\end{array}$ & $\begin{array}{l}1276 \\
(100 \%)\end{array}$ & $\begin{array}{l}389 \\
(100 \%)\end{array}$ & $\begin{array}{l}605 \\
(100 \\
\%)\end{array}$ & $\begin{array}{l}853 \\
(100 \\
\%)\end{array}$ & $\begin{array}{l}1337 \\
(100 \%)\end{array}$ \\
\hline
\end{tabular}


Tabela 45: Distribuição dos alunos do sexo masculino conforme se achavam em Doutrina Cristã de acordo com o critério do professor, por distritos e para o total da amostra. Portugal, 1867

\begin{tabular}{|c|c|c|c|c|c|c|c|c|c|c|c|}
\hline \multirow[b]{2}{*}{$\begin{array}{l}\text { Qualifi- } \\
\text { caçāo do } \\
\text { professor } \\
\text { em } \\
\text { Doutrina } \\
\text { Cristã }\end{array}$} & \multirow[b]{2}{*}{ Total } & \multicolumn{10}{|c|}{ Distrito } \\
\hline & & Aveiro & Coimbra & $\begin{array}{l}\text { Castello } \\
\text { Branco }\end{array}$ & Guarda & Évora & Lisboa & Portalegre & $\begin{array}{l}\text { Villa } \\
\text { Real }\end{array}$ & Vizeu & $\begin{array}{l}\text { Vianna } \\
\text { do } \\
\text { Castello }\end{array}$ \\
\hline Medíocre & $\begin{array}{l}6260 \\
(47.1 \%) \\
\end{array}$ & \begin{tabular}{|l}
659 \\
$(49.0 \%)$ \\
\end{tabular} & $\begin{array}{l}561 \\
(42.6 \%)\end{array}$ & \begin{tabular}{|l}
604 \\
$(49.6 \%)$ \\
\end{tabular} & \begin{tabular}{|l|}
640 \\
$(42.5 \%)$
\end{tabular} & $\begin{array}{l}277 \\
(48.8 \%)\end{array}$ & $\begin{array}{l}991 \\
(48.6 \%) \\
\end{array}$ & \begin{tabular}{|l}
262 \\
$(42.3 \%)$ \\
\end{tabular} & $\begin{array}{l}518 \\
(47.3 \%)\end{array}$ & $\begin{array}{l}581 \\
(43.4 \%) \\
\end{array}$ & $\begin{array}{l}1167 \\
(51.9 \%)\end{array}$ \\
\hline Suficiente & $\begin{array}{l}3922 \\
(29.5 \%)\end{array}$ & $\begin{array}{l}422 \\
(31.3 \%)\end{array}$ & $\begin{array}{l}371 \\
(28.2 \%)\end{array}$ & \begin{tabular}{|l|}
305 \\
$(25.0 \%)$
\end{tabular} & \begin{tabular}{|l|}
452 \\
$(30.0 \%)$
\end{tabular} & $\begin{array}{l}157 \\
(27.6 \%)\end{array}$ & $\begin{array}{l}546 \\
(26.8 \%)\end{array}$ & $\begin{array}{l}223 \\
(36.1 \%)\end{array}$ & $\begin{array}{l}302 \\
(27.5 \%)\end{array}$ & $\begin{array}{l}447 \\
(33.4 \%)\end{array}$ & $\begin{array}{l}697 \\
(31.0 \%)\end{array}$ \\
\hline Bom & $\begin{array}{l}3115 \\
(23.4 \%)\end{array}$ & $\begin{array}{l}265 \\
(19.7 \%)\end{array}$ & $\begin{array}{l}385 \\
(29.2 \%)\end{array}$ & $\begin{array}{l}309 \\
(25.4 \%)\end{array}$ & $\begin{array}{l}415 \\
(27.5 \%)\end{array}$ & $\begin{array}{l}134 \\
(23.6 \%)\end{array}$ & $\begin{array}{l}500 \\
(24.6 \%)\end{array}$ & $\begin{array}{l}134 \\
(21.6 \%)\end{array}$ & $\begin{array}{l}277 \\
(25.2 \%)\end{array}$ & $\begin{array}{l}310 \\
(23.2 \%)\end{array}$ & $\begin{array}{l}386 \\
(17.1 \%)\end{array}$ \\
\hline Total & $\begin{array}{l}13297 \\
(100 \%)\end{array}$ & $\begin{array}{l}1346 \\
(100 \%)\end{array}$ & $\begin{array}{l}1317 \\
(100 \%)\end{array}$ & $\begin{array}{l}1218 \\
(100 \%)\end{array}$ & $\begin{array}{l}1507 \\
(100 \%)\end{array}$ & $\begin{array}{l}568 \\
(100 \%)\end{array}$ & $\begin{array}{l}2037 \\
(100 \%)\end{array}$ & $\begin{array}{l}619 \\
(100 \%)\end{array}$ & $\begin{array}{l}1097 \\
(100 \%)\end{array}$ & $\begin{array}{l}1338 \\
(100 \%)\end{array}$ & $\begin{array}{l}1250 \\
(100 \%)\end{array}$ \\
\hline
\end{tabular}

Tabela 46: Distribuição dos alunos do sexo feminino conforme se achavam em Doutrina Cristã de acordo com o critério do inspetor, por distritos e para o total da amostra. Portugal, 1867

\begin{tabular}{|c|c|c|c|c|c|c|c|c|c|c|c|}
\hline \multirow[b]{2}{*}{$\begin{array}{l}\text { Qualifica- } \\
\text { ção do ins- } \\
\text { petor em } \\
\text { Doutrina } \\
\text { Cristã }\end{array}$} & \multirow[b]{2}{*}{ Total } & \multicolumn{10}{|c|}{ Distrito } \\
\hline & & Aveiro & Coimbra & $\begin{array}{l}\text { Castello } \\
\text { Branco }\end{array}$ & Guarda & Évora & Lisboa & Portalegre & $\begin{array}{l}\text { Villa } \\
\text { Real }\end{array}$ & Vizeu & $\begin{array}{l}\text { Vianna } \\
\text { do } \\
\text { Castello }\end{array}$ \\
\hline Medíocre & $\begin{array}{l}818 \\
(41.9 \%)\end{array}$ & $\begin{array}{l}100 \\
(55.2 \%)\end{array}$ & $\begin{array}{l}51 \\
(55.4 \%) \\
\end{array}$ & $\begin{array}{l}126 \\
(44.7 \%)\end{array}$ & $\begin{array}{l}66 \\
(40.5 \%)\end{array}$ & $\begin{array}{l}49 \\
(21.7 \%)\end{array}$ & $\begin{array}{l}240 \\
(40.5 \%)\end{array}$ & $\begin{array}{l}47 \\
(35.6 \%) \\
\end{array}$ & $\begin{array}{l}49 \\
(46.2 \%) \\
\end{array}$ & $\begin{array}{l}32 \\
(42.7 \%)\end{array}$ & $\begin{array}{l}58 \\
(55.8 \%)\end{array}$ \\
\hline Suficiente & $\begin{array}{l}569 \\
(29.1 \%)\end{array}$ & $\begin{array}{l}51 \\
(28.2 \%) \\
\end{array}$ & $\begin{array}{l}26 \\
(28.3 \%) \\
\end{array}$ & $\begin{array}{l}84 \\
(29.8 \%) \\
\end{array}$ & $\begin{array}{l}62 \\
(38.0 \%) \\
\end{array}$ & $\begin{array}{l}51 \\
(22.5 \%) \\
\end{array}$ & $\begin{array}{l}164 \\
(27.6 \%) \\
\end{array}$ & $\begin{array}{l}40 \\
(30.3 \%)\end{array}$ & $\begin{array}{l}35 \\
(33.1 \%) \\
\end{array}$ & $\begin{array}{l}30 \\
(40.0 \%)\end{array}$ & $\begin{array}{l}26 \\
(25.0 \%)\end{array}$ \\
\hline Bom & $\begin{array}{l}567 \\
(29.0 \%)\end{array}$ & $\begin{array}{l}30 \\
(16.6 \%)\end{array}$ & $\begin{array}{l}15 \\
(16.3 \%) \\
\end{array}$ & $\begin{array}{l}72 \\
(25.5 \%)\end{array}$ & $\begin{array}{l}35 \\
(21.5 \%)\end{array}$ & $\begin{array}{l}126 \\
(55.8 \%)\end{array}$ & $\begin{array}{l}189 \\
(31.9 \%)\end{array}$ & $\begin{array}{l}45 \\
(34.1 \%) \\
\end{array}$ & $\begin{array}{l}22 \\
(20.7 \%) \\
\end{array}$ & $\begin{array}{l}13 \\
(17.3 \%)\end{array}$ & $\begin{array}{l}20 \\
(19.2 \%)\end{array}$ \\
\hline Total & $\begin{array}{l}1954 \\
(100 \%) \\
\end{array}$ & $\begin{array}{l}181 \\
(100 \%)\end{array}$ & $\begin{array}{l}92 \\
(100 \%)\end{array}$ & $\begin{array}{l}282 \\
(100 \%)\end{array}$ & $\begin{array}{l}163 \\
(100 \%)\end{array}$ & $\begin{array}{l}226 \\
(100 \%)\end{array}$ & $\begin{array}{l}593 \\
(100 \%)\end{array}$ & $\begin{array}{l}132 \\
(100 \%)\end{array}$ & $\begin{array}{l}106 \\
(100 \%)\end{array}$ & $\begin{array}{l}75 \\
(100 \%)\end{array}$ & $\begin{array}{l}104 \\
(100 \%)\end{array}$ \\
\hline
\end{tabular}

Tabela 47: Distribuição dos alunos do sexo feminino conforme se achavam em Doutrina Cristã de acordo com o critério do professor, por distritos e para o total da amostra. Portugal, 1867

\begin{tabular}{|c|c|c|c|c|c|c|c|c|c|c|c|}
\hline \multirow[b]{2}{*}{$\begin{array}{l}\text { Qualifi- } \\
\text { cação do } \\
\text { professor } \\
\text { em } \\
\text { Doutrina } \\
\text { Cristã }\end{array}$} & \multirow[b]{2}{*}{ Total } & \multicolumn{10}{|c|}{ DISTRITO } \\
\hline & & Aveiro & Coimbra & $\begin{array}{l}\text { Castello } \\
\text { Branco }\end{array}$ & Guarda & Évora & Lisboa & Portalegre & $\begin{array}{l}\text { Villa } \\
\text { Real }\end{array}$ & Vizeu & $\begin{array}{l}\text { Vianna } \\
\text { do } \\
\text { Castello }\end{array}$ \\
\hline Medíocre & \begin{tabular}{|l|}
939 \\
$(38.4 \%)$ \\
\end{tabular} & $\begin{array}{l}142 \\
(55.3 \%)\end{array}$ & $\begin{array}{l}39 \\
(29.8 \%)\end{array}$ & $\begin{array}{l}81 \\
(28.9 \%) \\
\end{array}$ & $\begin{array}{l}103 \\
(35.4 \%)\end{array}$ & $\begin{array}{l}47 \\
(29.0 \%)\end{array}$ & $\begin{array}{l}280 \\
(38.8 \%) \\
\end{array}$ & $\begin{array}{l}57 \\
(27.3 \%)\end{array}$ & \begin{tabular}{|l|}
59 \\
$(42.4 \%)$ \\
\end{tabular} & \begin{tabular}{|l|}
48 \\
$(41.0 \%)$
\end{tabular} & $\begin{array}{l}83 \\
(59.3 \%) \\
\end{array}$ \\
\hline Suficiente & \begin{tabular}{|l|}
846 \\
$(34.6 \%)$
\end{tabular} & $\begin{array}{l}62 \\
(24.1 \%)\end{array}$ & $\begin{array}{l}54 \\
(41.2 \%)\end{array}$ & $\begin{array}{l}120 \\
(42.9 \%)\end{array}$ & $\begin{array}{l}100 \\
(34.4 \%)\end{array}$ & $\begin{array}{l}65 \\
(40.1 \%)\end{array}$ & $\begin{array}{l}251 \\
(34.8 \%)\end{array}$ & $\begin{array}{l}83 \\
(39.7 \%)\end{array}$ & \begin{tabular}{|l|}
32 \\
$(23.1 \%)$
\end{tabular} & \begin{tabular}{|l|}
42 \\
$(35.9 \%)$
\end{tabular} & $\begin{array}{l}37 \\
(26.4 \%)\end{array}$ \\
\hline Bom & $\begin{array}{l}662 \\
(27.0 \%) \\
\end{array}$ & $\begin{array}{l}53 \\
(20.6 \%) \\
\end{array}$ & $\begin{array}{l}38 \\
(29.0 \%) \\
\end{array}$ & $\begin{array}{l}79 \\
(28.2 \%) \\
\end{array}$ & $\begin{array}{l}88 \\
(30.2 \%) \\
\end{array}$ & $\begin{array}{l}50 \\
(30.9 \%) \\
\end{array}$ & $\begin{array}{l}190 \\
(26.4 \%)\end{array}$ & $\begin{array}{l}69 \\
(33.0 \%)\end{array}$ & $\begin{array}{l}48 \\
(34.5 \%)\end{array}$ & $\begin{array}{l}27 \\
(23.1 \%)\end{array}$ & $\begin{array}{l}20 \\
(14.3 \%)\end{array}$ \\
\hline Total & $\begin{array}{l}2447 \\
(100 \%)\end{array}$ & $\begin{array}{l}257 \\
(100 \%)\end{array}$ & $\begin{array}{l}131 \\
(100 \%)\end{array}$ & $\begin{array}{l}280 \\
(100 \%)\end{array}$ & $\begin{array}{l}291 \\
(100 \%)\end{array}$ & $\begin{array}{l}162 \\
(100 \%)\end{array}$ & $\begin{array}{l}721 \\
(100 \%)\end{array}$ & $\begin{array}{l}209 \\
(100 \%)\end{array}$ & \begin{tabular}{|l|}
139 \\
$(100 \%)$ \\
\end{tabular} & $\begin{array}{l}117 \\
(100 \%)\end{array}$ & $\begin{array}{l}140 \\
(100 \%)\end{array}$ \\
\hline
\end{tabular}


A proporção de alunas boas em Doutrina Cristã é um pouco maior conforme o parecer do inspector do que teria sido a avaliação do professor (29\% e $27 \%$ respectivamente); a de suficientes é, para o inspetor, menor do que o professor havia considerado (29.1\% e 34.6\%, respectivamente); e a de medíocres é, para o inspetor (41.9\%), maior em relação aos dados do professor (38.4\%).

Os alunos teriam, ainda, seu currículo composto por um rol complementar de matérias, as quais compreendiam, em seu conjunto, as seguintes áreas de estudo: sistema métrico, gramática, história portuguesa, corografia. Assim, o aproveitamento escolar das crianças abarcaria todo esse conjunto de conhecimentos típico da vida de escola. Aliás, no caso daquelas instituições educativas não-mantidas pelo Estado, havia um espaço suplementar para verificar o rendimento das alunas em prendas domésticas, tais como fiar na roca, meia e crochet, costura, bordado, corte, etc.. Entendia-se que os saberes escolares eram conteúdos a serem requisitados pela vida. Daí a necessidade de ministrar os saberes típicos do que se acreditava ser a vida feminina.

\section{A origem social da comunidade escolar}

Pela amostragem das escolas selecionadas, pudemos efetuar um painel com a porcentagem de profissões dos pais de alunos, tal como estas apareciam na última página do Relatório de inspeção. No conjunto, dos 19.524 pais envolvidos indiretamente nessa investigação, pudemos detectar a seguinte classificação:

Tabela 48: Distribuição dos alunos conforme profissões dos pais por distritos e para o total da amostra. Portugal, 1867

\begin{tabular}{|c|c|c|c|c|c|c|c|c|c|c|c|}
\hline \multirow[b]{2}{*}{$\begin{array}{l}\text { Profissão } \\
\text { dos pais }\end{array}$} & \multirow[b]{2}{*}{ Total } & \multicolumn{10}{|c|}{ DistRITO } \\
\hline & & Aveiro & Coimbra & $\begin{array}{l}\text { Castello } \\
\text { Branco }\end{array}$ & Guarda & Évora & Lisboa & Portalegre & $\begin{array}{l}\text { Villa } \\
\text { Real }\end{array}$ & Vizeu & $\begin{array}{l}\text { V. do } \\
\text { Castello }\end{array}$ \\
\hline Lavoura & \begin{tabular}{l|}
5456 \\
$(27.9 \%)$
\end{tabular} & \begin{tabular}{l|}
710 \\
$(38.0 \%)$
\end{tabular} & $\begin{array}{l}465 \\
(22.9 \%)\end{array}$ & $\begin{array}{l}557 \\
(27.3 \%)\end{array}$ & $\begin{array}{l}422 \\
(22.0 \%)\end{array}$ & $\begin{array}{l}105 \\
(13.4 \%)\end{array}$ & $\begin{array}{l}417 \\
(11.6 \%)\end{array}$ & $\begin{array}{l}150 \\
(13.7 \%)\end{array}$ & $\begin{array}{l}761 \\
(47.9 \%)\end{array}$ & \begin{tabular}{l|}
650 \\
$(38.9 \%)$
\end{tabular} & $\begin{array}{l}1219 \\
(41.6 \%)\end{array}$ \\
\hline Jornaleiro & $\begin{array}{l}3824 \\
(19.6 \%)\end{array}$ & $\begin{array}{l}392 \\
(21.0 \%)\end{array}$ & $\begin{array}{l}684 \\
(33.6 \%)\end{array}$ & $\begin{array}{l}480 \\
(23.5 \%)\end{array}$ & $\begin{array}{l}404 \\
(21.1 \%)\end{array}$ & $\begin{array}{l}144 \\
(18.3 \%)\end{array}$ & $\begin{array}{l}644 \\
(18.0 \%)\end{array}$ & $\begin{array}{l}267 \\
(24.4 \%)\end{array}$ & $\begin{array}{l}334 \\
(21.1 \%)\end{array}$ & $\begin{array}{l}344 \\
(20.6 \%)\end{array}$ & $\begin{array}{l}131 \\
(4.5 \%)\end{array}$ \\
\hline Tecidos & $\begin{array}{l}1439 \\
(7.4 \%)\end{array}$ & $\begin{array}{l}134 \\
(7.3 \%)\end{array}$ & $\begin{array}{l}112 \\
(5.5 \%)\end{array}$ & $\begin{array}{l}226 \\
(11.1 \%)\end{array}$ & $\begin{array}{l}236 \\
(12.3 \%)\end{array}$ & $\begin{array}{l}107 \\
(13.6 \%)\end{array}$ & $\begin{array}{l}171 \\
(4.8 \%)\end{array}$ & $\begin{array}{l}59 \\
(5.4 \%)\end{array}$ & $\begin{array}{l}89 \\
(5.7 \%)\end{array}$ & $\begin{array}{l}130 \\
(7.8 \%)\end{array}$ & $\begin{array}{l}175 \\
(6.0 \%)\end{array}$ \\
\hline Comércio & $\begin{array}{l}1062 \\
(5.4 \%)\end{array}$ & $\begin{array}{l}113 \\
(6.1 \%)\end{array}$ & $\begin{array}{l}104 \\
(5.1 \%)\end{array}$ & $\begin{array}{l}84 \\
(4.2 \%)\end{array}$ & $\begin{array}{l}154 \\
(8.0 \%)\end{array}$ & $\begin{array}{l}49 \\
(6.2 \%)\end{array}$ & $\begin{array}{l}223 \\
(6.3 \%)\end{array}$ & $\begin{array}{l}65 \\
(5.9 \%)\end{array}$ & $\begin{array}{l}46 \\
(2.9 \%)\end{array}$ & $\begin{array}{l}90 \\
(5.4 \%)\end{array}$ & $\begin{array}{l}134 \\
(4.6 \%)\end{array}$ \\
\hline $\begin{array}{l}\text { Trabalha- } \\
\text { dor do } \\
\text { mar }\end{array}$ & $\begin{array}{l}839 \\
(4.3 \%)\end{array}$ & $\begin{array}{l}58 \\
(3.1 \%)\end{array}$ & $\begin{array}{l}5 \\
(0.2 \%)\end{array}$ & $\begin{array}{l}1 \\
(0.1 \%)\end{array}$ & $\begin{array}{l}7 \\
(0.4 \%)\end{array}$ & $\begin{array}{l}5 \\
(0.6 \%)\end{array}$ & $\begin{array}{l}313 \\
(8.8 \%)\end{array}$ & $\begin{array}{l}8 \\
(0.7 \%)\end{array}$ & $\begin{array}{l}23 \\
(1.4 \%)\end{array}$ & $\begin{array}{l}35 \\
(2.2 \%)\end{array}$ & $\begin{array}{l}384 \\
(13.1 \%)\end{array}$ \\
\hline $\begin{array}{l}\text { Funcio- } \\
\text { nário } \\
\text { Público }\end{array}$ & $\begin{array}{l}769 \\
(3.9 \%)\end{array}$ & $\begin{array}{l}55 \\
(2.9 \%)\end{array}$ & $\begin{array}{l}66 \\
(3.2 \%)\end{array}$ & $\begin{array}{l}62 \\
(3.0 \%)\end{array}$ & $\begin{array}{l}96 \\
(5.0 \%)\end{array}$ & $\begin{array}{l}30 \\
(3.8 \%)\end{array}$ & $\begin{array}{l}261 \\
(7.3 \%)\end{array}$ & $\begin{array}{l}56 \\
(5.1 \%)\end{array}$ & $\begin{array}{l}18 \\
(1.1 \%)\end{array}$ & $\begin{array}{l}38 \\
(2.3 \%)\end{array}$ & $\begin{array}{l}87 \\
(2.9 \%)\end{array}$ \\
\hline $\begin{array}{l}\text { Carpin- } \\
\text { teiro }\end{array}$ & $\begin{array}{l}752 \\
(3.8 \%)\end{array}$ & $\begin{array}{l}62 \\
(3.3 \%)\end{array}$ & $\begin{array}{l}81 \\
(4.0 \%)\end{array}$ & $\begin{array}{l}54 \\
(2.6 \%)\end{array}$ & $\begin{array}{l}57 \\
(3.0 \%)\end{array}$ & $\begin{array}{l}40 \\
(5.1 \%)\end{array}$ & $\begin{array}{l}191 \\
(5.3 \%)\end{array}$ & $\begin{array}{l}45 \\
(4.1 \%)\end{array}$ & $\begin{array}{l}36 \\
(2.3 \%)\end{array}$ & $\begin{array}{l}68 \\
(4.1 \%)\end{array}$ & $\begin{array}{l}118 \\
(3.9 \%)\end{array}$ \\
\hline Sapateiro & $\begin{array}{l}685 \\
(3.5 \%)\end{array}$ & $\begin{array}{l}25 \\
(1.3 \%)\end{array}$ & $\begin{array}{l}57 \\
(2.8 \%)\end{array}$ & $\begin{array}{l}110 \\
(5.4 \%)\end{array}$ & $\begin{array}{l}85 \\
(4.4 \%)\end{array}$ & $\begin{array}{l}54 \\
(6.9 \%)\end{array}$ & $\begin{array}{l}168 \\
(4.7 \%)\end{array}$ & $\begin{array}{l}72 \\
(6.6 \%)\end{array}$ & $\begin{array}{l}6 \\
(0.4 \%)\end{array}$ & $\begin{array}{l}44 \\
(2.6 \%)\end{array}$ & $\begin{array}{l}64 \\
(2.2 \%)\end{array}$ \\
\hline Pedreiro & $\begin{array}{l}511 \\
(2.6 \%)\end{array}$ & $\begin{array}{l}28 \\
(1.5 \%)\end{array}$ & $\begin{array}{l}78 \\
(3.9 \%)\end{array}$ & $\begin{array}{l}45 \\
(2.2 \%)\end{array}$ & $\begin{array}{l}24 \\
(1.2 \%)\end{array}$ & $\begin{array}{l}43 \\
(5.5 \%)\end{array}$ & $\begin{array}{l}118 \\
(3.3 \%)\end{array}$ & $\begin{array}{l}29 \\
(2.6 \%)\end{array}$ & $\begin{array}{l}6 \\
(0.4 \%)\end{array}$ & $\begin{array}{l}25 \\
(1.5 \%)\end{array}$ & $\begin{array}{l}115 \\
(3.9 \%)\end{array}$ \\
\hline
\end{tabular}




\begin{tabular}{|c|c|c|c|c|c|c|c|c|c|c|c|}
\hline Ferreiro & $\begin{array}{l}498 \\
(2.5 \%)\end{array}$ & $\begin{array}{l}30 \\
(1.6 \%)\end{array}$ & $\begin{array}{l}30 \\
(1.5 \%)\end{array}$ & $\begin{array}{l}64 \\
(3.1 \%)\end{array}$ & $\begin{array}{l}57 \\
(3.0 \%)\end{array}$ & $\begin{array}{l}24 \\
(3.1 \%)\end{array}$ & $\begin{array}{l}109 \\
(3.0 \%)\end{array}$ & $\begin{array}{l}44 \\
(4.0 \%)\end{array}$ & $\begin{array}{l}23 \\
(1.4 \%)\end{array}$ & $\begin{array}{l}41 \\
(2.4 \%)\end{array}$ & $\begin{array}{l}76 \\
(2.6 \%)\end{array}$ \\
\hline $\begin{array}{l}\text { Almo- } \\
\text { creve }\end{array}$ & $\begin{array}{l}353 \\
(1.8 \%)\end{array}$ & $\begin{array}{l}24 \\
(1.3 \%)\end{array}$ & $\begin{array}{l}27 \\
(1.3 \%)\end{array}$ & $\begin{array}{l}55 \\
(2.7 \%)\end{array}$ & $\begin{array}{l}66 \\
(3.4 \%)\end{array}$ & $\begin{array}{l}7 \\
(0.9 \%)\end{array}$ & $\begin{array}{l}36 \\
(1.0 \%)\end{array}$ & $\begin{array}{l}68 \\
(6.2 \%)\end{array}$ & $\begin{array}{l}24 \\
(1.5 \%)\end{array}$ & $\begin{array}{l}24 \\
(1.4 \%)\end{array}$ & $\begin{array}{l}22 \\
(0.8 \%)\end{array}$ \\
\hline $\begin{array}{l}\text { Proprie- } \\
\text { tário } \\
\text { Urbano }\end{array}$ & $\begin{array}{l}279 \\
(1.4 \%)\end{array}$ & $\begin{array}{l}21 \\
(1.1 \%)\end{array}$ & $\begin{array}{l}33 \\
(1.7 \%)\end{array}$ & $\begin{array}{l}32 \\
(1.6 \%)\end{array}$ & $\begin{array}{l}60 \\
(3.1 \%)\end{array}$ & $\begin{array}{l}46 \\
(5.9 \%)\end{array}$ & $\begin{array}{l}41 \\
(1.1 \%)\end{array}$ & $\begin{array}{l}5 \\
(0.5 \%)\end{array}$ & $\begin{array}{l}2 \\
(0.1 \%)\end{array}$ & $\begin{array}{l}12 \\
(0.7 \%)\end{array}$ & $\begin{array}{l}27 \\
(0.9 \%)\end{array}$ \\
\hline Moleiro & $\begin{array}{l}251 \\
(1.3 \%)\end{array}$ & $\begin{array}{l}30 \\
(1.6 \%)\end{array}$ & $\begin{array}{l}18 \\
(0.9 \%)\end{array}$ & $\begin{array}{l}31 \\
(1.5 \%)\end{array}$ & $\begin{array}{l}29 \\
(1.5 \%)\end{array}$ & $\begin{array}{l}10 \\
(1.3 \%)\end{array}$ & $\begin{array}{l}64 \\
(1.8 \%)\end{array}$ & $\begin{array}{l}18 \\
(1.6 \%)\end{array}$ & $\begin{array}{l}9 \\
(0.6 \%)\end{array}$ & $\begin{array}{l}22 \\
(1.3 \%)\end{array}$ & $\begin{array}{l}20 \\
(0.7 \%)\end{array}$ \\
\hline Trolha & $\begin{array}{l}109 \\
(0.6 \%)\end{array}$ & $\begin{array}{l}4 \\
(0.2 \%)\end{array}$ & $\begin{array}{l}9 \\
(0.4 \%)\end{array}$ & $\begin{array}{l}5 \\
(0.2 \%)\end{array}$ & $\begin{array}{l}6 \\
(0.3 \%)\end{array}$ & $\begin{array}{l}0 \\
(0.0 \%)\end{array}$ & $\begin{array}{l}17 \\
(0.5 \%)\end{array}$ & $\begin{array}{l}8 \\
(0.7 \%)\end{array}$ & $\begin{array}{l}0 \\
(0.0 \%)\end{array}$ & $\begin{array}{l}14 \\
(0.8 \%)\end{array}$ & $\begin{array}{l}46 \\
(1.6 \%)\end{array}$ \\
\hline Mendigo & $\begin{array}{l}97 \\
(0.5 \%)\end{array}$ & $\begin{array}{l}2 \\
(0.1 \%)\end{array}$ & $\begin{array}{l}7 \\
(0.3 \%)\end{array}$ & $\begin{array}{l}10 \\
(0.5 \%)\end{array}$ & $\begin{array}{l}13 \\
(0.7 \%)\end{array}$ & $\begin{array}{l}5 \\
(0.6 \%)\end{array}$ & $\begin{array}{l}5 \\
(0.1 \%)\end{array}$ & $\begin{array}{l}14 \\
(1.3 \%)\end{array}$ & $\begin{array}{l}7 \\
(0.4 \%)\end{array}$ & $\begin{array}{l}14 \\
(0.8 \%)\end{array}$ & $\begin{array}{l}20 \\
(0.7 \%)\end{array}$ \\
\hline Militar & $\begin{array}{l}67 \\
(0.3 \%)\end{array}$ & $\begin{array}{l}0 \\
(0.0 \%)\end{array}$ & $\begin{array}{l}0 \\
(0.0 \%)\end{array}$ & $\begin{array}{l}0 \\
(0.0 \%)\end{array}$ & $\begin{array}{l}0 \\
(0.0 \%)\end{array}$ & $\begin{array}{l}0 \\
(0.0 \%)\end{array}$ & $\begin{array}{l}44 \\
(1.2 \%)\end{array}$ & $\begin{array}{l}23 \\
(2.1 \%)\end{array}$ & $\begin{array}{l}0 \\
(0.0 \%)\end{array}$ & $\begin{array}{l}0 \\
(0.0 \%)\end{array}$ & $\begin{array}{l}0 \\
(0.0 \%)\end{array}$ \\
\hline Criado & $\begin{array}{l}63 \\
(0.3 \%)\end{array}$ & $\begin{array}{l}12 \\
(0.6 \%)\end{array}$ & $\begin{array}{l}7 \\
(0.3 \%)\end{array}$ & $\begin{array}{l}12 \\
(0.6 \%)\end{array}$ & $\begin{array}{l}0 \\
(0.0 \%)\end{array}$ & $\begin{array}{l}0 \\
(0.0 \%)\end{array}$ & $\begin{array}{l}5 \\
(0.1 \%)\end{array}$ & $\begin{array}{l}19 \\
(1.7 \%)\end{array}$ & $\begin{array}{l}0 \\
(0.0 \%)\end{array}$ & $\begin{array}{l}0 \\
(0.0 \%)\end{array}$ & $\begin{array}{l}8 \\
(0.3 \%)\end{array}$ \\
\hline Barbeiro & $\begin{array}{l}58 \\
(0.3 \%)\end{array}$ & $\begin{array}{l}0 \\
(0.0 \%)\end{array}$ & $\begin{array}{l}16 \\
(0.8 \%)\end{array}$ & $\begin{array}{l}10 \\
(0.5 \%)\end{array}$ & $\begin{array}{l}1 \\
(0.0 \%)\end{array}$ & $\begin{array}{l}2 \\
(0.3 \%)\end{array}$ & $\begin{array}{l}9 \\
(0.3 \%)\end{array}$ & $\begin{array}{l}5 \\
(0.5 \%)\end{array}$ & $\begin{array}{l}0 \\
(0.0 \%)\end{array}$ & $\begin{array}{l}2 \\
(0.1 \%)\end{array}$ & $\begin{array}{l}13 \\
(0.4 \%)\end{array}$ \\
\hline Tanoeiro & $\begin{array}{l}54 \\
(0.3 \%)\end{array}$ & $\begin{array}{l}2 \\
(0.1 \%)\end{array}$ & $\begin{array}{l}0 \\
(0.0 \%)\end{array}$ & $\begin{array}{l}0 \\
(0.0 \%)\end{array}$ & $\begin{array}{l}0 \\
(0.0 \%)\end{array}$ & $\begin{array}{l}2 \\
(0.3 \%)\end{array}$ & $\begin{array}{l}23 \\
(0.6 \%)\end{array}$ & $\begin{array}{l}3 \\
(0.3 \%)\end{array}$ & $\begin{array}{l}0 \\
(0.0 \%)\end{array}$ & $\begin{array}{l}9 \\
(0.5 \%)\end{array}$ & $\begin{array}{l}15 \\
(0.5 \%)\end{array}$ \\
\hline Pastor & $\begin{array}{l}37 \\
(0.2 \%)\end{array}$ & $\begin{array}{l}0 \\
(0.0 \%)\end{array}$ & $\begin{array}{l}0 \\
(0.0 \%)\end{array}$ & $\begin{array}{l}13 \\
(0.6 \%)\end{array}$ & $\begin{array}{l}0 \\
(0.0 \%)\end{array}$ & $\begin{array}{l}0 \\
(0.0 \%)\end{array}$ & $\begin{array}{l}0 \\
(0.0 \%)\end{array}$ & $\begin{array}{l}24 \\
(2.2 \%)\end{array}$ & $\begin{array}{l}0 \\
(0.0 \%)\end{array}$ & $\begin{array}{l}0 \\
(0.0 \%)\end{array}$ & $\begin{array}{l}0 \\
(0.0 \%)\end{array}$ \\
\hline Lavadeira & $\begin{array}{l}21 \\
(0.1 \%)\end{array}$ & $\begin{array}{l}0 \\
(0.0 \%)\end{array}$ & $\begin{array}{l}0 \\
(0.0 \%)\end{array}$ & $\begin{array}{l}0 \\
(0.0 \%)\end{array}$ & $\begin{array}{l}0 \\
(0.0 \%)\end{array}$ & $\begin{array}{l}0 \\
(0.0 \%)\end{array}$ & $\begin{array}{l}21 \\
(0.6 \%)\end{array}$ & $\begin{array}{l}0 \\
(0.0 \%)\end{array}$ & $\begin{array}{l}0 \\
(0.0 \%)\end{array}$ & $\begin{array}{l}0 \\
(0.0 \%)\end{array}$ & $\begin{array}{l}0 \\
(0.0 \%)\end{array}$ \\
\hline Serrador & $\begin{array}{l}21 \\
(0.1 \%)\end{array}$ & $\begin{array}{l}4 \\
(0.2 \%)\end{array}$ & $\begin{array}{l}8 \\
(0.4 \%)\end{array}$ & $\begin{array}{l}0 \\
(0.0 \%)\end{array}$ & $\begin{array}{l}0 \\
(0.0 \%)\end{array}$ & $\begin{array}{l}8 \\
(1.0 \%)\end{array}$ & $\begin{array}{l}1 \\
(0.0 \%)\end{array}$ & $\begin{array}{l}0 \\
(0.0 \%)\end{array}$ & $\begin{array}{l}0 \\
(0.0 \%)\end{array}$ & $\begin{array}{l}0 \\
(0.0 \%)\end{array}$ & $\begin{array}{l}0 \\
(0.0 \%)\end{array}$ \\
\hline Livros & $\begin{array}{l}12 \\
(0.1 \%)\end{array}$ & $\begin{array}{l}0 \\
(0.0 \%)\end{array}$ & $\begin{array}{l}8 \\
(0.4 \%)\end{array}$ & $\begin{array}{l}0 \\
(0.0 \%)\end{array}$ & $\begin{array}{l}0 \\
(0.0 \%)\end{array}$ & $\begin{array}{l}0 \\
(0.0 \%)\end{array}$ & $\begin{array}{l}4 \\
(0.1 \%)\end{array}$ & $\begin{array}{l}0 \\
(0.0 \%)\end{array}$ & $\begin{array}{l}0 \\
(0.0 \%)\end{array}$ & $\begin{array}{l}0 \\
(0.0 \%)\end{array}$ & $\begin{array}{l}0 \\
(0.0 \%)\end{array}$ \\
\hline Farmácia & $\begin{array}{l}12 \\
(0.1 \%)\end{array}$ & $\begin{array}{l}0 \\
(0.0 \%)\end{array}$ & $\begin{array}{l}5 \\
(0.2 \%)\end{array}$ & $\begin{array}{l}0 \\
(0.0 \%)\end{array}$ & $\begin{array}{l}0 \\
(0.0 \%)\end{array}$ & $\begin{array}{l}1 \\
(0.1 \%)\end{array}$ & $\begin{array}{l}6 \\
(0.2 \%)\end{array}$ & $\begin{array}{l}0 \\
(0.0 \%)\end{array}$ & $\begin{array}{l}0 \\
(0.0 \%)\end{array}$ & $\begin{array}{l}0 \\
(0.0 \%)\end{array}$ & $\begin{array}{l}0 \\
(0.0 \%)\end{array}$ \\
\hline Médico & $\begin{array}{l}6 \\
(0.1 \%)\end{array}$ & $\begin{array}{l}0 \\
(0.0 \%)\end{array}$ & $\begin{array}{l}0 \\
(0.0 \%)\end{array}$ & $\begin{array}{l}0 \\
(0.0 \%)\end{array}$ & $\begin{array}{l}0 \\
(0.0 \%)\end{array}$ & $\begin{array}{l}0 \\
(0.0 \%)\end{array}$ & $\begin{array}{l}2 \\
(0.0 \%)\end{array}$ & $\begin{array}{l}0 \\
(0.0 \%)\end{array}$ & $\begin{array}{l}0 \\
(0.0 \%)\end{array}$ & $\begin{array}{l}0 \\
(0.0 \%)\end{array}$ & $\begin{array}{l}4 \\
(0.1 \%)\end{array}$ \\
\hline Professor & $\begin{array}{l}1 \\
(0.1 \%)\end{array}$ & $\begin{array}{l}1 \\
(0.0 \%)\end{array}$ & $\begin{array}{l}0 \\
(0.0 \%)\end{array}$ & $\begin{array}{l}0 \\
(0.0 \%)\end{array}$ & $\begin{array}{l}0 \\
(0.0 \%)\end{array}$ & $\begin{array}{l}0 \\
(0.0 \%)\end{array}$ & $\begin{array}{l}0 \\
(0.0 \%)\end{array}$ & $\begin{array}{l}0 \\
(0.0 \%)\end{array}$ & $\begin{array}{l}0 \\
(0.0 \%)\end{array}$ & $\begin{array}{l}0 \\
(0.0 \%)\end{array}$ & $\begin{array}{l}0 \\
(0.0 \%)\end{array}$ \\
\hline $\begin{array}{l}\text { Pais in- } \\
\text { cógnitos }\end{array}$ & $\begin{array}{l}520 \\
(2.7 \%)\end{array}$ & $\begin{array}{l}33 \\
(1.8 \%)\end{array}$ & $\begin{array}{l}42 \\
(2.1 \%)\end{array}$ & $\begin{array}{l}35 \\
(1.7 \%)\end{array}$ & $\begin{array}{l}55 \\
(2.9 \%)\end{array}$ & $\begin{array}{l}20 \\
(2.5 \%)\end{array}$ & $\begin{array}{l}109 \\
(3.0 \%)\end{array}$ & $\begin{array}{l}29 \\
(2.6 \%)\end{array}$ & $\begin{array}{l}60 \\
(3.8 \%)\end{array}$ & $\begin{array}{l}69 \\
(4.1 \%)\end{array}$ & $\begin{array}{l}68 \\
(2.3 \%)\end{array}$ \\
\hline $\begin{array}{l}\text { Profissão } \\
\text { Desco- } \\
\text { nhec. }\end{array}$ & $\begin{array}{l}1269 \\
(6.5 \%)\end{array}$ & $\begin{array}{l}47 \\
(2.5 \%)\end{array}$ & $\begin{array}{l}92 \\
(4.5 \%)\end{array}$ & $\begin{array}{l}138 \\
(6.8 \%)\end{array}$ & $\begin{array}{l}140 \\
(7.3 \%)\end{array}$ & $\begin{array}{l}66 \\
(8.4 \%)\end{array}$ & $\begin{array}{l}512 \\
(14.3 \%)\end{array}$ & $\begin{array}{l}58 \\
(5.3 \%)\end{array}$ & $\begin{array}{l}126 \\
(7.9 \%)\end{array}$ & $\begin{array}{l}13 \\
(0.8 \%)\end{array}$ & $\begin{array}{l}77 \\
(2.6 \%)\end{array}$ \\
\hline Outras & $\begin{array}{l}459 \\
(2.3 \%)\end{array}$ & $\begin{array}{l}82 \\
(4.4 \%)\end{array}$ & $\begin{array}{l}81 \\
(4.0 \%)\end{array}$ & $\begin{array}{l}17 \\
(0.8 \%)\end{array}$ & $\begin{array}{l}7 \\
(0.4 \%)\end{array}$ & $\begin{array}{l}17 \\
(2.2 \%)\end{array}$ & $\begin{array}{l}71 \\
(2.0 \%)\end{array}$ & $\begin{array}{l}27 \\
(2.5 \%)\end{array}$ & $\begin{array}{l}18 \\
(1.1 \%)\end{array}$ & $\begin{array}{l}29 \\
(1.7 \%)\end{array}$ & $\begin{array}{l}110 \\
(3.8 \%)\end{array}$ \\
\hline Total & $\begin{array}{l}19524 \\
(100 \%)\end{array}$ & $\begin{array}{l}1869 \\
(100 \%)\end{array}$ & $\begin{array}{l}2035 \\
(100 \%)\end{array}$ & $\begin{array}{l}2041 \\
(100 \%)\end{array}$ & $\begin{array}{l}1919 \\
(100 \%)\end{array}$ & $\begin{array}{l}785 \\
(100 \%)\end{array}$ & $\begin{array}{l}3585 \\
(100 \%)\end{array}$ & $\begin{array}{l}1096 \\
(100 \%)\end{array}$ & $\begin{array}{l}1588 \\
(100 \%)\end{array}$ & $\begin{array}{l}1673 \\
(100 \%)\end{array}$ & $\begin{array}{l}2933 \\
(100 \%)\end{array}$ \\
\hline
\end{tabular}




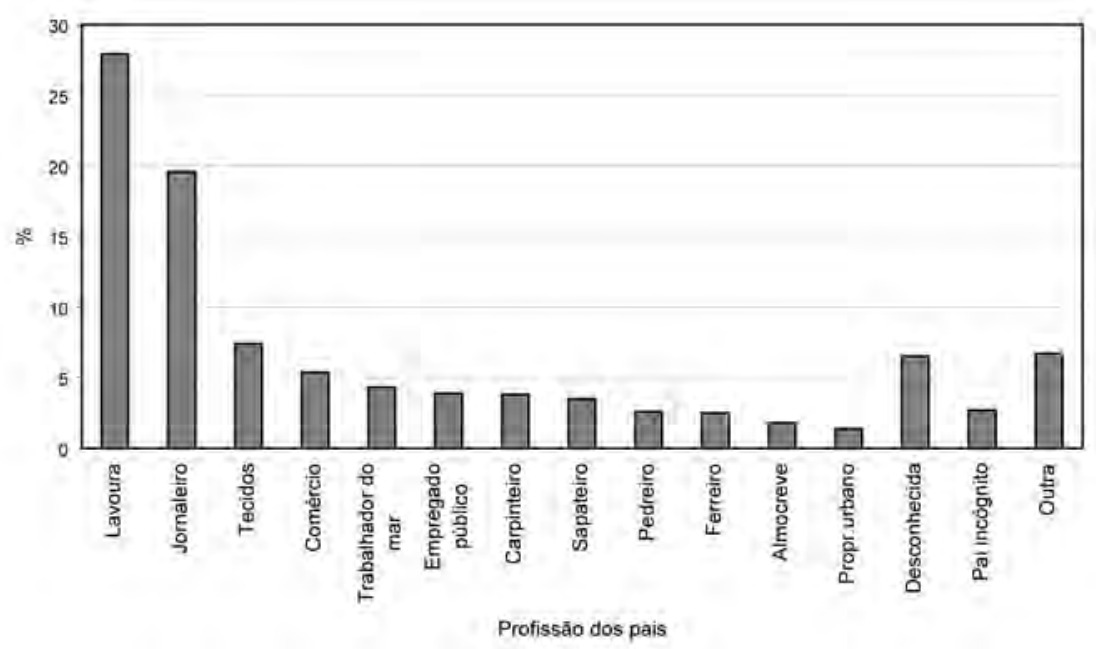

Figura 28: Profissões mais frequentes dos pais dos alunos para o total da amostra. Portugal, 1867.

A partir do trabalho com os dados específicos acerca da origem social dos alunos das escolas primárias, António Nóvoa traçou algumas hipóteses que, efetivamente, parece-nos virem a se confirmar:

Há efetivamente na escola portuguesa um conjunto de alunos muito heterogêneo, com uma proporção bastante elevada daqueles estratos sociais urbanos que não viviam diretamente da agricultura.

Quando se busca aproximação das práticas rotineiras, do dia-a-dia da sala de aula portuguesa, chamam a atenção, de um modo destacado, as referências ao material didático, particularmente aos compêndios efetivamente utilizados nas escolas. Tais obras possuem um singular significado para a reconstituição historiográfica das condutas preconizadas, dos valores, dos saberes elementares eleitos pelos educadores da meninice portuguesa. Algo do que dizia a aula, um pouco do que se dizia na aula, passava, sem dúvida, por aquele que seria - como já observou alguém - o livro mais importante da vida de pessoas; dado que dificilmente alguém permanecerá acompanhado por outro livro durante o decorrer de um ano - como ocorre rotineiramente com o livro escolar. Pelo seu conteúdo, mas também por suas feições e feitios, o livro didático é um dos principais protagonistas da narrativa escolar. Nessa direção, ele efetivamente produz um mundo próprio e o revela às jovens e inexperientes geraçôes como se de realidade se tratasse. Muito do homem adulto programado pela teia do social viria ali já esboçado. Esse repertório bibliográfico faz-se, pois, inventário precioso para que possamos efetivamente reconhecer aquilo que a vida escolar, ao menos, um dia pretendeu ser.

\section{Os compêndios mais utilizados e a realidade da leitura escolar}

O Relatório de Inspeção às Escolas Públicas efetuado no ano letivo de 1866-1867 fornece-nos a possibilidade de arrolar estatisticamente os compêndios existentes nas 
escolas em todo o território português naquela altura. $\mathrm{O}$ enunciado dessa proposta de listagem das obras aparece no Relatório da seguinte maneira: "livros usados pelos alunos com declaração do número de alunos que usam deles" ${ }^{274}$ Ora, tal orientação revela, desde logo, o reconhecimento da inexistência de quaisquer padronizaçóes ou critérios de uniformidade quanto às obras didáticas. Contudo, em certa medida, haveria um indicativo, posto que, no impresso oferecido aos inspetores, dez obras eram nomeadas perante o suposto de que existissem em profusão nas unidades escolares de Portugal. Percebe-se ali a sugestão das obras já arroladas pelo impresso do relatório da inspeção como significativas de algum julgamento anterior acerca dos manuais escolares mais em voga no referido período. Porém, ao contrário do que, a princípio, supunham técnicos e especialistas, em boa parte das escolas, a História Sagrada de Monteverde era mais utilizada do que a Encyclopédia de Latino Coelho, ou mesmo o Cathecismo de Montpellier, cujo uso, aliás, naquele Relatório específico, sequer aparecia. Havia, na época, tentativas localizadas de padronização dos manuais didáticos. Existia, por exemplo, no Bairro d'Alcântara, em Lisboa, uma escola mista situada na Rua de Santa Isabel, onde foram registrados 135 exemplares da versão traduzida e resumida do Cathecismo de Montpellier. Nas demais escolas da mesma região (todas as outras eram apenas masculinas), não existia, pelo relato do inspetor, nenhum outro exemplar daquela obra. Estavam todos concentrados naquela única instituição. No Concelho de Coimbra, foram também identificados exemplares do Cathecismo de Montpellier. No entanto, dentre as oito escolas do referido concelho, apenas duas - a da Sé Nova e a de Almaluques - continham tal obra, o que leva a crer que a versão resumida do Cathecismo tivesse sido até distribuída pelos alunos. ${ }^{275}$ Embora o Relatório de 1867 computasse os livros das crianças, deveria haver algum tipo de aconselhamento por parte do inspetor, com

${ }^{274}$ A relação de livros, bem como o enunciado acima transcrito, foram extraídos dos impressos padronizados para o Relatório da Inspeção de 1867. Vide, por exemplo, MR 1049 (Manuscritos transferidos do Ministério do Interior - Relação elaborada pelo Dr. Alcino Manuel Silva / Inspeção Extraordinária às Escolas Públicas e Particulares do Concelho de Elvas no Distrito de Portalegre).

${ }^{275}$ MR 1055 e MR 1049. O Cathecismo de Montpellier, que havia sido - como já pudemos anteriormente observar - já indicado por Pombal, viria a ser recomendado pelo texto intitulado Instrucção para os mestres de primeiras letras, brochura publicada no ano de 1815 pela Real Imprensa da Universidade, em Coimbra. A orientação dada aos mestres por aquele texto compreendia as matérias escolares que deveriam ser ensinadas às crianças, entre as quais salientava-se sobremaneira a Religião e a Civilidade, disciplinas que, nos termos daquela instrução normativa, viriam a "polir a natural rudeza dos meninos e dispô-los para viverem com o decoro, próprio de sua condição, na Igreja e no estado” (p. 1) O aprendizado da leitura, a bem dizer, principiaria com o catecismo. A partir dele, acreditava-se que seriam impressas na alma do estudante algumas das virtudes essenciais à 'civilidade cristã', o que compreenderia hábitos de humildade para com Deus, de modéstia para com os pais, os mestres e os superiores, de maneira geral, de caridade perante os iguais e os inferiores. Além disso, através do ensino catequético, os meninos adquiririam o hábito do acatamento e da obediência, o senso de oportunidade para seus atos, e finalmente a cortesia nos gestos e nas ações. Sugeria-se desde ali o cuidado para que a infância e a mocidade portuguesa não travassem em hipótese alguma contato com livros e impressos perniciosos à moralidade e à inocência. Nessa medida, embora fossem evidentemente admitidos outros livros recomendáveis sob esses aspetos para vida escolar, prescrevia-se à guisa de sugestão o uso do compêndio a que aqui nos referimos e que persistiria sendo, por todo aquele século XIX, como veremos logo adiante, um dos mais concorridos na sala de aula portuguesa. Dizia assim a Instrucção: "SSendo muito importante aproveitar os bons talentos, que nas escolas aparecem, não pouparão os Mestres mais copiosa instrução aos meninos, em que reconhecerem maior aptidão para algumas das sobreditas disciplinas. Portanto exercitá-los-ão na leitura de bons livros (...), e mormente na do Cathecismo de Montpellier, na da História Sagrada, e na de lugares escolhidos dos nossos Clássicos, em que venham espécies da História do Reino, ou de outra natureza, capazes de excitar à piedade, ao patriotismo e ao amor ao atual governo." (INSTRUCÇÃO para os mestres de primeiras letras, p. 8) 
o propósito de orientar os professores. Tal prática aparece com nitidez, por exemplo, no Concelho de Alenquer (Lisboa), onde há anotações manuscritas efetuadas no documento da inspeção, por meio das quais o inspetor responsável sugere ao professor a substituição dos Lusíadas pela obra de Simão de Nântua. ${ }^{276}$

O levantamento estatístico fornece-nos o seguinte retrato:

Tabela 49: Distribuição dos livros mais utilizados nas escolas de Portugal em 1867, segundo autores por distritos e para o total da amostra.

\begin{tabular}{|c|c|c|c|c|c|c|c|c|c|c|c|}
\hline & & Distrit & & & & & & & & & \\
\hline Livro & Total & Aveiro & Coimbra & $\begin{array}{l}\text { Castello } \\
\text { Branco }\end{array}$ & Guarda & Évora & Lisboa & Portalegre & $\begin{array}{l}\text { Villa } \\
\text { Real }\end{array}$ & Vizeu & $\begin{array}{l}\text { Vianna } \\
\text { do } \\
\text { Castello }\end{array}$ \\
\hline $\begin{array}{l}\text { 1.Methodo } \\
\text { Facillimo }\end{array}$ & $\begin{array}{l}3930 \\
(31.9)\end{array}$ & $\begin{array}{l}653 \\
(48.3 \%)\end{array}$ & $\begin{array}{l}344 \\
(29.6 \%)\end{array}$ & $\begin{array}{l}263 \\
(29.5 \%)\end{array}$ & $\begin{array}{l}680 \\
(48.0 \%)\end{array}$ & $\begin{array}{l}266 \\
(37.4 \%)\end{array}$ & $\begin{array}{l}669 \\
(25.2 \%)\end{array}$ & $\begin{array}{l}377 \\
(52.2 \%)\end{array}$ & $\begin{array}{l}302 \\
(30.1 \%)\end{array}$ & $\begin{array}{l}157 \\
(19.9 \%)\end{array}$ & $\begin{array}{l}219 \\
(13.7 \%)\end{array}$ \\
\hline $\begin{array}{l}\text { 2.Cartilha } \\
\text { de doutrina } \\
\text { cristã }\end{array}$ & $\begin{array}{l}2282 \\
(18.5 \\
\%)\end{array}$ & $\begin{array}{l}220 \\
(16.3 \%)\end{array}$ & $\begin{array}{l}121 \\
(10.4 \%)\end{array}$ & $\begin{array}{l}202 \\
(22.6 \%)\end{array}$ & $\begin{array}{l}309 \\
(21.8 \%)\end{array}$ & $\begin{array}{l}24 \\
(3.4 \%)\end{array}$ & $\begin{array}{l}34 \\
(1.3 \%)\end{array}$ & $\begin{array}{l}9 \\
(1.2 \%)\end{array}$ & $\begin{array}{l}385 \\
(38.3 \%)\end{array}$ & $\begin{array}{l}145 \\
(18.4 \%)\end{array}$ & $\begin{array}{l}833 \\
(52.0 \%)\end{array}$ \\
\hline $\begin{array}{l}\text { 3.Manual } \\
\text { Encyclope- } \\
\text { dico }\end{array}$ & $\begin{array}{l}1915 \\
(15.6 \\
\%)\end{array}$ & $\begin{array}{l}200 \\
(14.8 \%)\end{array}$ & $\begin{array}{l}172 \\
(14.8 \%)\end{array}$ & $\begin{array}{l}187 \\
(21.0 \%)\end{array}$ & $\begin{array}{l}195 \\
(13.7 \%)\end{array}$ & $\begin{array}{l}123 \\
(17.3 \%)\end{array}$ & $\begin{array}{l}302 \\
(11.4 \%)\end{array}$ & $\begin{array}{l}173 \\
(24.0 \%)\end{array}$ & $\begin{array}{l}175 \\
(17.4 \%)\end{array}$ & $\begin{array}{l}251 \\
(31.9 \%)\end{array}$ & $\begin{array}{l}137 \\
(8.6 \%)\end{array}$ \\
\hline $\begin{array}{l}\text { 4.Cathecis- } \\
\text { mo de } \\
\text { Montpellier }\end{array}$ & $\begin{array}{l}1332 \\
(10.8 \\
\%)\end{array}$ & $\begin{array}{l}147 \\
(10.9 \%)\end{array}$ & $\begin{array}{l}114 \\
(9.8 \%)\end{array}$ & $\begin{array}{l}87 \\
(9.8 \%)\end{array}$ & $\begin{array}{l}128 \\
(9.0 \%)\end{array}$ & $\begin{array}{l}27 \\
(3.8 \%)\end{array}$ & $\begin{array}{l}298 \\
(11.2 \%)\end{array}$ & $\begin{array}{l}4 \\
(0.6 \%)\end{array}$ & $\begin{array}{l}104 \\
(10.4 \%)\end{array}$ & $\begin{array}{l}201 \\
(25.6 \%)\end{array}$ & $\begin{array}{l}222 \\
(13.9 \%)\end{array}$ \\
\hline 5.Ventura & $\begin{array}{l}457 \\
(3.7 \%)\end{array}$ & $\begin{array}{l}23 \\
(1.8 \%)\end{array}$ & $\begin{array}{l}6 \\
(0.5 \%)\end{array}$ & $\begin{array}{l}3 \\
(0.3 \%)\end{array}$ & $\begin{array}{l}0 \\
(0.0 \%)\end{array}$ & $\begin{array}{l}137 \\
(19.2 \%)\end{array}$ & $\begin{array}{l}179 \\
(6.7 \%)\end{array}$ & $\begin{array}{l}24 \\
(3.3 \%)\end{array}$ & $\begin{array}{l}21 \\
(2.1 \%)\end{array}$ & $\begin{array}{l}6 \\
(0.8 \%)\end{array}$ & $\begin{array}{l}58 \\
(3.6 \%)\end{array}$ \\
\hline $\begin{array}{l}\text { 6.Figueire- } \\
\text { do Vieira }\end{array}$ & $\begin{array}{l}398 \\
(3.2 \%)\end{array}$ & \begin{tabular}{|l|}
14 \\
$(1.0 \%)$
\end{tabular} & $\begin{array}{l}38 \\
(3.3 \%)\end{array}$ & $\begin{array}{l}9 \\
(1.0 \%)\end{array}$ & $\begin{array}{l}8 \\
(0.6 \%)\end{array}$ & $\begin{array}{l}11 \\
(1.5 \%)\end{array}$ & $\begin{array}{l}243 \\
(9.1 \%)\end{array}$ & $\begin{array}{l}18 \\
(2.5 \%)\end{array}$ & $\begin{array}{l}3 \\
(0.3 \%)\end{array}$ & $\begin{array}{l}2 \\
(0.3 \%)\end{array}$ & $\begin{array}{l}52 \\
(3.2 \%)\end{array}$ \\
\hline $\begin{array}{l}\text { 7.Biblia } \\
\text { Infancia }\end{array}$ & $\begin{array}{l}392 \\
(3.2 \%)\end{array}$ & $\begin{array}{l}0 \\
(0.0 \%)\end{array}$ & $\begin{array}{l}116 \\
(10.0 \%)\end{array}$ & $\begin{array}{l}42 \\
(4.7 \%)\end{array}$ & $\begin{array}{l}0 \\
(0.0 \%)\end{array}$ & $\begin{array}{l}52 \\
(7.3 \%)\end{array}$ & $\begin{array}{l}161 \\
(6.1 \%)\end{array}$ & $\begin{array}{l}21 \\
(2.9 \%)\end{array}$ & $\begin{array}{l}0 \\
(0.0 \%)\end{array}$ & $\begin{array}{l}0 \\
(0.0 \%)\end{array}$ & $\begin{array}{l}0 \\
(0.0 \%)\end{array}$ \\
\hline $\begin{array}{l}\text { 8.Cardoso } \\
\text { Logares } \\
\text { Selectos }\end{array}$ & $\begin{array}{l}327 \\
(2.7 \%)\end{array}$ & $\begin{array}{l}11 \\
(0.8 \%)\end{array}$ & $\begin{array}{l}75 \\
(6.5 \%)\end{array}$ & $\begin{array}{l}14 \\
(1.6 \%)\end{array}$ & $\begin{array}{l}10 \\
(0.7 \%)\end{array}$ & $\begin{array}{l}8 \\
(1.1 \%)\end{array}$ & $\begin{array}{l}127 \\
(4.8 \%)\end{array}$ & $\begin{array}{l}39 \\
(5.4 \%)\end{array}$ & $\begin{array}{l}2 \\
(0.2 \%)\end{array}$ & $\begin{array}{l}10 \\
(1.3 \%)\end{array}$ & $\begin{array}{l}31 \\
(1.9 \%)\end{array}$ \\
\hline $\begin{array}{l}\text { 9.Caldas } \\
\text { Aulete }\end{array}$ & $\begin{array}{l}304 \\
(2.4 \%)\end{array}$ & $\begin{array}{l}46 \\
(3.4 \%)\end{array}$ & $\begin{array}{l}0 \\
(0.0 \%)\end{array}$ & $\begin{array}{l}3 \\
(0.3 \%)\end{array}$ & $\begin{array}{l}8 \\
(0.6 \%)\end{array}$ & $\begin{array}{l}5 \\
(0.7 \%)\end{array}$ & $\begin{array}{l}202 \\
(7.6 \%)\end{array}$ & $\begin{array}{l}27 \\
(3.7 \%)\end{array}$ & $\begin{array}{l}1 \\
(0.1 \%)\end{array}$ & $\begin{array}{l}4 \\
(0.5 \%)\end{array}$ & $\begin{array}{l}8 \\
(0.5 \%)\end{array}$ \\
\hline $\begin{array}{l}\text { 10.História } \\
\text { Sagrada }\end{array}$ & $\begin{array}{l}257 \\
(2.1 \%)\end{array}$ & $\begin{array}{l}7 \\
(0.5 \%)\end{array}$ & $\begin{array}{l}59 \\
(5.1 \%)\end{array}$ & $\begin{array}{l}47 \\
(5.3 \%)\end{array}$ & $\begin{array}{l}44 \\
(3.1 \%)\end{array}$ & $\begin{array}{l}19 \\
(2.7 \%)\end{array}$ & $\begin{array}{l}39 \\
(1.5 \%)\end{array}$ & $\begin{array}{l}9 \\
(1.2 \%)\end{array}$ & $\begin{array}{l}3 \\
(0.3 \%)\end{array}$ & $\begin{array}{l}0 \\
(0.0 \%)\end{array}$ & $\begin{array}{l}30 \\
(1.8 \%)\end{array}$ \\
\hline 11.Midosi & $\begin{array}{l}198 \\
(1.6 \%)\end{array}$ & $\begin{array}{l}0 \\
(0.0 \%)\end{array}$ & $\begin{array}{l}0 \\
(0.0 \%)\end{array}$ & $\begin{array}{l}0 \\
(0.0 \%)\end{array}$ & $\begin{array}{l}0 \\
(0.0 \%)\end{array}$ & $\begin{array}{l}19 \\
(2.7 \%)\end{array}$ & $\begin{array}{l}166 \\
(6.2 \%)\end{array}$ & $\begin{array}{l}12 \\
(1.6 \%)\end{array}$ & $\begin{array}{l}0 \\
(0.0 \%)\end{array}$ & $\begin{array}{l}1 \\
(0.1 \%)\end{array}$ & $\begin{array}{l}0 \\
(0.0 \%)\end{array}$ \\
\hline
\end{tabular}

${ }^{276}$ MR 1055. Distrito: Lisboa; Concelho: Alenquer. 


\begin{tabular}{|c|c|c|c|c|c|c|c|c|c|c|c|}
\hline $\begin{array}{l}\text { 12.Livro } \\
\text { dos } \\
\text { Meninos }\end{array}$ & $\begin{array}{l}173 \\
(1.4 \%)\end{array}$ & $\begin{array}{l}14 \\
(1.0 \%)\end{array}$ & $\begin{array}{l}2 \\
(0.2 \%)\end{array}$ & $\begin{array}{l}15 \\
(1.7 \%)\end{array}$ & $\begin{array}{l}8 \\
(0.6 \%)\end{array}$ & $\begin{array}{l}0 \\
(0.0 \%)\end{array}$ & $\begin{array}{l}110 \\
(4.1 \%)\end{array}$ & $\begin{array}{l}2 \\
(0.3 \%)\end{array}$ & $\begin{array}{l}7 \\
(0.7 \%)\end{array}$ & $\begin{array}{l}9 \\
(1.1 \%)\end{array}$ & $\begin{array}{l}6 \\
(0.4 \%)\end{array}$ \\
\hline $\begin{array}{l}\text { 13.Paleo- } \\
\text { grapho }\end{array}$ & $\begin{array}{l}98 \\
(0.8 \%)\end{array}$ & $\begin{array}{l}0 \\
(0.0 \%)\end{array}$ & $\begin{array}{l}2 \\
(0.2 \%)\end{array}$ & $\begin{array}{l}3 \\
(0.3 \%)\end{array}$ & $\begin{array}{l}7 \\
(0.5 \%)\end{array}$ & $\begin{array}{l}11 \\
(1.5 \%)\end{array}$ & $\begin{array}{l}75 \\
(2.8 \%)\end{array}$ & $\begin{array}{l}0 \\
(0.0 \%)\end{array}$ & $\begin{array}{l}0 \\
(0.0 \%)\end{array}$ & $\begin{array}{l}0 \\
(0.0 \%)\end{array}$ & $\begin{array}{l}0 \\
(0.0 \%)\end{array}$ \\
\hline $\begin{array}{l}\text { 14.Bandeira } \\
\text { Abecedário }\end{array}$ & $\begin{array}{l}76 \\
(0.6 \%)\end{array}$ & $\begin{array}{l}7 \\
(0.5 \%)\end{array}$ & $\begin{array}{l}69 \\
(5.9 \%)\end{array}$ & $\begin{array}{l}0 \\
(0.0 \%)\end{array}$ & $\begin{array}{l}0 \\
(0.0 \%)\end{array}$ & $\begin{array}{l}0 \\
(0.0 \%)\end{array}$ & $\begin{array}{l}0 \\
(0.0 \%)\end{array}$ & $\begin{array}{l}0 \\
(0.0 \%)\end{array}$ & $\begin{array}{l}0 \\
(0.0 \%)\end{array}$ & $\begin{array}{l}0 \\
(0.0 \%)\end{array}$ & $\begin{array}{l}0 \\
(0.0 \%)\end{array}$ \\
\hline 15.Lusíadas & $\begin{array}{l}51 \\
(0.4 \%)\end{array}$ & $\begin{array}{l}3 \\
(0.2 \%)\end{array}$ & $\begin{array}{l}5 \\
(0.4 \%)\end{array}$ & $\begin{array}{l}0 \\
(0.0 \%)\end{array}$ & $\begin{array}{l}0 \\
(0.0 \%)\end{array}$ & $\begin{array}{l}8 \\
(1.1 \%)\end{array}$ & $\begin{array}{l}20 \\
(0.9 \%)\end{array}$ & $\begin{array}{l}7 \\
(1.0 \%)\end{array}$ & $\begin{array}{l}1 \\
(0.1 \%)\end{array}$ & $\begin{array}{l}1 \\
(0.1 \%)\end{array}$ & $\begin{array}{l}6 \\
(0.4 \%)\end{array}$ \\
\hline $\begin{array}{l}\text { 16.Escola } \\
\text { Popular }\end{array}$ & $\begin{array}{l}44 \\
(0.4 \%)\end{array}$ & $\begin{array}{l}0 \\
(0.0 \%)\end{array}$ & $\begin{array}{l}35 \\
(3.0 \%)\end{array}$ & $\begin{array}{l}9 \\
(1.0 \%)\end{array}$ & $\begin{array}{l}0 \\
(0.0 \%)\end{array}$ & $\begin{array}{l}0 \\
(0.0 \%)\end{array}$ & $\begin{array}{l}0 \\
(0.0 \%)\end{array}$ & $\begin{array}{l}0 \\
(0.0 \%)\end{array}$ & $\begin{array}{l}0 \\
(0.0 \%)\end{array}$ & $\begin{array}{l}0 \\
(0.0 \%)\end{array}$ & $\begin{array}{l}0 \\
(0.0 \%)\end{array}$ \\
\hline $\begin{array}{l}\text { 17.Tesouro } \\
\text { Meninos }\end{array}$ & $\begin{array}{l}33 \\
(0.3 \%)\end{array}$ & $\begin{array}{l}2 \\
(0.1 \%)\end{array}$ & $\begin{array}{l}0 \\
(0.0 \%)\end{array}$ & $\begin{array}{l}8 \\
(0.9 \%)\end{array}$ & $\begin{array}{l}21 \\
(1.4 \%)\end{array}$ & $\begin{array}{l}0 \\
(0.0 \%)\end{array}$ & $\begin{array}{l}2 \\
(0.1 \%)\end{array}$ & $\begin{array}{l}0 \\
(0.0 \%)\end{array}$ & $\begin{array}{l}0 \\
(0.0 \%)\end{array}$ & $\begin{array}{l}0 \\
(0.0 \%)\end{array}$ & $\begin{array}{l}0 \\
(0.0 \%)\end{array}$ \\
\hline $\begin{array}{l}\text { 18.Rama } \\
\text { lhetinho } \\
\text { Puerícia }\end{array}$ & $\begin{array}{l}33 \\
(0.3 \%)\end{array}$ & $\begin{array}{l}0 \\
(0.0 \%)\end{array}$ & $\begin{array}{l}0 \\
(0.0 \%)\end{array}$ & $\begin{array}{l}0 \\
(0.0 \%)\end{array}$ & $\begin{array}{l}0 \\
(0.0 \%)\end{array}$ & $\begin{array}{l}2 \\
(0.3 \%)\end{array}$ & $\begin{array}{l}31 \\
(1.2 \%)\end{array}$ & $\begin{array}{l}0 \\
(0.0 \%)\end{array}$ & $\begin{array}{l}0 \\
(0.0 \%)\end{array}$ & $\begin{array}{l}0 \\
(0.0 \%)\end{array}$ & $\begin{array}{l}0 \\
(0.0 \%)\end{array}$ \\
\hline $\begin{array}{l}\text { 19.Ban- } \\
\text { deira } \\
\text { Tabuada }\end{array}$ & $\begin{array}{l}9 \\
(0.1 \%)\end{array}$ & $\begin{array}{l}6 \\
(0.4 \%)\end{array}$ & $\begin{array}{l}3 \\
(0.3 \%)\end{array}$ & $\begin{array}{l}0 \\
(0.0 \%)\end{array}$ & $\begin{array}{l}0 \\
(0.0 \%)\end{array}$ & $\begin{array}{l}0 \\
(0.0 \%)\end{array}$ & $\begin{array}{l}0 \\
(0.0 \%)\end{array}$ & $\begin{array}{l}0 \\
(0.0 \%)\end{array}$ & $\begin{array}{l}0 \\
(0.0 \%)\end{array}$ & $\begin{array}{l}0 \\
(0.0 \%)\end{array}$ & $\begin{array}{l}0 \\
(0.0 \%)\end{array}$ \\
\hline Total & $\begin{array}{l}12309 \\
(100 \%)\end{array}$ & $\begin{array}{l}1353 \\
(100 \%)\end{array}$ & $\begin{array}{l}1161 \\
(100 \%)\end{array}$ & $\begin{array}{l}892 \\
(100 \%)\end{array}$ & $\begin{array}{l}1418 \\
(100 \%)\end{array}$ & $\begin{array}{l}712 \\
(100 \%)\end{array}$ & $\begin{array}{l}2658 \\
(100 \%)\end{array}$ & $\begin{array}{l}722 \\
(100 \%)\end{array}$ & $\begin{array}{l}1004 \\
(100 \%)\end{array}$ & $\begin{array}{l}787 \\
(100 \%)\end{array}$ & $\begin{array}{l}1602 \\
(100 \%)\end{array}$ \\
\hline
\end{tabular}

Os livros indicados na tabela acima vêm ordenados de acordo com a frequência apresentada para o grupo total. Nesse quadro procuraremos relatar a mesma relação pela nomenclatura completa da obra:

Emílio Achilles MONTEVERDE, Methodo facillimo para aprender tanto a letra redonda como a manuscrita no mais curto espaço de tempo possivel.

António J. De Mesquita PIMENTEL (ABBADE DE SALAMONDE), Cartilha da doutrina christã.

Emílio Achilles MONTEVERDE, Manual encyclopedico para uso das escolas d'instrucçāo primária

CATECISMOS da diocese de Montpellier impressos por ordem do bispo Carlos Joaquim Colbert, para por elles ensinar a Doutrina Cristã aos meninos nas escolas de Portugal e do Brasil.

Duarte VENTURA, Arte de aprender a ler a letra manuscripta para uso das escholas em 10 liçōes progressivas do mais facil ao mais difficil.

Carlos Augusto de Figueiredo VIEIRA, Compendio elementar da Grammatica Portugueza.

BIBLIA da infância.

A. CARDOSO BORGES DE FIGUEIREDO, Logares selectos dos classicos portuguezes nos principais generos de discurso em prosa para uso das escholas.

Julio CALDAS AULETE e José Maria LATINO COELHO, Encyclopedia das escolas d’instrucção primária.

Emílio Achilles MONTEVERDE, Manual de História Sagrada: mimo á infância para uso das crianças da cathequese. Luiz Francisco MIDOSI, O expositor portuguez ou rudimentos de ensino da lingua materna.

LIVRO DOS MENINOS Chistãos ou instrucções religiosas de uma mãe.

CARLOS SILVA, O paleographo em escola calligraphica para aprender a leitura manuscripta approvado pelo Conselho Superior d' Instrucção Pública para uso das escolas.

J. S. BANDEIRA, Abecedário.

Luís de CAMÕES, Os Lusiadas.

Jerônimo Soares BARBOSA, Eschola popular das primeiras letras divididas em quatro partes.

Thesouro dos meninos.

Luiz Filipe LEITE, Ramalhetinho da puericia.

J. S. BANDEIRA, Nova taboada exacta e curiosa com o novo systema metrico-decimal de pesos e medidas, tabelas de reduç̧ão e exercicios de problemas para intelligencia do mesmo systema. 


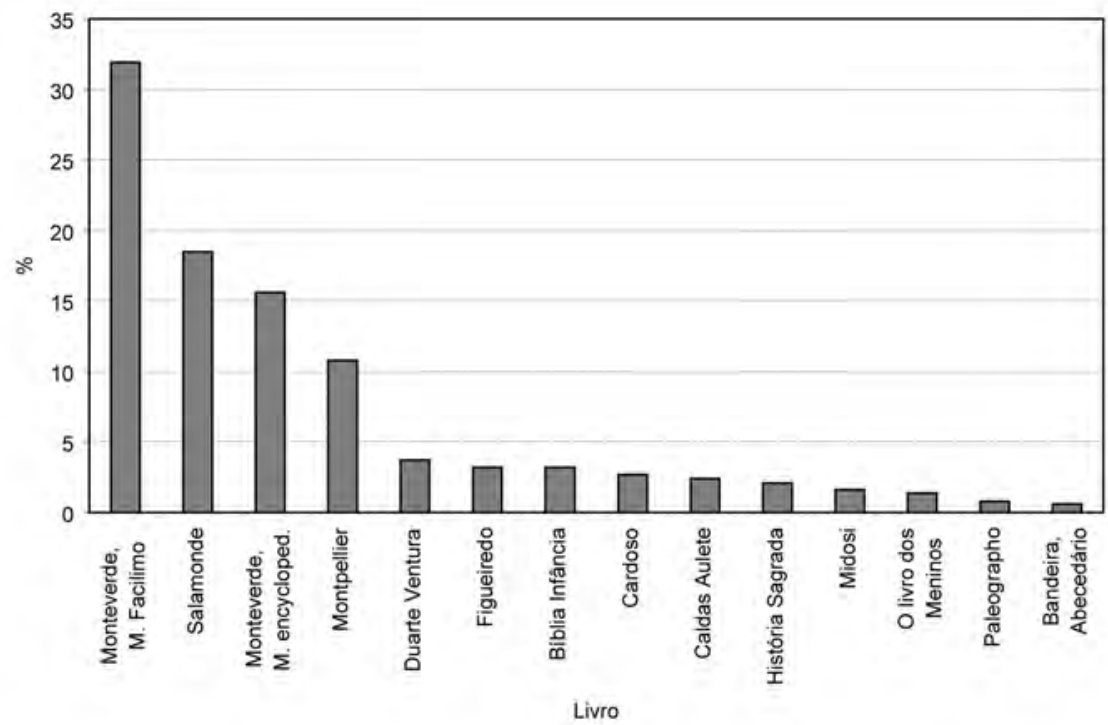

Figura 29: Distribuição dos livros mais utilizados nas escolas por autor para o total da amostra. Portugal, 1867.

Ocorria, de acordo com a referida estatística, uma concentração dos compêndios utilizados com maior frequência, os quais, por sua vez, seriam seguidos por outras obras de utilização mais rarefeita. O impresso do Relatório, arrolando algumas das obras efetivamente mais usadas, abarcava, de fato, as pistas essenciais para a compreensão de como tais suportes textuais contribuíram para apreensão dos saberes elementares da escola primária. Algumas outras obras, porém, muito embora fossem clássicas, não constavam da relação prevista por aquele impresso, a despeito de muitas delas serem bastante usadas nas escolas. A esse respeito, os dados quantitativos demonstram o grande uso que se fazia ainda, na escola primária portuguesa, tanto da Bíblia da Infância quanto da Cartilha de Midosi. Esses dois compêndios excediam numericamente o percentual de utilização do Livro dos Meninos e do Paleógrafo de Carlos Silva. Isso revela que, de alguma forma, aquela tácita previsão de uso majoritário posta nos dez compêndios já constantes do texto impresso no Relatório nem sempre se confirmava.

A relevância das pistas fornecidas pela tabela acima no tocante à apreensão da atmosfera pedagógica e metodológica da escola primária no último quartel do século XIX português conduz-nos a desejar perscrutar o interior desses conteúdos escolares, palmilhando o que, através deles, se contava sobre o homem e sobre o mundo, sobre a justiça e sobre a Humanidade, sobre o ser criança e sobre o ser adulto... enfim, por qual timbre se falava à infância. Procurar a dinâmica de cada obra em sua estrutura discursiva pareceu-nos estratégia imprescindível para avaliação. Ora se escolhia esta, ora se preferia aquela, ora se pretendia trabalhar com uma outra. Alguns dos textos escolares que sobrevivem com procura bastante intensa consistiam em impressos que tiveram presença na longa duração, como é o caso da Cartilha de 
Midosi e como é o caso do Cathecismo de Montpellier. Procuraremos nos debruçar sobre a estrutura discursiva de tais compêndios, com o propósito de reconstituir alguma coisa do substrato mental ali subjacente no que dizia respeito à formação que, por meio da escola, se pretendia efetivar. Faremos isso, entretanto, mediante o entrelaçar dos dados desse resultado específico de 1867 com as informaçóes coletadas a propósito do mesmo tema por parte da análise das obras didáticas destacadas pelos Relatórios de inspeção às escolas datados de 1875. O cruzamento entre ambas as mediçóes possibilitará uma maior aproximação dos costumes e dos usos dos impressos escolares: a dinâmica do processo mediante o qual o território do livro e a realidade da leitura eram dados a ver às crianças, nesse ato do aprendizado da escrita.

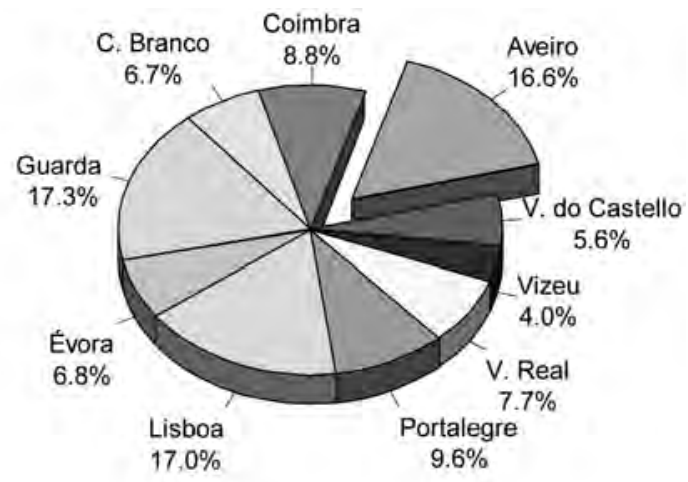

Figura 30: Distribuição das escolas conforme a utilização do livro Methodo Facillimo de Monteverde, por distrito. Portugal, 1867

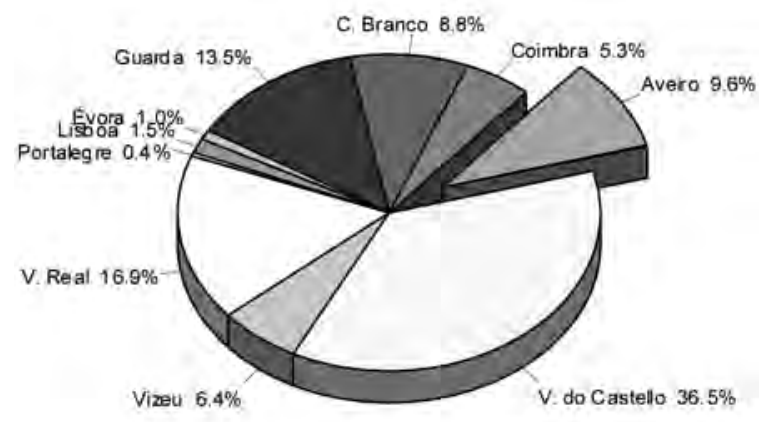

Figura 31: Distribuiçãa das escolas conforme a utilização da Cartilha do Abbade de Salamonde, por distrito. Portugal, 1867 


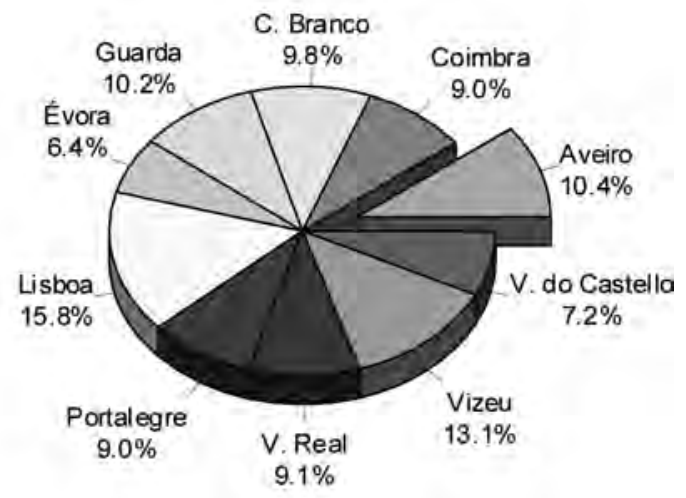

Figura 32: Distribuição das escolas conforme a utilização do Manual encyclopedico de Monteverde, por distrito. Portugal, 1867

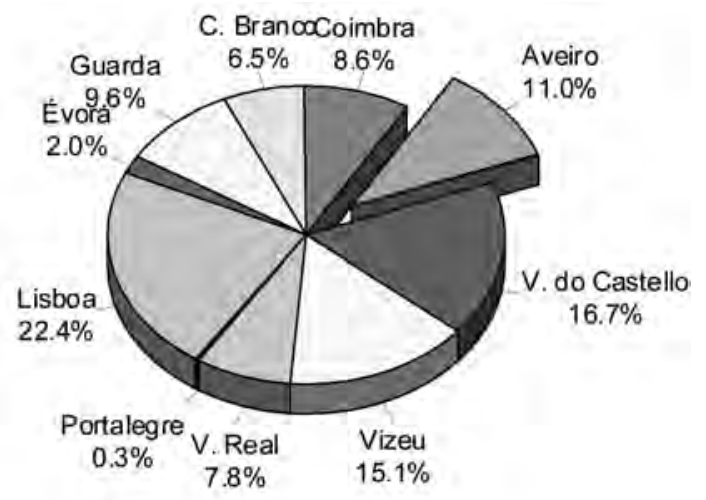

Figura 33: Distribuição das escolas conforme a utilização do Cathecismo de Montpellier, por distrito. Portugal, 1867

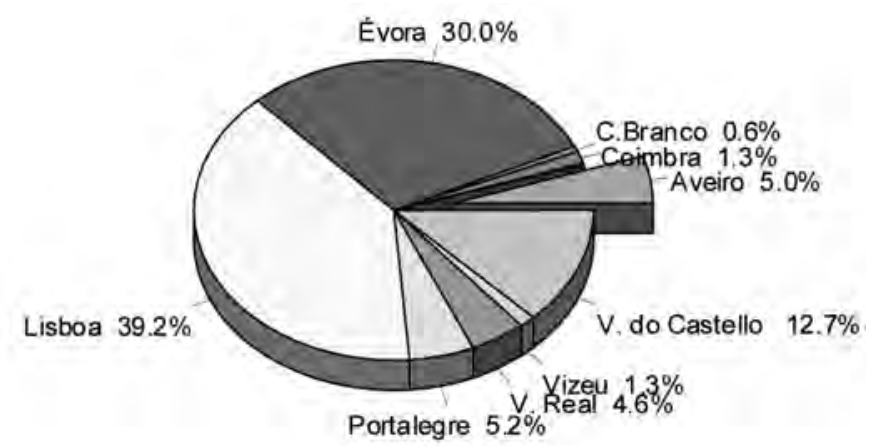

Figura 34: Distribuição das escolas conforme a utilização do Manuscripto Ventura, por distrito. Portugal, 1867 


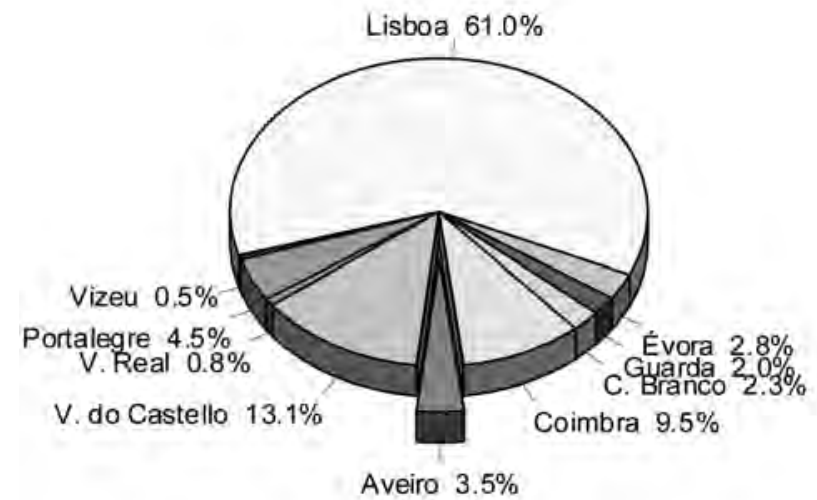

Figura 35: Distribuição das escolas conforme a utilização da Grammatica Portugueza de Figueiredo, por distrito. Portugal, 1867

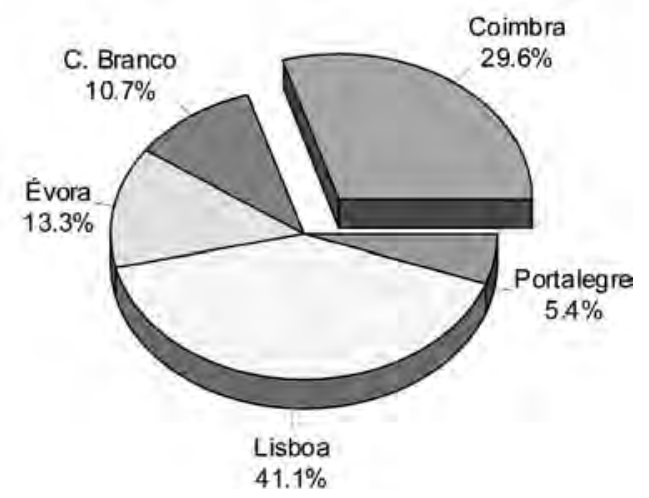

Figura 36: Distribuição das escolas conforme a utilização da Bíblia da Infância, por distrito. Portugal, 1867

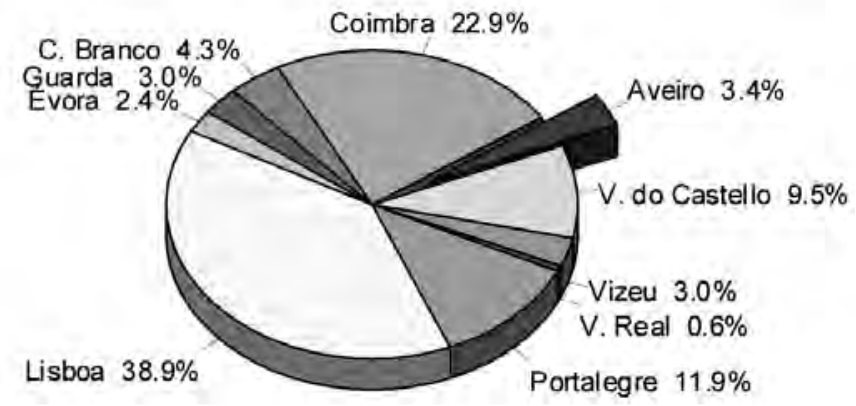

Figura 37: Distribuição das escolas conforme a utilização do livro Logares Selectos de Cardoso, por distrito. Portugal, 1867 


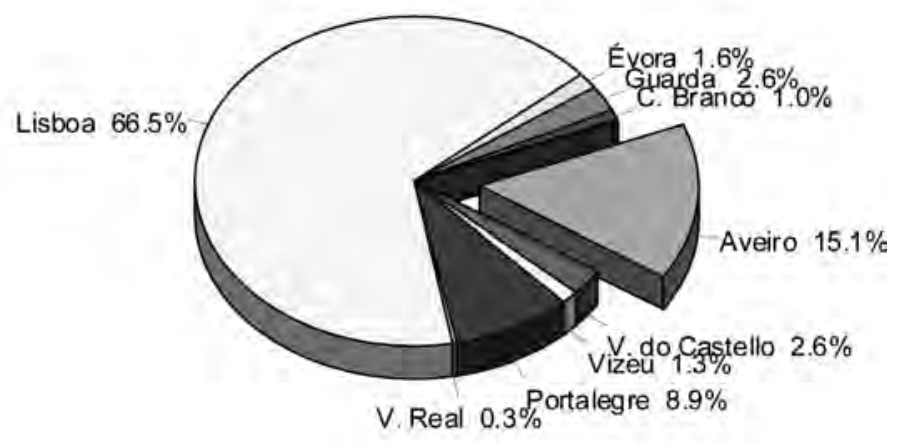

Figura 38: Distribuição das escolas conforme a utilização da Grammatica de Caldas Aulete, por distrito. Portugal, 1867

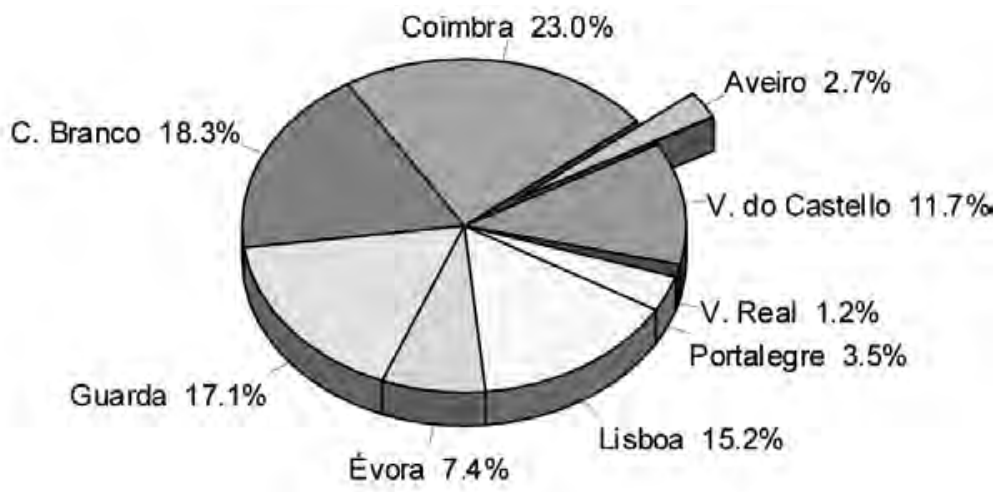

Figura 39: Distribuição das escolas conforme a utilização do livro História Sagrada, por distrito. Portugal, 1867

Tabela 50: Distribuição dos livros mais utilizados em 1867 conforme assunto, por distrito e para o total da amostra. Portugal, 1867

\begin{tabular}{|c|c|c|c|c|c|c|c|c|c|c|c|}
\hline \multirow[b]{2}{*}{ Assunto } & \multirow[b]{2}{*}{ Total } & \multicolumn{10}{|c|}{ Distrito } \\
\hline & & Aveiro & Coimbra & $\begin{array}{l}\text { Castello } \\
\text { Branco }\end{array}$ & Guarda & Évora & Lisboa & Portalegre & $\begin{array}{l}\text { Villa } \\
\text { Real }\end{array}$ & Vizeu & $\begin{array}{l}\text { Vianna } \\
\text { do } \\
\text { Castello } \\
\end{array}$ \\
\hline $\begin{array}{l}\text { Abece- } \\
\text { dários }\end{array}$ & $\begin{array}{l}13159 \\
(55.4 \%)\end{array}$ & $\begin{array}{l}1449 \\
(65.6 \%)\end{array}$ & $\begin{array}{l}1084 \\
(47.4 \%)\end{array}$ & $\begin{array}{l}1097 \\
(59.3 \%)\end{array}$ & $\begin{array}{l}1473 \\
(62.4 \%)\end{array}$ & $\begin{array}{l}703 \\
(47.0 \%)\end{array}$ & $\begin{array}{l}2443 \\
(44.3 \%)\end{array}$ & $\begin{array}{l}786 \\
(54.7 \%)\end{array}$ & $\begin{array}{l}1187 \\
(62.2 \%)\end{array}$ & $\begin{array}{l}820 \\
(50.3 \%)\end{array}$ & $\begin{array}{l}2117 \\
(67.1 \%)\end{array}$ \\
\hline $\begin{array}{l}\text { Civili- } \\
\text { dade }\end{array}$ & $\begin{array}{l}3253 \\
(13.7 \%)\end{array}$ & $\begin{array}{l}272 \\
(12.3 \%)\end{array}$ & $\begin{array}{l}321 \\
(14.0 \%)\end{array}$ & $\begin{array}{l}270 \\
(14.6 \%)\end{array}$ & $\begin{array}{l}326 \\
(13.9 \%)\end{array}$ & $\begin{array}{l}237 \\
(16.1 \%)\end{array}$ & $\begin{array}{l}664 \\
(12.0 \%)\end{array}$ & $\begin{array}{l}211 \\
(14.7 \%)\end{array}$ & $\begin{array}{l}351 \\
(18.4 \%)\end{array}$ & \begin{tabular}{|l|}
289 \\
$(17.7 \%)$
\end{tabular} & $\begin{array}{l}312 \\
(9.8 \%)\end{array}$ \\
\hline Religião & \begin{tabular}{|l|}
2895 \\
$(12.2 \%)$
\end{tabular} & $\begin{array}{l}164 \\
(7.4 \%)\end{array}$ & $\begin{array}{l}408 \\
(17.9 \%)\end{array}$ & $\begin{array}{l}220 \\
(11.9 \%)\end{array}$ & $\begin{array}{l}247 \\
(10.5 \%)\end{array}$ & $\begin{array}{l}132 \\
(8.9 \%)\end{array}$ & $\begin{array}{l}902 \\
(16.4 \%)\end{array}$ & $\begin{array}{l}99 \\
(6.9 \%)\end{array}$ & $\begin{array}{l}149 \\
(7.9 \%)\end{array}$ & $\begin{array}{l}233 \\
(14.3 \%)\end{array}$ & $\begin{array}{l}341 \\
(10.8 \%)\end{array}$ \\
\hline
\end{tabular}




\begin{tabular}{|l|l|l|l|l|l|l|l|l|l|l|l|}
\hline $\begin{array}{l}\text { Textos } \\
\text { Enciclo- } \\
\text { pédicos }\end{array}$ & $\begin{array}{l}2396 \\
(10.1 \%)\end{array}$ & $\begin{array}{l}257 \\
(11.6 \%)\end{array}$ & $\begin{array}{l}247 \\
(10.8 \%)\end{array}$ & $\begin{array}{l}204 \\
(11.0 \%)\end{array}$ & $\begin{array}{l}206 \\
(8.7 \%)\end{array}$ & $\begin{array}{l}134 \\
(9.1 \%)\end{array}$ & $\begin{array}{l}493 \\
(8.9 \%)\end{array}$ & $\begin{array}{l}233 \\
(16.2 \%)\end{array}$ & $\begin{array}{l}178 \\
(9.3 \%)\end{array}$ & $\begin{array}{l}265 \\
(16.3 \%)\end{array}$ & $\begin{array}{l}179 \\
(5.7 \%)\end{array}$ \\
\hline $\begin{array}{l}\text { Gramá- } \\
\text { tica }\end{array}$ & $\begin{array}{l}672 \\
(2.8 \%)\end{array}$ & $\begin{array}{l}19 \\
(0.8 \%)\end{array}$ & $\begin{array}{l}58 \\
(2.5 \%)\end{array}$ & $\begin{array}{l}9 \\
(0.5 \%)\end{array}$ & $\begin{array}{l}19 \\
(0.8 \%)\end{array}$ & $\begin{array}{l}30 \\
(2.0 \%)\end{array}$ & $\begin{array}{l}423 \\
(7.7 \%)\end{array}$ & $\begin{array}{l}27 \\
(1.9 \%)\end{array}$ & $\begin{array}{l}15 \\
(0.8 \%)\end{array}$ & $\begin{array}{l}4 \\
(0.2 \%)\end{array}$ & $\begin{array}{l}68 \\
(2.2 \%)\end{array}$ \\
\hline $\begin{array}{l}\text { Sistema } \\
\text { métrico }\end{array}$ & $\begin{array}{l}501 \\
(2.1 \%)\end{array}$ & $\begin{array}{l}29 \\
(1.3 \%)\end{array}$ & $\begin{array}{l}127 \\
(5.5 \%)\end{array}$ & $\begin{array}{l}25 \\
(1.3 \%)\end{array}$ & $\begin{array}{l}29 \\
(1.2 \%)\end{array}$ & $\begin{array}{l}59 \\
(4.0 \%)\end{array}$ & $\begin{array}{l}190 \\
(3.4 \%)\end{array}$ & $\begin{array}{l}27 \\
(1.9 \%)\end{array}$ & $\begin{array}{l}10 \\
(0.5 \%)\end{array}$ & $\begin{array}{l}0 \\
(0.0 \%)\end{array}$ & $\begin{array}{l}5 \\
(0.2 \%)\end{array}$ \\
\hline História & $\begin{array}{l}74 \\
(0.3 \%)\end{array}$ & $\begin{array}{l}3 \\
(0.1 \%)\end{array}$ & $\begin{array}{l}8 \\
(0.3 \%)\end{array}$ & $\begin{array}{l}0 \\
(0.0 \%)\end{array}$ & $\begin{array}{l}0 \\
(0.0 \%)\end{array}$ & $\begin{array}{l}27 \\
(1.8 \%)\end{array}$ & $\begin{array}{l}21 \\
(0.4 \%)\end{array}$ & $\begin{array}{l}7 \\
(0.5 \%)\end{array}$ & $\begin{array}{l}1 \\
(0.1 \%)\end{array}$ & $\begin{array}{l}1 \\
(0.1 \%)\end{array}$ & $\begin{array}{l}6 \\
(0.2 \%)\end{array}$ \\
\hline Outros & $\begin{array}{l}822 \\
(3.4 \%)\end{array}$ & $\begin{array}{l}17 \\
(0.8 \%)\end{array}$ & $\begin{array}{l}38 \\
(1.6 \%)\end{array}$ & $\begin{array}{l}26 \\
(1.4 \%)\end{array}$ & $\begin{array}{l}60 \\
(2.5 \%)\end{array}$ & $\begin{array}{l}153 \\
(10.4 \%)\end{array}$ & $\begin{array}{l}321 \\
(5.8 \%)\end{array}$ & $\begin{array}{l}46 \\
(3.2 \%)\end{array}$ & $\begin{array}{l}16 \\
(0.8 \%)\end{array}$ & $\begin{array}{l}18 \\
(1.1 \%)\end{array}$ & $\begin{array}{l}127 \\
(4.0 \%)\end{array}$ \\
\hline Total & $\begin{array}{l}23772 \\
(100 \%)\end{array}$ & $\begin{array}{l}2210 \\
(100 \%)\end{array}$ & $\begin{array}{l}2291 \\
(100 \%)\end{array}$ & $\begin{array}{l}1851 \\
(100 \%)\end{array}$ & $\begin{array}{l}2360 \\
(100 \%)\end{array}$ & $\begin{array}{l}1475 \\
(100 \%)\end{array}$ & $\begin{array}{l}5512 \\
(100 .)\end{array}$ & $\begin{array}{l}1436 \\
(100 \%)\end{array}$ & $\begin{array}{l}1907 \\
(100 \%)\end{array}$ & $\begin{array}{l}1630 \\
(100 \%)\end{array}$ & $\begin{array}{l}3155 \\
(100 \%)\end{array}$ \\
\hline
\end{tabular}

Observamos que, para toda a amostra, os livros mais utilizados foram abecedários, cartilhas e manuscritos (55.4\%), livros de religião (12.2\%) e textos enciclopédicos $(10.1 \%)$.

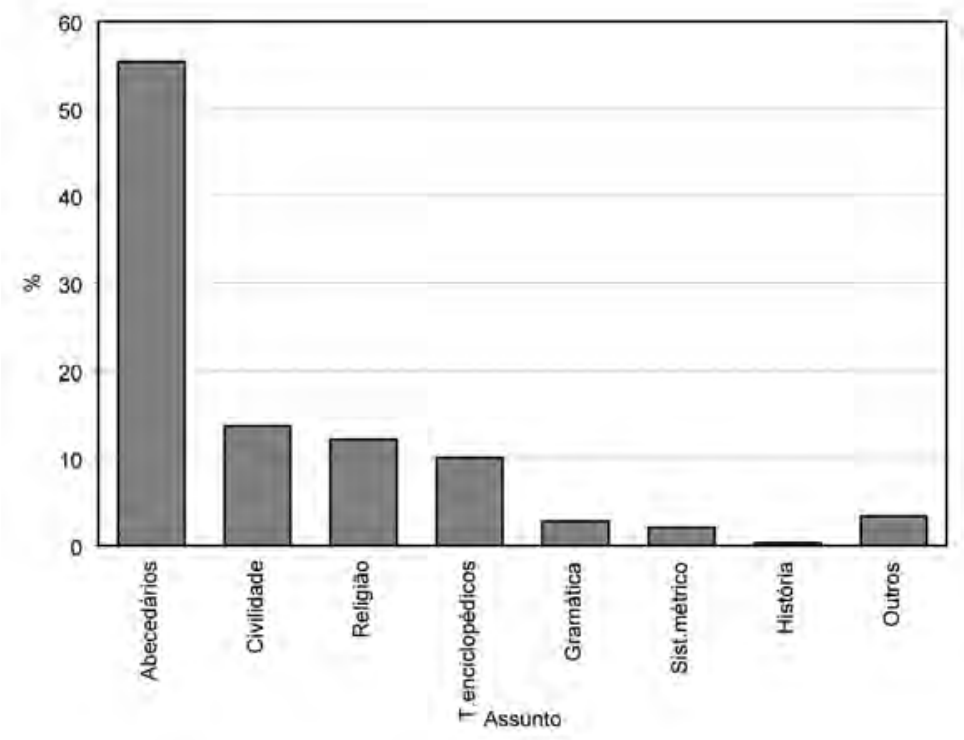

Figura 40: Distribuição dos livros mais utilizados nas escolas por assunto para o total da amostra. Portugal, 1867.

Detecta-se, pelo registro acima, a primazia dos manuscritos - aqui compreendidos como "abecedários, silabários, etc." A própria folha do impresso (anteriormente reproduzida) relativa aos "livros utilizados pelos alunos com a declaração do número de alunos que usam deles” coloca já o destaque inicial na pertença desse material variado pelos estudantes. Daí se segue que - como registram os gráficos e tabelas acima - havia em média $62,5 \%$ de abecedários, $13,8 \%$ de textos classificados como religiosos, 9,8\% de compêndios de cariz enciclopédico, 3,4\% de obras de história, 2,7\% de tratados de civilidade, $2,4 \%$ de sistema métrico e $1,5 \%$ de gramática. 
Ordenados pela frequência com que apareciam, depreende-se que, pela sequência, os livros mais utilizados e em maiores proporçôes na escola primária portuguesa eram os seguintes, pela ordem:

- Methodo facillimo para aprender a ler tanto a letra redonda como a manuscripta no mais curto espaço de tempo possivel, por Emílio Achilles Monteverde. Essa obra - que deverá ser analisada com mais atenção no capítulo específico sobre os compêndios - envolvia 31,9\% da frequência total, aparecendo em Aveiro, na Guarda e em Portalegre com aproximadamente 50\% dentre o total de compêndios naqueles distritos utilizados.

- Cartilha da Doutrina Christã composta por António J. De Mesquita Pimentel, era mais conhecida como a Cartilha do Abbade de Salamonde. Esse pequenino livro de orações e textos catequéticos era o que aparecia logo a seguir à Cartilha de Monteverde, abarcando, para o conjunto do território, um total de 18,5\% de utilização nas escolas primárias, sendo que, em alguns distritos do Norte do país, como Vianna do Castello e Villa Real, era utilizado de maneira maciça e concentrada, compreendendo respectivamente $52 \%$ e $38,3 \%$. Por outro lado, mais ao Sul, era pouco adotado pelos alunos de Lisboa (1,3\%), Évora $(3,4 \%)$ e Portalegre $(1,2 \%)$.

- Manual encyclopedico para uzo das escolas d'instrução primaria, por Emilio Achilles Monteverde. Era, como se percebe, uma obra do mesmo autor daquela primeira cartilha já anunciada, e contava com 15,6\% dentre os livros utilizados para instrução primária, proporção essa que, neste caso, era distribuída por praticamente todos os distritos consultados.

- Catecismos da Diocese de Montpellier, impressos por ordem do bispo Carlos Joaquim Colbert e traduzidos na lingua portugueza, para por eles se ensinar a doutrina Christã aos meninos nas escolas de Portugal e do Brazil. Embora possuísse um percentual de $25,6 \%$ em Viseu, contrastante com os 0,6\% de Portalegre, na proporção para o total da amostra, a utilização dessa tradução do Catecismo que havia sido recomendado pelo Marquês de Pombal, correspondia a 10,8\% dos compêndios trabalhados pelas escolas. ${ }^{277}$

- Arte de aprender a ler a letra manuscripta para uso das escholas em 10 liçóes progressivas do mais fácil ao mais difícil, por Duarte Ventura. Esse manuscrito em letra cursiva, ainda muito utilizado em Évora (19,2\%), representava para todo o país uma média de 3,7\%. Consistia em um conjunto de textos - basicamente extraídos dos Lusíadas e de obras biográficas sobre a vida de reis ilustres de Portugal.

277 Para se contrapor às práticas jesuíticas então predominantes, o Marquês de Pombal proporia a seu tempo a substituição das cartilhas a que a Companhia de Jesus recorria pela tradução do Catecismo de Montpellier de autoria de Colbert. Percebe-se, por aí, a resistência ao tempo por parte das práticas escolares. Sugerida em alvará régio cem anos antes, a Cartilha se mantinha entre as mais procuradas das obras escolares. 
A orientação do Relatório de 1867 acerca dos livros escolares contempla alguma imprecisão, posto que - com o primeiro item caracterizado como "abecedários, silabários, etc." - podem ter sido incluídas aí algumas obras bastante utilizadas e que eram impressas como litografias, expressando-se em termos de conteúdo e de texto através do recurso à letra cursiva. Observam-se, por exemplo, pistas reveladoras de tal possibilidade. O concelho de Montemor-o Novo, situado no distrito de Évora, localiza 103 manuscritos de Duarte Ventura, bem distribuídos por todas as escolas, dentre um conjunto de 393 obras. Verifica-se que alguns professores proporcionavam a seus alunos o trabalho com diferentes suportes textuais - como é o caso de José António Duarte, responsável pela escola da aldeia de Santa Eulália no concelho de Elvas, distrito de Portalegre. Seus alunos eram, no caso, os únicos daquele concelho que - de acordo com o que consta do próprio Relatório de Inspeção - possuíam exemplares dos Lusiadas, do Expositor Português de Midosi, do Compêndio de doutrina cristã e da Gramática nacional de Caldas Aulete. Por seu turno, no mesmo concelho de Elvas, na escola feminina da freguesia da Sé, sob os cuidados da Professora Maria do Carmo, encontraram-se todos os compêndios daquele concelho sob o título Cathecismo de doutrina para meninas. Geralmente, naqueles concelhos onde havia escassez de obras didáticas nas escolas, o percentual de abecedários e do Methodo facillimo de Monteverde era maior, sendo que, por vezes, também nessa mesma situação, havia um número mais significativo de exemplares do Manual enciclopédico. No concelho de Alandroal, em Évora, temos a exacerbação disso. Para as quatro escolas existentes, foram localizados apenas seis títulos diferenciados (todos pertencentes ao formulário inicial), divididos quantitativamente na seguinte proporção: 95 abecedários e silabários, 48 Methodo facillimo, 11 Manual encyclopedico, 3 Manuscripto de Duarte Ventura, 1 Paleógrafo de Carlos Silva e 1 Enciclopédia de Latino Coelho. O concelho de Arganil em Coimbra revela situação similar: havia lá 8 escolas, nas quais foram registrados nove títulos distintos: 97 Methodo facillimo, 91 abecedários e silabários, 87 Manual encyclopedico, 28 Cartilhas da doutrina cristã do Abbade de Salamonde, 25 caracterizados como "diversos", 42 Cathecismo popular, 2 Livro dos meninos, 2 Cathecismo de Montpellier, 2 Logares selectos de Cardoso.

Também em concelhos onde a proporção de livros pertencentes aos alunos aumentava consideravelmente era comum haver a primazia de abecedários, das duas obras de Monteverde e, por vezes, da Cartilha do Abade de Salamonde; o que confirmava, para os casos particulares, a tendência geral expressa pelo conjunto da amostra. Como exemplo típico, tomaríamos, nesse caso específico, o concelho de Águeda, no distrito de Aveiro; a divisão ali, para um conjunto de oito escolas, era primordialmente a seguinte: 140 abecedários, 114 Cartilhas da doutrina cristã do Abade de Salamonde, 107 Methodo facillimo, 52 Manual encyclopedico, 39 Cathecismo de Montpellier, ao que se seguiam, com pequena representatividade, outros nove títulos. Acerca dessa última obra, os dados revelam que sua utilização crescia de Lisboa para o Norte, tendo expressão bem menor nos distritos ao sul do Tejo. A Cartilha da doutrina cristã do Abade de Salamonde - que praticamente não era utilizada em Évora, Portalegre e Lisboa chegava a ter por sua vez - como vimos - $52 \%$ de adoção em escolas de Vianna do Castello. Melhor distribuídos, sem dúvida alguma, eram - naquilo que diz respeito ao conjunto do país - os dois compêndios básicos de Monteverde: tanto o Methodo facillimo quanto o Manual encyclopedico; embora, no primeiro caso, houvesse distritos 
em que a sua proporção ultrapassasse em muito a média geral, chegando a superar, em Portalegre, a casa dos $50 \%$.

\section{Os manuscritos dos alunos contando da escola que os guardou}

Anexos a alguns Relatórios de inspeção procedentes de Lisboa, pudemos encontrar manuscritos de alunos. ${ }^{278}$ Eram exercícios escritos por crianças (provavelmente ministrados pelo professor ou mesmo pelo inspetor no decorrer de sua visita); e que haviam sido anexados ao conjunto das informaçôes contidas no texto impresso, supondo-se que o inspetor em questão houvesse julgado significativos aqueles resultados que então encontrara. Aliás, talvez o próprio inspetor houvesse se dado conta de que o fato de somar à apreciação feita sobre as escolas o material das próprias crianças pudesse efetivamente contribuir para elucidar o parecer sobre o temário do ensino, tal como esse vinha se desenrolando. Indubitavelmente, essas peças, compostas por lições das próprias crianças, contribuíram muito para que se possa apreender os ecos da atmosfera da sala de aula na escola primária daqueles tempos em Portugal. Eram, de maneira geral, exercícios de cópia ou ditado, provavelmente integrantes da avaliação feita pelo inspetor - ou, pelo menos, dela ilustrativos. Alguns dos exercícios consistiam em problemas de aritmética e operações com números inteiros e com frações. Os textos discursivos ditados ou copiados eram compostos de excertos extraídos de várias obras. Abarcava-se, no conjunto, um mosaico de temas bastante representativo da cultura da escolarização. Assim, temos inúmeras lições sobre matéria moral, espiritual ou relativas mesmo à rememoração do passado glorioso de Portugal, na delimitação e expansão das fronteiras. Nisso tudo, havia um sentimento forte desse desejo de ser português, que cabia à escola incutir naquelas geraçōes ultra-jovens. De algum modo, podemos constatar a lógica do funcionamento escolar quando chegamos ao texto pertencente à criança - ao menos transcrito por ela, já que a escrita, enquanto ato de expressão do pensamento e manifestação da linguagem, era evidentemente algo que a escola ainda não lhe facultava. A escola era, pois, como fica nítido aqui, alguma coisa bastante alheia ao cotidiano, parecendo mesmo desejar, pelo afastamento, a construção de uma nova linguagem, de novos códigos, enfim, de elos diferenciados para pautar a vida social. A escola era, pelo conteúdo e pelo formato dos textos, a instituição de uma modalidade alternativa ao espaço até então rotineiro, aquilo que por fim separa e fratura a vida de todos os dias.

Os trechos selecionados indicavam situaçóes de cariz religioso ou moral, havendo, ainda, recomendações quanto ao estudo e à persistência necessária para o trabalho intelectual, sendo, algumas vezes, retratadas, inclusive, batalhas ou descrições de grandes e notáveis heróis da história portuguesa. Os erros eram marcados acima da palavra com uma sinalização numérica, de maneira que, a começar no erro 1, o examinador com facilidade avaliava o aluno pela quantidade de palavras grafadas erroneamente. Não aparecia nenhum outro tipo de anotação do educador na folha, exceto, algumas vezes, a idade do aluno, de modo a confirmar, geralmente, o bom desempenho do estudante.

${ }^{278}$ MR 1055. Distrito: Lisboa; Concelho: Bairro d'Alcântara. 
Parecem importantes nesses excertos escolhidos para a avaliação do aluno a disposição da escrita, o traçado do lápis, o capricho da letra, os erros mais frequentes - como elementos indicadores das crianças e da vida escolar. $\mathrm{O}$ conteúdo do texto, porém, ainda que fosse, na maioria das vezes, retirado de algum compêndio daqueles mais utilizados, revela o tom pedagógico da escola: aquilo que inspetor e/ou professor privilegiavam quer como valores, quer como matéria.

A preocupação com os aspectos moralizantes fica nítida logo à partida. A grande âncora da moral situa-se na consciência, mais do que na religião, embora esta também apareça com bastante frequência. A consciência coincide com um sentimento da alma, a partir do qual haverá condenação ou aprovação das ações humanas. Tratando-se de um sentimento involuntário, a consciência supõe o reconhecimento do bem, aquilo que evidentemente nos convida a praticá-lo. $\mathrm{O}$ desrespeito à consciência produz, como contrapartida, o remorso, que - por si próprio - ocasiona infelicidade. A lei divina, por sua vez, é apresentada como farol que assinala a possibilidade da salvação. Se o nascimento é igual para todo o gênero humano, as obras singularizam, pela diferença, cada um dos homens entre si.

A docilidade é apresentada como disposição para acatar conselhos das pessoas esclarecidas, mais vividas e mais experientes que as crianças. Por isso, as crianças precisam ser dóceis: para aprender a crescer com inteligência. A docilidade é necessária e deverá ser temperada com severidade e com prudência; com o propósito de que se possa aplicar com saber a experiência e o bom juízo à vida cotidiana. As virtudes humanas, recebidas das mãos da natureza, deveriam ser, no entanto, desenvolvidas e equilibradas pela força do raciocínio. A ociosidade é posta como mãe de todos os demais vícios, dado que é o tempo livre em demasia quem afasta o homem de seus deveres, chamando-o à corrupção dos costumes. A ociosidade é identificada como prática decorrente da ausência de hábito de trabalho. Não acostumar-se, portanto, a ofício algum acarretaria a sensação da miséria; e o homem que se toma por miserável tende a cometer delitos que apenas confirmam o parecer que já tinha sobre si próprio. Virtude seria, então, a prática do bem comum e a disposição de fazer tudo quanto pudesse ser útil aos outros e a si próprio. Assim, se o amor de Deus aparece como a virtude cristã por excelência, o amor dos homens e da Humanidade é posto como a primeira dentre as virtudes morais.

O estudo é apresentado como bem individual de inestimável valor porque instrui a mocidade, embelezando-lhe a razão, de modo a proporcionar, por decorrência, a beleza da velhice. Método de salvação da ignorância e (como decorrência dela) de salvação do jugo alheio, a instrução possibilitaria ao homem o falar e o escrever sobre qualquer assunto, tornando-se, a partir disso, instrumento de domínio e de poder, libertando o indivíduo da sujeição ao erro. Ainda que o conhecimento se aproximasse da ética, mediante a considerada propensão natural para conduzir o homem rumo ao julgamento justo - libertando-o, com isso, da ignorância e das crendices -, paira certa dúvida sobre a rota exclusivamente benéfica do estudo. A soberba - dizia outro trecho - age exatamente no sentido de esconder do homem suas imperfeições. Deve-se, portanto, recorrer ao silêncio como método. Ainda sobre o tema do estudo, há trechos (extremamente difíceis e complexos para a compreensão do aluno da escola primária, diga-se de passagem) a propósito do embaraço que o excessivo uso da memória poderia acarretar para o raciocínio. Oprimida com o peso excessivo de aprendizado inútil, 
a memória mobiliza automaticamente um recurso para libertação desse excesso. Reconhece-se, pois, a fugacidade do aprendizado escolar; e incentiva-se o aluno, não apenas a aprender, mas a tratar de não esquecer aquilo que aprendeu. O que se desejava, porém, que se retivesse com tanto estudo? Diz um trecho que a pretensão efetiva da educação portuguesa resumia-se a um bem ouvir e a um bem responder.

Procura-se incutir, subrepticiamente, a virtude da resignação de classe, aproximando a idéia da fortuna da acepção de saúde corporal que, entre os homens, apresentaria profundas diferenças. Há de se aceitar, por tal razão, a fortuna com que a nossa natureza nos dotou, gerindo-a do melhor modo possível: "gozar dela quando é boa, ter paciência quando não é, não usar de remédio senão na extrema necessidade.” 279 Para viver bem, então, do que é preciso? Apenas da moderação dos desejos. Desse modo, recomendava-se que os meninos aprendessem o que a sociedade deles esperava. Para isso, recordava o próprio exercício do aluno aquilo que seria caracterizado como leis: "o homem de juízo pensa sempre o que diz; mas nem sempre diz o que pensa." 280 Dever-se-ia, em silêncio, aprender como se nada se soubesse para, na sequência, cuidar de não esquecer o que foi aprendido. Mais do que isso, aconselha-se o menino que quer caminhar pela trilha da prudência:

"A virtude consiste em preencher exatamente os próprios deveres, e em sofrer com resignação qualquer adversidade que nos aconteça. Por pequeno que seja um menino, tem deveres e obrigaçôes que cumprir. Deve pois dar mostras de docilidade; ter o maior respeito a seus pais; numa palavra, é necessário que saiba reconhecer as diligências e cuidados dos mestres que lhe formam o coração e lhe cultivam o espírito." ${ }^{281}$

A formação do patriota era prioridade desse pequeno mosaico de saberes escolares e derivava basicamente da integração dos demais aspectos acima trabalhados. A tríade da formação civil/moral/religiosa persistia sendo o eixo norteador da conduta pública preconizada; conduta essa, aliás, que teria representado a norma de vida de todos os portugueses ilustres. Portugal era um país unido por uma comunidade de vocação; e a virtude é coroada como integrante dessa alma construída pelos passos da história. A ação exemplar e o feitio da coragem, do despreendimento e da lealdade eram marcas acentuadas na construção de um dado imaginário sobre a nacionalidade portuguesa

Não era só para o civismo que, entretanto, se pretendia dirigir a formação daquela juventude escolar. Talvez a forma de a escola educar se voltasse essencialmente para a composição dos hábitos da conduta social. Assim, regras de comportamento vinham prescritas por uma pedagogia onde instrução era nitidamente combinada à ordenação de uma aparência pública, capaz de regrar, até onde isso é possível, o tumultuado convívio dos homens em sociedade.

Os deveres em relação aos pais eram apresentados como primeiro exemplo das relaçôes hierárquicas do convívio humano. Obedecer aos pais é mandamento imperioso, ou dever intransitivo da criança, posto que seria a ordem natural das coisas quem determina esse

\footnotetext{
${ }^{279} M R 1054$

${ }^{280} M R$ 1055. Distrito: Lisboa. Concelho: Bairro d' Alcântara.

${ }^{281} M R 1054$.
} 
vínculo de subordinação. Outrossim, na sujeição perante os pais estaria, ainda, contido o hábito e o exercício de obediência e de disciplina, de resignação e de submissão. Aceitar-se-ia desde cedo a idéia de que há desigualdades no próprio gênero humano, desigualdades quanto ao poder, quanto à fortuna e quanto às aptidões; desigualdades essas que a instrução diminui, mas não corrige; a instrução, antes, nos induz a acatá-las.

As relaçôes para com Deus pautam a dinâmica da convivência entre os homens. Os sentimentos revelados pela fé seriam, pois, primordiais para a consolidação de outras formas de sentir e, nessa medida, a fé adquire caráter instrumental para o aprendizado das virtudes escolarizadas. Perante a justiça divina, caberia à Humanidade acatar, homenagear, amar, venerar, reconhecer, submeter-se e resignar-se. A disposição da vida coletiva e dos poderes distribuídos e organizados configura um conjunto harmonioso, mesmo que a lógica de tal harmonia parecesse incognoscível a cada um individualmente. Amar a Deus, em suma, ajudaria a aceitar o existente como natural; ajudaria a perceber no humano a revelação do desejo do sagrado. Isso facilitaria a vida em sua acepção coletiva. Por essa rota, a escola portuguesa permanecia - naquele último quartel do XIX - catequética e profundamente conservadora. Contudo, havia algo de desordem, confusão, conflito de métodos e de técnicas - o que dificultava, para a ação pedagógica, a obtenção da uniformidade e da normalização necessárias à eficiência. Por esse motivo, a cultura produzida pela escola era, acima de tudo, consolidada mediante tensões, disputas, resistências e lutas de representações. Haveria - pode-se dizer - algo que estava para além do exercício manifesto da sala de aula. O que fazia e o que dizia a escola sobre o comportamento cotidiano de seus atores principais? Como interagiam no espaço escolar professores e alunos, nas relações de formação e de poder que entre eles necessariamente se estabeleciam? Para reconstituir esse traçado, procuramos remeter a indagação para o outro Relatório, o de 1875. Passemos a ele. 


\title{
6. O RITUAL ESCOLAR: ENTRE VOZES E VERSÓES (INSPEÇÃO ÀS ESCOLAS EM I 875)
}

\begin{abstract}
"Existe ou não uma excepcional e efêmera coincidência entre todos os diversos tempos da vida dos homens? Questão imensa que nos pertence. Toda a progressão lenta termina um dia; o tempo das verdadeiras revoluçôes é também o tempo em que as rosas florescem."
\end{abstract}

(Fernand Braudel, História e Ciências Sociais, p. 63)

\section{Livros mais utilizados nas escolas de Portugal em 1875}

Havia em Portugal do XIX intensa preocupação quanto ao estabelecimento de critérios passíveis de se constituir como referências teóricas para a análise das práticas escolares. Foi, entretanto, a partir dos anos 70 que a preocupação com matrizes de pensamento entendidas como científicas predomina no cenário educativo. Acreditava-se que o exercício teórico caminharia em direção ao desvendamento dos enigmas da sala de aula. O estudo elucidaria o método. O método, por sua vez, conduziria os educadores para a compreensão das formas corriqueiras da aula; formas essas, tantas vezes, fugidias, talvez mesmo escondidas... Era preciso identificar os segredos da didática. Para tanto havia de se remeter a indagação para o coração da vida escolar: como o professor caminhava pela sala de aula, que atenção dava a este ou àquele aluno; de quais procedimentos se valia para ministrar o exercício, para passar a lição, para, enfim, ditar o dever escolar - dever que, por seu turno, compreendia inevitavelmente um dever ser, um dever fazer, um saber fazer...

A inspeção pretendia abarcar rastros de totalidade. Pretensiosa, ela desejava capturar por inteiro o pensamento e as práticas. Os inspetores desejavam as respostas e, por vezes, variavam o estilo das perguntas. Era preciso, de alguma maneira, aproximar-se daquilo que poderia parecer, aos olhos do próprio professor, trivial, insignificante, mas que configurava, ao fim e ao cabo, fenômeno extremamente precioso para o reconhecimento das táticas e estratégias desenvolvidas em classe. Inequivocamente, os inspetores cuidavam de indagar o que havia de diferente nesta ou naquela aula, particularmente quando elas obtinham bom resultado pedagógico. De qualquer maneira, cada relatório é composto por suas próprias representações, que geram muitas vezes intrigas diferenciadas, como num caleidoscópio, onde as distintas cores só poderão ser observadas em movimento... Cada relatório tem, portanto, a marca de sua singularidade, de sua distinção, de sua peculiaridade. Impressos todos iguais, ao serem 
preenchidos, tornam-se, todos e cada um, únicos, trazendo, no limite, a marca de sua produção, de seu tempo, de seu produtor, de seus aplicadores, de seu destinatário. É preciso, em virtude disso, estudar a forma de compor a organização desse relato. A partir dos dados obtidos pela análise da amostragem do Relatório de inspeção de 1875 por quase todos os distritos portugueses, pudemos classificar os livros mais utilizados pelas escolas portuguesas, chegando ao seguinte quadro:

Tabela 51: Distribuição dos livros mais utilizados nas escolas de Portugal em 1875, conforme títulos ou autores por distritos e para o total da amostra

\begin{tabular}{|c|c|c|c|c|c|c|c|c|c|c|c|c|c|c|}
\hline Livro & Total & Aveiro & $\begin{array}{l}\text { Coim- } \\
\text { bra }\end{array}$ & $\begin{array}{l}\text { Castello } \\
\text { Branco }\end{array}$ & Évora & Lisboa & $\begin{array}{l}\text { V. } \\
\text { Real }\end{array}$ & Porto & $\begin{array}{l}\text { Porta- } \\
\text { legre }\end{array}$ & Braga & $\begin{array}{l}\text { Bra- } \\
\text { gança }\end{array}$ & Beja & Santarém & $\begin{array}{l}\text { Ponta } \\
\text { Delgada }\end{array}$ \\
\hline $\begin{array}{l}\text { 1. Método } \\
\text { facillimo }\end{array}$ & $\begin{array}{l}143 \\
(23.9 \\
\%)\end{array}$ & $\begin{array}{l}10 \\
(35.7 \\
\%)\end{array}$ & $\begin{array}{l}8 \\
(20.5 \\
\%)\end{array}$ & $\begin{array}{l}9 \\
(25.7 \\
\%)\end{array}$ & $\begin{array}{l}28 \\
(19.5 \\
\%)\end{array}$ & $\begin{array}{l}16 \\
(24.7 \\
\%)\end{array}$ & $\begin{array}{l}10 \\
(38.5 \\
\%)\end{array}$ & $\begin{array}{l}19 \\
(23.0 \\
\%)\end{array}$ & $\begin{array}{l}10 \\
(22.7 \\
\%)\end{array}$ & $\begin{array}{l}3 \\
(10.7 \\
\%)\end{array}$ & $\begin{array}{l}10 \\
(50.0 \\
\%)\end{array}$ & $\begin{array}{l}8 \\
(29.7 \\
\%)\end{array}$ & $\begin{array}{l}10 \\
(28.5 \%)\end{array}$ & $\begin{array}{l}2 \\
(7.7 \%)\end{array}$ \\
\hline $\begin{array}{l}\text { 2. Manual } \\
\text { encyclopedico }\end{array}$ & $\begin{array}{l}114 \\
(19.0 \\
\%)\end{array}$ & $\begin{array}{l}8 \\
(28.6 \\
\%)\end{array}$ & $\begin{array}{l}6 \\
(15.4 \\
\%)\end{array}$ & $\begin{array}{l}9 \\
(25.7 \\
\%)\end{array}$ & $\begin{array}{l}25 \\
(17.5 \\
\%)\end{array}$ & $\begin{array}{l}6 \\
(9.2 \\
\%)\end{array}$ & $\begin{array}{l}6 \\
(23.1 \\
\%)\end{array}$ & $\begin{array}{l}15 \\
(18.2 \\
\%)\end{array}$ & $\begin{array}{l}10 \\
(22.7 \\
\%)\end{array}$ & $\begin{array}{l}3 \\
(10.7 \\
\%)\end{array}$ & $\begin{array}{l}10 \\
(50.0 \\
\%)\end{array}$ & $\begin{array}{l}6 \\
(22.2 \\
\%)\end{array}$ & $\begin{array}{l}10 \\
(28.5 \%)\end{array}$ & $\begin{array}{l}0 \\
(0.0 \%)\end{array}$ \\
\hline 3.Paleographo & $\begin{array}{l}48 \\
(8.1 \\
\%)\end{array}$ & $\begin{array}{l}3 \\
(10.7 \\
\%)\end{array}$ & $\begin{array}{l}1 \\
(2.6 \\
\%)\end{array}$ & $\begin{array}{l}0 \\
(0.0 \\
\%)\end{array}$ & $\begin{array}{l}13 \\
(9.1 \\
\%)\end{array}$ & $\begin{array}{l}4 \\
(6.1 \\
\%)\end{array}$ & $\begin{array}{l}0 \\
(0.0 \\
\%)\end{array}$ & $\begin{array}{l}7 \\
(8.4 \\
\%)\end{array}$ & $\begin{array}{l}1 \\
(2.3 \\
\%)\end{array}$ & $\begin{array}{l}2 \\
(7.1 \\
\%)\end{array}$ & $\begin{array}{l}0 \\
(0.0 \\
\%)\end{array}$ & $\begin{array}{l}4 \\
(14.8 \\
\%)\end{array}$ & $\begin{array}{l}7 \\
(20.0 \%)\end{array}$ & $\begin{array}{l}6 \\
(23.1 \%)\end{array}$ \\
\hline $\begin{array}{l}\text { 4.Logares } \\
\text { Selectos }\end{array}$ & $\begin{array}{l}42 \\
(7.0 \\
\%)\end{array}$ & $\begin{array}{l}1 \\
(3.6 \\
\%)\end{array}$ & $\begin{array}{l}4 \\
(10.2 \\
\%)\end{array}$ & $\begin{array}{l}1 \\
(2.9 \\
\%)\end{array}$ & $\begin{array}{l}7 \\
(4.9 \\
\%)\end{array}$ & $\begin{array}{l}1 \\
(1.5 \\
\%)\end{array}$ & $\begin{array}{l}4 \\
(15.4 \\
\%)\end{array}$ & $\begin{array}{l}10 \\
(12 \\
\%)\end{array}$ & $\begin{array}{l}8 \\
(18.3 \\
\%)\end{array}$ & $\begin{array}{l}1 \\
(3.6 \\
\%)\end{array}$ & $\begin{array}{l}0 \\
(0.0 \\
\%)\end{array}$ & $\begin{array}{l}1 \\
(3.7 \\
\%)\end{array}$ & $\begin{array}{l}2 \\
(5.7 \%)\end{array}$ & $\begin{array}{l}2 \\
(7.7 \%)\end{array}$ \\
\hline 5.Midosi & $\begin{array}{l}36 \\
(6.0 \\
\%)\end{array}$ & $\begin{array}{l}0 \\
(0.0 \\
\%)\end{array}$ & $\begin{array}{l}0 \\
(0.0 \\
\%)\end{array}$ & $\begin{array}{l}0 \\
(0.0 \\
\%)\end{array}$ & $\begin{array}{l}8 \\
(5.6 \\
\%)\end{array}$ & $\begin{array}{l}12 \\
(18.6 \\
\%)\end{array}$ & $\begin{array}{l}0 \\
(0.0 \\
\%)\end{array}$ & $\begin{array}{l}0 \\
(0.0 \\
\%)\end{array}$ & $\begin{array}{l}1 \\
(2.3 \\
\%)\end{array}$ & $\begin{array}{l}0 \\
(0.0 \\
\%)\end{array}$ & $\begin{array}{l}0 \\
(0.0 \\
\%)\end{array}$ & $\begin{array}{l}1 \\
(3.7 \\
\%)\end{array}$ & $\begin{array}{l}0 \\
(0.0 \%)\end{array}$ & $\begin{array}{l}0 \\
(0.0 \%)\end{array}$ \\
\hline $\begin{array}{l}\text { 6.Biblia } \\
\text { Infancia }\end{array}$ & $\begin{array}{l}35 \\
(5.8 \\
\%)\end{array}$ & $\begin{array}{l}0 \\
(0.0 \\
\%)\end{array}$ & $\begin{array}{l}11 \\
(28.2 \\
\%)\end{array}$ & $\begin{array}{l}3 \\
(8.6 \\
\%)\end{array}$ & $\begin{array}{l}9 \\
(6.3 \\
\%)\end{array}$ & $\begin{array}{l}8 \\
(12.3 \\
\%)\end{array}$ & $\begin{array}{l}0 \\
(0.0 \\
\%)\end{array}$ & $\begin{array}{l}1 \\
(1.2 \\
\%)\end{array}$ & $\begin{array}{l}2 \\
(4.5 \\
\%)\end{array}$ & $\begin{array}{l}0 \\
(0.0 \\
\%)\end{array}$ & $\begin{array}{l}0 \\
(0.0 \\
\%)\end{array}$ & $\begin{array}{l}0 \\
(0.0 \\
\%)\end{array}$ & $\begin{array}{l}0 \\
(0.0 \%)\end{array}$ & $\begin{array}{l}0 \\
(0.0 \%)\end{array}$ \\
\hline 7. Montpellier & $\begin{array}{l}33 \\
(5.5 \\
\%)\end{array}$ & $\begin{array}{l}2 \\
(7.1 \\
\%)\end{array}$ & $\begin{array}{l}0 \\
(0.0 \\
\%)\end{array}$ & $\begin{array}{l}3 \\
(8.6 \\
\%)\end{array}$ & $\begin{array}{l}17 \\
(11.9 \\
\%)\end{array}$ & $\begin{array}{l}1 \\
(1.5 \\
\%)\end{array}$ & $\begin{array}{l}0 \\
(0.0 \\
\%)\end{array}$ & $\begin{array}{l}8 \\
(9.6 \\
\%)\end{array}$ & $\begin{array}{l}2 \\
(4.5 \\
\%)\end{array}$ & $\begin{array}{l}0 \\
(0.0 \\
\%)\end{array}$ & $\begin{array}{l}0 \\
(0.0 \\
\%)\end{array}$ & $\begin{array}{l}0 \\
(0.0 \\
\%)\end{array}$ & $\begin{array}{l}0 \\
(0.0 \%)\end{array}$ & $\begin{array}{l}0 \\
(0.0 \%)\end{array}$ \\
\hline 8.Ventura & $\begin{array}{l}26 \\
(4.3 \\
\%)\end{array}$ & $\begin{array}{l}2 \\
(7.1 \\
\%)\end{array}$ & $\begin{array}{l}0 \\
(0.0 \\
\%)\end{array}$ & $\begin{array}{l}0 \\
(0.0 \\
\%)\end{array}$ & $\begin{array}{l}5 \\
(3.5 \\
\%)\end{array}$ & $\begin{array}{l}1 \\
(1.5 \\
\%)\end{array}$ & $\begin{array}{l}0 \\
(0.0 \\
\%)\end{array}$ & $\begin{array}{l}9 \\
(10.8 \\
\%)\end{array}$ & $\begin{array}{l}0 \\
(0.0 \\
\%)\end{array}$ & $\begin{array}{l}9 \\
(32.1 \\
\%)\end{array}$ & $\begin{array}{l}0 \\
(0.0 \\
\%)\end{array}$ & $\begin{array}{l}1 \\
(3.7 \\
\%)\end{array}$ & $\begin{array}{l}1 \\
(2.9 \%)\end{array}$ & $\begin{array}{l}13 \\
(50.0 \%)\end{array}$ \\
\hline 9. Fradesso & $\begin{array}{l}20 \\
(3.3 \\
\%)\end{array}$ & $\begin{array}{l}0 \\
(0.0 \\
\%)\end{array}$ & $\begin{array}{l}0 \\
(0.0 \\
\%)\end{array}$ & $\begin{array}{l}2 \\
(5.6 \\
\%)\end{array}$ & $\begin{array}{l}9 \\
(6.3 \\
\%)\end{array}$ & $\begin{array}{l}1 \\
(1.5 \\
\%)\end{array}$ & $\begin{array}{l}0 \\
(0.0 \\
\%)\end{array}$ & $\begin{array}{l}1 \\
(1.2 \\
\%)\end{array}$ & $\begin{array}{l}2 \\
(4.5 \\
\%)\end{array}$ & $\begin{array}{l}0 \\
(0.0 \\
\%)\end{array}$ & $\begin{array}{l}0 \\
(0.0 \\
\%)\end{array}$ & $\begin{array}{l}4 \\
(14.8 \\
\%)\end{array}$ & $\begin{array}{l}1 \\
(2.9 \%)\end{array}$ & $\begin{array}{l}0 \\
(0.0 \%)\end{array}$ \\
\hline 10. Salamonde & $\begin{array}{l}18 \\
(3.0 \\
\%)\end{array}$ & $\begin{array}{l}0 \\
(0.0 \\
\%)\end{array}$ & $\begin{array}{l}2 \\
(5.1 \\
\%)\end{array}$ & $\begin{array}{l}6 \\
(17.1 \\
\%)\end{array}$ & $\begin{array}{l}0 \\
(0.0 \\
\%)\end{array}$ & $\begin{array}{l}0 \\
(0.0 \\
\%)\end{array}$ & $\begin{array}{l}3 \\
(11.5 \\
\%)\end{array}$ & $\begin{array}{l}0 \\
(0.0 \\
\%)\end{array}$ & $\begin{array}{l}0 \\
(0.0 \\
\%)\end{array}$ & $\begin{array}{l}6 \\
(21.4 \\
\%)\end{array}$ & $\begin{array}{l}0 \\
(0.0 \\
\%)\end{array}$ & $\begin{array}{l}0 \\
(0 . \%)\end{array}$ & $\begin{array}{l}1 \\
(2.9 \%)\end{array}$ & $\begin{array}{l}0 \\
(0.0 \%)\end{array}$ \\
\hline 11. Monteiro & $\begin{array}{l}17 \\
(2.8 \\
\%)\end{array}$ & $\begin{array}{l}0 \\
(0.0 \\
\%)\end{array}$ & $\begin{array}{l}0 \\
(0.0 \\
\%)\end{array}$ & $\begin{array}{l}0 \\
(0.0 \\
\%)\end{array}$ & $\begin{array}{l}6 \\
(4.2 \\
\%)\end{array}$ & $\begin{array}{l}11 \\
(17.0 \\
\%)\end{array}$ & $\begin{array}{l}0 \\
(0.0 \\
\%)\end{array}$ & $\begin{array}{l}0 \\
(0.0 \\
\%)\end{array}$ & $\begin{array}{l}0 \\
(0.0 \\
\%)\end{array}$ & $\begin{array}{l}0 \\
(0.0 \\
\%)\end{array}$ & $\begin{array}{l}0 \\
(0.0 \\
\%)\end{array}$ & $\begin{array}{l}0 \\
(0.0 \\
\%)\end{array}$ & $\begin{array}{l}0 \\
(0.0 \%)\end{array}$ & $\begin{array}{l}0 \\
(0.0 \%)\end{array}$ \\
\hline 12. Motta & $\begin{array}{l}15 \\
(2.5 \\
\%)\end{array}$ & $\begin{array}{l}0 \\
(0.0 \\
\%)\end{array}$ & $\begin{array}{l}2 \\
(5.1 \\
\%)\end{array}$ & $\begin{array}{l}0 \\
(0.0 \\
\%)\end{array}$ & $\begin{array}{l}1 \\
(0.7 \\
\%)\end{array}$ & $\begin{array}{l}2 \\
(3.1 \\
\%)\end{array}$ & $\begin{array}{l}3 \\
(11.5 \\
\%)\end{array}$ & $\begin{array}{l}7 \\
(8.4 \\
\%)\end{array}$ & $\begin{array}{l}0 \\
(0.0 \\
\%)\end{array}$ & $\begin{array}{l}0 \\
(0.0 \\
\%)\end{array}$ & $\begin{array}{l}0 \\
(0.0 \\
\%)\end{array}$ & $\begin{array}{l}0 \\
(0.0 \\
\%)\end{array}$ & $\begin{array}{l}0 \\
(0.0 \%)\end{array}$ & $\begin{array}{l}0 \\
(0.0 \%)\end{array}$ \\
\hline $\begin{array}{l}\text { 13.Simão de } \\
\text { Nantua }\end{array}$ & $\begin{array}{l}13 \\
(2.2 \\
\%)\end{array}$ & $\begin{array}{l}0 \\
(0.0 \\
\%)\end{array}$ & $\begin{array}{l}0 \\
(0.0 \\
\%)\end{array}$ & $\begin{array}{l}0 \\
(0.0 \\
\%)\end{array}$ & $\begin{array}{l}5 \\
(3.5 \\
\%)\end{array}$ & $\begin{array}{l}0 \\
(0.0 \\
\%)\end{array}$ & $\begin{array}{l}0 \\
(0.0 \\
\%)\end{array}$ & $\begin{array}{l}0 \\
(0.0 \\
\%)\end{array}$ & $\begin{array}{l}4 \\
(9.1 \\
\%)\end{array}$ & $\begin{array}{l}0 \\
(0.0 \\
\%)\end{array}$ & $\begin{array}{l}0 \\
(0.0 \\
\%)\end{array}$ & $\begin{array}{l}0 \\
(0.0 \\
\%)\end{array}$ & $\begin{array}{l}2 \\
(5.7 \%)\end{array}$ & $\begin{array}{l}2 \\
(7.7 \%)\end{array}$ \\
\hline $\begin{array}{l}\text { 14.Enciclopé- } \\
\text { dia das escolas }\end{array}$ & $\begin{array}{l}7 \\
(1.2 \\
\%)\end{array}$ & $\begin{array}{l}0 \\
(0.0 \\
\%)\end{array}$ & $\begin{array}{l}0 \\
(0.0 \\
\%)\end{array}$ & $\begin{array}{l}1 \\
(2.9 \\
\%)\end{array}$ & $\begin{array}{l}2 \\
(1.4 \\
\%)\end{array}$ & $\begin{array}{l}0 \\
(0.0 \\
\%)\end{array}$ & $\begin{array}{l}0 \\
(0.0 \\
\%)\end{array}$ & $\begin{array}{l}0 \\
(0.0 \\
\%)\end{array}$ & $\begin{array}{l}0 \\
(0.0 \\
\%)\end{array}$ & $\begin{array}{l}2 \\
(7.2 \\
\%)\end{array}$ & $\begin{array}{l}0 \\
(0.0 \\
\%)\end{array}$ & $\begin{array}{l}1 \\
(3.7 \\
\%)\end{array}$ & $\begin{array}{l}0 \\
(0.0 \%)\end{array}$ & $\begin{array}{l}1 \\
(3.8 \%)\end{array}$ \\
\hline
\end{tabular}




\begin{tabular}{|c|c|c|c|c|c|c|c|c|c|c|c|c|c|c|}
\hline $\begin{array}{l}\text { 15. Gramática } \\
\text { de Figueiredo }\end{array}$ & $\begin{array}{l}7 \\
(1.2 \\
\%)\end{array}$ & $\begin{array}{l}0 \\
(0.0 \\
\%)\end{array}$ & $\begin{array}{l}0 \\
(0.0 \\
\%)\end{array}$ & $\begin{array}{l}0 \\
(0.0 \\
\%)\end{array}$ & $\begin{array}{l}1 \\
(0.7 \\
\%)\end{array}$ & $\begin{array}{l}0 \\
(0.0 \\
\%)\end{array}$ & $\begin{array}{l}0 \\
(0.0 \\
\%)\end{array}$ & $\begin{array}{l}3 \\
(3.6 \\
\%)\end{array}$ & $\begin{array}{l}2 \\
(4.5 \\
\%)\end{array}$ & $\begin{array}{l}1 \\
(3.6 \\
\%)\end{array}$ & $\begin{array}{l}0 \\
(0.0 \\
\%)\end{array}$ & $\begin{array}{l}0 \\
(0.0 \\
\%)\end{array}$ & $\begin{array}{l}0 \\
(0.0 \\
\%)\end{array}$ & $\begin{array}{l}0 \\
(0.0 \\
\%)\end{array}$ \\
\hline 16. Lusíadas & $\begin{array}{l}6 \\
(1.0 \\
\%)\end{array}$ & $\begin{array}{l}1 \\
(3.6 \\
\%)\end{array}$ & $\begin{array}{l}0 \\
(0.0 \\
\%)\end{array}$ & $\begin{array}{l}0 \\
(0.0 \\
\%)\end{array}$ & $\begin{array}{l}4 \\
(2.8 \\
\%)\end{array}$ & $\begin{array}{l}0 \\
(0.0 \\
\%)\end{array}$ & $\begin{array}{l}0 \\
(0.0 \\
\%)\end{array}$ & $\begin{array}{l}0 \\
(0.0 \\
\%)\end{array}$ & $\begin{array}{l}0 \\
(0.0 \\
\%)\end{array}$ & $\begin{array}{l}0 \\
(0.0 \\
\%)\end{array}$ & $\begin{array}{l}0 \\
(0.0 \\
\%)\end{array}$ & $\begin{array}{l}0 \\
(0.0 \\
\%)\end{array}$ & $\begin{array}{l}1 \\
(2.9 \\
\%)\end{array}$ & $\begin{array}{l}0 \\
(0.0 \\
\%)\end{array}$ \\
\hline $\begin{array}{l}\text { 17.Escola } \\
\text { Popular }\end{array}$ & $\begin{array}{l}5 \\
(0.8 \\
\%)\end{array}$ & $\begin{array}{l}0 \\
(0.0 \\
\%)\end{array}$ & $\begin{array}{l}5 \\
(12.9 \\
\%)\end{array}$ & $\begin{array}{l}0 \\
(0.0 \\
\%)\end{array}$ & $\begin{array}{l}0 \\
(0.0 \\
\%)\end{array}$ & $\begin{array}{l}0 \\
(0.0 \\
\%)\end{array}$ & $\begin{array}{l}0 \\
(0.0 \\
\%)\end{array}$ & $\begin{array}{l}0 \\
(0.0 \\
\%)\end{array}$ & $\begin{array}{l}0 \\
(0.0 \\
\%)\end{array}$ & $\begin{array}{l}0 \\
(0.0 \\
\%)\end{array}$ & $\begin{array}{l}0 \\
(0.0 \\
\%)\end{array}$ & $\begin{array}{l}0 \\
(0.0 \\
\%)\end{array}$ & $\begin{array}{l}0 \\
(0.0 \\
\%)\end{array}$ & $\begin{array}{l}0 \\
(0.0 \\
\%)\end{array}$ \\
\hline $\begin{array}{l}\text { 18.Livro } \\
\text { Meninos }\end{array}$ & $\begin{array}{l}4 \\
(0.7 \\
\%)\end{array}$ & $\begin{array}{l}1 \\
(3.6 \\
\%)\end{array}$ & $\begin{array}{l}0 \\
(0.0 \\
\%)\end{array}$ & $\begin{array}{l}0 \\
(0.0 \\
\%)\end{array}$ & $\begin{array}{l}0 \\
(0.0 \\
\%)\end{array}$ & $\begin{array}{l}0 \\
(0.0 \\
\%)\end{array}$ & $\begin{array}{l}0 \\
(0.0 \\
\%)\end{array}$ & $\begin{array}{l}2 \\
(2.4 \\
\%)\end{array}$ & $\begin{array}{l}0 \\
(0.0 \\
\%)\end{array}$ & $\begin{array}{l}1 \\
(3.6 \\
\%)\end{array}$ & $\begin{array}{l}0 \\
(0.0 \\
\%)\end{array}$ & $\begin{array}{l}0 \\
(0.0 \\
\%)\end{array}$ & $\begin{array}{l}0 \\
(0.0 \\
\%)\end{array}$ & $\begin{array}{l}0 \\
(0.0 \\
\%)\end{array}$ \\
\hline $\begin{array}{l}\text { 19. Cartilha } \\
\text { Nacional }\end{array}$ & $\begin{array}{l}4 \\
(0.7 \\
\%)\end{array}$ & $\begin{array}{l}0 \\
(0.0 \\
\%)\end{array}$ & $\begin{array}{l}0 \\
(0.0 \\
\%)\end{array}$ & $\begin{array}{l}0 \\
(0.0 \\
\%)\end{array}$ & $\begin{array}{l}2 \\
(1.4 \\
\%)\end{array}$ & $\begin{array}{l}1 \\
(1.5 \\
\%)\end{array}$ & $\begin{array}{l}0 \\
(0.0 \\
\%)\end{array}$ & $\begin{array}{l}0 \\
(0.0 \\
\%)\end{array}$ & $\begin{array}{l}1 \\
(2.3 \\
\%)\end{array}$ & $\begin{array}{l}0 \\
(0.0 \\
\%)\end{array}$ & $\begin{array}{l}0 \\
(0.0 \\
\%)\end{array}$ & $\begin{array}{l}0 \\
(0.0 \\
\%)\end{array}$ & $\begin{array}{l}0 \\
(0.0 \\
\%)\end{array}$ & $\begin{array}{l}0 \\
(0.0 \\
\%)\end{array}$ \\
\hline $\begin{array}{l}\text { 20. Mimo à } \\
\text { infância }\end{array}$ & $\begin{array}{l}3 \\
(0.5 \\
\%)\end{array}$ & $\begin{array}{l}0 \\
(0.0 \\
\%)\end{array}$ & $\begin{array}{l}0 \\
(0.0 \\
\%)\end{array}$ & $\begin{array}{l}1 \\
(2.9 \\
\%)\end{array}$ & $\begin{array}{l}0 \\
(0.0 \\
\%)\end{array}$ & $\begin{array}{l}0 \\
(0.0 \\
\%)\end{array}$ & $\begin{array}{l}0 \\
(0.0 \\
\%)\end{array}$ & $\begin{array}{l}0 \\
(0.0 \\
\%)\end{array}$ & $\begin{array}{l}1 \\
(2.3 \\
\%)\end{array}$ & $\begin{array}{l}0 \\
(0.0 \\
\%)\end{array}$ & $\begin{array}{l}0 \\
(0.0 \\
\%)\end{array}$ & $\begin{array}{l}1 \\
(3.7 \\
\%)\end{array}$ & $\begin{array}{l}0 \\
(0.0 \\
\%)\end{array}$ & $\begin{array}{l}0 \\
(0.0 \\
\%)\end{array}$ \\
\hline $\begin{array}{l}\text { 21.Rama- } \\
\text { lhetinho da } \\
\text { puerícia }\end{array}$ & $\begin{array}{l}2 \\
(0.3 \\
\%)\end{array}$ & $\begin{array}{l}0 \\
(0.0 \\
\%)\end{array}$ & $\begin{array}{l}0 \\
(0.0 \\
\%)\end{array}$ & $\begin{array}{l}0 \\
(0.0 \\
\%)\end{array}$ & $\begin{array}{l}1 \\
(0.7 \\
\%)\end{array}$ & $\begin{array}{l}1 \\
(1.5 \\
\%)\end{array}$ & $\begin{array}{l}0 \\
(0.0 \\
\%)\end{array}$ & $\begin{array}{l}0 \\
(0.0 \\
\%)\end{array}$ & $\begin{array}{l}0 \\
(0.0 \\
\%)\end{array}$ & $\begin{array}{l}0 \\
(0.0 \\
\%)\end{array}$ & $\begin{array}{l}0 \\
(0.0 \\
\%)\end{array}$ & $\begin{array}{l}0 \\
(0.0 \\
\%)\end{array}$ & $\begin{array}{l}0 \\
(0.0 \\
\%)\end{array}$ & $\begin{array}{l}0 \\
(0.0 \\
\%)\end{array}$ \\
\hline $\begin{array}{l}\text { 22. Thesouro } \\
\text { Meninos }\end{array}$ & $\begin{array}{l}1 \\
(0.2 \\
\%)\end{array}$ & $\begin{array}{l}0 \\
(0.0 \\
\%)\end{array}$ & $\begin{array}{l}0 \\
(0.0 \\
\%)\end{array}$ & $\begin{array}{l}0 \\
(0.0 \\
\%)\end{array}$ & $\begin{array}{l}0 \\
(0.0 \\
\%)\end{array}$ & $\begin{array}{l}0 \\
(0.0 \\
\%)\end{array}$ & $\begin{array}{l}0 \\
(0.0 \\
\%)\end{array}$ & $\begin{array}{l}1 \\
(1.2 \\
\%)\end{array}$ & $\begin{array}{l}0 \\
(0.0 \\
\%)\end{array}$ & $\begin{array}{l}0 \\
(0.0 \\
\%)\end{array}$ & $\begin{array}{l}0 \\
(0.0 \\
\%)\end{array}$ & $\begin{array}{l}0 \\
(0.0 \\
\%)\end{array}$ & $\begin{array}{l}0 \\
(0.0 \\
\%)\end{array}$ & $\begin{array}{l}0 \\
(0.0 \\
\%)\end{array}$ \\
\hline Total & $\begin{array}{l}599 \\
(100 \\
\%)\end{array}$ & $\begin{array}{l}28 \\
(100 \\
\%)\end{array}$ & $\begin{array}{l}39 \\
(100 \\
\%)\end{array}$ & $\begin{array}{l}35 \\
(100 \\
\%)\end{array}$ & $\begin{array}{l}143 \\
(100 \\
\%)\end{array}$ & $\begin{array}{l}65 \\
(100 \\
\%)\end{array}$ & $\begin{array}{l}26 \\
(100 \\
\%)\end{array}$ & $\begin{array}{l}83 \\
(100 \\
\%)\end{array}$ & $\begin{array}{l}44 \\
(100 \\
\%)\end{array}$ & $\begin{array}{l}28 \\
(100 \\
\%)\end{array}$ & $\begin{array}{l}20 \\
(100 \\
\%)\end{array}$ & $\begin{array}{l}27 \\
(100 \\
\%)\end{array}$ & $\begin{array}{l}35 \\
(100 \\
\%)\end{array}$ & $\begin{array}{l}26 \\
(100 \\
\%)\end{array}$ \\
\hline
\end{tabular}

Os títulos completos dessas 22 obras escolares - tal como elas aparecem no cômputo total da amostragem que compreende os distritos de Aveiro, Coimbra, Castello Branco, Évora, Lisboa, Villa Real, Porto, Portalegre, Braga, Bragança, Beja, Santarém e Ponta Delgada - é o que, abaixo, relacionamos:

Emílio Achilles MONTEVERDE, Methodo facillimo para aprender a ler tanto a letra redonda como a manuscrita. Emílio Achilles MONTEVERDE, Manual encyclopedico para uso das escolas d'instrucção primária.

Carlos SILVA, O paleographo em escla calligraphica para aprender a leitura manuscripta.

A. CARDOSO BORGES DE FIGUEIREDO, Logares selectos dos classicos portuguezes nos principais generos de discurso em prosa para uso das escolas.

Luís Francisco MIDOSI, $O$ expositor portuguez ou rudimentos do ensino da língua materna.

Biblia da infancia.

CATECISMOS da diocese DE MONTPELLIER impressos por ordem do Bispo Carlos Joaquim Colbert e traduzidos na lingua portuguesa para por eles ensinar a Doutrina Christã aos meninos nas escolas de Portugal e do Brasil.

Duarte VENTURA, Arte de aprender a ler a letra manuscripta para uso das escholas em 10 liçôes progressivas do mais fácil ao mais difficil.

Fradesso.

António J. De Mesquita PIMENTEL (Abbade de Salamonde), Cartilha da doutrina christã.

A. A. M.MONTEIRO DE CAMPOS, Compêndio de sistema métrico-decimal em forma de diálogo para uso das escolas de instruç̧ão primária.

MOTTA E VEIGA, História.

Simão de Nântua

Júlio CALDAS AULETE, Grammatica nacional

Carlos Augusto FIGUEIREDO VIEIRA, Compendio elementar de Grammatica Portugueza.

Luís de CAMÕES, Os Lusíadas.

Eschola popular das primeiras letras divididas em quatro partes.

Livro dos meninos christãos ou instrucçôes religiosas de uma mãe a seus filhos, traduzido do francês. 
Júlio CALDAS AULETE, Cartilha nacional ou methodo legographico para aprender simultaneamente a ler, escrever, ortographar e desenhar.

Emílio Achilles MONTEVERDE, Mimo á infancia ou manual de história sagrada para uso das crianças que frequentam as aulas tanto em Portugal como no Brasil.

266 Luíz Felipe LEITE, Ramalhetinho da puerícia.

Tesouro dos meninos

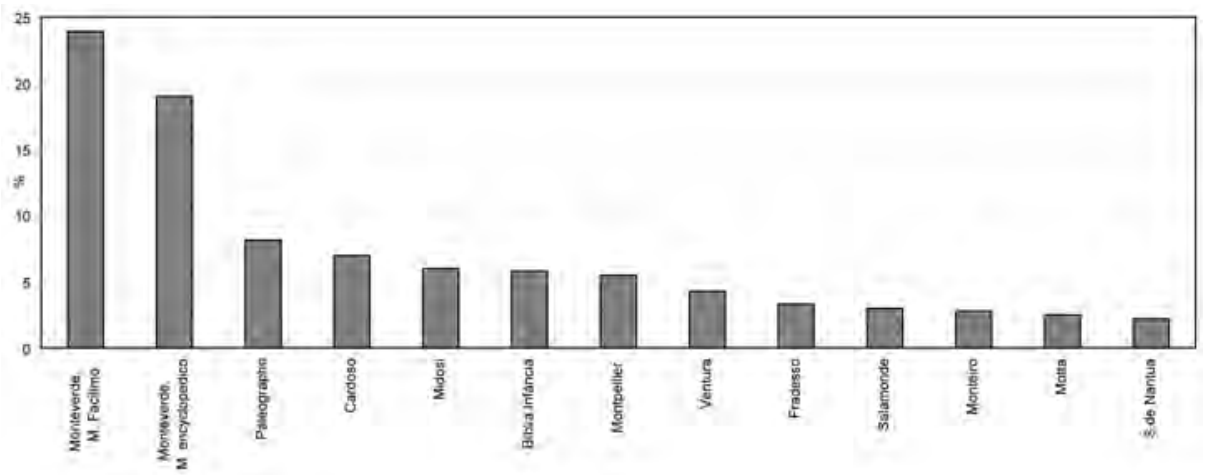

Figura 41 : Distribuição dos livros mais utilizados nas escolas por autor ou título para o total da amostra. Portugal, 1875.

Verifica-se que, dentre as obras escolares mais utilizadas em Portugal nesse período, destacam-se o Methodo Facillimo (23,9\%) e o Manual Encyclopédico (19\%), de Emílio Achiles Monteverde, bem distribuídos por todos os distritos consultados. Além dessas, observa-se $O$ Paleographo em escala calligraphica para aprender a leitura manuscripta de Carlos Silva, com uma proporção equivalente a $8,1 \%$ para o total da amostra tendo este revelado crescimento perante os $0,8 \%$ de utilização que registrara na inspeção de 1867. A seguir vinham os Logares Selectos de Cardoso (7\%), a Cartilha de Midosi - intitulada $O$ expositor portuguez - com um total de $6 \%$ de utilização. Vinham ainda na sequência - como podemos observar pela tabela acima - a Bíblia da infância (5,8\%), o Cathecismo de Montpellier (5,5\%), o texto de Ventura, intitulado Arte de aprender a ler a letra manuscripta para uso das escholas em 10 liçôes progressivas do mais fácil ao mais difícil (4,3\%), o Compêndio do sistema métrico de Fradesso da Silveira (3,3\%) e a Cartilha da doutrina christã por António J. de Mesquita Pimentel, mais conhecida como a Cartilha do Abade de Salamonde (3\%). Os compêndios destacados nem sempre coincidem com aqueles escolhidos pelo levantamento da inspeção de 1867 . Diferenças quanto ao procedimento e quanto aos próprios critérios analíticos possibilitam, como margem de erro, essa variação. Além disso, bem ou mal, eram já passados oito anos. Note-se, porém, a persistência de inúmeros dos compêndios arrolados, em ambas as inspeçóes. Destacaríamos, assim, que 1875 apresenta uma utilização ainda maior dos textos de Monteverde por parte das escolas portuguesas. Por outro lado, nota-se um decréscimo do percentual de utilização de textos de caráter religioso, como é o caso do Cathecismo de Montpellier. De algum modo, procuramos selecionar esses textos - todos eles - qualificados pelos contemporâneos como os mais representativos e, a partir da análise de seu conteúdo, procuraremos averiguar quais eram as coisas ensinadas nas escolas portuguesas de finais do XIX. 
Tabela 52: Distribuição dos livros mais utilizados nas escolas de Portugal em 1875 conforme assunto por distritos e para o total da amostra

\begin{tabular}{|c|c|c|c|c|c|c|c|c|c|c|c|c|c|c|}
\hline & & Distr & ITO & & & & & & & & & & & \\
\hline Assunto & Total & Aveiro & Coimbra & $\begin{array}{l}\text { Castello } \\
\text { Branco }\end{array}$ & Évora & Lisboa & $\begin{array}{l}\text { V. } \\
\text { Real }\end{array}$ & Porto & $\begin{array}{l}\text { Porta- } \\
\text { legre }\end{array}$ & Braga & Bragança & Beja & $\begin{array}{l}\text { Santa- } \\
\text { rem }\end{array}$ & $\begin{array}{l}\text { Ponta } \\
\text { Delgada }\end{array}$ \\
\hline História & $\begin{array}{l}124 \\
(12.0 \\
\%)\end{array}$ & $\begin{array}{l}0 \\
(0.0 \\
\%)\end{array}$ & $\begin{array}{l}4 \\
(6.8 \\
\%)\end{array}$ & $\begin{array}{l}0 \\
(0.0 \\
\%)\end{array}$ & $\begin{array}{l}36 \\
(14.9 \\
\%)\end{array}$ & $\begin{array}{l}37 \\
(23.4 \\
\%)\end{array}$ & $\begin{array}{l}7 \\
(15.6 \\
\%)\end{array}$ & $\begin{array}{l}13 \\
(9.6 \\
\%)\end{array}$ & $\begin{array}{l}11 \\
(17.7 \\
\%)\end{array}$ & $\begin{array}{l}1 \\
(2.8 \\
\%)\end{array}$ & $\begin{array}{l}0 \\
(0.0 \\
\%)\end{array}$ & $\begin{array}{l}3 \\
(6.2 \\
\%)\end{array}$ & $\begin{array}{l}4 \\
(8.2 \\
\%)\end{array}$ & $\begin{array}{l}8 \\
(9.8 \\
\%)\end{array}$ \\
\hline Religião & $\begin{array}{l}129 \\
(12.5 \\
\%)\end{array}$ & $\begin{array}{l}6 \\
(12.2 \\
\%)\end{array}$ & $\begin{array}{l}12 \\
(20.3 \\
\%)\end{array}$ & $\begin{array}{l}8 \\
(6.3 \\
\%)\end{array}$ & $\begin{array}{l}48 \\
(19.9 \\
\%)\end{array}$ & $\begin{array}{l}17 \\
(10.8 \\
\%)\end{array}$ & $\begin{array}{l}0 \\
(0.0 \\
\%)\end{array}$ & $\begin{array}{l}13 \\
(9.6 \\
\%)\end{array}$ & $\begin{array}{l}7 \\
(11.4 \\
\%)\end{array}$ & $\begin{array}{l}1 \\
(2.8 \\
\%)\end{array}$ & $\begin{array}{l}0 \\
(0.0 \\
\%)\end{array}$ & $\begin{array}{l}5 \\
(10.4 \\
\%)\end{array}$ & $\begin{array}{l}2 \\
(4.1 \\
\%)\end{array}$ & $\begin{array}{l}10 \\
(12.2 \\
\%)\end{array}$ \\
\hline Gramática & $\begin{array}{l}61 \\
(5.9 \\
\%)\end{array}$ & $\begin{array}{l}1 \\
(2.0 \\
\%)\end{array}$ & $\begin{array}{l}4 \\
(6.8 \\
\%)\end{array}$ & $\begin{array}{l}1 \\
(2.0 \\
\%)\end{array}$ & $\begin{array}{l}13 \\
(5.4 \\
\%)\end{array}$ & $\begin{array}{l}11 \\
(7.0 \\
\%)\end{array}$ & $\begin{array}{l}5 \\
(11.2 \\
\%)\end{array}$ & $\begin{array}{l}11 \\
(8.1 \\
\%)\end{array}$ & $\begin{array}{l}5 \\
(8.1 \\
\%)\end{array}$ & $\begin{array}{l}2 \\
(5.6 \\
\%)\end{array}$ & $\begin{array}{l}0 \\
(0.0 \\
\%)\end{array}$ & \begin{tabular}{|l}
2 \\
$(4.2$ \\
$\%)$
\end{tabular} & $\begin{array}{l}0 \\
(0.0 \\
\%)\end{array}$ & $\begin{array}{l}6 \\
(7.3 \\
\%)\end{array}$ \\
\hline $\begin{array}{l}\text { Sist. } \\
\text { Métrico }\end{array}$ & $\begin{array}{l}99 \\
(9.6 \\
\%)\end{array}$ & $\begin{array}{l}2 \\
(4.2 \\
\%)\end{array}$ & $\begin{array}{l}12 \\
(20.3 \\
\%)\end{array}$ & $\begin{array}{l}4 \\
(8.2 \\
\%)\end{array}$ & $\begin{array}{l}18 \\
(7.5 \\
\%)\end{array}$ & $\begin{array}{l}16 \\
(10.1 \\
\%)\end{array}$ & $\begin{array}{l}1 \\
(2.2 \\
\%)\end{array}$ & $\begin{array}{l}14 \\
(10.3 \\
\%)\end{array}$ & $\begin{array}{l}3 \\
(4.8 \\
\%)\end{array}$ & $\begin{array}{l}1 \\
(2.8 \\
\%)\end{array}$ & $\begin{array}{l}0 \\
(0.0 \\
\%)\end{array}$ & $\begin{array}{l}8 \\
(16.7 \\
\%)\end{array}$ & $\begin{array}{l}3 \\
(6.1 \\
\%)\end{array}$ & $\begin{array}{l}17 \\
(20.7 \\
\%)\end{array}$ \\
\hline Cartilhas & $\begin{array}{l}445 \\
(43.0 \\
\%)\end{array}$ & $\begin{array}{l}31 \\
(63.3 \\
\%)\end{array}$ & $\begin{array}{l}17 \\
(28.8 \\
\%)\end{array}$ & $\begin{array}{l}26 \\
(53.1 \\
\%)\end{array}$ & $\begin{array}{l}93 \\
(38.6 \\
\%)\end{array}$ & $\begin{array}{l}68 \\
(43.0 \\
\%)\end{array}$ & $\begin{array}{l}20 \\
(44.4 \\
\%)\end{array}$ & $\begin{array}{l}55 \\
(40.4 \\
\%)\end{array}$ & $\begin{array}{l}18 \\
(29.0 \\
\%)\end{array}$ & $\begin{array}{l}26 \\
(72.1 \\
\%)\end{array}$ & $\begin{array}{l}10 \\
(50.0 \\
\%)\end{array}$ & \begin{tabular}{|l|}
23 \\
$(47.9$ \\
$\%)$
\end{tabular} & $\begin{array}{l}28 \\
(57.1 \\
\%)\end{array}$ & $\begin{array}{l}30 \\
(36.6 \\
\%)\end{array}$ \\
\hline Civilidade & \begin{tabular}{|l|}
61 \\
$(5.9$ \\
$\%)$
\end{tabular} & $\begin{array}{l}1 \\
(2.0 \\
\%)\end{array}$ & $\begin{array}{l}4 \\
(6.8 \\
\%)\end{array}$ & $\begin{array}{l}1 \\
(2.0 \\
\%)\end{array}$ & $\begin{array}{l}8 \\
(3.3 \\
\%)\end{array}$ & $\begin{array}{l}3 \\
(1.9 \\
\%)\end{array}$ & $\begin{array}{l}6 \\
(13.3 \\
\%)\end{array}$ & $\begin{array}{l}15 \\
(11.0 \\
\%)\end{array}$ & $\begin{array}{l}8 \\
(12.9 \\
\%)\end{array}$ & $\begin{array}{l}1 \\
(2.8 \\
\%)\end{array}$ & $\begin{array}{l}0 \\
(0.0 \\
\%)\end{array}$ & $\begin{array}{l}1 \\
(2.1 \\
\%)\end{array}$ & $\begin{array}{l}2 \\
(4.1 \\
\%)\end{array}$ & $\begin{array}{l}11 \\
(13.4 \\
\%)\end{array}$ \\
\hline $\begin{array}{l}\text { Textos } \\
\text { enciclopé- } \\
\text { dicos }\end{array}$ & $\begin{array}{l}115 \\
(11.1 \\
\%)\end{array}$ & $\begin{array}{l}8 \\
(16.3 \\
\%)\end{array}$ & $\begin{array}{l}6 \\
(10.2 \\
\%)\end{array}$ & $\begin{array}{l}9 \\
(18.4 \\
\%)\end{array}$ & $\begin{array}{l}25 \\
(10.4 \\
\%)\end{array}$ & $\begin{array}{l}6 \\
(3.8 \\
\%)\end{array}$ & $\begin{array}{l}6 \\
(13.3 \\
\%)\end{array}$ & $\begin{array}{l}15 \\
(11.0 \\
\%)\end{array}$ & $\begin{array}{l}10 \\
(16.1 \\
\%)\end{array}$ & $\begin{array}{l}4 \\
(11.1 \\
\%)\end{array}$ & $\begin{array}{l}10 \\
(50.0 \\
\%)\end{array}$ & $\begin{array}{l}6 \\
(12.5 \\
\%)\end{array}$ & $\begin{array}{l}10 \\
(20.4 \\
\%)\end{array}$ & $\begin{array}{l}0 \\
(0.0 \\
\%)\end{array}$ \\
\hline Total & $\begin{array}{l}1034 \\
(100 \\
\%)\end{array}$ & $\begin{array}{l}49 \\
(100 \\
\%)\end{array}$ & $\begin{array}{l}59 \\
(100 \\
\%)\end{array}$ & $\begin{array}{l}49 \\
(100 \\
\%)\end{array}$ & $\begin{array}{l}241 \\
(100 \\
\%)\end{array}$ & $\begin{array}{l}158 \\
(100 \\
\%)\end{array}$ & $\begin{array}{l}45 \\
(100 \\
\%)\end{array}$ & $\begin{array}{l}136 \\
(100 \\
\%)\end{array}$ & $\begin{array}{l}62 \\
(100 \\
\%)\end{array}$ & $\begin{array}{l}36 \\
(100 \\
\%)\end{array}$ & $\begin{array}{l}20 \\
(100 \\
\%)\end{array}$ & $\begin{array}{l}48 \\
(100 \\
\%)\end{array}$ & $\begin{array}{l}49 \\
(100 \\
\%)\end{array}$ & $\begin{array}{l}82 \\
(100 \\
\%)\end{array}$ \\
\hline
\end{tabular}

Para a amostra toda, em 1875, as maiores porcentagens de livros correspondiamem a cartilhas (43\%), seguidos de religião (12.5\%), história (12\%), e textos enciclopédi$\cos (11.1 \%)$. Gramática e civilidade tiveram as menores porcentagens $(5,9 \%$ cada uma). Na verdade, a essa altura, os tópicos concernentes à civilidade e à gramática estavam já contidos em todas as outras categorias, particularmente nos compêndios de caráter enciclopédico e nos que eram apresentados na forma de cartilhas. 


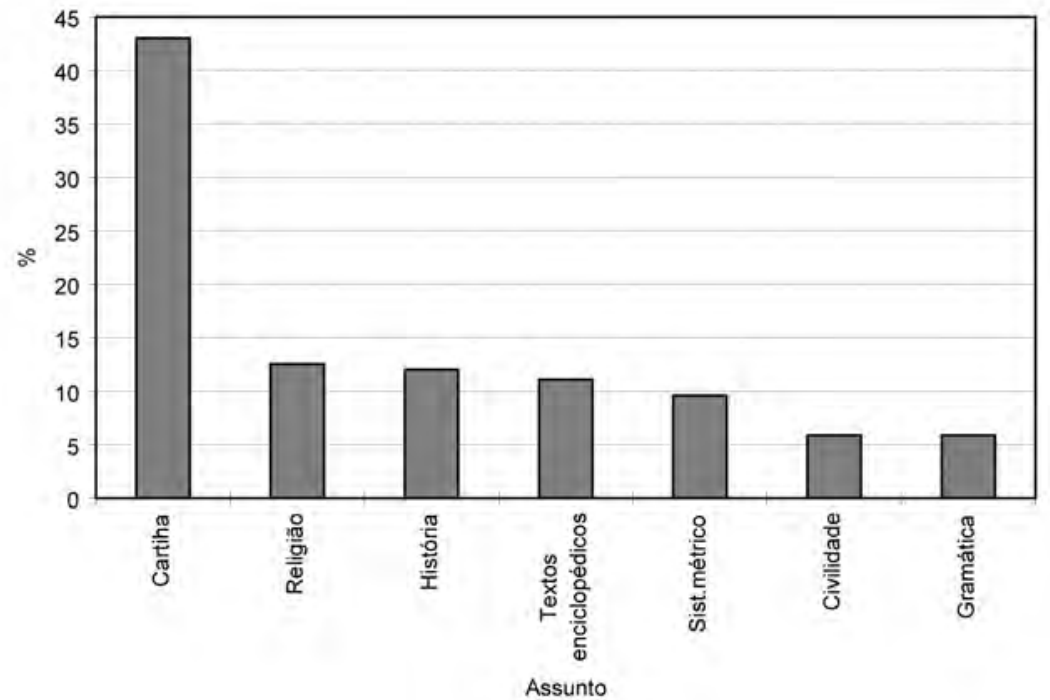

Figura 42 : Distribuição dos livros mais utilizados nas escolas, por assunto para o total da amostra. Portugal, 1875.

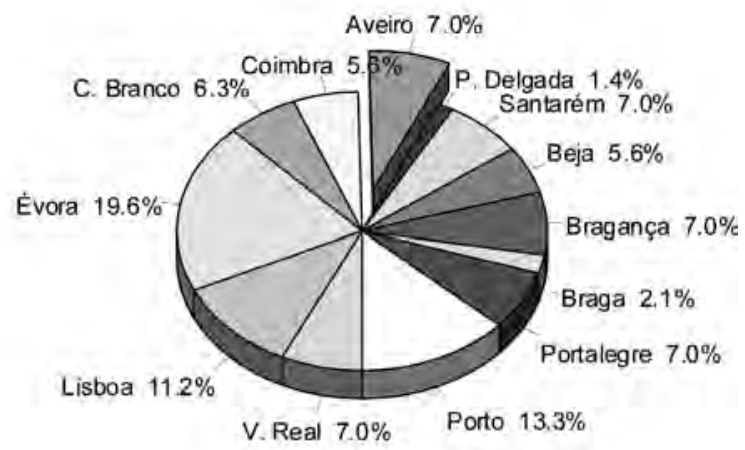

Figura 43: Distribuição das escolas segundo a utilização do livro Metodo Facillimo de Monteverde, por distrito. Portugal, 1875 


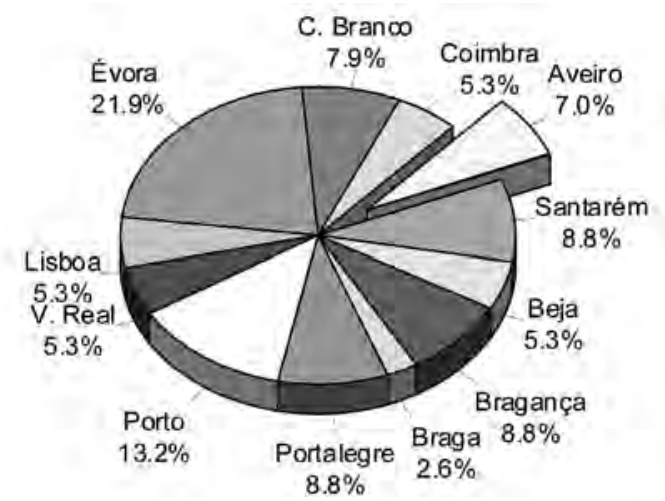

Figura 44: Distribuição das escolas segundo a utilização do livro Manual encyclopedico de Monteverde, por distrito. Portugal, 1875

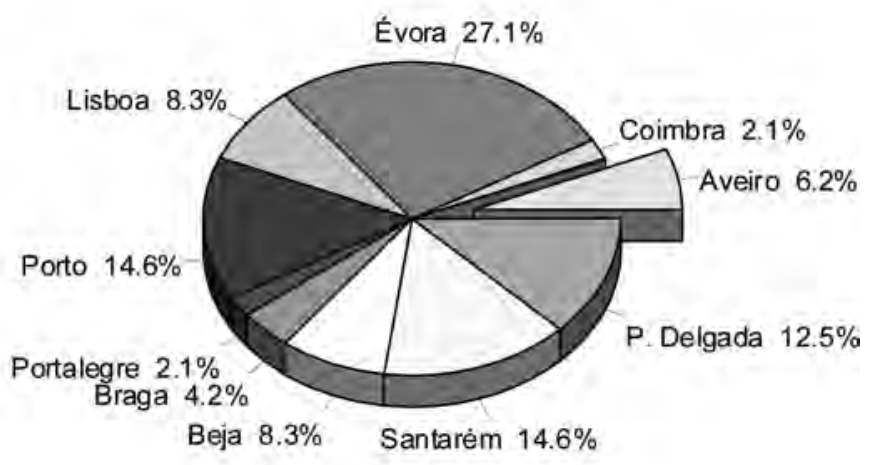

Figura 45: Distribuição das escolas segundo a utilização do livro Paleographo de C. Silva, por distrito. Portugal, 1875

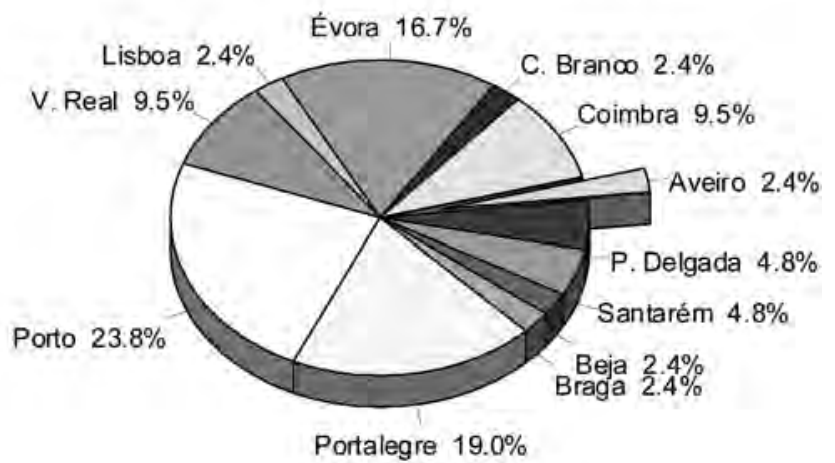

Figura 46: Distribuição das escolas segundo a utilização do livro Logares Selectos de Cardoso, por distrito. Portugal, 1875 


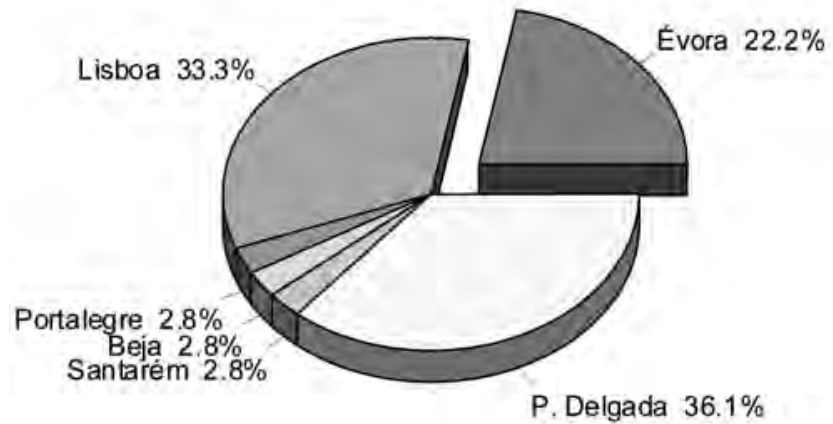

Figura 47: Distribuição das escolas segundo a utilização do livro Expositor Portuguez de Midosi, por distrito. Portugal, 1875

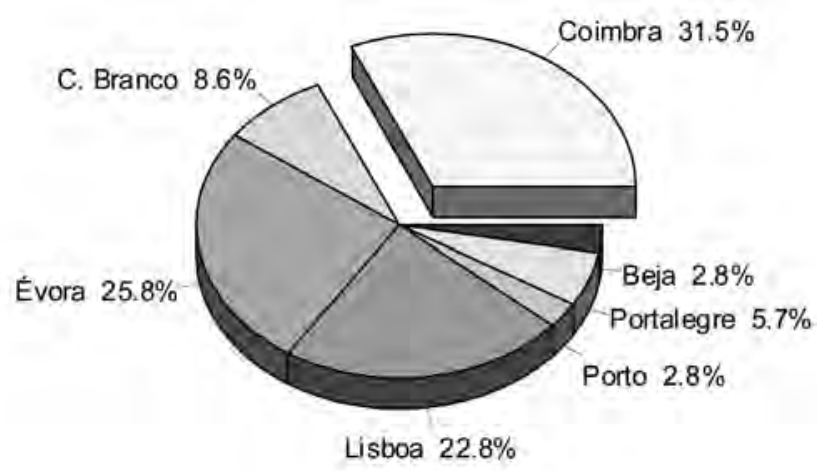

Figura 48: Distribuiçāo das escolas segundo a utilização do livro Biblia da Infancia, por distrito. Portugal, 1875

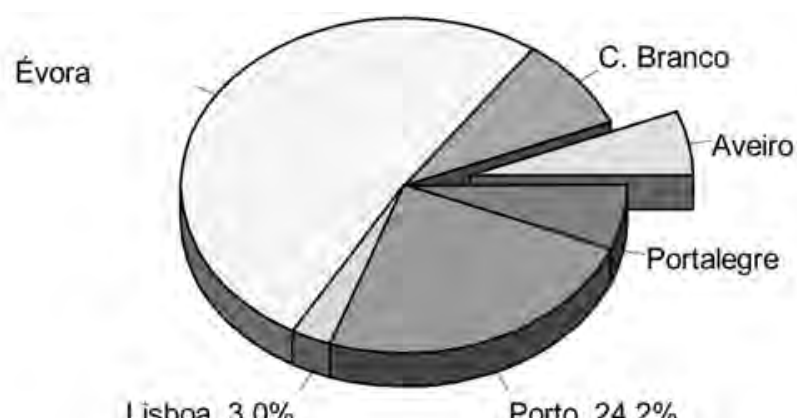

Lisboa $3.0 \%$

Porto $24.2 \%$

Figura 49: Distribuição das escolas segundo a utilização do livro Cathecismo de Montpellier, por distrito. Portugal, 1875 


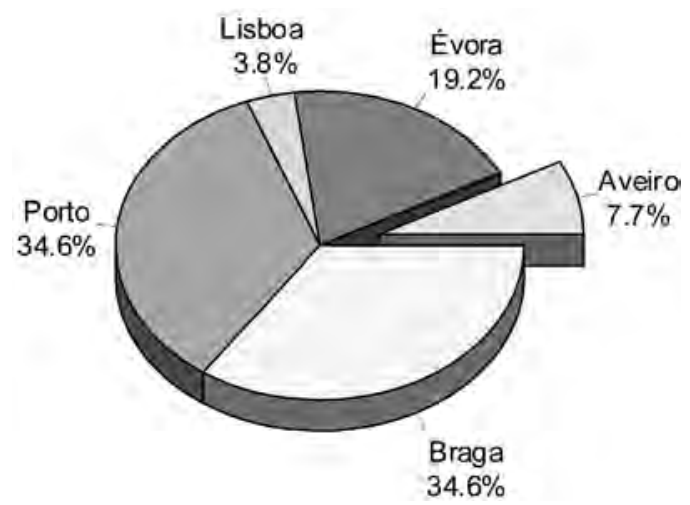

Figura 50: Distribuição das escolas segundo a utilização do livro Manuscripto de Duarte Ventura, por distrito. Portugal, 1875

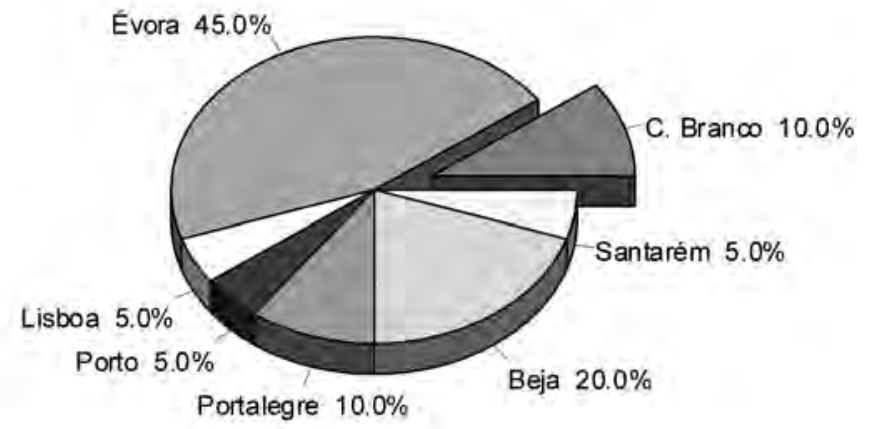

Figura 51: Distribuição das escolas segundo a utilização do livro Compêndio de Sistema Métrico de Fradesso da Silveira, por distrito. Portugal, 1875

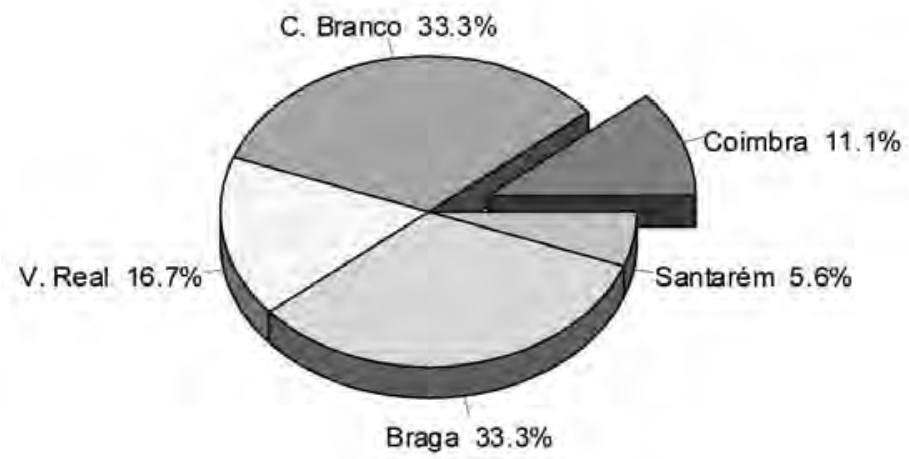

Figura 52: Distribuição das escolas segundo a utilização do livro Cartilha do Abbade de Salamonde, por distrito. Portugal, 1875 


\section{Modos e maneiras de inspeccionar alunos e professores}

No que diz respeito aos livros escolares, a inspeção efetuada no ano de 1875 permitiu um questionamento mais espontâneo do que a de 1867. Em 1875, indagava-se apenas sobre quais seriam os compêndios mais usados na escola, sem qualquer indicação daqueles que eventualmente eram os que mais apareciam. Recorde-se que a inspeção de 1867 , pelo contrário, indicava alguns poucos compêndios que vinham já copiados no impresso a ser preenchido, o qual, aliás, tinha por enunciado - como já pudemos anteriormente observar - o seguinte: "livros usados pelos alunos com declaração do número de alunos que usam deles”. As obras que já vinham no formulário evidentemente revelavam uma tendência, mas, indubitavelmente, em termos metodológicos, representariam um direcionamento da espontaneidade do professor e mesmo do inspetor. Como esse mecanismo restritivo não aparecia no Relatório de 1875, e, pelo fato de se solicitar agora os compêndios utilizados na escola, sem vinculá-los à posse dos alunos, julgamos que os dados de 1875, especificamente a esse respeito, podem ser mais fidedignos dos que os que relatamos anteriormente acerca da inspeção efetuada em 1867.

A análise efetuada para o ano de 1875, com exceção da questão dos livros escolares, não contempla abordagem estatística, posto que esta inclusive já foi feita por António Nóvoa. Procuramos os relatos, a voz do inspetor e centramo-nos basicamente em algumas regióes bastante circunscritas, de maneira a estabelecer o diálogo entre a escola e seus autores, de maneira a reconstituir o itinerário de uma vida de escola que não coincide exatamente com o que se dizia dela, o que dificulta talvez o encontro de universais teorias explicativas e que nos confunde, por fazer confluir aspectos à primeira vista contraditórios. Pensar a escola do ponto de vista da história é necessariamente contar uma história; ou várias, e procurar, pela materialidade intrínseca ao relato, afastar-se da sedução do pressuposto.

Assim como se fazia em 1867, o texto impresso do Relatório enviado em 1875 para efeito de inspeção às escolas públicas versava sobre aspectos concernentes ao edifício da escola, ao mobiliário, à ventilação e à adequação ou não do espaço físico para o funcionamento escolar. Questionava-se acerca do estado de conservação material da escola e das condições morais e pedagógicas. Indagava-se ainda sobre a capacidade física da sala de aula e sobre a ventilação, a luz e as condições higiênicas. Outras informações suplementares deveriam vir contidas no preenchimento do impresso:

- Existência ou não de habitação do professor no edifício escolar;

- Estado da mobília e sua adequação para as finalidades da instrução;

- Recebimento ou não, por parte dos alunos, de papel, de tintas e de penas, entregues pela própria escola;

- Oferecimento ou não, por parte da escola, de outros subsídios, tais como livros escolares ou vestuário, para seus estudantes;

- Existência ou não de biblioteca popular na localidade onde funciona a escola ou no próprio edifício escolar;

- Existência de catálogo de livros pertencentes à biblioteca, onde essa existisse;

- Ocorrência de leituras públicas por parte do professor ou de outras pessoas da região e os resultados colhidos por essa prática; 
- Por fim, indagava-se se havia, no local da escola, comissão promotora do ensino primário.

$\mathrm{Na}$ sequência do formulário, havia um espaço com linhas em branco acompanhado pelo seguinte enunciado: "observações gerais acerca do edifício, da mobília e utensílios escolares." Ali previa-se que o inspetor discorresse, de modo mais espontâneo, a respeito do que pudera observar na visita à escola. A seguir, vinham as informações relativas ao professor e ao serviço escolar: nome, estado civil, idade, estado físico, regime de trabalho, tempo de serviço no magistério público e na respectiva cadeira, comportamento moral e civil - quesitos que, no conjunto, antecediam os critérios de avaliação (como distinta, regular ou medíocre) sobre a formação literária do professor e sua aptidão para o ensino. As respostas deveriam ser aqui, pelo pequeno espaço reservado no impresso, curtas, sintéticas e objetivas; e as questões eram variadas o suficiente para permanecerem basicamente as mesmas daquele modelo de 1867, anteriormente analisado.

Indagava-se se o professor regia a cadeira com zelo e assiduidade, se era capaz de manter a disciplina na escola, se exercia outra profissão estranha ao magistério ou se proferia lições particulares. Outro item relevante procurava aferir os modos de ensino adotados na vida escolar e o método utilizado pelo professor para cada uma das disciplinas sob sua responsabilidade. Questionava-se a existência ou não de programas organizados pelo professor e as disciplinas que estes eventualmente compreendiam. Finalmente, a propósito desse item relativo ao trabalho docente, solicitavam-se informaçôes acerca dos compêndios mais usados na escola, dos registros de matrícula, de faltas e de aproveitamento dos alunos, dos castigos que o professor costumava aplicar a seus discípulos, das eventuais recompensas e dos exames.

Eram - como pudemos verificar - basicamente as mesmas questôes, colocadas talvez de modo a possibilitar maior recorrência à dissertação e à análise, sem excessiva preocupação quanto ao cômputo numérico que, no caso de 1867 , predominava no roteiro do formulário. $\mathrm{Na}$ verdade, uma abordagem qualitativa era efetivamente incentivada por parte da própria confecção prevista para o relato do inspetor, posto que, a partir de todos os quesitos colocados para aferir a condição do professor, havia no final um outro espaço de linhas brancas reservado para "observações gerais sobre o professor e o serviço escolar".

O último aspecto que se procurava apreender correspondia ao problema específico dos alunos, o movimento deles em termos da comparação entre os registros da matrícula efetuados e a regularidade da frequência escolar. O Relatório compreendia ainda o preenchimento de três mapas específicos sobre a questão dos alunos. O primeiro dizia respeito a uma análise retrospectiva da relação entre alunos matriculados, os de frequência regular e os prontos no fim do ano letivo anterior, de 1873-1874, aferindo também quantos daquele conjunto teriam sido aprovados em exames finais nas próprias escolas e quantos deles teriam sido aprovados em exames de admissão perante algum liceu. O segundo mapa supunha a distribuição, tanto dos alunos que frequentam a escola quanto daqueles que efetivamente lá estavam no dia da inspeção, em termos de disciplinas e de classes a que pertenciam. Finalmente, o último mapa compreendia a avaliação propriamente dita dos alunos inspecionados, de acordo com os níveis que houvessem obtido nas diversas disciplinas, a saber: 
Leitura, Escrita, Aritmética, Sistema Métrico, Gramática, Doutrina Cristã, Corografia, História Pátria e Desenho. Com sua preocupação descritiva, o Relatório abarcava, finalmente, um espaço com linhas brancas, para o preenchimento livre do inspetor, onde ficassem registradas suas "observações gerais sobre a frequência escolar e aproveitamento dos alunos”282. Sem dúvida alguma, foi através do preenchimento dessas linhas brancas do Relatório impresso que nós pudemos obter as mais preciosas pistas a respeito do registro da vida cotidiana da escola portuguesa e do modo pelo qual os usos e costumes escolares são produtores de uma cultura institucional específica.

\section{Professores que não gostam de ensinar e alunos que fogem as aulas}

Situada na freguesia de Trouxemil, do concelho de Coimbra, havia uma escola mantida pelo Estado, sob responsabilidade do professor José Augusto Mendes Diniz, secular, de 40 anos de idade. Em relação à casa escolar, o edifício da escola, pertencente à Junta de Paróquia, era considerado bem situado para a afluência dos alunos, bem conservado e com boas condições morais e pedagógicas. Comportando até 40 alunos na sala de aula, o prédio da escola teria, ainda, boas condiçôes higiênicas, luz e ventilação suficientes. A mobília e os utensílios da escola eram adequados e em boa quantidade para o número de alunos que frequentavam as aulas. Oferecido parcialmente pela Câmara Municipal e pela Junta de Paróquia, o mobiliário encontrar-se-ia, porém, em sofrível estado, segundo consta dos termos do Relatório.

O professor dispunha de bom estado físico e teria habilitações nas áreas de Francês, Latim, Lógica e Retórica. Vitalício no cargo, exercia o magistério público há já 16 anos, estando naquela cadeira de instrução primária há 7 . Embora sua capacidade literária, bem como a aptidão que demonstrava para o ensino, fossem qualificadas de regulares, seu comportamento moral e civil é qualificado de medíocre por parte do Relatório da inspeção de 1875 . O mapa estatístico concernente à frequência dos alunos no ano letivo de 1873-1874 revela que, dentre um total de 35 alunos matriculados ( 16 menores de 10 anos; 15 entre 10 e 12 anos; 4 entre 12 e 14 anos), apenas 12 possuíam frequência regular, entendendo-se que isso compreendia o comparecimento a pelo menos metade das aulas ministradas.

O Relatório destaca a falta de zelo e de assiduidade do professor, que ministraria uma única lição diurna por pouco mais de duas horas, porque havia, sem autorização, suprimido a outra. Não haveria, tampouco, programas organizados pelo professor, sendo irregulares os registros de matrículas, de faltas e de aproveitamento dos alunos.

${ }^{282}$ MR 1072. (livro do Ministério do Reino). Inspecção das escolas públicas e particulares do distrito de Évora. Quesitos aos inspetores das escolas primárias mantidas pelo Estado. 1875. Procuramos estudar, em termos qualitativos, alguns desses relatórios, escolhidos praticamente ao acaso, observando porém o preenchimento dessas observaçôes facultativas ao inspetor que, em muitos casos, permancia em branco, sem que o inspetor expusesse efetivamente um parecer mais específico sobre cada uma das escolas em particular. Veremos que, nas páginas seguintes, os relatos que nos permitimos efetuar com as considerações literalmente expressas no Relatório podem ser compreendidos como uma micro historieta da atmosfera cotidiana da escolarização portuguesa naquele final de século XIX. 
Os compêndios mais utilizados na escola seriam - tal como constam do Relatório - os seguintes: "Monteverde ${ }^{283}$, Cathecismo da doutrina christã da escola popular, Bíblia da infância, Manual encyclopedico, Sistema métrico do Augusto Moura e Taboada do mesmo." No tocante aos castigos comumente aplicados às crianças, o Relatório considera-os "morais e físicos e [o professor] é demasiado rigoroso na aplicação destes." Julgando insuficiente o aproveitamento dos alunos às aulas daquele professor, o inspetor pondera as razões, responsabiliza o "desleixo do professor" como provável causa, e tece, além disso, outras considerações reveladoras de seu parecer sobre o estado pedagógico da referida escola:

"O professor não tem simpatias na localidade; pelo contrário, é muito mal visto, a ponto de os pais não quererem que seus filhos sejam ensinados por ele e alguns os mandaram às escolas (...) que ficam distantes. É exagerado na aplicação dos castigos e disto me fizeram queixa na ocasião da visita. Advertindo-o de que não devia alterar as horas das aulas, e muito menos dar só uma lição por dia sem ter para isso autorização superior, respondeu-me que podia bem com a responsabilidade de tais atos porque não precisava do magistério público para viver e que unicamente pretendia ser professor mais três anos para completar os vinte de serviço. Em vista de tudo isto, procedi na administração do Concelho de Coimbra a sumário de testemunhas escolhidas entre as pessoas mais autorizadas do sítio e o remeti ao Exmo. Sr. Governador Civil para dar o competente andamento." 284

Na Freguesia de S. Thiago do Escoural, no Concelho de Montemor-o-Novo, no Distrito de Évora, a escola pública existia porque a Câmara Municipal de Montemor alugava uma casa de propriedade da mesma Câmara ao professor. Esse imóvel, no entanto, não disporia de quaisquer condições morais e pedagógicas - o que era comum à época. A mobília e os utensílios escolares teriam sido ministrados pela Câmara, a cargo de quem estaria sua reparação e conservação. Dizem as linhas do Relatório reservadas para as observaçóes gerais que

"A casa da escola faz parte da habitação de um ferreiro que tem sua oficina contígua à escola e faz por esta passagem para uma casa interior, cujo uso reservou para si e para sua família, de modo que estão a passar continuamente a mulher e os filhos do ferreiro, por meio dos alunos, com água, lenha e outras coisas de que o serviço doméstico carece. Esta mesma casa, em tais condições, está sob a influência e proteção do regedor, alugada ao professor (...) A mobília, que consiste em quatro bancos e uma mesa em que apenas podem escrever seis alunos, poderia bem figurar em qualquer alpendre, mas nunca numa escola. Utensílios limitam-se a um quadro preto."

Pela avaliação efetuada, o professor deixaria muito a desejar no tocante a suas habilitações literárias, além de possuir o péssimo hábito de embriagar-se. Diz, aliás,

${ }^{283}$ Quando os inspetores anotavam apenas Monteverde, estavam a referir-se ao Methodo faccilimo... daquele autor.

${ }^{284} M R$ 1071. (livro do Ministério do Reino) Inspecção das escolas públicas e particulares do distrito de Coimbra. Quesitos aos inspectores das escolas primárias mantidas pelo Estado. 1875 Distrito: Coimbra; Concelho: Coimbra; Freguezia: Trouxemil. 
sobre isso o inspetor, que "a sua capacidade só pode medir-se pela quantidade de líquido que pode conter; a sua aptidão é nula." Não tendo autoridade alguma para manter a disciplina em sala de aula, o docente não revelaria nem zelo e nem autoridade adequados. Além do mais, exercia paralelamente a profissão de sangrador. No que concerne à metodologia de ensino adotada, empregava o modo individual, ensinando de maneira repetitiva e maçante, fazendo-se acompanhar pelo estampido da palmatória que, ao alcance da mão, costumava deixar em cima da mesa. O professor utilizava em sala de aula os dois compêndios de Monteverde (o Methodo facillimo e o Manual encyclopedico), o Manuscripto de Ventura e o Compêndio do sistema métrico de Fradesso da Silveira. Em termos dos castigos aplicados, consta o seguinte do Relatório: "o soco e a palmatoada num excesso tal que já muitas vezes lhe tem ido a vizinhança tirar os pobres rapazes das mãos." Nas "observações gerais sobre o professor e serviço escolar", lê-se:

\begin{abstract}
"É inconvenientíssima, imoral até a conservação deste homem no professorado, cuja classe está desonrando:- nada ensina, nada sabe, a embriaguez habitual torna-o completamente estúpido e mau; os alunos espreitam, antes de entrar para aula, o estado em que se acha o professor e repetidas vezes vêm gritando pelas ruas aos companheiros - não vão lá que o mestre está bêbado; algumas vezes tem caído nas ruas, e mesmo na aula, em tal estado que vão chamar o regedor para ir esconder ao escárnio do público, principalmente dos seus alunos; mais poderia dizer, mas repugna-me tamanha miséria."
\end{abstract}

Ademais, o inspetor diz que só não levantou processo contra tal professor porque todas as autoridades da região tinham conhecimento de seus procedimentos e de sua indigna conduta. A frequência da escola era - como não podia deixar de ser - irregular e o aproveitamento dos alunos era pífio, havendo, não raras vezes, falta de comparecimento do próprio professor à hora de entrada e retirada dos alunos antes do tempo necessário para o término da lição. Havia, no cômputo total, 27 alunos matriculados, dos quais apenas 12 frequentavam regularmente a escolar diurna. Eram meninos entre 8 e 13 anos, todos eles qualificados pelo inspetor como medíocres em todas as matérias escolares. No ano anterior, por seus turno, o professor não apresentara nenhum aluno pronto no final do ano - segundo constava dos termos do relatório. Enfim, conclui o inspetor:

\begin{abstract}
"As causas gerais do pouco aproveitamento dos alunos acresce o que já disse nas observações a respeito do professor. A frequência é geralmente irregular e interrompida nas épocas em que o serviço dos campos emprega também o braço das crianças, e aqui muito mais do que em outras partes. Além disto um grande número de pais não quer mandar seus filhos a esta escola para não darem a seus filhos aqueles exemplos de embriaguez e não os exporem à brutalidade do professor." 285
\end{abstract}

${ }^{285}$ MR 1072 (livro do Ministério do Reino) Inspecção das escolas públicas e particulares do distrito de Évora. Quesito aos inspetores das escolas primárias mantidas pelo Estado. 1875. Concelho: Montemor-o-Novo; Freguesia: S. Thiago do Escoural. 


\section{Velhos professores, métodos facílimos e leitura em livro}

A escola primária do sexo feminino situada no extinto convento de São Francisco na freguesia de São Pedro em Évora é dirigida por Carlota da Soledade Campos, que, com seus 67 anos de idade e 33 de magistério, encontra-se já sem agilidade e com problemas de vista. A casa escolar não é de fato a mais apropriada, tanto por ficar excessivamente distante em termos da afluência dos alunos, quanto pela existência de uma escada muito alta em caracol, cuja subida se faz necessária a todos os que desejem atingir a sala de aula.

O edifício, por sua vez, cedido gratuitamente pela Câmara Municipal de Évora, comporta duas celas de frades, numa das quais se ensinam os lavores, ficando a outra reservada para os exercícios literários. Com uma área de 12 metros quadrados cada uma delas, poderiam ser ali comportadas 14 ou 15 alunas, no máximo - segundo relata o inspetor. Todo o restante do convento é aproveitado como habitação da professora, que, surpreendentemente, teria 44 alunas matriculadas no ano letivo de 1873-1874, das quais, entretanto, apenas 16 tiveram frequência regular. Embora a professora houvesse argumentado que, no ano seguinte, a escola seria frequentada basicamente pelas mesmas alunas do ano anterior, o inspetor verifica que as alunas matriculadas no ano letivo de 1874-1875 eram, no total, 48 meninas para aquela escola diurna, sendo que apenas 8 eram aquelas que efetivamente compareciam às aulas. Das "observaçôes gerais acerca do edifício, mobília e utensílios escolares” consta o seguinte:

\footnotetext{
"Triste idéia foi a de colocar a escola neste edifício, que só à custa de muitas despesas se poderia apropriar para o uso escolar, e ainda assim o grande número de degraus que é mister subir, torná-lo-ia sempre inconveniente. A escola está pois ali quase esquecida; nem munícipes nem município lhe têm dado a mais pequena atenção; houve um vereador que lhe mandou há anos uma mesa que pertenceu ao tribunal judicial, tão grande que não coube pela porta da casa que servem d'aula, e tão alta que só de pé as alunas poderiam escrever nela; o que fez com que a professora a mandasse arrumar a um canto do corredor, onde inutilmente se conserva."
}

A escola não possuía registros adequados de matrícula, ao que o inspetor declara havê-los inventado consoante informações que lhe teriam sido fornecidas. Segundo ele, os registros resumiam-se a pequenas folhas, onde constavam mal escritos os nomes das alunas, com tantos erros ortográficos que se faziam quase incompreensíveis. Alguns dos mapas escolares chegaram inclusive a ser, pela professora, simplesmente copiados de anos letivos anteriores. $\mathrm{O}$ comentário anexado pelo inspetor à folha impressa era o seguinte: "os números de matrícula são inventados por mim; a idade é a que as alunas declararam; meses de frequência não foi possível averiguá-los, porque nem professoras nem alunas sabiam; os registros de matrícula são umas folhas dispersas, quase ininteligíveis."

Indagada sobre o método que utiliza, a professora prontamente responde: "método facílimo"; confundindo, pois, evidentemente, a intenção da pergunta, ao remeter-se àquele que, a seus olhos, parecia de fato "o método". Seu comentário sobre o uso do Método Facílimo é um indicador do impacto simbólico que o livro de Monteverde tivera a seu tempo: indubitavelmente o compêndio mais utilizado pelas escolas portuguesas da época. Ainda que, pela análise do inspetor, não pudesse ser qualificada como especialmente zelosa, a professora era assídua, costumando utilizar 
3 horas da manhã para os exercícios escolares, acrescidas de outras 3 horas vespertinas para o ensino dos lavores a suas alunas. Nesse horário, as meninas - cuja idade variava entre 7 e 11 anos - aprendiam a fazer meia, ponto de crochet, a coser e a bordar. A professora talvez desse mais valor ao ensino de tais afazeres do que à transmissão do domínio da escrita, julgado menos útil para uma mulher...

O inspetor do Distrito de Évora - António Pereira da Silva - foi também o responsável pela visita à escola primária de sexo feminino localizada à Rua da Mouraria no 33, da freguesia de São Mamede na cidade de Évora.

A escola era dirigida por Carolina Júlia da Motta Pereira, de 27 anos de idade e 5 de tempo de serviço no magistério público. Naquele ano letivo de 1874-75, havia 35 alunas matriculadas, das quais frequentavam regularmente a escola apenas 12 . A irregularidade da frequência, bem como a falta de meios indispensáveis para um bom ensino, o abandono com que a Câmara deixava a escola eram fatores que contribuíam para o mau aproveitamento escolar das alunas. A professora tinha diploma do curso de $1^{\circ}$ grau de instrução primária conferido pela Escola Normal, sendo portanto vitalícia, com satisfatória capacidade literária para o ofício ao qual se dedicava.

\begin{abstract}
"Visitei a escola em 6 de Abril - primeiro dia de aula depois das férias -, época fatal para conhecer do aproveitamento dos alunos, após 15 dias de interrupção nos exercícios escolares; a classe da sociedade a que pertence a máxima parte das frequentantes é a menos favorecida da fortuna e isto basta para se afirmar desde logo que a frequência é irregularíssima e por consequência bem pouco o aproveitamento. Além disto, a largueza dos programas leva a professora a ser exigente na compra de livros, a que as famílias se excusam por carência de meios; e daí vem muitas vezes a declaração formal dos pais - de que não querem que suas filhas aprendam mais do que a ler em livro (e para isso lhe serve o primeiro que lhe vem à mão) e fazer os lavores próprios do seu sexo." 286
\end{abstract}

As observações dos inspetores a respeito do serviço escolar contemplavam aspectos comuns para quase todos os distritos, com alguma frequência na proporção encontrada para um conjunto de problemas cuja compreensão nos pareceu relevante, para que nos pudéssemos aproximar do dia-a-dia da escola portuguesa, de seus dilemas, de seus impasses. Segundo consta das observaçôes sobre o serviço escolar, era muito habitual, praticamente em todas as regiōes, haver irregularidade nos registros de matrícula dos estudantes, pela nítida dificuldade de compreensão acerca do preenchimento dos quadros e mapas padronizados. ${ }^{287}$ Ao professor não eram fornecidos, ao que

${ }^{286}$ MR 1972. Concelho: Évora. Freguesia: São Mamede da cidade de Évora.

${ }^{287}$ A respeito das limitaçôes quanto à própria veracidade dos dados da averiguação que fazia, diante da carência de informações, diz o inspetor da escolar da freguesia de Taveira no concelho de Coimbra: "O registro da matrícula dos alunos é bastante irregular, pois nem para ele há um livro, achando-se farto em folhas avulsas de papel, nem tem os dizeres suficientes, faltando-lhe a data da entrada dos alunos para a aula e a nota da qual o seu aproveitamento $e$ comportamento bem como da classe a que pertence cada ano. Não tem o registro da frequência de modo que não foi possivel ver qual o numero de alunos que regularmente frequentam a aula; para nesta parte encher os mapas $n^{\circ} 1$ e 2 foi preciso calcular aproximadamente essa frequência segundo a informação do professor. " [MR 1071. (livro do Ministério do Reino) Inspecção das escolas públicas e particulares do distrito de Coimbra (círculos 1 e 2). Quesitos aos inspetores - 1875. Concelho: Coimbra; Freguesia: Taveira] 
parece, os instrumentos analíticos para entender esse universo da avaliação. Não havia inspeção regular e a visita do inspetor não era, portanto, algo integrado ao cotidiano das escolas. Com professores amedrontados e apreensivos do julgamento da inspeção, não havia, por outro lado, qualquer iniciativa pedagógica dirigida à orientar os mestres sobre aquilo que lhes faltava. Nessa medida, com dificuldades concernentes ao controle escolar, muitas escolas que figuravam no cômputo inicial do inspetor não estavam em funcionamento. ${ }^{288}$ Às vezes, a escola existia formalmente, mas as faltas do professor eram tão frequentes que o inspetor não podia sequer emitir qualquer parecer sobre aquilo que realmente encontrara. ${ }^{289}$

Embora se tratasse de um conjunto de escolas públicas, o inspetor manifestava com alguma frequência a expectativa de que o professor fornecesse de seu próprio bolso o custeio de livros e de materiais escolares, havendo, além disso, um tom de repreensão crítica quando o mestre se recusava a melhorar, através do fornecimento de material gratuito, as condições pedagógicas de sua classe. ${ }^{290}$ Dificuldades quanto ao convencimento das populações para que enviassem as crianças à escola não pareciam ser equacionadas, posto que as famílias hesitavam em reconhecer os benefícios da instrução e, mesmo quando declaradamente o faziam, demonstravam acreditar que o valor da escola estaria reduzido a esse conhecimento elementar da 'leitura em livro'. Mais do que isso, supunha-se ser perda de tempo. Se nem sua meta primeira a escola conseguia efetivar como produto, a comunidade não via sentido maior em delegar parcela de sua responsabilidade educativa, parcela do tempo da jornada de trabalho, parcela de poder, àquela instituição que, de alguma forma, deixara de cumprir o que havia prometido.

Existiam, em algumas regiōes, atuando de maneira assistemática e ainda incipiente, comissōes promotoras da instrução pública, organizadas por setores da sociedade civil

${ }^{288} \mathrm{O}$ professor da freguesia de Eiras no concelho e distrito de Coimbra, estava, por exemplo, gravemente doente e por essa razão, por ocasião da inspeção, não foi encontrado na escola. As aulas haviam sido suspensas há mais de uma mês, dado que o professor inclusivamente deitava já sangue pela boca. Essa escola, por acaso, parecia ter bom aproveitamento por parte dos alunos, antes de ter tido seu funcionamento interrompido: "segundo as informaçôes colbidas soube que os alunos tinham regular aproveitamento quando a escola funcionava, e que esta era muito frequentada, não só por alunos da freguesia de Eiras, mas ainda por muitos das freguesias próximas e nas quais não há escolas. Como a aula tem estado fechada, e quase todos os alunos matriculados são de fora da localidade, apenas se reuniram na ocasiāo da visita quatro dos mais adiantados que inspecionei para formar o meu juízo acerca do adiantamento e da aptidão do professor." (MR 1071. Distrito e concelho: Coimbra. Freguesia: Taveira)

${ }^{289}$ Sobre a escola da freguesia de Castello Viegas, diz o inspetor: " no dia 9 de Junho encontrei a escola fechada porque o professor estava em Coimbra doente, sem que tivesse participado isso ao Comissário dos Estudos e ao Administrador do Concelho. Só nos fins de Julho o participou e foi nomeado interinamente por um parente do mesmo professor e que vive com ele, segundo me informaram. No dia 30 de Agosto, fui a Castello Viegas para fazer a inspeção e outra vez encontrei a escola fechada porque o professor interino não deu aula nesse dia nem no imediato. Fui porém à casa da escola e não encontrei livros nem apontamento algum acerca da escrituração escolar. Alguns escritos que lá vi dos alunos eram maus." (MR 1071. Concelho: Coimbra. Freguesia: Castello Viegas)

${ }^{290}$ A escola pública existente na freguesia de Anturede no concelho de Coimbra tinha frequência pequena, de apenas três alunos, embora houvesse na localidade inúmeras crianças em idade e condições de aprender a ler. Pelas observaçōes do inspetor sobre o cotidiano escolar, podemos observar o tom severo da crítica efetuada: " $o$ professor é muito desleixado. Não tem um registro regular de matrícula e de frequência dos alunos porque não quer comprar à sua custa os livros necessários para isso. Não tem na casa da escola água para ele e para os alunos e não raras vezes abandona a aula para ir beber água na casa dos vizinhos. Os alunos pedem para ir à fonte, que é longe, e aí se ajuntam e demoram a brincar." (MR 1071. Concelho: Coimbra. Freguesia: Anturede) 
interessados em fazer prosperar as condições culturais da população. A escola situada na freguesia de Sernache, no concelho de Coimbra era mista. Seu professor era um eclesiástico de 56 anos de idade. Havia no local uma comissão promotora do ensino primário, comissão que o relato do inspetor julgava, entretanto, incompleta, por decorrência da morte de um dos seus mais destacados membros, o Visconde de Condeixa. Como princípio, essa comissão promovia atividades voltadas para incentivar os pais a mandarem seus filhos à escola, proporcionando também a distribuição da alguns prêmios para aqueles alunos que mais se destacassem. Além disso, a comissão se encarregara de fazer alguns reparos no edifício escolar, de maneira a acomodar convenientemente a dinâmica pedagógica da instituição. Nos termos do Relatório, lê-se o seguinte:

"O edifício em que se acha estabelecida a escola foi a antiga casa da cadeia e a Câmara Municipal cedeu-o à Junta de Paróquia para a escola pública. Tem três casas, sendo a principal que serve para a aula, e as outras duas ficaram separadas daquela por uma parede em que apenas há uma porta que as comunica. Deitada abaixo a parede, pode-se fazer uma razoável casa de aula com capacidade para um curso de cem alunos. A comissão promotora, agora completada, de acordo com a Junta, ficara em boas condições de empreender esta obra, que é urgente, por não ter a escola capacidade bastante para os alunos que a frequentam."291

Muitas vezes, o retrato feito do professor de escola primária é rígido no que concerne à apreciação dos métodos utilizados para a manutenção da disciplina escolar. O professor raramente é elogiado; quando não é acusado de autoritário, é qualificado de ignorante; quando não se diz que é ríspido nas maneiras, é julgado pouco habilidoso ou preguiçoso. Enfim, a análise da inspeção usualmente aborda o que supõe ser o registro da incompetência e incompletude docente. Acima de tudo, o professor carece. Sua carência - de bons modos, de habilidades científicas e literárias, de remuneração condigna, de boa formação pedagógica, de utilização de metodologia apropriada - é, nessa medida, praticamente intransitiva. Acusa-se, de fato, o professor por ele não se mostrar capaz de domínio nem da disciplina e nem do conteúdo. Quando a escola fracassa - e na maior parte das vezes, era isso que ocorria - ao professor caberá a maior parcela da culpa. Um dos dados mais nítidos do papel pouco instrutivo da escola portuguesa daqueles tempos era o fato de os relatórios sequer analisarem a quase ausência total de alunos considerados pelos professores como "prontos no fim do ano". Não havia praticamente, em toda a amostra que pudemos analisar, alunos aprovados em qualquer exame de liceu, o que revela que o mundo do liceu era então um ambiente à parte, que, em princípio, em nada teria a ver com a estrutura e a lógica de funcionamento da escola primária. Esta continuava a ser regida pelo signo de uma prática intransitiva.

A escola primária do sexo masculino da freguesia de São Bento do Matto na Vila Nova do Príncipe funciona em edifício que pertence ao professor, alugado pela Câmara Municipal de Évora, de quem o mestre recebe subsídio de renda. Toda mobília e utensílios escolares pertencem ao professor: um quadro-preto, 7 bancos, 1 mesa para

${ }^{291}$ MR 1071. Concelho: Coimbra. Freguesia: Sernachel. 
o mestre, uma cadeira; tudo novo, embora insuficiente para os 36 alunos, dos 46 matriculados, que efetivamente frequentam a escola. Thiago da Encarnação Ferreira é um secular de 44 anos, vitalício, tendo 19 anos e 6 meses de serviço no magistério público. Suas habilidades estariam reduzidas à aptidão para o exercício da leitura, para as habilidades da escrita e para o cálculo de uma elementar aritmética. As condições físicas e materiais do edifício escolar também não pareciam estar em melhores condições:

"A casa em que funciona a aula é muito pequena, teto baixo de telha (...) e chão de terra batida, sem reparo algum nem para o frio nem para o calor, nem para o pó. Quando visitei a escola, estava o professor de chapéu na cabeça, e mais tarde achei-lhe razão porque, soprando então o vento com alguma força, a terra que andava levantada na aula sentia-se na carne e em todos os objetos em que se pegava. A Câmara mandou fazer três enormes bancas, tão grandes que nem uma só pode estar na aula, e com a superfície em dois planos tão inclinados que nem uma folha de papel deixada ali lhe fica em cima. O professor, quando as recebeu, mandou-as arrumar numa casa grande onde estão sem poderem servir." ${ }^{292}$

Havia informações - registradas pelo inspetor como provenientes de "pessoa de toda fé" - de que o professor faltava às aulas inúmeras vezes, deixando a escola sob o encargo dos alunos mais adiantados. As aulas duram em média duas horas pela manhã e outras duas à tarde, sendo que, ao que informa o professor, mais do que isso seria impossível, dado que as crianças costumeiramente eram empregadas nas fábricas de cortiça da região e não se prescindia, em termos familiares, dos proventos de tal ofício infantil.

O professor adotaria o modo misto de ensino: simultâneo-mútuo no que concerne à leitura, aritmética e doutrina cristã, sendo a escrita feita como dever de casa pelos alunos. No que tange aos métodos utilizados, o inspetor declara que "nenhum conhece o professor senão o rotineiro." Os registros de matrícula, faltas e aproveitamento dos alunos eram imperfeitos e irregulares. Como castigo, o professor recorria a palmatoadas. A propósito do serviço escolar e das habilidades e costumes do professor, o Relatório declara o seguinte:

"Este professor - áspero no trato, grosseiro nas maneiras e de poucos conhecimentos -, seguindo em seu ensino um processo muito moroso, em que predomina o modo mútuo, dirigido por dois ou três alunos mais adiantados da aula, não tem dado de seu trabalho fruto que mereça mencionar-se. Em escrita principalmente tem os seus alunos muito atrasados, o que certamente é devido a ser esse exercício feito na ausência do professor; e salvo algum de grande aptidão, os mais, ou não escrevem absolutamente nada, ou tão mal que a muito favor se lhe dá a qualificação de medíocre. Não é porém assim na Aritmética em que a facilidade com que os alunos fazem as quatro operaçôes deixa bem ver que é a esta parte do ensino que o professor dá mais atenção. Em leitura tem o professor de lutar com uma grande dificuldade que é a acentuação espanhola que todos têm proveniente do grande trato que há com indivíduos daquela nação, mal a que o próprio professor não pode fugir."

${ }^{292}$ MR 1072. Concelho: Évora. Freguesia: São Bento do Matto na Villa Nova do Principe. 
A frequência da escola era irregular; e, dos 36 alunos que iam regularmente à escola, muitos o faziam apenas por um período - ou só de manhã, ou só à tarde - perdendo, com isso, as lições do outro período em que, geralmente, estavam ganhando "alguns vinténs".

\section{Estímulo do professor e êxito do aluno: uma via de mão dupla}

Havia, por parte de alguns inspetores, o reconhecimento da dificuldade material com que se defrontava um professor que, não raras vezes, dava tudo de si para proporcionar a seus discípulos o melhor ensino de que era capaz. Faltava tudo na escola: bons recursos didáticos e habilitação técnica para bem aproveitar os que existiam. Faltavam livros, mapas, estampas e quadros de gravuras, não sendo raras as vezes em que o mestre improvisava e recorria a estímulos visuais, chegando inclusive a arrancar folhas de compêndios para mostrá-las soltas a um grupo maior de alunos.

$\mathrm{Na}$ freguesia da Sé de Évora, o professor Francisco Maria Monteiro fizera um quadro com páginas retiradas do Método Facílimo de Monteverde, compreendendo essa improvisação do método como uma alternativa de projeção da estratégia possível perante a carência de instrumentos pedagógicos apropriados. Nos termos do inspetor, o resultado não havia sido, em hipótese alguma, bem sucedido (apesar de todos os esforços encetados pelo professor para isso), tão grande era a defasagem daquela escola quanto aos utensílios necessários para o êxito do ensino.

"Assim o professor ser impossibilitado de poder dar liçôes em classes por falta de tabelas de leitura, de quadros pretos, de mapas, de estampas, de um bom contador mecânico, e de muitos outros objetos enfim que a pedagogia aconselha, vê-se obrigado a colar a uns quadros de madeira que ainda lhe restam folhas arrancadas ao Método Facílimo para poder formar alguns grupos. Para o sistema métrico nem tem quadros de pesos e medidas, nem coleçôes destes, como há em muitas escolas da Estremadura. Para o ensino da geografia geral e particular do País, não tem mapas.". 293

O professor daquela escola de Évora era um homem de 50 anos, que possuía, além do diploma de professor de primeiras letras, aprovação em exame de latinidade. Com 20 anos de exercício na cadeira de instrução primária no magistério público, tinha capacidade literária bastante regular, embora lhe faltassem, aos olhos do inspetor, conhecimento e sagacidade nos procedimentos metodológicos do ensino. O inspetor comenta que Francisco Maria Monteiro - o mestre da escola - não lia francês, o que o impedia de travar contato com os processos renovados e modos de ensino em voga nos países mais adiantados da Europa. Mesmo assim, o inspetor reconhece ser aquele professor o único da cidade de Évora que "tem apresentado todos os anos alunos habilitados nos exames de instrução primária de admissão aos liceus.” Isso intrigava o técnico da inspeção, posto que as condições objetivas da sala de aula daquele indivíduo não eram das melhores.

${ }^{293}$ MR 1072. Distrito e Concelho: Évora. Freguesia: Sé - Escola primária masculina no Edifício Casa Pia. 
$\mathrm{Na}$ verdade, naquele específico ano letivo, o professor Monteiro contava com uma frequência regular - segundo ele - correspondente a 90 alunos. Pelo que o próprio inspetor confirmava, havia efetivamente mais de 90 crianças em sala de aula no dia de sua supervisão. Um único homem, sem bons monitores, sem qualquer outro auxiliar com quem dividir o trabalho, evidentemente teria enorme dificuldade para liderar e grupo e ensinar. Era o que ocorria. Mesmo assim o professor adotava a tática de dedicar-se mais diretamente àqueles alunos que maior esperanças lhes traziam quanto ao aprendizado. Dizia o inspetor sobre a opção que fizera o professor Monteiro: "vendo o professor a impossibilidade de levar toda a aula ao ponto que deseja, dedica-se com particular afinco àquela porção de alunos que maiores esperanças lhe fizeram conceber, e - força é confessá-lo - a ela sacrifica a máxima parte de seus discípulos."

O bom professor era, nesse caso, o profissional capaz de se valer adequadamente dos insuficientes recursos materiais e científicos de que dispunha, revelando, nessa medida, criatividade, imaginação e habilidade para convidar e incitar os alunos ao aprendizado, mantendo, com isso, uma regularidade na frequência e no afluxo dos estudantes à escola. O bom professor era, implicitamente, aquele que parecia colher o impossível das condições postas no limite do possível.

Havia um bom professor na escola primária do sexo masculino com sede no largo da Igreja na aldeia de Egreginha na freguesia de Nossa Senhora da Consolação do Concelho de Arraiolos no distrito de Évora. Bem situado para a afluência dos alunos, o edifício escolar pertencia à Junta de Paróquia, que, por sua vez, havia também ministrado a mobília e os utensílios escolares. O professor Manoel Joaquim Galvão, de 50 anos de idade, tinha 9 anos de serviço exercendo aquela cadeira no magistério público. No ano que se havia passado, entre 1873-74, de seus 43 alunos matriculados, menos de 30 tinham frequência regular, e, mesmo assim, nenhum deles foi considerado aprovado em exames finais na própria escola. Matricularam-se no ano letivo de 1874-75 33 alunos, dos quais só 10 frequentavam regularmente a escola diurna. Mesmo assim, este professor é saudado pelas dificuldades com que se defrontava e pelo modo de enfrentar as enormes adversidades de seu trabalho:

"Ver as dificuldades com que este professor luta e presenciar o trabalho insano a que se dá constantemente para aliviar a elas, não causa só admiração, enche de espanto. São os alunos filhos de criados dos lavradores circunvizinhos, que residem ou em Évora, ou em Arraiolos, portanto pobres; apresentam-se na aula sem livros - sem coisa nenhuma enfim que seja instrumento de ensino; a aula também os não tem, - como remediar isto?... faz o professor e tem sobre a mesa maços e maços de papeletas que dá aos alunos durante as horas da escola - umas de nomes - de máximas morais - de trechos copiados da Bíblia - outras de números de regras de aritmética, outras, enfim, de preceitos gramaticais; é por estas papeletas que os alunos lêem e aprendem algumas regras. Que faria este professor em frente de uma aula bem provida de utensílios escolares?”294

${ }^{294}$ MR 1072. Distrito: Évora. Concelho: Arraiolos. Freguesia: Nossa Senhora da Consolação, na aldeia da Egreginha (escola primária do sexo masculino com sede no largo da Igreja). 
O inspetor António Pereira da Silva inspecionou oito alunos em sua visita de 5-5-75. Desses, havia dois alunos considerados bons em todos os quesitos - Leitura, Aritmética, Doutrina Cristã -, exceto em Escrita, onde os oito foram efetivamente julgados medíocres. Sabe-se que a escola do século XIX, particularmente no período estudado, ainda ensinava habitualmente a leitura antes de proceder ao ensino da escrita. Não havia, portanto, correspondência entre o saber ler e o ser capaz de escrever. Cinco dentre os oito alunos nessa escola inspecionados sabiam ler, mas não eram capazes de escrever, dado que o tempo e as condições da escola não os teriam permitido alcançar esse estágio da aprendizagem. Suspeitamos que esse não era, em hipótese alguma, um caso isolado, até porque - lembre-se - encontramos depoimentos de pais que declaravam que, quando aprendessem a ler por livros, as crianças poderiam e deveriam deixar a vida escolar. A escrita não era tomada como uma necessidade tão relevante quanto a leitura. Curiosamente, os oito alunos da escola da aldeia de Egreginha, a despeito das dificuldades em Escrita, foram todos qualificados como bons em Doutrina Cristã. Em Aritmética, havia três bons, três suficientes e dois medíocres. Dividindo a aula em duas horas pela manhã acrescidas de outras duas horas e meia à tarde, o método do professor é o que aqui vinha designado de "rotineiro" e o modo de ensino variava entre o simultâneo (para a leitura) e o individual. Sobre o aproveitamento dos alunos, registre-se o seguinte:

\footnotetext{
"Pelo que acima expus pode supor-se qual será o aproveitamento dos alunos, cuja frequência é irregularíssima, como o de todas as aulas desta aldeia, e desprovidos de todos os elementos do bom ensino. Há todavia nesta escola alunos que revelam muita inteligência e que em todas as disciplinas seriam distintos se o professor com sua diligência e trabalho pudesse suprir aquelas faltas: em Doutrina Cristã estão superiores aos de todas as escolas que tenho visitado, em leitura de letra manuscrita, a que estão mais habituados em virtude das papeletas de que falei, estão muito regulares, e em Aritmética - $1^{\circ}$ classe - ler números - contar de cor - a fazer pequenas operaçôes de somar, diminuir e multiplicar, muito exercitados. Enfim, no que depende só do professor, há razão bastante para dizer que em tais condições não se poderá fazer mais.”
}

De algum modo, o inspetor deixa transparecer que o modo simultâneo era a chave do sucesso em sala de aula. Em outros sítios do país, outros inspetores também averiguavam a inadequação de procedimentos individuais e mútuos de ensino, pouco sistemáticos para o exercício do ensino e do aprendizado, além de morosos no tocante à rapidez do percurso do conhecimento transmitido. Dizia-se que faltava método à escola. Por método entendia-se, porém, um composto bastante complexo (e talvez confuso) de crenças e de expectativas, que envolviam do desejo de organização e de disciplinarização da vida escolar à obtenção de procedimentos uniformes e científicos de proceder ao trabalho educativo. Era preciso selecionar saberes escolares; era urgente compor uma trajetória própria de apropriação da cultura pela via da instituição. Mas não era isso que se encontrava nos diferentes cantōes do país.

Muitas vezes, a própria casa da escola era estabelecida em locais inadequados, dificultando o que, com uma considerável frequência, impedia o afluxo dos alunos, sem que nada fosse feito pelas autoridades responsáveis com o fito de alterar a situação. Havia escolas que ficavam mesmo junto ao rio, sendo inundadas em épocas 
de cheias. ${ }^{295}$ Havia escolas que ficavam excessivamente distantes, o que levava a que os alunos precocemente desistissem de sua tentativa escolar. Havia escolas cujo inspetor lamentava...

Com luz escassa e ventilação insuficiente, o prédio em questão é considerado pelo inspetor uma "masmorra de granito", sendo assim inabitável. O professor não vivia lá, mas a $5 \mathrm{~km}$ de distância. Ele tinha, na época, 57 anos e o inspetor o julgava inapto para o exercício do magistério, onde, apesar da elevada idade, estaria há apenas seis meses. "Soletra e conta muito mal - comenta o inspetor - Tem alguma vivacidade natural, mas na idade em que se acha nem é capaz de aprender, nem pode ser, por nenhum modo, apto para ensinar." 296 Secular e casado, o professor António José Domingos da Costa possuía bom comportamento moral e civil. Acerca das condições materiais de funcionamento da casa escolar, o inspetor relata:

“É uma vergonha, é uma dor, é um escândalo perante a consciência nacional que uma escola mantida pelo Estado e gratificada por um município se apresente a emparelhar com o covil das feras. Pela dignidade nacional, pelo bem da instrução, por Deus, por tudo, eu peço aos que superintendem neste serviço público que a escola de Pedraido ou seja extinta ou imediatamente provida e reformada. (Chama por ela o merecimento e a necessidade do concelho de Celorico de Basto)."

Não há dados estatísticos com relação aos alunos que frequentaram o ano letivo anterior, o que se deveria ao fato de o atual professor (interino) exercer esse cargo há apenas um mês e a referida cadeira ter estado vaga de professor definitivo por quatro anos. A mesma cadeira, "tendo sido ocupada por outros interinos, estes não prestaram ao atual os menores esclarecimentos acerca do movimento anterior desta triste e miserável escola."

Sem critérios de zelo e de assiduidade, o professor garantia a disciplina perante imposição indiscriminada do medo. Lecionando no período diurno, daria aulas pela manhã: no verão, das quatro às seis e meia. Diz que tal horário foi adequado segundo comodidade sua e das famílias. Utilizando apenas uma tabuada e a Cartilha da Doutrina Christã, de autoria de António J. De Mesquita Pimentel, o popular Abade de Salamonde, dizia ensinar pelo modo individual. Em relação aos procedimentos e técnicas utilizados em sala de aula, consta do Relatório que "ensina rudemente. Não tem modos nem idéia do que seja método, porque ignora tudo. Todo o método cifra-se em gravar na memória dos alunos os sinais da linguagem ideográfica e fonética com algumas combinaçōes rudimentares. Nada mais.” Seus registros de matrículas eram irregularíssimos, até porque - ironizava o inspetor - o professor não seria capaz de "ligar as sílabas na

\footnotetext{
${ }^{295}$ Sobre a escola situada no concelho de Loure, freguesia de São Thiago no distrito de Coimbra, o inspetor faz as seguintes observaçōes gerais acerca do edifício, mobília e utensílios escolares: "o local em que estabeleceram o edifício da escola é péssimo, e segundo a opiniāo de pessoas autorizadas que a este respeito ouvi, não se encontraria em toda a Villa de Loure um sítio mais impróprio e até insalubre. A casa está junto ao rio, e amiudadas vezes no inverno entram nela inundaçôes, tendo por este motivo de se interromper as aulas durante alguns dias. Perto da casa, e quase contígua a ela, estão também o matadouro e o açougue."(MR 1071. Distrito: Coimbra. Concelho: Loure. Freguesia: São Thiago).

${ }^{296} M R 1067$ (Livro do Ministério do Reino). Inspecção das escolas públicas e particulares do distrito de Braga (círculos 3 e 4). Quesitos aos inspetores - 1875. Concelho: Fafe. Escola primária do sexo masculino. Freguesia: Pedraido.
} 
escrita”. Os castigos físicos aplicados, ele os dava com a palma das mãos, posto que - nos termos daquele Relatório assinado pelo inspetor Joaquim Ignácio d'Abreu Vieira - "nem o fatal instrumento da palmatória eu pude encontrar na aula.” A respeito das características próprias da rotina escolar, o inspetor relata o que pudera observar:

"Homem verdadeiramente rústico, o professor entretém a escola como meio de receber a mensalidade e de ganhar certo prestígio entre os seus companheiros das selvas. Cheguei ao local da escola às seis e meia horas da manhã e já os pequenos rezavam em algazariado a Salve-Rainha da despedida. Entrei a custo e a medo na aula (porque a entrada para ela é um perigo) e vi o professor meio nu da cintura para cima e descalço. Os discípulos trajavam o mesmo uniforme. Tinha tudo um aspecto de selvajaria, que me assustou a consciência de homem livre."

A escola que se desenhava naquele Portugal do século XIX era, até certo ponto, bastante distinta das ambições preconizadas pelos discursos políticos e intelectuais a respeito dos presumidos efeitos dessa multiplicação da cultura letrada. Cabe indagar se aquela escolarização em curso realmente espraiva os códigos de cultura, ou se, pelo contrário, ao reafirmar seus segredos sem ser capaz de desvendá-los, ela não estaria quem sabe - talvez afastando as populaçôes do potencial mobilizador da leitura. Indagar sobre a composição desse cotidiano exige da investigação perscrutar os interiores mais secretos da instituição que lhe dá vida... Urgia encontrar e identificar naquela "fôrma escolar" 297 - aparentemente tão uniforme - traços e sinais da vida institucional. A escola com que trabalhamos deixou vestígios fortuitos aos quais podemos conferir significado. Regressar a eles parece ser, ainda, a única condição de confrontar suspeitas sociológicas com ocorrências da história. Em um tempo que nos foi legado apenas pelo fragmento, parece-nos essencial voltar a olhar... No parecer do inspetor de Évora, por exemplo, o professor que cumpria horários, que se esforçava por manter a ordem e a disciplina da vida escolar, esse sim - a despeito das incapacidades científicas e literárias - atenderia os reclamos da didática.

O edifício da escola primária mista com sede no Terreiro do Castelo na aldeia de Monte de Trigo na freguesia de São Julião no Concelho de Portel, situado no distrito de Évora, pertencia à Junta de Paróquia, que o havia expressamente mandado fazer para servir como escola. Como mobília, a casa contava com uma banca, quatro bancos grandes e cinco pequenos, um quadro preto pertencente à escola e um contador mecânico feito pelo professor. Como declara o inspetor, o espaço físico

${ }^{297} \mathrm{O}$ trabalho de Guy VINCENT, intitulado L'éducation prisonnière de la forme scolaire: scolarisation et socialisation dans les sociétés industrielles empresta de Merleau-Ponty e da teoria da Gestalt a noção de forma para adequá-la ao tema da escola, enquanto objeto e prática socialmente e históricamente instituídos. A inteligibilidade de uma dada forma estaria posta, assim, na adequação de seu funcionamento a regras arbitrárias e supra-pessoais. A escola, ao delimitar para seus estudantes e seus profissionais espaço e tempo definidos, ao estabelecer o escrito como o modo autorizado de travar relaçôes sociais, teria se organizado a si própria mediante normas homogêneas e constantes que podem ser reconhecidas como paradigmas dessa ordem escolarizada que modela as sociedades contemporâneas (G. VINCENT, op. cit., p. 30). No caso brasileiro, Marta Carvalho, trabalha também a ideia de fôrma em sua tese de doutorado intitulada Molde nacional e forma cívica: higiene, moral e trabalho no projeto da Associação Brasiliera de Educação (1924-1931). [tese de doutorado mimeografada]. São Paulo: Faculdade de Educação da USP, 1986. 
utilizado pela escola abarcava o aproveitamento feito pela própria Junta de Paróquia de uns casaróes que careciam de boas condições de luz e de ventilação, mas, em termos de sua área, era suficientemente amplo para atender ao número de alunos que regularmente comparecia às aulas.

O professor, José Pedro Barbosa, secular de 49 anos, embora considerado medíocre quanto à sua capacidade literária, revelava desejo de instruir e, portanto, possuía - de acordo com o parecer da inspeção - aptidão para o ensino. O método simultâneo era por ele utilizado apenas para exercícios de leitura, sendo individualizado o processo de aprendizado nas restantes matérias. Como castigo, ele punha os alunos em pé, mudava-os de lugar, aplicava-lhes palmatoadas. Valia-se da carta de sílabas, utilizava compêndios como o Methodo facillimo e o Manual enciclopédico, recorria ao Sistema Legal de Pesos e Medidas de Fradesso da Silveira e ao Cathecismo de Montpellier. O inspetor não pôde fazer qualquer apreciação comparativa com o ano letivo anterior, pelo fato de aquele professor encontrar-se na referida escola há apenas nove meses. Dos 32 alunos e 14 alunas matriculadas na escola, eram 24 os meninos e 7 as meninas que efetivamente compareciam às aulas de modo regular. Pela descrição oferecida no Relatório, não é negativa a apreciação efetuada dos méritos didáticos desse profissional do magistério público:

"Se este professor juntasse o saber à honradez, ao zelo e ao empenho que põe em cumprir as obrigaçôes do seu cargo, não acharia professor que o igualasse. À falta porém de quem o encaminhe e lhe dê conhecimento de melhores processos de ensino, faz com que não seja maior o fruto de seu trabalho: é pontualíssimo à hora da aula e antes de para ali ir dá uma volta pela aldeia levando diante de si os alunos, indo buscar outros à casa, chamando-os, pedindo aos pais que pelo menos dispensem os filhos por uma hora, enfim, faz tudo (...) para que a sua aula seja mui concorrida: admitiu, logo que tomou posse da cadeira, algumas meninas que tem na aula ao seu lado dirigidas em parte por uma sua filha de 16 anos; tem hoje matriculadas 14, número que tende a aumentar. Finalmente, o Prior, homem que merece toda a confiança, louvando o procedimento deste professor, afirma que se conhece uma grande diferença para melhor nos rapazes da aldeia desde a entrada do professor, mais tratáveis e mais civilizados." ${ }^{298}$

A atitude do professor perante seus alunos em sala de aula era percebida como fator determinante do sucesso escolar. $\mathrm{O}$ amor ou a rejeição que os estudantes sentiriam à vida escolar em muito dependeria - na suposição dos contemporâneos - do modo perante o qual o professor apresentava o lugar social daqueles conhecimentos expressos em classe. Pelo próprio encadeamento do relato, nota-se o quanto o estímulo do professor era apreendido com destacada sinalização do apego ao estudo por parte daqueles que, ao fim e ao cabo, na condição de discípulos, procurariam copiar seu entusiasmo, procurariam seguir seu exemplo:

"A frequência desta escola seria quase nula, como era antes da vinda deste professor, se não foram os esforços deste, nos quais só escapam os que pelos pais são levados ou mandados para

${ }^{298}$ MR 1072. Distrito: Évora. Concelho: Portel. Freguesia: São Julião. Escola primária mista com sede no Terreiro do Castelo na aldeia de Monte de Trigo. 
os campos. No dizer da gente da localidade, nunca a escola foi tão concorrida; por isto se vê quão difícil é levar o povo das aldeias a compreender que a instrução de um filho vale bem o sacrifício de um pequeno cômodo como (...) o de ir levar o almoço ou jantar ao pai, serviço que a mãe bem poderá fazer muitas vezes; de modo que o aparecerem na escola 16 ou 20 crianças tem, numa povoação como esta, de chamar-se boa frequência. $\mathrm{O}$ aproveitamento dos alunos atuais é pouco, mas sendo certo que há dez meses ainda nada sabiam, e atenta a maneira que o professor usa em seu ensino, necessariamente muito morosa, não pode dizer-se que é tão pouco como a respeito de outras já disse, mormente vendo que a diligência do professor faz esperar melhor futuro, embora não possa ir mais além do ler, escrever e contar."

Os resultados constatados da escolarização seriam, sobretudo, mudanças de atitudes, formação de hábitos de afabilidade e disciplina. Serão esses os indicadores de um professor bom? Diz o Relatório que a população não identificava os benefícios da instrução e que um bom professor como aquele acima descrito costumava buscar em casa as crianças que, se fossem à escola, apenas deixariam, por algumas horas, de 'servir' o espaço doméstico. A criança portuguesa era tida como um precoce trabalhador que, ao ser furtado pela escola, deixaria de cumprir um conjunto de obrigaçôes que a família lhe reservara. No parecer de Guy Vincent, a forma escolar esboçada entre os séculos XVI e XVII e efetivada pelo século XIX coincidiu com a redistribuição dos próprios espaços de poder dentro das sociedades européias de então, através da consolidação da vida urbana e da rearticulação entre os domínios civis e religiosos. Diríamos, por acréscimo, que essa forma de escola tem, ainda, a competência de readequar as funçôes educativas do tecido societário, cindindo e fraturando os espaços da vida familiar, para estruturar o papel social desempenhado por outras instituições pedagógicas, nomeadamente a escola. Vale recordar, a esse respeito, que os autores tendem a identificar o problema social da escolarização, antes de qualquer outra coisa, com a constituição de um modo específico de socialização (valorizado ou não pelos grupos dirigentes), no qual haveria todo um conjunto de regras e prescrições impessoais e anônimas que ditam lugares, espaços e condutas. Aprender as relações de mando e de subordinação era um dos efeitos desejados para a intitucionalização desse ritual de escola. Disciplinar os atores sociais ali envolvidos também fazia parte do currículo não manifesto da vida escolar. Mas, em Portugal, a escola da qual se projetava a fôrma, ainda não estava, em hipótese alguma, pronta...

\section{O método simultâneo como maestro da orquestra escolar}

Percebe-se pelos relatos que - a despeito da enorme variedade e dificuldades encontradas por aquele conjunto de escolas públicas portuguesas - havia algo em comum entre elas, ainda que fosse apenas a delimitação de um espaço próprio para o aprendizado, muitas vezes em mau estado, é verdade, um tempo específico para a duração das liçôes, um profissional dotado de uma dada competência e autorização para o exercício de um ofício (nem sempre a tempo inteiro), e a definição de um universo de saberes, ainda precários, mal estruturados e parcamente seriados, mas já postos como representantes de um fundo de cultura imprescindível à escola ou, por outras 
palavras, como conteúdos civilizatórios que a escola vinha paulatina e incessantemente elegendo como seus. ${ }^{299}$

\begin{abstract}
"Está a casa da escola situada a uma altura aproximadamente de 15 metros, sobranceira à rua principal e única da aldeia; para se entrar nela, trepa-se por um íngreme carreiro, tortuoso e escavado pelas águas do monte, a cuja meia encosta está a porta da escola voltada para o mesmo monte, de modo que o que estiver sentado na cadeira do professor em frente da porta verá os animais que descem do monte por aquele carreiro de baixo para cima e parecer-lhe-á que lhe vêm cair dentro da escola. A casa é úmida, mal reparada e em ocasião de copiosa chuva ameaçada de ser invadida pelas águas que do monte seguem aquele carreiro: - é todavia a única que o professor pôde arrendar e nem por um maior preço acharia outra. Utensílios escolares não há nenhuns, nem da aula, nem dos alunos, e a mobília (...) imprópria e insuficiente.”300
\end{abstract}

Assim o inspetor descreve a escola primária do sexo masculino que funcionava sediada na aldeia de Brottas no concelho de Mora - distrito de Évora. Como em outras ocasiôes, o inspetor analisa e julga aquilo que observa mediante a recorrência a um modelo prévio, pressuposto que o permite fazer apreciações sobre a adequação ou não de prédios, mobílias e instrumentos pedagógicos. Há uma idéia de escola que baliza esse julgamento. Essa idéia, ainda que possa não ter qualquer correspondência com níveis concretos de realidade, permite que se proceda a generalizações que tendem a encontrar um modelo já traçado para o formato escolar. Esse formato corresponde antes a uma projeção idealizada do que a uma realidade concretizada. A escola verdadeira era julgada, porém, a partir de suas faltas, carências e incompletudes perante aquela referência ideal uniforme e padronizada.

A escola de Brottas que vínhamos analisando tinha apenas dois bancos pertencentes à Paróquia, uma pequena mesa e três cadeiras pertencentes ao professor como conjunto completo da mobília disponível. O professor José Ferreira dos Santos, secular de 33 anos, tinha exame de instrução primária no Liceu de Leiria, além do diploma de professor. Embora tivesse seu bom comportamento moral e civil atestado pelo pároco da aldeia, "a sua capacidade literária é medíocre e a sua aptidão para o ensino é a de um professor que, privado de conhecimentos pedagógicos e de instrumentos de ensino, nem ao menos pode comunicar a seus discípulos o pouco que sabe." $301 \mathrm{O}$ inspetor critica neste professor especificamente a sua suposição de que do ensino da leitura dependeriam todas as demais matérias do currículo escolar. Os alunos, não sendo capazes de dominar a competência da leitura, não estariam aptos a estudar nada mais. Apenas um dos alunos dentre os onze que frequentavam regularmente a escola começava a "fazer ligaçôes". A cartilha adotada era o Methodo facillimo de Monteverde, mas o professor declarava valer-se também do Manual

${ }^{299}$ Indicamos a esse respeito o trabalho - A cultura escolar como objeto histórico - apresentado por Dominique Julia no XVo ISCHE, em Lisboa, no mês de Julho de 1993, a cujo manuscrito pudemos ter acesso através da Professora Dra. Marta Maria Chagas de Carvalho, da Faculdade de Educação da Universidade de São Paulo. A referida pesquisadora, por sua vez, já trabalhava a idéia da escola como uma forma/ fôrma de civismo e disciplina, em seu trabalho de doutorado defendido na FEUSP em 1986: Molde nacional e forma cívica.

${ }^{300}$ MR 1072. Distrito: Évora. Concelho: Mora. Freguesia: Nossa Senhora das Brottas.

${ }^{301}$ MR 1072. Distrito:Évora. Concelho: Mora. Freguesia: Nossa Senhora das Brottas. 
encyclopedico e do Cathecismo de Montpellier, embora não explicitasse qual uso fazia de cada uma dessas obras didáticas.

Os castigos que o docente diz aplicar são "repreensões, estar de pé numa cadeira, retenção da aula depois de os companheiros saírem, palmatoadas nos casos extremos". O aproveitamento daqueles onze alunos, dentre um total de dezenove matriculados, era absolutamente precário - como já pudemos observar - e o inspetor atribui isso às famílias, que eram negligentes e, sob hipótese alguma, contribuíam para o sucesso dessa ainda incipiente escolarização. Tendo boa vontade e - nos termos do inspetor - "desejo de se tornar útil”, o referido professor afligia-se com as precaríssimas condições de trabalho a que se via submetido e que o impediam - dizia ele - de "dar provas de sua aptidão". O inspetor concorda e acrescenta:

"E, realmente, eu, que sou chamado para ser juiz deste professor, se me achara nas condições dele, não faria mais. Alunos que entram na escola à hora que as famílias os têm dispensado do seu serviço e que se apresentam pedindo ao professor da parte de suas mães que lhes tome a lição logo - que têm de ir prestar outros serviços, - que interrompem a frequência por meses inteiros, - que não têm um livro, uma ardósia, nem meios para os comprar ! Uma escola sem instrumento algum d'ensino! Qual seria o professor, por mais hábil que se imagine, capaz de fazer progredir a sua escola, sem meios de subsistência, e muito menos para acudir as necessidades do serviço escolar, e sem autoridade para se fazer respeitar pelas famílias, que na sua crassa ignorância também entendem poder regular o serviço escolar em harmonia com o doméstico?"

A escola não tinha evidentemente condições apropriadas em termos de luz, de ventilação e de higiene, improvisada que era em cima daquela encosta. Era muito difícil manter ali quaisquer condições pedagógicas: o chão era esburacado, o teto de telha encontrava-se em mau estado, a chaminé estava arruinada e as paredes também não prestavam. Se havia mesmo algum modelo escolar, essa escola era o antimodelo. Quanto aos aspectos concernentes à frequência escolar e ao aproveitamento dos alunos, o inspetor acrescenta o seguinte:

"Os frequentadores desta escola, não só agora, mas há muito, são crianças geralmente menores de 10 anos, que ainda não podem suportar os trabalhos do campo, mas que já são aptos para ir levar um ou mais animais a pasto, recolhê-los, chegá-los à água; e por isso, enquanto não satisfazem esta obrigação, não vão para a escola, ou não entram lá a hora alguma, ao mais leve pretexto. Chegados à idade de serem aproveitados no serviço da moenda, apanho de azeitona, são completamente retirados da escola. Daqui vem que o professor se vê na necessidade, para ter discípulos, de admitir crianças de 4 e 5 anos, cuja aplicação é impossível. O aproveitamento é quase nenhum, como se vê no mapa do resultado da inspeção. Poderia porém ser maior se, nas estações de primavera e verão, em vez de duas lições diárias, houvesse uma só das 11 da manhã às duas da tarde, hora em que se recolhem os animais à casa, de descanso para os guardadores; e, durante as estações do outono e inverno, haver uma lição à noite, para o que o Pároco e outros habitantes que me fizeram conhecer a conveniência desta mudança, se prontificariam a fornecer luz."

Se o relato é verdadeiro, a mesma população que não se esmerava por enviar seus filhos à escola reconhecia no discurso a necessidade de se valorizar uma instrução que 
fosse adequada aos horários da comunidade e às necessidades familiares. Para tanto, pais e pároco até "forneceriam luz".

Quem era, no parecer da inspeção, o professor bem sucedido, o professor habilidoso, o professor apto para seu ofício? Nem sempre era o que mais ensinava, mas era sem dúvida o que revelava melhor conhecimento de compêndios e de métodos de ensino, era aquele reconhecidamente diligente no trato e cioso da disciplina de seu grupo-classe. Era enfim aquele que revelava domínio dos instrumentos e dos procedimentos necessários para reger a orquestra da escolarização. Era, enfim, o que se fazia capaz de ensinar pelo método simultâneo.

Consta do Relatório sobre a escola primária do sexo masculino no rocio de São Francisco, que fica situado na Freguesia de São Salvador de Alcaçovas no concelho de Vianna do Além-Tejo, também pertencente ao distrito de Évora:

\begin{abstract}
"A casa em que funciona a escola era antigamente uma capela; está, como disse, em muito boas condições; - pena é porém que não tenha mais capacidade, já para os alunos que a frequentam, já também para maior número, porque decerto essa escola há de ser necessariamente muito frequentada, quando a povoação conhecer bem e apreciar o benefício da instrução que lhe está ministrando o atual professor. A mobília é boa e muito apropriada; tem alguns utensílios escolares - tabelas para exercícios de leitura e aritmética - dois mapas de Portugal de Bittencourt - mapa-mundi - quadro preto e exemplares de desenho - quadro de pesos e medidas - tudo muito bem conservado e com muita limpeza." 302
\end{abstract}

Tratava-se da classe do professor Aurélio Augusto d'Aguilar, secular de 27 anos, que possuía apenas seu diploma de professor aprovado na Escola Normal. Trabalhava há cinco anos no magistério público e revelava boa capacidade literária e aptidão para o ensino. A escola era alugada e o edifício pertencia à Ordem de São Francisco, pertencente à Junta de Paróquia. Foi a Câmara quem ministrou a mobília e os utensílios escolares. Além disso, a Câmara havia também fornecido compêndios, de modo a possibilitar que todos os alunos deles se servissem durante a aula. A Junta de Paróquia colaborava também com a escola, oferecendo-lhe papel, penas e tintas. Matriculados na escola no ano letivo anterior (1873-4), havia 51 alunos dos quais 25 tiveram frequência regular. Desses, entretanto, nenhum foi considerado "pronto no fim do ano", "aprovado em exame final na própria escola" ou "aprovado em exame de admissão perante algum liceu".

O professor teria pedido que se declarasse no mapa relativo ao movimento escolar do ano imediatamente anterior que, "de todos os alunos a que se referem estes números, apenas dois soletravam, quando tomou conta da escola em 5 de agosto de 1873, - os demais eram analfabetos.” Aqui, onde os compêndios eram gratuitamente oferecidos aos estudantes, curiosamente não há nem sinal de obras de Monteverde. Foram arrolados naquela escola os seguintes livros: "as primeiras leituras pelas tabelas de Ramos Paz, conjuntamente com a Cartilha Nacional de Caldas Aulete, Simão de Nântua, Bíblia da Mocidade, Quadros históricos de Siveira da Motta, Caligraphia de Bittencourt, História

${ }^{302}$ MR 1072. Distrito: Évora. Concelho: Vianna do Além-Tejo. Freguesia: São Salvador das Alcaçovas. Escola primária do sexo masculino com sede no rocio de São Francisco nas Alcaçovas. 
de Portugal é ensinada pelos programas feitos pelo professor, Cathecismo de doutrina cristã, Desenho por Motta e Guira."

Além de castigos (privação de recreio, de joelhos, repreensões), o professor costumava recompensar com "alguns livros, estampas e outros objetos próprios para o ensino”. No parecer do inspetor, um professor como aquele honraria a Escola Normal, tanto pela inteligência, quanto por sua dedicação e capacidade para levar a peito o ofício do magistério.

"Considero-o o primeiro professor do Círculo Escolar que me foi incumbido. O serviço escolar é feito segundo os preceitos dos melhores pedagogistas (...); os alunos estão divididos em classes e estas em grupos; o ensino da leitura, escrita e aritmética é dado a todos os alunos; o de gramática prática só três (pela sua pouca idade) o não recebem; o da história começa pela constituição da família; o da geografia pelo conhecimento da sua localidade; enfim, todo ensino é racional e metódico."

Esse processo orientado por critérios racionais e metódicos era reconhecidamente bem sucedido. Havia um enorme respeito da comunidade local pela capacidade e pela dedicação daquele professor, de acordo com depoimento que havia sido prestado ao inspetor pelas "pessoas principais daquela vila". No ano de 1874-5, efetivamente, dos 37 alunos matriculados, 30 frequentariam habitualmente a escola. Pelas informações fornecidas ao inspetor por um "cavalheiro respeitável” da região, "que visita amiudadas vezes a escola” - José Augusto d'Azevedo Fragoso -, quando o professor tomara posse da cadeira, os alunos eram de fato analfabetos. O aproveitamento dos alunos vinha consideravelmente progredindo e poderia se tornar cada vez maior, se não houvesse a época da azeitona que retirava todas aquelas crianças da vida escolar. Mesmo assim, quanto ao mérito, aqueles estudantes não eram dos piores, posto que, entre os oito alunos inspecionados, apenas um era medíocre em leitura, sendo um considerado satisfatório e todos os outros seis, bons. Em escrita, os oito foram tidos por satisfatórios; mas em aritmética havia já três medíocres, sendo que em Doutrina Cristã eram todos bons.

Pelo exposto acima, verifica-se que o bom professor era aquele que se fazia capaz de selecionar conhecimentos e seriar seus alunos por níveis distintos de aprendizagem. Por tais procedimentos e critérios analíticos, a pouco e pouco, acompanhamos o universo valorativo que balizava aquelas considerações de ordem pedagógica. A escola que se desejava era substancialmente a escola capaz de sistematizar e transmitir o rol dos conhecimentos eleitos, aprovados e escolarizados. Outrossim, a escola desejada era também a escola capaz de produzir um determinado conjunto de comportamentos, hábitos, atitudes e crenças, diluídos e imbricados pelo feito de uma bem-dirigida socialização. A escola portuguesa do século XIX, se possuía já alguma uniformidade e homogeneidade, ao apresentar eixos de conteúdos comuns, nada tinha de impessoal, nem de anônimo. ${ }^{303}$ Disciplinar e normatizar suas práticas significava inclusive recorrer ao parecer da comunidade que a circundava.

\footnotetext{
${ }^{303}$ A institucionalização da escola, no parecer de Guy VINCENT, envolveria esse aspecto de obediência irrestrita a regras supra-pessoais que regulariam o movimento dos atores e normatizariam as próprias redes de relações de poder. A adesão e a obediência estruturariam coletivamente um sistema simbólico codificado, no qual a própria intervenção do professor, justamente para ser perfeita, deve ser a menor possível; substituída, como no mo-
} 
Com base nas informações obtidas da vizinhança é que, como exemplo de uma prática então corriqueira, o inspetor da escola sediada na freguesia de Tórgueda com sede em Mouçós, no concelho e no distrito de Villa Real, profere seu julgamento sobre o professor: "o professor tem a instrução suficiente para bem exercer o magistério e, segundo me informaram, é assíduo e zeloso no ensino de seus alunos. Tem requisitado da Junta de Paróquia, por várias vezes, os utensílios necessários, mas debalde a resposta é sempre a seguinte: vá fazendo como os seus antecessores." 304

$\mathrm{O}$ inspetor considera aqui que o pais seriam os verdadeiros e maiores responsáveis pelo parco aproveitamento dos alunos, "porque dizem que lhes são precisos para a lavoura”. Além disso, o fato de os alunos serem profundamente carentes e não apresentarem nenhuma condição para adquirir compêndios também contribuiria para os maus resultados que o inspetor dizia verificar. $\mathrm{Na}$ verdade, consta que, em todo aquele distrito de Villa Real, as escolas quase em sua totalidade careceriam de mobílias, de utensílios e de materiais pedagógicos apropriados. A frequência, pelo que se pôde constatar desse registro, era extremamente baixa. No tocante aos métodos, não havia clareza e precisão quando o Relatório da inspeção qualificava de analítico ou de sintético este ou aquele procedimento da alfabetização. De qualquer modo, quando se põe a discorrer sobre o método, é porque o inspetor pareceu confiar na rotina descrita e observada na escola e no professor. É isso que ocorrerá com aquele mesmo inspetor quando chega à escola primária para meninos com sede em Fonteitas, na freguesia d'Andraes.

Dirigida por António Alves Ferreira, um secular de 33 anos, a referida escola funcionaria em um edifício que fôra comprado pelos próprios habitantes daquela povoação e dos povos circunvizinhos. O professor era vitalício naquele cargo, ocupando a mesma cadeira há sete anos. Acerca do método adotado na escola, o inspetor entusiasma-se: "modo simultâneo e mútuo; na leitura, a soletração moderna; na escrita, a imitação de exemplares e, para mais, o método sintético e analítico." 305 Os alunos matriculados naquela escola eram mais de cem, sendo a frequência regular de cinquenta ou sessenta, havendo, inclusive, alguns, dentre esses, bastante adiantados - de acordo com o Relatório da inspeção. Os outros costumavam empregar-se na cultura dos campos durante períodos bastante extensos da primavera, do verão e do outono; o que comprometeria o bom resultado na escola. De qualquer modo, a apreciação do inspetor favorece o docente: "o professor é dos melhores deste distrito pelo zelo que emprega no ensino dos alunos, tendo ministrado tinta, papel e abecedários

\footnotetext{
delo lassaliano, por um conjunto de mecanismos objetivados, regulamentados, codificados e, no funcionamento da vida escolar, imediatamente identificáveis, na rotina fixa e uniforme que se apresentaria de modo invariável. Essa escola - como recorda Vincent -, congelando contextos de significados, cria outros eixos para conferir-lhes sentidos; sentidos fixos, impessoais, quase anônimos (Guy VINCENT , L'éducation prisonnière de la forme scolaire..., p. 33). A idéia era, até onde isso fosse possível, despersonalizar as relações sociais, constituindo redes disciplinares que se mostrassem capazes de gerir as próprias práticas. Limita-se a polissemia e procura-se transmutar os valores e as regras em uma segunda natureza, em uma auto-imposição de valores e de códigos completamente interiorizados. A regra, portanto, deixaria de ser pensada como uma imposição exterior, para se tornar uma auto-disciplina, um auto-governo, uma verdadeira apropriação simbólica do registro recomendado pela sociedade.

${ }^{304}$ MR 1086. (livro do Ministério do Reino) Inspecção das escolas públicas e particulares do distrito de Villa Real. Concelho: Villa Real. Escola da freguesia de Tórgueda com sede em Mouçós.

${ }^{305}$ MR 1086. Distrito: Villa Real. Concelho: Villa Real. Freguesia: Andraes. Escola primária masculina mantida pelo estado com sede em Fonteitas.
} 
de Monteverde aos mais pobres; e é um dos que tem dado discípulos habilitados para o exame de admissão nos liceus". ${ }^{306}$

Existiam casos, no entanto, em que os pais, tinham bastante influência sobre o processo de escolarização de seus filhos. E preferiam ministrar em casa os ensinamentos necessários a uma pronta instrução primária, poupando-os dos "caminhos escabrosos" que conduziam as crianças até a escola. Era isso que alegavam os membros da Junta de Paróquia e os pais dos meninos de Cortinhas, na freguesia de Fragoso, do concelho de Barcelos - em Braga. Aquela era, aliás, uma escola que não possuía sequer espaço definido e separado, posto que - dirigida por um pároco em tempos de secularização - confundia-se com o próprio recinto reservado à paróquia. Em termos de seus atributos, o lugar não tinha realmente nada que pudesse ser qualificado de convidativo, sendo, então, compreensível, aos olhos do inspetor, aquela radical opção dos pais, que, sabendo ler, preferiam eles mesmos ensinar em casa seus filhos:

"É tudo péssimo. A casa é um perfeito pardieiro. Muito velha e acanhadíssima, custa a crer até que um sacerdote viva em semelhante possilga. A sala destinada aos exercícios escolares, que é ainda assim, a melhor parte do casebre, tem apenas uma janela por onde entra a custo uma luz escassa e nem vidraça tem para resguardo do vento e da chuva. A mobília compõe-se de alguns bancos muito toscos e de umas caixas (...) que servem de mesas. Numa palavra: tudo ali respira miséria. Observando ao professor a necessidade que havia de se remover dali a escola, respondeu-me que muito breve ia proceder a obras na casa e que esperava que esta ficaria em boas condiçôes." 307

Tal escola estava sob os cuidados do padre José Martins da Cruz, de 32 anos, que valorizava o ensino prático da aritmética, nomeadamente do sistema métrico. Considerando que o referido professor tinha o curso do liceu e o do seminário, o inspetor destaca que, embora demonstrasse aptidão, destreza e habilidades didáticas, ele efetivamente poderia fazer melhor uso de seus conhecimentos,

“... habilitando os alunos em Gramática, História Pátria e no Desenho Linear, de que estes não têm as mais leves noções. São raros, é verdade, os professores que se dedicam ao ensino daquelas disciplinas; mas o que é verdade também é que, se uns as não ensinam porque não sabem, e outros porque não lhes sobra o tempo, quando a escola é frequentada por grande número de alunos, o professor Fragoso sabe e os seus discípulos não são tantos que lhe não chegue o tempo para os prelecionar nas referidas matérias." 308

Questionava-se sobre o ofício docente, as dificuldades e limitações alegadas e sua correspondência ou não para com a realidade. O que se esperava do professor era a

${ }^{306}$ Id. Ibid.

${ }^{307}$ MR 1067. (livro do Ministério do Reino) Inspecção das escolas públicas e particulares do distrito de Braga (círculos 3 a 5). Quesitos aos inspetores - 1875. Concelho: Barcellos. Freguesia: Fragoso. Escola primária do sexo masculino mantida pelo estado no lugar de Cortinhas.

${ }^{308}$ MR 1067. Distrito: Braga. Concelho: Barcellos. Freguesia : Fragoso. Escola primária do sexo masculino mantida pelo Estado no lugar de Cortinhas. 
"ação sensata", a "mediatez" entre os obstáculos e o potencial tomado como inerente ao seu ofício. ${ }^{309}$ Aquele que sabia mais, por que razão não renderia mais que seus colegas em pior situação? $O$ recurso à prudência, o discernimento, a ponderação, o equilíbrio, a serenidade e a sensatez eram efetivamente atributos desejados para o êxito na ainda inextrincável ação docente. Deslindar a emaranhada teia da função social atribuída à escola significa reconhecer a diferença entre um e outro professor, uma e outra escola, verificar - na distância das tipologias - o que se pode esperar neste e naquele. De algum modo, os Relatórios de inspeção favoreciam tal empreendimento.

\section{Ler e escrever ao mesmo tempo, todos juntos}

Em Lisboa, existia no Bairro Oriental uma escola pertencente à Freguesia de São Thiago e Santa Cruz do Castelo, mas que havia obtido autorização para funcionar na Sé, onde então se encontrava. O edifício, cujo proprietário era Augusto Saraiva de Carvalho, era alugado anualmente por $60 \$ 000$ réis, pagos pelo próprio professor. Este, por sua vez, habitaria o edifício da escola e o mobiliário todo pertencia a ele: eram 3 mesas, 12 bancos, 1 quadro preto, 2 mapas de Portugal, 1 mapa das Ilhas, quadro de sistema métrico, pesos e medidas. O material dos alunos era, em geral, comprado por eles mesmos, sendo que o professor se encarregava de fornecer-lhes tinta; dava também, a alguns, papel e penas e não recebia do Estado qualquer ajuda de custo para tais despesas.

António Francisco Moreira de Sá, o professor, era casado e tinha 49 anos de idade por ocasião daquela visita da inspeção. Não se encontrando à época em bom estado de saúde, requerera sua aposentadoria por incapacidade física. Por habilitaçôes literárias, consta que teria apenas o exame de instrução primária e o curso de comércio. Era já vitalício no cargo que ocupava, exercendo a profissão de professor há 26 anos e nove meses, com bom comportamento moral e civil e regular capacidade literária, de acordo com o julgamento daquele inspetor. Recebia um ordenado de 150\$000; tendo ainda gratificaçōes por volta de $40 \$ 000$. Era considerado "escritor público", por ser autor de inúmeros compêndios elementares para uso das escolas primárias; e isso o singularizaria no quadro do magistério. O professor Moreira de Sá dava aulas todos os dias, com duas liçôes diurnas - a primeira das 8 horas às $11 \mathrm{hrs}$. e a segunda das 2 hrs. às 5 hrs. Estruturando seus horários de modo a aproveitar ao máximo o tempo de que dispunha, dividia-o em períodos fixos dispostos para as várias matérias. Além disso, classificava seus alunos em grupos de adiantamento, de modo a conduzi-los a melhor aproveitar a distribuição dos conteúdos em função de níveis seriados de aprendizagem. No tocante aos métodos por este professor empregados,

\footnotetext{
${ }^{309}$ As idéias de ação sensata e de mediatez tomamo-as emprestadas a Daniel HAMELINE, para quem "tudo se passa no entre". A legimidade do sensato estaria portanto posta no terreno do consensual, na mediatez entre as referências e as realidades. Diz o autor que "é por isso que a entrada na pedagogia pelos objetivos conserva um caráter prometedor, ainda que paradoxal. Formular objetivos em termos de resultados esperados acentua a mediatez da ação a empreender e a compreender. O previsto passa precisamente mesmo no meio, apelando a uma negociação e a uma prestação de contas, de modo que a formação se mantenha à justa distância dos desvios assinalados (Daniel HAMELINE, O educador e a ação sensata. In: António NÓVOA - org., Profissão professor, p. 54) .”
} 
consta do Relatório: "para a leitura, a soletração antiga. Para a escrita, ensina riscos e pontos, depois curvas e letras, e por fim, faz cópias exemplares. Para as outras disciplinas passa liçóes que faz decorar pelos alunos, e faz explicações reunindo em classe os que têm o mesmo adiantamento." 310

No tocante aos compêndios didáticos, Moreira de Sá utilizava os que ele próprio havia escrito para as matérias de catecismo, geografia e sistema métrico. Lembre-se que esse último, pelos dados que pudemos obter a partir do trabalho estatístico com os Relatórios da inspeção de 1867 e 1875, era bastante utilizado nas escolas portuguesas. Mas o professor não se valia apenas de seus próprios manuais. Pelo contrário: recorria também às Cartas do $A B C$, ao Método facílimo de Monteverde, aos Quadros históricos, à Gramática de Vieira, ao Desenho de Motta e Guira. Tendo em condições regulares os seus registros de matrículas e aproveitamento dos alunos, o docente era considerado zeloso e criterioso quanto à obtenção da disciplina em classe, sendo também cioso da limpeza necessária à sala de aula. Em relação às medidas tomadas no tocante aos castigos, o Relatório de 1875 diz que naquela escola especificamente eram usadas "admoestaçóes, palmatoadas poucas vezes, o que se chama perdóes." Na altura da inspeção, a escola estava para ser fechada ou até suprimida. Do parecer do inspetor, consta o seguinte a propósito disso: "convém que se mantenha num outro ponto porque onde estava tinha muito vizinhas as aulas dos professores Rusell e Sabino Pires, e mais para o lado do Castelo é muito necessária." No dia a seguir à referida inspeção, o professor jubilou-se.

A respeito dos alunos, dos 61 matriculados no ano letivo de 1874-5 na escola diurna, 32 frequentavam regularmente as aulas, sendo que, em relação ao tempo de frequência, seu aproveitamento era considerado regular. É fato curioso que os escolares inspecionados hajam todos sido considerados bons em doutrina cristã, tendo também uma média geralmente satisfatória nas demais matérias: leitura, escrita, aritmética, sistema métrico, gramática, corografia, história pátria e desenho. Note-se que os alunos inspecionados foram apenas seis, com idades variadas de 5, 7, 9, 10 (dois alunos) e 12 anos. Os outros estudantes não haviam ido às aulas quando do comparecimento do inspetor.

Era comum os professores encarregarem-se de fornecer material escolar a seus alunos quando estes não apresentavam condições de comprar os utensílios necessários à aula. Moreira de Sá efetivamente parecia, pelo relato da inspeção, um profissional bem-sucedido, capaz e hábil na adequação do método e da utilização de variados recursos para aprendizagem de seus alunos. Isso não foi, entretanto, suficiente para manter o funcionamento de sua escola, que, como vimos, teria sido em breve suprimida. Cabe lembrar que, em Lisboa, em que pese a concentração de escolas públicas em sítios mais centrais, havia, nessa ocasião, carência de uma rede efetivamente estatal de escolarização, o que levava a proliferarem as iniciativas privadas, de escolas mantidas por congregações religiosas e mesmo por particulares, embora na investigação que fizemos não tenhamos priorizado a averiguação de tais instituições.

A escola a que temos nos referido é, pois, fundamentalmente a escola pública, que recebe, enquanto tal, financiamento da esfera do Estado para desenvolver o ofício da instrução. A sala de aula da escola portuguesa conformava-se, em determinado sentido,

${ }^{310}$ MR 1074 (livro do Ministério do Reino) Quesitos aos inspectores das escolas primárias públicas e particulares do distrito de Lisboa (círculo 1 a 3) - 1875. Bairro Oriental. Freguesia: São Thiago e Santa Cruz do Castelo. 
como uma branda procura por um modo escolar uniforme, já sob o exemplo dos mais 'civilizados' países europeus. Interiorizar regras era, para a vida do educando, incorporá-las, conformando, a partir do uso automático das mesmas, uma segunda natureza, mais contida, mais normalizada, mais homogênea, mais cordata, mais obediente e conformada a aceitar a realidade social e suas implicaçôes econômico-políticas como se de algo imutável se tratasse. O trabalho escolar lidaria, nessa medida, com representaçôes, expectativas, ambições e inconfomismo, de maneira a transmutar tudo isso em padrôes e eixos de conduta adequados e aceites, perante visões de mundo tipificadas e moralizadoras. Pode-se dizer que o trabalho da escola tinha como objetivo primeiro a disposição para a incorporação de regras. O poder da escolarização era, nessa medida, antes volitivo do que cognitivo, ou mesmo valorativo. O ler, escrever e contar representavam, enquanto símbolo da cultura especificamente escolar, o caminho para chegar a isso. Havia, portanto, quem acreditasse que daí a escola não deveria passar...

\begin{abstract}
"É, quanto é possível, bom o serviço escolar desta aula, mas a professora tornar-se-á dentro em pouco numa máquina de ensinar a ler, escrever e contar, perdendo toda a instrução pedagógica que teve em sua frente, se continuar no isolamento em que se acha: a rotina tomará seu domínio e o zelo esfriará. Ouvida, mas não atendida pelas autoridades locais, a quem dirige suas reclamaçōes, vai tornando-se quase indiferente aos processos de sua escola e, impossibilitada de poder ministrar o ensino a toda uma classe, desceu já há muito tempo para o modo individual e, tomando-lhe este muito tempo, falta-lhe para o ensino de outras disciplinas. Além disto, suas alunas, pertencendo à classe menos favorecida, apresentam-se-lhes na escola logo com a recomendação expressa de não se lhe ensinar mais do que ler, escrever e contar; e assim está a professora debaixo da direção de gente analfabeta sem conhecimento algum do que precisa nem do que deve à sociedade, só, sem apoio nem consideração!"311
\end{abstract}

A professora dessa referida escola, situada no Rocio da Villa na freguesia do Calvário do concelho de Montemor-o-Novo, era Maria Leopoldina Lamego, de 25 anos, portadora do curso de $1^{\circ}$ Grau da Escola Normal. Vitalícia no cargo, ela exercia há 5 anos o magistério público. Irrepreensível em sua conduta moral - segundo o inspetor - "no dizer de todas as pessoas que a conhecem", teria regular capacidade literária associada a boa aptidão para o ensino.

O edifício da escola era alugado pela Câmara a um particular e, em termos de conservação, estava bastante arruinado. Embora houvesse, no próprio espaço escolar, casa para habitação do professor, esta se encontrava em estado inabitável e a professora moraria em outro lugar, na companhia de sua mãe e de um tio. O edifício da escola estava em tão mau estado que o inspetor chega a dizer que nenhum particular desejaria arrendá-lo e que a Câmara o arrendara à escola talvez exclusivamente para beneficiar o senhorio. Próxima de duas tabernas e de uma cavalaria, a escola estaria, ainda, em local impróprio. Para evidenciar isso, dizia o inspetor: "para se ter luz é mister abrir duas janelas que não têm vidraças, e, quando houver mau tempo, que tenha de fechar as janelas, fica sem luz e sem ar.” A mobília e os utensílios escolares

${ }^{311}$ MR 1072. Distrito:Évora. Concelho: Montemor-o-Novo. Freguesia: Calvário. Escola primária do sexo feminino com sede no Rocio da Villa. 
consistiam em duas mesas, nas quais - segundo o inspetor - poderiam escrever 16 alunas, mais quatro bancos sem costas. Além disso, havia um quadro-negro fornecido pela Câmara e "um contador mecânico aplicado ao ensino da Aritmética e sistema métrico da invenção de D. Allexandre e dado por este à professora."

As alunas todos os meses ofereceriam uma dada quantia em dinheiro à professora para compra de tinta. As penas e o papel, traziam-nos de casa. Faltando a essa escola todas as condições necessárias ao bom ensino, a frequência das 34 alunas regulares (das 56 matriculadas) até que era boa, com exceção da época dos serviços rurais, como a vindima e a azeitona...

“(...) de modo que as alunas assaz assíduas nas outras épocas, naquelas faltam e perdem o que haviam aprendido. Isto acompanhado de todas as outras causas (...) em relação ao material da escola e ao abandono em que se acha faz o desespero da professora e lança-lhe no coração o desânimo e a perda da fé, que é o pior mal moral que aflige a nossa classe.”

Também em termos de aproveitamento, aquela escola não era das piores, pois, das oito meninas inspecionadas pela inspeção, havia sete que liam satisfatoriamente e uma era boa em leitura. Das mesmas oito, havia 3 suficientes em escrita e outras 5 que liam bem. Nenhuma das alunas inspecionadas foi julgada medíocre em Aritmética e em Doutrina Cristã. A aptidão da professora para o ensino estaria então posta em sua capacidade de superar as adversidades e de conseguir transmitir às suas crianças as necessárias habilidades da leitura e da escrita.

Haveria, por parte de muitos registros da inspeção, o reconhecimento tácito da inexistência do modo simultâneo ou da aplicação de um ensino centrado a partir da exposição do professor e do diálogo deste para com o conjunto de alunos, tal como isto era concebido pelos principais tratados teóricos da educação tradicional. Naquelas regiōes mais afastadas das zonas centrais, nas aldeias, havia enorme dificuldade quanto à efetivação da idéia de classe, enquanto nível de aprendizado graduado em séries. Muitas vezes, os exercícios eram ministrados como lição de casa e o trabalho do professor não ultrapassava o ofício da correção individualizada durante o tempo da aula. Há registros que atestam essa prática. Aliás, chegados a este ponto, é possível suspeitar que a pretensa uniformidade de ensino, os projetos de um primeiro degrau universalizante, capaz de homogeneizar a infância escolar, não passavam de um sonho de esperanças frustadas no caminho da escolarização portuguesa. Aquela escola, ainda que estivesse formalmente sob a tutela do Estado, não possuía qualquer clivagem de unificação ou mesmo normatização de práticas, de procedimentos didáticos e mesmo de espaço pedagógico. O espaço e o tempo da escola ainda não estavam, para angústia da inspeção, verdadeiramente regularizados:

"O edifício em que a escola funciona é o antigo paço do concelho que foi concedido à Junta de Paróquia; esta, destinando a maior casa para aula, arrendou o resto (...); de modo que frequentes vezes a rendeira atravessa a escola com diferentes objetos de uso doméstico, sem que lhe cause o mais pequeno embaraço a presença do professor e seus alunos, nem a do inspetor; - está em sua casa!... O soalho de madeira - carcomido e com largos buracos - oferece aos alunos (a par do perigo de meterem por eles os pés) a distração de espreitarem o que se passa lá embaixo e de deixar cair diferentes objetos para os buscar (...) pedem todos os dias repetidas 
licenças ao Sr. Professor. O teto, bastante arruinado, deixa passar a água de chuva em grande quantidade. A mobília, imprópria e insuficiente, apresenta o aspecto da decrepitude. Os utensílios escolares - propriedade do professor - consistem num pequeno mapa de Portugal e num quadro de pesos e medidas do novo sistema enrolado ao canto da casa." 312

O edifício dessa escola era cedido gratuitamente pela Junta de Paróquia da freguesia de São Paulo de Pávia, no concelho de Mora - Junta de Paróquia que também "deu uma mesa e dois bancos pequenos, alguns alunos levaram de sua casa cadeiras e assentos de cortiça. Os utensílios escolares - um mapa de Portugal e outro de pesos e medidas - são de propriedade do professor." Às custas do docente é que também a mobília vinha sendo reparada.

José do Carmo Pedroso, de 33 anos, era o professor. Não morava na escola porque obviamente o prédio não comportava condições satisfatórias para sua estadia. Considerado medíocre, pelo Relatório de Inspeção, em termos de sua capacidade literária, o professor empregava para o ensino o modo individual. Em termos de método - desabafa o inspetor:

“(...) nenhum que seja racional. É a forma de repetição em comum e em voz alta, cada aluno em sua liçāo, fazendo uma gritaria em que nem professor nem alunos se entendem. É assim que lêem, recitam doutrina, repetem as províncias de Portugal e a nomenclatura de pesos e medidas, chamados singularmente nada respondem. A isto chama o Professor - Método Castilho!"

O inspetor anota que, embora no ano letivo que então corria (1874-5), houvesse 23 alunos matriculados, nenhum deles frequentava regularmente a escola e as aulas - atribuindo a irregularidade da frequência às causas comuns a todas as escolas de terras pequenas acrescidas do fator primeiro que, nesse caso, seria a própria ignorância e inabilidade do professor. Dos oito alunos inspecionados, apenas um lia regularmente, sendo os outros 7 medíocres em leitura. Em escrita, a situação era equivalente, e o inspetor reputa o mestre-escola como grande responsável pelas dificuldades de seus discípulos.

"Custa crer que haja sido este professor aprovado na escola normal; e muito mais que se lhe tenha dado provimento vitalício. Incapaz de dirigir uma aula, sem ciência, nem método, nem autoridade, há 11 anos se conserva nessa povoação sem que, em tão largo espaço, se possa indicar um só moço sabendo ler, escrever e contar sob seu doutrinamento. Assim, ao apresentar-me à Junta de Paróquia e a alguns particulares a solicitar sua cooperação para o melhoramento da escola, todos se recusaram formalmente a dar qualquer subsídio, enquanto a escola for dirigida por tal professor. Não sei o que o governo fará, mas pela minha parte, asseguro que a conservação de homens tais no professorado é fomento da ignorância. Não deixa ao menos esperanças de melhorar um pouco com as reflexões e advertência que lhe fiz; pareceu-me até que não percebia."

Sem vocação, o professor é inclusive responsabilizado pelo abandono dos alunos; em todos os sentidos...

${ }^{312}$ MR 1072. Distrito: Évora. Concelho: Mora. Freguesia: São Paulo de Pávia. Escola primária do sexo masculino com sede na Praça de Pávia. 
"Esta escola é mui pouco frequentada e por alunos de tenra idade - alguns de 4 anos e os maiores de 10 - ; faltam pelo menos à metade das lições em cada mês e a essas que assistem, é com tão pouca atenção e tão pouco interesse, que nenhum proveito delas podem tirar. Avalio o que será nos dias ordinários, quando, apesar da minha presença, baldados foram os esforços do professor para os conter em sossego no dia da inspeção."

Percebemos pelos relatos que a disciplina era uma tentativa e que a própria escolarização não passava, em alguns casos, de esforço mal-sucedido, posto que as populações praticamente nada esperavam do aprendizado escolar e os alunos não revelavam qualquer tipo de apego por uma escola de recitação de catecismos. Para professores e inspetores, a vida escolar era, antes de qualquer coisa, o empenho para a descoberta do método. Aquela escola, com más condiçóes materiais e docentes despreparados, não se fazia capaz de atingir sua missão de irradiar as habilidades da leitura, da escrita e do cálculo. Com práticas arcaicas de mal conduzida devoção, o processo de secularização da sociedade portuguesa incorporaria indubitavelmente um veio bastante acentuado de ensino religioso, que, acoplado ao estudo da corografia portuguesa, no âmbito da escola, se traduziria no reforço de processos áridos de memorização desacompanhada. Aliás, mesmo quando a Doutrina Cristã não era efetivamente a tônica do processo de ensino, era pelo método catequético que, cambaleante, era regida a vida escolar.

Através do mapa da inspeção de 21 de Maio de 1875, dos 8 alunos inspecionados na escola primária masculina com sede no Largo da Igreja na alta de Vera Cruz, no concelho de Portel - também em Évora -, obtemos os seguintes dados: em leitura, havia 4 alunos bons e outros 4 suficientes; em escrita, 2 suficientes e 6 medíocres; em Aritmética, 5 bons e 1 medíocre; em Doutrina Cristã, apenas 1 suficiente e todos os demais medíocres; em Aritmética, 5 bons e 1 medíocre. $\mathrm{O}$ inspetor anota, no canto de baixo, à direita de seu mapa, o seguinte:

"Declarou o professor ter alunos adiantados em todas as disciplinas, mas, no exame a que procedi não responderam uma palavra, e verifiquei então, como digo nas observaçôes e no Relatório, que os alunos estudavam Corografia e História, lendo-a no Manual enciplopédico. Não tinha pois outra qualificação que lhe dar senão a de zero." 313

Francisco Moraes Ramalho, secular de 50 anos de idade, é professor temporário, embora tenha já ultrapassado nove anos de serviço no magistério público. No parecer do inspetor, tem pouca aptidão e capacidade para o ensino. A casa de escola - mandada construir pela Câmara Municipal -, embora fosse suficientemente espaçosa para a frequência que naquela povoação poderia abrigar, apresentava problemas:

"Pena é que na construção não observassem as prescrições higiênicas; completamente isolada de todas as outras edificações, em sítio elevado, com duas janelas laterais e outra no fundo em frente da porta, nos dias de vento cruzam-se as correntes de ar, a ponto de terem de fechar

${ }^{313}$ MR 1072. Distrito: Évora. Concelho: Portel. Freguesia: Vera Cruz. Escola primária masculina com sede no Largo da Igreja na Alta de Vera Cruz. 
porta e janelas, que, sendo envidraçadas, têm todavia a maior parte dos vidros quebrada e alguma está até a um canto da aula completamente inutilizada; o quadro preto é o único utensílio escolar que ali há."

A mobília era composta por duas mesas e quatro cadeiras, além de bancos, onde se sentavam os alunos, sendo que esses bancos eram de propriedade do professor. Ministrando 3 horas de aulas pela manhã e mais 3 horas à tarde, o professor ministrava o ensino individualizado, dizendo-se adepto e partidário do "método rotineiro". Ensinando pela cartilha de Monteverde - o tão propagado Methodo facillimo -, a sua aula contava também com outros compêndios: Manual encyclopedico, Cartas de nomes, Sistema métrico de Barreiros, História de Portugal de Moreira de Sá, Corografia de Perdigão e Cathecismo de Montpellier. A disciplina dos 14 alunos que frequentemente iam à escola era mantida, o que reiterava as suspeitas do inspetor no sentido de acoplar o sucesso da organização escolar a uma bem regrada e disciplinada rotina. Mesmo assim - faz a ressalva o próprio inspetor - faltava ali método. E, sob todos os pontos de vista, o método deveria vir atrelado ao conhecimento pedagógico do professor. Sem quaisquer habilitações, faltariam, neste caso, as competências necessárias para o domínio dessa arquitetura do ensino simultâneo:

\begin{abstract}
"Se as informaçôes que me deram acerca deste professor forem verdadeiras, nenhuma censura merece quanto à assiduidade no serviço escolar, mas é certo que são tão acanhados seus conhecimentos que, por muito tempo que trabalhe, pouco conseguirá. Desconhece o professor, não faz mesmo idéia de que haja modos de ensino mais prontos e mais profícuos do que o individual; imagina que a gramática, a história, a corografia, se aprendem pela simples leitura de compêndios, que a escrita e a aritmética só se devem ensinar quando o aluno tem adquirido um certo grau de desenvolvimento. A ortografia é completamente ignorada pelo professor."
\end{abstract}

Quando comenta do aproveitamento dos alunos, o inspetor observa que, embora não soubessem escrever, os alunos estavam aptos para leitura. Verificamos, pelo relato, a preocupação quanto àquele estilo, ainda imerso em práticas imemoriais, de ensinar a escrita muito depois do aprendizado do ato de ler, o que reduzia muito o próprio conjunto de leitores. A escola contentava-se, ao que parecia, ao ensino da representação escrita pela sua metade...

\footnotetext{
"A frequência é regular, como em todas as povoações rurais;- o aproveitamento dos alunos é pouco, já por esta causa, já também pela falta de saber do professor. Pareceu a este que em todas as disciplinas e em todas as classes devia dar alunos habilitados, ou porque julgou que perderia se os não desse, ou porque imaginou que não lhe seriam examinados. $\mathrm{O}$ aproveitamento em leitura e aritmética, se não fôra a idade dos alunos e o tempo de frequência, era muito em favor do professor, mas o das outras disciplinas, como verifiquei no exame, era completamente nulo na maior parte dos alunos; conheciam a história, a gramática, a corografia, somente pela leitura. O que sobretudo estranhei foi a grande ignorância dos alunos em Doutrina Cristã."
}

Havia uma escola de meninas na Rua do Balcão na Vila de Mora. Era uma escola diferente. Ali não havia palmatória. A professora julgava que castigos ditos "morais" 
poderiam ser mais eficazes para obtenção da disciplina coletiva. Por castigos morais entendiam-se práticas de constrangimento e de humilhação que revelassem, pela visibilidade, a culpa e o flagrante do delito cometido. Tratava-se, com tais penas, de conter e deter futuras transgressões, pelo exemplo; não mais o exemplo da violência física, mas o recurso à violência simbólica, considerada mais adequada porque mais eficaz. Às alunas infratoras das regras escolares, determinava-se "repreensão, isolamento, de pé, de joelhos", além da utilização de letreiros, onde se poderia ler: "teimosa; preguiçosa; desobediente" ${ }^{314}$

O edifício, pertencente a um particular, teria sido alugado pela Câmara para o funcionamento da casa de escola por um preço exorbitante, a ponto de ter essa renda provocado celeuma entre os habitantes daquela terra. A mobília compunha-se de uma mesa velha, cujo primeiro destino teria sido a sala de jantar, dois bancos e 36 cadeiras novas. Como utensílio didático, havia apenas o quadro-negro, que, aos olhos do inspetor, "parece ter sido uma tampa de caixote".

A professora - Dona Virgínia Adelaide d'Assunção Reis -, com 23 anos de idade e portadora de curso da Escola Normal, era temporária, estando há apenas 8 meses no exercício da carreira. Ministrando aulas pela manhã e à tarde, dividia suas seis horas diárias entre o que se entendia serem os lavores e os exercícios literários. A disciplina das 39 alunas que frequentavam regularmente a escola era mantida, mesmo sem o recurso a castigos corporais.

Embora utilizasse os compêndios de Monteverde (Methodo facillimo e Bíblia da infância), a mestra se dizia adepta do método Castilho e declarava adequar os modos de ensino às diferentes situaçôes colocadas em sala de aula. Utilizava, assim, o modo simultâneo para as classes mais adiantadas e o ensino mútuo para os principiantes, nas disciplinas de Leitura, Aritmética e Doutrina. Nas demais matérias, o modo de ensino era o individual. Para a prática da leitura, empregava também os princípios advindos da metodologia desenvolvida por Castilho. Para exercícios de escrita orientava os alunos a cobrirem letras por ela mesma preparadas, à lápis. No restante, declarava utilizar metodologia rotineira. Pelo repertório pedagógico que expunha, bem como pelo resultado demonstrado pela própria situação de seus alunos, a professora foi bem vista pelo olhar da inspeção; embora, das oito meninas inspecionadas, houvesse 4 que não liam...

\footnotetext{
"Nada pode dizer-se em relação a esta professora e desempenho de suas funções escolares que não seja em seu abono. Tomando há 8 meses conta de uma escola frequentada por 42 alunas, de que só 4 liam alguns nomes, muito para louvar é o adiantamento que tem tido em tão pouco tempo, embora as qualificações da inspeção não sejam as melhores: e, sem dúvida alguma, se pode assegurar que, se a professora tivesse à sua disposição utensílios e mobília própria de modo que pudesse empregar rigorosamente o modo misto, maior seria o adiantamento das alunas. Mas com uma só mesa, em que apenas podem escrever 6 alunas, com 7 ardósias, sem exemplares de escrita, sem tabelas de leitura, sem coisa alguma, enfim, que possa servir para o ensino intuitivo, muito tem feito a professora."
}

${ }^{314}$ MR 1072. Distrito: Évora. Concelho: Mora. Freguesia: Nossa Senhora Da Graça. Escola primária do sexo feminino com sede na rua do Balcão da Vila de Mora. 
O relato da prática de ensino dessa professora constitui exemplo de atuação bem recebida e procurada pela população. Uma escola que explicitamente ensinava a ler, a escrever e a contar; um ensino que combinava atividades e modelos didáticos variados com o propósito de aprimoramento da ação pedagógica. Uma escola, decerto, que intercalava o modo simultâneo com alguma atenção às individualidades. Uma escola, enfim, que se propunha a olhar para si mesma. O ensino era, subitamente, atraente; havia alegria, dinâmica e vivacidade na estrutura da aula.

Também sobre a dinâmica de dispositivos e recursos didáticos bem sucedidos notamos, pelo excerto abaixo transcrito - extraído do Relatório da inspeção à escola primária masculina situada em Portel -, que ser versado em metodologias de aprendizagem também era qualificação reputada essencial para definir o bom professor. Na Rua da Escola Régia, em Portel, o docente Manuel José Rodrigues (de 42 anos) - temporário no magistério público e lecionando há apenas 11 meses - era assim descrito pelo inspetor:

"É um professor inteligente, zeloso e cheio de boa vontade; bem educado, ainda que de gênio forte; se tivera tido algumas lições de Pedagogia e fôra ajudado de melhores meios de ensino seria um excelente professor; e pontual no cumprimento de suas obrigações, bem morigerado e sabendo fazer-se respeitar. Nos onze meses que rege esta aula (por testemunha de pessoas que bem conheciam o estado dos alunos que mal soletravam quando o professor tomou conta deles) tem colhido muito bons resultados; pela minha parte, afirmo que em nenhuma escola das que até hoje visitei ouvi ler com mais correção e melhor acento do que nesta. A escrita não está a par da leitura, e isso é seguramente devido à falta de bons exemplares. A aritmética e sistema métrico, se foram mais dirigidos pela prática, dariam melhores resultados; contudo todos os alunos fazem expeditamente as operações." 315

Este docente, como fica explícito pela avaliação da inspetoria, possui, em relação aos 71 alunos matriculados, 40 com frequência regular. Dos oito meninos inspecionados, todos particamente liam e escreviam com destreza. O aproveitamento dos alunos, considerando o pouco tempo em que estariam debaixo da liderança daquele professor, era tido por bastante satisfatório, embora houvesse, como era hábito, elevado índice de abandono da vida escolar em prol de serviços domésticos. Aqui, o segredo seria a adequação metodológica, pois, apesar de carecer da necessária preparação pedagógica, o professor procurava alfabetizar a partir de metodologia alternativa inovando a rotina tradicional, perante o recurso ao ensino fonético desenvolvido por Castilho. Ao que parece, fazia algum sucesso.

"A casa de escola era antigamente uma igreja ou capela, mais comprida do que larga, um pouco abaixo do nível da rua e recebendo luz tão somente por um dos lados, por duas janelas que, estando a boa altura para os de dentro, estão todavia tão baixas para os de fora, que são acessíveis a todos que passam, por pequena que seja sua estatura, do que resulta ser a aula muitas vezes perturbada, com grande desespero do professor, por alguns (...) que se divertem em distrair os alunos. A mobília, aliás, feita segundo os preceitos pedagógicos, foi todavia

${ }^{315}$ MR 1072 Distrito: Portel. Freguesia: Santa Maria da Alagoa - em Portel. Escola primária masculina com sede na rua da Escola Régia em Portel. 
tão economicamente construída, que, faltando-lhe a precisa solidez, em pouco tempo se tem estragado, carece de reparos e alguns bancos há que não podem deixar de ser substituídos por novos. O quadro preto é bom; o único utensílio pertencente à escola.Um mapa pequeno de Portugal que há na escola pertence ao professor."

Um bom professor; uma má escola. Esta parecia ser, no caso, a situação. O inspetor preocupa-se com a inexistência na povoação - como, de resto, em todas as demais vilas e aldeias do Alentejo - de alguém que promovesse a concorrência da população à escola. As exigências domésticas concorriam, em patamar desigual e, portanto, desleal, com as exigências da escola; e essa seria, talvez, a principal causa para que os alunos abandonassem a vida escolar antes de poderem ser qualificados como prontos no final do ano letivo, antes também de poderem prestar exames em liceus e na própria escola. Era a família quem, em última instância, forçava as crianças a abreviarem o tempo de escola para precocemente ingressarem no espaço do trabalho.

Outra escola que funcionava bem era a conhecida Escola do Conde do Ferreira, com sede no Largo do Sacramento de Nossa Senhora da Villa em Montemor-o-Novo. O nome da escola vinha do fato de o Conde Ferreira haver legado ao município a casa da escola. O edifício, aliás, estava já em mau estado de conservação, com reparações por serem feitas, particularmente de suas madeiras "expostas à ação do tempo". ${ }^{316}$ A casa prevista para habitação do professor ficou por acabar, estando, portanto, inabitável. A mobília estava em bom estado, sendo suficiente para os 60 alunos (dentre os 104 que haviam se matriculado no ano letivo de 1874-5) que frequentavam regularmente a escola. Utensílios, havia apenas 2 quadros-pretos.

"Quando esta cadeira foi posta a concurso, ofereceu a Câmara ao Professor que nela fosse provido
uma gratificação de $50 \$ 000$ em vez da de $30 \$ 000$ que por lei lhe devia dar, e a mais uma gratifi-
cação de $10 \$ 000$ por cada aluno a que apresentasse aprovado em exame de admissão ao concurso
dos liceus: este incentivo acabou porque o Ministério do Reino, quando o orçamento da Câ-
mara ali subiu à aprovação, foi cortada aquela verba, requereu o professor a restituição dela como
condição do seu concurso, mas não foi ainda atendido; entretanto, não tem deixado de mandar
a exame todos os anos alguns alunos - este ano tem só dois: os números 64 e 134 do mapa no3.
Em vista do que teve exposto nas respostas aos quesitos pode o governo avaliar de que vantagem
será no nosso país uma inspeção permanente às escolas, completamente desembaraçada de todas
as peias e atritos administrativos que não melhoram, ou antes agravam, o mal que há no nosso
professorado, e não sustentam nem incitam o que há de bom. O Professor atual tornar-se-ia um
bom professor se o não desgastassem com o abandono que o deixam, a ele e à sua escola."

Desde que foi aberta aquela aula, a Câmara - responsável pela reparação e conservação do mobiliário - não tomou sequer conhecimento da escola. Os alunos, que não recebiam nenhum tipo de material, todos os meses levavam ao professor 20r. ou 40r. para comprar a tinta. Penas e papel, eles traziam de casa. Teria havido no local uma Comissão Promotora do Ensino Primário - presidida por D. Alexandre -, mas, como declara o inspetor,

${ }^{316}$ MR 1072. Distrito: Évora. Concelho: Montemor-o-Novo. Freguesia: Nossa Senhora da Villa em Montemor. Escola masculina com sede no Largo do Sacramento / Escola do Conde Ferreira. . 
"funcionou pouco tempo: há mais de quatro anos que este cavalheiro deixou, por motivos que não posso anunciar, de ter o interesse que outrora mostrou pelo progresso da instrução dos seus concidadãos, e, desde esse tempo, não só cessaram as visitas à escola, mas deixaram de celebrar-se os exames escolares e de se distribuírem aos alunos os prêmios que a Câmara dava aos mais distintos."

No ano letivo anterior (1873-4), dos 85 alunos com frequência regular, 4 foram considerados prontos no fim do ano e aprovados em exames de admissão perante algum liceu. No ano letivo que então corria - 1874-5 - todos os alunos inspecionados foram considerados bons em leitura, pelo menos suficientes em escrita, sendo a quase metade deles medíocre em aritmética. O professor - Álvaro Teixeira de Carvalho -, de 25 anos de idade, tinha aprovação em exames de Português, Francês, Inglês e o curso de $1^{\circ}$ Grau da Escola Normal, sendo considerado pelo inspetor o mais apto dentre todos os que pudera observar, no que dizia respeito à sua capacidade literária. Para o inspetor, a marca decisiva para o êxito pedagógico e didático desse docente estaria posta em sua formação: "a Escola Normal é a principal causa do aproveitamento e regularidade da sua escola." O comportamento moral e civil do professor era também dos mais recomendáveis - dado que na comunidade era "benquisto e tido em consideração". Tinha já mais de 5 anos de experiência e era vitalício no magistério público.

"A frequência desta escola é proporcionalmente a mais regular que tenho encontrado, o que seguramente é devido à maneira por que o professor dirige os seus exercícios e ao bom tratamento que dá aos seus alunos; procuram estes por seus próprio impulso não faltarem a alguma das liçôes e quando seus serviços domésticos os inibem de assistir a uma diligenceiam sempre assistir a outra; - a variedade do trabalho em comum é também um bom meio de lhe não tornar enfadonha a estada na escola. O mapa no 2 mostra, o que em poucas aulas se encontra, o ensino da leitura - escrita e aritmética dado igualmente a toda a escola, e o mesmo aconteceria a todas as disciplinas se pudesse empregar o ensino intuitivo. Nestas três disciplinas o aproveitamento é muito regular."

Nota-se que, além da formação que tivera para o magistério, outros atributos contribuiriam para o sucesso deste mestre-escola. Sua aula era pautada pelo modo simultâneo de ensino que, como destaca o inspetor, não era ainda uma característica comum à maioria das escolas. $\mathrm{O}$ registro da inspeção fala acima em aprendizado da "leitura-escrita" e o faz de maneira proposital. Como veremos adiante, esse professor declararia utilizar do método legográfico, que, por sua vez, consistia na tentativa de Caldas Aulete relativamente ao ensino das habilidades da leitura e da escrita simultaneamente. Verificamos que, como já ficou caracterizado para o caso da escola feminina de Mora - descrita logo atrás -, outro fator determinante da prática exitosa no magistério era a variedade de atividades didáticas e de trabalho coletivo, o que a inspeção julgava determinante para cativar a atenção e o interesse dos alunos evitando, assim, o enfado em relação às liçôes da escola. A propósito, no que dizia respeito especificamente ao aprendizado dos alunos, o inspetor acrescenta:

“(...) em geral é regular. Além dos alunos que examinei, assisti à lição das duas classes, ou grupos em que estão divididos os principiantes, pelo método legográfico; palpei as vantagens 
dele e verifiquei nas classes mais adiantadas uma correção na pronunciação tanto mais louvável quão difícil é debelar nestas terras o vício pátrio de acrescentar um -e- a todas as palavras terminadas em -r-, e mudar o e final em ei ."

Apesar de ser grande o número de alunos que acorriam àquelas aulas, o professor mantinha a disciplina em classe sendo, ainda, por todas as informações que o inspetor diz ter podido obter, zeloso e assíduo em seu serviço. A instrução primária era extremamente concorrida desde sua chegada naquela localidade. Ministrando aulas divididas em três horas pela manhã mais três horas à tarde, o docente ensinava também o francês a alunos particulares, em seu tempo de intervalo. Como modo de ensino adotado, o inspetor tem dificuldade em precisar: "misto, simultâneo, mútuo" - diz, tentando não errar. O método adotado - como já pudemos anotar - era o legográfico, de Caldas Aulete. No parecer do inspetor, o professor só não fazia uso do método intuitivo "porque lhe faltam os meios de o empregar com resultado, pois que, como já disse, não tem a aula coisa que prenda a vista; que desperte a curiosidade tão natural na mocidade e que ponha a desenvolver-lhe a inteligência”.

Nessa escola, a Cartilha Nacional de Caldas Aulete era o compêndio mais utilizado, seguida pela Bíblia da Infância de Monteverde, as Leituras Populares de Brito Aranha, Logares Selectos de Cardoso, Quadros Históricos de Silveira da Motta, História de Portugal de Midosi, Moral-Cathecismo de João Felix Pereira, Corografia de Henrique Freire, Compêndio de Desenho de Theodoro da Motta. Embora não tivesse registros escritos ou anotaçôes muito regulares, o professor distribuía bem o seu tempo e - no parecer da inspeção - as matérias eram bem organizadas, divididas e classificadas por tempo, por horários das lições e por níveis de aprendizado dos alunos. Já se observava que a chave do sucesso passaria por aí. Além disso - outro dado interessante e que coincide com a também considerada boa professora das meninas na vila de Mora -, este docente não costumava aplicar qualquer tipo de castigos físicos sobre seus alunos. Deixava-os, antes, privados de irem a casa no intervalo das liçôes e ficavam também às vezes de joelhos no meio da sala; mas não apanhavam. Boa formação, modo simultâneo, ensino concomitante da leitura, da escrita e do cálculo, criatividade e variedade de situações e exercícios pedagógicos, organização do tempo e dos horários, classificação das matérias, abolição do castigo físico, substituição, talvez, do medo pela curiosidade; seria esse o segredo da vitória na instrução primária?

\section{O poder local dentro da escola e o trabalho infantil}

Ao pensarmos no projeto pombalino enquanto uma arquitetura sistematizada e harmoniosa de uma rede centralizada de escolas, supervisionadas e controladas pelo poder central, ao pensarmos na pedagogia pombalina como uma verdadeira geometria social do político, surpreendemo-nos ao nos depararmos com a crua e desordenada realidade daquele final de século XIX, quando a responsabilidade pela escolarização, na maior parte das vezes, sob o encargo das Câmaras e das Juntas de Paróquias, ficava circunscrita ao poder local, quando não era deixada exclusivamente em mãos da boa vontade e da generosidade do próprio professor. Que tipo de forma escolar era essa que se vinha criando? Havia sentido e unidade nisso? Estamos falando do século que, 
ao desejar refundar a nação, projetou a invenção de tradições pela via da escola nacional; mas estamos mesmo diante da acepção da escola única? Quem era, afinal, essa escola, que tanto carecia de um quadro de 'pesos e medidas'?

“(...) a Junta não tem cuidado da sua reparação, nem ao menos consertado os telhados, do que resulta penetrar-lhe em abundância a água da chuva; e além da frieza e umidade decorrente da inferioridade do solo em relação ao da rua, acresce a contínua passagem de toda espécie de veículo para a estação do caminho-de-ferro, de modo que os exercícios escolares não podem ser dirigidos com a devida quietação, já pela distração dos alunos, já pelo ruído inevitável. A mobília oferecida pela Junta é imprópria (...) Utensílios escolares limitam-se a um quadro-preto dado pelo professor, porque a Câmara de Montemor não lhe deu mais do que o cavalete. A um canto duma casa interior onde dormia o professor Castelo Branco achou-se um quadro do novo sistema de pesos e medidas coberto de pó e teias de aranha e sem réguas; roguei ao professor atual que que o mandasse por-lhe umas réguas e que salvasse um instrumento de ensino tão necessário e cuja falta eu lamentara em todas as escolas - um cidadão útil que m’ouvia encarregou-se de o mandar colocar na escola devidamente." ${ }^{17}$

O edifício da escola situada na freguesia de Santo António de Vendas Novas havia sido gratuitamente cedido pela Junta de Paróquia, mas faltavam-lhe todas as condições pedagógicas possíveis. Além de estar colocada exatamente na passagem para o caminho de ferro, a casa era fria e úmida; a mobília que compunha o espaço escolar era insuficiente, inadequada e estava, além de tudo, em péssimo estado. O professor responsável por aquela cadeira não era o que então estaria a regê-la, quando ocorre a visita da inspeção. Na verdade, o professor efetivo era João de Lemos Seixas Castello Branco, que se encontrava internado no hospital de Évora desde 25 de Janeiro daquele ano de 1875.

"Do professor Castello Branco, nada posso dizer porque na escola nada achei que pudesse dar-me os esclarecimentos necessários. É este um dos muitos casos que revelam bem a nossa organização das escolas: - o professor adoeceu gravemente, veio para o hospital de Évora e, ao passar por Montemor, disse verbalemente ou por escrito que deixava em Vendas Novas para o substituir a Dinis José dos Santos; o administrador deu-se por satisfeito, não participou ao Comissário de Estudos e não deu ao professor em exercício nomeação de interino, de modo que está servindo sem forma alguma legal, e se o Prof. Castello Branco lhe não deu alguma coisa, servirá de graça."

O professor então em exercício, Dinis José dos Santos, mostrava-se zeloso e - considerando o que ele mesmo dizia sobre o estado dos alunos anteriormente à sua chegada - muito havia feito, conseguindo significativo progresso com o adiantamento de seus estudantes. Ministrando seis horas diárias divididas nos períodos matutino e vespertino - como, aliás, era hábito, para as escolas primárias naquela época - ensinava também alguns adultos à noite, utilizando para essas liçōes suplementares a própria casa de escola.

${ }^{317}$ MR 1072. Distrito: Évora. Concelho: Montemor-o-Novo. Freguesia: Santo António de Vendas Novas. Escola primária do sexo masculino no Rossio de Vendas Novas. 
Procurando empregar o modo simultâneo de ensino, o mestre conduzia suas aulas mediante a repetitiva rotina, que - de acordo com o inspetor - era comum a todas as escolas onde os professores desconheciam metodologia. O professor substituto desconhecia, também, o valor do vencimento a que teria direito, posto que, segundo ele, desde que principiara a ministrar aquelas aulas, em 25 de Janeiro, nada recebera. As dificuldades daquele professor teriam sido acrescidas - como ele mesmo atesta - pelo fato de não haver quaisquer registros de matrículas e de movimentação de alunos no período que antecedia a sua chegada. A ser verdadeiro o estado em que havia encontrado a escola, aquele docente substituto teria efetivamente feito substantiva melhoria dos níveis do aprendizado escolar. Mesmo assim, ele manifestava sua preocupação quanto ao fato de não haver naquela freguesia exames anuais de instrução primária. A esse repeito, recorda sua própria experiência anterior, naquela cadeira que outrora regia:

\begin{abstract}
"diz o professor que quando regeu anteriormente esta mesma cadeira deu parte à Câmara que fazia ao fim de agosto os exames escolares e que desejava que a Câmara ou algum vereador assistisse esses exames. A Câmara respondeu que fosse o Professor e os alunos a Montemor - a 4 léguas de distância."
\end{abstract}

Será que não havia valorização da escola por parte das municipalidades? Será que o exame escolar não era tomado ali no Alentejo como componente importante da instrução elementar? Seja como for, parece-nos que, entre representações e práticas sobre a escolarização, as distâncias parecem ser maiores que as aproximaçóes. De qualquer modo, a preocupação do substituto em agradar o inspetor é, por outro lado, notória. Não sendo particularmente zeloso quanto à limpeza da sala de aula, ao saber que o inspetor entrara em Vendas Novas, Dinis José dos Santos mandou imediatamente um de seus alunos varrer a escola, de maneira que, quando ocorreu finalmente a chegada da inspeção, havia ainda "uma grande poeirada". Como recurso didático, este docente costumava evitar os castigos físicos, utilizando a palmatoada em ocasiōes extraordinárias, mas preferindo a ela as repreensões e a conservação do alunos em pé durante o período de seu castigo. Além de dedicar-se a seus deveres específicos, o professor declarou ter contribuído para tornar a sua aula mais concorrida, através de trabalho que fizera - nos meses de fevereiro e março - junto aos pais daquela comunidade, para que enviassem e mantivessem seus filhos na escola. Um pai, que era proprietário da região, confirmara: tudo aquilo que os alunos aprenderam de sistema métrico, de história e de gramática, foi inteiramente decorrente do esforço e do empenho daquele professor. ${ }^{318}$. Realmente, pelo resultado da averiguação do inspetor, dentre os oito alunos aleatoriamente selecionados, havia apenas dois que não liam nem escreviam, pelo menos de maneira suficiente. Sobre o professor anterior, em compensação, assegura o inspetor o seguinte:

318 "Como já disse, a ser verdadeira a informação do professor Dinis, muito progresso têm feito os alunos sob sua direção; è à sua diligência se deve a maior concorrência que a escola agora tem, porque nos meses de fevereiro e março, andou pedindo aos pais que lhe mandassem os filhos para a escola: e esse pouco ensino que a inspeção revela em sistema métrico, gramática e história, é todo devido a ele, o que, por um proprietário-pai de um aluno e dos melhores da aula me foi confirmado." (MR 1072. Distrito:Évora. Concelho: Montemor-o-Novo. Freguesia: Santo António de Vendas Novas) 
"Nada posso dizer de positivo a respeito do professor e seu serviço. As informações que me deram são que o estado físico do professor ainda antes de se recolher ao hospital era já tal que não podia, embora com boa vontade, desempenhar-se de seus deveres escolares: cheio de dores, mal podendo arrastar-se em duas muletas, assistia à aula, é verdade, mas nenhum interesse tomava pelo adiantamento dos alunos: há esperança de poder melhorar um pouco, mas não de se curar; pelo que mais utilidade viria ao ensino em aposentar este pobre homem, dando-lhe um bocadinho de pão, do que conservá-lo na direção de uma aula, cujo serviço carece de um certo vigor e bem-estar físico que ele já não pode ter."

Em Montemor-o-Novo, na freguesia de Santa Maria Maior de Cabrela, havia uma escola primária para meninos com sede na Rua Direita de Cabrela. O edifício dessa escola, bem localizado para a concorrência dos alunos que ao estudo acorriam, pertencia ao Prior daquela freguesia, havendo sido diretamente alugado ao professor "que o paga à custa do trabalho de escrituração que presta ao mesmo Prior" ${ }^{319}$ Com a porta fechada, nota-se a ausência de luz e de ventilação na escola. Sobre as condiçôes interiores à sala de aula, "utensílios não há e mobília consiste numa só mesa em péssimo estado e nuns bancos que prestou a Mesa da Misericórdia”.

O professor António Joaquim Xavier é um secular de 36 anos, interino há dois anos e meio no magistério público. Apresentava bom comportamento moral e civil e sua conduta era aprovada pelos concidadãos que o inspetor consultou. Todavia, no que dizia respeito a sua capacidade literária e aptidão para o ensino, os resultados da inspeção não lhe foram favoráveis. Com registros deficientes de matrícula, habituou-se a adotar formas rotineiras de gerir a sala de aula, "não tendo conhecimento de nenhum outro método que a Pedagogia aconselha, nem possibilidade de o empregar sem utensílios alguns". Curioso é que, quanto aos castigos aplicados, o professor se recusasse a adotar a prática da palmatoada, contrariando com isso - como ele próprio costumava declarar - a expectativa e mesmo o desejo das famílias de seus alunos. Como castigo, limitava-se, então, a aplicar "a repreensão, fazê-los pôr de pé e alguns outros estímulos que as circunstâncias lhe sugerem, o que naquela povoação lhe é censurado, tratando de brando e queixando-se de que não usa da palmatória, mão que aquela gente julga indispensável para o bom ensino."

Sobre o cumprimento do serviço escolar pelo docente, o inspetor recorda que o magro salário que se costumava obter no magistério, prejudicava inevitavelmente o potencial de desempenho dos profissionais naquele ofício envolvidos, especialmente quando se tratava da condição e do lugar ocupados pelos 'interinos'. Além disso, a carência de utensílios escolares dificultava sobremaneira o trabalho escolar:

“O professor está servindo interinamente este lugar por nomeação do Administrador do Concelho de Montemor de $1^{\circ}$ de maio de 1873 (...) Em virtude da classificação de suficiente que obteve no exame que fez para o magistério primário - em Évora - em 15 de Dezembro de 1874 requereu ser provido nesta cadeira ou em qualquer das outras que indicou em seu requerimento, e deseja ansiosamente sair deste estado de interinidade, porque não pode viver com tal ordenado. O serviço escolar, pelas respostas já dadas, não pode ser desempenha-

${ }^{319} \mathrm{Mr}$ 1072. Distrito: Évora. Concelho: Montemor-o-Novo. Freguesia: Santa Maria Maior de Cabrela Escola primária do sexo masculino com sede na rua Direita de Cabrela. 
do, os alunos não têm onde escrever, não têm ardósias, não há quadro preto, os exercícios, portanto, de escrita e de aritmética, são feitos pelos alunos em casa e submetidos à correção do professor na hora da aula."

O aproveitamento dos 17 alunos que efetivamente frequentavam a escola foi considerado regular, sendo que poderia evidentemente ser melhorado se houvesse condições apropriadas para o trabalho escolar, aprimoramento na situação material dos objetos didáticos e dos utensílios utilizados na atividade docente, se os salários da profissão do magistério fossem mais apropriados e se a frequência daqueles meninos à escola fosse minimamente regularizada em termos de assiduidade, permanência e observância aos horários e ao cronograma escolares:

"A maior parte dos alunos que frequentam a aula pertence a famílias pouco favorecidas que se empregam nos serviços de campo, e muitas vezes a grande distância da povoação; a necessidade de ir buscar lenha, água e ir levar almoço e jantar aos pais que andam longe, faz com que a frequência, proporcionalmente muito regular, não seja contudo acompanhada da comparência à hora própria; e alunos há que, não deixando de vir à aula, assistem contudo nela só uma hora, hora e meia, faltando umas vezes de manhã e vindo de tarde ou vice-versa; de modo que não duvido afirmar que é regular o aproveitamento; porque, atendendo a todas as razóes a par do tempo que têm de escola, o aproveitamento é proporcionalmente regular em relação às disciplinas leitura, escrita e aritmética; enquanto às outras é pouco ou nulo, como se vê no respectivo mapa."

Havia - como se percebe - uma rota agendada para a escolarização que, para se efetivar enquanto projeto, deveria se dar concomitante e homogeneamente por todas as classes de ensino primário que, no território nacional, estivessem, de algum modo, sob a égide do Estado. A forma escolar, que se tencionava pôr a funcionar, vinha sendo engendrada, em seus horários, em seu lento e multiforme compasso, em seu ritmo, que, de moderno, nada parecia ter...

O estudo do cotidiano inevitavelmente nos afasta das tipologias e dos pré-julgamentos, que - tantas vezes - capturam e aprisionam o olhar do estudioso do fenômeno educativo. Corre-se o risco - nessa reconstituição daquilo que é, por definição, o trivial - de formatar a análise perante elementos pouco elucidativos da acepção do genérico, do fato social enquanto uma totalidade. De qualquer modo, preferimos acreditar, com Azanha, que o estudo da atmosfera cotidiana poderá vir a se constituir em estratégia privilegiada para recortar alguns contornos da identidade coletiva, tanto por suas especificidades quanto pelos rastros da dimensão societária. Compreender a história da escola deve ser, antes de qualquer coisa, apreender algumas das dimensões postas pela vida corriqueira das práticas da relação de ensino-aprendizagem. ${ }^{320}$ É, portanto, ao indiciarmos a particularidade da história da escola, que nos tornamos aptos a recompor sua perspectiva mais abrangente, mais genérica, suas

\footnotetext{
${ }^{320}$ Acerca da relevância e da carência de estudos que, através dos registros dados pela cotidianidade, mostrem-se capazes de aferir o percurso da escola, trazendo vida às práticas escolares efetivamente implementadas, e não tomando-as como um mero epifenômeno do trajeto das disposições legislativas, Azanha recorda os historiadores da educação daquilo que pareceria óbvio se não fosse tão ausente do quadro das preocupações de nossas investigações acadêmicas mais usuais (José Mário Pires AZANHA, Uma idéia de pesquisa educacional, p. 58).
} 
tendências. Ao percorrermos essa variada gama de escolas e de situações pedagógicas que foram estruturadas a partir de relatos de protagonistas da época, procuramos elementos, no mínimo, para fazermos as perguntas corretas, se quisermos efetivamente nos aproximar daquele universo pedagógico posto na dinâmica da sala de aula da escola portuguesa de meados do século XIX. O cotidiano é indubitavelmente aquilo que mais rapidamente desaparece. Daí a necessidade de sequestrar o que os indícios nos permitem relatar desse dia-a-dia, aparentemente tão familiar e tão estranhamente outro. Era talvez a mesma escola que, em cada sítio, adquiriria um feição muito sua, muito particular, muito única: experiências que, ao se entrecruzarem, nunca se encontram de fato...

A escola primária do sexo masculino de Vianna do Alentejo estava sediada no Largo de São João da Villa, na freguesia de Nossa Senhora de Annunciação do distrito de Évora. A Câmara Municipal de Vianna cedera gratuitamente o edifício para funcionar como casa de escola, o que era hábito em vários concelhos da região. O edifício, a propósito, encontrava-se em bom estado de conservação, considerado com boas condições para receber aquela população escolar que para lá acorria. Tinha mobiliário apropriado, doado pela Câmara. Os utensílios dos quais se dispunha eram basicamente dois mapas de Portugal de Bittencourt, um mapa-mundi, um quadro de pesos e medidas. A Câmara fornecia também papel, penas e tintas a todos os alunos que frequentavam a escola, sem exceção, satisfazendo em suas "despesas diversas" as necessidades da escola, posto que não havia no orçamento municipal verba específica para tal auxílio. Verifica-se - pelo relato do inspetor - que se tratava de uma localidade que efetivamente apostava no valor da instrução e na necessidade do bom uso da escolarização por parte das crianças da região. Mostra a existência de mobilização de pais e da comunidade para exigir dos poderes públicos o investimento nos assuntos escolarização da infância portuguesa. O inspetor revela outras agremiações da sociedade civil daquela localidade empenhadas no incentivo à educação escolar: "a Mesa da Misericórdia fornece a escola de livros para todos os alunos sem exceção e a Associação de Caridade tem dado vestuário a alguns alunos da escola como prêmio de sua boa frequência; o número depende dos meios de que pode dispor." 321

O professor estava ausente e por isso não puderam ser encontrados os registros e os mapas da inspeção. Luiz Bernardino Pacheco, professor temporário, não chegou a dois meses na cadeira, por ter ficado "mentalmente alienado". Ele havia tomado posse em 23.11.74 e deixou a função em 7.1.75. Enquanto lá esteve, revelou - ao que consta - bom comportamento moral e civil. Sob esse aspecto, as autoridades locais foram unânimes em certificar ao inspetor "as boas qualidades do professor" afastado, declarando, por tal razão, lamentarem sua perda.

De acordo com o relato das pessoas consultadas, o professor dava duas lições de três horas cada uma e às vezes ultrapassava o período previsto para essas aulas, prolongando as liçôes dos alunos. Chegou a recompensar mais de uma vez os alunos destacados, oferecendo-lhes livros apropriados à sua idade. Havia anualmente a ocorrência de exames naquela escola, posto que - segundo o inspetor - essa era uma

${ }^{321} M R$ 1072. Distrito: Évora. Concelho: Vianna do Alentejo. Freguesia: Nossa Senhora de Annunciação. Escola primária masculina de Vianna com sede no Largo de São João da Villa. 
prática já tradicional naquele concelho. O júri para tais exames compunha-se de "pessoas de conhecida aptidão nomeadas pelo Administrador do Concelho". Satisfeito com o entusiasmo da comunidade para os assuntos relativos à instrução, mas decepcionado com a situação pela qual a escola fôra fechada, o inspetor preocupa-se com aquela contraditória condição de uma escola vazia a despeito do enorme potencial educativo da região onde se instalara:

"Não posso dizer coisa alguma a respeito do professor nem do serviço escolar porque a escola
está fechada. Depois da retirada do professor, atacado de alienação mental, tem o administra-
dor do Concelho procurado em vão quem interinamente o substituísse porque em Vianna nin-
guém quer ir exercer o lugar por tão pequeno ordenado, e de fora muito menos. Assim, con-
tinua a escola fechada até que o Governo resolva o que se há de fazer num caso semelhante."

Fronte do mestre: pai, médico, sacerdote, juiz... A ciência pela virtude

Percebemos que o entusiasmo é matizado pela ausência de um salário que se compatibilizasse minimamente com as exigências de um profissional do magistério. Pareciam ser, de fato, bastante pequenos os estímulos para que pessoas relativamente ilustradas optassem por se entregar ao ofício do ensino. Sem benefícios materiais, mesmo o lugar social ocupado por esse educador escolar não era dos mais valorizados pelas famílias e pela sociedade, de maneira geral. O lugar de professor de aldeia era, então, extremamente sacrificado, já que, na grande maioria das vezes, enviava-se o docente para uma região na qual ele ficaria desterrado, posto que não teria ambiente profissional que o pudesse abrigar. Solitário e frustrado com o trabalho, era comum ocorrerem casos de indiferentismo do professor por sua atividade cotidiana, em uma rotina que nem sempre lhe poderia parecer suportável. Esse professor de aldeia, descrito por vezes de modo algo romântico pela literatura da época, contraria os próprios ideais que eventualmente haviam sido para ele traçados. Não há modelo, não há roteiro explicativo, não há paradigma, não há sequer a homogeneização institucional da escola, tão cara a nossos atuais historiadores da educação. Havia, isso sim, um veio de desesperança, de descrédito, de desânimo por uma profissão na qual as mais variadas tentativas, por vezes, pareciam todas elas inócuas: o desapego por uma prática desencontrada, a estagnação do pensamento sobre a mesma prática, a relutância em se permitir acreditar na mudança. O retrato do professor é, na aldeia, o esboço de um antecipado fracasso... Sobre a escola para meninos situada na Praça da aldeia de Oriolla na freguesia de Nossa Senhora da Assunção de Benalverge do concelho de Portel, também localizado no distrito de Évora, consta do relato do inspetor:

"A Câmara de Portel, aproveitando uma pequena casa (...) nos antigos paços do concelho desta vila (...) e acrescentando-lhe um pequeno recanto que ali havia, formou uma só casa, que destinou para escola; não teve porém em atenção alguma nem a diferença de nível que havia no pavimento da antiga casa para o espaço acrescentado, nem as condiçôes de luz e de ventilação; ficou, portanto, uma só casa dividida em duas partes, uma das quais - os dois terços de todo o espaço - está vinte e dois centímetros mais elevada do que a outra, assaz escura e pouco arejada. O professor, para melhorar ainda estas condições, pintou-a de amarelo e encarnado, imitando 
uns grandes cortinados. A mobília, que já indiquei, é imprópria e na única mesa que há para os alunos escreverem, não mais de três o podem fazer. Utensílios escolares não há nenhum e parece que nunca fizeram falta ao professor." 322

O professor, com 34 anos de magistério público, chegara aos 61 anos muito trêmulo, sofrendo de padecimento nervoso. Embora tivesse bom comportamento moral, sua aptidão para o ensino era quase nula. Seu empenho profissional afrouxara e sua assiduidade fora prejudicada por seu precário estado emocional. A escola, no dia da inspeção, encontrava-se imunda e pelo chão podiam ser verificadas inúmeras pontas de cigarro. O docente ensinava a leitura pelo modo simultâneo, utilizando cartas de sílabas e o Methodo facillimo. Dos 20 alunos matriculados, apenas 9 frequentavam regularmente a escola, todos eles com baixíssimo aproveitamento, ao que o inspetor acrescenta o seguinte:

"A frequência desta escola não pode bem avaliar-se pelos registros de frequência, porque estes não
passam de uma relação de nomes feita talvez no princípio do ano, sem apontamento de faltas
nem indicação alguma; - uma coisa informe que só o professor entende. Entretanto é certo que os
alunos são tão pouco frequentadores como os de outras aldeias, mas é também de toda evidência
que o professor não faz diligência alguma para lhes fazer apreciar a instrução. O aproveitamento
dos alunos é pouquíssimo, as escritas são feitas na ausência do professor, os erros de ortografia
gravíssimos, a forma das letras péssima. A aritmética é toda teórica; apenas dois alunos a custo
realizam alguns problemas simples em que não tinham que aplicar mais do que a multiplicação."

Nas observações que faz sobre o professor e as condições postas para o trabalho docente, o inspetor relativiza a severidade de suas anteriores afirmações. De fato reconhece ele -, a responsabilidade pelo mau ensino não poderia ser posta sobre o educador escolar:

"É este também um dos professores que nenhum serviço está já fazendo à instrução, não tanto pelos seus poucos conhecimentos, como por esse indiferentismo de que se deixam apossar alguns professores que, desterrados, por assim dizer, de toda a sociedade humana, no meio de uma pequena aldeia, quase que perdem o sentimento de sua dignidade. Seu serviço é mau, seu interesse pelo progresso da escola é nenhum: enfim, basta entrar na escola para se ver que a ordem, a regularidade e a disciplina são coisas completamente ali desconhecidas; o ensino é como o demonstra o mapa do resultado da inspeção, em que as qualificações de medíocre são quase de favor.”

Pelo relato, observamos que a idéia de uma escola capaz de habilitar as populações para as habilidades da leitura, da escrita e do cálculo elementar era apenas um vago desejo, sobre o qual pesava a realidade eminentemente oral das aldeias portuguesas. A forma escolar continuava a ser, naquele final de século, apenas a expressão de uma disponibilidade futura. Os contornos tomados por aquela escolarização permitem-nos porém visualizar certos traços, algumas tendências, esparsas regularidades. Estas, de algum modo, contrapõem-se ao pensamento erudito acerca do objeto da escolarização.

${ }^{322}$ MR 1072. Distrito: Évora. Concelho: Portel. Freguesia: Nossa Senhora da Assunpção de Benalverge. Escola masculina com sede na Praça da aldeia de Oriolla. 
Ou seja: nem tudo o que era presumido como verdade da escola, assim pode ser confirmado. Indagar quem é essa escola específica, por meio das miudezas e das aparentes trivialidades de sua vida cotidiana, permite-nos indagar sobre a identidade das rotinas escolares de maneira geral. Quais são as representações sociais implícitas nos rituais do dia-a-dia da escolarização?

Buscava-se compor um encadeamento de conteúdos, procedimentos e divisões dos alunos por idades e por níveis de aprendizado. Buscava-se estruturar um modo de ensino posto a agir no coletivo e, em função dele, o aprendizado ocorreria. A escola precisava aprender a ensinar o ler, o escrever e o contar. Para tanto, era fundamental que ela também ensinasse as crianças a se comportarem. O público desse projeto escolar era a parcela da população de camadas médias e inferiores da sociedade; um público que, ao que consta, não acreditava muito nos presumidos efeitos da instrução preconizada.

A escola mantida pelo Estado no último quartel do século XIX em Portugal era, acima de tudo, uma instituição com competências dispersas, com um perfil ainda a se definir. Pudemos observar pelos relatos que, embora uma sala de aula média da escola primária contasse com três horas de aula pela manhã acrescidas de mais três horas à tarde, nem sempre esse horário definia com precisão o ritmo de seu funcionamento. Aliás, o próprio edifício escolar, nos aspectos concernentes à sua pertença e manutenção, revelava algumas indefiniçôes, posto que, muitas vezes, pertencia à Câmara, mas, em alguns caso, era financiado pela Junta de Paróquia, às vezes pela Misericórdia ou pelo próprio professor. Não se havia chegado ainda, nessa medida, a uma casa de escola uniforme e homogênea para todo o território do país, independentemente de sua localização. O ensino português buscava sua dimensão pública, lidando, porém, com sua herança clerical. A mobília e os utensílios escolares eram ora fornecidos por uma instância, ora emprestados por outra.

Pelos Relatórios diversos, podemos aferir que, aos olhos do inspetor, reconhecidas por esse técnico as parcas condiçôes pedagógicas de que dispunha o profissional do ensino em Portugal, o docente bem-sucedido era aquele que lidava com algumas variáveis nem sempre destacadas nos trabalhos de pedagogia ou mesmo de didática. O bom professor - pela percepção dos inspetores - era o que tivesse os atributos da imaginação para superar a carência de meios e de instrumentos pedagógicos para seu trabalho diário; criatividade, para, na ausência de uma sólida formação e na incapacidade de atualizar seus procedimentos metodológicos, inventar modos de ensinar, técnicas variadas de aprendizagem, de maneira a tornar o ensino, antes de mais nada, caracterizado pela curiosidade intelectual despertada e vivificada no aluno, que então passaria a gostar de aprender; entusiasmo pela sua função e pelo ofício que escolhera, a despeito da precariedade da remuneração no magistério obtida; paciência para encontrar formas de obtenção da necessária disciplina sem a excessiva recorrência aos instrumentos de punição física, que tanto amedrontavam as crianças; tenacidade para persistir no magistério, enfrentando um significativo rol de dificuldades e obstáculos, particularmente derivados da desvalorização social daquela profissão, a despeito dos discursos em contrário; disciplina e organização, de maneira a efetivar em sua sala de aula maneiras coletivas de ensinar. Desejava-se que a figura do professor fosse sempre o diapasão do processo de ensino-aprendizado; e valorizava-se sua liderança indeclinável no grupo-classe. O modo simultâneo era, por essa razão, 
recomendado. Para além do professor verdadeiro, cria-se, pelo discurso, um roteiro prescritivo das características, dos dotes e dos atributos que deveriam ser perfilhados por aquele mestre desenhado para o esquadro público da função social que lhe foi designada:

"O discípulo não deve ver em seu mestre unicamente um homem sabedor do que ensina; deve tê-lo na conta de cidadão honesto e miserabilíssimo. A fronte do mestre, como a do pai, e a do médico, e a do sacerdote, e a do juiz, deve orná-la a dupla auréola da ciência e da virtude. Se o discípulo duvidar por um momento da probidade do professor, pode e deve duvidar da verdade de suas preleções." 323

Verifica-se então que tal professor idealizado não correspondia exatamente às representações mentais coletivas daquelas populaçôes que viam, na maioria dos casos, na figura do mestre, antes o retrato do homem comum do que esse arauto da virtude que, entretanto, pedagogos pareciam buscar descrever. Com sua honradez e retidão equiparada à honradez e à retidão dos párocos, dos juízes, há aqui uma transferência de sacralidade. Portador do conhecimento, o professor é muito mais do que um erudito que guarda para si as verdades que descobre. O professor desenlaça o enigma e dá a chave do conhecimento, partilhando seu acesso com as populações com as quais interage. É portador, destarte, de um saber que traz, por definição, a vocação da partilha. Nessa medida, ao contrário de uma certa percepção cotidiana, o professor estaria envolvido por uma aura de sacralidade, seja pela responsabilidade social de sua tarefa, seja porque, assim como o pároco, ele também se dedica à formação de corações e de almas infantis. O conhecimento escolar seria filtrado e regido pelo professor. Mas quem se encarregaria de controlar e regrar o professor que, não agindo conforme as normas da moral preconizada, não incitasse seus alunos também a fazê-lo? Essa tarefa estaria reservada ao livro didático: o livro da juventude que, no caso português, seria, antes de tudo, o livro do professor, o livro de organização e ordenação da aula e dos conteúdos nela ministrados, nela distribuídos. O compêndio escolar, não era à toa, tinha em grande parte dos casos uma feição de cariz enciclopédico, de modo que um conjunto vasto de matérias poderia estar ali contido.

\section{O compêndio escolar e seus desacertos}

O tema do livro didático povoaria corações e mentes de educadores em todo o decorrer do século XIX. Prescrevendo instrução e disciplina, conformando saberes, valores e hábitos de civilidade, o compêndio escolar situava-se não apenas como os primeiros guias da cultura letrada, mas existia como fonte de organização do trabalho docente e de preparo dos conteúdos e das estratégias de aula por parte dos professores, que se valiam desse recurso para orientar sua enciclopédica prática. O professor primário não é um matemático, não é linguista, não é historiador ou cientista. Aliás, na imensa maioria das vezes, detem-se na pequenez do aprendizado

${ }^{323}$ João José de Sousa Telles, Os exames de instrução primária e secundária, p. 13. 
da escolarização primária. Esse professor, carente de formação adequada, mal remunerado e despreparado para exercer o controle sobre a própria disciplina de seus discípulos, esse professor solicitava da escola o livro. Era uma forma de sistematizar o estudo para ministrar a aula na forma do ensino simultâneo. Além disso, intelectuais e editores pretendiam fazer do professor português um sujeito enciclopédico. Desejava-se fazer da sala de aula da escolarização primária o local apropriado para que se pudesse aprender um pouco de todas as coisas. Centrado na atenção, na memória e na imaginação do mestre e do estudante, o 'manual enciclopédico' não sabe ao certo para quem se dirige; seu interlocutor não é claro, pois compreenderia, por princípio, qualquer agente da civilização. Seja como for, sua diretriz faz história na longa duração...

Reconhece-se na ausência do livro escolar, um dos grandes nódulos do ensino português. Na verdade, desejava-se fazer permanecer o espírito enciclopédico para a confecção de obras infantis, posto que esse estilo permitiria uma melhor adequação e delimitação das lições, classificadas por períodos e por chaves temáticas, de maneira a que o ensino pudesse ganhar em interesse e em amenidade. Por outro lado, criticava-se sobremaneira a 'montagem' de manuais em função exclusivamente de uma coletânea de excertos extraídos do trabalho de autores variados. Os teóricos da educação e mesmo os homens envolvidos em processos de editoração de textos ou até jornalistas passariam a defender a possibilidade de apresentação dos conteúdos dos compêndios à luz de metodologias e estratégias de aprendizagem mais atraentes. Propunha-se, de algum modo, um ensino que chamasse a intuição, um modelo de 'liçôes de coisas', uma seleção de conteúdos, de valores e de saberes, postos como úteis e apropriados ao desenvolvimento cognitivo da criança. Cada vez mais a tendência era essa. E, no entanto, continuava-se a modelar o ensino perante um conjunto de compêndios que, muitas vezes, não eram considerados os mais adequados. O império do Manual enciclopédico, de acordo com os testemunhos de seu tempo, atravessaria a fronteira do século. Acerca da materialidade de seu uso, verifique-se o depoimento contido no texto que, a 8/5/1903, Ribeiro da Silva redigiria para o periódico $A$ escola:

"O mal provém de se ministrar nas aldeias o ensino particular em casas desprovidas de condições higiênicas indispensáveis a uma casa de educação. A arbitrariedade avariada na escolha dos livros, a indisciplina, a rotineira de processos e métodos, a deficiência de instrução - eis as tristes consequências da iniciativa particular de ensino, quando exercido por indivíduos sem autenticidade nem habilitação legal. Na escola da nossa aldeia temos presenciado alunos que, viciados no método de soletração que os mestres assalariados a 3 vinténs por mês, lhes têm ministrado, já são inconciliáveis para o método de leitura de João de Deus. Depois apresentam-se na escola oficial uns com o Monteverde, outros com a Cartilha do Abade de Salamonde e outros até com o Lunário Perpétuo. Em exercícios mnemônicos, vêm eles desenvolvidos porque tudo o que lêm é de cor. Na maior parte dessas escolas particulares não há classes, não há horário, não há programas, não há métodos, não há disciplina." ${ }^{24}$

${ }^{324}$ A ESCOLA: bi-semanário dedicado aos interesses da instrucção e do magistério, número 20, anno 1, 8/5/1903, p. 1. Os grifos são de nossa autoria. 
Percebe-se, pelo excerto acima transcrito, o quanto alguns dos compêndios mais utilizados pelos critérios da inspeção de 1867 e da de 1875 permaneceram como balizas e referências da escola portuguesa em suas práticas mesmo depois da virada do século. De algum modo, as práticas escolares resistiam então às prescriçóes de gabinete, como se não desejassem qualquer tipo de alteração na gramática interna que as estruturava. No entanto, compreender o porquê do êxito editorial de alguns desses compêndios supóe que sejamos capazes de indagar a própria orientação de sua utilização, de seus usos, do modo perante o qual o livro escolar era manuseado por alunos e por professores. Quais os segredos desses recursos didáticos e em que medida eles efetivamente conformavam práticas de instrução?

Para tanto, sugere-se que esses dicionários - que nada mais seriam do que modelos alternativos de manuais enciclopédicos - abarcassem artigos claros, escritos com simplicidade e com método rigoroso, devendo levar em consideração o desenvolvimento infantil nas suas diferentes etapas, mas buscando - pelo modelo que pretendiam seguir - apresentar temas complementares uns aos outros. Desejava-se, de algum modo, correspondendo àqueles anseios tantas vezes expressos pelos inspetores de 1875, tornar o ensino atraente porque variado, de modo que a aula se compusesse como um mosaico criativo, capaz de entrelaçar inúmeros elos que, conectados, trariam uma adequada compreensão de realidade. $\mathrm{O}$ essencial do padrão enciclopédico era que, se o aluno falhasse em algum dos temas, não fracassaria nos demais, o que o estimularia e o incitaria a dar continuidade a sua vida escolar. Manusear o compêndio seria, sob tal perspectiva, uma forte estratégia de estímulo para o estudante.

O professor aprende pelo livro e o livro se torna progressivamente uma âncora material e um interlocutor do espírito. O aluno aprende com o professor e conversa com o livro. Em ambos os casos, há uma relação triangular entre o suporte material do impresso, o conteúdo do conhecimento letrado e os sujeitos que aprendem. A escola, ao lidar com o campo da cultura letrada, transforma o livro em protagonista da cultura escolar. A infância e a juventude terão indelevelmente a companhia do impresso, para o bem e para o mal. A organização e o roteiro das aulas passará pelo conteúdo e pelo formato desses livros. Aprendemos a ler pelos livros. E nos esquecemos de um livro pela leitura que fizemos do outro. A escola, que nos ensinou a ler, também nos ensinou um modo todo próprio de lidar com a competência da leitura e com o repertório da cultura letrada. Isso é o que veremos no último capítulo deste livro. 
(Página deixada propositadamente em branco) 


\section{O LIVRO DA ESCOLA QUER FORMAR PROFESSORES E CIVILIZAR ALUNOS}

"Toda a história é escolha. É-o até devido ao acaso que aqui destruiu e ali salvou os vestígios do passado. É-o, sobretudo, porque o historiador cria os seus materiais, ou se quiser recria-os: o historiador que não vagueia ao acaso como um trapeiro à busca de achados, mas parte com uma intenção precisa, um problema a resolver, uma hipótese de trabalho a verificar." (Lucien Febvre, Combates pela História, p. 19)

Dizia-se na minha meninice...

O presente capítulo buscará desenvolver o tema da leitura escolar e do compêndio didático como registros exemplares das representaçôes e práticas de uma escola que é, por um lado, dita e projetada e, por outro, posta a agir em sua lide cotidiana. A questão intelectual aqui colocada é: o que fazia e como agia em Portugal a escola do ler, escrever e contar em meados do XIX? Buscar pistas que permitam rastrear essa indagação é o objetivo a que este trabalho, desde o princípio, se propôs. Reconstruir o cotidiano dessa escola que se pretende narrar pode se tornar, porém, tarefa inglória caso não sejam considerados seus conteúdos culturais e valorativos: os saberes internos à escola, constitutivos do repertório de uma certa mundividência especificamente escolar, construída por interlocução com a sociedade portuguesa da época. Narravam-se, descreviam-se e prescreviam-se para o aluno códigos de cultura e gestos de civilidade, que aproximavam instrução e disciplina como quesitos de civilização. Por ser assim, e pelo fato de não haver cursos de formação do magistério, deve-se destacar o lugar proeminente ocupado pelos compêndios escolares, não apenas como possíveis primeiros livros com que a infância trava contato, mas também como prováveis guias de orientação e do preparo de aulas dos professores..

O tema da alfabetização ganhara já substantiva relevância, como se viu, no discurso político e nas representações mentais da intelectualidade portuguesa, no decorrer de todo o século XIX. Interessa aqui rastrear o percurso da materialidade das práticas, com o propósito de identificar permanências e inflexões que certamente ocorreram ao longo do tempo. Todo o eco dos diagnósticos e propósitos declarados só ganham significado se postos ao lado daquilo que se compreender como vestígios da escola em sua cotidianidade. Apreender, pela intersecção, representações e práticas da escola narrada consistirá, talvez, estratégia privilegiada de apropriação da atmosfera cultural de um tempo e de um objeto que, tendo sido eleito por nós, não nos escolheu. 
Ao analisar o que denominou "caminhos do ABC" no ensino de primeiras letras da escola portuguesa no século XVIII, Rogério Fernandes atenta para conteúdos e práticas desse aprendizado inicial pelos compêndios efetivamente utilizados pela sala de aula do escolar principiante. Sua indagação tem por pressuposto metodológico o inevitável confronto entre o discurso e as práticas ou, em suas palavras, entre "a produção teórica, construída às vezes ao arrepio da experiência cotidiana, e o vivido educativo e escolar que, eventualmente, a desmentia ou defraudava". ${ }^{325}$

Ao referir-se aos manuais didáticos utilizados pela escola portuguesa no decorrer do século XVIII, Fernandes destaca o primado de uma orientação ético-religiosa, expressa pelo conteúdo do próprio compêndio escolar, que fazia por incutir valores e normas de conduta preconizados pela moral imperante a partir de referenciais cristãos veiculados pelos inúmeros catecismos e 'bíblias de infância' que corriam à época. Ocorre que a existência e efetiva utilização de livros não evitava - como destaca o referido autor - o primado da utilização de manuscritos, posto que os próprios manuais eram indiretamente dirigidos antes como guias didáticos para os mestres de primeiras letras do que para o efetivo manusear do aluno. Havia, em alguns casos, sugestóes dos autores das cartilhas quanto à necessidade de utilização do ponteiro em sala de aula, o que - no parecer de Fernandes - viria a confirmar a hipótese de que a obra escolar era, antes de mais nada, o livro do professor.

No que diz respeito ao século XIX, constatar-se-ão a continuidade e a ruptura desse modelo: continuidade pela persistência de práticas escolares enraizadas em padrões herdados de tempos atrás; ruptura pelo esforço empreendido pelos teóricos da pedagogia com o fito de alçar o país ao sentido do século no qual os progressos da razão humana foram referendados pelo esforço governamental na irradiação do conhecimento produzido, mediante expansão da escola primária, templo privilegiado de preparo de cidadãos para a pátria e de indivíduos aptos para a produção da riqueza nacional. Desse modo, o tema da escola ganharia nova substância, ao mesmo tempo em que persistia sendo o mesmo...

O século XIX julgava a si próprio como o tempo de irradiação das conquistas cintíficas obtidas pelos duzentos anos que lhe antecederam. Havia chegado a hora de partilhar o saber acumulado pelos séculos precedentes. Ocorre que o aumento do rol de conhecimentos teria bifurcado e multiplicado também as áreas do conhecimento em que este ou aquele campo era suposto atuar. A idéia do conhecimento enciclopédico seria, por essa razão, abraçada pelos intelectuais do século XIX, que, muitas vezes, se iludiam perante a hipótese de a instrução ser efetivamente o grande diferencial que pontuaria a grandeza do mundo moderno; grandeza essa que habilitaria o homem para utilizar, de modo racional e apropriado, as conquistas provenientes do campo da natureza e da técnica. A sociedade (ou as classes dominantes dessa sociedade) tinha efetivamente um discurso sobre a ciência, sobre a moral, sobre a religião. Cumpria apresentar esse discurso às pessoas. A escola, em alguma medida, serviria para isso.

Pretendia-se produzir, sistematizar, veicular e inculcar relatos e narrativas sobre a vida nacional, sobre o ser humano, sobre Deus e sobre o mundo. Desejava-se contar aos adultos - por meio de jornais e revistas que circulavam à época - versões

\footnotetext{
${ }^{325}$ Rogério FERNANDES, Os caminhos do ABC: sociedade portuguesa e ensino de primeiras letras, p. 223
} 
coerentes acerca da história pátria e seus devidos heróis, da geografia e das fronteiras do país, dos novos sistemas de medidas e dos modos de sua aplicação, das recentes conquistas no campo da higiene e da prevenção de doenças epidêmicas. Novos conteúdos culturais teriam, curiosamente, a função de perpetuar e consolidar tradições, costumes e hábitos. Assim entendia Herculano quando, n’O Panorama, qualificava aquele periódico que então dirigia como divulgador de "conhecimentos úteis". De fato, pensava-se o mundo perante códigos herdados de um enciclopedismo didático. Entre o sábio e o ignorante, se impusera com o século XIX uma nova categoria, intermediária, formada pela escola ou pelos jornais, que teria o conhecimento apenas do essencial, e não muito; enfim, um tipo de gente que - segundo diziam os contemporâneos - não existia em tempos mais remotos. $\mathrm{O}$ povo reclamava ter direito a uma compreensão ampliada dos fenômenos que envolvem o homem em sua circunscrição espaço-temporal. Fazer caminhar a civilização pela senda daquilo que os homens ilustrados supunham ser a tendência à perfectibilidade exigia, pois, a instrução. Esta era a tarefa da escola: criar o homem semi-cultivado, a classe média e sua ideologia. O livro de escola, nessa direção, supre a apontada lacuna. Vivia-se, sem dúvida alguma, um tempo de manuais enciclopédicos...

O manual escolar tem uma dada textura, um formato e uma feição que lhe são típicos; é como se ele falasse à infāncia, e o fizesse de um modo muito particular, diria-se quase inconfundível. Ao possuir ritmo e compasso próprios, o manual supõe-se invariavelmente capaz de impor todo um processo de ortodoxia da leitura, que engloba regras de um bom manusear acopladas a feixes temáticos expressos na divisão das lições que elegem, nessa ordenação, os temas do conhecimento que se pretende fazer apreender pelos corações e intelecto dos meninos portugueses. Se, até certo ponto, o texto escrito não tem correspondência direta por ser reconstruído nas práticas cotidianas de sala de aula, mesmo assim, deve-se destacar a força adquirida pelo efeito irradiador de alguns desses compêndios, utilizados em profusão pelos mestres de primeiras letras. Tratando-se do primeiro contato da criança com o mundo do impresso e da leitura, a cartilha de alfabetização é um mundo outro, desconhecido, que aterroriza e seduz aqueles que se dispõem a decifrá-lo...Uma leitura que não se sabe ao certo o que é , mas que se apresenta aos olhos de seus ousados pretendentes como se de um oráculo se tratasse, decifrando, num gesto de inversão, todos os que desejam desvendar o enigma da palavra escrita.

As cartilhas de alfabetização, como suportes discursivos que se propõem a dar a ver um dado conjunto de conteúdos culturais, representam instrumento privilegiado para a imersão no território da leitura e da escrita, particularmente no tocante ao acesso das crianças a esse tão poderoso quanto misterioso mundo do escrito. Ao apresentar como naturais temas, discursos e abordagens, a cartilha delineia, pelo percurso de sua construção, dispositivos que induzem o aprendiz de leitor a efetuar, de maneira entrelaçada, a descoberta das imagens e dos signos gráficos com a interpretação de todo um feixe de versões de mundo apresentadas como verdades absolutas imperativas. A esse respeito, suspeita-se que muito do que se conta às crianças na escola resulta num dado estilo de subtrair a infância de si própria: das suas brincadeiras, dos seus sonhos, do universo simbólico eivado de fantasia e, portanto, de sua criatividade. A leitura escolar não é a leitura da fruição, do prazer; é antes o mundo do dever recomendado a essa gente pequena, como orientação para a vida em sociedade. Sob tal perspectiva, costumava-se 
destacar a necessidade e a importância do lugar do mestre de primeiras letras, responsável pela decifração do compêndio para um aluno que, deixado por si, jamais saberia decodificar seus textos, suas mensagens, sua semântica.

Ao travar interlocução com a abstração de uma suposta meninice exemplar, os próprios saberes elementares, apresentados como via de acesso à cultura erudita, costumam romper com o espontâneo, com a imaginação e com o território da oralidade específica da razão sensitiva da meninice. Por sua vez, na outra margem, há o cronograma do futuro. Assim, transforma-se precocemente a criança no homem da manhã seguinte. Tal orientação revela-se como a interpretação mais acabada da vertente adulta de interpretação da realidade sobre o imaginário infantil: dos valores, das normas de conduta, dos processos de ordenação do social. Desse modo, causa estranheza o sucesso editorial que alguns desses compêndios de alfabetização obtiveram no curso de uma duração longa em Portugal do último quartel do século XIX.

A história da escola primária portuguesa confundiu-se, naquele tempo, com a história de um dado conjunto de compêndios escolares que, por aparecerem em profusão, marcaram o território da sala de aula em seus símbolos e liturgias. Muitos desses trabalhos foram relegados ao esquecimento, permanecendo entre as estantes de alguma biblioteca, ou em prateleiras de alfarrabistas, como exemplares empoeirados de uma memória calada. Sobre o fenômeno editorial que Monteverde havia representado à sua época, a surpresa expressa-se, ora pela contra-mão, a partir de seus adversários, ora por aqueles que, pelos seus manuais, ingressaram no universo da escrita. Em qualquer caso, é forte a referência desse autor que foi, em certa medida, relegado pela posteridade. Ouve-se falar dele ainda no final do século XIX, quando, há tempos, os pedagogos reconheciam isso; para recordar, emprestam-se as lembranças de Ferreira-Deusdado:

"Dizia-se na minha meninice de escola quando se falava de um pequeno estudante - já lê no Monteverde, o que equivalia a dizer que já estava na carreira das letras. Seguir um curso monteverdeano integralmente era honrar-se quase com um diploma acadêmico. Começava-se pelo Methodo facilimo para aprender a ler, depois o Manual encyclopedico, mais tarde o Mimo à infancia e o Resumo da historia de Portugal. O espírito sensatamente pedagógico, a concatenação clara das matérias, a visão penetrante sobre a inteligência juvenil, fizeram com que os livros de Monteverde gozassem de uma justa popularidade que constituía ao mesmo tempo um verdadeiro triunfo no método. Só assim se explica o amplo acolhimento das suas obras que fizeram esgotar numerosas edições de muitos milhares de exemplares cada uma. Só da penúltima e antepenúltima edição do Manual Encyclopedico foram tirados cerca de 130000 exemplares. $\mathrm{O}$ venerando educador Monteverde triunfou brilhantemente durante anos de todas as dificuldades opostas à evangelização de suas idéias." 326

Ao que tudo indica, o êxito do livro de Monteverde ultrapassaria esse período e atingiria mesmo o último quartel do século ${ }^{327}$. A partir dos anos 70, particularmente,

${ }^{326}$ FERREIRA-DEUSDADO, O Manual Encyclopedico de Monteverde. In: Revista de Educação e Ensino, VIII ano, n 8, 1893, p. 56.

327 Embora não fosse de seu feitio o elogio alheio, tornando-se célebre por apenas se auto-elogiar, Castilho, a dada altura, assume a defesa do enciclopedismo imperante à época, trazendo como exemplo exatamente o êxito 
havia uma nítida demanda por livros de instrução primária. Desde os anos 50, a escolarização portuguesa era falada pela recorrência ao 'discurso' do método de ensino. O método de ensino era visto como o responsável pelo fracasso na escola. Ora, supunha-se que o método era uma ausência na escola portuguesa, onde professores, sem qualquer formação específica para o magistério, tinham sérias dificuldades para ensinar conteúdos que, por sua vez, também não dominavam. Por causa disso, os intelectuais da época, com significativa freqüência, queixavam-se da má qualidade dos livros dirigidos à vida escolar.

Conhecer a escola primária portuguesa no século XIX supõe, por ser assim, uma breve incursão pelo conteúdo de tão concorrido compêndio, ainda que apenas para elucidar algumas indagações: quem comprava, quem lia, como se lia e por quê? Em editorial do periódico Educação Nacional, que então dirigia, em 9 de junho de 1901, no no 246, Antonio Figueirinhas ratifica o parecer da unanimidade, pelo menos à guisa de situar a memória de suas raízes pedagógicas pela dinâmica de evocação do estudante que fôra. Sobre o Manual de Monteverde, o testemunho é revelador. A recordação de Figueirinhas parece, a esse respeito, bastante precisa. Em suas palavras:

\begin{abstract}
"Eu ainda pertenço àquele tempo em que o livro mais apreciável que entrava na maioria das escolas era o Manual Encyclopedico e a Cartilha do Mestre Ignácio. O a-b-c era o mais rudimentar, o que apareceu no momento em que a utilidade do ler se tornou patente. Não se imagina a alegria que me diluviou o espírito quando cheguei, depois de provações terríveis, ao Manual. Pensávamos nós, os rapazes d'então, que esse livro era o 'non plus ultra' da ciência humana $\mathrm{e}$ que quem ali chegasse não tinha mais campo a percorrer nas aquisiçôes intelectuais. Saber aquele livro de cor e as contas da caixaria, eis tudo quanto era preciso para abarrotar todos os barbeiros da aldeia e todos os regedores, podendo-se até embarrilar o senhor padre cura da freguesia. E eu, perdoem-me a imodéstia, consegui no lance verdadeiros sucessos porque tinha a consciência de ser um portento no Manual, pois que o sabia quase de cor, sem perceber nada de tudo quanto a memória se encarregava de armazenar." 328
\end{abstract}

Acerca do significado da produção editorial de cunho enciclopédico para as escolas, parece haver, aí traduzida, a vocação jornalística que, à época, fervilhava nos países europeus, voltada para sua vertente pedagógica. Os saberes escolares teriam, desde a Renascença, um tom enciclopedista que o século XIX faria por acirrar. A idéia da cultura enciclopédica tornara-se bastante cara aos contemporâneos, posto que traduzira pretensamente uma súmula da conquista da realidade pelo homem. Talvez fosse a pretensão moderna de onipotência e de absoluto domínio sobre o universo

obtido pelo manual de Monteverde. Para Castilho, o efetivo uso do Manual Encyclopedico nas escolas primárias portuguesas significava o vigor que a idéia do enciclopedismo ia ganhando em Portugal. Para firmar sua convicção, declara-se o que aparentemente se pergunta: "não são só os institutos de educação estrangeiros que reconhecem e adotam o grande princípio do enciclopedismo; o nosso mesmo país já até certo ponto o vai admitindo. Que outra coisa é senão um começo de homenagem a ele, o que o Conselho Superior de Instrução Pública exerce nas suas instruções para os exames dos professores primários e secundários ? O Manual encyclopédico do senhor Monteverde não foi pelo mesmo Conselho Superior aprovado para uso das escolas primárias? Não está em todas elas em Portugal e no Brasil? Não se reimprime de contínuo e em grande cópia?” A. F. CASTILHO, Resposta aos novíssimos adversários do Methodo Portuguez, volume II, p. 168.

${ }^{328}$ A. FIGUEIRINHAS, Educação Nacional, 9-6-1901, n 246, p. 281. 
circundante que faria por tornar relevante o súmario enciclopedista do saber. Os contemporâneos julgavam que não haveria nada mais apropriado para a escola. O próprio pressuposto da vida escolar residia nessa confiança do aluno na capacidade do mestre. $\mathrm{O}$ mestre deveria revelar às gerações emergente conteúdos fixos e praticamente imutáveis que seriam, em seu conjunto, basicamente um fundo de cultura de feição especificamente escolar. É assim que ao mestre de escola competia dar a impressão de ser sempre aquele que conhece um pouquinho de tudo. Daí talvez o sucesso editorial que o Manual Encyclopedico de Monteverde conseguiria.

Ao folhear o Manual Encyclopedico, o leitor, embrenhado em conteúdos tão arcaicos quanto atuais, depara-se com o semblante mais típico da escola primária. Parece, de início, que se está diante de um guia para o professor dirigir e dividir suas aulas; não seria isso? De todo modo, a impressão que se tem é a de que os conhecimentos escolares são muito mais o pretexto para o aprendizado de certas competências, de um dado repertório. Dentro do espírito enciclopedista, havia de se familiarizar a criança com determinado conjunto de temas que lhe seriam de fato ensinados em uma aprendizagem posterior, caso ela vencesse essa dificílima etapa de escolarização primária, na qual os únicos conhecimentos efetivamente ensinados são os do "ler, escrever e contar". Além disso, evidentemente, a escola que produz e reproduz a moralidade traz, contida nos compêndios, sejam eles quais forem, toda uma gama de prescrições, de hábitos de conduta, recomendados para o homem civilizado. A escola, que diz preparar para o mundo, fala do mundo às crianças; de um mundo para o qual são necessários alguns sutis ensinamentos, dos quais a escolarização também se encarrega: o aprendizado do silêncio, da modéstia, da aceitação do existente como necessário, das rotinas cotidianas... É essa escola, essa cultura escolar de que o caso português é ilustrativo, que passa a ser aqui investigada.

Pode-se dizer que a investigação da leitura escolar é variável necessária para se compreender os esforços encetados por parte de certos grupos sociais quanto ao controle, à preservação e à perpetuação dos valores, dos costumes existentes ou pretendidos, das tradiçôes, enfim. Na verdade, a competência do ensino da leitura conferia singularidade ao papel da escolarização, dando-lhe efetiva visibilidade, mesmo que essa escola ainda não se tivesse estendido às camadas majoritárias da população. $\mathrm{O}$ povo observava a vida escolar. Fazia isso interessado, sobretudo, em saber quais valores, quais hábitos, qual vocabulário e, finalmente, quais conteúdos formariam o repertório dessa escola. Era como se, antes de formar para o ensino da escrita, a escola pretendesse ensinar as crianças a se portarem bem e a falarem bem o português correto - livre de quaisquer entonações regionais. Isso era o que se pretendia se os professores também não pertencessem aos vários distritos de Portugal; cada um com suas particularidades. Parecia imprescindível conferir às novas geraçôes a capacidade de expressão que as habilitasse para o mundo do trabalho, especialmente a vida comercial. Esperava-se também da escola que ela, ao ensinar, dirigisse e regrasse a leitura espontânea, pela apropriação muito particular que faria do acervo de conhecimentos historicamente acumulados pela humanidade. A escola recriava, a seu modo, os conteúdos humanos relativos ao saber passível de ser repartido pelos homens. Chega, às vezes, a parecer que os conteúdos pedagógicos foram todos eles inventados ali, na própria escola. Daí a importância tão grande dos livros didáticos. Eram eles que efetivamente traçavam aquilo que seria o guia orientador, a diretriz básica da vida escolar. Por ele, o professor estudava. Atráves dele, a leitura e o mundo seriam contadas às crianças. 
Compreender a escola, como querem Anne-Marie Chartier e Jean Hebrard, significa percorrer essencialmente dois territórios discursivos: por um lado, os textos oficiais e, por outro, aqueles verdadeiramente destinados a formar e a informar os professores. Os autores referem-se, então, a um diálogo entre as recomendações de ministros e inspetores e a vida cotidiana que se projetava todos os dias na escola, onde o lugar do manual escolar e a leitura que o professor faria dele eram, sem dúvida, tão ou mais importantes que as leis e as portarias que sobre a escolarização se publicavam. Como é que os professores construíam suas aulas? Aqueles professores - que, na grande maioria das vezes, não tinham qualquer formação específica sobre os conteúdos culturais que ensinariam -, que fariam eles? Por onde estudariam? Como organizavam o diálogo que deveriam ter com os estudantes e, inversamente, o diálogo que necessitariam ter com as matérias de ensino? Como ensinar, quando nunca se teve a oportunidade de ler um manual, ou roteiro qualquer, de pedagogia? Talvez esses professores se valessem dos compêndios; compêndios que lhe dariam, no mínimo, o tom a partir do qual eles poderiam compor a sinfonia da aula ${ }^{329}$. A partir dessa suposição, desenvolveu-se a hipótese seguinte; posteriormente confirmada por inúmeros testemunhos do século XIX: o Manual Encyclopedico era - pode-se dizer - um verdadeiro paradigma da escola portuguesa da segunda metade dos oitocentos. Por ele, realmente gerações e gerações de discípulos e aprendizes principiariam sua interação com o mundo da cultura escrita, folheando aquelas grossas e ilustrativas páginas...

O texto era sagrado e deveria ser mantido como tal. A leitura escolar deveria ser feita mediante a recorrência a trechos seletos e à disposição das matérias na seqüência e na profundidade que o compêndio daria a cada uma delas. O aluno deveria ler em voz alta e ser capaz de reproduzir com correção e clareza aquilo que leu. A leitura - como observam os estudiosos da questão - teria origem exatamente no ato da catequese e, por essa razão, a memorização era tão valorizada. O sistema de perguntas e respostas fora simbolicamente mantido, mesmo quando não era mais o Cathecismo de Montpellier que dominava o cenário. O "modelo escolar" mantém - com espírito de exatidão - a herança recebida da Igreja que no Antigo Regime o construiu. Fica muito claro para o caso português que a leitura da escola derivava, em grande parte, do intento de uniformização lingüística, do controle dos falares e dos sotaques regionais. Havia de se ensinar a escrever - se fosse possível. Mas, acima e além disso, havia de se ensinar à criança o falar com correção. Cabe recordar, entretanto, que, no percurso de todo o século XIX, a leitura escolar na escola primária portuguesa não supunha o célebre livro único. Talvez se caminhasse para isso; mas, por enquanto, tratava-se apenas da indicação de alguns compêndios que passavam pelo crivo e pela censura do Conselho Superior de Instrução Pública. Todos os que fossem aprovados poderiam ser utilizados. Ocorre que, muitas vezes, a escola se valia de um livro único para uso dos alunos em classe. Muitas vezes ela própria - escola - fornecia para os alunos exemplares do livro que adotava. Isso aparece claramente nos relatórios de inspeção consultados. Há inclusive casos de alguns professores que compravam, por iniciativa própria, os compêndios a serem utilizados com as crianças. Em algumas outras situações, ainda, a escola era tão carente, e tudo ali funcionava de maneira tão precária que não havia praticamente livros. O professor - ele sim - teria um Manual

\footnotetext{
${ }^{329}$ Circe Bittencourt, em sua tese sobre a história do ensino de História no Brasil, já demonstrou - para o caso brasileiro - a veracidade dessa hipótese segundo a qual o livro escolar forma também os professores que a ele recorrem.
} 
Encyclopedico, por meio do qual ele estudaria e transcreveria no quadro excertos e exercícios para os alunos copiarem. A leitura era, antes, coletiva e em voz alta, para depois ser individualizada, silenciosa. Havia um ritmo escolar que a atividade leitora ajudava a marcar. Sem dúvida alguma, há alguns textos que registaram, como ninguém, a história da escola portuguesa do século XIX, em seus usos e costumes...

Como se viu anteriormente, o livro escolar era, para o caso português, um elemento essencial, sobretudo para orientar e nortear o próprio cerimonial da aula. Era como se seu conteúdo, particularmente o de textos mais aprofundados como o do Manual, fossem direcionados antes como leituras recomendadas aos professores, de modo que, a partir delas, a aula pudesse ser construída. A escola valia-se daqueles filtros de cultura seleta para elaborar mecanismos muito particulares de apropriação cultural. Havia algumas obras escolares que resistiam ao tempo; e o velho livro continuava a ser utilizado, mesmo quando ele não era mais recomendado pelos órgãos superiores. As obras de Monteverde foram, indubitavelmente, um expressivo referencial a seu tempo, posto que, por um período de várias décadas, representaram alguns dos títulos encontrados com maior freqüência em sala de aula.

\begin{abstract}
"Emílio Achilles Monteverde, se não é um pedagogista na rigorosa acepção do termo, é um insigne vulgarizador das letras pátrias. Todos os leitores portugueses de uma certa geração conhecem desde a sua puerícia o Manual Encilopédico (...) que foi o livro mais espalhado em Portugal na segunda metade do século XIX. Monteverde é, sem dúvida, um dos propagadores incansáveis do ensino primário, não só pela fama que merecidamente alcançou no país, mas pelos lucros que indiretamente das suas edições lhe provieram." 330
\end{abstract}

Por essas palavras, Ferreira-Deusdado caracterizava a relevância da obra didática de Monteverde no conjunto daquilo que hoje se denominaria "saberes escolares" do ensino primário português na trilha do século XIX. A ênfase que entoaria o caráter de propagador de conhecimento é ressaltada como atributo que destacou aquele autor de manuais como um irradiador de idéias, disseminador de crenças, porta-voz de costumes e de códigos de conduta a serem espraiados. Enfim, um Monteverde educador da meninice portuguesa. O aprendizado "monteverdeano" perpassava uma coletânea de textos didáticos, todos eles dirigidos à escola primária, cada um voltado para um determinado bloco de matérias, sendo o primeiro deles a Cartilha de alfabetização. Assim, suas obras, aprovadas pelo Conselho Superior d'Instrução Pública, revelavam êxito pela própria tiragem editorial:

1. Methodo facillimo para aprender a ler tanto a letra redonda como a manuscripta no mais curto espaço de tempo possivel. Os capítulos anteriores já comprovavam que este foi o trabalho mais utilizado de Monteverde, superando o próprio sucesso do Manual Encyclopedico. As amostras recolhidas dos relatórios de inspeção de 1867 e 1875, guardados no Arquivo Nacional da Torre do Tombo não deixam motivo para a dúvida. Qualquer estudo acerca das práticas de alfabetização em Portugal do século XIX exigiria rigorosa análise dessa cartilha,

${ }^{330}$ M.A. Ferreira - Deusdado, Educadores portugueses, p. 439. 
cuja reprodução editorial é, por si, reveladora. Segundo dados do Diccionário Bibliographico Portuguez - pelo estudo de Innocencio F. da Silva - entre 1836 (ano da $1^{a}$ edição) e 1866 (ano da 9a edição), 414.350 exemplares da referida cartilha foram editados. ${ }^{331}$

2. O Manual Encyclopedico, que, dentre todos os textos de Monteverde, foi o mais proeminente e comentado pelos estudiosos da educação da virada do século (para ser curiosamente relegado ao esquecimento pela historiografia da educação que se segue a esse período), situa-se na mesma vereda que palmilhou uma certa tendência da produção didática francesa, na esteira do movimento iluminista, cuja tônica enciclopédica era recorrente ${ }^{332}$. A fé no progresso das ciências e das artes como alicerce de desenvolvimento da civilização pontuaria a fronteira da razão como matriz de entendimento do mundo. A dinâmica da configuração dos progressos da ciência viria, no caso português, conjugada a todo um temário religioso, moral e de civilidade, matérias assentadas no próprio conjunto programático do referido compêndio. À primeira edição do Manual Encyclopedico (que custava na época 480 réis), datada de 1838 , seguiram-se outras 8 , sendo a $9^{a}$ de 1870, perfazendo, nesse período, um conjunto de 156.000 exemplares. A tiragem editorial foi extremamente forte entre os anos 50 e 70, chegando a haver algumas ediçôes com mais de 40.000 exemplares.

3. O mimo à infancia ou manual de História Sagrada, indicado expressamente para uso das escolas portuguesas e brasileiras, revela, apesar de constituir uma obra didática menor em termos de êxito público, o projeto editorial de Monteverde em relação ao Brasil. Em 1859 estava no prelo, com uma tiragem editorial de 7.000 exemplares. Em 1869, a 2a edição era já de 10.500 exemplares. Ornado com 100 estampas, esse livro ensinava a história sagrada, procurando oferecer a ela um contorno acessível para a população infantil. A intenção provavelmente era a de ocupar o lugar preenchido por manuais excessivamente antigos, supostamente inadequados ou mesmo provenientes de tradução de originais estrangeiros. Sabe-se que, na época, eram muito lidos o Cathecismo de Montepellier e a Bíblia da Infância. A história sagrada era então dividida em sete épocas para conduzir a um efeito mais diretamente didático. No final de cada lição, para facilitar o esforço de memorização, colocava-se um rol de questôes sobre o tema da unidade correspondente, estratégia inovadora para o caso português daquela época. Havia, nesse sentido, uma orientação didática que o editor fornecia aos professores que eventualmente viessem a adotar o livro. Nos termos do anúncio que Monteverde fazia, seu mimo era claro e ordenado quanto ao conteúdo, fornecendo ao professor um método que o ajudasse a gravar as lições na memória do estudante.

Facilmente, em termos até mesmo quantitativos, pode-se perceber que a obra didática de Monteverde pretendia atingir um universo mais amplo do que o dos

${ }^{331}$ Do Diccionario Bibliographico Portuguez extraímos as informações acerca do número de exemplares de várias ediçōes de cada obra de Monteverde. Das inúmeras ediçōes localizadas do Manual Encyclopédico, a última data de 1952, agora sob o título Manuel Enciclopédico para Portugal e Brasil

332 Sobre o componente pedagógico do movimento enciclopedista francês, indica-se a tradução do "Discurso Preliminar" da Enciclopedie francesa, editada pela UNESP. 
leitores portugueses: havia ali, indubitavelmente, um prospecto para o Brasil. As obras de Monteverde abrangiam um universo de proposta pedagógica maior do que o próprio domínio do reino. Talvez a pretensão fosse a de assinalar o controle simbólico sobre os povos que outrora teriam constituído o império colonial português. De qualquer modo, a unidade linguística permitia concretizar tal pretensão.

\section{Eu ainda pertenço àquele tempo do Manual Encyclopedico}

O Manual Encyclopedico deveria dar continuidade às lições do Methodo facillimo para aprender a ler. Ele era assim anunciado. Organizado de maneira a tecer a confluência entre preceitos ético-religiosos e conteúdos de cariz científico-tecnológico, o Manual dialogava com uma dada acepção de sociedade, tomando por interlocutor prioritário o tipo ideal de cidadão do futuro. Dirigido também para as escolas do Brasil, parece bastante ilustrativo o artigo que se publicava a 22 de janeiro de 1851 no jornal brasileiro $A$ Voz Paraense. Tratava-se, no caso, de uma resenha sobre a $5^{\text {a }}$ edição do livro de Monteverde, edição esta que havia sido significativamente melhorada e adequada a parâmetros mais rigorosos em termos gramaticais e de aritmética. $\mathrm{O}$ autor, a partir de estudo que fizera de trabalhos desenvolvidos no exterior, havia introduzido modificaçōes no texto, procurando sempre atualizá-lo e aprimorá-lo. Nos termos da resenha, que, por seu turno, vinha publicada na $7^{\text {a }}$ edição (1859) do Methodo facillimo, tem-se o seguinte:

"A estes melhoramentos dados à $5^{\mathrm{a}}$ edição do Manual, acrescentou o seu autor os Elementos de civilidade, e adicionou, em todas as matérias de que se compóe a obra, o sistema e o método que se tem reconhecido como os mais vantajosos. Ousamos pois indicar esta obra como adaptá-la ao ensino da Instrução Primária, pelo método simultâneo, que, sobre ser muito menos trabalhoso do que o individual, é atualmente seguido nas nossas escolas públicas e particulares, e o mais acomodado a promover o adiantamento dos alunos." ${ }^{333}$

O Manual Encyclopedico começa com a apresentação do que intitula de "Princípios gerais de moral". Ali, explicita-se a moral como uma ciência direcionada para o bem, cuja origem etimologicamente seria costumes. Procura-se discorrer sobre a necessidade de a alma humana controlar o corpo, frear as paixões, impedindo o indivíduo de ser acometido pela propensão natural ao vício, à ociosidade e à preguiça. Sendo assim, ao dever de conservar o corpo, estaria atada a necessidade de o homem desenvolver seus potenciais e aptidóes para o trabalho, que o tornasse útil em relação à sociedade e ocupado em relação a si mesmo. Haveria deveres codificados em relação aos semelhantes, postos como uma derivação da autoridade de Deus. Esses deveres constituiriam as normas recomendadas de conduta; dentre as quais destacam-se algumas máximas de solidariedade: "não faças a outrem o que não quiseras que te fizessem / Devemos

${ }^{333}$ ARTIGO extraído da Voz Paraense, de 22 de Janeiro de 1851, apud. E. A. MONTEVERDE, Methodo facillimo para aprender a ler..., p. 157. 
fazer bem aos nossos semelhantes / Devemos ser agradecidos aos nossos bemfeitores / Devemos guardar a nossa palavra e cumprir as nossas promessas." 334

Como bem atesta Figueirinhas, era preciso saber de cor o Manual e ter habilidade para as contas do caixa. O instrumental teórico naquele compêndio contido veiculava como universais códigos de civilidade que, de fato, comporiam um dado perfil da urbanidade prescrita. Outrossim, toda uma ética do trabalho era veiculada no compêndio, de maneira a utilizar a naturalização das relações de poder como estratégia aliada a critérios de interdependência, decalcados de pretensa hierarquia entre os seres humanos "superiores" e os "inferiores". A linha de subordinação, por principiar na própria relação dos pais com os filhos, traçaria elos de obediência inelutáveis, na trilha mestre/discípulo e daí na relação com o mundo do trabalho, onde há patrão e empregado. $\mathrm{O}$ texto, ao recomendar benevolência, brandura e indulgência perante os inferiores, não perde, por tal razão, a brutalidade do diagnóstico:

\begin{abstract}
"Os nossos inferiores são aqueles que, por diversas condições, tais como empregos, serviços, educação ou outra causa qualquer, estão colocados abaixo de nós na ordem social. Assim, desde os filhos até os criados, todos, em uma família, são inferiores ao pai e à mãe. Na escola e outros estabelecimentos da educação, os discípulos são os inferiores do mestre. Geralmente em todas as posiçôes, em todas as situações imagináveis, os indivíduos que têm chefes são os inferiores desses mesmos chefes ${ }^{335 "}$.
\end{abstract}

Tratando da sociedade como se ela estivesse eterna e invariavelmente cindida por categorias ou classes sociais diferenciadas, procurava-se habituar o discípulo a isso, sugerindo-lhe regras de comportamento, de urbanidade, que conduzissem os modos distintos de tratamento. Perante os superiores, dever-se-ia - a partir da referência paternal - ser submisso, modesto, moderado, circunspecto, respeitoso. Os inferiores solicitam dos que estão acima deles na escala social um tratamento pleno em benevolência, brandura e bondade. A severidade, no caso, deverá ter sempre por contraponto a indulgência. O tratamento mais solto, livre, espontâneo e indubitavelmente criativo é entretanto aquele que se pode/deve dispensar aos iguais.

A moral é caracterizada como a ciência que recorta e seleciona o patamar do dever enquanto âncora de sustentação da conduta humana: deveres para com Deus, para com os semelhantes, superiores e inferiores, deveres para com os pais e mestres, deveres para consigo mesmo. O amor que os filhos deveriam prestar aos pais estaria já consagrado desde os hebreus, que o teriam escrito "metade na primeira Tábua da lei, que se referia ao direito de Deus, e metade na segunda Tábua, que dizia respeito ao próximo, como sendo metade divino e metade humano" 336 . O filho deveria ser, portanto, em relação a seus pais, sempre modesto e submisso, pedindo licença inclusive para expor suas observações acerca de qualquer assunto. A autoridade paterna seria, historicamente, o modo encontrado pela sociedade para conter os "filhos desobedientes, se porventura os houvesse". Em todos os povos de que se teria notícia, teria

\footnotetext{
${ }^{334}$ E. A. MONTEVERDE, Manual Encyclopedico, $10^{\text {a }}$ edição, p. 7.

${ }^{335}$ E.A. MONTEVERDE, Manual Encyclopedico (4ª edição), pág. 25.

${ }^{336}$ E. A. MONTEVERDE, Manual Encyclopedico, 4a edição, p. 10.
} 
existido o dever de regrar as relações dos filhos perante os pais pelo signo do acatamento, da obediência, da docilidade. Essa "piedade filial" contribuiria para o "bem-estar" das sociedades.

Ao tomar por interlocutor privilegiado um dado padrão civilizatório, o discurso circunscreve componentes de subjetividade individual apresentados como quesitos imprescindíveis para aperfeiçoar o tecido social. Recomenda-se que cada um se possa expressar em público a partir de níveis de autocondicionamento - capazes de frear e de dirigir a leitura que o outro faz de cada ser humano por meio da visibilidade de seus gestos e expressões. A representação de si próprio perante o outro estrutura na $8^{a}$ edição do Manual uma unidade própria que, pelo menos até a $4^{a}$ edição, não existia enquanto tal: civilidade. A civilidade é apresentada literalmente como "a prática de todas as atenções para com os nossos semelhantes na sociedade, evitando, assim nas palavras como nas ações, tudo quanto possa ofendê-los ou desagradar-lhes. A civilidade é o sinal distintivo de uma boa educação, e dispõe logo os outros em nosso favor." ${ }^{337}$ O título dessa unidade, bem como sua caracterizaração preliminar são já ilustrativos de um território de atitudes de "distinção"; sinal da boa educação no trato de uns para com os outros em função de um suporte que transcenderia o próprio homem, quando este, na vida social, vê-se na obrigação de se comportar em consonância com as regras do viver junto. Assim, diz o texto:

\begin{abstract}
"Aonde tem origem a civilidade? Nos sentimentos de um coração bem formado. Quais são esses principais sentimentos? O respeito aos superiores; a benevolência para com os iguais e a indulgência para com os inferiores. Mas não nos prescreve a religião o dever de exercer esses sentimentos? Certamente. A verdadeira civilidade, em toda a extensão da palavra, tal qual a devemos considerar não é outra coisa mais do que essa caridade inteiramente fraternal que o Evangelho nos prescreve: 'Não faças a outrem o que não quiseras que te fizessem; faze-lhes o que quiseras que te fizessem" 338 .
\end{abstract}

$\mathrm{Na}$ verdade, como rito, a escola institui e mobiliza práticas de civilidade. A civilidade corresponde a um determinado conjunto de atitudes que ensinam o indivíduo a se comportar. São prescriçôes de gestos e de atitudes que devem ser aprendidas desde o berço até a escola. Prescrevem-se coisas simples, como regras mínimas de aparência, vestimenta e asseio corporal. Alguns padrões e parâmetros de conduta civil - que acompanham gestos singelos, como o assoar-se, o espirrar, o cuspir no chão e o apagar a luz com um sopro - precisariam ser reconhecidos e incorporados. Além disso, era necessário também identificar as normas de conduta recomendadas para a visita de amigos e de parentes: prazos, bilhetes, como entrar, quando sair, etc.. A civilidade dispunha, ainda, sobre a maneira pela qual os homens deviam se comportar na rua ou em lugares públicos, como proceder quando entrassem nas igrejas. Deve tembém a civilidade regrar os modos de se conduzir à mesa, como usar os talheres. Enfim, a civilidade era acima de tudo a civilização dos costumes; e a es-

${ }^{337}$ E. A. MONTEVERDE, Manual Encyclopedico, 8a edição, p. 240.

${ }^{338}$ E. A. MONTEVERDE, Manual Encyclopedico, $8^{\text {a }}$ edição, p. 240. Esse debate sobre o tema da civilidade no livro escolar tem como suporte teórico os trabalhos de Norbert Elias, em especial O processo civilizador. 
cola, o rito dessa iniciação civilizatória... A civilidade era, em uma palavra, o aprendizado da postura. ${ }^{339}$

A civilidade prescrita abarca estratégias de agir e de falar, capazes de despertar a afeição do outro, estreitando, com isso, laços de solidariedade social. Era imprescindível ao homem em sociedade o saber ouvir e o saber falar. Era necessário reconhecer o momento apropriado para defender suas razões e, no mesmo acorde, saber calar e abdicar de argumentos teimosos. A lei da sociedade exigia a configuração do ritual; ritual esse que competia à escola instaurar. A escola ritualizada não reproduziria então a teia da sociedade, mas produziria alguma coisa de inédito, de insuspeito, de inusitado. A escola, assim, pelo discurso e pela prática, engendraria estratégias de produção de consenso, capazes de garantir a ordem pública, conformando cada um para ocupar espaços - alguns já bem delimitados e outros por delimitar - no contorno da sociedade.

Dizem os livros de escola que a família se configura como célula primeira da vida social, "a sociedade mais pequena". Ao caracterizar o povo civilizado como o grupo social urbano, letrado e comercial, na outra margem, estaria já posto o incivilizado, reconhecido, desde logo, pelo que lhe falta - em sua condição iletrada de organização rural e agrícola. A nação é a coletividade sujeita a leis, costumes e língua comuns; distinguindo-se, dentre sua população, cinco classes, assim arroladas: classe produtiva, classe industriosa, classe comercial, classe mercenária ("composta de todos aqueles que alugam o seu trabalho a um indivíduo ou ao todo da sociedade"), classe dos empregados (funcionários públicos). O poder do Estado jurídico decorreria do conjunto de forças constitutivas da nação. Por sua vez, a nacionalidade - na esteira do alerta que Ribeiro Sanches fizera a um século - tinha por imperativo categórico o equilíbrio demográfico, mediante o seguinte pressuposto: "a força de uma nação depende da população, isto é, da relação que existe entre a extensão superficial e o número de almas que nela há; das forças de mar e terra, cujo aumento depende da população e das rendas do Estado; da indústria, manufatura e comércio, que de um Estado podem fazer um poderoso Império ${ }^{340}$ ". Em todo o passeio geográfico pelas fronteiras da Europa; depois, pela demarcação de cada província portuguesa, uma a uma, os vários aspectos climáticos, populacionais ou produtivos seriam reveladores do semblante de um povo saudoso de tempos gloriosos pela aventura das navegaçōes. Um Portugal em busca da identidade que a perda do Brasil porventura abalara; um Portugal que se desejava fazer reconhecer ao olhar da infância; um Portugal que sublinha sua vocação, recordando às gerações mais jovens exemplos heróicos de vultos grandiosos na senda de um certo talento para a epopéia. Nessa perspectiva, O Manual Encyclopedico tece breves comentários sobre os principais literatos portugueses, seguidos por "noções

339 "Cometerá uma incivilidade aquele que se encostar à parede, aos móveis, principalmente à cadeira de outrem, fizer trejeitos, etc. Qual é pois a melhor postura quando se está em pé diante de pessoas de respeito? Ter a cabeça e o corpo direitos, os braços caídos, mas um deles algum tanto dobrado, tudo sem afetação e os pés pouco afastados. Que postura deve guardar quem está sentado ? A mais modesta e a menos incômoda para os que se acharem a seu lado. Não deve sentar-se atravessado, nem passar o braço pelas costas da cadeira. É incivil adormecer, bocejar, recostar-se, balancear-se, cruzar as pernas, descansar os pés nas travessas das cadeiras, esfregá-los no sobrado, levantar-se sem precisão quando todos estiverem sentados, ficar sentado quando os outros se levantarem, e descansar a cabeça na mão" (E. A. MONTEVERDE, Manual Encyclopedico, 8a edição, p. 215). O item de onde se retirou o referido excerto intitula-se "Como se deve estar diante das pessoas de respeito.

${ }^{340}$ E.A. MONTEVERDE, Manual Encyclopedico, 8 a edição , p. 379. 
gerais de física" e desembocando na mitologia greco-romana. Tal linha descontínua que tece a ordenação do discurso revela a coexistência de uma configuração do real eivada de misticismo, na mescla entre paganismo supersticioso, religiosidade e conhecimento científico. Por essa tríplice encruzilhada, o Manual pretendia falar ao coração do homem do povo, que nele se reconheceria e por ele far-se-ia capaz de superar as próprias limitações. Nessa circularidade entre cultura popular e conhecimento erudito esteve contida parte do segredo da fórmula enciclopédica tão notoriamente aplaudida no transcurso de gerações de crianças portuguesas.

\section{A escola como liturgia}

O Manual Encyclopedico tornar-se-ia, por seu efeito irradiador, uma referência intransponível a dada altura, angariando adesão e rejeição, consoante o interlocutor. Já o $\mathrm{n}^{\circ} 31$ do periódico O Panorama revelaria o parecer de Herculano a propósito da obra recém-editada naquele mesmo ano de 1837. Tido como literatura da infância, o livro preencheria, segundo aquele jornal, uma reconhecida lacuna na vida intelectual do país: ao expor com clareza e simplicidade um conjunto temático de conotação efetivamente enciclopédica, o texto capacitaria a infância para travar contato com o universo da cultura em suas mais variadas expressões. Várias resenhas da obra, ainda em seu nascedouro, recomendavam aos especialistas sua adoção, evocando o que ali se dizia sobre o homem, sobre o conhecimento, sobre a civilização. A enorme receptividade daquele manual que, segundo os dados dos relatórios de inspeção de 1867 e 1875 , teria sido adotado na quase totalidade das escolas do reino - em todos os distritos, nas mais pequeninas aldeias - permite qualificá-lo como um livro de referência privilegiado pelo professor primário no transcurso de décadas. Havia, sem dúvida, uma estratégia editorial acionada por Monteverde que facilitou o efeito irradiador do texto. Monteverde fizera parte do Conselho de Sua Magestade, tendo sido Comendador da Ordem de Cristo; toda sua atuação qualificá-lo-ia antes como político de seu tempo do que propriamente como apóstolo da causa da instrução. A par disso, parece-nos, no entanto, evidente que a aceitação pública e a resistência ao tempo que fizeram por consubstanciar a era do Manual Encyclopedico foram também tributárias de práticas de leitura e de um universo de leitores que se sentiram identificados com o repertório simbólico expresso pela dinâmica interna àquele discurso enciclopédico. Tanto é assim, que se tornou hábito festividades solenes de escolas oferecerem aos alunos mais destacados exemplares do Manual. ${ }^{341}$.

Outros autores, ao apresentarem suas obras didáticas, passaram a fazê-lo pela interlocução com o texto de Monteverde: o Manual ia ganhando, com isso, expressões evidentes de candidato a unanimidade nacional. Poder-se-ia ser contra ele, mas já não

${ }^{341}$ A esse respeito, exemplificar-se-ia, recordando que a sessão comemorativa do $5^{\circ}$ aniversário da inauguração da Escola Castilho, que teria ocorrido em janeiro de 1881 no salão do Liceu Nacional de Lisboa, procederia à distribuição de prêmios aos alunos mais destacados. Tais recompensas ao mérito corresponderiam ao recebimento de volumes encadernados do Manual Encyclopedico, do Paes de Família e das Memórias do Visconde de Castilho, fazendo por parecer que, se o objeto da escola representava homenagem à didática de Castilho, o veículo de sua prática era, curiosamente, o texto de Monteverde. 
seria possível passar sem a sua menção. O impacto de tal proeminência no mercado, em alguns casos, ganha o timbre da rivalidade, como se depreende do teor da introdução da Enciclopédia das escolas d'instrução primária, que vem a público em 1854, sob autoria de Julio Caldas Aulete e José Maria Latino Coelho. Caldas Aulete, aliás, sabia que se defrontava com Monteverde e perdia para ele no texto indicado como cartilha de primeiras letras. Por mais que sua Cartilha Nacional fosse apreciada e debatida pelos especialistas, por mais que realmente os professores estivessem, em grande número, adotando aquele compêndio que pretendia ensinar o ensino concomitante da leitura e da escrita, mesmo assim, o Methodo facillimo de Monteverde ainda fazia mais sucesso. Havia nele qualquer coisa de imbatível, impermeável a concorrências...Caldas Aulete desejava, então, ao menos, destronar o reinado de Monteverde no nível médio da escola elementar. Para os meninos que já soubessem ler, ele propunha uma obra alternativa. Ao longo da introdução dessa nova Encyclopedia das escolas de instrucção primaria, Latino Coelho e Caldas Aulete observavam aos leitores que o problema fulcral da escola portuguesa estaria posto no dilema e nas dificuldades dos professores e especialistas da educação quanto ao método de ensino e da expressão de tal perplexidade na carência de obras didáticas apropriadas para a escola de instrução primária. Acreditava-se que era a ausência do bom livro um dos problemas básicos que obstaculizavam o bom ensino, como se o próprio método pudesse vir codificado pelo texto dirigido diretamente à escola, ao professor e até ao aluno. O professor não é por definiçãa - um escritor e um humanista especializado nas múltiplas áreas do conhecimento. Reconhecia-se a falta de livros apropriados; partia-se inclusive dela para propor este novo. A grande questão colocada aos educadores da época consistiria, pois, na inadequação do material didático utilizado em sala de aula perante o destinatário precípuo: a criança da escola primária. Dessa maneira, as obras apresentariam ora uma complexidade demasiada para a capacidade cognitiva do aluno, ora uma simplificação exagerada. Por causa disso, o mercado editorial passava a ser ocupado por obras que pretenderam situar-se como alternativa perante aquela situação. Monteverde, mais do que ninguém, valeu-se da demanda social por livros para crianças e, sob esse aspecto, malogrou o projeto de Latino Coelho e Caldas Aulete. A substituição pretendida não resultou e Monteverde permaneceu, praticamente até o final do século, com a indisputável liderança entre aqueles que escreviam para a infância. O imaginário das práticas escolares em Portugal exige a leitura de seu entrecruzado discurso enciclopédico.

Ao costurar uma teia de múltiplos significados, o compêndio escolar produz interdisciplinaridade ao recriar, até certo ponto pela invenção, um tipo específico de saber, que veicula como absoluto e legítimo. Esse monopólio interpretativo traduz sempre determinado leque de escolhas, naquilo que uma época elege como pedagogicamente correto. $\mathrm{O}$ mundo contado às crianças resulta, pois, de um arbítrio, circunscrito por uma dinâmica social, política e econômica, cuja expressão mais nítida é exatamente o acolhimento de determinados textos por um círculo maior ou mais restrito de leitores. Os textos de Monteverde - no caso em pauta, o Manual Encyclopedico - podem ser qualificados como uma das versôes vencedoras acerca do que se pretendia contar às crianças. De fato, a sociabilidade prescrita, os códigos de civilidade, a apresentação aritmética do mundo do trabalho, os valores que normatizariam as sugestões de conduta - abnegação, esforço, perseverança, obediência, caridade, tolerância, 
honestidade, resignação -, configuram, em seu conjunto, uma construção do tipo ideal para pensar o futuro homem português. A escola, cujo traço simbólico é a formação das almas infantis, elege e classifica um dado manancial de discursos e de representaçóes, os quais, entrecruzados na dinâmica do cotidiano, instaurariam o crivo de uma suposta normalidade do real. Esta é apresentada como natural, o que facilita estratégias de hierarquias e exclusóes perante o argumento de tal autoridade, dita e confundida com conhecimento.

Pelo exposto, verifica-se que, adotado em profusão nas escolas, o Manual Encyclopedico correspondeu historicamente à versão oficialmente aprovada sobre como falar do mundo às crianças. A utilização efetiva do texto nas classes de escolas primárias revela, por sua vez, alguma correspondência perante o desejo de equacionamento dos anseios intelectuais do magistério primário. Ao produzir a ilusão de discorrer sobre tudo, o Manual perfilha a vontade de saber e a vontade de, sabendo, ser capaz de ensinar: utopias de professor primário. Haveria, na entrelinha do seu discurso, o firme propósito de estruturar partilhas de conceitos e compreensão de significados, que, apresentados como inequívocos, modelariam uma específica forma de olhar para o mundo. O texto do Manual Encyclopedico demonstra, além de tudo isso, a existência de alguma interlocução entre o componente do discurso teórico - dos políticos, dos jornais e das revistas - acerca das práticas escolares e o ritual cotidiano das salas de aula. Há nitidamente uma semi-correspondência entre aquilo que se pensava e aquilo que, de fato, era o dia-a-dia das escolas primárias de Portugal daquele tempo.

O século XIX português pretendeu encontrar o livro da infância: um livro que ensinaria a ler e a escrever, mas que falaria também das virtudes públicas e privadas necessárias à vida social. Havia uma tendência para que aqueles tempos fossem de fato entendidos como o tempo da leitura e, nessa condição, como o tempo de se esboçar manuais enciclopédicos e métodos facílimos... Em artigo intitulado "Estudos sobre os diferentes métodos de ensino do ler e escrever", publicado em O Panorama no ano de 1854 , J. M. Latino Coelho destacava a precariedade na qual permaneciam as escolas do ler, escrever e contar, obstaculizando o próprio progresso da instrução. Naquela época, ainda era muito frequente nas práticas o uso de abecedários e manuscritos para o ensino da leitura e da escrita ${ }^{342}$. Com a finalidade de proceder à regeneração da pátria mediante a valorização da instrução popular, os teóricos da educação frisavam a necessidade social de utilização da letra impressa, tipográfica, como parâmetro essencial do processo da alfabetização, que, em larga escala, ainda privilegiava apenas o ensino da letra manuscrita.

Nota-se, entre os articulistas desse período, a preocupação com a inexistência de orientação para os professores traçarem diretrizes em relação àquilo que se poderia entender como o conjunto dos 'saberes elementares escolarizados' ${ }^{343}$. Era preciso haver livros para explicarem a matéria aos professores; para ensinarem o quê e como ensinar.

${ }^{342}$ Em Os caminhos do ABC; sociedade portuguesa e ensino das primeiras letras, Rogério Fernandes reconstitui o panorama do ensino dos saberes elementares da escola portuguesa no século XVIII, o autor considera a "hipótese de que a iniciação à leitura se fizesse basicamente por letra manuscrita, a despeito da existência de cartilhas impressas" (R. FERNANDES, op.cit., p. 247).

${ }^{343}$ Utiliza-se aqui a expressão de Hebrard, em seu ensaio sobre "A escolarização dos saberes elementares na Europa Moderna”. 
Eram prescritas sugestôes que impulsionassem a unidade da escola, tendo em vista dois objetivos matriciais: a eficácia do intuito alfabetizador e a inculcação de valores morais. Tratava-se de um período marcado por intenso fervilhar de debate e circulação de idéias acerca do temário da leitura, da utilização pela escola do texto impresso; até para espraiar códigos de conduta profissional capazes de dar uniformidade à atuação do professor em sala de aula.

Vista muitas vezes com entusiasmo, a imprensa, com todo seu apelo à leitura, poderia tornar-se, todavia, veículo perigoso de irradiação e circulação de idéias más. É assim que autores da época, ciosos por acoplar instrução e virtude, nos próprios jornais onde escrevem, costumavam precaver seus leitores contra a leitura desavisada, espontânea, convidativa porque atraente... Submergir no mundo desconhecido do escrito poderia representar um ato de subversão da ordem e de questionamento das práticas corriqueiras e das instituições tidas por naturais. Por ser assim, convida-se o leitor-interlocutor a proceder à gesta da leitura reflexiva que, sob tal estatuto, exigia como imperativo o recorrente afastamento da atração exercida por leituras frívolas, em prol do que se supunha ser o estudo sério para formação de hábitos. Tal concepção do lugar social da leitura possibilitaria o pensar por si próprio, atividade derivada, no caso, da própria atitude de desconfiança perante as tentações exercidas pelo texto impresso, como veículo material do espraiar da ciência. O progresso da civilização só poderia ser acatado se viesse acompanhado do esforço de moralização. Aqui estaria a obra precípua da escola e do ritual do ensino da leitura e da escrita. Sob a mesma orientação, havia intenso entusiasmo com um jornalismo de cunho pedagógico, que pretendia a divulgação dos conhecimentos úteis, o que, por sua vez, coincidirá com a intensificação do processo de editoração de compêndios escolares.

\section{Método Facílimo para aprender a ler no mais curto espaço de tempo possível}

Até o título é sugestivo: uma cartilha que se pretende dar a ver por ensinar a ler no mais curto espaço de tempo. Acreditava-se ser imprescindível alterar padrôes de espacialização e de temporalidade para que se pudesse verdadeiramente acompanhar a modernidade. A $7^{a}$ edição do compêndio que Emilio Achilles Monteverde escrevera para o ensino inicial da leitura - Methodo facillimo para aprender a ler tanto a letra redonda como a manuscripta no mais curto espaço de tempo possivel - (com data de 24-8-1859), principia com uma advertência do autor, apresentando ao leitor a obra que, em edição precedente, teria esgotado em três anos os 80.000 exemplares de que dispunha. Além disso, Monteverde sugere, desde o princípio, o vínculo entre o sucesso desse compêndio e sua notória ambição, expressa já no próprio título, de elaborar um método; método, aliás, que se auto-intitulava facílimo e que se dispunha a ensinar crianças a ler com brevidade, no mais curto espaço de tempo possível. Evidentemente, temos aí a busca incessante do domínio da destreza quanto ao ensino como um elemento profundamente competitivo no que toca à concorrência entre os compêndios didáticos em voga naquela época. Todos queriam ensinar a ler por um método fácil. Todos queriam ensinar a ler rapidamente. Na verdade, supunha-se haver um segredo, uma alquimia escondida no magistério, pertencente apenas a alguns, que não a confessavam para ninguém. O que muitos autores de manuais então faziam era apropriar-se 
desse imaginário, dessa convicção partilhada para procurar vender seus trabalhos à luz de sua constante referência. Dizia-se, então, com extrema freqüência, que esta ou aquela cartilha em particular - que a cada momento se anunciava - ensinava com mais brevidade, de uma maneira mais fácil, sem cansar o aprendiz, por procurar ser atraente. Ao que parece, pela quantidade de livros que de fato conseguia vender, Monteverde teria conseguido convencer seus leitores.

$\mathrm{Na}$ verdade, Monteverde pretendia explicitamente que a utilização escolar de sua cartilha fosse sucedida pelo uso de seu Manual Encyclopedico, anunciado ao final da mesma cartilha "para ajuizar da utilidade que da sua adoção poderá resultar aos estudiosos" ${ }^{344}$. Evidentemente, a primeira indagação a ser feita é a seguinte: qual o segredo do êxito editorial desta obra de ensino da leitura? O que fez do Methodo facillimo a cartilha mais utilizada em Portugal do século XIX? Com o fito de equacionar esse enigma, procurou-se - como já se fizera para o caso do Manual - percorrer suas páginas e descobrir ao menos alguns rastros. Buscou-se, por exemplo, reconstituir vestígios indicativos de maneiras pelas quais o texto era lido; há sinais nesse sentido...

Não há dúvidas de que o Methodo facillimo de Monteverde foi a cartilha que maior alcance teve em Portugal no período compreendido entre 1850 e 1880 . Ocorre que, anteriormente a ela, não haveria nenhum livro escolar que conseguisse suas enormes tiragens. À primeira edição do Methodo facillimo datada de 1836 , seguiram-se a de 1837 , a de 1841 , a de 1845 e a de 1851, perfazendo, até então, um total de 134.350 exemplares, que eram vendidos - cada um deles - por 100 réis. A 6a edição sozinha, assim como $7^{\mathrm{a}}$, datadas repectivamente de 1856 e 1859 , foram já publicadas com 80.000 exemplares cada uma; a edição seguinte, com data de 1863 , foi lançada com 100.000 exemplares, e a 9a edição teve, em 1866, 150.000 exemplares a serem vendidos. Supõe-se que, pela proximidade que tinha perante os poderes políticos e econômicos constituídos, Monteverde tenha se destacado naquela altura como o escritor oficial autorizado e preferido pela "corte". Há inclusive indícios de que seus livros tenham obtido um reconhecimento e um incentivo governamental, quando eram distribuídos por autoridades centrais, distritais e municipais para uso das escolas. Justino Magalhães relata, por exemplo, que a 6-10-1843, o governo enviava para o Governador Civil de Castelo Branco, para que fossem utilizados em escolas de meninas daquela região, cinquenta exemplares do Methodo facillimo para aprender ler, quarenta exemplares do Manual Encyclopedico - ambos de Monteverde - além de alguns outros exemplares do Cathecismo de Montpellier, obra que também era - como se pôde constatar pelo levantamento feito a partir dos relatórios de inspeção - extremamente utilizada naquela época. ${ }^{345} \mathrm{O}$ favorecimento dado aos compêndios de Monteverde ficava nítido, também, considerando-se a facilidade com que o autor contara para lançar edições com tiragem sempre superior ao número médio de compêndios editados por outros autores. De todo modo, há que se reconhecer a facilidade de divulgação de Monteverde - cujas obras eram enviadas também para as colônias,

${ }^{344}$ Emilio Achiles MONTEVERDE, Methodo facillimo de aprender a ler tanto a letra redonda como a manuscripta no mais curto espaço de tempo possivel, p. 1.

${ }^{345}$ Justino Pereira MAGALHÃES, Ler e escrever no mundo rural do antigo regime: um contributo para a história da alfabetização e da escolarização em Portugal, p. 218. 
particularmente para o Brasil. Eram livros fáceis de ser adquiridos, acessíveis em termos de preço, encontravam-se em toda a parte e o autor podia fazer anúncios em revistas de grande porte.

Retomando, depois dessa breve digressão, o Methodo facillimo, verifica-se, já à partida, a preocupação de Monteverde quanto ao estabelecimento de protocolos de leitura que garantissem eixos e diretrizes analíticas capazes de orientar o próprio percurso da alfabetização. Era como se aqui o autor se preocupasse com a conformação de estratégias de ensino-aprendizado que realmente contribuíssem para que sua cartilha se tornasse método, e que este método ensinasse a ler e a escrever simultaneamente e no mais breve espaço de tempo possível. Com tal objetivo, a cartilha principia com um prefácio intitulado "Diversos métodos ou modos do ensino elementar". Tratava-se de uma explicação preliminar acerca das diferenças entre o ensino individual, o ensino simultâneo e o ensino mútuo, sugerindo curiosamente - a superioridade desse último modo de ensinar em relação aos demais, particularmente naquilo que dizia respeito ao aprendizado da leitura, escrita e cálculo.

Considera-se que o ensino individual é pouco proveitoso, tendo em vista o elevado número de alunos que acorriam às classes e à dificuldade de sistematização do trabalho docente perante a dispersão do aprendizado, que corria sem qualquer orientação de equipe. O ensino simutâneo - por sua vez - teria como características o "fazer seguir ao mesmo tempo a toda uma classe a mesma lição de leitura, escrita, cálculo, etc., isto é, o professor manda ler a cada um em voz alta, e os outros o vão seguindo em seus livros ou cadernos." ${ }^{446} \mathrm{O}$ professor passa sucessivamente de uma a outra classe (já que na mesma sala de aula os alunos estariam agrupados por níveis de aprendizado), tendo todo o cuidado para que todas as crianças às quais não estiver diretamente assistindo estejam a todo momento ocupadas com exercícios. A vantagem desse modo coletivo de ensinar era - segundo o texto - o constante e recíproco estímulo das crianças umas às outras, o que contribuiria para um coletivo aproveitamento das liçôes. Como contrapartida, muitas vezes, o professor não era capaz de dar conta de classes diversas ou turmas com diferente adiantamento pedagógico, o que prejudicaria o trabalho docente se não houvesse nenhum ajudante ali disponível. O ensino mútuo era, nessa medida, o termo médio, o justo meio entre o individual e o coletivo; apresentado pelo autor como "o método simultâneo modificado". Partia-se do pressuposto segundo o qual as crianças - "grandes imitadoras" - imitam mais facilmente os seus companheiros do que as pessoas de idade mais avançada; e, sobre este princípio, fundou-se o ensino de umas crianças para com as outras, conhecido como ensino mútuo. Um único professor bastaria para uma escola inteira, por maior que fosse o número de alunos que a freqüentassem. Porém, “à testa de cada classe ou turma há um discípulo denominado Monitor ou Decurião, que faz as vezes de Mestre, e transmite aos outros as lições que ele próprio recebeu em uma classe superior". ${ }^{347}$ Assinalando a vantagem

${ }^{346}$ E. A. MONTEVERDE, Methodo facilllimo para aprender a ler tanto a letra redonda como a manuscripta no mais curto espaço de tempo possivel, p. 5.

${ }^{347}$ E. A. MONTEVERDE, Methodo facillimo para aprender a ler tanto a letra redonda como a manuscripta no mais curto espaço de tempo possivel, p. 6. 
do ensino mútuo para o aprendizado da leitura, escrita e aritmética elementar, Monteverde destaca a relevância do fator "habilidade docente" para o sucesso daquela estratégia de ensino.

$\mathrm{Na}$ seqüência do mesmo prefácio, estabelecem-se as distinções entre os "métodos de ensinar a ler", classificados como método antigo; novo método de soletração; método sem soletração. O método antigo era aquele no qual o processo da alfabetização principiaria pelo reconhecimento das letras, tomadas estas sucessivamente pelos nomes que já lhes eram usuais: éme, éne, ó, pê, quê, érre, ése.... Esse método - que, como destaca Rogério Fernandes em seu trabalho, era criticado desde o século XVIII como obstáculo ao êxito da aprendizagem dos discípulos - persistia com enorme força nas escolas portuguesas, embora fosse qualificado de "vicioso" pelo fato de não haver qualquer correspondência entre a pronúncia da letra e a conformação das sílabas com elas formadas (posto que a junção de 'eme' e 'a' não forma ' $m a$ ').

O novo método de soletração fora criado exatamente para a correção de tal desvio. Sua estrutura consiste fundamentalmente em pronunciar as consoantes como se estas fossem seguidas por um e mudo; como por exemplo be, ce, gue, je, etc.. Esclarece Monteverde que alguns autores preferiam este novo método de soletração ao antigo, ressalvando, porém, que havia quem se recusasse a adotar qualquer processo que envolvesse a prática da soletração das letras. Esses últimos preconizariam então o ensino cujo ponto de partida não mais fosse a identificação das letras, mas sim a sonoridade das sílabas. Tal processo da silabação deslocaria o elemento básico da palavra, dado que aqui o essencial era o leitor identificar nas consoantes o valor que elas, de fato, teriam na leitura de cada palavra em particular, sem autonomizar tais consoantes com um valor sonoro deslocado e nomenclatura destituída de qualquer significado. Os métodos, então, variavam entre o método alfabético (antigo e moderno) e o método silábico. Recorda-se que há aqui confronto entre procedimentos distintos de análise e síntese para o gesto de alfabetizar.

O método silábico é posto aparentemente como o mais avançado, embora não se possa dizar que Monteverde explicitamente se declare seu partidário. Muitas vezes, os autores de cartilha deixavam de apresentar seu parecer sobre as questôes de metodologia e didática, até para não contrariarem seus potenciais adeptos. A esse respeito, o próprio João de Deus - como se viu - começava o processo do ensino da leitura pelo reconhecimento da palavra, partindo depois para as sílabas e finalmente para seu desdobramento nas letras. Apesar disso, embora João de Deus teorize acerca da necessidade de se partir do significado, da semântica e não das questôes de ordem fonética, ele - mesmo assim - garante a seus adversários que jamais pretendeu começar pela compreensão da palavra o processo do ensino da leitura. Também Monteverde - que teria sido, no mínimo, o predecessor mais importante de João de Deus quanto à prática escolar - apenas sugere o método que tem por preferido...

"Partindo desse princípio, deve-se ler, por exemplo, a palavra a mi go sem decompor as sílabas, isto é, sem nomear cada uma das letras de per si, como sucede pelo método antigo. Como, porém, cada um dos métodos de que acima se fez menção tem as suas vantagens e seus inconvenientes, e sejam diversas as opiniōes sobre o modo mais proveitoso de se ensinar a ler, observaremos que o melhor método é um professor hábil e zeloso dos seus deveres; o melhor 
método é aquele que conduz mais longe com maior brevidade; finalmente, o melhor método é aquele que forma melhor os seus discípulos." ${ }^{348}$

Tal discurso introdutório daquele prefácio, dirigido evidentemente aos professores, consistia em uma breve preleção pública sobre o ato de ensinar. Ao pontuar os modos de ensino em geral e da alfabetização em particular, Monteverde convida os alfabetizadores à reflexão sobre seu ofício. Entre convicções e embaraços, o autor revela a si próprio e à sua cartilha pela recorrência ao pluralismo e a uma suposta abertura metodológica. Esse parecer teórico era também um modo de educar e incitar a confiança dos leitores. Aproximava deles o texto, dizia-se a eles que se conhecia a arte do ensino, que se sabia como proceder em uma sala de aula, que se tinha portanto a experiência da prática e que, por causa dela, se poderia falar em teoria. Os requisitos de uma boa alfabetização eram, naquele imaginário do XIX: a capacidade individual do professor para tornar atraente o aprendizado; a habilidade quanto ao domínio dos conteúdos e o zelo quanto à observação do ritmo de aprendizagem de cada aluno; a ordem, organização e metódica disciplina capaz de trazer sistematização e continuidade à seqüência das lições; finalmente a brevidade no método. Aliadas essas virtudes umas às outras, a escola primária conseguiria ser exitosa. Pensar os modos de ensinar a ler era, para esses autores de meados do XIX português, meditar sobre o método: o que fazer em sala de aula? Como proceder nos rituais da escolarização? Como constituir práticas docentes bem-sucedidas e capazes de ensinar os alunos a aprenderem? O tema do método de ensino é objeto prioritário na discussão do ensino da leitura e da escrita. A rigor, o que significa o ensino ministrado para aquele aluno que nada dele apreendeu? O método da escola surge pela base; com o fito de ensinar o ler, o escrever e o contar. Ensina também professores e alunos, como deverão ambos se comportar...

\section{Ler e escrever: ao mesmo tempo, todos juntos}

O processo de ensino da leitura e da escrita começava com o alfabeto, que vinha impresso em largos quadros, ocupando página inteira: em primeiro lugar, as letras maiúsculas; na página seguinte, as minúsculas. Elas seriam, na seqüência, divididas entre vogais e consoantes, postas em itálico e expressas como manuscritas. Eram, no cômputo total, sete páginas iniciais só com o alfabeto. As letras vão e vêm, sem qualquer combinação sonora. Dali, partia-se diretamente para as sílabas e, aqui, desde o princípio, procurava-se aliar o som à composição de significados variados que iam sendo combinados. $\mathrm{Na}$ verdade, tratava-se de compreender a leitura quase como a transposição do valor sonoro das palavras; antes de se pensar no significado correspondente a elas. $\mathrm{O}$ aluno deveria reconhecer a identidade das sílabas, quando estas viessem integradas em diferentes vocábulos: pelo som, haveria a lembrança do conceito; o reconhecimento da palavra, trazendo por sua vez a lembrança do som. Considera-se, portanto, a sílaba como ponto de partida do processo, o elemento

${ }^{348}$ E. A. MONTEVERDE, Methodo facillimo para aprender a ler tanto a letra redonda como a manuscripta no mais curto espaço de tempo possivel, p. 7. 
gerador da leitura. Por essa razão, são 22 as páginas que contêm quase exclusivamente tábuas de sílabas.

Os primeiros exercícios do texto tratam da alegoria de um filho ingrato, semelhante na fábula a uma serpente e de um menino mal-intencionado, salvo pelo próprio cão que prentendia, entretanto, matar. É bastante explícita a tonalidade das prescrições morais veiculadas pelo texto do compêndio; como se a mensagem se dirigisse expressamente ao adulto que, de antemão, se sabia que a criança viria a ser. $\mathrm{O}$ mundo do texto, da leitura e do livro escolar aparece, pois, como um universo pontuado pelo signo da severidade, com discurso austero, que pretende tanto persuadir quanto amedrontar. As letras desencarnadas das primeiras páginas atemorizam o leitor principiante por revelarem bruscamente sua rasteira ignorância. Pelo prefácio do autor, sabe-se que 'os caminhos do ABC' deveriam principiar pela silabação. Mesmo assim, o alfabeto vinha ali, antes das sílabas, para se dar a ver a todos os que não soubessem ler... Já de início, havia o tom prescritivo de uma gramática pontuada por textos de cunho moralizante, o que revelava também o olhar civilizador de uma escolarização que pretende antes formar do que informar, que deseja veicular valores a serem introjetados pelas portas da alma. Os conselhos à mocidade situam-se, pois, como lembretes dos valores que comporiam o código de honra do homem português: religião, generosidade, disciplina, caráter, perseverança e equilíbrio.

$\mathrm{Na}$ seqüência, era apresentado um resumo da doutrina cristã, composto por: oração dominical; saudação angélica; salve-rainha; símbolo dos apóstolos; confissão dos pecados; os quatorze artigos da fé; os dez mandamentos da lei de Deus e os cinco da lei da Igreja; os sete pecados capitais; as quatorze obras de misericórdia; os sete sacramentos da Igreja. Supunha-se que o ato da leitura viesse como complemento da idéia de dívida e dos deveres que o homem precisa se impor durante a existência: do dever para com Deus evidentemente derivariam todos os demais. A cartilha é catequética porque a ação escolar - ela mesma - desmembrar-se-ia da catequese. Tratava-se fundamentalmente de uma leitura daquilo que se deveria saber de cor: a leitura em voz alta, compartilhada por ser essencialmente coletiva a repetida de maneira intensa. As virtudes da fé são expostas como se de conhecimento se tratasse e o tom de catecismo que permeia a cartilha surge - como se disse - indisfarçável. A escola auxilia aqui a Igreja e a família, atualizando e recordando um saber que é, por definição, exterior e anterior a ela. Monteverde aproveita o capítulo de teologia para anunciar serenamente seu compêndio especificamente religioso, estimulando os leitores a adquirirem o Mimo á infancia ou manual de História Sagrada, cuja adoção seria - segundo ele - de valia e de utilidade para escolas primárias do Brasil de Portugal. ${ }^{349}$ Por elidir o sujeito da enunciação, o texto didático apresenta normas de conduta civis e religiosas como atos derivados do acesso ao conhecimento. O saber teria, então, por suposto, determinadas práticas de virtude nesse movimento que visualiza como aprendizado da leitura a recitação de obras de misericórdia. Dentre elas, destacar-se-iam as espirituais: dar bons conselhos; ensinar os ignorantes; consolar os tristes; castigar os que erram; perdoar as injúrias; sofrer com paciência as fraquezas do próximo; rogar as Deus pelos vivos e defuntos." 350

\footnotetext{
${ }^{349}$ E. A. MONTEVERDE, Methodo facillimo para aprender a ler..., p. 55.

${ }^{350}$ E. A. MONTEVERDE, Methodo facillimo para aprender a ler..., p. 54.
} 
A esperança é, pelo texto, compreendida como uma atitude virtuosa, já que supõe o ato do sujeito contar com a graça de Deus neste mundo e com a sua glória no outro. Caridade, por seu turno, significa, pela letra do texto, o amor a Deus sobre todo o resto; e o amor a si mesmo e ao próximo como decorrência do sentimento que se tem para com a divindade. Desse enlace entre o amor de si e o amor dedicado ao outro decorrem algumas virtudes explicitadas na condução do comportamento do menino: por um lado, recomenda-se gratidão e obediência aos pais e aos mestres; por outro, recomenda-se ao menino que não seja "importuno, falador ou intrigante", que saiba alcançar atitudes honradas, as quais, em hipótese alguma, se coadunam com a mentira e a dissimulação. A idéia de honra como máxima virtude é acompanhada aqui por valores como lealdade, companheirismo e humildade. A instrução é o corolário da honra, posto que o obscurantismo seria naturalmente um convite ao vício.

De acordo com tal conjunto de recomendações, incitava-se, também, o menino a ser serviçal, condescendente e caritativo, fugindo de sentimentos nefastos, como a inveja, a soberba, a ambição e a vingança. A instrução, apresentada como "adorno do rico e riqueza do pobre", propiciaria - como consta do excerto acima transcrito - a manifestação e a exploração do talento, considerado valor próprio do gênero humano. Ainda que fosse aqui apresentado como uma paixão, o estudo, "de todas as paixões é a mais constante e a menos sujeita ao desgosto". A razão seria o instrumento que dirige o homem inteligente em direção ao sucesso e à virtude, à luz de uma mundividência muito peculiar - alguma coisa que dialoga em particular com o futuro, apontando a direção desejada para esse futuro. É como se a escola pretendesse traçar o prefácio do livro da vida, sublinhando - como num ensaio - o roteiro da peça que deverá, na seqüência, ser encenada. Há, nessa medida, um prospecto de geração expresso por tais máximas e pensamentos morais.

Reconhece-se no traçado escolar muito mais do que o desejo de ensinar a ler e a escrever; a não ser que se considere a perspectiva da alfabetização como uma alfabetização virtual, no sentido de capacitar as gerações mais jovens a uma dada leitura das realidades do mundo físico, do mundo humano e do mundo divino. A moralidade é um elemento fundamental da vida escolar; entrelaçando-se inclusive ao desenvolvimento cognitivo e intelectual. De qualquer maneira, não se poderia sequer classificar os valores de cunho religioso e moralizante como objetivos ocultos do currículo escolar: pelo contrário, ficava claro aos contemporâneos que essa constelação de virtudes que a cartilha arrolava representava de fato a finalidade última do processo escolar. Era interessante aprender a ler, se isso fosse possível. Era necessário aprender a falar corretamente, à medida do que a pátria e os governantes julgassem razoável. Era importante aprender a pensar pela cartilha oficial; e era imprescindível aprender a rezar...

Procurando firmar, por um lado, o aprendizado da leitura escolar e, por outro, as convicções religiosas, na contramão dos pecados capitais era já apresentado um rol de virtudes que seriam todas elas imediatamente contrárias àqueles: contra a soberba, preconizava-se a humildade; contra a avareza, a liberalidade; contra a lúxúria, a castidade; contra a ira, a paciência; contra a gula, a temperança; contra a inveja, a caridade; contra a preguiça, a diligência. Era como se o ensino fosse entremeado por uma ininterrupta ladainha que fundia e confundia fé com conhecimento, ensino com catequese. Para tal finalidade, a utilização dos provérbios era providencial: porque os provérbios recordam e reatualizam uma sabedoria popular 
muito antiga; porque os provérbios remodelam valores e fixam princípios a serem mantidos; porque os provérbios são singelos e facilmente apreensíveis e memorizados pela sua sonoridade; enfim, porque os provérbios recompóem a tradição que caberia à escola perpetuar.

$\mathrm{Na}$ interface entre o ato de instruir e a atitude da pregação, metodologicamente o professor acreditaria estar apenas a recordar um conjunto de máximas que seriam, até certo ponto, correntes e partilhadas pela vida da comunidade. Ao repetir uma máxima ou um provérbio, a escola estaria apenas a educar o ouvido do aluno, chegando, por meio dessa estratégia, a procedimentos analíticos de uma leitura que se desdobra do ritmo sonoro à extensão do fraseado, até chegar à singularidade das palavras, dividindo finalmente estes vocábulos nas partículas compostas por seus elementos fônicos. Leiam-se, a partir disso, as breves sentenças morais contidas nos seguintes adágios:

"1. Quem muito dorme, pouco aprende.

2. Homem honrado, antes morto que injuriado.

3. Mau é o rico avarento; mas pior é o pobre soberbo.

4. Não bebas coisa que não vejas; não assine carta que não leias.

5. A boda nem batizado, não vá sem ser convidado.

10. O prudente tudo há de provar, antes de armas tomar.

12. Azeite, vinho e amigo, o mais antigo.

14. Na casa onde não há pão, todos pelejam, nenhum tem razão.

17. Mais vale quem Deus ajuda do que quem muito cedo madruga.

18. Se queres ser pobre sem o sentir, mete obreiros e deita-te a dormir.

20 Mocidade ociosa faz velhice vergonhosa.

23. Guarda-te do homem que não fala e do cão que não ladra." 351

Em seu trabalho sobre as apropriações populares dos usos da palavra impressa, Nathalie Davis caracteriza tal reminiscência de uma certa sabedoria "proverbial": breves, densos, prescritivos, os provérbios tanto agendam normas de ação como traduzem ocultos significados. Mensagens que entrelaçam e aliam geraçôes, os provérbios carregam consigo a autoridade que o tempo e o estilo lhes conferiram. Enraizados como valores e códigos definidores de cultura do povo, já Erasmo os teria recomendado para instrução moral das crianças. Quando bem talhados, enfeitavam a língua e eram valorizados como uma sabedoria arcaica, quase atemporal, anônima e por isso universal. Tal sabedoria convivia harmoniosamente com a cultura popular e com o analfabetismo. No caso de Portugal, pelo menos, embora nem sempre coincidindo com triviais murmúrios, havia a valorização pela escola desse linguajar proveniente do povo comum. O provérbio tem o rosto da aldeia - como já anotava Nathalie Davis. Já para André Jolles, o provérbio seria, antes de tudo, qualificado como uma locução da linguagem, fechada enquanto cadeia de significados tendentes ao didatismo, posto que atualiza uma experiência passada, mobilizando-a para marcar sua analogia em relação à situação presente. Jolles destaca o fato de o

${ }^{351}$ E. A. MONTEVERDE, Methodo facillimo para aprender a ler.... Os provérbios ou adágios aqui arrolados constam das páginas 133, 134 e 135 da $7^{\text {a }}$ edição (publicada em 1859). 
provérbio não ter por vocação o ensinamento ou a moral, mas que seria apenas uma "breve sentença arguta", capaz de somar em poucas palavras uma experiência que, entretanto, é compartilhada por uma tendência à generalização. Através do tom proverbial, a coletividade se apropria de uma experiência - por definição - tendente à universalidade. Grimm já teria pontuado a sentença contida no provérbio como um "lampejo de uma verdade pressentida desde longa data e que encontra por si mesma sua expressão mais elevada" ${ }^{352}$.

O provérbio é sabedoria graciosa, enunciada e anunciada porque repetida por todo o povo; atualizada sempre por remeter-se na origem a tempos imemoriais. O provérbio cristaliza e manifesta a sobrevivência da tradição oral, no rescaldo mais profundo de uma memória que persiste embutida para ser, pela recordação do fraseado, reavivada. O provérbio, finalmente, age com o propósito de recordar um inconsciente coletivo que se supõe sempre presente. Sua tarefa então é de organizar e armazenar, para as geraçôes futuras, experiências vividas e sentidas pelas gerações passadas. Por tudo isso, o provérbio é, por definição, verdadeiramente educativo.

Assim, os saberes escolares deslizam entre o excerto bíblico e o fraseado popular: ensina-se aquilo de que se recorda; e de qualquer maneira, com tal procedimento, interage-se com a formação dos hábitos. O texto do Methodo facillimo de Monteverde traz, nessa perspectiva, o diálogo entre a memorização do passado e a inferência quanto à predisposição para o futuro. As máximas, sentenças e pensamento morais formam o corpo mais denso do compêndio, assumindo por vezes as formas de perguntas diversificadas, como as que seguem:

"P. Qual é a coisa que aonde entra, nunca mais sai?

R. A suspeita.

P. A obra que nunca se pode acabar?

R. A que nunca se principiou.

P. A coisa que se estima depois de perdida?

R. A saúde.

P. A melhor espada?

R. A prudência, pois com ela se vence muita coisa.

P. Quais as três coisas mais difíceis de executar ?

R. Guardar um segredo; esquecer-se de uma unjúria, e saber bem empregar as horas vagas.

P. Quais são os verdadeiros bens ?

R. A Saúde, a boa reputação, o hábito de trabalhar, a instrução e os talentos.

P. Qual é o fim da educação ?

R. Desenvolver a inteligência, inspirar o amor da sabedoria e da virtude; formar homens religiosos e cidadãos úteis à pátria e a si mesmos." 353

A subordinação da instrução à virtude vem geralmente acompanhada dos atributos intrínsecos a tal aliança. A instrução é pois apontada sempre como a riqueza do pobre;

${ }^{352}$ Wilhelm GRIMM, apud. André JOLLES, Formas simples, p. 135.

${ }^{353}$ E. A. MONTEVERDE, Methodo facillimo para aprender a ler..., p. 601. 
e através dela, é o talento natural que virá à tona. O aprendizado é posto como critério para frear e dominar as paixões e colocá-las sob o crivo da razão e da virtude. A instrução conseqüentemente se processaria como um intermitente esforço do indivíduo que se cultiva, a fim de contrapor à brutalidade de desordenadas paixóes involuntárias a paixão imeditamente contrária.

Corretivo do erro e contraponto da ociosidade, a instrução surge como formação de hábitos que a aquisição de conhecimento escolar faz por aplicar. "Sinal distintivo de boa educação" e "testemunho exterior de benevolência, atenções e deferência", a civilidade também é tomada como matéria dessa escola que conduz a criança em direção à aceitação do adulto. Não há aqui qualquer disfarce sobre a função moralizadora da escola primária; e as crianças deveriam copiar do quadro-negro:

"A docilidade é uma disposição natural a receber, com doçura e reconhecimento, os conselhos das pessoas esclarecidas. A docilidade é também algumas vezes o fruto da reflexão e do amor da verdade. Deve sempre ser dirigida pelo raciocínio e é essencialmente necessária aos mancebos, os quais, não se podendo guiar por si mesmos, devem necessariamente deixar-se guiar por aqueles que os excedem em experiência e instrução." 354

Acoplada a essa meta de docilidade, o compêndio ensina a resignação dos espíritos perante a vida material, o trabalho, as riquezas. Sugere-se que o indivíduo recolha o fruto do seu trabalho, sabendo dele tirar o proveito do contentamento. Omite-se no discurso quaisquer conflitos entre classes sociais e as distinções de fortuna são, pelo artifício da palavra tecida, naturalizadas. Há, no conjunto, uma acepção de moral, posta como vetor da consciência e eixo regulador da conduta. Não é por acaso que os textos definidores da moral, da consciência, da virtude e do vício venham como conjunto harmonicamente escrito com letra manuscrita, mais próximo portanto da escrita individual, íntima, familiar... A moral escolar, sob derivação da doutrina cristã, apresenta um roteiro de atitudes, padrões de comportamento e de conduta, que, na verdade, constitui a urbanidade recomendada. Ao imbricar, de maneira interdisciplinar, o universo valorativo com os saberes derivados das distintas áreas do conhecimento, a escola conforma seus rituais mediante uma metafísica que aparentemente a transcende.

Chega-se, então, a suspeitar que o processo de escolarização pública em um país como Portugal teria, no século XIX, uma prioridade inequívoca que, contudo, não estaria dada à partida, e nem mesmo poderia ser compreendida como decorrência deste ou daquele aspecto da vida nacional. A escola teria por função precípua a divulgação de conhecimentos úteis e agiria, nesse sentido, como uma instituição concorrente do livro. A extensão das práticas de leitura - e conseqüentemente do público leitor - poderia conduzir, aos olhos dos contemporâneos, à sublevação dos valores e das tradições vigentes.

Preservar o equilíbrio social seria, pois, regrar a leitura e trazer regulamentos normalizadores do ato de ler, com o propósito de se valer do instrumento do texto impresso, apropriar-se mesmo desse recurso para adequá-lo, transformá-lo moldá-lo,

${ }^{354}$ E. A. MONTEVERDE, Methodo facillimo para aprender a ler..., p. 70. 
de acordo com a moral e os bons costumes. São detalhes fugazes e sinais imprecisos que revelam a outra face de uma escola que não pretende apenas se fazer conhecer, mas tem por intenção velada o desejo de irradiação de padrões de comportamento que possibilitam o controle de uns sobre os outros, o auto-controle de cada um sobre o seu corpo e, fundamentalmente, o engendramento de um arbitrário de cultura e de valores necessários para modelar mentes, físicos e corações, tendo como meta expectativas da permanência e da aceitação do artifício da ordem como se de natureza se tratasse. A escola conduz o aprendiz a acatar como natural o existente, não apenas por seus saberes, mas talvez fundamentalmente pelos "fazeres ordinários da classe" 355 . Mesmo assim, poder-se-ia indagar se a escola portuguesa no compêndio didático reproduz linearmente a ordem social ou se sobre ela exerce um efeito de apropriação, que tanto reflete quanto modifica aquilo que, ao apreender a seu modo, reinventa... Nesse caso, poder-se-ia acreditar que o conhecimento escolar tem uma originalidade própria.

Conferindo significados ao ato de compreensão do real por escrito, há inegavelmente o explícito intuito de conferir significado valorativo à realidade. Era preciso controlar quem escreve, os produtores do relato impresso. Era preciso controlar a leitura, posto que, subordinado à escrita, o gesto de ler poderia ser fonte de corrupção de costumes e valores. O par leitura/escrita, temido porque perigoso, cada vez mais fugia a qualquer controle institucional.

A instrução e o conhecimento vêm inexoravelmente subordinados à virtude. Para frear os instintos traiçoeiros, a consciência agiria paradoxalmente como reguladora racional das emoções, proporcionando o sentimento de satisfação diante da prática do bem e, ao contrário, o de inquietação e remorso pela lembrança do mal praticado. De certo modo, a ação da consciência amadurecida corresponderia ao efeito de vigilância adulta sobre as crianças. Em razão disso, a virtude finalmente é definida como a aplicação sistemática da ação humana em direção ao bem comum. Os conceitos que remetem ao tema da moralidade, bem como as lições de vida veiculadas pelo compêndio, procuram referenciar o comportamento humano do futuro, a partir de uma dada recorrência ao passado. A ética preconizada pela escola era provavelmente a ética do subordinado, a ética dirigida ao servo; não é a ética do senhor, não se trata dos padrôes normativos pensados para o nobre. Trata-se, antes de tudo, de educar as camadas menos favorecidas quanto à fortuna. Havia de se oferecer os códigos de linguagem e de comportamento que se supunham adequados. Mas era imprescindível a qualquer preço que a escola se voltasse para que a ordem social, para que as disparidades de renda, de propriedade e de poder fossem todas elas aceites, acatadas e introjetadas no sentido de torná-las quase uma segunda natureza. Ainda que fosse também religiosa, a moral escolar era principalmente uma moral disciplinar, que deveria, enquanto tal, incorporar a obediência para com os mais poderosos; a conformação com as distribuições e interditos que a sociedade constituída colocava a cada um em particular; o

${ }^{355}$ A expressão é de Anne-Marie CHARTIER, extraída do título do texto que foi por ela apresentado na Faculdade de Educação da Universidade de São Paulo, em 1995. Para a educadora francesa, esses "fazeres ordinários” são variáveis ignoradas ou não controladas na maior parte das investigações sobre a escola; sendo entretanto elementos-chave para a compreensão da transmissão do "savoir faire" profissional. (Anne-Marie CHARTIER, "Le 'faires ordinaires' de la classe: un enjeu pour la recherche et pour la formation”, p. 12). 
temor para com os mais fortes e mais ricos; a reverência perante aqueles cujo talento levou mais adiante...

Além da obediência aos mais velhos, por onde evidentemente tudo começava, a tradição recomenda o trabalho, sempre auxiliado pelo conhecimento que, por seu turno, conduziria à modéstia. No entanto, a guarda e o auxílio divino seriam graça cujo controle pertence somente ao homem. Havia uma combinação entre as prescriçóes religiosas e uma ética do trabalho que parecia ser desejada para compor a sociedade do futuro. Com essa dinâmica, o ensino português caminhava em direção a um equilíbrio valorativo, capaz de combinar distintos e, por vezes, contrapostos estilos de virtudes. O que se fazia com isso em sala de aula era, em qualquer situação, uma caixa preta que não seria tampouco decifrada ao primeiro olhar. Ao convidar o estudante para adentrar na arte da escrita, parecem ser voltadas para o professor as recomendações e a explicação que o compêndio oferece. Sua complexidade, em termos de vocabulário e do texto, revela que, aqui, não se supunha a leitura do principiante; fala-se, acima de tudo, com o mestre.

A escola moderna configura a idéia de classe: a classe como fronteira simbólica do rito da escolarização. Indubitavelmente o território da classe situa o lugar disciplinar da escola, como instituição eivada pela ótica do olhar: olhar magistral, mas também micro-olhares, que - na expressão de Eirick Prairat - se colocam como dispositivos reguladores do espaço escolar. Há, para esse autor, uma nova acepção do dizível em educação quando a escola estrutura parâmetros inéditos para dizer e manifestar o espaço do possível e do visível.

A posição do aluno para o rito da escrita era essencial aos olhos do educador escolar. Aliás, a tarefa de escrever punha-se na obra de Monteverde como um ofício equivalente à percepção do som traduzido pelas letras. O lugar da escrita para a vida escolar era compreendido como a representação gráfica do que antes se ouviu. Não há, assim, qualquer menção à idéia de representação dos símbolos e dos significados do real e das coisas, a partir da convenção gráfica que o homem criou. O professor deveria cuidar da postura corporal do estudante durante o ato da escrita, de maneira que tanto o corpo quanto o modo específico de pegar na pena pudessem ser objeto de cauteloso treinamento. Acerca da geometria do movimento corporal posto como imprescindível para a tarefa de gestão do corpo enquanto este escreve, diz Monteverde:

"O corpo deve-se manter direito, e a cabeça um pouco inclinada para diante, o lado esquerdo
mais chegado à mesa do que o direito. A perna esquerda algum tanto estendida, e o pé direito
perpendicular ao sobrado. O braço esquerdo coloca-se, não paralelamente à borda da mesa,
mas sim obliquamente, por isso é que essa posição é a mais natural, e segura-se o papel com
a mão esquerda. Pega-se na pena com os três primeiros dedos da mão direita, a saber: o dedo
polegar, o index e o dedo do meio. Os dedos anular e o mínimo devem ficar algum tanto
dobrados, e chegados para a palma da mão, sendo neles que esta descansa quando escreve."

A partir dali seriam apresentados exercícios para a prontidão da escrita: o treino de traçados e de letras de maneira corrida. Eram, no total, 32 exercícios; a maioria

${ }^{356}$ E. A. MONTEVERDE, Methodo facillimo..., p. 76-7. 
deles com letras cursivas repetidas inúmeras vezes na mesma linha. Era como se a letra de forma, que já se conhecia, houvesse sido transposta agora para a escrita das palavras. A escrita exigiria, no entanto, um novo e diferente aprendizado, em termos do domínio gráfico, do reconhecimento e capacidade de utilização do espaço do papel.

$\mathrm{Na}$ seqüência, o compêndio introduzia uma parte do que chamava História Natural e que, de fato, consistia em uma relação das origens, dos usos e dos perigos dos seguintes animais: cavalo, touro, elefante, orangotango, águia, galo, peru, pavão, poupa, porco espinho, jibóia, crocodilo, gafanhoto.

Como unidade central, havia o estudo dos algarismos: os numerais arábicos e seus correspondentes romanos; a tabuada até o 10; o estudo das unidades de medida e das correspondências no Sistema Legal de Pesos e Medidas, onde se ensinavam basicamente as noçôes essenciais do metro, do litro e do grama, em suas diferentes unidades. Lembre-se que o sistema métrico decimal havia sido normalizado há pouco tempo em Portugal (1852) - tendo sido previsto para entrar em vigor apenas a partir 1862. Ora, era necessário uniformizar as medidas até então designadas por convençôes regionais e parâmetros exclusivamente tradicionais. A escolarização das novas unidades de medida era compreendida, por seu turno, como a possibilidade de Portugal realmente entrar para a vida européia. Em virtude desse desejo internacionalista, os portugueses prentendem adequar à nova mensuração os corações e as mentes. Para a pretendida unidade, o papel da escola parecia essencial. Tratava-se de fato de levar o aluno a se habituar com aquilo cujo uso efetivo era ainda muito novo, se é que havia.... Com essa finalidade, a edição datada de 1859 introduzia o sistema métrico-decimal, mostrando efetivamente suas equivalências:

"P. A que medidas de Portugal correspondem as unidades das novas medidas?

R. O metro, como já se disse, corresponde a um côvado, um palmo, quetro polegadas, quatro linhas, quatro pontos, ou a quatro palmos e meio, com pouca diferença. $\mathrm{O}$ are é um decâmetro quadrado, isto é, um quadrado, tendo dez metros por cada lado, ou quarenta e cinco palmos, pouco mais ou menos. O stere equivale a um metro cúbico, ou a um sólido com seis faces quadradas como as de um dado, e de um metro ou quatro palmos e meio, aproximadamente, em comprimento, altura e largura. O litro, para medir líquidos, vale um decímetro cúbico, e corresponde a três quartilhos, com pouca diferença; e para medir secos, quase a dois selamins. O grama equivale a vinte grãos, e o kilograma ou mil gramas, a dois arráteis, duas onças, seis oitavas, dois escrópulos, e dezoito grãos, isto é, ao peso de um litro d'água destilada, ou na sua maior pureza, contida em um centímetro cúbico. (...) O metro é pois, como se viu, a base de todas as novas medidas" 357

Supunha-se que o mundo estava já apresentado à criança que do conhecimento escolar soubesse verdadeiramente fazer uso. No curso da cartilha, Monteverde fala um pouco do dinheiro português, da composição do ano e das principais capitais da Europa. Era como se, por uma revoada, o mundo inteiro estivesse ali, na pretensão que o autor revelava de tê-lo contado à infância. Ao crescer e descobrir por si mesma essa realidade, o jovem apenas recordaria aquilo que o rito da escola já um dia lhe

${ }^{357}$ E. A. MONTEVERDE, Methodo facillimo..., p. 114. 
mostrara... Cabe indagar ainda até que ponto a escolarização, tal como estava constituída em Portugal do XIX, também não falava com os pais dessas crianças; até que ponto não eram eles - adultos - também interlocutores do compêndio. Poderia haver a suposição de que a criança conta ao pai aquilo que aprendeu. Poderia haver a suposição de que a escola também interferiria na escala de valores da sociedade pelo fato de possibilitar a mudança de rotinas; ainda que fossem pequeninas rotinas como a de calcular por grãos aquilo que já fora transformado em grama. Tratava-se de uniformizar o espaço, é verdade; mas urgia, como contrapartida, homogeneizar símbolos, criar valores e referências comuns, superar, pela aposta no universal, todo e qualquer regionalismo... Era necessária a escola para perpetuar valores, sim; mas também e talvez fundamentalmente para mudar esses valores, para questioná-los, para dialogar com eles. A escola cria a recria a sociedade que a abraça. Essa sociedade queria escola porque, contraditoriamente, queria mudar, permanecendo sempre a mesma. Na mesma direção, a escola pretendia a perpetuação e a mudança; e talvez por isso - quem sabe - ela era, como se viu, procurada e desdenhada pela mesma sociedade. Compreender a marcha da ritualização escolar portuguesa exige portanto que se compreenda a que veio a escola de que falavam os contemporâneos e em que medida ela correspondia àquilo que verdadeiramente se compreendia por escola. Finalmente, poder-se-ia também indagar qual a relação entre a política do livro didático e a prática escolar.

\section{Método legográfico ou Cartilha Nacional de Caldas Aulete}

Julio Caldas Aulete, amigo íntimo e parceiro de Latino Coelho na Enciclopedia das escolas, fora professor da Escola Normal primária de Marvilla, da Escola Acadêmica e do Liceu de Lisboa, obtendo - como se vê - intensa experiência prática no exercício do magistério. Seus estudos prediletos versavam também sobre instrução primária popular. Foi deputado às Cortes durante várias legislaturas e em sua carreira obteve aprovação do Conselho Superior de Instrução Pública para muitas de suas obras; dentre as quais destacaram-se a Selecta Nacional: curso pratico de litteratura portugueza e a Cartilha Nacional: methodo legographico para aprender simultaneamente a ler, escrever, ortographar e desenhar. Além disso, Caldas Aulete fez um novo e rico dicionário de língua portuguesa. Sua atuação como educador era reconhecida e provavelmente valorizada pelos poderes constituídos à época, posto que já o relatório de inspeção dirigido às escolas públicas durante o ano letivo de 1866-1867 indagava explicitamente dos professores quanto ao método de ensino adotado se estes recorriam ou não ao método legográfico, o qual, por sua vez, estaria em Portugal, como se disse, representado pela Cartilha Nacional. ${ }^{358}$

${ }^{358} \mathrm{O}$ Relatório de Inspeção dirigido às escolas do Estado, que havia sido em 1866 impresso pela Imprensa Nacional tinha um item chamado "regimen, disciplina e policia da escola". Ali havia espaço para o professor pornunciar-se quanto aos métodos e aos modos de ensino. No quesito relativo ao "método de ensinar a primeira leitura", constavam as seguintes alternativas, que vinham já impressas: "Soletração antiga; soletração moderna; silabação fônica; método português; método legográfico". Além dessa referência explícita, havia outras, particularmente na folha reservada para "livros usados pelos alunos com a declaração do número de alunos que usam deles". Dentre os 
A Selecta Nacional era uma coletânea dirigida ao curso secundário destinada essencialmente a exercícios de leitura, de análise e de composição - como o próprio autor declara na Introdução. Procura expor para o aluno trechos selecionados dos grandes escritores, que teriam brindado com suas obras a própria língua portuguesa, no parecer de seu tempo. Ao lê-los, o estudante poderia, a um só tempo, tomar conhecimento do assunto e fruir o estilo, o que o ajudaria a se expressar melhor, fosse verbalmente, fosse por escrito. Ninguém melhor do que o próprio autor para definir sua obra e, na seqüência, traçar diretrizes acerca do método que se deveria empregar ao adotá-la. Caldas Aulete sugere, em todos os níveis, o que chama redação oral:

"O modo por que se hão de fazer os exercícios de redação oral nas escolas elementares é o seguinte: escolhido pelo professor para a lição de leitura de um trecho, que deverá ser dos mais fáceis e dos que as crianças possam ter maior desejo de ler, o professor fará repetir a leitura dele tantas vezes quantas sejam necessárias para o pronunciarem com clareza e inteligência. Depois convida-las-á a que refiram oralmente o assunto do trecho. O professor há de animá-las e auxiliá-las muito neste exercício. Quanto maior o número de palavras e frases empregarem do texto escolhido, mais profícuas serão estas narrações. O professor nunca se deve mostrar enfadado de ouvir seus juvenis expositores, para assim conseguir que percam certa timidez que, em geral, as crianças manifestam quando têm de se referir a algum fato perante pessoas que julgam superiores." 359

Foi em 12 de Junho de 1850 que Francisco Júlio Caldas Aulete dirigiu um ofício ao Secretário do Conselho Superior de Instrução Pública - José António Amorim - explicitando o que entendia ser a novidade da obra que pretendia fazer aprovar por aquele órgão. Tratava-se de um trabalho dirigido às escolas, originalmente sob o título Livro da infancia ou methodo facil e racional para ensinar a ler. $\mathrm{Na}$ verdade - segundo consta do manuscrito de apresentação da obra - aquela cartilha de ensinar a ler realmente fazia parte de um projeto mais amplo do autor; uma coleção que - nos termos do ofício - ele intitularia Biblioteca das escolas primárias, e que deveria, em seu conjunto, contemplar compêndios voltados para os diferentes níveis de aprendizado na instrução primária. O livro que então apresentava ao juízo crítico do Conselho Superior de Instrução Pública era, na verdade, o primeiro da pretendida série. Aquele dito Primeiro livro da infância ensinaria, portanto, os primeiros caminhos do ato de ler "por um método fácil e porventura racional, proscrevendo como pernicioso o sistema até aqui seguido em todos os livros que para a primeira instrução da infância se tem adotado em Portugal" 360 . Caldas Aulete reconhecia e enfatizava que seu método partia do desejo de suprimir a soletração do ensino da leitura. Para isso, já bem antes de João de Deus, dava

11 livros ali previstos, havia a Encyclopedia de Latino Coelho. Isso de alguma forma representava a boa inserção e fácil trânsito do autor no Conselho Superior de Instrução Pública.

${ }^{359}$ F. Julio CALDAS AULETE, Selecta Nacional: curso pratico de litteratura portugueza, p. X-XI.

${ }^{360} M R M c ̧ 3527$ - Livro da infância ou methodo facil e racional para ensinar o ler, por Francisco Julio Caldas Aulete. Ofício dirigido ao Secretário do Conselho Superior de Instrução Pública apresentando a novidade da obra que então era lançada. 
algumas modificações sonoras às vogais por meio de acentuação variada, embora não partisse - como mais tarde faria o poeta - do sentido da reunião de vogais entre si, mas da sonoridade que essa aliança traria, mediante a referida junção daqueles sons simples. ${ }^{361}$

O autor explicitava, ainda, que, na introdução, dirigia-se aos professores, explicando o mecanismo do método sem soletração. Para que a leitura pudesse identificar e ao mesmo tempo ultrapassar os limites da sílaba, ele as dividia na própria palavra por um pequeno intervalo, que auxiliava o aprendiz a reconhecer o som e apreender simultaneamente o sentido da palavra e da frase. ${ }^{362}$ Nota-se visivelmente a prioridade dada ao tema do método, pelos termos do ofício com que Caldas Aulete apresenta ao Conselho Superior de Instrução Pública o livro que acabara de escrever. Notoriamente, como se viu, as questôes concernentes à didática e às metodologias do ensino passariam a ser o eixo temático do debate educativo em Portugal daqueles anos 50. Caldas Aulete, mais do que a inovação quanto ao conteúdo, recorda que sua cartilha aponta para uma nova forma de proceder ao ensino. Essa estratégia de uma aprendizagem sem soletração era o que, ao fim e ao cabo, daria razão ao reconhecimento e ao êxito da posterior Cartilha Nacional: método legográfico para aprender simultaneamente a ler, escrever, ortographar e desenhar. Vê-se assim que, quer nos debates intelectuais, quer nas polêmicas encetadas pela imprensa, quer nos relatórios de inspeção, a mesma tendência apontaria os anos 50 como o tempo dos métodos e das técnicas. Como nunca, a Pedagogia ia ganhando ares e pretensão de profissionalismo.

Caldas Aulete, no Directorio que acompanhava a sua cartilha de ensino simultâneo da leitura e da escrita, dirigia-se aos professores e procurava fixar diretrizes que dessem a eles parâmetros de condução das aulas e de orientação para o ensino do ler e do escrever. Assim, o autor pedagogicamente sugeria... Procurava expor, antes de tudo, a necessidade de o educador incentivar a fala da criança: "conversai com as crianças para as exercitar a falar, já que as famílias descuram este importante ensino que é uma das causas dos alunos fazerem tão pouco progresso nas escolas públicas." 363 Indicam-se alguns exercícios para os mestres que adotassem o ensino pelo método legográfico, cuja inovação consistia em ensinar a um só tempo a ler e a escrever. Na verdade, partia-se do pressuposto de que o ensino combinaria os elementos da leitura oralizada e da transposição imediata pela cópia e, logo depois, pelo ditado. A ideia era a de compor uma rotina pedagógica que possibilitasse a instalação do ensino

361 “iu; io; ái; áe; áu; áo; éo; $\hat{e} u$; óe; ôi; êi; ôu”- Era assim que vinham apresentadas as vogais reunidas na cartilha que posteriormente Caldas Aulete publicaria . (Julio CALDAS AULETE, Cartilha Nacional).

362 Posteriormente, a Cartilha Nacional de Caldas Aulete apresentaria as frases sem desmembrar as palavras ou as sílabas, divididas realmente por aquele pequeno intervalo a que se referia o autor no ofício ao Conselho Superior da Instrução Pública. De qualquer maneira, o êxito da supressão da soletração pareceria pela notoriedade ganha pela mesma cartilha já inconteste. Note-se que a lição do p e do t vinham já seguidas pela tentativa de formação das frases, exatamente como o autor teria anteriormente indicado. Então, escrevia-se o seguinte, da maneira expressa a seguir: "O pi pi pa pôu a pá pa na pá de pão ao pé do pa pá. // O pá té ta do Ti to me ttêu o tó tó no lêi to da ti ti." (Julio CALDAS AULETE, Cartilha Nacional: methodo legographico para aprender simultaneamente a ler, escrever, ortographar e desenhar).

${ }^{363}$ Júlio CALDAS AULETE, Directorio, In: Cartilha nacional: methodo legographico para aprender simultaneamente a ler, escrever, ortographar e desenhar. 
simultâneo. Mesmo assim, procedimentos herdados do modo de ensino mútuo eram também mobilizados, quando Caldas Aulete indicava o aproveitamento de alguns exercícios que deveriam ser dirigidos em pequenos grupos por decuriōes ou munitores treinados. Seriam basicamente exercícios de desenho, de linhas retas e curvas, a estampa livre a propósito das diferentes liçōes do compêndio, as figuras evocadas pelos padrôes de medidas de capacidade, medidas de peso do sistema métrico etc. Além disso, o decurião deveria recordar as palavras de cada lição, fazendo exercícios que pudessem fixar na memória dos alunos o que foi aprendido. $\mathrm{O}$ decurião - por exemplo - ditaria palavras; os alunos deveriam repeti-las de cor; depois diriam as letras de que a palavra ditada era composta. O decuriāo ditava outra vez a palavra e só nessa ocasião é que os alunos iriam escrevê-las nas ardósias ou em papel comum. Terminada a lição de ditado, o decurião mandará os alunos trocarem entre si os papéis onde anotaram o que haviam escrito. Cada aluno poderia corrigir a lição do colega para conferir se havia ali algum tipo de erro ortográfico. Havendo algum, o decurião mandaria o aluno reescrever corretamente a palavra, vinte vezes ou mais, para que pudesse de fato fixar na memória a emenda, e não o erro. Entretanto, para além de tudo isso, o decurião era também quem ensinaria a postura ao iniciante: como se sentar, como pegar na pena, como colocar a tinta, como debruçar-se sobre o papel, como exercitar a caligrafia e a disciplina escolar... O decurião mostrava, enfim, a normatividade da escola e deveria - também ele - ser copiado no que ali ditava sobre os comportamentos:

"10 processo: $\mathrm{O}$ decurião ensinará a cada um dos seus alunos a pegar na pena e a exercitar os dedos no movimento necessário para a formação das letras e a ter o corpo direito numa posição natural. $2^{\circ}$ processo: $\mathrm{O}$ decurião ensinará a seguir com um ponteiro ou pena seca as vogais $\mathrm{i}, \mathrm{u}, \mathrm{o}, \mathrm{a}, \mathrm{e}$, que se acham no princípio desta lição. Isto com o duplo fim não só dos alunos adquirirem o hábito de pegar na pena e de moverem os dedos convenientemente, mas também de fixarem mais na memória a forma das letras. $3^{\circ}$ processo: $\mathrm{O}$ decurião ensinará a escrever em papel ou nas ardósias com um lápis ou pena molhada em tinta estas mesmas letras. E este processo se empregará para o estudo das outras letras e palavras. O decurião durante este exercício há de repetir aos alunos os seguintes preceitos: As letras devem guardar a mesma distância, a mesma inclinação e a mesma igualdade nos grossos e finos." ${ }^{364}$

Havia, no decorrer da própria cartilha, relatos que induziam o aluno a comportamentos sociais que a escola valorizava: o asseio, a obediência, a disciplina, a polidez, o esforço e a perseverança. Era nítido o intuito do autor da cartilha de regrar o cotidiano pedagógico, quando, na última página daquele diretório, ele compunha um modelo de horário para distribuição das matérias de estudo no tempo exato da escolarização primária. Era já a grade curricular que parecia ser aqui arquitetada; a nova escola dos novos tempos que o século XIX visivelmente desejava instituir: um tempo rápido, eficaz, preenchido de maneira eficiente; um tempo enfim da produtividade...

${ }^{364}$ Júlio CALDAS AULETE, Directorio, In: Cartilha nacional: methodo legographico para aprender simultaneamente a ler, escrever, ortographar e desenhar. 
Horário de uma escola primária e o Expositor Portuguez

\begin{tabular}{|c|c|c|c|c|c|}
\hline HORAS & SEGUNDA-FeIRA & TERÇA-FEIRA & QUARTA-FEIRA & SEXTA-FeIra & SÁBADO \\
\hline Das 8 às $8 \mathrm{~h} 45^{\prime}$ & $\begin{array}{l}\text { princípios de } \\
\text { leitura } P\end{array}$ & desenho D & escrita D & desenho D & $\begin{array}{l}\text { princípios de } \\
\text { leitura } P\end{array}$ \\
\hline Das 9 às $9 \mathrm{~h} 45^{\prime}$ & escrita D & $\begin{array}{l}\text { princípios de } \\
\text { leitura } \mathrm{P}\end{array}$ & desenho D & contas D & escrita D \\
\hline Das 10 às $10 \mathrm{~h} 45^{\prime}$ & ortografia D & ortografia D & $\begin{array}{l}\text { princípios de } \\
\text { leitura } P\end{array}$ & escrita D & ortografia D \\
\hline Das 11 às $11 \mathrm{~h} 45^{\prime}$ & desenho D & escrita D & contas D & $\begin{array}{l}\text { princípios de } \\
\text { leitura } \mathrm{P}\end{array}$ & desenho D \\
\hline Das 2 às $2 \mathrm{~h} 45^{\prime}$ & $\begin{array}{l}\text { contas e sistema } \\
\text { métrico D }\end{array}$ & escrita D & desenho D & $\begin{array}{l}\text { conhecimentos } \\
\text { reais } \mathrm{P}\end{array}$ & escrita D \\
\hline Das 3 às $3 \mathrm{~h} 45^{\prime}$ & escrita D & $\begin{array}{l}\text { conhecimentos re- } \\
\text { ais (as } 2 \text { classes) P }\end{array}$ & $\begin{array}{l}\text { exercícios de } \\
\text { falar P }\end{array}$ & ortografia D & $\begin{array}{l}\text { contas e sistema } \\
\text { métrico D }\end{array}$ \\
\hline Das 4 às $4 \mathrm{~h} 45^{\prime}$ & religiāo P & $\begin{array}{l}\text { exercícios de falar } \\
\text { (as } 3 \text { classes) P }\end{array}$ & $\begin{array}{l}\text { ginástica (as } 2 \\
\text { classes) P }\end{array}$ & $\begin{array}{l}\text { religião (as } 2 \\
\text { classes) P }\end{array}$ & $\begin{array}{l}\text { recitação (as } 2 \\
\text { classes) P }\end{array}$ \\
\hline Das 8 às $8 \mathrm{~h} 45^{\prime}$ & desenho D & desenho D & escrita D & leitura corrente $\mathrm{P}$ & escrita D \\
\hline Das 9 às $9 \mathrm{~h} 45^{\prime}$ & leitura corrente $\mathrm{P}$ & escrita D & leitura $\mathrm{P}$ & escrita D & desenho D \\
\hline Das 10 às $10 \mathrm{~h} 45^{\prime}$ & escrita D & ortografia D & ortografia D & gramática $\mathrm{P}$ & leitura corrente $\mathrm{P}$ \\
\hline Das 11 às $11 \mathrm{~h} 45^{\prime}$ & gramática P & leitura P & desenho D & problemas D & gramática $\mathrm{P}$ \\
\hline Das 2 às $2 \mathrm{~h} 45^{\prime}$ & $\begin{array}{l}\text { aritmética no } \\
\text { quadro P }\end{array}$ & problemas D & $\begin{array}{l}\text { sistema métrico no } \\
\text { quadro } \mathrm{P}\end{array}$ & desenho D & aritmética $\mathrm{P}$ \\
\hline Das 3 às $3 \mathrm{~h} 45^{\prime}$ & problemas D & $\begin{array}{l}\text { conhecimentos re- } \\
\text { ais (as } 2 \text { classes) } \mathrm{P}\end{array}$ & problemas D & ortografia D & problemas D \\
\hline Das 4 às $4 \mathrm{~h} 45^{\prime}$ & $\begin{array}{l}\text { religiáo (assiste a } \\
\text { 1classe) P }^{\text {a }}\end{array}$ & $\begin{array}{l}\text { exercícios de falar } \\
\text { (as } 2 \text { classes) P }\end{array}$ & $\begin{array}{l}\text { ginástica (as } 2 \\
\text { classes) P }\end{array}$ & $\begin{array}{l}\text { religiāo (as } 2 \\
\text { classes) P }\end{array}$ & $\begin{array}{l}\text { recitação (as } 2 \\
\text { classes) P }\end{array}$ \\
\hline
\end{tabular}

Os primeiros horários, compreendidos das 8 horas às $4 \mathrm{~h} 45^{\prime}$, correspondem às matérias previstas para a $1^{\text {a }}$ classe. Os horários das linhas de baixo, compreendidos também entre 8 horas e $4 \mathrm{~h}^{\prime} 5^{\prime}$, correspondem às matérias previstas para a $2^{\mathrm{a}}$ classe.

P. Esta letra significa que as liçôes hão de ser dirigidas pelo professor.

D. Esta letra significa que as lições hão de ser dirigidas por um decurião com a ajuda de um professor.

N.B. Os exercícios feitos com as duas classes reunidas podem-se prolongar além dos 45 minutos.

FONTE: Julio CALDAS AULETE, Directorio, In: Cartilha Nacional.

Monteverde e Caldas Aulete não eram obviamente os únicos autores de livros didáticos que teriam tido papel destacado na feitura e na aprovação de obras destinadas à instrução. O século XIX era - como já se tem muitas vezes dito - o século da leitura. Mas inequivocamente era também o século da irradiação dos compêndios de escola. Havia desejo de concorrência naquele mercado do livro didático. Um queria se notabilizar mais do que o outro. A lógica comercial imperante combinava-se ali à notória rivalidade quanto à procura do melhor método, do mais eficaz modelo de ensino. Talvez tenha sido o próprio êxito desse mercado do comércio didático o que colocou nos anos 50 o debate sobre a metodologia e as estratégias de ensino como eixo inarredável da discussão pedagógica. Parecia cada vez mais urgente descobrir o segredo daquilo que atrás se nomeou alquimia do magistério. Com o propósito de decifrarem esse segredo de como bem ensinar para os alunos 
bem aprenderem, os compêndios empenhavam-se em procurar superarem-se uns aos outros.

Innocencio Francisco da Silva, em seu Diccionario bibliographico portuguez, editado em 1893, referia-se à $5^{\mathrm{a}}$ e à $7^{\mathrm{a}}$ ediçóes d' $O$ Expositor portuguez, datadas respectivamente de 1852 e 1860, nas seguintes palavras: "não hei tido ocasião de verificar a data da primeira edição, feita em Londres, deste compêndio, cuja extração total de 72.000 exemplares é prova demonstrativa da sua utilidade e da pública aceitação que obteve não só em Portugal mas no Brasil." ${ }^{665}$ Por causa da atuação política liberal que tivera, particularmente quando funda com Paulo Midosi e Garrett, entre outros, o jornal O portuguez, Luís Francisco Midosi foi perseguido político, preso, e teve de emigrar para a Inglaterra em 1828. De volta a Portugal, com a instauração definitiva do liberalismo a partir de 1834 , passou a exercer um acentuado papel político junto aos poderes centrais. Em 1836, Midosi seria nomeado Governador Geral do distrito de Portalegre.

De acordo com o que informa o Relatório da Inspeção datada de 1875, O expositor portuguez ou rudimentos de ensino da lingua materna representaria $6 \%$ do total de livros encontrados nas escolas, sendo que, em Lisboa, esse percentual crescia para $18,6 \%$. Era nitidamente uma obra voltada para o uso das escolas portuguesas e brasileiras. A cartilha pricipiava com quadros de palavras acompanhados de suas respectivas gravuras. Então, correspondendo à palavra árvore, vinha no mesmo quadro o desenho da árvore. A palavra que compunha cada quadro vinha posta pela ordem alfabética e a letra era representada em cima. No mesmo quadro da árvore, as letras A e a vinham acompanhando a gravura e a palavra. Esta, por sua vez, era já repartida nas sílabas que a constituíam. Era então grafada do seguinte modo: ár-vo-re.

Mais adiante, após as listas do abecedário - em suas diferentes formas de grafia -, das sílabas e das palavras, já divididas por diferentes liçōes (e, no caso destas últimas, sempre com a separação das sílabas), começava a segunda seção, correspondente ao que o autor intitulara de "Liçôes de ler soletrando". Tratava-se, na verdade, de textos escritos com as palavras também divididas em sílabas, de acordo com o modelo transcrito a seguir:

\begin{abstract}
"Hen-ri-que, ven-do um cão que pas-sa-va, dis-se-lhe: Cão-zi-nho, que-res tu brin-car co-migo? Não, tor-nou-lhe o cão; eu não de-vo es-tar o-ci-o-so: vou le-var nes-ta al-co-fa a car-ne a meu a-mo; e não que-ro que e-le es-pe-re por mim. Hen-ri-que fi-cou tris-te, e ven-do um passa-ri-nho que an-da-va o-cu-pa-do a le-var pa-lhas, per-gun-tou as-sim: - Pas-sa-ri-nho, e tu, que-re-rás a-ca-so brin-car co-mi-go ? Não, res-pon-deu o pas-sa-ri-nho; eu não pos-so es-tar o-ci-o-so, por-que é tem-po de fa-zer o meu ni-nho. Hen-ri-que pôs-se a pen-sar e dis-se consi-go: Que é is-to? Nin-guém es-tá o-ci-o-so se-não eu? Na-da: va-mos pa-ra o mes-tre. Dei-tou a cor-rer pa-ra a es-co-la e a-pren-deu as li-ções tão bem que o mes-tre di-zi-a que Hen-ri-que era um bom ra-paz, e o me-lhor es-tu-dan-te que lá an-da-va." 366
\end{abstract}

Pelo compêndio de Midosi, percebe-se claramente o quanto a época se valia do recurso à soletração. No caso do Methodo facillimo de Monteverde, percebia-se que o

\footnotetext{
${ }^{365}$ INNOCENCIO Francisco da Silva, Diccionario bibliographico portuguez, tomo V, p. 289.

${ }^{366}$ Luiz Francisco MIDOSI, O expositor portuguez ou rudimentos de ensino da lingua materna, 4a edição, p. 48-9.
} 
traço gerador da leitura não era exatamente a letra, mas a sílaba, que vinha sempre acompanhada de sua utilização na palavra. Evidentemente isso explica, mesmo em termos metodológicos, o sucesso editorial de Monteverde, que ensinava ao mesmo tempo a leitura e a escrita; e veladamente propugnava - como já se pôde observar acima - o ensino simultâneo enquanto modo mais eficaz de conduzir a uma aprendizagem homogênea e organizada para todos os alunos da classe. O sucesso de João de Deus era pautado, por sua vez, pela tentativa do poeta de substituir o ensino das letras ou sílabas pelo ensino da palavra, em seu significado próprio, como correspondendo a escrita antes ao sentido do que à sua representação gráfica. $\mathrm{Na}$ época, isso não era costumeiro, e o próprio João de Deus muitas vezes negava que seu ensino fosse analítico - provavelmente como forma de aplacar a ira dos opositores; ou talvez porque não percebesse o alcance de sua proposta pedagógica. Seja como for, para aquele período, as cartilhas de instrução primária ainda pareciam dar o tom e a coloração do debate acerca do método...

\section{Os valores que a escola referendava e, na outra margem, instituía}

Manuel Justino Pires era um professor particular de instrução primária que habitava na cidade de Elvas. Em 1851, ele escreve uma cartilha de cinqüenta páginas, oferece-a à mocidade elvense e coloca na capa - quase a título de epígrafe - as seguintes palavras: "transmite o professor, a par das letras, as luzes da moral e da virtude" 367. O livro - que a 25 de Setembro de 1851 foi remetido ao Conselho Superior de Instrução Pública, acompanhado por um ofício do autor dirigido ao Presidente daquele mesmo Conselho, o Sr. Reitor da Universidade de Coimbra - teria sido "autorizado para entrar na lista dos compêndios elementares" na reunião do Conselho datada de 24-10-1851. No ofício que enviara ao Reitor, o autor solicitou a publicação de sua obra alegando razões de ordem moral. Pires julgava que seu trabalho, talvez mais do que os então em vigor na instrução de primeiras letras, primava pelo espírito da religiosidade e da civilidade cristãs, o que então corresponderia às necessidades da pátria quanto à formação de cidadãos úteis.

"Dedicado, na falta de pessoas competentes, ao triste e penoso exercício do Magistério, cujas funções exerço na qualidade de Professor particular de Instrução Primária, desde o primeiro de Outubro de 1834, tenho sempre trabalhado para bem educar a puerícia, ensinando-lhe, a par dos conhecimentos literários, as máximas da Religião e Civilidade Cristã para formar membros úteis à Pátria e à Sociedade. Não como vil mercenário, mas como pai cuidadoso, tenho procurado, durante dezesseis anos de minhas fadigas, o método mais fácil para transmitir aos meninos aquelas disciplinas que são próprias da sua inteligência e que fazem o objeto da instrução elementar; por isso tenho coordenado e mandado imprimir alguns opúsculos destinados a facilitar-lhes esta mesma instrução, exemplares dos quais foram remetidos a esse Sapientíssimo Conselho, com as classificações do meu exame, em 1848. Ultimamente, conhecendo a necessi-

${ }^{367}$ M. J. PIRES, Rudimentos da leitura portugueza com exercicios para soletrar em lettra redonda, italica, gothica e manuscripta offerecidos á mocidade elvense. 
dade de regular o método dos rudimentos da leitura portuguesa, escolhi o termo médio entre aqueles, uns dos quais pecam por defeito, outros por excesso, e me animei a mandar imprimir o incluso folheto que tenho a honra de oferecer à censura de V. Exa e do Eminente e assaz erudito Conselho Superior de Instrução Pública, para, no caso de ser aprovado, poder adotar-se nas aulas. Se ele carecer de censura, estimarei muito ter ocasião de conhecer os meus erros para corrigi-los; e se merecer aprovação, folgarei em poder enobrecê-lo com este título, quando porventura chegar a reimprimir-se." 368

A cartilha de Manuel Justino Pires era bastante simples, escrita com uma grafia arcaica. Logo a seguir ao quadro do alfabeto, vinha um pequenino texto, designado "exercício para soletrar em letra manuscrita", cujo conteúdo parecia revelar antes o intento de ensinar a infância a bem se comportar do que a proceder diretamente ao ensino da leitura. Tratava-se da história de um menino que proferia algumas "tolices, palavras livres e juramentos execratórios" para sua mãe, que o repreendeu, proibindo-o de proferir aqueles insultos. As crianças - adverte a mãe - não deveriam nunca repetir expressões que só ficam bem na boca dos libertinos. O menino, obediente, não volta a dizer tais coisas em presença de sua mãe. Mas a mãe acaba por saber que ele mantinha o mesmo tom de comentários quando acompanhado de seus colegas. Zangada, ela diz ao filho:

"Pois que, meu filho, perdeste o amor de Deus? Não sabeis que ele vos ouve, e vos vê em toda a parte? Não vos atreveis a falar diante de mim, e tendes o arrojo de falar diante de Deus? Sabeis pois que deveis temer a Deus mais do que a mim? Ele é vosso Criador, vosso primeiro Pai, e vosso Juiz. Mudai de conduta, meu filho, eu quereria antes ver-vos morto a meus pés, do que vivo com tais vícios. Eu vos proíbo a companhia daqueles de quem aprendeste a falar (...). Estas palavras fizeram uma tal impressão no espírito deste menino, que ele se emendou e foi sempre obediente à sua mãe; e Deus recompensou sua boa conduta entrando depois numa Religião, onde fez grandes progressos nos estudos e na virtude, morrendo em avançada idade, com todos os sinais de predestinado." 369

Na $14^{\text {a }}$ edição do livro de Luiz Francisco Midosi, intitulado O Expositor portuguez ou rudimentos de ensino da língua materna, lia-se o seguinte: "a civilidade é uma convenção tácita entre os homens de se enganarem reciprocamente." ${ }^{370}$ Tratava-se de uma frase incluída no conjunto de máximas e sentenças morais que, basicamente, compunha uma unidade da referida obra. Essa máxima, entretanto, não constava de edições anteriores (estando ausente particularmente da $4^{a}$ edição de 1846, a qual tivemos acesso, e com a qual vínhamos anteriormente trabalhando). Como se justifica essa

${ }^{368}$ Arquivo Central das Secretarias de Estado. Ministério do Reino. Mç 3527. Manuel Justino PIRES, Ofício encaminhado ao presidente do Conselho Superior de Instrução Pública e Reitor da Universidade de Coimbra. a propósito apreciação que aquele órgão deveria fazer do referido compêndio de autoria do autor, que era na ocasião ali apresentado.

${ }^{369}$ A. J. PIRES, Rudimentos da leitura portugueza com exercicios para soletrar em letra redonda, italica, gothica e manuscripta, p. 37-8.

${ }^{370}$ Luiz Francisco MIDOSI, O expositor portuguez ou rudimentos de ensino da lingua materna, 14aa: nova edição revista e aumentada, 1877, p. 127. 
inclusão em tom de crítica de alguma coisa que, até os anos 50, era virtude indiscutível? Tratava-se provavelmente de uma reticência em relação a algo que representava como máscara social - como se esta máscara estivesse, ela mesma, colocada em questão. Em que medida reforçar elos de civilidade não corresponderia a incutir na criança o hábito estudado da hipocrisia? Esta última - como já constava da definição dada na $4^{\text {a }}$ edição da cartilha, datada de 1846 - correspondia ao seguinte: "a hipocrisia é a máscara da virtude cobrindo o vício. O hipócrita procura iludir seus semelhantes, cometendo crimes sob a proteção das falsas aparências da virtude." ${ }^{371}$

\section{Bordas de livros e indícios de leitura...}

Nota-se, pela trilha daquilo que a posteridade guardou, que o livro didático trazia, talvez como nenhum outro, a marca de sua passagem pela vida do leitor. Anotado, rabiscado, rasgado, encapado, remendado, ele guarda ainda consigo os vestígios de sua tumultuada e contraditória utilização. O compêndio escolar - como se sabe - é um livro que não pertence diretamente ao leitor. Pelo menos, a princípio, ele pertence fundamentalmente ao mestre, que abrirá as portas do conhecimento àquele que, no início do aprendizado, não é suposto possuir as habilidades plenas para decifrar a magia do escrito. Haveria pois um longo processo, com ou sem técnicas de soletração, mas que tinha por pressuposto básico o recurso à cópia, ao ditado, à leitura em voz alta e em voz baixa. Existe - é fato - todo um ritual que leva o aluno a dominar o segredo do livro; este segredo será tão mais caro quanto parecerem distantes os primeiros dias de escola.

O livro era o primeiro; era às vezes o único. O livro escolar era por isso sagrado ao trazer a possibilidade de abertura dos outros livros, que poderiam ser, como este, manuseados, copiados, usados, lidos e compreendidos. Já aqui se abordou o tema dos valores e dos saberes contidos na vida de sala de aula em Portugal do XIX. Trata-se agora de falar dos usos de uma escrita que relê o texto; das bordas, das margens, do registro que individualiza o exemplar que se possui. De algum modo, buscar-se-á compreender a ânsia pela reinvenção de sentidos, que caminha do leitor ao texto, e que provavelmente estará por detrás dos livros que a escola lê. Desejava-se de fato, pela trilha da leitura, reiventar e reviver novos significados, que, ao serem criados pelo ato de ler, ficariam então inscritos também no texto e muito particularmente no coração do leitor. Não era sem um certo carinho que a puerícia portuguesa ia à escola. Pode-se notar, pelos vestígios obtidos, a existência nítida do apego e a procura por aproximação do mundo letrado.

Em quase todos os exemplares localizados foram encontrados vestígios de leitura. Ao menos o seu nome, o proprietário do exemplar costumava anotar. Muitas vezes também indicava o local de onde falava: uma vila, uma aldeia, o distrito em que morava; ou até o nome da escola e a data. Seria a data de aquisição ou de fato a data do princípio da leitura? Poderia ser a data que coincidia com o término do período

${ }^{371}$ Luiz Francisco MIDOSI, O expositor portuguez ou rudimentos de ensino da lingua materna, 4 a edição, 1846 , p. 129. 
escolar, quando certamente o livro deixaria de estar tão presente na vida de seu leitor. $\mathrm{Na}$ maioria dos casos, cabe apenas suspeitar do indício exato da data, não se podendo entretanto afirmar com certeza a que etapa da vida do leitor-estudante ela verdadeiramente corresponde; exceto quando o próprio leitor do presente conversa com seu virtual leitor do futuro. Foram averiguados exemplares esparsos, com o fito de reconstituir essa marca leitora, para procurar nela a inscrição dos usos. Estes, todavia, certamente se estendiam para além das fronteiras da escola...

Várias vezes Domingos Martins P. Moura escreveu seu nome e a data de Junho de 1866 no exemplar que possuía da Grammatica portugueza, de Carlos Augusto Figueiredo Vieira. Era um traçado de letra irregular e mal feito, que talvez representasse o desejo do estudante de convencer a si próprio que, se a gramática era sua, havia que aprendê-la. Não era este o único caso. Já Fernando da Silva Correia anotava o próprio nome na página de rosto, como se ela, a rigor, viesse na seqüência do título do livro - Grammática portuguêsa ensinada pelos exemplos - e do nome de seu autor - Ulisses Machado. Tornava ali nítido que ele mesmo, leitor, desejava fazer parte da composição que unia texto, escritor e tipografia. A pertença do exemplar ficaria pois mais do que registrada: ela tornaria único aquele compêndio. Não era qualquer livro; nem tampouco qualquer $2^{\mathrm{a}}$ edição da gramática de Ulisses Machado. Era - como o dono do livro fazia questão de sublinhar acima do título - 'esta'. O acréscimo à lápis do pronome demonstrativo 'esta' seria seguido pelo título impresso da gramática portuguesa e era realmente a tentativa de singularizar o leitor e, por conseqüência, seu material impresso: seu exemplar. Havia também quem marcasse as notas das provas escolares divididas por etapas do ano letivo. Francisco Botto registrou em seu Compendio de chorografia de Portugal - cujo autor era João Félix Pereira - que teria a matéria de corografia às terças e sextas. Posteriormente, indicaria o seguinte: "no dia 3 de Maio de 1873 fiz exame de instrucção Primaria." O dono da Grammática portuguêsa de António Garcia Ribeiro de Vasconcelloz não se identificava, mas teria desenhado, no primeiro verso em branco que pôde ocupar, a figura de uma ponte sobre um rio, com a vista para o horizonte... Já a primeira página em branco do exemplar ao qual se teve acesso da Encyclopedia das escolas d'instrucção primaria, de autoria de Julio Caldas Aulete e José Maria Latino Coelho, vinha com o seguinte texto, redigido em caprichada letra caligráfica: "este livro pertence a Manuel Soares de Castro, natural da Freguesia de S. Pedro de Olinda, termo de Oliveira de Azaméis, bispado de Aveiro, que o mandou encadernar em Lisboa no ano de mil oitocentos e sessenta e cinco. Morador na rua da Amoreira no 28. Freguesia de São Paulo. Ano de 1865." Cada um dos leitores proprietários deixava anotado um modelo único, distinto, inimitável do depoimento que pretendia oferecer à posteridade.

Havia também, entre os livros, bilhetes e cartas sigilosas: cartas de pessoas que talvez tivessem usado o compêndio na infância e depois o guardaram como relíquia, e que, na primeira oportunidade, transformaram-no em cofre de segredos... São inúmeros os exemplares que trazem vestígios de alunos que preservaram com extremo zelo e cuidado o seu livro de escola. Além de copiar poesias em seu exemplar com data de 1868 (5 $5^{\text {a }}$ edição) e desenhar frondosas árvores na capa do compêndio de Henrique Carlos Midosi (Poesias selectas), a estudante que se alcunhava 'Nema' proferia maldiçôes contra quem eventualmente pegasse seu livro e não viesse em seguida devolvê-lo: "se algum dia te perder / a pessoa que te achar / e o não venha entregar / ao inferno irá parar / de cabeça para baixo / e os pés para o ar." 
Em 5-3-1899 foi oferecido a alguém que assinava Falcão, pela escola onde ele estudava, um prêmio por aproveitamento referente ao ano letivo de 1897-1898. Era isso que vinha registrado na primeira folha em branco do compêndio Sciencia infantil: livro de leitura para as escolas, de autoria de Emílio Vidigal Salgado. Posteriomente, o mesmo dono do livro faria, em papel colado no verso da capa dura, o seguinte testemunho: "oito anos depois (1906), tive por namorada - a minha primeira conquista ... - a filha do autor deste livrinho infantil, Emília Vidigal Salgado.” De fato, parecia efetivamente notória a busca de deixar recados aos que viriam depois... O livro - escolar ou não - era um templo privilegiado para receber mensagens do passado e para deixar mensagens para o futuro - para contar os segredos e para transcrever sensações, emoções, significados. Era como se a anotação do leitor pudesse, ela mesma, inscrever sua narrativa e reinventar o próprio texto impresso na obra. O livro representava uma ampliação do espaço e do tempo; ampliação que pertencia exclusivamente - como em segredo - ao leitor que o possuía e que poderia, como, por contrapartida, contar também para ele - livro - seus mais íntimos e escondidos segredos: talvez estrelas e constelaçóes... No contracanto entre livro e leitor, o papel da escola era com carinho recordado como um rito de passagem para a cultura das letras. 


\title{
CONSIDERAÇÓES Finais
}

\author{
"Muito longe daqui, nem eu sei quando, \\ Nem onde era esse mundo em que eu vivia.. \\ Mas tão longe... que até dizer podia \\ Que enquanto lá andei, andei sonhando..." \\ Antero de Quental. \\ No circo (A João de Deus)
}

É freqüente, no campo da educação, indagarmo-nos sobre quais teorias aplicamos em sala de aula. É freqüente comentarmos que escolas e professores são refratários a mudanças e inovações; que seriam apegados - por demais - a modelos tradicionais de ensino. Porém dificilmente o debate debruça-se sobre a indagação daquilo que se tem chamado de ensino tradicional. Tradicional, por definição, é algo que radica na idéia de tradição. Podemos, então, compreender que ensino tradicional é aquele cuja âncora é firmada na raiz de uma dada tradição. Sendo assim, é de se supor que todos os modelos de ensino que, de alguma maneira, são defendidos por nossa contemporaneidade possuem alguma raiz em alguma tradição. Se isso for verdade, o consenso sobre o que vem sendo nomeado ensino tradicional pode parecer um pouco mais difícil de ser obtido. É possível, todavia, verificar que os estudos produzidos no campo da cultura escolar concentram-se nos modos de ser e de agir, nos usos e nos costumes que compõem historicamente nossa forma de ser escola. Tais estudos procuram estabelecer o diálogo entre as representações que as sociedades fazem do lugar social ocupado pela escola e as práticas que se desenrolam no processo da escolarização. Nesse sentido, trata-se de confrontar o aparato legal que versa sobre os currículos, e - mais do que isso - o discurso político da educação, com os hábitos e as rotinas do ensino efetivamente praticado. Vestígios como livros didáticos, cadernos escolares, planos de aula tornam-se documentação prioritária para a compreensão dos modos pelos quais se constitui pela escola um dado processo civilizador.

É possível verificar que a constituição da escola moderna acontece como um movimento que, primeiramente, é estruturado a partir de referências religiosas. Cabe lembrar que, quando a prensa tipográfica foi inventada em meados do século XV, passa a haver, a pouco e pouco, a irradiação de uma competência leitora que poderia ser perigosa aos olhos dos poderes instituídos. Tratava-se, nesse sentido, de regrar a leitura; contra possibilidades imprevistas de aprendizado dos códigos que norteiam 
a capacidade da escrita. Os colégios religiosos, durante a Idade Moderna, ocuparam esse papel.

Progressivamente a idéia de escola passa a ser vista como um direito público. Mais do que uma política de Estado, tratava-se de erradicar do povo sua condição de ignorância; como se essa fosse a outra face do direito da cidadania: o dever do esclarecimento pela formação do voto consciente. Viver na sociedade contemporânea - protegido e/ou punido pela mesma legislação; todos iguais - requereria o firmamento de uma igualdade matricial quanto ao acesso às oportunidades de formação. No território pedagógico, poder-se-iam superar formas de vida consideradas arcaicas. Para tanto, o primeiro movimento era o de colocar na mesma classe todas as crianças, habitantes das cidades e dos campos. O ensino ministrado deveria contemplar referências comuns de conteúdo e de método. Todavia o modelo dessa escola que pretendia fincar a igualdade tomava por igual aquilo que, em princípio, era diverso. A forma de ser escola produzia estranheza. Uma estrutura padrão e ritualizada era, para tanto, produzida. Novas regulaçôes para o tempo firmaram, na escola, a grade curricular dos horários. O espaço da vida escolar é classificado por classes, onde níveis de aprendizado e faixas de idade firmam agrupamentos. Compunha-se o modelo da escola seriada. A escola se apresenta como instituição autorizada a falar à infância; a estabelecer a transição entre família e vida social. Para isso, ali se reinventavam as formas de lidar com a cultura. Rituais de formação direcionam-se pelo tom solene do exame. A escola que instaura pretensamente a homogeneidade é também aquela que aciona um conjunto de minuciosos dispositivos para firmar fronteiras e estabelecer limites entre os que possuirão êxito e os que sairão fracassados do seu sistema. Para propor formas efetivamente novas de contemplar o tema da educação escolar, será fundamental alterar a compreensão da idéia norteadora da escola moderna: aquela que ensina a um coletivo como se estivesse falando com um só. Aquela que fala da diferença proclamando padrōes unitários. Sem transformar o coração desse ritual, dificilmente conseguiremos reinventar o movimento interno da escola. Por causa disso, é necessário, sim, interpelar e dialogar com essa tradição. Só não se poderá, em nome da transformação, desconhecê-la.

O século XIX foi para a Europa o tempo de redesenhar a nação. Pautado também pelo signo da reconstrução política, o caso de Portugal apresenta algumas especificidades no conjunto europeu. Seja como for, qual teria sido, nas representações e nos quadros mentais do cenário português, o ofício atribuído à escola primária? Como a escola era retratada pelos registros internos ao seu cotidiano? Pretendemos averiguar a via de mão dupla existente entre a sensibilidade popular e o rescaldo de cultura erudita no âmbito do repertório das práticas e dos saberes escolares. Compreendemos que a vida da escola tem uma dinâmica que entrelaça esses dois universos. Afinal, a escola projetada não será a mesma escola apropriada pelas crianças em sala de aula. Sem chegar ao ruído e às travessuras das classes de alunos, pouco se pode aferir sobre a realidade educacional de um dado país.

Ao propugnar o ensino universal e de boa qualidade como veículo de combate contra o atraso da nação portuguesa perante os demais países europeus, confere-se à escola o estatuto de regeneração. Reerguer Portugal decadente torna-se, pois, a missão precípua da instrução pública. É como se o espraiar da cultura pudesse reconstruir a vocação de grandeza do povo português. Há também, nesse indício 
iluminista, recorrente tonalidade econômica: fortalecida a rede de ensino, as novas geraçôes capacitar-se-iam para impulsionar o progresso sem ferir a ordem. O debate intelectual sobre os rumos da pedagogia viria acompanhado por uma considerável produção editorial que buscava adaptar as novas idéias para o nível do senso comum. Nesse sentido, almanaques e enciclopédias dirigidos às famílias, compêndios de civilidade divulgados para as escolas, além de todo um conjunto de manuais escolares que se pretendiam apropriados aos novos modelos educativos, veiculavam procedimentos de análise da criança, métodos e estratégias de ensino, vendidos como a adequação prática da modernidade pedagógica. Elegiam-se, pelo encontro da produção editorial com o pensamento pedagógico, crivos de legitimidade para os saberes específicos e singulares da escola primária, que eram, por sua vez, eleitos como indispensáveis para a construção do futuro e, com isto, para a edificação do homem novo. Por essas características, o debate pedagógico só ganha significado mediante interlocução com os referenciais trazidos pelo cotidiano escolar.

A investigação desses temas apontava para a necessidade de rastreamento de duas realidades: aquele determinado modelo de escola e, na outra margem, o que se desejava que ela viesse a ser. Era, também, imprescindível inferir - pelo estudo das representações e das práticas sobre a escolarização - o que se pretendia fazer da escola e o que ela teimava em fazer das realidades, recorrendo ao diálogo entre pensamento e ação; entre o discurso e a vida da escola. Para tanto, paralelamente aos discursos, procuramos estudar os rituais cotidianos: aquilo que a escola fazia por rotina, o modo e o conteúdo do que ensinava, os valores e práticas disciplinares por que se pautava, as hierarquias e as demarcações de fronteiras de gênero, de classe, de região, que, naquele território da aula, se expressavam... A tese a que nos propusemos pretendia vistoriar essa intersecção entre projeto e realidade...

A escola socialmente se apresenta como instituição reguladora da leitura espontânea. Quanto mais a sociedade portuguesa popularizava o veículo do impresso, mais o universo da leitura disputava seu lugar contra o predomínio da oralidade cultural. Sucede que, quanto maior o grau de leitura do indivíduo, maior seria o nível de sua informação sobre as coisas do homem e do mundo: sabia-se disso em Portugal do XIX. Se a leitura não tivesse, portanto, regras e regulações, ao menos no início do processo de seu aprendizado, o indivíduo poderia, através dela, aproximar-se de novos e transgressores valores; poderia, através da ampliação de repertório oferecida pelo próprio domínio do ato de ler, contrapor-se aos eixos e parâmetros de organização da realidade.

Poderíamos dizer que há uma semicorrespondência, no caso português, entre o discurso apregoado e a prática escolar, dado que a imprensa teve papel primordial na produção de algumas verdades pedagógicas, configurando um novo modo de olhar para a infância, para suas etapas específicas, para sua linguagem, para seu desenvolvimento, para seu aprendizado. Apesar de não se modificarem radicalmente práticas já costumeiras, com o avanço do saber pedagógico, mudara essencialmente o discurso do professor. O próprio material da inspeção de 1867 parece muito mais delimitado no tocante à procura do método do que os relatórios anteriores ainda presos por uma certa análise estrutural do papel da escola e de suas finalidades. Verifica-se assim entre discurso intelectual, revistas pedagógicas e inspeção às escolas - uma certa progressão que tendencialmente caminha por três etapas: entre 1820 e 1850, o acento no tema político da escolarização como estratégia privilegiada de exercício da 
cidadania liberal; entre 1850 e 1870 , o predomínio da indagação sobre a questão do método, dos modos de ensino, das táticas e procedimentos desenvolvidas em sala de aula; finalmente, entre 1870 e 1910 , passa-se a falar da educação pelo crivo de uma ciência pedagógica. Há uma mudança no estilo da enunciação do discurso, que pontua técnicas e visões teóricas que, se bem aplicadas, garantiriam o científico resultado dessa que se entendia a si mesma como ciência positiva prescritiva.

Percebemos, pelo trajeto que procuramos neste trabalho reconstituir, que, enquanto em Portugal já se criticava, por tratados pedagógicos, por jornais e por revistas, a chamada pedagogia tradicional, os autores de compêndios e os professores reunidos em Congressos, até o final do século, procuravam, ao contrário, as regras e os segredos para implementação do chamado ensino simultâneo. Este, por sua vez, reforçaria a possibilidade da aula expositiva, considerada tão necessária quanto bem-sucedida; aula expositiva essa que será, entretanto, o próprio paradigma do ensino tradicional.... Poderíamos mesmo compreender o século XIX português como uma longa e infatigável procura do modo simultâneo e das suas conseqüentes orientações para o preparo da aula expositiva. Sobre a apreciação que os portugueses faziam da escola, havia, sim, quem quisesse escola para seus filhos; havia, entretanto, evidentemente, os que não faziam caso disso; havia também crianças que, apanhando na escola, fugiam dela; mas havia finalmente crianças para quem a escola não era tão má, pelo fato de eventualmente até contribuir para livrá-las dos maus-tratos familiares, do trabalho na lavoura ou, no caso das meninas, do próprio trabalho doméstico.

Para os portugueses do século XIX - particularmente para aqueles que defendiam a opção pela escolarização -, a escola traria um potencial que, seguramente, não se limitava à mera reprodução da ordem, mas que, muito além disso, agiria no sentido de criar alguma coisa que, embora não se soubesse muito ao certo o que era, representava em termos sociais um aperfeiçoamento quando comparado ao presente. A educação, desse modo, compreenderia, de alguma maneira, o desejo de a Humanidade intervir voluntariamente na determinação do futuro, como se a história pudesse ser ela mesma pré-ordenada. Por ser assim, a escola acredita ser, ao mesmo tempo, o rito e o ensaio. É rito porque procura reatualizar nas novas geraçōes o conhecimento/ reconhecimento do passado, de maneira a que a juventude possa continuar e melhorar a herança que recebe dos que vieram antes. Mas é também ensaio, pelo fato de os contemporâneos julgarem que, reproduzindo nas etapas de desenvolvimento humano as próprias fases de evolução dos homens na história, a infância teria de ser alertada dos erros, para se precaver contra eles e para, chegada a idade adulta, ser capaz de forjar por si um futuro sempre melhor; como os adultos que a educaram seguramente sonharam.... Até certo ponto, poder-se-ia mesmo acreditar que a preocupação com a criança e com sua educação corresponde ao desejo social de domínio, controle, poder de mando e de intervenção sobre o curso da história. Notável instrumento de conformação do futuro, o rito escolar lida, pois, com um imaginário que fala sempre com o adulto em que a criança um dia se transformará. A escola é, sob tal perspectiva, uma opção que a história traçou; uma opção que quer ver a civilização pelo escrito...

Acerca do tema, vale recordar que a opção pela escola significava ainda a luta contra determinações ambientais, dado que, por suposto, educar seria minimizar a influência do meio, regrando, ao fazer isso, o acaso, o inadvertido... A escola que quer 
regrar o inesperado deseja diminuir os riscos do imprevisto e a ação do imponderável na História. Educa-se, então, para ilusoriamente intervir no trajeto e na construção do futuro. Educa-se para enfrentar o tempo e vencê-lo. Educar é, por assim dizer, produzir um tempo outro, tanto diferente quanto inovador. Por essa razão eram tão intensos os debates e tanto se dividiam partidários e opositores da escolarização. A criança, assim como a história, não é um destino inexorável, mas uma possibilidade em curso. A acepção de perfectibilidade, tão cara ao século XIX, é, para o caso português, o supremo ideal da pedagogia, rebatendo o fatalismo de todos os que procuram a vida escolar apenas como eixo de reprodução do existente. Sabe-se que tanto o determinismo rácico/étnico quanto a abordagem teórica que entende a escola exclusivamente pelo ato de uma necessária reprodução das classes por sua origem econômica conduzem ambos a um inexorável niilismo, uma descrença absoluta, que, ao fim e ao cabo, acarreta mesmo a negação do ato educativo, fundamentalmente do ato educativo exercido pela instrução escolar.

Se a finalidade fosse apenas a estática reprodução do existente, não seria necessária a escola: a família cumpre muito melhor esse papel. Irredutivelmente, para a reprodução e manutenção da ordem, a estrutura familiar seria pedagogicamente suficiente e convincente. A escolarização, ao contrário, pode potencializar o conflito de valores. A escolarização tem, inclusive, a potência de subverter a ordenação social, a perenidade dos laços de parentesco primário, os próprios alicerces do poder instituído. De algum modo, há uma visível concorrência entre escola e família, por disputarem ambas as instituições a gerência de coraçōes, mentes e almas. Evidentemente, é a escola quem conceitua a família e naturaliza nela as relaçōes de poder, quando postula, como conhecimento e paradigma da vida humana, o dever supremo do respeito e obediência aos pais.. Ao ir para a escola, entretanto, a criança trava contato com o primeiro ambiente social que compreende como seu, separado do núcleo familiar. Pais não entram na escola. A vida escolar, nesse sentido, constrói referências distintas, libertando, em certa medida, a criança da ingerência dos elos de sua socialização primária. A escola, ao transformar a criança em aluno, gera uma nova identidade, fundamental para a construção da autonomia do sujeito.

Evidentemente, há a busca de, pela trilha da instrução, fixar valores e saberes no corpo da sociedade. Mas valores são vários; e nem sempre eles combinam uns com os outros. Por tal razão, é tão intensa quanto tensa a relação da dinâmica escolar com os parâmetros da coletividade. Há contradiçôes, conflitos e complementaridade entre o poder familiar e a escola; há contradiçôes, conflitos e complementaridade entre o poder local e a escola; há contradiçôes, conflitos e complementaridade entre o poder central e a escola. Outrossim, sabe-se que o ato da educação, supondo uma agenda para conformar o futuro, pode se traduzir como uma pista para a transformação dos valores. Basta, para isso, que haja na sociedade embate ético. Seja como for, o imaginário escolar expressa ainda as inquietações da própria vida social quanto à sua subjetividade. As dificuldades, os lugares vazios atuarão sempre no sentido de favorecer um deslocamento de saberes, de conteúdos, de crenças... Há, no espaço escolar, uma constelação de problemas que remetem, quer à interlocução travada com a família, quer à interlocução travada com os demais poderes instituídos.

Conferindo significados ao ato de apreensão do real pelo escrito, o projeto escolar atribui, sem dúvida, equilíbrio simbólico e valorativo à realidade. De algum modo, 
poderíamos dizer que o gesto educativo subtrai da infância algo dela mesma, subordinando sua oralidade ao tempo da leitura, subordinando sua espontaneidade à civilidade da sala de aula. A escrita é a linguagem da escola, enquanto a linguagem da família é oralizada. Quando recusa a linguagem coloquial, criticando, muitas vezes, a própria pronúncia com que o aluno sonoriza sua realidade, a escola veda-lhe a experiência individual acumulada, mostra-lhe que ali seu mundo será outro; ali não cabem mais a fantasia e a imaginação. Ali deve-se penetrar no sério e severo panorama do escrito. Quando se impóe pela escola uma ética do dever, a infância fica então proibida de ser o que fôra até então. Daí o caráter ritual da instituição que fornece à juventude o lugar de uma verdadeira iniciação - em direção a outras tarefas, a outras missões, a outros rituais...

Nessa perspectiva a escola age como um rito de sacrifício do presente em nome do futuro. A escola, que conta do passado àqueles que viverão o futuro, representa, portanto, fundamentalmente, o alheamento e a fuga do momento atual... Sacralizando o passado e voltando-se para dialogar com o futuro, o tempo da escola é móvel, mas não consegue se delinear bem; não corresponde nem ao passado, que pretende glorificar como uma imagem exemplar, nem ao futuro, porque este sempre ainda não chegou... A escola tampouco pode ser compreendida no presente, porque se afastou propositalmente de sua temporalidade originária para falar do passado ao futuro. A escola sem tempo é, portanto, a idade mítica; é também o tempo do sacrifício. Deverá compor a passagem para o mundo adulto, em nome de uma felicidade que virá depois. Compreender a escola como um rito significa também compreender o minucioso exercício de gradual separação entre a criança e a família, afastamento esse proporcional à aproximação entre a criança e o resto do mundo, particularmente o mundo do futuro. Compreender a escola como um rito exige, como condição metodológica, o esforço incessante de apreender na vida escolar a confluência entre a tendência à conservação e o anseio por mudança. Rito de iniciação por proporcionar às crianças o cultivo da cultura letrada, a escola é também rito de passagem por instituir códigos de transição da vida familiar para a vida na coletividade social. Ensino simultâneo, divisão por séries, por idades, por níveis de aprendizado, grade curricular, distribuição de matérias no espaço e no tempo. A escola que a contemporaneidade construiu é, pois, a instituição que ordena e classifica; mas é principalmente aquela que ensina a ler, escrever, contar e se comportar... 


\section{Fontes Manuscritas}

\section{A. Biblioteca Geral da Universidade de Coimbra (B.G.U.C.)}

\section{- Códices e Títulos:}

Carta de Garret dirigida ao Imperador D. Pedro IV em 17.4.1835 (não catalogada)

1326. Papéis vários

1339. Papéis do Arquivo da Junta da Directoria Geral dos Estudos

1341. Papéis do A. da Junta da D. G. dos Estudos

1344. Papéis relativos à instrucção pública destes reinos

2530. Papéis relativos à instrucção pública destes reinos

2531. Papéis relativos à instrucção pública destes reinos

2532. Papéis relativos à instrucção pública destes reinos

2533. Papéis relativos à instrucção pública destes reinos

2534. Papéis relativos à instrucção pública destes reinos

2535. Papéis relativos à instrucção pública destes reinos

2536. Papéis relativos à instrucção pública destes reinos

3210. Decretos de D. Maria I e D. Maria II

\section{B. Arquivo Nacional da Torre do Tombo (A.N.T.T.)}

\section{- Códices e Títulos:}

\section{Arquivo Central das Secretarias de Estado. Ministério do Reino}

(M. R.): Mç. 3526; Mç. 3527; Mç. 3528; Mç. 3882; Lv. 1077; Lv. 1076; Lv. 1084; Lv. 1113; Lv. 1114; Lv. 1094.

MR 1056. (livro do Ministério do Reino) Inspecção das escolas públicas e particulares do distrito de Portalegre classificação de alunos, disciplinas, mobiliário, etc. - 1867

MR 1050. (livro do Ministério do Reino) Inspecção das escolas públicas e particulares do distrito de Évora - classificação dos alunos, disciplinas, livros, mobiliário, etc. - 1867

MR 1048. (livro do Ministério do Reino) Inspecção das escolas públicas e particulares do distrito de Castelo Branco - classificação dos alunos, disciplinas, livros, mobiliário, etc. - 1867

MR 1049. (livro do Ministério do Reino) Inspecção das escolas públicas e particulares do distrito de Coimbra classificação dos alunos, disciplinas, mobiliário, etc. - 1867

MR 1055. (livro do Ministério do Reino) Inspecção das escolas públicas do distrito de Lisboa - classificação dos alunos, disciplinas, mobiliário, etc. - 1867

MR 1054. (livro do Ministério do Reino) Inspecção das escolas particulares do distrito de Lisboa - Registo - 1867

MR 1057. (livro do Ministério do Reino) Inspecção das escolas particulares do distrito do Porto - Registos - 1867 
MR 1058. (livro do Ministério do Reino) Inspecção das escolas públicas do distrito de Santarém - Registos - 1867

MR 1059. (livro do Ministério do Reino) Inspecção das escolas particulares do distrito de Santarém - classificação dos alunos, livros, disciplinas etc. - 1867

MR 1062. (livro do Ministério do Reino) Inspecção das escolas públicas e particulares do distrito de Viseu - Registos - 1867

MR 1063. (livro do Ministério do Reino) Inspecção das escolas públicas e particulares do distrito de Angra do Heroísmo - Quesitos aos inspectores - 1867

MR 1046. (livro do Ministério do Reino) Inspecção das escolas públicas e particulares do distrito de Aveiro classificação dos alunos, livros, disciplinas, mobiliário, etc. - 1867

MR 1060. (livro do Ministério do Reino) Inspecção das escolas públicas e particulares do distrito de Viana do Castelo - classificação dos alunos, livros, disciplinas, etc. - 1867

MR 1061. (livro do Ministério do Reino) Inspecção das escolas públicas e particulares do distrito de Vila Real classificação dos alunos, disciplinas, mobiliário, etc. - 1867

MR 1051. (livro do Ministério do Reino) Inspecção das escolas públicas e particulares do distrito da Guarda classificação, livros, etc. - 1867

MR 1071. (livro do Ministério do Reino) Inspecção das escolas públicas e particulares do distrito de Coimbra (círculos 1 e 2). Quesitos aos inspectores - 1875

MR 1072. (livro do Ministério do Reino) Inspecção das escolas públicas e particulares do distrito de Évora. Quesitos aos inspectores - 1875

MR 1074. (livro do Ministério do Reino) Quesitos aos inspectores das escolas primárias públicas do distrito de Lisboa (círculos 1 a 3) - 1875

MR 1076. (livro do Ministério do Reino) Inspecção das escolas particulares do distrito de Lisboa (círculos 4 a 8). Quesitos aos inspectores - 1875

MR 1080. (livro do Ministério do Reino) Inspecção das escolas particulares do distrito do Porto (círculo 1). Quesitos aos inspectores - 1875

MR 1082. (livro do Ministério do Reino) Inspecção das escolas públicas do distrito do Porto. Quesitos aos inspectores - 1875

MR 1079. (livro do Ministério do Reino) Inspecção das escolas primárias públicas e particulares do distrito de Portalegre. Quesitos aos inspectores - 1875

MR 1067. (livro do Ministério do Reino) Inspecção das escolas públicas e particulares do distrito de Braga (círculos 3 a 5). Quesitos aos inspectores - 1875

MR 1068. (livro do Ministério do Reino) Inspecção das escolas públicas e particulares do distrito de Bragança (círculo 1). Quesitos aos inspectores - 1875

MR 1064. (livro do Ministério do Reino) Quesitos aos inspectores das escolas públicas e particulares do distrito de Aveiro (círculos 1 e 2) - 1875

MR 1066. (livro do Ministério do Reino) Quesitos aos inspectores das escolas públicas e particulares do distrito de Beja - 1875

MR 1070. (livro do Ministério do Reino) Inspecção das escolas públicas e particulares do distrito de Castelo Branco (círculos 4 a 6). Quesitos aos inspectores - 1875

MR 1085. (livro do Ministério do Reino) Inspecção das escolas públicas e particulares do distrito de Santarém (círculos 3 e 4). Quesitos aos inspectores - 1875

MR 1086. (livro do Ministério do Reino) Inspecção das escolas públicas do distrito de Vila Real (círculos 1 a 3 ). Quesitos aos inspectores - 1875

MR 1077. (livro do Ministério do Reino) Inspecção das escolas públicas e particulares do distrito de Ponta Delgada (círculo 1). Quesitos aos inspectores - 1875

MR 1045. Ministério do Reino. Direcção Geral da Instrução Pública - Livro de Ponto (1894-1899)

MR 1117. Ministério do Reino. Relatórios das Secções do Conselho Superior de Instrucção Pública - Livro de Ponto (1844-1858)

MR 1113. Ministério do Reino. Registo de despachos do Conselho Geral Director do Ensino Primário e Secundário e petiçōes várias (1840-1845)

MR 1121. Actas das Sessōes da comissão encarregada da Reforma da instrução secundária (1876-1879)

PROVAS d' escriptos dos alumnos da clafse mais adiantada da escola d'ensino mutuo de Braga offerecidas ao Ilmo. e Exmo. Sr. Conde de Villa Pouca, a quem esta escola deve a sua existência e bom arranjo. Pelo profefsor agradecido Carlos da Silva Seguier. Ministério do Reino, Arquivo Central das Secretarias de Estado, Livro 1.113.

PROVAS d'escriptos dos alumnos, que frequentarão a escola d'ensino mutuo da cidade de Braga, no anno de 1850. Ministério do Reino, Arquivo Central das Secretarias de Estado, Livro 1.114. 


\section{Biblioteca Pública de Évora (B.P.E.)}

- Códices e Títulos:

Cota $\frac{\text { CIX }}{1-18}$ fl

Fragmentos de um livro de registo da Directoria Geral dos Estudos

Cota CXXIX 1 vol. fol. 94 folhas. Livro pertencente à Directoria Geral dos Estudos $2-8$

Cota CXXIX
$2-7$ 1 masso fol. $\begin{aligned} & \text { Papeis relativos à junta da Directoria Geral dos Estudos, em tempo de } \\ & \text { Joaquim de Santa Clara }\end{aligned}$

\section{Arquivo Distrital de Vila Real}

-CONFERENCIAS mensaes do professorado do conselho de Braga (1884-1889)

- Livro das Actas das Sessōes das Conferências Pedagógicas n’este Círculo de Villa Real, 3a Circunscrição Escolar. 
(Página deixada propositadamente em branco) 


\section{FONTES IMPRESSAS}

A CABULOGIA ou moral em acção; parte primeira. Coimbra: Typographia da Opposição Nacional, 1845.

A Cartilha Maternal e a Imprensa. Lisboa: Typographia das Horas Romanticas, 1877.

A CIVILIDADE pela redacção da Educação Nacional. Porto: Livraria Figueirinhas, 1907.

A DISTRACÇĀO instructiva; jornal litterario publicado por uma Sociedade d'Estudiosos. vol 1, n 4, 1842.

A ESCOLA PRIMÁRIA. director: José Nunes da Fonseca. Composição e impressão na typographia d'Os Sucessos. Ilhavo, 3/5/1910 - no 1 .

A ESCOLA REPUBLICANA contendo o programa que o Centro Almirante Reis de Cascais promove em favor da nova escola de Birre. Lisboa: Typ. Paulo Guedes e Saraiva, 1910.

A ESCOLA: bi-semanário dedicado aos interesses da instrucção e do magistério. Director José Falcão Ribeiro, Typ. Rua do Norte 6, 1903.

A FEDERAÇÃO ESCOLAR: órgão semanal do professorado primário. Coimbra: Imprensa Acadêmica, 1899-1910. A ILLUSTRAÇÃO; jornal universal. Volume 1 (ornado de 160 gravuras). Lisboa: Na Imprensa Nacional, 1846.

A INSTRUCÇÃO do povo e o Methodo João de Deus; representação á camara dos srs. deputados publicada no Diario do Governo no 163 de 26 de Julho de 1897. Lisboa: Typ. Minerva Central, 1898.

A INSTRUCÇÃO e o povo; jornal cientifico e literario da Sociedade Civilizadora. Primeiro Anno. Coimbra: Imprensa da Universidade, 1855.

A INSTRUCÇÃO PORTUGUEZA; revista semanal. Directores: M. J. Felgueiras e Carlos Affonso. $1^{\circ}$ anno, volume I. $\mathrm{n}^{\mathrm{OS}} 1$ a 13, Porto: Typographia Occidental, 1886.

A MULHER E A CRIANÇA: revista mensal (Orgão da Liga Republicana das Mulheres Portuguesas). Anno 1. № 1. Lisboa: Typographia de Francisco Luiz Gonçalves, 1909.

A PENÍNSULA. Porto, 1852.

A VOZ DO PROFESSOR; quinzenal pedagógico órgão da associação do professorado primário terceirense - Angra do Heroísmo. ano II. 1910. Diretor e proprietário Joaquim Machado Tristão.

ABBADE de SALAMONDE. Cartilha da doutrina christã. Porto: Typographia de S. J. Pereira, 1850.

ABBADE METASTAZIO. Olimpiade, opera dramatica do Abbade Metastazio. Lisboa: Officina de Domingos Gonsalves, 1787.

ABECEDÁRIOS novos para uso do Asylo da Infancia de Coimbra. Coimbra: Imprensa da Universidade, 1851.

ABREU, José Maria de. Almanak da instrução pública em Portugal. Coimbra: Imprensa da Universidade, 1857.

Adivinhas portuguesas colhidas na tradição oral da provincia do Alentejo.

ALBUM D'O SÉCULO. Lisboa: Empreza do Jornal 'O Seculo', 1898.

ALBUM Poesias Coleccionadas. No 1. Alcobaça: Typ. de Antonio Miguel d'Oliveira, 1892.

ALBUQUERQUE, Antonio Maria Seabra d' (coord.) Selecta da infancia (approvada para uso das escholas primarias). Coimbra: Imprensa da Universidade, 1870.

ALBUQUERQUE, Luiz da Silva Mouzinho de. Ideas sobre o estabelecimento da instrucção publica dedicadas á nação portugueza e offerecidas a seus representantes. Paris: Impresso por A. Bobéé impressor da Sociedade Real Academica das Sciencias de Paris, 1823.

ALMANACH das senhoras para 1872. 20 anno. Lisboa: Typographia de Souza e Filho, 1871.

ALMANACH dos bons fadinhos para o anno de 1908 (bissexto). Lisboa: Typographia Universal, 1908.

ALMANAQUE illustrado do jornal pedagogico Educação Nacional. $4^{\circ}$ anno da sua publicação. Porto: Livraria Figueirinhas Editora, 1908.

ALVES DOS SANTOS. A nossa escola primária: o que tem sido, o que deve ser. Porto: Casa Editora de A. Figueirinhas, s/d. ALVES DOS SANTOS. O ensino primário em Portugal (nas suas relações com a história geral da nação). Porto: Companhia Portuguesa Editora, 1913. 
ALVES, A. Alfredo. Methodo de leitura e escrita. Lisboa: Livraria Ferreira e Oliveira, 1906.

AMOR, Manuel Antunes. Cartilha do adulto ou curso de leitura e escrita em 49 liçôes. 2a edição. Lisboa: Depósito Geral Livraria J. Rodrigues e $C^{i a}, 1935$

AMOR, Manuel Antunes. Cartilha moderna: método legográfico analítico-sintético de ensino inicial educativo. nova edição. primeira parte (método). Lisboa: Livraria Brazileira, 1914.

370 AMOR, Manuel Antunes. Cartilha moderna: método legográfico de ensino inicial educativo. nova edição. segunda parte (leitura). Lisboa: Livraria Brazileira, 1915.

AMOR, Manuel Antunes. Compendio de desenho para a 1 1a, $2^{a}$ e $3^{a}$ classe. Paris-Lisboa: Aillaud e C ${ }^{\mathrm{ia}}, 1906$.

AMORIM, Francisco Gomes de. A velhice á infancia; a proposito de um legado, deixado por Francisco Gomes de Araujo ao Asylo de Mendicidade com destino á fundação e sustento de uma escola. Lisboa: Imprensa Nacional, 1881.

ANNUARIO da Escola de Ensino Normal de Vianna do Castelo; anno lectivo de 1903-1904. Lisboa: Imprensa Nacional, 1905.

AO PARTIDO LIBERAL PORTUGUEZ a associação popular promotora da educação do sexo feminino. Lisboa: Imprensa União Typographica, 1858.

ARCHIVO PITTORESCO: semanário ilustrado. Lisboa: Typografia de Castro Irmão, 1857-1868.

ARCHIVO UNIVERSAL: revista hebdomadaria. 20 volume. Lisboa: Typographia Universal, 1859.

ARTE D'AMAR ou preceitos e regras amatorias ás damas: receita para melancólicos ou descripção do reino do amor. Lisboa: Impressão de Elias José da Costa Sanches, 1836.

AULETE, Julio Caldas. Cartilha Nacional: methodo ledographico para aprender simultaneamente a ler, escrever, ortographar e desenhar. $4^{\mathrm{a}}$ edição. Lisboa: Imprensa Nacional, 1873.

AULETE, F. Julio Caldas e COELHO, José Ma Latino. Encyclopedia das escolas d'instrucção primaria. Lisboa: Typographia Universal, 1854.

AULETE, F. Julio Caldas. Selecta nacional: curso pratico de litteratura portugueza, $1^{\text {a }}$ parte. $5^{\mathrm{a}}$ e $7^{\mathrm{a}}$ ediçóes. Lisboa: Typographia da Academia Real das Sciencias, 1882/1886.

AZEVEDO, Domingos de. Grammatica nacional ou methodo moderno para se aprender a fallar e escrever sem erros e mesmo sem auxílio de mestre a língua portugueza. Lisboa, 1880.

BANDEIRA, J. S. Nova Taboada exacta e curiosa com o novo systema metrico-decimal de pesos e medidas, tabelas de reducção e exercicios de problemas para intelligencia do mesmo systema. $6^{\mathrm{a}}$ edição. Coimbra: Imprensa da Universidade, 1879.

BANDEIRA, J. S. Novo methodo de leitura e pronunciação para se aprender a ler perfeitamente em pouco tempo. Coimbra: em Casa de Augusto Orcel, 1856.

BARBOZA, I. de Vilhena. Exemplos de virtudes cívicas e domésticas colhidos na historia de Portugal. $3^{\text {a }}$ edição (approvada pelo Governo para uso das escholas) Lisboa: Typographia de Manoel José Pereira, 1875.

BARREIROS, Carlos José. Elementos de moral para uso das escolas. $3^{\mathrm{a}}$ ed. Typographia Leal, 1858.

BARROS, João de. A escola e o futuro; notas sobre educação. Porto: Livraria Portuense de Lopes e Companhia, 1908.

BASTOS, Antonio. Grammatica intuitiva da língua portuguesa. Porto: Livraria Editora de António Figueirinhas, 1901.

BASTOS, Teixeira. Ideias geraes sobre a evolução da Pedagogia em Portugal. Coimbra: Imprensa da Universidade, 1892.

BATHLEEM, Abbade René. Catecismo da educação. trad. Casa Editora de A. Figueirinhas, 1927.

BELDEMONIO. A má lingua; profissão de fé. (folhteto impresso sem data).

BETTENCOURT, Barbosa de. Leituras portuguesas coligidas por -, (aprovadas pelo decreto de 7 de Setembro de 1907) Lisboa: Typographia José Bastos, s/d.

BETTENCOURT, J. Barbosa de. Trechos escolhidos de autores portugueses para uso da $4^{a}$ e $5^{a}$ classe. (approvado pelo decreto de 7 de setembro de 1907) Lisboa: Livraria Aillaud, 1907.

BIBLIOTECA do povo e das escolas. $1^{\circ}$ ano. $1^{\mathrm{a}}$ série. $4^{\mathrm{a}}$ edição retocada. Introdução ás sciencias physico-naturaes. Lisboa: David Corazzi, 1881.

BIBLIOTECA do povo e das escolas. $1^{\circ}$ ano. $1^{\text {a }}$ série. $4^{\mathrm{a}}$ edição retocada. Historia de Portugal desde os tempos anteriores à fundação da monarchia até a epoca presente. Lisboa: David Corazzi, 1883.

BIBLIOTECA do povo e das escolas. $1^{\mathrm{o}}$ ano. $1^{\mathrm{a}}$ série. $4^{\mathrm{a}}$ edição retocada. Arithmetica pratica. Lisboa: David Corazzi, 1881.

BIBLIOTECA do povo e das escolas. $1^{\circ}$ ano. $1^{\text {a }}$ série. $4^{\mathrm{a}}$ edição retocada. Zoologia. Lisboa: David Corazzi, 1881.

BIBLIOTECA do povo e das escolas. $1^{\circ}$ ano. $1^{\text {a }}$ série. $4^{\mathrm{a}}$ edição retocada. Chorografia de Portugal. Lisboa: David Corazzi, 1881 .

BIBLIOTECA do povo e das escolas. $1^{\mathrm{o}}$ ano. $1^{\mathrm{a}}$ série. $4^{\mathrm{a}}$ edição retocada. Physica elementar. Lisboa: David Corazzi, 1881. BIBLIOTECA do povo e das escolas. $1^{\circ}$ ano. $1^{\text {a }}$ série. $4^{\mathrm{a}}$ edição retocada. Botanica. Lisboa: David Corazzi, 1881. BIBLIOTECA do povo e das escolas. $1^{\circ}$ ano. $1^{a}$ série. $4^{\mathrm{a}}$ edição retocada. Astronomia popular. Lisboa: David Corazzi, 1881. 
BIBLIOTECA do povo e das escolas. $1^{\circ}$ ano. $1^{\text {a }}$ série. $4^{\mathrm{a}}$ edição retocada. Desenho linear. Lisboa: David Corazzi, 1881.

BIBLIOTECA do povo e das escolas. $1^{\circ}$ ano. $1^{\text {a }}$ série. $4^{\mathrm{a}}$ edição retocada. Natação. Lisboa: David Corazzi, 1883.

BIBLIOTECA do povo e das escolas. $1^{\circ}$ ano. $1^{\text {a }}$ série. $4^{\mathrm{a}}$ edição retocada. Electricidade. Lisboa: David Corazzi, 1883.

BIBLIOTECA do povo e das escolas. $1^{\mathrm{o}}$ ano. $1^{\mathrm{a}}$ série. $4^{\mathrm{a}}$ edição retocada. Propaganda de instrução para portuguezes e brasileiros. Historia de Portugal desde os tempos anteriores á fundação da monarchia até á epocha presente., David Corazzi, 1883.

BIBLIOTECA do povo e das escolas. $1^{\circ}$ ano. $1^{\text {a }}$ série. $4^{\mathrm{a}}$ edição retocada. Mythologia. Lisboa: David Corazzi, 1883 BIBLIOTECA do povo e das escolas. $1^{\mathrm{o}}$ ano. $1^{\mathrm{a}}$ série. $4^{\mathrm{a}}$ edição retocada. Philosophia do direito. Lisboa: David Corazzi, 1883.

BIBLIOTECA do povo e das escolas. $1^{\circ}$ ano. $1^{\mathrm{a}}$ série. $4^{\mathrm{a}}$ edição retocada. Prática de escripturação. Lisboa: David Corazzi, 1883.

BIBLIOTECA do povo e das escolas. $1^{\circ}$ ano. $1^{\mathrm{a}}$ série. $4^{\mathrm{a}}$ edição retocada. O Codigo fundamental da nação portugueza. Lisboa: David Corazzi, 1884

BIBLIOTECA do povo e das escolas. $1^{\mathrm{o}}$ ano. $1^{\mathrm{a}}$ série. $4^{\mathrm{a}}$ edição retocada. O Cholera e seus inimigos. Lisboa: David Corazzi, 1884.

BIBLIOTECA do povo e das escolas. $1^{\mathrm{o}}$ ano. $1^{\mathrm{a}}$ série. $4^{\mathrm{a}}$ edição retocada. Historia contemporanea. Lisboa: David Corazzi, 1885.

BIBLIOTECA do povo e das escolas. $1^{\circ}$ ano. $1^{a}$ série. $4^{a}$ edição retocada. Grammatica ingleza. Lisboa: David Corazzi, 1885.

BIBLIOTECA do povo e das escolas. $1^{\mathrm{o}}$ ano. $1^{\mathrm{a}}$ série. $4^{\mathrm{a}}$ edição retocada. Caminhos de Ferro. Lisboa: David Corazzi, 1886.

BIBLIOTECA do povo e das escolas. $1^{\circ}$ ano. $1^{\text {a }}$ série. $4^{\mathrm{a}}$ edição retocada. O Navio. Lisboa: David Corazzi, 1885.

BLANCHARD, Pedro. Thesouro dos meninos; obra classica dividida em tres partes: moral, virtude e civilidade. Vertida em portuguez por Matheus José da Costa. $3^{\text {a }}$ edição. Lisboa: Impressão Régia, 1817.

BOLETIM da Direç̧ão Geral de Instrucção Pública. Lisboa: Imprensa Nacional, 1902.

BORDALO, José Joaquim. O traficante ou retrato de muitos homens. Lisboa: Impressão de Alcobia, 1823.

BORDALO, José Joaquim. Os mestres charlatôes ou o poeta esquentado. Lisboa: Imprensa da Rua dos Fanqueiros, 1825.

BOTELHO Manuel Francisco de Medeiros. Plano geral de estudos primários e secundários. Coimbra: Imprensa da Universidade, 1869.

BOTELHO, Manuel Francisco de Medeiros. O que é e o que deve ser a Instrucção Nacional. Coimbra: Imprensa da Universidade, 1872

BRAGA, António Rodrigues. A educação na instrução primária. Coimbra: Imprensa da Universidade, 1911.

BRAGA, Teófilo. História da Universidade de Coimbra nas suas relaçōes com a Instrucção Publica Portugueza, Lisboa: Academia Real da Ciencias, 4 vols., 1892-1902.

BRAGA, Teófilo. História das idéias republicanas em Portugal. Lisboa: Vega, s/d.

BRAGA, Teóphilo. História da literatura portuguesa; volume $V$ - O Romantismo. Mira-Sintra: Europa américa, s/d.

BRAGA, Theophilo. João de Deus: escorço biographico. Lisboa: Portugal-Brasil, s/d.

BRANCO, Camillo Castello. O demonio de ouro. Primeiro Volume. Lisboa: Companhia Editora de Publicações Illustradas, s/d.

BRAY, Madame C. Physiologia das escolas. traduzida por Manoel Pinheiro Chagas. Lisboa: Livraria de Madame Marie Lallemant, 1876.

BREVE desenho da educação de um menino nobre. Lisboa: Officina Morazziana, 1787.

BRUNSWICK, H. Curso de língua franceza (para uso dos portuguezes e brazileiros). $4^{\mathrm{a}}$ ed. Porto: Ernesto Chardron, 1892.

CABRAL, Marianno José. Cartilha Sagrada. Ponta Delgada: Botelho e Irmãos, 1858.

CÂMARA, João da; AZEVEDO, Maximiliano de e BRANDÃO, Raul. Livro de leitura para as escolas de instrucção primaria (approvado por decreto de 4 de Setembro de 1903) para a $4^{\mathrm{a}}$ classe. Lisboa: Livraria Ferreira, 1903.

CÂMARA, João da (e outros). A escola e a vida: Leituras para a $4^{a}$ classe. $2^{\text {a }}$ ed. Lisboa: Aillaud e Bertrand, s/d.

CÂMARA, João da. Novas do outro mundo: carta de João de Deus. Lisboa: Empreza do Occidente, s/d.

CAMPOS, Agostinho de. Educar na família, na escola e na vida. Lisboa: Typ. 'A Editora Limitada', s/d.

CAMPOS, Agostinho dos. Analphabetismo e educação. Lisboa: Typographia do Diario Illustrado, 1904.

CANCIONEIRO de músicas populares contendo letra e música de cançôes, serenatas, chulas, danças, descantes, cantigas dos campos e das ruas, fados romances, hymnos nacionaes, canticos patrioticos, canticos religiosos de origem popular, canticos líturgicos popularisados, cançôes políticas, cantilenas, cantos marítimos, etc. e cançonetas estrangeiras vulgarisadas em Portugal. 3 tomos, prefácio de Theophilo Braga. Porto, Casa Moreira de Sá, s/d. 
CANTIGAS Amorosas e ao desafio. Colecção: Serōes d'Aldeia. Lisboa: Francisco Silva s/d.

CARNEIRO, Bernardino J. da S. Elementos de geographia e chronologia para uso das escholas (approvado pelo Conselho Superior de Instrucção Pública). 8ª ed. Coimbra: Imprensa Litteraria, 1868.

CARVALHO, Antonio José Fernandes. A doutrina christã e princípios de moral ensinados às crianças, (approvados officialmente para uso das escolas primárias). Braga: Cruz e Companhia Editores, 1906.

CARVALHO, Antonio José Torres de. A mulher portugueza: impressões de viajantes estrangeiros. Colecção: Correio Elvense. Elvas: António José Torres de Carvalho, 1904.

CARVALHO, Joaquim Martins de. "O uso da palmatória". In O Conimbricense. Coimbra: Typographia Joaquim Martins de Carvalho, $47^{\circ}$ anno, 5-12-1893.

CARVALHO, Joaquim Martins de. Uma festa civilisadora: distribuição de premios a alumnos em Condeixa.

CARVALHO, Manoel Pedro Henrique de. Memoria sobre a maneira de dirigir a educação nacional, segundo a forma de cada governo e sobre o modo de firmar a moral da nação. Lisboa: Typographia a Santa Catharina, 1834.

CARVALHO, Marta Maria Chagas de. A escola e a república. São Paulo: Brasiliense, 1989.

CARVALHO, Marta Maria Chagas de. Molde nacional e fôrma cívica: higiene, moral e trabalho no projeto da Associação Brasileira de Educação (1924-1931). Faculdade de Educação da USP: [tese de doutorado mimeografada]. 1986.

CARVALHO, Marta Maria Chagas. O novo, o velho, o perigoso: relendo a Cultura Brasileira. Cadernos de Pesquisa da Fundação Carlos Chagas. v.71. no8. p.29-36.

CARVAlHO, Marta Maria Chagas. Pelo ensino público, leigo e gratuito. Revista da Universidade de São Paulo. n6. Julho/setembro 1987.

CASAL RIBEIRO, J. M. do e CASTILHO, A. F. de. Cartas sobre as Escolas Populares. Lisboa: Typographia Universal, 1859.

CASTANHEIRA, José Correia Marques. Compêndio de moral e doutrina christã, direitos e deveres dos cidadãos, economia doméstica. Coimbra: Imprensa da Universidade, 1904.

CASTANHEIRA, José Correia Marques. Doutrina christã e moral: para uso dos alumnos das Escolas primarias em harmonia com os programmas officiaes. Coimbra: Imprensa da Universidade, 1903.

CASTANHEIRA, José Correia Marques. Elementos de moral: coordenados em harmonia com o programma official para uso das escolas normais e districtais. Coimbra: Imprensa da Universidade, 1902.

CASTILHO, A. F. de. Discurso Preliminar da quarta edição do Methodo Portuguez Castilho; offerecido pelo auctor á consideração de todas as pessoas illustradas, patrióticas e influentes. Lisboa: Typ do Progresso, 1857.

CASTILHO, A. F. de. Elementos da palavra fallada na lingua portugueza: adittamento ao Methodo Portuguez Castilho pelo seu author. Lisboa: Typ. Universal, 1853.

CASTILHO, A. F. de. Ou eu ou elles: tosquia de um camello: carta a todos os mestres das aldeias e das cidades. Lisboa: Empreza da Historia de Portugal Sociedade Editora, 1910.

CASTILHO, Alexandre Magno. Almanach de lembranças luso-brasileiro para o ano de 1860 (com 446 artigos e 101 gravuras). Lisboa: Typographia Franco-Portuguesa, 1859.

CASTILHO, António Feliciano Ajuste de contas com os adversários do methodo portuguez. Lisboa: Empreza da História de Portugal, 1909.

CASTILHO, António Feliciano. Camões: estudo histórico-poético liberrimamente fundado sobre um drama francez. $3^{a}$ ed. Lisboa: Empreza da História de Portugal, 1906.

CASTILHO, António Feliciano. Felicidade pela agricultura. vol II. 2a ed. Lisboa: Empreza da História de Portugal, s/d.

CASTILHO, António Feliciano. Felicidade pela instrução; cartas a um jornal de Lisboa. $3^{\mathrm{a}}$ ed. Lisboa: Empreza da História de Portugal, 1909.

CASTILHO, António Feliciano. Methodo portuguez - Castilho para o ensino rapido e aprasivel do ler, escrever e bem falar. Volumes I, II, III. 5a ed. Lisboa: Empreza da História de Portugal, 1908.

CASTILHO, António Feliciano. Noções rudimentares para uso das escolas. Lisboa: Empreza da História de Portugal, s/d.

CASTILHO, António Feliciano. Noçôes rudimentares para uso das escholas dos amigos das letras e artes em S. Miguel. volume II. Lisboa: Empreza da História de Portugal, 1909.

CASTILHO, António Feliciano. Resposta aos novissimos impugnadores do methodo portuguez, volume I, II e III. (publicada no Diario do Governo de 25 de março de 1856 até 28 de agosto de 1857) Lisboa: Empreza da História de Portugal, 1909.

CASTILHO, António Feliciano. Telas Literárias. Volume IV das obras completas revistas anotadas e prefaciadas por um de seus filhos. Lisboa: Empreza da História de Portugal, 1907.

CASTRO, José Ferreira da Silva. Manual das famílias ou os primeiros rudimentos d'educação physica e moral, Coimbra: Imprensa Commercial e Industrial, 1874. 
CATECISMOS da Diocese de Montpellier impressos por ordem do Bispo Carlos Joaquim Colbert e traduzidos na língua portugueza para por elles se ensinar a Doutrina Christã aos meninos nas escolas de Portugal e do Brazil. Novíssima edição muito melhorada e accrescentada com o Novo Systema Metrico Decimal. Porto: Na Nova Typographia, 1861.

CATHARINO, Manuel Lourenço. Systema metrico-decimal adequado as escholas d'instrucção primária. Coimbra: Imprensa Conimbricense, 1856.

CENSOR PROVINCIANO, periódico semanário de philosophia, política e literatura redigido por José Pinto Rebelo de Carvalho. Coimbra: Imprensa da Universidade, 1822-1823.

CHAGAS, Manuel Pinheiro. História de Portugal; edição popular e illustrada. volumes I - II. Lisboa: Escriptorio da Empreza, s/d.

CHAGAS, Manuel Pinheiro. Elogio historico do socio de merito Alexandre Herculano de Carvalho e Araujo. Lisboa: Typographia da Academia, 1890.

CIRNE JR., Francisco do Amaral. Resumo da história da pedagogia. Porto: Livraria Universal de Magalhães e Moniz, 1881.

CIRNE JUNIOR, Francisco do Amaral. Exame da Cartilha Maternal; relatório apresentado ao Exmo Snr Comissário d'estudos do Distrito do Porto. Porto: Typografia de Manuel José Pereira, 1879.

COELHO, F. Adolpho. "Exercícios corporaes e desenvolvimento moral". In Boletim da direcção geral de instrucção pública. Anno IV, Janeiro, Junho, Fasc I-VI. Lisboa: Imprensa Nacional, 1905.

COELHO, F. Adolpho. Alexandre Herculano e o ensino público. Lisboa: J. A. Rodrigues e Companhia, 1910.

COELHO, F. Adolpho. Contos Populares Portuguses. Lisboa: Dom Quixote, 1985.

COELHO, F. Adolpho. Cultura e analfabetismo. Edição fac-similada. Lisboa: Instituto Português de Património Cultural, 1984.

COELHO, F. Adolpho. Leituras portuguesas. Primeira parte. Nova edição. Lisboa: M. Gomes Editor, 1906.

COELHO, F. Adolpho. O trabalho manual na eschola primaria. Lisboa: Imprensa Democrática, 1882.

COELHO, F. Adolpho. Os elementos tradicionaes da educação; estudo pedagógico. Porto: Livraria Universal, 1883.

COELHO, F. Adolpho. Para a história da instrução popular. In: Revista de Educação e Ensino. Lisboa: Imprensa de Lucas Evangelista Torres, 1895.

COELHO, F. Adolpho. Parecer apresentado ao Conselho Superior de Instrução Pública pelo vogal F. A. Coelho sobre o ensino da moral no Liceu de Maria Pia. Lisboa: Imprensa Nacional, 1914.

COELHO, J. Augusto A reforma do ensino primário. Porto: Livraria Figueirinhas Editora, 1909.

COELHO, J. Augusto. Manual Prático de pedagogia; para o uso dos professores em geral e em especial dos professores de ensino médio e primário. Porto: Livraria Editora José Figueirinhas Jr., s/d.

COELHO, J. Augusto. Noções de pedagogia elementar. 2a ed. Lisboa: empreza da História de Portugal Sociedade Editora, 1907.

COELHO, J. Augusto. O ensino inicial da leitura; princípios fundamentaes, suas applicações ao Methodo Portuguez de Castilho e à Cartilha Maternal de João de Deus. Lisboa: Imprensa Lucas, 1898

COELHO, J. Augusto. Princípios de pedagogia. Tomos I a IV. São Paulo: Teixeira e Irmãos, 1891.

COELHO, J. M.Latino. Typos Nacionaes; com um prefácio de Júlio Dantas. Lisboa: Santos e Vieira, s/d.

COELHO, Trindade. $A B C$ do povo.

COELHO, Trindade. O terceiro livro de leitura. Lisboa: Aillaud, 1903.

COELHO, Trindade. Para a escola. In: Os meus amores: contos e baladas. 10a ed. Lisboa, Portugália, s/d.

COELHO, Trindade. Pão nosso ou leituras elementares e encyclopédicas para uso do povo. Paris - Lisboa: Aillaud e $\mathrm{C}^{\mathrm{ia}}, 1904$.

COELHO, Trindade. Primeiras noçôes de educação cívica (adoptado officialmente no ensino primário). Paris-Lisboa: Livraria Aillaud, 1906.

COLLEÇÃO de leis e documentos officiaes publicados desde 15 de agosto de 1834 até 31 de dezembro de 1835. Lisboa: Imprensa Nacional, 1837.

COLLECÇÃO de cantigas populares colhidas em diferentes terras das provinvias e ilhas adjacentes. Lisboa: J. J. Bordalo, 1879 .

COMEDIA NOVA intitulada o sabio em seu retiro. Lisboa, 1787.

COMPENDIO histórico do estado da Universidade de Coimbra no tempo da invasão dos denominados jesuítas e dos estragos feitos nas sciencias e nos professores e directores que a regiam, pelas maquinaçóes e publicações dos novos Estatutos por elles fabricados. Lisboa: Na Regia Officina Typografica, 1771.

"CONCURSO de livros do ensino primário e normal”. In Boletim da direcção geral de instrucção pública. Anno III, Janeiro-Março 1904, Fasc. I-III. Lisboa: Imprensa Nacional, 1904.

CONTOS de fadas e lobisomens. Livraria do povo no 29. Porto: Em Casa de A. R. de Cruz Coutinho, 1884.

CORREIA, Velhinho. O ensino e a educação em Portugal, Porto: Typographia 'Porto Medico', 1907. 
CORMENIN, M. de Colloquios Aldeões, versão de A. F. Castilho. Porto: Imprensa Comercial, 1849.

COSTA, Antonio da. A instrução nacional. Lisboa: Imprensa Nacional, 1870.

COSTA, Antonio da. Auroras da instrução pela iniciativa particular. Lisboa: Imprensa Nacional, 1884.

COSTA, Antonio da. História da instrucção popular em Portugal. Porto: Educação Nacional, 1935.

374 COSTA, José Daniel Rodrigues da. Entremezes de cordel. Lisboa: Editorial Estampa, 1973.

COUTO E MELO, João Crysostomo. Gramática filosófica da linguagem portuguêza composta e oferecida a el rei nosso senhor por___. Lisboa: Na Im-pressão Régia, 1818.

CUNHA, Augusto José da. Arithmetica pratica. Lisboa: Typographia Universal de Thomaz Quintino Antunes, 1874.

CUNHA, D. Luis da. Testamento político de D. Luis da Cunha. São Paulo: Alfa Omega, 1976.

CUNHA, José Anastacio. A voz da razão esclarecida contra as argucias irreligiosas da 'Voz da Razão'. Vianna: Typ. de Andre Joaquim Pereira, 1859.

D’ALMADA, Antão. Leituras progressistas: cartilha de $1^{\circ}$ grau. Vizeu: Typographia da Folha, 1896.

DEBAY, A. Hygiene e physiologia do casamento: história natural dos homens e mulheres casados. versão de Sousa Viterbo. 3a ed. Lisboa: Calçada de S. Francisco, 1893.

DEUSDADO, M. A. Ferreira. Educadores portugueses. Coimbra: Livraria França-Amado, 1909.

DEVERES DOS FILHOS. Tradução de João de Deus. $3^{\text {a }}$ ed. Lisboa: Imprensa Nacional. 1880.

DIAS, , A. Epiphanio da Silva. Grammatica portugueza elementar (obra approvada pela Junta Consultiva de Instrução Pública). 9a edição. Lisboa: Typographia Mattos Moreira, 1889.

DIAS, C. Claudino. Methodo analythico-sinthetico de aprender a ler. Paris - Lisboa: Guillard-Aillaud, 1888-1889.

DIAS, J. Simões. A história de oiro; poesia heroi-comica. Elvas: Typ. da Democracia Pacífica, 1869.

DIAS, J. Simôes. A instrucção secundaria; discurso parlamentar. 2a ed. Coimbra: Imprensa da Universidade, 1883.

DIAS, J. Simões. Historias contemporaneas: primeiro volume; As Mães. Vizeu: Livraria Accademica, 1877.

DIAS, José Simões e CUNHA, Joaquim Paes da. Manual de leitura e analyse para uso das escólas primarias e secundarias. Vizeu: Editores Gouvea e Salvador. 1883.

DIAS, José Simões. Novo livro de leitura para as escolas primárias de Portugal e Brazil; com excerptos dos principaes escriptores portuguezes compilados por João diniz e precedido de uma carta do Porto: Livraria Universal Magalhães e Moniz, 1881.

DIAS, Mauricio José (e outros). Ao Ilustrissimo Senhor João Manuel de Freitas: primeiro mestre da Escola Typographica da Imprensa Nacional de Lisboa; offerecido no dia 8 de junho de 1867 em homenagem de gratidão e cordialidade pelos seus respeitosos discípulos.

DICCIONARIO Bibliographico Portuguez; estudos de Innocencio Francisco da Silva applicaveis a Portugal e ao Brazil continuados e ampliados por Brito Aranha em virtude do contracto celebrado com o governo portuguez. 23 tomos. Lisboa: Imprensa Nacional, 1893.

DICCIONARIO dos sonhos ou arte de explicar por meio de exemplos tirados dos prophetas, magos e história dos oráculos as visôes nocturnas e outros mistérios do sonno. (obra dedicada especialmente às damas portuguezas) Lisboa: Henrique Zefferino Livreiro Editor, 1890.

DINIS, Júlio. A morgadinha dos canaviais. $2^{\text {a }}$ ed. Mira-Sintra: Europa-América, s/d.

DINIS, Júlio. As pupilas do Senhor Reitor. $3^{\mathrm{a}}$ ed. Sintra: Europa-América, s/d.

DINIS, Júlio. Os fidalgos da casa mourisca. Mira-Sintra: Europa América, s/d.

DINIS, Júlio. Seróes da provincia. Lisboa: Europa-América, 1971.

DINIZ, João. O novo livro de leitura; para a $3^{\text {a }}$ classe das escholas de instrucção primaria elementar (illustrado com 50 gravuras, e escolhido em concurso por portaria de 20 de setembro de 1897). 10a edição. Porto: Magalhães e Moniz, 1899.

DIRECTORIO (folha dactilografada e anônima com regras para utilização da Cartilha Nacional - s/d).

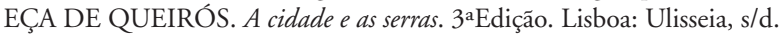

EÇA DE QUEIRÓS. A ilustre casa de Ramires. 2a ed. Lisboa: Ulisséia, s/d.

EÇA DE QUEIRÓS. O conde de Abranhos. Mira-Sintra: Europa-américa, s/d.

EÇA DE QUEIRÓS. O crime do padre Amaro. São Paulo: Ática, 1982.

EÇA DE QUEIRÓS. O mistério da estrada de Sintra. Mira-Sintra: Europa-América, s/d.

EÇA DE QUEIRÓS. O primo Basílio. Porto: Lello e irmãos. s/d.

EÇA DE QUEIRÓS. Os Maias. 3aEd. Mira-Sintra: Europa-América, s/d.

EÇA DE QUEIRÓS. Obras. Volumes I a IV. Porto: Lello e Irmãos, s/d.

EÇA DE QUEIRÓS. Uma campanha alegre. volumes I e II. Mira-Sintra: Europa-América, s/d.

EDITAL de Convocação a Concurso Geral para provimento das Cadeiras e Escolas dos Estudos do Reino, que se acharem vagas; e de Aviso a todos os Professores, que actualmente estiverem em exercício de quaisquer das mesmas cadeiras. Coimbra: Real Imprensa da Universidade, 1801. 
EDUCAÇÃO Nacional. Porto: Typographia Universal, 1899-1902.

ENCYCLOPEDIA DAS FAMILIAS: revista de instrução e recreio. 9 volumes. Lisboa: Manuel Lucas Torres, 1897/ 1900/ 1901/ 1902/ 1903/1904/1905/ 1906 /1910.

ENCYCLOPEDIA popular: leituras amenas apropriadas a todas as edades, sexos, estados, profissóes e intelligencias. $\mathrm{n}^{\circ}$ 2. $2^{\text {a }}$ ed. Lisboa: Typographia Universal de Thomaz Quintino Antunes, 1867.

ENCYCLOPEDIA pratica milhóes de coisas; revista mensal illustrada redigida por um grupo de homens de letras. Vols 1 a 8. Lisboa: Typographia Lusitana Editora, 1907.

ENSINO obrigatório ou colecção completa da legislação sobre instrução primária. $2^{\mathrm{a}} \mathrm{ed}$. Porto: Imprensa popular de A. G. Vieira Paiva, 1882

ERASTO ou o amigo da mocidade: conversações familiares nas quaes à mocidade de ambos os sexos se dão sufficientes noções sobre a maior parte dos conhecimentos humanos (obra interessante para os pais e mãis de familias, e geralmente para todas as pessoas encarregadas da educação da mocidade). $2^{\text {a }}$ edição - de novo traduzida e conforme a $5^{\text {a }}$ e última de Paris. Coimbra: Imprensa da Universidade, 1822.

ESCHOLA instituida pelo sr. Casal Ribeiro; relatório de 1862. Lisboa: Typographia de Castro Irmão, s/d.

ESCHOLA POPULAR DAS PRIMEIRAS LETRAS dividida em quatro partes; (parte segunda). Catecismos de doutrina e civilidade christam para instrução e para exercicio da Leitura. Coimbra: Na Real Imprensa da Universidade, 1828.

ESCOLA CASTILHO fundada e sustentada por iniciativa e subscrição particulares em honra e memória do Visconde de Castilho. Boletim no 1: Janeiro de 1876; Boletim no 2: Dezembro de 1876; Boletim nº 6: Janeiro de 1881; Boletim no 4: Janeiro de 1878. Lisboa: Typographia das Horas Romanticas, 1877.

ESCOLA FUNDAMENTAL ou methodo facil para aprender a ler, escrever e contar, com os primeiros elementos da doutrina christã; util à mocidade que deseja plenamente instruir-se por hum professor. Nova edição. Lisboa: Typographia Rollandiana., MDCCCXXXVIII.

EUSEBIO, António. Recordaçôes da minha vida. Setúbal: Typographia Mascarenha, 1904.

F.P.F.C. A recepção de hum maçon. Lisboa: Impressão de Eugenio Augusto, 1827.

FACA, Zacharias Alves. Academia das mulheres, ou o liberalismo do seculo combatido até pela fraqueza deste sexo. Coimbra: Imprensa da Universidade, 1823.

FALCÃO, José. Cartilha do povo para a gente do campo (parte 1). Edição popular promovida pelos estudantes republicanos de Coimbra. Vila Nova de Famalicão: Typographia Minerva, 1896.

FERNANDES, Conceição. A instrução primária (poesia). Lisboa: Imprensa Social (Secção da casa do povo portuense), 1906.

FERREIRA, Bettencourt. Um filósofo português no século XIX: Dr. Manuel Ferreira-Deusdado. Lisboa: Empresa Literaria Fluminense, s/d.

FIGUEIREDO, A. C. Borges de. Instituiçōes elementares de rhetorica para uso das escholas. $8^{\mathrm{a}}$ e $10^{\mathrm{a}}$ ed. Coimbra: Imprensa Litteraria, 1873/1883.

FIGUEIREDO, A. C. Borges de. Logares selectos dos classicos portugueses nos principaes generos de discurso em prosa para uso das escolas. 16 ${ }^{\mathrm{a}}$ ed. Coimbra: Imprensa da Universidade, 1879.

FIGUEIREDO, Fidelino de. A educação na futura democracia portuguesa. Lisboa: Cernadas e Companhia, 1911.

FIGUEIREDO, Manoel de Andrade. Nova eschola para aprender a ler, escrever e contar offerecida a augusta magestade do senhor D. João V rey de Portugal. $1^{\text {a }}$ parte. Lisboa Occidental: Na Officina de Bernardo da Costa Carvalho Impressos do Sereníffimo Senhor Infante.

FIGUEIRINHAS, A. Primeiro livro de leitura. Porto: Editores Figueirinhas, s/d.

FIGUEIRINHAS, A. Segundo livro de leitura. Porto: Editores Figueirinhas, s/d.

FOLHETIM da voz acadêmica: Delenda Thibur; primeira aos homens da cigarra e do ermo dedicada a todos os ramalhudos Ortigões da escola do ABC repentino. Typ Rua da Vinha 53, s/d.

FONSECA, Francisco Antonio Fernandes da. Momentos de saudade: poemeto. Braga: Typographia de Seminario de S. Caetano, 1857.

FONSECA, José da (org.). Prosas selectas ou escolha dos melhores lugares dos autores portuguezes antigos e modernos. Nova edição. Lisboa: Typographia Rollandiana, 1838.

FORJAZ, A. O amigo dos meninos, introdução: compreendendo um abcedario de leitura e numeração, e uns primeiros exercicios de leitura, e n'estes o pequeno catecismo de doutrina cristã da Diocese de Coimbra, em caracteres variados, para uso especialemente do asilo da infancia de Coimbra. Coimbra: Imprensa da Universidade, 1854.

FREIRE, Henrique (org.): Livros para a eschola primaria: selecta de poesias infantis compiladas e annotadas por . 2a ed. Madeira: Typographia Commercial, 1882.

FREITAS, Urbino de. O ensino natural da linguagem. Porto: Typografia Central, 1884.

GARRETT, Visconde de Almeida. Da Educação; cartas dirigidas a uma senhora illustre, encarregada da instituição de uma jovem princeza. $3^{\mathrm{a}}$ ed. Lisboa: Empreza da Historia de Portugal Sociedade Editora, 1899. 
GARRETT, Visconde de Almeida. Obra política: doutrinação da sociedade liberal (1827). Lisboa: Editorial Estampa, 1992.

GARRETT, Visconde de Almeida. Portugal na balança da Europa. Lisboa: Horizonte, s/d.

GOMES, Joaquim Ferreira. (organizador).Relatórios do Conselho Superior de Instrução Pública (1844-1859), Coimbra: Instituto Nacional de Investigação Científica, 1985.

GRAÇAS ao levantar da escola (poesia datilografada). 1853.

GRÁCIO, Rui. História da História da Educação em Portugal: 1945-1978, Cultura - História e Filosofia, vol. II, 1983, pp. 135-184.

GUERREIRO, Custodio dias. Memorias e parecer apresentados nos Congressos Pedagógicos de Lisboa e Porto. Lisboa: Typographia Estevão Nunes, 1898.

HerCulano, A. (Deputado pelo Porto). Da Eschola Polytechnica e do Collegio dos Nobres. Lisboa: Na Typographia da Sociedade Propagadora de Conhecimentos Uteis, 1841.

HERCULANO, A. Da propriedade litteraria e da recente convenção com França: carta ao senhor Visconde d'Almeida Garrett. Lisboa: Imprensa Nacional, 1851.

HERCULANO, Alexandre. Casamento civil: primeira carta. Lisboa: Imprensa de J. G. de Sousa Neves, 1866.

HERCUlANO, Alexandre. Composiçōes Várias. Lisboa: Aillaud Alves, Bastos e Cia, s/d.

HERCULANO, Alexandre. O bobo. Ulisséia, s/d.

HERCULANO, Alexandre. Opúsculos. Tomo VIII: Questóes Públicas, 2a ed. Lisboa: Antiga Casa Bertrand - José Bastos e $\mathrm{C}^{\mathrm{ia}}$, s/d.

ILLUSTRAÇÃO POPULAR; folha dedicada ao recreio e instrucção. Lisboa: Typographia de Francisco Xavier de Sousa e Filho, 1866-1868.

INVOCAÇÃO a Deus antes de começar o estudo (poesia datilografada). 1853.

JARDIM, Luiz. A instrucção primaria no municipio de Lisboa. Lisboa: Typographia de Chistóvão Augusto Rodrigues, 1877.

JARDIM, Manoel dos Santos Pereira. Discurso lido em sessão do Conselho Superior de Instrucção Pública de 2 de janeiro e projecto de lei apresentado. Coimbra: Imprensa da Universidade, 1852.

JOÃO DE DEUS. Cartilha Maternal ou arte da leitura. $3^{\mathrm{a}}$ ed. Lisboa: Imprensa Nacional, 1878.

JOÃO DE DEUS, Cartilha Maternal ou arte da leitura. Segunda Parte. Lisboa: Imprensa Nacional, 1912.

JOÃO DE DEUS. Pedagogia: a Cartilha Maternal e a crítica. Lisboa: Antiga Casa Bertrand - José Bastos, 1897.

JOÃO DE DEUS. Prosas. Lisboa: Bertrand, 1898.

JORNAL DA INFANCIA. Mattos Moreira e Cardosos Editores, 1883

LACERDA, José Ma d'Almeida e Araujo Correa de. Relatórios do comissário dos estudos do distrito de Lisboa pertencentes aos anos de 1854, 1855, 1856. Lisboa: Typographia Rua da Condeça nº 3, 1858.

LARANJEIRA, Manuel. A Cartilha Maternal e a physiologia. Porto: Typ. do Porto Medico de Magalhães e Figueiredo, 1909.

LEÃO, Alfredo Teixeira Pinto. Livro de leitura para as escolas de instrucção primaria; aprovado pela Junta Consultiva de Instrucção Publica e adoptado em varios lyceus nacionaes para os exames de admissão. $7^{a}$ edição aumengtada. Porto: Cruz Coutinho, 1885.

LEGOUVÉ, Ernesto. O estudo da falla. Tradução do Abbade d' Arcozello. Porto: Livraria Portuense de Clavel, 1882.

LEIS de 2 de Maio de 1878 e 11 de Junho de 1880 sobre a Reforma da Instrucção Primária e regulamentos e providências para a execução das referidas leis. Lisboa: Imprensa Nacional, 1881.

LEITÃO, António. Elementos de pedagogia em harmonia com os programas das escolas normais. $6^{\mathrm{a}}$ ed. Coimbra: França e Armenio Livreiros - Editores, 1916.

LEITÃO, António. Legislação escolar; regime legal da escola primária. Coimbra: França e Armenio, 1913.

LEITÃO, Joaquim. A peste: aspectos moraes da Epidemia Nacional. Lisboa: Agencia Universal de Publicações, 1899.

LEITÃO, Joaquim. Junto do altar (folheto impresso em homenagem a João de Deus). 1895.

LEITE, Luiz Felipe. Do ensino normal em Portugal. Coimbra: Imprensa da Universidade, 1892.

LEITE, Luiz Filipe. O engeitado. Lisboa: Tipographia Universal, 1854.

LEITE,Luiz Felipe. Ramalhetinho da puerícia. (Livrinhos d'oiro sob os auspícios do Dr. A. F. de Castilho), Lisboa: Sociedade Faria e Cia, 1854.

LEITURAS para a escola primária; obra approvada por decreto de 23 de outubro de 1897 para a $1^{\text {a }}$ classe das Escolas de Instrução Primária. Lisboa: Lvraria de Antonio Maria Pereira, 1897.

LEMOS, António de. A recitação e os recitadores; arte de ser gentil, recitando com arte, na sociedade (palestra satirico-humoristica). Porto: Officina Typographica (a vapor) do Instituto de Surdos-Mudos Araújo Porto, 1910.

LEONARDO, Manuel Severo. Novo e breve resumo calligrafico; muito util para se aprender a escrever com metho- 
do, dando à penna movimento regular para adquirir accento theorico e conseguir escrever expedito. Lisboa: Na Impressão Regia, 1827.

LIGA NACIONAL DE INSTRUÇÃO. $1^{\circ}$ Congresso pedagógico de instruç̧ão primária e popular realizado em abril de 1908. Lisboa: Imprensa Nacional, 1909.

LIVRO dos meninos christãos ou instrucções religiosas de uma mãe a seus filhos. Traduzido do francez. $2^{\text {a }}$ ed. Lisboa: Typographia G. M. Martins, 1867.

LOBATO, António José dos Reis. Arte da grammatica da lingua portuguesa; composta e offerecida do Ilmo e Exmo Senhor Sebastiāo José de Carvalho e Mello, Ministro e Secretário de Estado de Sua Magestade Fidelíssima da Repartição dos Negócios do Reino (...) augmentada com a parte d'ortographia por José Joaquim Bordalo, director do Collegio que se denomina do Livramento na cidade de Lisboa. Lisboa: Na impressão de Alcobia, anno 1824.

LOBO, Roque Ferreira. Lições de um pae a uma filha sua na primeira idade. Nova edição. Tomo I. Lisboa: Typographia Universal de Thomaz Quintino Antunes, 1869.

LOPES, A. Simões. Cartilha infantil; parte 1 ou quadros de leitura para as escolas populares (methodo de leitura sem soletração). Lisboa: Imprensa Nacional, 1875.

LOPES, A. Simões. Cartilha infantil: exercícios graduados de leitura corrente; continuação dos quadros de leitura para as escolas populares. $2^{\text {a }}$ parte. Lisboa: Imprensa Nacional, 1875.

LOPES, A. Simões. Cartilha infantil: o livro do mestre. Porto: Companhia Portuguesa Editora, 1913.

LOPES, A. Simóes. Conferências pedagógicas do Porto em 1883; relatorios, programmas, horarios, actas, resoluçóes e mais trabalhos do primeiro congresso de professores primarios reunidos no Porto, sob a direcção de A. Simões Lopes, Inspector d'ensino primario. Porto: Livraria Portuense de Clavel e Cia Editores, 1883.

LOPES, A. Simões. Selecta de manuscripto para uso das escolas d'ensino primário. 23a ed. Porto: Livraria Portuense de Lopes e Companhia, 1887.

LOPES, José Quintino Travassos. Leituras correntes e intuitivas e primeiras lições de cousas. Segunda Parte: dedicada ás creanças de 10 a 12 annos. 2a edição. Lisboa: Livraria de Antonio Maria Pereira, 1893.

LOPES, José Quintino Travassos. Leituras correntes e intuitivas. Lisboa: Typographia e Stereotypia Moderna, 1897.

M. DE CORMENIN Colóquios aldeões (obra premiada pela Academia Franceza). Versão de António Feliciano de Castilho. Porto: Imprensa Commercial, 1879.

MACEDO, José Agostinho de. Parecer: sobre a maneira mais facil, simples e exequivel da convocação das Cortes gerais do Reino no actual Systema Politico da Monarchia representativa e constitucional. Lisboa: Typographia Lacerdina, 1820.

MACHADO, Bernardino. A crise politica e financeira e o ensino, Lisboa: Imprensa Nacional, 1893.

MACHADO, Bernardino. À nação portugueza, o magistério primário. Coimbra: Typ. França Amado, s/d.

MACHADO, Bernardino. Notas d'um pae: as creanças. Coimbra: Imprensa da Universidade, 1901.

MACHADO, Bernardino. O Ensino. Coimbra: Typographia França-Amado, 1898

MACHADO, Ulysses. Aritmética prática e geometria elementar. 11ª edição. Lisboa: Livraria J. Rodrigues, 1916.

MACHADO, Ulysses. Grammatica portuguêsa ensinada pelos exemplos. (I fascículo: morphologia e sintaxe). $2^{\mathrm{a}} \mathrm{ed}$. Lisboa: Typographia e Lithographia de A. E. Barata, 1897.

MACHADO, Ulysses. Livro de leitura para a segunda classe do ensino primário geral, 15ª ed. Lisboa: Centro Tipografico Colonial, s/d.

MACHADO, Ulysses. Livro de leitura para a terceira classe do ensino primário geral, $13^{\mathrm{a}} \mathrm{ed}$. Lisboa: Imprensa Limitada, s/d.

MANUEL Claudio, Treva e luz. Figueira, 1904.

MARIA, José da Virgem. Novo methodo de educar os meninos e meninas principalmente nas villas e cidades. 2 tomos. Lisboa: Impressão regia, 1815.

MARTINS, Oliveira. Alexandre Herculano. Lisboa: Horizonte, s/d.

MARTINS, Oliveira. História de Portugal. Reimpressão. Lisboa: Guimarães Editora, 1991.

MARTINS, Oliveira. Portugal contemporâneo. Reimpressão. Lisboa: Guimarães Editora, 1986.

MARTIRES, J. B. R.e SANTOS, A. F. Livro de leitura para as escolas de instrução primária: $2^{a}$ e $3^{a}$ classes. $7^{\text {a }}$ ed. Lisboa: Aillaud e Bertrand / Rio de Janeiro: Francisco Alves, 1912.

MARTYRES, José Bartolomeu Rita dos e SANTOS, António Francisco dos. Livro de leitura para as escolas de instrução primária: 2a e $3^{\text {a }}$ classe. Lisboa: Bertrand, 1909.

MATTOS, Alfredo Filippe. O passado, o presente e o futuro da escola primaria portuguesa. Lousã: Typ de Julio Ribeiro dos Santos, 1907.

MAYA, Delfim Maria D’Oliveira. Theoria da litteratura, particularmente da litteratura em prosa para uso das aulas de litteratura nacional. Porto: Typographia de A. J. Silva Teixeira, 1880.

MELLO, Carlos de. Elementos de geographia geral. Lisboa: Typographia do Commercio, 1893. 
MELLO, Joaquim Lopes Carreira de. Compendio de chorographia de Portugal e domínios para uso das aulas de instrucção primária. 2a edição revista e augmentada. Lisboa: Typographia de Castro e Irmão, 1835.

MELLO, Joaquim Lopes Carreira de. Compendio de Historia de Portugal desde os primeiros povoadores até nossos dias. Lisboa: Typographia de Casro e Irmão, 1855.

378 MELLO, Joaquim Lopes Carreira de. Resumo da história geral profana para uso dos alumnos das escolas de instrucção primaria do $1^{\circ}$ e $2^{\circ}$ grau. Lisboa: Typographia Universal, 1865.

MELLO, Joaquim Lopes Carreira. Liçôes portuguezas de literatura e de moral ou selecta portugueza; obra clássica para uso das escholas approvada pelo Conselho Superior d'Instrucção Pública. 2 tomos. Lisboa: Typographia Universal, 1862.

MELO, João Chrysóstomo do Couto e. Novo método de ensinár e aprendêr a pronunciação e lêitura da linguágem portuguêza pâra úso das escólas particuláres do exército e oferecido a súa majestáde fidelissima pêlo diréctôr da escóla gerál o bacharel formádo em matemática Lisbôa: Impressão Régia, 1817.

MEMORIA sobre a fundação e progressos do Real Collegio das Ursulinas de Pereira. Coimbra: Na Imprensa da Universidade, 1850.

MENDONÇA, Lopes de (e outros). Poesias. Lisboa: Typ. Baeta Dias, 1895.

MENEZES, P. A. de. Educação. 2a edição. Braga: Pap. Universal e Typ. a Vapor, 1906.

MEY, Gustavo. A Bíblia das escolas ou história resumida do antigo e do novo testamento para uso das escholas católicas. trad. Friburgo em Brisgau: Typographia de B. Herder Editor, 1894.

MIDOSI, Henrique C.. Poesias selectas para leitura, recitação e analyse dos poetas portuguezes em conformidade com programmas adoptados para o curso de portuguez e litteratura. 14a ed. Lisboa: Imprensa Nacional, 1884.

MIDOSI, Henrique Carlos. Poesias selectas nos diversos generos de composições poéticas para a leitura, recitação e analyse grammatical. 5a ed. Lisboa: Imprensa Nacional, 1868.

MIDOSI, Luiz Francisco. Compendio de Historia de Portugal para instrucção da mocidade. 14a edição. Lisboa: Imprensa Nacional, 1872.

MIDOSI, Luiz Francisco. O expositor portuguez ou rudimentos do ensino da língua materna. Quarta edição, ornada de estampas e muito aumentada. Lisboa: Na Imprensa Nacional, 1846.

MINISTÉRIO dos Negócios do Reino: Direcção Geral da Instrucção Pública, 7-7-1871.

MODELOS de mobilia para escolas de instrucão primária; organisados por ordem da Direcção Geral da Instrucção Publica. Lisboa, 1877.

MONTEIRO DE CAMPOS, A. A. M.. Compendio de sistema metrico decimal; em forma de dialogo para uso das escolas de instrucção primaria. $31^{\text {a }}$ edição revista, correcta e augmentada. Lisboa: Editora de Francisco Romero, s/d.

MONTEIRO, José de Souza. Elogio historico de José Maria Latino Coelho; Secretario Geral da Academia Real das Sciencias de Lisboa. Lisboa: Typographia da Academia, 1898.

MONTEIRO, José Leite. O ultramontismo na instrucção publica de Portugal. Coimbra: Imprensa Litteraria, 1863.

MONTEVERDE, Emilio Achilles. Grammatica franceza theorica e pratica; methodo inteiramente novo em Portugal para se aprender, com muita brevidade e perfeiçāo, a fallar e escrever o idioma francez por meio do portuguez. $4^{\mathrm{a}}$ edição revista e muito melhorada. Lisboa: Imprensa Nacional, 1857.

MONTEVERDE, Emílio Achilles. Manual encyclopedico para uso das escolas d’instrução primária. (approvado pelo Conselho Geral d'Instrucção Pública). 4a , 8ª e 10a ediçōes. Lisboa: Imprensa Nacional, 1843, 1865 e 1874.

MONTEVERDE, Emílio Achilles. Methodo facillimo para aprender a ler tanto a letra redonda como a manuscrita no mais curto espaço de tempo. $7^{\mathrm{a}} \mathrm{ed}$. Lisboa: Imprensa Nacional, 1859.

MONTEVERDE, Emílio Achilles. Methodo facilísimo para aprender á leer y escribir á un mismo tiempo, con la mayor brevedad posible; traducido del portugués de la décima edicion de 150.000 ejemplares, aumentado e adaptado á las escuelas de Espanã. Lisboa: Imprensa Nacional, 1871.

MONTEVERDE, Emílio Achilles. Mimo á infancia ou manual de historia sagrada para uso das crianças que frequentão as aulas tanto em Portugal como no Brasil. (approvado pela Junta Consultiva da Instrução Pública) $3^{\text {a }}$ ed. Lisboa: Imprensa Nacional, 1877.

MORAES, Manuel Corrêa de. Liçôes moraes, civis e domesticas de uma mãi para uma filha. Lisboa: Typographia Francisco Xavier de Souza, 1848.

MOREIRA, João M. e CORRÊA, João M. Nova selecta portugueza colligida, annotada e acompanhada d'um tratado de composição e derivação para uso das aulas de portuguez e litteratura. Porto: Typ. José da Silva Mendonça, 1902.

MOREIRA, João M. Leituras Portuguezas. 3a classe. Porto: typographia José S. Mendonça, 1903.

MOURA, Carneiro de. A instruç̧ão educativa e a organização geral do Estado: RELATORIO. Lisboa: Imprensa nacional, 1909.

MUSEU PITTORESCO; jornal d'instrução e recreio. Lisboa: Na Impressão Galhardo e Irmãos, 1840. 
NATIVIDADE, Maria Vieira. O culto da árvore. 2a ed. Alcobaça: Oficina de António M. D’Oliveira, 1913.

NECESSIDADE e objeto do ensino primario, ou o mestre d'escola (Diálogos de Timon). Lisboa: Typ. Dois Artistas, 1850.

NO DIA DA FESTA: numero unico para beneficio da Associação das Escolas Moveis pelo Methodo de João de Deus. Figueira da Foz: Typographia Barata Salgueiro, 1907.

NOGUEIRA, Domingos d'Almeida. Resumo da História de Portugal. Lisboa: A Liberal Officina Typograffica, 1903.

NOGUEIRA, J. V. Paula. A festa escolar da árvore. Lisboa: Typographia A Editora, 1908.

NOVA Arte d'Escrita. Lisboa: Typographia J.B. Morando, 1840.

NOVA FARÇA intitulada o velho fanfarrão. Lisboa: Impressão Regia, 1825.

NOVO e gracioso entremez intitulado a ratoeira em que amor pilha os pobres namorados. Lisboa: Typ. de Mathias José Marques da Silva, 1840.

NOVO ENTREMES: A toleima castigada ou o pasbogues dentro do pote. Calçada de Sant'Anna 136, Typ. A. F. Alcobia, s/d.

NOVO entremez: o velho honrado e prudente. Lisboa: Officina de Franciso Sabino dos Santos, 1779.

NUNES JUNIOR, J.B. Simples noçôes de instrução cívica; indispensáveis a todos os que desejam fazer exame de Instrução Primária, em harmonia com os programas de ensino primário e acomodados à ortografia oficial. Lisboa: Tipografia Maurício, 1911.

NUNES, A. Castanheira. Duas palavras a respeito da ortografia actual e projecto de reforma. Lisboa: Casa Portugueza, 1879 .

NUNES, A. Castanheira. Mestre de leitura portugueza. Lisboa. Tipografia progressista de P.A. Borges, 1879.

O ACADEMICO; publicação scientifica e litteraria redigida por João de Deus Ramos, Eduardo José Coelho, Antero Tarquínio de Quental e outros. Coimbra: Imprensa da Universidade, 1860.

O AMIGO DO ESTUDO; jornal bimensal. Responsável: A. M. Seabra d'Albuquerque. Coimbra: Imprensa da Universidade, 1867 - ${ }^{\text {os }} 1$ até 10.

O BARATÍSSIMO ou o pequeno civilizador popular, semanário de conhecimentos usuaes e de literatura para as classes laboriosas. $5^{\text {a }}$ série. 8-1-1849.

O CALLIGRAPHO Ventura da Silva; a sua obra nacional. Porto: Livraria Portuense, s/d.

O CONIMBRICENSE. Responsável: Joaquim Martins de Carvalho. Coimbra: Imprensa Conimbricense, 1857-1874 .

O DESENJOATIVO THEATRAL; jornal recreativo e moral. $\mathrm{n}^{\circ}$ 2. Lisboa: Imprensa de C. A. Silva Carvalho, 1838.

O ECHO DA MOCIDADE. Anno 1, n 1. Coimbra, Typographia do Notícias de Coimbra, 24.1.1909.

$O$ EDUCADOR; folha quinzenal acadêmica. Anno 1. No 1. Lisboa: Typ do Comércio, 7-6-1910

O ENSINO; semanário pedagógico. Porto: Imprensa Civilização, 1910.

O ENSINO: revista d'instrução primária. director: Teophilo Ferreira. Lisboa: Typographia de Eduardo Roza, 1885.

O GAROTO. Anno 1, $\mathrm{n}^{\circ}$ 7. Lisboa: Imprensa Sousa e Santos, maio de 1907.

O GORRO: jornal dos alunos do lyceu de Coimbra. Coimbra: Typographia Litteraria, $1^{\circ}$ anno, números 1 a 9 , 1909-1910.

O GRILLO. Poiares: Typographia do Notícias de Coimbra, anno 1. № 2. 28/11/1909.

O INSTITUTO; jornal cientifico e litterario. Coimbra: Imprensa da Universidade, 1850 - 1870.

O JARDIM LITTERARIO: semanário de instrução e recreio, 1849.

O JORNAL dos pequeninos; brinde permanente da publicação para as crianças. Directora: Anna de Castro Osório. Lisboa: Imprensa Libânio da Silva, anno 1. 1907. ${ }^{\text {os }} 2 / 9$

O LIVRO DA PRIMEIRA LEITURA. Lisboa: Antiga Casa Bertrand, 1903.

O LIVRO DAS ESCOLAS; biblioteca popular ou a instrução ao alcance de todas as classes e de todas as intelligencias dedicada ao povo portuguez por uma sociedade de homens de letras. Lisboa: Lallement-frères e Companhia, 1875.

O LIVRO DOS MENINOS em que se dão as idéas geraes, e definiçoens das coifas que os meninos devem faber, traduzido da língua franceza para a portugueza por João Rozado de Villalobos e Vasconcellos. Lisboa: Typografia Rollandiana, 1778.

O LYCEU, semanário scientifico e litterario. Coimbra: Imprensa Litteraria, 1867.

O MOSAICO: jornal d'instrução e recreio; cujo lucro é applicado a favor das Casas d'Asylo da Infancia Desvalida. $\mathrm{n}^{\circ}$ 28. Lisboa: Imprensa Nacional, 1839.

O NOSSO COLLEGIO. $\mathrm{n}^{\mathrm{O}}$ 5. anno de 1908-1909. Campolide: Typ. Adolpho Mendonça, 1909.

O PANORAMA contemporâneo; publicação quinzenal. Director; Trindade Coelho. $1^{\circ}$ anno. $\mathrm{n}^{\text {os }} 1$ a 9. Coimbra: Escriptorio da Empreza: Rua do Corpo de Deus 95, 1883. 
O PANORAMA: jornal litterario e instructivo da sociedade propagadora dos conhecimentos úteis. Lisboa: Na Typographia da Sociedade, 1837.

O PEQUENO mensageiro para a juventude. Anno III. Abril 1903, n² 25. Lisboa: Typ. João Ferreira de Medeiros, 1903.

$380 \quad O$ RECREIO; jornal das famílias. Dezembro de 1836, nº 12, tomo 2.

O REGIMEN vigente da instrucção primaria. Lisboa: Imprensa Nacional, 1904.

O UNIVERSO ILLUSTRADO; semanário de instrução e recreio. $1^{\circ}$ anno 1877. Tomo 1. Lisboa: Typografia de Mattos Moreira e Cia, 1877.

ORAÇÃO ESCHOLAR na abertura solemne do Lyceu Nacional Bracarense no anno lectivo de 1886 a 1887. Braga: Typ. de Bernardo A. de Sa Pereira, 1886.

“ORGANIZAÇÃO da direcção geral de instrucção pública, decreto no 2 de 24 de dezembro de 1901”. In Boletim da direcção geral de instrucção pública coordenado pelo respectivo director geral. Anno I, Janeiro-Maio 1902, Fasc. I-V. Lisboa: Imprensa Nacional, 1902.

"ORGANIZAÇĀO do orçamento das despezas de instrucção primária". In Boletim da direcção geral de instruç̧ão pública coordenado pelo respectivo director geral. Anno II, Janeiro-Abril 1903, Fasc. I-IV. Lisboa: Imprensa Nacional, 1903.

ORTIGÃO, Ramalho. As Farpas. volumes 1-15. Lisboa: Clássica Editora, 1991.

OS TRES rivaes enganados; a saloia fingida; a creada latina. Porto: Casa de Cruz Coutinho, 1878.

OSORIO, Anna de Castro. A minha patria. Setubal: Livaria Editora Para as Crianças, 1906.

OSORIO, Anna de Castro. Para as crianças; publicação mensal, fundada em 1895. Setubal: Livaria Editora Para as Crianças, s/d.

PARA AS MĀES. In Encyclopedia das famílias: revista ilustrada de instrução e recreio - $24^{\circ}$ anno. nº 287 . Lisboa: Ed. Manuel Lucas Torres, 1910. p. 817.

PASSATEMPO dramatico em que se mostra o valor de hum bom concelho para a emenda de huma vida desordenada: composto para instrucção de huns e devirtimento de outros. Lisboa: Officina de Caetano Ferreira da Costa, 1775.

PATO, Bulhão. POESIA dedicada às protectoras das Casas d'Asylo da Infancia Desvalida de Lisboa. Lisboa: Imprensa Nacional, 1856.

PAZ, José Ramos. Novo methodo para aprender a ler. Porto: Typographia de Sebastiāo José Pereira, 1852.

PELICO FILHO, Silvio. História da instrução popular em Portugal. Coimbra: Officinas da LVMEN, 1823.

PEREIRA, João Félix. Almanach da saude para o anno de 1869; obra indispensavel aos paes de familia, aos directores de collegios e aos parochos; contendo noções de hygiene, modo de tractamento e de prevenção das principaes doenças e enfermidades. Lisboa: Typ. de J. Germans, 1868.

PEREIRA, João Felix. Compendio de chorographia de Portugal para uso das aulas de instrucção primária e secundária. Lisboa: Typ. do Povo, 1871.

PEREIRA, João Felix. Compendio de geographia para uso da instrucção secundária. $7^{\mathrm{a}}$ ed. Lisboa: Typographia de António José Germano, 1868.

PEREIRA, João Felix. Resumo da Historia de Portugal. 5a edição. Lisboa: Typ. de Cruz, 1858.

PICHENOT, Abbade. Tratado pratico de educação materna. Tradução Livre. Lisboa: Typographia Universal de Thomaz Quintino Antunes, 1873.

PIMENTEL, António J. Mesquita. Cartilha da doutrina christā. Porto: Imprensa Moderna, 1897. Abbade de Salamonde.

PINHEIRO, Francisco Mendes. Grammatica elementar da lingua portuguesa para uso das escholas. Coimbra: Imprensa da Universidade, 1870.

PINHEIRO, Thomaz Bordallo. O livro de português (biblioteca de instrução profissional). Lisboa: Tip. da Emprêsa do Diário de Notícias, s/d.

PINTO, Apolino Augusto A. A. Método intuitivo de leitura. Coimbra: Imprensa da Universidade, 1905.

PIRES, Antonio Thomaz. Adivinhas portuguezas recolhidas da tradição oral na provincia do Alentejo. Elvas, s/d.

PIRES, M. J. Rudimentos da leitura portugueza com exercicios para soletrar em lettra redonda, italica, gothica e manuscripta offerecidos á mocidade elvense. Lisboa: Imprensa Nacional, 1851.

POESIAS provinvianas amorosas e ao desafio. Colecção: Seróes d'aldeia. Francisco Silva, s/d.

PRINCIPIOS GERAES do methodo de ensino mutuo chamado de Lancaster; para instrução das pessoas que se dedicão ao conhecimentos d'este ensino. nova edição. Lisboa: Imprensa Elias José da Costa Sanches, 1837 (autor provável: João Crysostomo do Couto e Melo).

PROGRAMMA dos festejos academicos para a inauguração do monumento a Luiz de Camóes. Coimbra: Imprensa da Universidade, 1881

PROGRAMMAS e horarios para as escolas de instrucção primaria e ensino normal; decretos de 18 de outubro, 27 de novembro e 4 de dezembro de 1902. Lisboa: Imprensa Nacional, 1905. 
QUARTIN, Alfredo. Uma noite nas margens do Tejo; poemeto com uma carta de João de Deus. Lisboa: Typographia Universal, 1878.

QUENTAL, Antero de. Alexandre Herculano. Barcellos: Typographia da Aurora do Cavado, 1896.

QUENTAL, Antero de. Causas da decadência dos povos peninsulares. Lisboa: Ulmeiro, 1987.

QUENTAL, Antero de. Odes Modernas. Coimbra: Imprensa da Universidade, 1926.

QUENTAL, Antero de. Prosas da época de Coimbra. 2a ed. Lisboa: Livraria Sá da Costa Editora, 1982.

QUENTAL, Antero de. Sonetos completos. Prefácio de Oliveira Martins. Porto: Nova Crítica, 1980.

RAMOS, João de Deus. A instrução do povo; boletim das escolas móveis pelo methodo João de Deus: bibliothecas ambulantes e jardins-escolas. III ano, $2^{\text {a }}$ série, $\mathrm{n}^{\text {OS }} 2$ e 3, Janeiro a Junho de 1909. Lisboa: Associação de Escolas Móveis, 1909.

RAMOS, João de Deus. Guia prático e theorico da Cartilha Maternal ou arte da leitura. Coimbra: Imprensa da Universidade, 1901.

RAPOSO, José António Simōes. Instruç̧ão popular: o primeiro livro da escola; cartilha de leitura preliminar e elementar. Lisboa: Ferreira Machado, 1895.

RAPOSO, José Antonio Simões. Instrucção popular: o terceiro livro de leitura; leitura corrente e elementar coordenada segundo um methodo analytico e racional e disposta por uma ordem que pareceu ao auctor natural, fácil e gradual para uso dos alumnos da terceira cadeira da instrucção primaria da Real Casa Pia de Lisboa e approvado pelo Conselho Superior de Instrucção Publica para uso das escolas primarias de $1^{\circ}$ grau. $8^{a}$ edição. Lisboa: Ferreira Machado e Companhia, 1890.

REFLEXOES sobre educação publica por J.A.B. Lisboa: Typographia de Filippe Nery, 1835.

REGIME vigente do Ensino Normal na Escola Normal de Nova Goa. Nova Goa: Imprensa Nacional, 1908.

REGRAS para aprender a aparar pennas coordenadas por A.J.C.G. para uso dos alumnos do Collegio d'Humanidades, sito na Calçada do Marquez de Tancos No 7. Lisboa: Lith de Lopes e Bastos, 1850.

RELATÓRIOS do Conselho Superior de Instrução Pública (1944-1859). Organização Joaquim Ferreira Gomes. Lisboa: INIC, 1985.

REVISTA ACADÊMICA; jornal litterario e scientífico publicado em Coimbra. volume primeiro (de 1845 a 1848). Coimbra: Imprensa de E. Trovão, MDCCCXLVIII.

REVISTA DAS ESCOLAS; publicação periódica quinzenal. Porto, 1895.

REVISTA DE EDUCAÇÃO E ENSINO. Fundador e diretor Ferreira Deusdado. Lisboa: Imprensa de Lucas Evangelista Torres, vols I a XV.

REVISTA ILLUSTRADA; publicação quinzenal, n 31. 2 Anno. Lisboa, 1891.

REVISTA POPULAR; semanario de litteratura e industria. Volumes 1 e 6. Lisboa: Imprensa Nacional, 1849-1854-1855.

REVISTA PEDAGÓGICA; órgão do professorado official açoreano. Ano 2. no 29. Ponta Delgada: Tipografia de Alice Moderno, maio de 1907.

REVISTA UNIVERSAL LISBONENSE; jornal dos interesses physicos, moraes e litterarios por uma sociedade estudiosa. Volumes 1 a 13. Lisboa: Imprensa Nacional, 1842-1853.

RIBEIRO, José Silvestre. História dos estabelecimentos scientificos, litterarios, artisticos de Portugal, nos successivos reinados da monarchia, Lisboa: Typographia da Academia Real das Sciencias, 17 vols., 1871-1892.

ROCHA, Joaquim José da. Principios caligraficos reduzidos a dialogos para uso dos proprios discipulos. Lisboa: Typographia de Eugenio Augusto, 1835.

ROQUETE, J. F. Livro d'ouro dos meninos para servir d'introdução ao thesouro da adolescencia e da juventude. Paris: Na Livraria portugueza de J. P. Aillaud, 1844.

ROQUETE, J. F. Thesouro da mocidade portugueza ou a moral em acção; escolha de factos memoraveis e anecdotas interessantes, próprias para inspirar o amor á virtude, e para formar o coração e o espírito; obra extrahida dos melhores auctores nacionaes e estrangeiros precedida de um discurso preliminar e ornada de estampas, offerecida á mocidade portugueza e brazileira. $5^{\text {a }}$ edição mui correta e consideravelmente melhorada. Paris: Em Casa de V. J. P. Aillaud Moulon e Cia., 1857.

SAlAZAR, Manoel José Satirio. Plano do Collegio de Escrita, de pencionistas de assistencia em casa; estabelecido por (professor de escrita ingleza, franceza e portugueza, nesta corte há 26 annos: aulista do quinto curso da Real Aula do Commercio e author do novo methodo de ensinar a perfeita forma de letra corrente, proprio para os meninos que se destinarem ao commercio). Lisboa: Impressão Regia, 1805.

SALGADO, Emílio Vidigal. Sciencia infantil: livro de leitura para as escolas. Lisboa: Livraria Industrial, 1883.

SAMPAIO, Antonio Rodrigues. Decreto organico dos lyceus nacionais e regulamentos e instrucçōes para sua execução; 1872 a 1873. Lisboa: Imprensa Nacional, 1873.

SANCHES, A. N. Ribeiro. Cartas sobre a educação da mocidade. Porto: Editorial Domingos Barreira, s/d.

SANCHES, A. N. Ribeiro. Dificuldades que tem um reino velho para emendar-se (e outros textos). Porto: Inova, s/d. 
SANCHES, A. N. Ribeiro. Obras. 2v. Coimbra: Universidade de Coimbra, 1966.

SARAIVA, J. A. Noçôes gerais de grammatica portugueza para uso dos alunos que pretendem fazer os exames de instrução primaria e portuguez. Coimbra: Imprensa Litteraria, 1864.

SÉRGIO, António. Introdução Geográfico-Sociológica à História de Portugal. 5 a ed. Lisboa: Livraria Sá da Costa Editora, 1982.

SERGIO, António. O ensino como factor de ressurgimento nacional: defeitos dos nossos métodos de ensino e maneiras de os corrigir: linhas gerais de uma nova organização. Porto: Tipografia da Renascença Portuguesa, 1918.

SERGIO, António. Sobre educação primária infantil. $2^{\mathrm{a}} \mathrm{ed}$. Lisboa: Inquérito, s/d.

SERPA, José Freire de. A moira de Montemor; romance. Coimbra: Imprensa da Universidade, 1840.

SERRA, Alfredo Henrique B. Método Moderno: ensino inicial de leitura, escrita e contas. Porto: Casa Editora de Figueirinhas, 1917.

SILVA, Carlos (calligrapho portuguez). O paleographo em escala calligraphica para aprender a leitura manuscripta; approvado pelo conselho Superior d'Instrucção Publica para uso das escolas. Lisboa: Lith. J. L. Palhares, 1867.

SILVA, Joaquim Carneiro. Breve tratado theorico das letras typographicas, oferecido a Sua Alteza Real o Príncipe Regente Nosso Senhor. Lisboa: Regia Officina Typografica, 1808.

SILVA, Joaquim José Ventura da. Regras methodicas para se aprender a escrever o caracter da letra inglesa, acompanhadas de humas noçôes de Aritnmética oferecidas ao augustíssimo senhor Dom Pedro, principe da Beira. Lisboa: Officina de Simão Thaddeo Ferreira, 1808.

SILVA, José Carvalho e BAPTISTA, José nunes. Primeiro livro de leitura para as escolas de instrucção primária. $1^{\mathrm{a}}$ classe. Lisboa: Antiga Casa Bertrand, s/d.

SIMÕES, Augusto Filippe. Educação physica. Terceira edição correcta e aumentada. Lisboa: Livraria Ferreira, 1879.

SOUSA, José de. Notas de pedagogia philosophica. Lisboa: Adolpho, Modesto e Companhia Impressores, 1890.

SPENCER, Herbert. Educação intellectual, moral e phisica. Com um prefácio de Ricardo d'Almeida Jorge). Porto: Livraria Moderna, s/d.

SUMMULA da Doutrina Christã summariamente explicada para melhor a entenderem e reterem na memoria os meninos e rusticos; ordenada por um paroco para o uso de seus freguezes e dos mais a quem agradar. Lisboa: Typographia Salles, 1843.

TARROZO, Domingos. O monopolio da sciencia official; discussão d'um problema politico. Bibliotheca Moderna, 1888 .

TELLES, João José de Sousa. Ensino intuitivo: livro destinado ás mães e paes de família e ás professoras e professores de instrucção primária. Lisboa: Typographia Universal T. Q. Antunes, 1873.

TELLES, João José de Sousa. Os exames de instrucção primaria e secundaria. Lisboa: Ferreira Lisboa e Companhia, 1875.

THESOURO de meninas. Paris: Typographia A. Parent, s/d.

UNIVERSO PITTORESCO; jornal de instrução e recreio. Lisboa: Na Imprensa Nacional, tomo I (1839-1840) e tomo III (1843-1844).

URCULLU, D. José de. Liçôes de moral, de virtude e de urbanidade; escriptas no idioma hespanhol por __, e traduzidas para o portuguez da $3^{\mathrm{a}}$ edição de Londres de 1828 por Francisco Freire de Carvalho. Lisboa: Typographia Rollandiana, 1838.

URCULLU, José de. Tratado elementar de geografia astronómica, fisica e histórica antiga e moderna. $1^{\circ}$ tomo. Porto: Imprensa de Álvares Ribeiro, 1835.

VASCONCÉLLOZ, A. Garcia Ribeiro de. Grammatica portuguesa para uso dos alumnos dos lyceus (ensino secundário official). Paris e Lisboa: Aillaud e Cia, s/d.

VEIGA, Manuel Rodrigues da, Elucidario da collecção de manuscriptos. Lisboa: Typographia da Bibliotheca Lisbonense, 1869.

VEIGA, Manuel Rodrigues da. Colecção de manuscriptos em escala paleographa para uzo das escolas. Tomo $1^{\circ}$. Lisboa: Lith de Lopes, 1868.

VEIGA, Theodolinda Amelia C.L. da. Elementos de instrucção moral para uzo da mocidade portugueza. Lisboa: Typ. de F. X. de Souza, 1857.

VELLOSO, Rodrigo. "O ultramontanismo na instrução pública em Portugal". In: Folhas ao Vento. Coimbra: Imprensa Litteraria, 1863.

VENTURA, Duarte. Arte de aprender a ler a letra manuscripta para uso das escholas em 10 liçóes progressivas do mais facil ao mais difficil. Paris: Guillard Aillaud, 1888.

VERNEY, Luís António. Verdadeiro método de estudar. 3a ed. Porto: Ed. Domingos Barreira, s/d.

VIDAL, Angelo. Escripta das Escolas Primárias. Porto: Livraria Fernandes Editora, 1910.

VIDAL, Angelo. Manuscripto das Escolas Primárias. Porto: Livraria Fernandes Editora, 1908. 
VIDAL, Angelo. Puerilidades; para festas das creanças. Porto: Livraria Fernandes Editora, 1908.

VIEIRA, Carlos Augusto de Figueiredo. Compêndio elementar de grammatica portugueza (adoptado para uso das escholas pelo Conselho Superior de Instrucção Publica e usado desde o anno de 1855 na Eschola de El-Rei).

VIEIRA, Carlos Augusto Figueiredo. Compendio elementar da grammatica portugueza. Porto: Typographia de Sebastião José Pereira, 1855.

VILHENA, Firmino de. Creanças. Aveiro: Imprensa Aveirense, 1885.

VOZ DA SÄA RAZĀO ou resposta ao impio author do folheto intitulado 'Voz da Razão'. Coimbra: Imprensa Christã da Rua dos Coutinhos (com licensa da Commissão de Censura), 1823.

WANZELLER, Fortunato Rafael Hermano. Compendio calligrafico ou regras geraes da calligrafia; muito necessario para uso da mocidade, como tambem para toda a qualidade de pessoa poder aprender methodicamente a escrever com perfeição, o caracter da letra portugueza, o appelidade letra ingleza, com todas as regras d'escrita, sem que para isso seja necessário de professor: dividida em seis liçôes e com as estampas analogas. Lisboa: Typographia de José Baptista Morando, 1840. 
(Página deixada propositadamente em branco) 


\section{Bibliografia}

AGUlHON, Maurice. 1848- o aprendizado da República. São Paulo: Paz e Terra, 1991.

ALAIN, É. Reflexões sobre educação. São Paulo: Saraiva, 1978.

ALBUQUERQUE, Luis. Notas para a história do ensino em Portugal, Coimbra: Textos Vértice, 1960.

ALVES, Luis Alberto Marques. Subsídios para a História da Educação em Portugal (1750-1890). Cadernos Estudos Contemporâneos no 4. Porto, Secretaria de Estado da Cultura/Centro de Estudos Humanísticos, 1986.

ANDRADE, António Alberto Banha de. A Reforma Pombalina dos estudos secundários no Brasil, S. Paulo, U.S.P., 1978.

ANDRADE, António Alberto Banha de. Verney e a cultura do seu tempo, Coimbra: Por Ordem da Universidade, 1966.

ANDRADE, António Alberto Banha de. Verney e a projecção da sua obra, Lisboa: Instituto de Cultura Portuguesa/ Biblioteca Breve, 1980.

ANTUNES, Manuel (et. al.). Como interpretar Pombal? Lisboa: Brotéria, 1983.

ARAÚJO, Ana Cristina Bartolomeu de. Modalidades de leitura das Luzes no tempo de Pombal. Separata da Revista de História. volume X. Porto: Centro de História da Universidade do Porto, 1990. P. 105-127.

ARIÈS, Philippe. Essais de mémoire; 1943-1983. Paris: Editions du Seuil, 1993.

ARIES, Philippe. História social da família e da criança. 2aed. Rio de Janeiro: Zahar, 1981.

ARIÈS, P. DUBY, G. História da vida privada. São Paulo: Companhia das Letras, 1991. Volumes II, III, IV,V.

ARNAUD, Pierre. Le militaire, l'écolier, le gymnaste; naissance de l'éducation physique en France (1869-1889). Lyon: Presses Universitaires de Lyon, 1991.

AZANHA, José Mário Pires. Experimentação educacional: uma contribuição para sua análise. São Paulo: EDART, 1975.

AZANHA, José Mário Pires. Educação: alguns escritos. São Paulo: Editora Nacional, 1987.

AZANHA, José Mário Pires. Uma idéia de pesquisa educacional. São Paulo: Edusp/Fapesp, 1992.

BACZKO, A. Utopies pédagogiques de la Révolution Française. In: LIBRE 8; politique, antropologie, philosophie. Paris: Payot, 1980

BACZKO, Bronislaw. «Former l'homme nouveau... Utopie et pédagogie pendant la Révolution Française» in Libre (politique-antropologie-philosophie), no 80-8, Paris: Petite Bibliothèque Payot, 1980, pp. 89-132.

BACZKO, Bronislaw. Les imaginaires sociaux: mémoires et espoirs collectifs. Paris: Payot, 1984

BACZKO, Bronislaw. Lumières de l'Utopie - Critique de la Politique, Paris: Payot, 1978.

BACZKO, Bronislaw. Une Education pour la démocratie (textes et projets de l'époque révolutionaire), Paris: Garnier, 1982.

BADINTER, Elisabeth. L'amour en plus: histoire de l'amour maternel (XVII ${ }^{\mathrm{a}}-\mathrm{XX}^{\mathrm{a}}$ siècle). Paris: Flammarion, 1980.

BARATA, José Oliveira. Algumas reflexôes sobre a literatura de cordel no setecentismo português. Separata da Miscelânea de estudos em honra do Prof. A. Costa Ramalho. Coimbra: Imprensa de Coimbra Limitada, 1992.

BARATA, José Oliveira. António José da Silva: criação e realidade. Volumes I e II. Coimbra: Serviço de Documentação e Publicações da Universidade, 1985.

BARATA, José de Oliveira. A angústia como fonte de criação. In: Psiquiatria clínica, 9, (4), 1988, p. 231-4.

BARNARD, H. C. Education and the French Revolution. Cambridge: At the University Press, 1969

BARTHES, Roland. O prazer do texto. Lisboa: Edições Setenta, 1988.

BARTHES, Roland. O rumor da língua. Lisboa: Ediçôes Setenta, 1987.

BASTIDE, Paul. La doctrine de l'éducation universelle dans la philosophie d'Auguste Comte. 2 vols. Paris: P.U.F., 1957. 
BEISIEGEL, Celso de Rui. Política e educação popular: a teoria e a prática de Paulo Freire no Brasil. São Paulo: Ática, 1982.

BETHLENFALVAY, Marina. Les visages de l'enfant dans la littérature française du XIXe siècle; esquisse d'une tipologie. Genève: Librairie Droz, 1979.

386 BETTELHEIM, Bruno e ZELAN, Karen. La lecture et l'enfant. Trad. Paris: Robert Laffont, 1983.

BITTENCOURT, Circe M. F. Livro didático e conhecimento histórico. 1993.369 p. Tese (doutorado). Faculdade de Filosofia, Letras e Ciências Humanas da Universidade de São Paulo, São Paulo, 1997.

BLOCH, Marc, A sociedade feudal.. $2^{\circ}$ ed. Lisboa: Edições 70, 1987.

BLOCH, Marc. Introdução à história. $4^{\mathrm{a}} \mathrm{ed}$. Sintra: Europa-América, s.d.

BOLLÈME, G. O povo por escrito. São Paulo: Martins Fontes, 1988.

BONIFÁCIO, Ma de Fátima. Seis estudos sobre o liberalismo português. Lisboa: Estampa, 1991.

BOTO, Carlota Malta Cardozo dos Reis. A educação como estratégia no iluminismo francês. Confluências: Actas do Colóquio Le Maître et son Disciple. Faculdade de Letras da Universidade de Coimbra, nº 9. Dezembro de 1993. p. 249-261.

BOTO, Carlota. A escola do homem novo: entre o iluminismo e a revolução Francesa. São Paulo: Editora UNESP, 1996.

BOTO, Carlota. Cem anos de discursos sobre a leitura: mais um. Revista USP n ${ }^{\circ} 29$. Universidade de São Paulo, maio de 1996. p. 201-208.

BOTO, Carlota Malta Cardozo dos Reis. Escola, voto e nação: análise do discurso republicano no Brasil. Revista Portuguesa de Pedagogia. ano XXIX. Coimbra: Faculdade de Psicologia e Ciências da Educação da Universidade de Coimbra. no 1, 1995. p. 35-50.

BOTO, Carlota. Iluminismo e educação em Portugal: o legado do século XVIII ao XIX. São Paulo: Revista da Faculdade de Educação. USP. 1996.

BOTO, Carlota. Lição da escola em Portugal: o Manual enciclopédico. Revista Portuguesa de Educação. Braga: Universidade do Minho, 1995. (8) , número 1. p. 21-31.

BOTO, Carlota Malta Cardozo dos Reis. Nacionalidade, escola e voto: a Liga Nacionalista de São Paulo. Perspectivas: Revista de Ciências Sociais. Universidade Estadual Paulista, São Paulo, Volumes 17/18, 1994-5, p.145-163.

BOTO, Carlota. Nova História e seus velhos dilemas. Revista USP n ${ }^{\mathrm{O}} 23$. Universidade de São Paulo, Dezembro de 1994.p. 23-33.

BOTO, Carlota. O enciclopedismo de Ribeiro Sanches: pedagogia e medicina na confecção do Estado. Cadernos de Cultura - Medicina na Beira Interior, da pré-história ao século XX. $\mathrm{n}^{\mathrm{O}}$ 8. Castelo Branco, Novembro de 1994.p. 21-25.

BOTO, Carlota. O mundo por escrito: alguns aspectos da alfabetização portuguesa no século XIX. Comunicação apresentada no Primeiro Congresso Luso-Brasileiro de História da Educação: leitura e escrita em Portugal e no Brasil (1500-1970). Lisboa, Fundação Gulbenkian, 23-26 de janeiro de 1996. Atas no prelo.

BOTO, Carlota. O ensino tradicional e sua tradição: histórias e raízes. In: Fórum: Suplemento do Jornal da Unesp. Universidade Estadual Paulista, Outubro 2006, ano XX, no 216. http://www.unesp.br/aci/jornal/216/ supled.php p.4.

BOTO, Carlota. Rascunhos de escola na encruzilhada dos tempos. (dissertação de mestrado mimeografada). São Paulo: Faculdade de Educação da USP, 1990.

BOTO, Carlota e STANGE, Mariana Cláudia Broens. Corporação universitária: ofício de mestres e estudantes. Universidade e sociedade. São Paulo, ANDES - 9, 1995. p.118-121.

BOURDIEU, P. A economia das trocas simbólicas. 2aEd. São Paulo: Perspectiva, 1982.

BUENO, Belmira Oliveira $e$ alli. Docência, memória e gênero: estudos alternativos sobre a formação de professores. In: Psicologia USP. São Paulo, volume 4, números 1/2., 1993.

BRASLAVSKY, Berta P. De. Problemas e métodos no ensino de leitura. Trad. São Paulo: Melhoramentos / Editora da Universidade de São Paulo, 1971.

BRAUDEL, Fernand. Écrits sur l'histoire. Paris: Flammarion, 1969.

BRAUDEL, Fernand. História e ciências sociais. 4aEd. Lisboa: Presença, s.d.

BURKE, Maria Lúcia Garcia Pallares. Nísia Floresta: o carapuceiro e outros ensaios de tradução cultural. São Paulo: Hucitec, 1996.

BURKE, Peter. A Escola dos annales (1929-1989); a Revolução Francesa da historiografia. 2a edição. Trad. São Paulo: Unesp, 1992.

BURKE, Peter. Cultura popular na Idade Moderna. São Paulo: Companhia das Letras, 1989.

BURKE, Peter. Sociologia e História. Trad. 2a edição. Porto: Afrontamento, 1980.

CAMBI, Franco. Storia della pedagogia. Roma: Editori Laterza, 1995.

CANETTI, Elias. Crouds and Power. Trad. Carol Stewart. Penguin 
CARR, E. H. Que é história? Rio de Janeiro: Paz e Terra, 1982.

CARVALHO, Laerte Ramos de. As reformas pombalinas da instrução pública, São Paulo: Edusp/Saraiva, 1978.

CARVALHO, Rómulo. História do ensino em Portugal. Desde a fundação da nacionalidade até ao fim do regime de Salazar Caetano, Lisboa: Fundação Calouste Gulbenkian, 1986.

CARVALHO, Adalberto Dias de. Utopia e educação. Porto: Porto Editora, 1994.

CARVALHO, Marta Maria Chagas de. A escola e a república. São Paulo: Brasiliense, 1989.

CARVALHO, Marta Maria Chagas de. Molde nacional e forma cívica: higiene, moral e trabalho no projeto da Associação Brasiliera de Educação (1924-1931). [tese de doutorado mimeografada]. São Paulo: Faculdade de Educação da USP, 1986.

CATANI, Denice. Educadores à meia-luz. [tese de doutorado mimeo.] São Paulo: FEUSP, 1989.

CATANI, Denice Barbara. Ensaios sobre a produção e circulação dos saberes pedagógicos. Faculdade de Educação da Universidade de São Paulo, Tese de Livre-Docência, 1994. (Mimeografado).

CATROGA, Fernando, TORGAL, Luís Reis, MENDES José Amado. História da história em Portugal: séculos XIX-XX. Lisboa: Círculo de Leitores, 1996.

CATROGA, Fernando José de Almeida. (coord). Política, história e revolução. In: Antero de Quental: Revista de História das Ideias. v. 13. Coimbra, Faculdade de Letras / Instituto de História e Teoria das Ideias, 1991.

CATROGA, Fernando José de Almeida. A militância laica e a descristianização da morte em Portugal (1865-1911). 2 volumes. Coimbra, mimeografado, 1988.

CATROGA, Fernando. O republicanismo em Portugal: da formaçāo ao 5 de outubro de 1910. Coimbra: Faculdade de Letras, 1991.

CATROGA, Fernando. Os inícios do positivismo em Portugal: o seu significado político-social. In: Revista de História das Idéias. vol. 1. Coimbra: Impressora da Universidade, 1977.

CERTEAU, Michel de. A escrita da história. Rio de Janeiro: Forense-Universitária, 1982.

CERTEAU, Michel de. Histoire e psycanalyse entre science e ficcion. Paris: Gallimard, 1987.

CERTEAU, Michel de. L'invention du quotidien; arts de faire. Paris: Gallimard, 1990.

CERTEAU, Michel de e outros. Une politique de la langue; la Rev. Française et les patois: l'enquête de Gregoire. Paris: Gallimond, 1975.

CHANDEIGE, Michel. Lisboa ultramarina. Rio de Janeiro: Zahar, 1992

CHARLE, Christophe. Naissance des intellectuels: 1880-1900. Paris: Les Éditions de Minut, 1990.

CHARTIER, Anne-Marie e HEBRARD, Jean. Discursos sobre a leitura - 1880-1980. São Paulo: Ática, 1995.

CHARTIER, Anne-Marie e HEBRARD, Jean. L'invention du quotidien: une lecture, des usages. [Mimeografado]. Feusp, 1995.

CHARTIER, Anne-Marie. L'école éclatée. [Mimeografado]. Feusp, 1995.

CHARTIER, Anne Marie. Les faire ordinaires de la classe: un enjeu pour la recherche et pour la formation. [Mimeografado]. Feusp, 1995.

CHARTIER, Roger. A história cultural entre práticas e representações. Trad. Lisboa: Difel, 1990.

CHARTIER, Roger (et alli). La correspondance: les usages de la lettre au XIXe siècle. Paris: Arthème Fayard, 1991.

CHARTIER. Roger. Lectures et lecteurs dans la France d'Ancien Regime. Paris: Editions du Seuil, 1987.

CHAUNU, Pierre. La civilisation de l'Europe des lumières. Paris: Flammarion, 1982.

CHAUÍ, Marilena. Ideologia e Educação. Educação e Sociedade. Cortez Editora/Autores Associados/Cedes. Ano II. n5. Janeiro 1980. p.24.

CHOPPIN, Alain. Manuels scolaires: histoire et actualité. Paris: Hachette, 1992.

CIDADE, Hernani. Portugal histórico-cultural. Lisboa: Presença, 1985.

Colóquio Educação e Sociedade. 2. Lisboa: Calouste Gulbenkian, fevereiro/93.

CLAUSSE, A. A relatividade educativa: esboço de uma história e de uma filosofia da escola. Coimbra: Almedina, 1976.

COMÉNIO, J. A. Pampaedia (educação universal). Introdução, tradução e notas Joaquim Ferreira Gomes. Coimbra: Instituto de Estudos Psicológicos e Pedagógicos, 1971.

COMO interpretar Pombal? Lisboa: Ediçôes Brotéria, 1983.

COMPENDIO histórico do estado da Universidade de Coimbra (1771). Lisboa: Por Ordem da Universidade, 1972.

COMTE, A. Cours de philosophie positive. Paris: Garnier, s/d. 2 vols.

CONDORCET. Esquisse d'un tableau historique des progrès de l'esprit humain. Paris: Flammarion, 1988.

CONDORCET. Instrução pública e organização do ensino. trad. Porto: Livraria Educação Nacional, 1943.

CORDEIRO, Jaime Francisco Parreira. O ensino de História e a Universidade. (mimeografado). São Paulo: UNESP, 1995.

COSTA, Fernando Marques (org.). Do Antigo Regime ao Liberalismo. Lisboa: Vega, s/d.

COSTA, Maria José. Um continente poético esquecido: as rimas infantis. Porto: Porto Editora, 1992. 
DARNTON, R. Boemia literária e revolução. trad. São Paulo: Companhia das Letras, 1987

DARNTON, Robert. O lado oculto da Revolução; Mesmer e o final do Iluminismo na França. Trad. Denise Bottmann. São Paulo: Companhia das Letras, 1988.

DAVIS, Nathalie. Culturas do povo: sociedade e cultura no início da França Moderna. Rio de Janeiro: Paz e Terra, s/d.

DEBESSE, M. e MIALARET, G. (org.) Tratado das ciências pedagógicas: v. 2, história da pedagogia. trad. São Paulo: Companhia Editora Nacional: Editora da Universidade de São Paulo, 1974

DECLARAÇÃO dos direitos do homem e do cidadão. In: Expresso, 1\%/7/1989

DILTHEY, G. Historia da la pedagogia. Buenos Aires: Losada, 1960

DURKHEIM, E. Éducation et sociologie. Paris: Felix Alcan, 1922

DURKHEIM, Emile. L'évolution pédagogique en France. 2e ed. Paris: Presses Universitaires de France, 1969.

EBY, F. História da educação moderna: século XVI / Século XX; teoria, organização e prática educacionais. Porto Alegre: Globo, 1978.

ECO, Umberto. Como se faz uma tese. trad. São Paulo: Perspectiva, 1983.

ELIADE, Mircea. Mitos, sonhos e mistérios. Lisboa: Edições 70, 1989.

ELIADE, Mircea. O mito do eterno retorno: arquétipos e repetição. Lisboa: Ediçôes 70, 1984.

ELIADE, Mircea. O sagrado e o profano: a essência das religiōes. Lisboa: Livros do Brasil, s/d.

ELIAS, Norbert. A sociedade de corte. trad. Lisboa: Estampa, 1987.

ELIAS, Norbert. A sociedade dos individuos. Lisboa: Dom Quixote, 1993.

ELIAS, Norbert. O processo civilizador. 2 volumes. Rio de Janeiro: Zahar, 1994.

ENCONTRO de história da educação em Portugal: comunicaçôes. Lisboa: Fundação Calouste Gulbenkian, 1988.

ENFANCE. tome 42, no 4/1989. Paris: P.U.F., 1989

FALCON, FRANCISCO JOSÉ CALAZANS. A época pombalina. São Paulo: Ática, 1982.

FEBVRE, Lucien. Combates pela história. 2a ed. Lisboa: Presença, s.d.

FERNANDES, Rogério. "António Sérgio, Ministro da Instrução Pública", Revista de História das Ideias, vol. 5, tomo 2, 1983, pp. 603-700.

FERNANDES, Rogério. A pedagogia portuguesa contemporânea, Venda Nova, Amadora, Instituto da Cultura e da Língua Portuguesa, 1979.

FERNANDES, Rogério. As ideias pedagógicas de F. Adolfo Coelho, Lisboa: Instituto Gulbenkian de Ciência/Centro de Investigação Pedagógica, 1973.

FERNANDES, Rogério. Bernardino Machado e os problemas da instrução pública. Lisboa: Livros Horizonte, s/d.

FERNANDES, Rogério. João de Barros: Educador Republicano, Lisboa: Livros Horizonte, s.d. (1971).

FERNANDES, Rogério. O pensamento pedagógico em Portugal, Lisboa: Instituto da Cultura Portuguesa/Biblioteca Breve, 1978.

FERNANDES, Rogério. Os caminhos do $A B C$ : sociedade portuguesa e ensino das primeiras letras. Porto: Porto Editora, 1994.çl

FERREIRA, Alberto (coord.). Antologia de textos da Questão Coimbrā. Lisboa: Moraes, 1980.

FERREIRA, Alberto (coord.). Antologia de textos pedagógicos do século XIX português, Lisboa: Fundação Calouste Gulbenkian/Centro de Investigação Pedagógica, 3 vols., 1971-1975.

FERREIRA, Alberto e MARINHO, Maria José (orgs.). Bom senso e bom gosto: (a Questão Coimbrã). Volumes I a IV. Lisboa: Imprensa Nacional Casa da Moeda, 1966.

FERREIRA, Alberto. Estudos de cultura portuguesa (século XIX), Lisboa: Moraes Editores, 1980.

FERREIRA, António Gomes. A criança em dois tratados setecentistas de Puericultura, Rev. port. de pedagogia, 21, 1987, 151-167.

FERREIRA, António Gomes. A criança no conhecimento médico de seiscentos. In: Revista portuguesa de pedagogia. Ano XXIII. Coimbra: Faculdade de Psicologia e Ciências da Educação, 1989.

FERREIRA, António Gomes Alves. A criança no Portugal de setecentos: contributo para o estudo da evolução dos cuidados e das atitudes para com a infância. Volumes I e II. (tese de doutoramento mimeografada). Coimbra: Universidade de Coimbra, 1996.

FERREIRA, António Gomes. O ensino de um mestre de primeiras letras nos finais de setecentos. In: Revista portuguesa de pedagogia. Ano XXIV. Coimbra: Faculdade de Psicologia e Ciências da Educação, 1990.

FERREIRA, António Gomes. O perigo do amor: argumentos sobre a fundamentação das relaçôes socio-afectivas na família portuguesa do Antigo Regime. In: revista Educação e tecnologia. Braga, volume XVI, Agosto de 1995. p. 49-58.

FERREIRA, António Gomes. Um relance sobre a criança no século XVI, Rev. port. de pedagogia, 21, 1987, 169-198. (em colab. com Ana Maria Patrício Lopes Pereira).

FERREIRA, Tito Lívio. Portugal no Brasil e no mundo. São Paulo: Nobel, 1984. 
FERRO, Marc. Falsificaçôes da história. Trad. Sintra: Europa-América, s/d.

FORQUIN, J. C. Escola e cultura: as bases sociais e epistemológicas do conhecimento escolar. Porto Alegre: Artes Médicas, 1989.

FOUCAULT, Michel. A arqueologia do saber. 2a ed., trad. Rio de Janeiro: Forense - Universitária, 1986.

FOUCAULT, Michel. As palavras e as coisas; uma arqueologia das ciências humanas. $3^{\mathrm{a}}$ ed., trad. São Paulo: Martins Fontes, 1985

FOUCAULT, Michel. Histoire de la folie à l'âge classique. Paris: Gallimard, 1972.

FOUCAULT, Michel. L'ordre du discours. Paris: Gallimard, 1971.

FOUCAULT, Michel. Surveiller et punir. Paris: Gallimard, 1975.

FROEBEL, Frédéric. L'education de l'homme. Trad. Paris: Librarie Classique, s/d.

FURET, François. A oficina da história. Lisboa: Gradiva, s.d.

FURET, F. e OZOUF, J. Lire et écrire; l'alphabétisation des français de Calvin à Jules Ferry. Paris: Les editions de Minuit, 1977.

GARRIDO, Álvaro Francisco Rodrigues. Ensaio sobre o pensamento do lente republicano Alves dos Santos. (trabalho de final de curso do Mestrado em História Contemporânea de Portugal : História Cultural e das Mentalidades). mimeografado. Universidade de Coimbra, Faculdade de Letras, 1993.

GAUER, Ruth Maria Chittó. A modernidade portuguesa e a Reforma Pombalina de 1772. Porto Alegre: EDIPUCRS, 1996.

GINZBURG, Carlo. Mitos, emblemas e sinais. São Paulo: Companhia das Letras, 1989.

GINZBURG, Carlo. O queijo e os vermes; o cotidiano e as idéias de um moleiro perseguido pela Inquisição. São Paulo: Companhia das Letras, 1987.

GLÉNISSON, Jean. Iniciação aos estudos históricos. trad. 4a ed. São Paulo: Difel, 1983.

GOLDMAN, Noemi e ARFUCH, Leonor. (Realização). Historia y prácticas culturales: entrevista a Roger Chartier. [Mimeografado]. Feusp, 1995.

GOMES, Joaquim Ferreira. A educação infantil em Portugal, Coimbra: Livraria Almedina, 1977.

GOMES, Joaquim Ferreira. A introdução e o prolongamento da obrigatoriedade escolar em Portugal. separata da Revista portuguesa de pedagogia, Coimbra, 1985.

GOMES, Joaquim Ferreira. A mulher na universidade de Coimbra. Coimbra: Livraria Almedina, 1987.

GOMES, Joaquim Ferreira. Dez estudos pedagógicos, Coimbra: Livraria Almedina, 1977.

GOMES, Joaquim Ferreira. Estudos de história e de pedagogia, Coimbra: Livraria Almedina, 1984.

GOMES, Joaquim Ferreira. Estudos para a história da educação do século XIX, Coimbra: Livraria Almedina, 1980.

GOMES, Joaquim Ferreira. Estudos para a história da Universidade de Coimbra. Coimbra: Imprensa de Coimbra, 1991.

GOMES, Joaquim Ferreira (org.). História da educação em Portugal, Lisboa: Horizonte, 1988.

GOMES, Joaquim Ferreira. Martinho de Mendonça e a sua obra pedagógica, Coimbra: Universidade de Coimbra, 1964.

GOMES, Joaquim Ferreira. Novos estudos de história e de pedagogia. Coimbra: Livraria Almedina, 1986.

GOMES, Joaquim Ferreira. O Marquês de Pombal e as reformas do ensino, 2a ed. Coimbra: INIC, 1989.

GOMES, Joaquim Ferreira. O Marquês de Pombal, criador do ensino primário oficial, Revista de história das ideias, vol. IV, tomo II, 1982, pp. 25-41.

GOMES, Joaquim Ferreira. Um bisneto do marquês de pombal, promotor da instrução primária. separata de Biblos (vol. LVII), Coimbra, 1981.

GRAFF, Harvey J. Os labirintos da alfabetização: reflexōes sobre o passado e o presente da alfabetização. Porto Alegre: Artes Médicas, 1995.

GUSDORF, Georges. Les principes de la pensée au siècle des lumières. Paris: Payot, 1971

GUIA do Estudante: História. Faculdade de Letras da Universidade de Coimbra: Publicação do Conselho Pedagógico, Ano Lectivo 1992/1993.

GVIRTZ, Silvina. El discurso escolar a traves de los cuadernos de clase: Argentina 1930 - 1990. (mimeo.). Buenos Aires: Facultad de Filosofia y Letras, 1995.

HANNOUN, Hubert. Le paris de l'éducation. Paris: P.U.F., 1996.

HELLER, Agnes. Everyday life. Trad. London and New York: Routledge and Kegan Paul, 1984.

HÉBRARD, Jean. A escolarização dos saberes elementares na época moderna. Tradução. In: Teoria e educação, 2, 1990. P. 65-109.

HÉBRARD, Jean. La leçon et l'exercice: quelques réflexions sur l'histoire des pratiques de scolarisation. [ mimeografado ] Paris: Service d'histoire de l'éducation. INRP-CNRS, 1995.

HERBART, J. F. Comment élever nos enfants: pédagogie généralle. Trad. Paris: Librairie Schleicher, 1908.

HOBSBAWN, E. J. Naçôes e nacionalismos desde 1780; programa, mito e realidade. trad. São Paulo: Paz e Terra, 1990. 
HUNT, Lynn (organizadora). A nova história cultural. São Paulo: Martins Fontes, 1995.

INFANTE, Miguel. Arquivo Central das Secretarias de Estado/ Ministério do Reino (instrumentos de descrição ARQBASE). Junho de 1991, Inventários do Instituto Português de Arquivos (IPA).

JOLLES, André. Formas simples: legenda, saga, mito, adivinha, ditado, caso, memorável, conto, chiste. São Paulo: Cultrix, 1976.

KANT, I. A paz perpétua e outros opúsculos. Trad. Lisboa: Ediçōes 70, 1990

KANT, I. Fundamentação da metafisisca dos costumes. 2aed. São Paulo: Abril Cultural, 1984 (Os Pensadores II).

LE GOFF, Jacques. Histoire e mémoire. Paris: Gallimard, 1988.

LEFEBVRE, Henri. Critique de la vie quotidienne. 2 volumes. Paris: L'Arche Editeur, 1977.

LEFORT, Claude. Pensando o politico; ensaios sobre democracia, revolução e liberdade. trad. Rio de Janeiro: Paz e Terra, 1991.

LEON, Antoine. Introdução à história da educação. trad. Lisboa: D. Quixote, 1983.

LÖWITH, Karl. O sentido da história. trad. Lisboa: Ediçōes Setenta, 1991.

LOPES, Eliane Marta Teixeira. Origens da educação pública: a instrução na revolução burguesa do século XVIII. São Paulo: Loyola, 1981.

MACFARLANE, Alan. História do casmento e do amor. São Paulo: Companhia das Letras, 1990.

MACHADO, Fernando Augusto. Almeida Garret e a introdução do pensamento educacional de Rousseau em Portugal. Rio Tinto: Edições Asa, 1993.

MAGALHÃES, Justino Pereira. A formação do mapa escolar do Distrito de Braga. In: Revista cultural Bracara Augusta. Volume XVII. Braga Câmara Municipal, 1992.

MAGALHĀES, Justino Pereira. Apontamentos sobre componentes estruturais da história da alfabetização. In: Forum, 9/10. Braga: Unidade de Educação de Adultos, 1991.

MAGALHÃES, Justino Pereira. Apontamentos para a história da instrução pública em Braga. In: Revista cultural Bracara Augusta. Braga, s.d.

MAGALHÃES, Justino. Contributo para a história das instituições educativas: entre a memória e o arquivo. [Mimeografado]. Braga, 1995.

MAGALHÃES, Justino. Fontes locais para a História da Educação: uma proposta de sistematização. In: Sociedade Portuguesa de Ciências da Educação, Ciências da Educação: investigação e ação; actas do II Congresso da Sociedade Portuguesa de Ciências da Educação, 1995. P. 341-351.

MAGALHÃES, Justino Pereira. Há um século os professores de Vila Real proclamam uma educação em que o homem complete o cidadão e uma escola que liberte a família e inicie à divisão social do trabalho e ao Estado. [mimeografado, cedido pelo autor].

MAGALHÃES, Justino Pereira. Ler e escrever no mundo rural do Antigo Regime: um contributo para a história da alfabetização e da escolarização em Portugal. Instituto de Educação da Universidade do Minho: Serviço de Publicaçōes, Braga, 1994.

MAGALHÂES, Justino. Linhas de investigação em História da educação e da alfabetização em Portugal: um domínio do conhecimento em renovação. [Mimeografado]. Campinas, III Seminário nacional de estudos e pesquisas: história, sociedade e educação no Brasil, 1995.

MAGALHĀES, Justino. Um contributo para a história do processo de escolarização da sociedade portuguesa na transição do Antigo Regime. In: Educação, sociedade e culturas, no 5, 1996, p.7-34.

MAINGUENEAU. Les livres d'école de la république (1870-1914); discours et idéologie. Paris: Le Sycomore, 1979.

MANACORDA, M. A. História da educação; da Antiguidade aos nossos dias. trad. São Paulo: Cortez Autores Associados, 1989.

MANNHEIM, Karl. Ideologia e utopia. 4aEdição. Rio de Janeiro: Guanabara, 1986.

MARQUES, A. H. de Oliveira. História de Portugal, Lisboa: Palas Editores: vol. I, $8^{a}$ edição, 1980; vol. III, 2a edição, 1981.

MARROU, Henri-Irénée. Sobre o conhecimento histórico. Trad. Rio de Janeiro: Zahar, 1978

MARTIN, Henri-Jean. Histoire et pouvoirs de l'écrit. Paris: Académie Perrin, 1988.

MARX, K. , ENGELS, F. A ideologia alemã. Lisboa: Avente, 1981.

MATOS, Sérgio Campos. Historia, mitologia e imaginário nacional; a história no curso dos Liceus (1895-1939). Lisboa: Horizonte, 1990.

MATTOSO, José. A escrita da história: teoria e métodos. Lisboa: Editorial Estampa, 1988.

MATTOSO, José (direcção). História de Portugal. Quinto Volume: O Liberalismo (1807-1890). Lisboa: Círculo de Leitores, 1993.

MATTOSO, José (direcção). História de Portugal. Sexto Volume: a Segunda Fundação (1890-1926). Lisboa: Estampa, 1994. 
MATTOSO, José. Identificação de um país: ensaio sobre as origens de Portugal. 2 volumes. $4^{\mathrm{a}}$ edição. Lisboa: Editorial Estampa, 1991.

MAUXION, Marcel. L'éducation par l'instruction et les théories pédagogiques de Herbart. Paris: Felix Alcan Editeur, 1901.

MAYER, Arno J. A força da tradição; a persistência do Antigo Regime. Trad. São Paulo: Companhia das Letras, 1987

MEDINA, João. Oh! a República!...; estudos sobre o republicanismo e a primeira república portuguesa. Lisboa: Instituto Nacional de Investigação Científica, 1990.

MESSER, A. Historia de la pedagogia. Barcelona: Labor, 1930

MIARALET, G. e VIAL J. História mundial da educação. 4 volumes. trad. Porto: Rés Editora, s/d.

MONCADA, Luis Cabral de Oliveira. Um «Iluminista» português no século XVIII: Luiz António Verney, Coimbra: Arménio Amado, 1941.

MÓNICA, Maria Filomena. Educação e Sociedade no Portugal do Salazar. Lisboa: Presença, 1978.

MOTA, Carlos Guilherme (Org). Brasil em perspectiva. 5a edição, São Paulo: Difusão Européia do Livro, 1974

MOTA, Carlos Guilherme (Org.). Revolução Francesa: 200 anos depois. São Paulo, Revista do Gabinete de Leitura Ruy Barbosa, no 3, agosto 89

MOTA, Carlos Guilherme. Europeus no Brasil na época da independência: um estudo. In Anais do Museu Paulista, tomo XIX, 1965

MOTA, Carlos Guilherme. Idéia de Revolução no Brasil (1789-1801). 2a edição, São Paulo: Cortez, 1989

MOTA, Carlos Guilherme. Nordeste, 1817. São Paulo: Perspectiva/Edusp, 1972.

NAGLE, Jorge. Educação e linguagem: para um exame do discurso pedagógico. São Paulo: EDART, 1976.

NAGLE, Jorge. Educação e sociedade na Primeira República. São Paulo: EPU, MEC, 1976.

NIETZSCHE, F. Seconde considération intempestive; de l'utilité et de l'inconvénient des études historiques pour la vie (1874). trad. Paris: Flammarion, 1988.

NITZSCHE. Ecce Homo. trad. Mira-Sintra: Europa américa, s/d.

NOVAIS, Fernando A. Portugal e Brasil na crise do antigo sistema colonial. (1777-1808). $3^{a}$ ed. São Paulo: Hucitec, 1985.

NOGUEIRA, Marco Aurélio. As desventuras do liberalismo. Rio de Janeiro: Paz e Terra, 1984.

NÓVOA, António (org). Avaliaçōes em educação: novas perspectivas. Lisboa: Educa, 1992.

NÓVOA, António (org.). Os professores e as reformas de ensino na viragem do século (1886-1906). Lisboa: Edições Asa, 1992.

NÓVOA, António (org). Profissão de professor. Porto: Porto Editora, 1991.

NÓVOA, António (org). Reformas educativas e formação de professores. Lisboa: Educa, 1992.

NÓVOA, António. Uma educação que se diz nova. Texto mimeografado para o curso proferido na Unesp, câmpus de Marília (S.P.), em abril de 1996, sob o título: Educação e sociedade: abordagens históricas e comparadas.

NÓVOA, António (org). Vidas de professores. Porto: Porto Editora, 1992.

NÓVOA, António Manuel Sampaio da. Do mestre-escola ao professor do ensino primário - subsídios para a história da profissão docente em Portugal (séculos XVI-XX), Análise Psicológica, 3, série V, 1987, 413-440.

NÓVOA, António Manuel Sampaio da. Era uma vez uma escola, Lisboa: Instituto de Estudos para o Desenvolvimento/Edições Rolim, s.d. (1986)

NÓVOA, António Manuel Sampaio da. História da educação. (Mimeografado). Faculdade de Psicologia e Ciências da Educação/Universidade de Lisboa, 1994.

NÓVOA, António Manuel Sampaio da. Jornal Mensal da Educação: publicada há 150 anos a primeira revista pedagógica portuguesa, O Jornal da Educação, no 86, 1985, 14-15.

NÓVOA, Notas sobre la influencia de la Revolucion Francesa en la educación en Portugal. In: La Revolucion Francesa y su influencia en la educacion en España. Separata da Universidad Nacional de Educacion a Distancia. P. 183-205.

NÓVOA, António Manuel Sampaio da. Le Temps des Professeurs - Analyse socio-historique de le profession enseignante au Portugal (XVIIIe - XXe siècle), 2 vols, Lisboa: Instituto Nacional de Investigação Científica, 1987.

OLIVEIRA, António Resende de. As instituiçōes de ensino. In: Nova história de Portugal III, capítulo V A cultura e o ensino, s/d.

ORTIGÃO, Ramalho. As Farpas. volumes 1-15. Lisboa: Clássica Editora, 1991.

OSTROGORSKI, Moisei. La démocratie et les partis politiques. Paris: Seuil, 1979.

OZOUF, Jacques et OZOUF, Mona. La république des instituteurs. Paris: Seuil, 1992.

OZOUF, M. L'école de la France. Paris: Gallimard, 1984

OZOUF, M. La fête revolutionnaire; 1789-1799. Paris: Gallimard, 1976

OZOUF, Mona. L'école de la France; essais sur la Révolution, l'utopie et l'enseignement. Paris: Gallimard, 1989 
OZOUF, Mona. L'école, l'église et la republique (1871-1914). Paris: Cana, 1982.

OZOUF, Mona. L’homme régénéré; essais sur la Revolution Française. Paris: Gallimard, 1989.

OZOUF, Mona. Nous les maîtres d'école: autobiographies d'instituteurs de la Belle Époque. Paris: Gallimard, 1993.

PERRY, Marvin. Civilização ocidental: uma história concisa. São Paulo: Martins Fontes, 1985.

PESTALOZZI. Como enseña Gertrudes a sus hijos. trad. Ediciones de la lectura. Espasa Calpe, S.A., s/d.

PETITAT, André. Produção da escola: produção da sociedade; análise socio-histórica de alguns momentos decisivos da evolução escolar no Ocidente. Porto Alegre: Artes Médicas, 1993.

PINA, Ana Maria Ferreira. De Rousseau ao imaginário da Revolução de 1820. Lisboa: INIC, 1988

PROUST, Jacques. Diderot et l' Encyclopedie. Paris: Armand Colin, 1967

PUBLICAÇÕES periódicas portuguesas existentes na Biblioteca Geral da Universidade de Coimbra (1911-1926), Coimbra: Biblioteca Geral da Universidade, 1991.

PUBLICAÇÕES periódicas portuguesas existentes na Biblioteca Geral da Universidade de Coimbra (1641-1910), Coimbra: Biblioteca Geral da Universidade, 1983.

REIS, Carlos. Estatuto e perspectivas do narrador de ficção de Eça de Queiroz. 3a ed. Coimbra: Almedina, 1984.

REIS, Carlos e PIRES, Maria da Natividade. História crítica da literatura portuguesa (volume V, O Romantismo). Lisboa: Verbo, 1993.

REIS, Carlos. Introdução à leitura d'Os Maias. Coimbra, Almedina, 1991.

REIS, Carlos. Leitura dos Maias. Coimbra: Minerva, 1990.

REIS, Carlos. Eça de Queirós e o discurso da História. In: Queirosiana: estudos sobre Eça de Queirós e sua geração. Números 7/8. Dezembro 1994 -julho 1995.

REIS, Carlos. Um bardo dos tempos novos: a imagem queirosiana de Antero. [mimeografado] Ponta Delgada: Universidade dos Açores, 1993.

RÉMOND, R. O século XIX (1815-1914). São Paulo: Cultrix, 1989.

REVEL, Jacques. A invenção da sociedade. trad. Lisboa: Difel, 1990.

RIBEIRO, Maria Manuela de Bastos Tavares. A memória da Revolução Francesa nos movimentos revolucionários de 1848 em Portugal e no Brasil. Coimbra, separata da Revista de História das Idéias, vol. 11, 1989.

RIBEIRO, Maria Manuela Tavares. Livros e leituras no século XIX. In: História da vida privada e do quotidiano. Lisboa: Editorial Presença, 1996.

RIBEIRO, Maria Manuela Tavares. Pensamento social e direitos humanos. In: Revista de História. Vol. X. Porto: Centro de História da Universidade do Porto, 1990.

RIBEIRO, Maria Manuela Tavares. O cristianismo social de 1848. In: Revista de história das idéias. Vol. 9. Coimbra: Faculdade de Letras, 1987.

RIBEIRO, Maria Manuela Tavares. Portugal e a Revolução de 1848. In: Ler História. №. 16. Coimbra: Faculdade de Letras, 1989.

RIBEIRO, Orlando. Portugal, o Mediterrâneo e o Atlântico; esboço de relações geográficas. 6 ${ }^{\text {a. }}$ edição. Viseu: Livraria Sá da Costa Editora, 1991.

RICOEUR, P. Interpretação e ideologia. 3aEd. Rio de Janeiro: Francisco Alves, 1988.

ROCHE, Daniel . Les républicains des lettres. Paris: Arthème Fayard, 1988

ROSANVALON, Pierre. L'état en France; de 1789 à nos jours. Paris: Éditions du Seuil, 1990

SANTOS, Maria de Lourdes Costa Lima dos. Intelectuais portugueses na primeira metade de oitocentos. Lisboa: Presença, 1985.

SANTOS, Maria Helena Carvalho dos (coord.). Pombal revisitado. Lisboa: Estampa, 1984.

SARAIVA, A. J. e LOPES, Oscar. História da literatura portuguesa. 16a ed. Porto: Porto Editora, s/d.

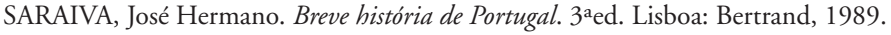

SARAIVA, José Hermano. Itinerário português: tempo e alma. Lisboa: Gradiva, 1987.

SARTRE, Jean-Paul. Que é a literatura?. 2a ed. São Paulo: Ática, 1993.

SCHAFF, Adam. História e verdade. Trad. Ma Paula Duarte. 2a ed. São Paulo: Martins Fontes, 1983.

SENNET, R. O declínio do homem público; as tiranias da intimidade. trad. São Paulo: Companhia das Letras, 1988

SERRÃO, Joaquim Veríssimo. Herculano e a consciência do liberalismo português. Lisboa: Bertrand, 1977.

SERRÃO, Joaquim Veríssimo. História de Portugal - vol. VII (1807-1832), Lisboa: Editorial Verbo, 1984.

SERRÃO, Joel. Cronologia geral da história de Portugal. 5Ed. Lisboa: Horizonte, 1986

SERRÃO, Joel. Da regeneração à república. Lisboa: Livros Horizonte, 1990.

SERRÃO, Joel. Pequeno dicionário da história de Portugal. Porto: Figueirinhas, 1993.

SERRÃO Joel. Temas oitocentistas: para a história de Portugal no século passado. Tomos I e II. Lisboa: Livros Horizonte, 1980 
SILVA, Maria Beatriz Nizza da. A educação de um príncipe no período pombalino, Revista de História das Ideias, 4 (1), 1982-1983, 377-383.

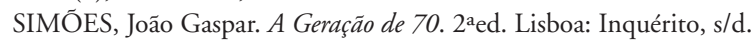

SNYDERS, G. Escola, classe e luta de classes. 2aEd. Lisboa: Moraes, 1981.

SNYDERS, G. La pedagogie en France aux XVIIe et XVIIIe siècles, Paris: Presses Universitaires de France, 1965.

SNYDERS, Georges. La joie à l'école. Paris: P.U.F., 1986

SOUZA, Laura de Mello e. O diabo e a Terra de Santa Cruz. São Paulo: Companhia das Letras, 1989.

SOUZA, Maria Cecília Cortez Cristiano de. A leitura entre o sonho e a insônia: a auto-biografia de Luís Gama, abolicionista e ex-escravo. [Mimeografado] São Paulo: FEUSP, 1995.

STAROBINSKI, Jean. 1789: os emblemas da razão. Trad. São Paulo: Companhia das Letras, 1988

STAROBINSKI, Jean. J. J. Rousseau: la transparence et l'obstacle. 2e edition. Paris: Gallimard, 1971

TACCA, Oscar. As vozes do romance. Coimbra: Almedina, 1983.

TYACK, David e CUBAN, Larry. Tinkering toward Utopia: a century of school reform. London: Harvard University Press, 1995

TORGAL, Luís Reis e VARGUES, Isabel Nobre. A Revolução de 1820 e a instrução pública. Porto: Paisagem, 1984.

TRAÇA, Maria Emília. O fio da memória: do conto popular ao conto para crianças. Porto: Porto Editora, 1992.

VARELA, Julia e ALVAREZ-LURIA. A maquinaria escolar. In: Teoria e educação. 6, p.68-95,1992.

VARGUES, Isabel Nobre. Entre o exercício da cidadania política e a adopção do constitucionalismo: o papel da Universidade vintista. In: Separata do volume $5^{\circ}$ das Actas do Congresso 'História da Universidade'. Coimbra: Universidade de Coimbra, 1991.

VEYNE, Paul. Acreditavam os gregos em seus mitos? São Paulo: Brasiliense, 1984

VEYNE, Paul. Como se escreve a história. trad. São Paulo: Ediçōes 70, 1983.

VIAL, F. La doctrina educativa de J. J. Rousseau trad. Buenos Aires: Ed. Labor, 1931

VIAL, Francisque. Condorcet et l'éducation démocratique. Genève: Slatkine reprints, 1970.

VIÑAO FRAGO, António. Alfabetização na sociedade e na história. Porto Alegre: Artes Médicas, 1993.

VINCENT, Guy. L'école primaire française: etude sociologique. Lyon: Presses Universitaires de Lyon / Editions de la Maison des Sciences de l'Homme, 1980.

VINCENT, Guy (org). Léducation prisonnière de la forme scolaire: scolarisation et socialisation dans les sociétés industrielles. Lyon: Presses Universitaires de Lyon, 1994.

WEBER, Max. Le savant e le politique. Paris: Librairie Plon, 1959. 


\section{Série Investigação}

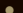

Imprensa da Universidade de Coimbra

Coimbra University Press

2012

- U

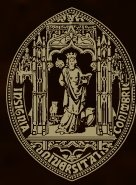

C •

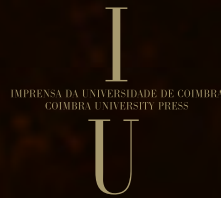

